ISSN: 2306-9716 (Print) ISSN: 2664-6110 (Online)

МІНІСТЕРСТВО ЗАХИСТУ ДОВКІЛЛЯ ТА ПРИРОДНИХ РЕСУРСІВ УКРАЇНИ ДЕРЖАВНА ЕКОЛОГІЧНА АКАДЕМІЯ ПІСЛЯДИПЛОМНОЇ ОСВІТИ ТА УПРАВЛІННЯ

\title{
EКОЛОГІЧН НАУКИ
}


Екологічні науки : науково-практичний журнал / Головний редактор Бондар О.I. - К. : Видавничий дім «Гельветика», 2020. - № 6(33). - 194 с.

Головний редактор: Бондар О.І., доктор біологічних наук

Заступник головного редактора: Нагорнева Н. А.

Науковий редактор: Машков О.А., доктор технічних наук

Відповідальний редактор: Сікачина В. Г.

\section{Редакційна колегія:}

Гандзюра В.П., доктор біологічних наук

Єрмаков В.М., доктор технічних наук

Захматов В.Д., доктор технічних наук

Іващенко Т.Г., кандидат технічних наук

Коніщук В.В, доктор біологічних наук

Лукаш О.В., доктор біологічних наук,

Машков В.А., доктор технічних наук

Михайленко Л.С., доктор біологічних наук

Нецветов М.В., доктор біологічних наук

Ольшевський С.В., доктор технічних наук

Риженко Н.О., доктор біологічних наук

Рудько Г.І., доктор геолого-мінералогічних наук,

доктор географічних наук, доктор технічних наук

Улицький О.А., доктор геологічних наук

Фінін Г.С., доктор фізико-математичних наук

Шматков Г.Г., доктор біологічних наук

На підставі Наказу Міністерства освіти і науки України № 409 від 17.03.2020р. (додаток 1) журнал внесений до Переліку наукових фахових видань України (категорія «Б») у галузі біологічних наук (091 - Біологія), природничих наук (101 - Екологія, 103 - Науки про Землю) та технічних наук (183 - Технології захисту навколишнього середовища).

Журнал публікує (після рецензування та редагування) статті, які містять нові теоретичні та практичні здобутки в галузі екологічних наук.

Статті у виданні перевірені на наявність плагіату за допомогою програмного забезпечення StrikePlagiarism.com від польської компанії Plagiat.pl.

Журнал включено до міжнародної наукометричної бази Index Copernicus International (Республіка Польща) 


\section{MICT}

\section{ЕКОЛОГІЧНИЙ МОНІТОРИНГ.}

Шевченко Р.Ю. Методологія організації еколого-геодезичних і картографічних досліджень новітніх екологічних загроз у м. Києві. . 7

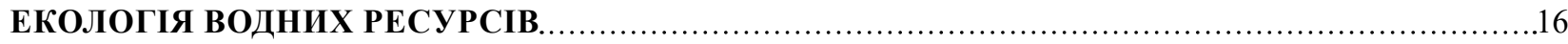

Бурлуцька М.Е., Романчук М.С., Погорелова М.П. Норма річного стоку в басейні річок Приазов'я.............16

Мальований М.С., Афтаназів І.С., Тимчук І.С., Баландюх Ю.А., Жук В.М., Копій М.Л. Оцінка стадій життєвого циклу гідробіонтів у технологіях очищення поверхневих та стічних вод...........................23

Наконечна Ю.О., Чугай А.В. Сучасний стан мережі поверхневих водотоків Північно-Західного Причорномор'я

Петроченко О.В., Петроченко В.I. Науково-методичне забезпечення розроблення планів

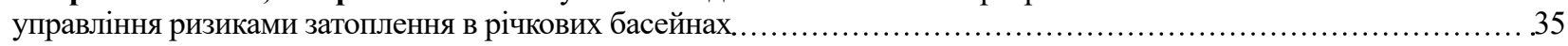

Пількевич Ю.Г., Розорінов Г.М. Датчик для вимірювання температури в прісних водоймах .....................45

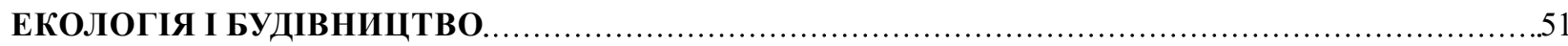

Салій І.В., Кияшко В.Т., Косарчук В.В., Агарков О.В., Ковальчук В.В., Чаусов М.Г. Сучасні методи аналізу напружено-деформованого стану дорожнього одягу.

ЕКОЛОГІЯ І ВИРОБНИЦТВО

Горобей М.С., Улицький О.А., Бойко К.Є., Клименко О.О. Аналіз результатів досліджень техногенного забруднення довкілля територій навколо вуглевидобувних підприємств. .57

Гринь Г.І., Кузнєцов П.В., Гринь С.О. Дослідження технологічних параметрів гідрохімічного вилучення сполук ванадію із техногенних відходів.

Машков О.А., Іващенко Т.Г., Тупкало В.М. Методологічні аспекти екологічного аудиту системи менеджменту підприємств

Поліщук О.І., Лесів М.С., Антоняк Г.Л. Динаміка пігментів фотосинтезу в рослинах на території нафтовидобувних районів Львівської області. .

Хохлов А.В., Хохлова Л.Й. Очищення піщаних грунтів від нафтозабруднень застосуванням біосорбційних комплексів.

\section{ЗАГАЛЬНІ ПРОБЛЕМИ}

ЕКОЛОГІЧНОЇ БЕЗПЕКИ.

Боженко А.Л., Кубов В.И. Анализ особенностей шумового загрязнения при использовании ветрогенераторов в условиях юга Украины ....

Валерко Р.А., Герасимчук Л.О. Екологічна оцінка стану сільських населених пунктів Житомирської області......96

Гришко В.М., Лисенко О.І. Ефективність використання препарату «Антистрес» на врожайність різних за стійкістю гібридів кукурудзи на грунтах за надлишкового вмісту хрому і нікелю

Ivanenko I.M., Fedenko Yu.M., Lesik S.M., Kutsan N.V. Ferrites as adsorbents: review.

Кірсанова В.В., Биковець Н.П., Бражник І.Д. Енергоефективність морських суден як важливий елемент декарбонізації атмосфери

Шевченко Р.Ю., Шевченко 3.М. Історія екологічних катастроф у місті Києві

\section{ЗБЕРЕЖЕННЯ БІОЛОГІЧНОГО}

Красовський В.В. Селекція крупноплідних форм унабі справжнього (Zizyphus jujuba Mill.)

у Хорольському ботанічному саду. 
Галаган О.К., Дух О.І., Ковалевич О.В. Поводження з відходами у місті Кременці (Тернопільська область)......133

ПРОБЛЕМИ ЕКОЛОГО-ЗБАЛАНСОВАНОГО РОЗВИТКУ.

Боруцька Ю.З., Дудяк Р.П., Бугіль С.Я. Формування екосвідомості студентської молоді крізь призму екологізації туризму.

Єрмішев О.В., Бацилсва О.В., Кученко Т.А. Демографічні процеси та стан здоров’я населення як стримуючий фактор сталого розвитку Чернігівщини.

Гетьман В.I., Мовчан М.М. Функціональне зонування територій національних природних парків світу та України.

Мордатенко І.Л. Сучасний стан насаджень історичної ландшафтної ділянки «Дружній сад» у дендропарку «Олександрія» НАН України.

СИСТЕМА ЕКОЛОГІЧНОЇ ОСВІТИ ДЛЯ СТАЛОГО РОЗВИТКУ 168

Лазебна О.М., Волошина Н.О. Сучасні тенденції методичного контенту екологічної освіти.

ТЕОРЕТИКО-МЕТОДОЛОГІЧНІ ПИТАННЯ В ГАЛУЗІ ОХОРОНИ ДОВКІЛЛЯ

Комарова I.O. Taraxacum officinale Wigg як біоіндикатор акумуляції важких металів у грунті гірничо-металургійного регіону

Хом’як І.В., Мшанецька В.В., Костюк В.С., Шпаковська Л.В., Демчук Н.С., Андрійчук Т.В., Онищук І.П. Оцінка екосозологічного потенціалу території за допомогою аналізу синфітоіндикаційних моделей динаміки.

Чугай А.В., Бучинська І.В., Ільїна В.Г. Методика оцінки техногенного навантаження на складники довкілля та їі програмна реалізація. 


\section{CONTENTS}

\section{ENVIRONMENTAL MONITORING}

Shevchenko R. Methodology of organization of ecological-geodetic and cartographic researches of the newest ecological threats in Kyiv 7

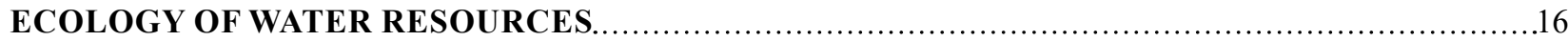

Burlutska M., Romanchuk M., Pogorelova M. Annual runoff rate in the basin of the rivers of the Azov Sea ............16

Malovanyy V., Aftanaziv I., Tymchuk I., Balandiukh Ju., Zhuk V., Kopiy M. Hydrobionts life cycle stages

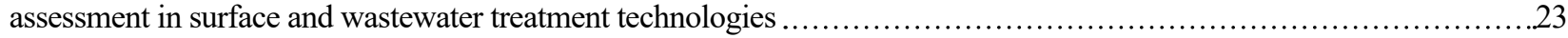

Nakonechna Yu., Chugai A. Current state of the surface water network of the North-Western Black Sea .................29

Petrochenko O., Petrochenko V. Scientific and methodological support for the development

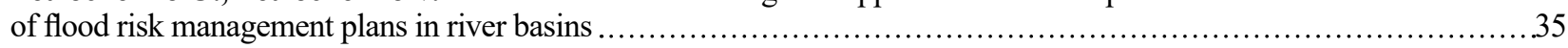

Pilkevych Yu., Rozorinov H. A sensor for measuring of temperature in fresh reservoirs .............................45

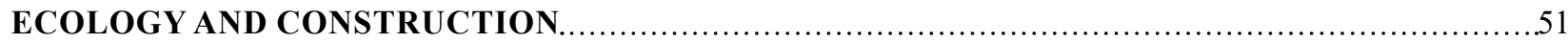

Salii I., Kiyashko V., Kosarchuk V., Agarcov O., Kovalchuk V., Chausov M. Modern methods of analysis of stress-strain state of road pavement

Horobei M., Ulytskyi O., Boiko K., Klymenko O. Analysis of the results of research on man-made pollution of the territories around coal mining enterprises

Gryn G., Kuznetsov P., Gryn S. Research of technological parameters of hydrochemikal extraction of vanadium composition from technological waste

Mashkov O., Ivashchenko T., Tupkalo V. Methodological aspects of environmental audit of enterprise management system

Polishchuk A., Lesiv M., Antonyak H. Dynamics of photosynthetic pigments in plants growing in oil-producing areas of Lviv region....

Khokhlov A., Khokhlova L. Purification of sandy soils from oil with the use of biosorption complexes .86

GENERAL ENVIRONMENTAL SAFETY ISSUES 91

Bozhenko A., Kubov V. Analysis of the noise pollution caused by wind turbines in the south of Ukraine .................91

Valerko R., Herasymchuk L. Ecological assessment of the condition of rural settlements of Zhytomyr region ...........96

Gryshko V., Lysenko O. The effectiveness of the preparation “Antistres" for the yield of children for the stiffness of corn hybrids on the soil for excess chromium and nickel

Ivanenko I.M., Fedenko Yu.M., Lesik S.M., Kutsan N.V. Ferrites as adsorbents: review. ....

Kirsanova V., Bykovets N., Brazhnik I. Energy efficiency of sea vessels as an important element of decarbonization of the atmosphere

Shevchenko R., Shevchenko Z. History of ecological catastrophe in the city of Kyiv ...................................120

PRESERVATION OF BIOLOGICAL AND LANDSCAPE DIVERSITY ...................................

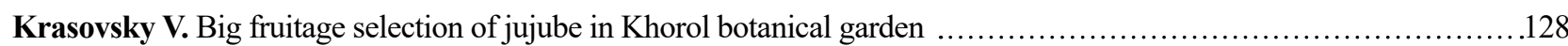

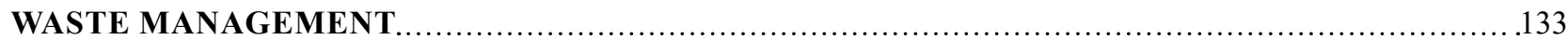

Halahan O., Duch O., Kovalevich O. The waste management in the city Kremenets (Ternopil region) ...................133

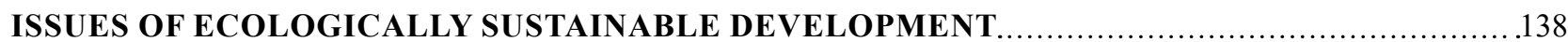

Borutska Yu., Dudiak R., Bugil S. Formation of eco-consciousness of student young people through the prise of environmental tourism 
Yermishev O., Batsylyeva O., Kuchenko T. Demographic processes and the state of health of the population as a stimulating factor of sustainable development of Chernihiv region

DEVELOPMENT OF THE UKRAINIAN NATURE RESERVE FUND

Getman V., Movchan M. Functional zoning of the territories of national natural parks of the world and Ukraine 153

Mordatenko I. The current condition of plants of historical landscape area "Druzhnii sad" in the dendrological park "Alexandria" NAS of Ukraine

ECOLOGICAL EDUCATION SYSTEM FOR SUSTAINABLE DEVELOPMENT. 168

Lazebna O., Voloshyna N. Current trends in methodological content of environmental education 168

THEORETICAL AND METHODOLOGICAL ISSUES IN ENVIRONMENTAL PROTECTION. 172

Komarova I. Taraxacum officinale Wigg as a bioindicator of heavy metals accumulation in soil of the mining and metallurgical region 172

Khomiak I., Mshanetska V., Kostiuk V., Shpakovska L., Demchuk N., Andriichuk T., Onyshchuk I.

Assessment of the ecosozological potential of the territory through the analysis of synphytoindication dynamic models ..... 178

Chugai A., Buchynska I., Ilina V. Methods of assessment of technogenic load on components of the environment and its software implementation. 


\title{
ЕКОАОГІЧНИЙ МОНІТОРИНГ
}

\author{
УДК 528.9:551:504 \\ DOI https://doi.org/10.32846/2306-9716/2020.eco.6-33.1
}

\section{МЕТОДОАОГІЯ ОРГАНІЗАЦІЇ ЕКОАОГО-ГЕОДЕЗИЧНИХ I КАРТОГРАФІЧНИХ ДОСАІДЖЕНЬ НОВITHIX ЕКОАОГIЧНИХ ЗАГРОЗ У М. КИЕВI}

\author{
Шевченко Р.Ю. \\ Державна екологічна академія післядипломної освіти та управління \\ вул. Митрополита Василя Липківського, 35, корп. 2, 03035, м. Київ \\ azimut90@ukr.net
}

\begin{abstract}
Актуалізовано напрями вивчення новітніх екологічних небезпек і загроз, багато десятиліть на них не звертали уваги, вони навіть вважалися навколонауковими. Таке нехтування призвело до того, що сучасна теорія катастрофічних явищ не підкріплена значною емпіричною базою еніологічних, астрономо-космологічних, геокосмогонічних вимірювань. Нині в закладах вищої освіти запроваджується навчальна дисципліна «Геоаномальні зони та їхній вплив на біоту». Навантаження геологічно активних зон на природне й техногенне середовище досить значне. Недооцінювання їхнього впливу на живі організми, техносферу та безпеку життєдіяльності громадян у повсякденних умовах стало згубним і непередбачуваним. Геоаномальні новітні екологічні небезпеки мають прямі та непрямі ознаки: постійні аварії на теплотрасах, перманентні трощі, спостереження аномальних атмосферних явищ і небезпечних метеорологічних умов погоди, конфліктні ситуації, пригоди тощо. 3 метою їхнього наукового моніторингу запропоновано методи еколого-геодезичних і картографічних досліджень на основі астрономо-космологічних вимірювань. Еколого-геодезичні методи передбачають вивчення динаміки висот місцевості залежно від вихідних нівелірних датумів. Їх порівнювання дає змогу визначати ймовірність виникнення локалізованих небезпечних сейсмічних стоячих хвиль на території м. Києва. Це зумовлено надзвичайною поверховістю конструкцій у центрі м. Києва. Дослідження рівневих висотних поверхонь реалізується із застосуванням гравіметричних, астрономо-гравіметричних, геоелектромагнітних вимірювань за відповідними рівневими поверхнями висот: ортометричних, геодезичних, нормальних, динамічних, відносних і локальних. За геоінформаційними даними укладається еколого-геодезична (гіпергенезична) карта м. Києва, що відображає ізосейстами амплітуду коливання стоячих сейсмічно-гравітаційних хвиль, демонструє динаміку руху вертикальних і горизонтальних переміщень грунтових і тектонічних підмурків Північно-Західних експозицій Українського щита. Відображено дослідження космічних загроз та аерокосмічних небезпек. Розраховано період виникнення катастрофічних явищ космогонічного характеру, що $є$ наслідком природних і техногенних катастроф у м. Києві. Надано рекомендації щодо поліпшення та нівелювання геопатогенного впливу геоактивних аномальних зон міста на біоту, описано географію геопатогенних зон м. Києва. Ключові слова: новітні екологічні небезпеки, гіпергенезія, екологічна геодинаміка, екокосмологія, геопатогенні зони, геодезичні технології, картографування.
\end{abstract}

Methodology of organization of ecological-geodetic and cartographic researches of the newest ecological threats in Kyiv. Shevchenko R.

Updated areas of study of the latest environmental hazards and threats, for many decades they did not pay attention, even considered scientific. This neglect has led to the fact that the modern theory of catastrophic phenomena is not supported by a significant empirical basis of eniological, astronomical-cosmological, geocosmogonic measurements. Recently, the discipline "Geoanomalous zones and their impact on biota" has been introduced in higher education institutions. The impact of geologically active zones on the natural and manmade environment is huge and underestimating their impact on living organisms, the technosphere and the safety of life of citizens in everyday conditions has become disastrous and unpredictable. The facts of the impact of geoanomalous latest environmental hazards have direct and indirect features: constant accidents on heating mains in the same place, permanent cracks, observations of abnormal atmospheric phenomena and dangerous weather conditions, conflicts, accidents and more. For the purpose of their scientific monitoring methods of ecological-geodetic and cartographic researches on the basis of astronomical-cosmological measurements are offered. Ecological and geodetic methods include the study of the dynamics of altitudes depending on the original level dates. Their comparison allows to determine the probability of localized dangerous seismic standing waves on the territory of Kyiv. This is due to the extraordinary number of storeys in the center of Kyiv. The study of level altitude surfaces is realized with the use of gravimetric, astronomicalgravimetric, geoelectromagnetic measurements on the corresponding level surfaces of heights: orthometric, geodetic, normal, dynamic, relative and local. According to geoinformation data, an ecological-geodetic (hypergenesis) map of Kyiv is compiled, which reflects the amplitude of oscillations of standing seismic-gravitational waves, demonstrates the dynamics of vertical and horizontal movements of soil and tectonic foundations of the North-Western expositions. Studies of space threats and aerospace hazards are shown. The period of occurrence of catastrophic phenomena of cosmogonic nature, which is a consequence of natural and man-made disasters in Kyiv, is calculated. Recommendations for improving and leveling the hepatogenic effect of geoactive anomalous zones of the city on the biota are given, the geography of hepatogenic zones of Kyiv is described. Key words: latest ecological dangers, hypergenesis, ecological geodynamics, ecocosmology, hepatogenic zones, geodetic technologies, mapping. 
Постановка проблеми. 3 розвитком нових технологій вивчення Землі та її гравітаційного поля, підвищення точності астрономо-геодезичних повторних вимірювань, більш вагомого значення набуває кінематичний аспект геодезичних досліджень новітніх екологічних небезпек, що викликані вертикальними та горизонтальними рухами контрольних точок (реперів) земної поверхні та збуренням земного гравітаційного поля у часі.

Науково обгрунтовується новий напрямок у науці про Землю, який інтегрує методологічні засади геодезії, геофізики, астрономії та океанології. Головна наукова проблема полягає у вивченні зміни положення і елементів гравітаційного поля Землі в часі та іiі картографічна інтерпретація 3 метою доведення кореляції із природними катастрофами. Пропонується дефініція - екологічна геодинаміка. Наукова проблема відповідної методології об'єднує завдання, сформульовані членом-кореспондентом Академії наук проф. М.С. Молоденським у 1985 р., у якій висвітлено динамічні сили, що $є$ причиною зміни фігури і гравітаційного поля Землі, які викликають надзвичайні ситуації природного характеру.

Актуальність дослідження. Новітні екологічні загрози та небезпеки - це реальні складові географічної оболонки Землі, навколишнього природного та техногенного середовища, що взаємодіють на відповідних частотах геомагнітного резонансу і в залежності від значень його потенціалу впливають на довкілля, техносферу та соціокультурне середовище геопатогенно або геовітально. Зокрема це такі актуальні напрямки їх екологічного моніторингу: еніологія або еніогеографія (дослідження геоаномальних зон та їх вплив на біоту, аномальні аерокосмічні та метеорологічні явища та загрози, локалізовані землетруси). Наприклад, останнім часом українські сейсмологічні станції Інституту геофізики НАН України постійно, раз на місяць, фіксують коливання астеносферної оболонки в районі Київської агломерації. Прилади фіксують коливання земної кори від 2,3-4,1 бала за міжнародною шкалою землетрусів Ріхтера. 3 появою аномальних зон Беньофа можна говорити про деформаційні явища, викликані початком сейсмічної активності. Вони пов'язані з ростом Українських Карпат та великими розломами Українського щита. Потенційно йомовірно, що це є наслідком або причиною змін кліматичних поясів на території України та, певною мірою, синоптичних показників зимових температур.

Зв' язок авторського доробку з важливими науковими та практичними завданнями. Дослідження виконувалося в рамках комплексного пошукового вивчення «Наукові основи проєкту «Атласна картоінформаційна система моделей оцінки впливу на навколишнє середовище м. Києва». У проєкті використовувалися три напрямки організації еколого-геодезичних та картографічних досліджень: епістемологічні, трасформаційні та еволюційні.
Аналіз останніх досліджень і публікацій. В авторській розробці гіпергенезичної карти м. Києва, що була укладена у 2000 р., сформульовано космологічні закони та визначені передові космічні технології у моніторингу та прогнозі екологічних катастроф у м. Києві [6]. Було використано наукові ідеї науковців Національного університету кораблебудування ім. адмірала Макарова: Л.М. Маркіна й О.Л. Гержева [2]. Опрацьовано науковий матеріал проф. М.П. Петрика, який удосконалив уявлення про Всесвіт та внутрішню будову Землі у розрізі інформаційно-польової взаємодії геофізичної енергії та біогеоценозів [3]. Значну увагу приділено науковим польовим дослідженням геофізичних новітніх небезпек геопатогенних зон і природних аномалій учених: І. Чуда [5], В. Ляшенка, П. Міхліна [1].

Виділення не вирішених раніше частин загальної проблеми, котрим присвячусться означена стаття. Сьогодні методологічно не сформульована теорія новітніх екологічних небезпек на території великого міста, не запроваджені технології астрономо-геодезичного, геологічного та еколого-картографічного моніторингу їх потенційного впливу на біоту та показники еколого-біологічної, економіко-соціальної та політико-географічної рівноваги існування цивілізації та людського простору. У методології екологічного обсерваційного моніторингу довкілля-простору не враховані питання еніології, уфології, геохронології та інших наукових напрямків неоекологічної теорії катастрофічних явищ та загроз. Завдяки чому вчені не можуть достовірно та своєчасно прогнозувати виникнення надзвичайних ситуацій та оцінити справжні наслідки для довкілля.

Новизна. Для потреб широкомасштабного екологічного моніторингу із оцінки впливу на довкілля із залученням неоекологічних теорій та перевірки гіпотез як експериментальний полігон вивчення обрано м. Київ - високоурбанізований населений пункт зі значною територію, де стикаються дві фізико-географічні зони (Полісся та Лісостепу), дві геологолітологічні тектонічні структури (Український щит та розломи поліської геоморфологічної зони), формується місцевий синоптико-кліматичний макрорайон екстремальних явищ, спостерігається підвищення рівня показників геоелектромагнітного (природного та техногенного), гравітаційного та сейсмологічного потенціалу. Такі чинники, як забруднення повітря, грунтів, поверхневих та природних вод на території м. Києва, зокрема катастрофічне обміління р. Дніпро (за даними геопорталу Google Map Satellite), є загрозою для здоров’я людей. Залучення до наукового дослідження матеріалів вчених-аматорів, еколого-астрологічні карти, еколого-еніологічні картосхеми, плани міського геопатогенезу, підвищать рівні оцінки патогенного впливу на довкілля новітніх екологічних загроз та стають теоретичною основою (підмурку) формулювання спеціалізованої методології захисту. 
Методологічне або загальнонаукове значення. Методологія організації еколого-геодезичних та картографічних досліджень $є$ складником формулювання авторського наукового напрямку еколого-природоохоронних та моніторингових досліджень - екологічного києвознавства, що передбачає такі галузі дослідження у м. Києві: екологія довкілля та система природокористування міської топоніміки, атласне та картографічне вивчення трансформації міського простору Києва, астрономічні та навігаційні основи києвознавства, еколого-географічні, гідрометеоролого-синоптичні особливості довкілля м. Києва та їх вплив на розвиток екологічного туризму та екскурсійної рекреації. Значення даної парадигми, представленої в статті, закладає основи формулювання теорії новітніх екологічних загроз на території великого міста для потреб туризму, екскурсології та рекреації, тощо.

Виклад основного матеріалу. Еколого-геодезичне картографування м. Києва - це новітній напрям спеціалізованого проблемного еколого-моніторингового картографування на основі астрономо-геодезичних і космогеодезичних баз даних високоточного вимірювання.

Еколого-геодезична карта - це геопросторова еколого-динамічна модель трансформації довкілля під випливом природних (астрономічних і геоїдальних) та техногенних чинників. Вона є основною (базовою) моделлю оцінки впливу на довкілля в екологічній геодезї природокористування та при картографуванні надзвичайних ситуацій. Інша іiі назва - гіпергенезична (еколого-геодезична) карта. Вона демонструє райони, місця, поширення надзвичайних ситуацій геодинамічного характеру. У перекладі «giper» означає - «надто», «genesis»«nоходження». На карті відображаються території 3 великим аномальним геофоном, що має ендоземне енергетичне походження. Мається на увазі візуалізація об'єктивних даних про характер та швидкість руху блоків земної кори під м. Києвом.

Вивчаючи рух земної кори в сейсмоактивних частинах міста, можна отримати дані щодо сейсмічної екологічної небезпеки, в тому числі великих землетрусів, повільніших деформацій, що дає змогу правильнішого розуміння тектонічних процесів.

Для проведення відповідного гіпергенезичного (еколого-геодезичного моніторингу) розглянемо відповідні практичні методи.

Геодезичний метод - це астрономо-геодезичне нівелювання - визначення перевищень точок квазігеоїда (геоїда) відносно поверхні референц-еліпсоїда. Згідно з теорією ізостазії (2іпотеза Пратта), астеносфера лежить на одній глибині. Тоді щільність земних мас під час переходу від одного до іншого стовпа земної кори є неоднорідною. Наприклад, м. Київ має середню висоту гір рівною максимальному значенню 180-205 м. над рівнем моря, а середня глибина р. Дніпро в районі міста має позначку - 7,8 м. За такими вихідними реперними даними можна визначити рух земної кори (динаміку висот $H$ ) у вертикальних та горизонтальних напрямках.

Висоти $H$ визначають відступи точок від еліпсоїда по нормалі до нього. Існує наступна ієрархія висот: ортометричні (абсолютні), геодезичні, нормальні (узагальнені), відносні (умовні), динамічні та локальні. Це демонструється на карті нівелювання м. Києва. Точність даних залежить від густоти точок, у яких відомі значення висот земної поверхні над еліпсоїдом. Значення висот отримують, як правило, із нівелювань, проте отримані висоти віднесені не до еліпсоїда, а до деякої іншої поверхні - рівневої, за яку приймають рівень моря, тобто поверхні геоїда. Якщо припустити, що нівелірні висоти відраховуються від поверхні, яка визначається рівнянням $W=$ const і збігається 3 рівнем моря, то задача буде полягати у визначенні нівелірних висот точок фізичної поверхні Землі, а також у визначенні висот геоїда від вибраного еліпсоїда. Визначенні таким чином висоти $H$ називають геодезичними висотами (рис. 1).

Відрізок $M_{1} M$ представляє відстань від нульпункту висот - геоїда до фізичної поверхні Землі, яку називають ортометричною висотою точки $M$ [4]. Отже, ортометрична висота - це висота точки фізичної поверхні Землі над поверхнею геоїда, відкладена по силових лініях поля сили ваги (за прямовисними лініями), що проходять через цю точку.

Для їх фізичного визначення пропонуються прийоми астрономічного та гравіметричного нівелювання. Так, за останнім, розраховуючи відхилення прямовисних ліній висот квазігеоїда можна визначити значення зсувів тектонічних плит. Загальну схему визначення висот представлено на рис. 1.

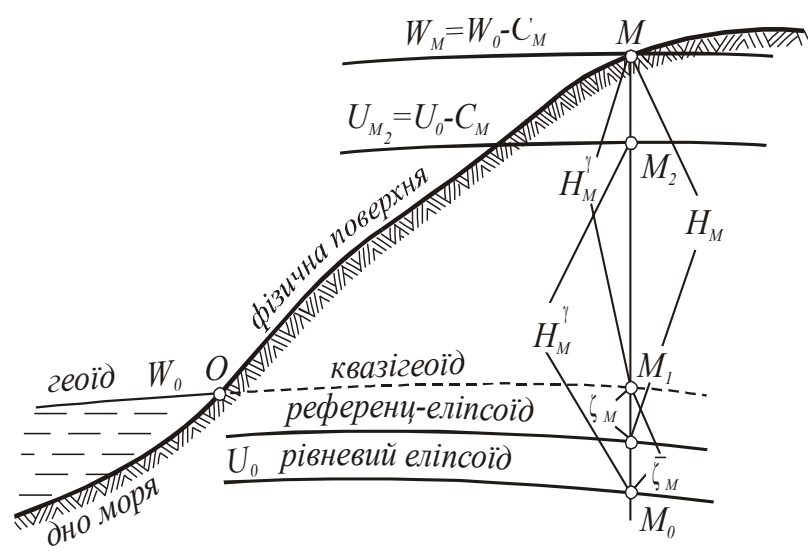

Рис. 1. Система гіпергенезичних висот у м. Києві

Отже, нормальною висотою $H^{\gamma}{ }_{M}$ точки $M$ фізичної поверхні Землі називається відрізок $M_{0} M_{2}$ силової лінії, що проходить через точку $M$ в полі нормального потенціалу сили ваги, між рівневими поверхнями $U=U_{0}$ (рівневий еліпсоїд) і $U_{M_{2}}=U_{0}-C_{M}$. 
Якщо від точок фізичної поверхні Землі відкласти по силових лініях нормального гравітаційного поля вниз їх нормальні висоти, то отримаємо поверхню квазігеоїда. Тоді нормальну висоту можна розглядати як висоту точки фізичної поверхні Землі над квазігеоїдом.

Геодезична висота $H_{M}$ точки $M$ дорівнює сумі нормальної висоти $H_{M}^{\gamma}$ і аномалії висоти $\bar{\zeta}_{м}$. Аномалія висоти $\bar{\zeta}_{\mu}$ дорівнює відрізку $M_{2} M$ і називається висотою квазігеоїда над відліковою поверхнею. Суттєвих поправок за те, що геодезичні висоти відкладають не по силових лініях нормального поля, а по нормалях до еліпсоїда, не виникає.

Висоти $N$ визначають за допомогою глобальних гравітаційних моделей Землі, висоти (аномалії висот) $\bar{\zeta}$ - методом астрономічного чи астрономо-гравіметричного нівелювання.

Перевагою нормальних висот над ортометричними є те, що вони відповідають такому поділу геодезичної висоти Н на гіпсометричний і геоїдальний складники, за якого кожна з них може бути однозначно і строго визначена тільки за вимірами на фізичній поверхні Землі.

Ортометричні висоти мають істотний недолік принципового характеру - вони не можуть бути обчислені точно, оскільки необхідно брати до уваги ту чи іншу модель розподілу мас в тілі Землі. Від цього ганджу ортометричних висот вільні нормальні висоти, які обгрунтував проф. М.С. Молоденський під час розробки загальної теорії фігури Землі.
Фотограмметричний метод визначення висот під час укладення топографо-географічних карт використовує візуально-порівняльну морфологічну різницю (відтворення зсувів) за допомогою польових геодезичних методів: нівелювання та побудови тріангуляції I класу. Такі процедури необхідні для визначення руху земної кори. Його ще називають інженерно-геологічним методом.

Поширення сейсмічних хвиль нерівномірне в просторі, що є наслідком неоднорідності геологічної будови.

Накопичена інформація формується в екологогеологічну ГІС та відображається на карті м. Києва. Методи побудови гіпергенезичної карти представлено на рис. 2.

На гіпергенезичній карті м. Києва показані можливі епіцентри землетрусів. Слід зазначити, що гіпергенезична карта використовується як карта надзвичайних ситуацій природного та техногенного характеру.

Картографічний моніторинг сейсмічної небезпеки м. Києва дозволяє вказувати на тенденцію розвитку сейсмічності даної території. Електронна карта сейсмічності земної кори у м. Києві дає можливість прогнозувати рухи блоків Українського щиту. Тому будівельні організації та установи різних форм власності повинні враховувати, що м. Київ знаходиться у зоні середньої сейсмічної активності. Якщо проаналізувати карту (рис. 4), можна зробити висновок, що небезпечними є Печерський, Шевченківський та Дніпровський райони столиці.

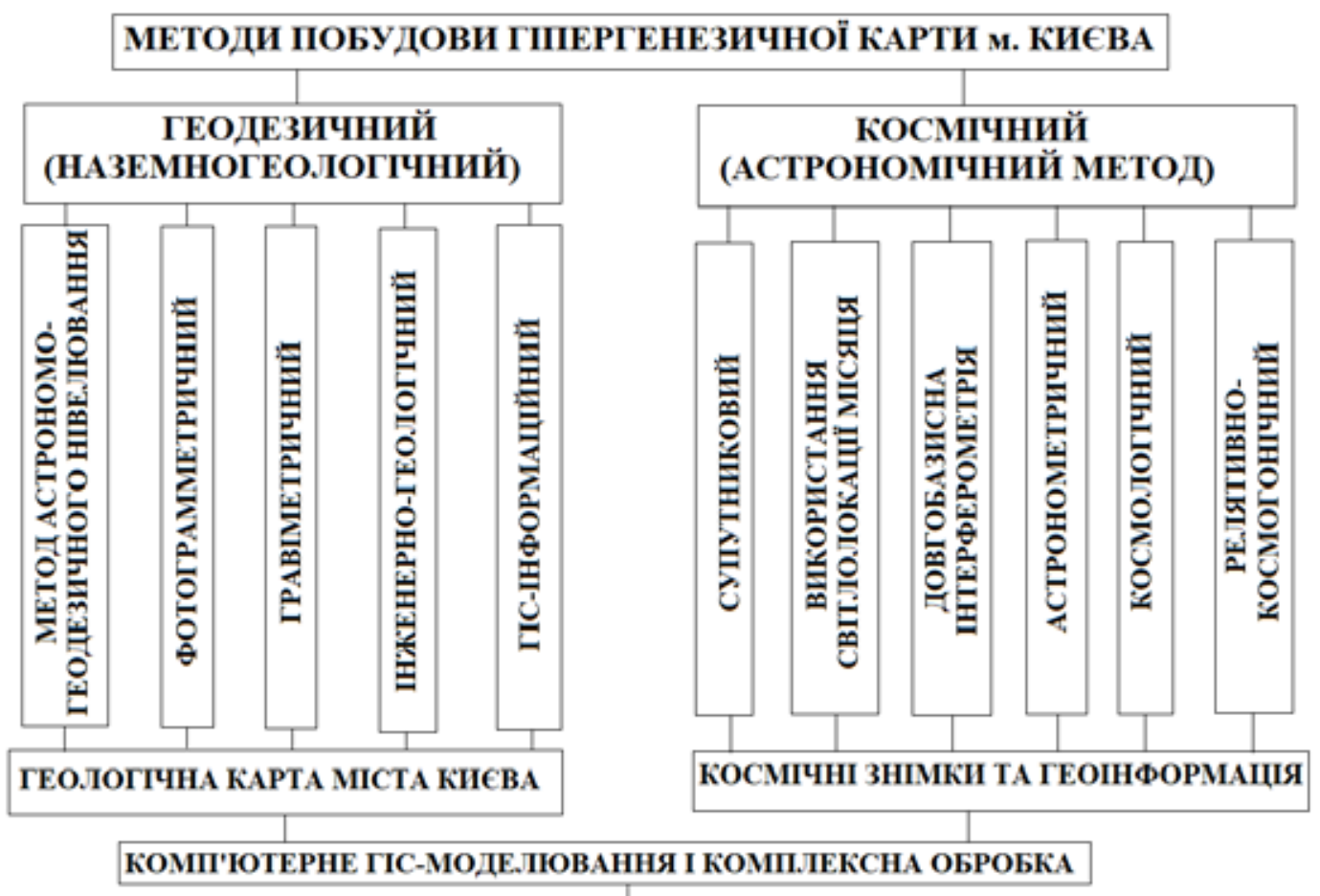

ПРОЄКТ ГІІЕРГЕНЕЗИЧНОЇ (ЕКОЛОГО-ГЕОДЕЗИЧНОЙ) КАРТИ КИЄВА У МАСШТАБІ 1 : 40000

Рис. 2. Методи побудови гіпергенезичної карти м. Києва 
Астрономічними ігеодезичнимиметодами на базі геофізичних даних зонами підняття є вулиці Мазепи та Лаврська, Омельяновича-Павленка, проспект Перемоги (Брест-Литовський), проспект Героїв Сталінграду (Володимира Івасюка), Маяковського та ур. Видубичі (сельклінальні зони).

Антиклінальні території мають велику сейсмічну аномалію - зону Беньофа, тобто епіцентри землетрусів.

Через все тематичне поле карти проходять ізосейсти - лінії з однаковими амплітудами коливання межі Мохо. Це лінія розповсюдження сейсмічних хвиль, канали за якими проходить енергетична напруга земної кори м. Києва.

Флексури вісі Спредінга розділяють місто на дві геолого-енергетичні підзони, які рухаючись один до одного підвищують самосейсмічність астеносфери. До цього визначаються ще й особливості геологічної будови земної кори у місті.

Використані оцінки показують, що геодинамічні варіації коливання сейсмічних хвиль проходять на глибини, величини якої якраз характеризує відступи квазігеоїда від геоїда:

$$
\Delta H^{g}=\left(1-\frac{\gamma_{m}}{g_{m}}\right) \cdot H_{\text {вим. }}
$$

де: $\Delta H^{g}-$ трансформація ортометричної висоти, $H^{\gamma}$ - нормальна висота, $g_{m}$ - прискорення

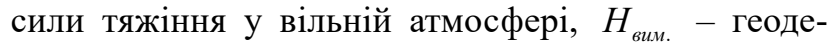
зична висота від рівня астеносфери, $\gamma_{m}-$ нормальна сила ваги.

Розрахуємо показники руху земної кори під м. Київ. Визначимо, що: $g_{m}=9.8 \mathrm{~m} / \mathrm{c}^{2}$, $g_{m}-\gamma_{m}=0.003 \mathrm{M} / \mathrm{c}^{2}$ та $H_{\text {вим. }}=5 \mathrm{\kappa m}$, то різниця $H^{\gamma}-H^{g}=2.4 м$; для більш рівнинних районів м. Києва, при $g_{m}-\gamma_{m}=0.0005 \mathrm{M} / \mathrm{c}^{2}$ та $H_{\text {вим. }}=1 \mathrm{\kappa M}$ різниця буде біля $5 \mathrm{~cm}$.

Одним із провідних методів в дослідженні є супутниковий. За даними супутникового радіовисотоміра визначається висота геоїда на даній місцевості (рис. 3). Потім дані порівнюються із гравіметричними даними.

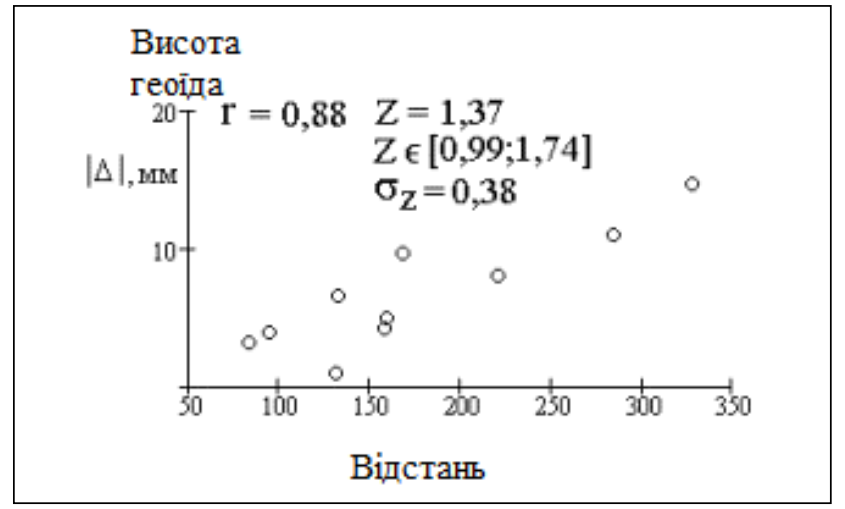

Рис. 3. Профіль висоти геоїда, отриманий методом GPS-нівелювання
За цими даними укладається карта астрономо-геодезичних висот м. Києва - основа гіпергенезичної карти міста.

Наступний метод, що застосовувався в моніторингу, - світлолокації Місяия. Він дозволяє вивчати динаміку руху земної кори. Сутність методу полягає у вимірюванні напрямків імпульсивними лазерними далекомірами до кутових відбивачів, доставлених на поверхню Місяця американським космічним апаратом. Визначається Грінвицький зоряний час проходження відбивача через місцевий меридіан. Найбільш точні стаціонарні прилади дозволяють зафіксувати динамічні явища із Землі із середньоквадратичною похибкою 0,2 м.

Головним є метод довгобазисної радіоінтерферометрії. Його принцип дії такий: прийом синусоїдального радіосигналу 3 квазару здійснюється антенами 1 та 2 від випромінювача, значно віддаленого порівняно $з$ довжиною бази між антенами. Це необхідно для того, щоб вважати напрями радіопроменів на нього 3 антен паралельними. Зрівняння фаз, прийнятих антенами сигналів, визначається час проходження фронту хвилі від антен 2 до антени 1. Знаючи швидкість світла можна визначити довжину переміщення фронту хвилі 32 в 1, а по ньому при відомій відстані між базами відповідний кут. За різницями прийому сигналу визначають рух земної кори. При цьому потрібно робити поправку за «хрест Ейнштейна» (гравітаційне лінзування), кривизну простору-часу та релятивістські космогонічні ефекти.

Після завершення всіх лабораторних камеральних обробок створюється проєкт гіпергенезичної (еколого-геодезичної) карти у масштабі 1 : 40 000. Нами розраховано, якщо землетрус у Карпатах більше 7 балів, то згідно закону Гутеаберга-Pіхтера, час проходження сейсмічної хвилі від епіцентру землетрусу до м. Києва пройде за 1 хв 2 сек.

3 погляду запобігання відповідній надзвичайній ситуації природного характеру постає проблема проведення моніторингу землетрусів у м. Києві. Він проводиться на базі картоінформаційних технологій.

Укладена гіпергенезична карта м. Києва (рис. 4) демонструє сучасні рухи земної кори в горизонтальних і вертикальних напрямках. Створена на основі картографічного забезпечення «Призрак»- геодезичної геоінформаційної оболонки моделювання сейсмо-тектонічної ситуації на десятиріччя наперед. Це дає змогу запобігти масовим руйнуванням під час потужного землетрусу понад 7 балів.

Модель запрограмована так, що в разі такого землетрусу, наприклад катастрофічного (10-12 балів), столиця України матиме значні матеріально-технічні втрати внаслідок провокування землетрусом похідних техногенних катастроф. Це руйнування київської греблі, вибухи технологічних систем забезпечення. Тому такі явища можуть спровокувати масштабну катастрофу. 
Гіпергенезична карта м. Києва - фундамент розроблення нової запобігальної програми в разі таких надзвичайних ситуацій. Місто Київ у територіальному плані на 2020 рік представляє щільно забудований антропогенний та техногенний ландшафт iз невеликою часткою природних комплексів. А це означає, що в разі надзвичайної ситуації екологогеологічного характеру центральною стане проблема ліквідації саме техногенних наслідків катастрофи. Наприклад, для міста розрахована верхня критична межа кількості поверхів у забудовах. Це максимум 16 поверхів. Зараз є споруди понад 30 та 45 поверхів. I це $є$ небезпекою. Не кажучи вже про проблему гасіння пожеж на таких висотних рівнях.

Карти геодинаміки м. Києва повинні стати фундаментом усіх інженерних і будівельних робіт у м. Києві.

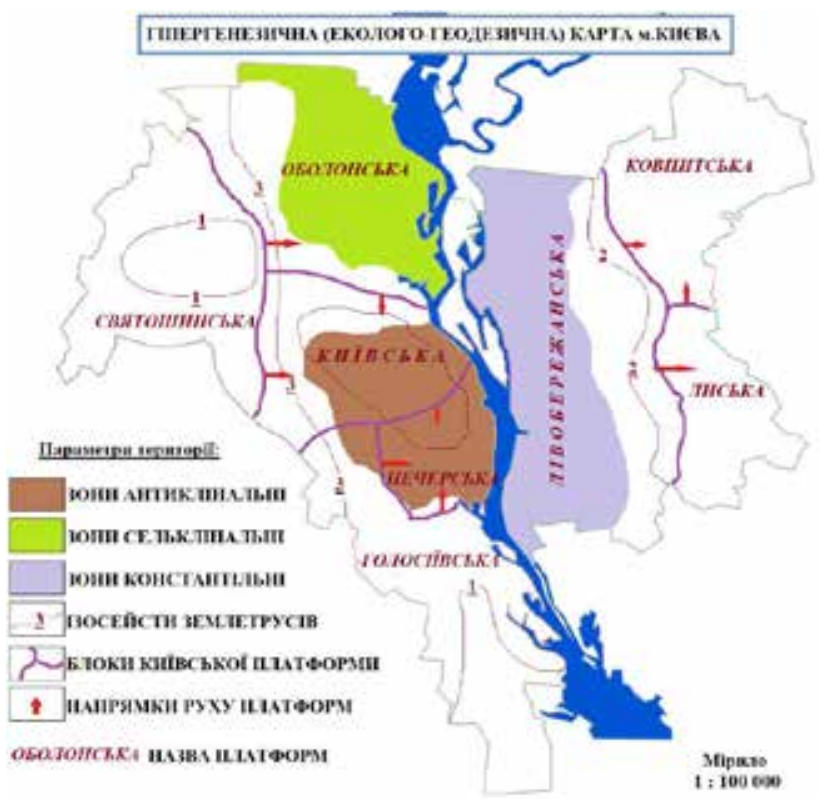

Рис. 4. Гіпергенезична карта м. Києва

Сейсмічний комп 'ютерний моніторинг дає повну інформацію про дійсні природні явища, які спостерігаються 3 рухами земної кори. Використовуючи вище зазначені методи складається проєкт сейсмічного моніторингу надзвичайних ситуацій за допомогою технічних прийомів космічної геодезії. Метою ітерації $\epsilon$ визначення координат точок місцевості та моделювання їхнього «топографічного дрейфу». За цим показником визначаються горизонтальні рухи астеносфери. Отже, визначається геодинаміка рельєфу Київської агломерації.

Вищевикладені методи та їх застосування дають змогу забезпечувати корегування «Генерального плану м. Києва» із розширення міста, недопущення будівництва небезпечних інженерних конструкцій та споруд. Проєктування за технологією підвищеної сейсмостійкістю необхідно проводити на платформах м. Києва з урахуванням аномалій магнітного, гравітаційного поля та регенерацією ендогенних процесів під астеносферою міста.

Результатом проведеного картографічного аналізу є візуалізація природної сейсмічності міста. Якщо топографічна маса міста не має ознак дії внутрішніх енергетичних сил планети, то необхідно брати до уваги сейсмоконстантність території, що спостерігається в м. Києві.

У м. Києві активно розвиваються ендогенні процеси, викликані тектонічними та техногенними вертикально-горизонтальними рухами Землі - формування «чаші опускання» м. Києва. У 2020 р. цей показник наближується майже до одного метра.

Створена гіпергенезична (еколого-геодезична) карта $€$ картографічним документом запобігання у системі розробки програми екологічної безпеки м. Києва. Карта є керівним документом при виникненні катастрофи, за матеріалами якої необхідно проєктувати заходи ліквідації наслідків екологічного лиха.

Іншою новітньою екологічною загрозою $\epsilon$ космічні та аномальні космічні явища та загрози, геопатогенні зони та аномалії, що викликають значну кількість катастроф у м. Києві. Необхідно визначити генезис та періодику екологічних катастроф у м. Києві.

Сучасний прогноз екологічних катастроф здійснюється за допомогою математичного аналізу, космічних знімків та обтрунтування отриманих даних космологічними законами. Це новітня задача у дослідженні генезису катастроф. Отже, необхідно з'ясувати, як впливають процеси в космічному просторі на розвиток планети у цілому, а також кореляцію між енергетичним балансом планети та періодичністю катастроф у м. Києві.

Зосередимо увагу на космологічному червоному зсуві. 3 наукової точки зору, завдання дослідження космологічного зсуву обумовлена багатьма факторами: точністю вимірювання космічних об'єктів та відстані до них. Невидимі чорні діри змушують підвищити точність вимірювань, використовувати інтерферометри типу Merlyn.

Космологічний червоний зсув - це зсув ліній у бік довгих хвиль у спектрі, який отриманий від далекого космічного джерела. Обираємо для м. Києва галактику $C$ (рис. 5). Вибір узгоджується із співвідношення різниці прийнятої і випущеної довжин до випущеної довжини хвилі із Головної астрономічної обсерваторії у Голосіїві. Якщо лінія водню ЛайманАльфа 3 довжиною хвилі $\lambda_{1}=1216 \mathrm{~A}, \mathrm{~A}-$ астрономічна одиниця на довжині хвилі $\lambda_{2}=4864$ А, то червоний зсув Галактики $\mathrm{Z}$ дорівнює:

$$
Z=\frac{\lambda_{1}-\lambda_{2}}{\lambda_{2}}=\frac{4864-1216}{1216}=3
$$

Отже, робимо висновок, що чим вище число $\mathrm{Z}$, тим простір-час на даній ділянці (м. Київ) алотроnічний. Це тягне за собою ймовірність космічних 
катастроф на рівні 0,3-0,4 за розподілом Гауса. Це може проявлятися у вигляді частих метеоритних дощів та зоною постійної перегелізації небезпечних космічних об'єктів. Для Києва показник $Z=3$. Ймовірність таких явищ невелика, від 0,1 до 0,3 одиниць розподілу за Пуасоном.

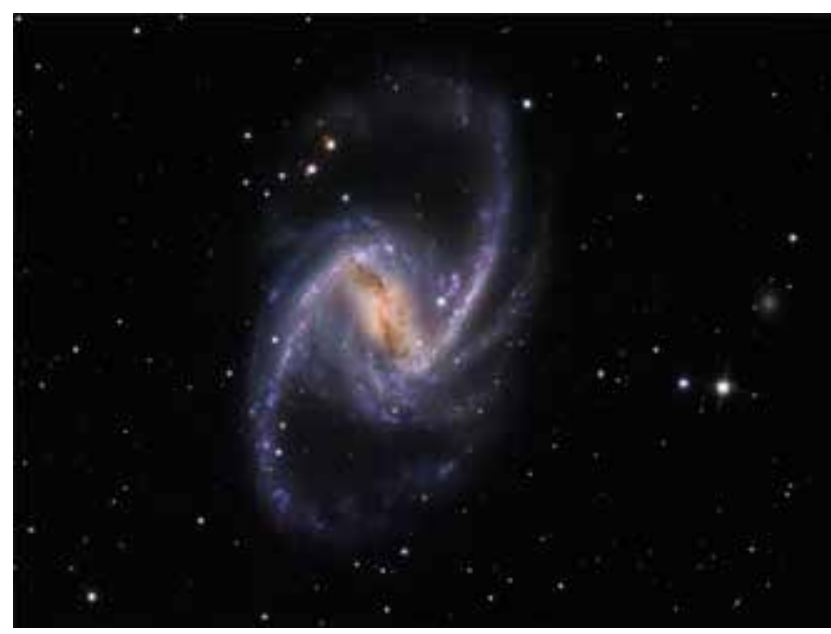

Рис. 5. Галактика NGS 1365

Червоний зсув називають ще ефектом Доплера. Знаючи червоний зсув $\mathrm{Z}$ визначаємо швидікість відліту NGS 1365. Якщо швидкість невелика порівняно зі швидкістю світла, то це можна представити у вигляді формули:

$$
\mathrm{V}=\mathrm{C} * \mathrm{Z}=300000 \mathrm{\kappa м} / \mathrm{c} * 3=900000
$$

У даному випадку Z > 1. Це означає, що швидкість NGS 1365 пов'язана із більш складним процесом, зв'язаним із кривизною простору-часу.

Кривизна простору-часу зв'язана з гравітацією або зі зміною щільності просторової космічної речовини. Щільність речовини Сонячної системи галактики Чумацького шляху (рукав Оріону) дорівнює $10^{-29}$ до $10^{-31} \mathrm{\Gamma} / \mathrm{cm}^{3}$.

При червоному зсуві розраховуємо відстань до NGS 1365, застосовуючи закон Хаббла:

$$
\mathrm{V}=\mathrm{H}_{0} * \mathrm{r}
$$

$\mathrm{H}_{0}$ - постійна Хаббла та дорівнює 75 км/(c *Мпк).

Використовуючи дані для галактики М 104 (бачимо у зимні місяці на небосхилі широти м. Києва): $\lambda_{1}=21 \mathrm{~cm}, \lambda_{2}=21,2 \mathrm{~cm}$, то червоний зсув галактики $\mathrm{Z}$ дорівнює:

$$
\begin{gathered}
Z=\frac{\lambda_{1}-\lambda_{2}}{\lambda_{2}}=\frac{21,0-21,2}{21,2}=-0,01 \\
r=\frac{V}{H_{0}}=\frac{C^{*} Z}{H_{0}}=\frac{300000 * 0,01}{75}=40 \mathrm{Mn} \kappa
\end{gathered}
$$

Мnк - мегапарсек, парсек, одиниця вимірювання в астронометрії та дорівнює часу, що проходить світло за один астрономічний рік.
Червоний зсув є мірою часу катастроф для даної території планети звідки спостерігається. Дані, які підраховані вище компонуються в $\epsilon \partial u$ ний закон виникнення та циклічності катастроф Герцишпрунга-Рессела.

Для м. Києва за результатами спостережень галактик M 104 та NGS 1365 розрахована періодичність природних катаклізмів, яка має середньостатистичне значення 10,9 років.

Періодичність глобальних екологічних катастроф для м. Києва становить біля двох тисяч років. Це підтверджено археологічно київським дослідником В. Хвойком на стоянці Кирилівській на Подолі. Були знайдені докази сильного землетрусу, що зруйнував місто, яке існувало на території сучасної столиці України. Також ця теорія підтверджує гіпотезу изиклічності ц̧ивілізаизії на нашій планеті.

За даними наукових досягнень в області позагалактичної астрономї та космогонії отримуємо математично обгрунтований модельований синусоїдальний час періодизації виникнення катастроф. Треба зазначити, що відповідна теорія надзвичайно ефективна при прогнозуванні цих процесів у моніторингу впливу гравітаційного випромінювання на екологічні катастрофи у м. Києві. Це дозволяє виявити взаємозв'язок між обміном енергії планети та енергетичним балансом довкілля-простору із часом.

Космологічні закони, за якими визначені для м. Києва період екологічних катастроф та напруга земної кори є інноваційним у динамічній геодезї, а також при картографуванні нетрадиційних надзвичайних ситуацій природного характеру (космічного тенезу).

Застосування космологічних законів в наукових дослідженнях набагато менші ніж передові космічні фотограмметричні технологї. Їх застосування $\epsilon$ на зародковому етапі, у зв'язку з накопиченням нових фактичних даних про геофізичні особливості сейсмічно активних зон земної кори. Вивчення їх динаміки за допомогою високочутливої геофізичної апаратури визначає кореляцію зі станом здоров'я людей на визначених територіях.

Відповідні дослідження мають за мету виявляти тісні зв'язки між станом здоров'я людини та локалізацією геоаномальних зон, функціонування біогеоценозів м. Києва. Визначення на їх території аномальних значень теплового, гравітаційного, електромагнітного поля та радіаційного випромінювання.

Основними джерелами енергетичних випромінювань є ендогенні (з надр Землі) та екзогенні (з Космосу). Припустимо, що біосфера нашої планети має єдине енергетичне поле із своєрідною структурою та такими головними складовими енергетичних випромінювань, як електромагнітні, електричні, теплові, інфрачервоні, надвисокочастотні поля. Регулятором взаємодії живих організмів 3 енергією навколишнього простору є енергетичні 
оболонки, що оточують всі живі й неживі об'єкти матеріального світу.

Використовуючи космологічні закони та космічні технології (космічні знімки, дані дистанційного зондування) складаються геоенергоаномальні карти м. Києва. Таким чином створюємо прогнозні геопросторові моделі екологічних катастроф за даними визначення енергетичного потенцііалу території м. Києва.

Геоенергоаномальні зони поєднані 3 геологічними аномаліями. Це розломи, тріщини в земній корі, ділянки значної концентрації напружень високих теплових потоків з надр Землі, карстові підземні порожнини, підземні потоки, рудникові штольні, родовища металів.

За своєю формою геоенергоаномальні зони поєднуються із геоекологічними аномаліями. Це смуги, лінії (лінеаменти) та кільцеві утворення різного діаметру. Найдовші 3 таких смуг або лінеаментів дешифруються на космічних знімках м. Києва.

Згідно з результатами досліджень за допомогою передових космічних програмних засобів: SarSAT, UniSat, UfoSAT, геоенергоаномальні зони визначені в системі геодезичних координат.

Геоенергоаномальні зони відіграють надзвичайно важливу роль. По-перше, це канали вертикального перетікання електромагнітної енергії в системі «літосфера - атмосфера-Космос». По-друге, як канали перетікання речовини із глибинних зон Землі до іiі поверхні. Контроль за цим явищем - сейсмічний екологічний контроль на Печерську проводить Державне космічне агентство України. По-третє, як регуляторний механізм у розрядці тектонофізичних напружень шляхом електромагнітного перевипромінювання надлишку енергії в атмосферу та іоносферу. Останнє, зокрема, підтверджується тим, що над геоенергоаномальними зонами земної кори спостерігаються ділянки особливих екоенергетичних і метеорологічних збурень в атмосфері.

Дослідженнями встановлено, що в геопатогенних зонах спостерігаються негативні процеси: нерівномірні осідання будівельних конструкцій, підвищена корозійність трубопроводів та інші фактори. Особливо небезпечними є ділянки, розташовані в місцях перетину геопатогенних зон кількох напрямків. Варто зазначити, що місця для будівництва таких споруд, як Чорнобильська, Рівненська та Хмельницька АЕС, були обрані проєктувальниками невдало. Адже ці станції споруджено саме там, де перетинаються геопатогенні лінеаменти.

Іншим методом виявлення геоенергоаномальних зон є аналіз даних космічного дистанційного зондування. Такі зони виявлені і на території м. Києва. На космічному знімку м. Києва та прилеглих територій вдалося розпізнати два довгих лінеаменти, що перетинаються у вигляді літери $\mathrm{X}$ та три концентричні кільцеві зони. Такі структури видно на космічних знімках решти території України, а також інших країн. Це так звана сітка Хартмана.

Центр складної сітки кільцевих геоенергоаномальних зон розташований на горі Клинець, поряд зі Старокиївською горою. Проблема енергоаномальних зон м. Києва потребує подальшого дослідження. Ймовірно, що геопатогенними $\epsilon$ не всі кільцеві зони, а тільки їхні сегменти (рис. 6). Іншу деталізацію мають геопатогенні зони представлені на карті I. Чуда та карті аномалій В. Ляшенка.

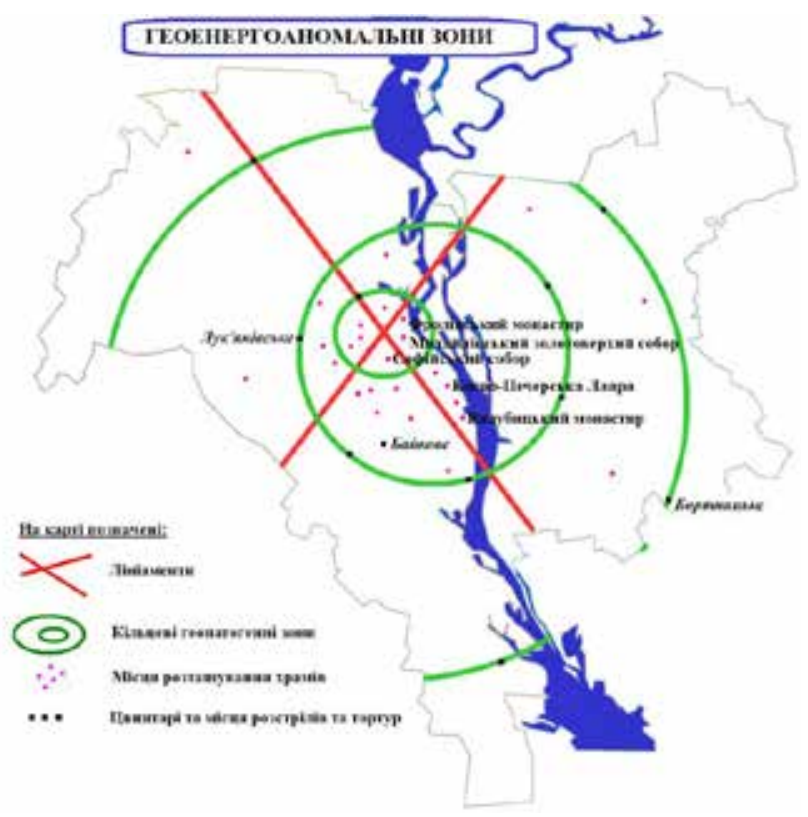

Рис. 6. Карта геоенергоаномальних зон м. Києва

Деякі аспекти знайшли своє відображення в еколого-астрологічних картах м. Києва. За їх допомогою, на думку еніологів, можливо визначати часові характеристики потенційних природно-техногенних небезпек. До переваг цих еколого-астрологічних карт можна віднести те, що це саме карта, а не схеми міста. Вони виконані фахівцями-картографами на базі топографічної картооснови Києва. Це дозволяє з високою точністю поєднувати геоінформацію кожного окремого явища природи 3 енергетикою міста і оцінювати їх резонанс. Після ретельного аналізу відповідної карти Києва (https://www. zagorodna.com/uk/statti/astrologichna-karta-kiyeva. html), визначена гора Дитинка, як центр кола, що височіє посеред урочища Гончарі-Кожум'яки. У карті дається досить докладний опис районів Києва, настільки, наскільки це можливо в рамках даного видання. Показані деякі загальні моменти, які характерні для прояву енергетики на місцевості, а також на деяких можливостях професійного використання цих карт. Звичайно, що дана інформація може бути виключно рекомендаційною та такою, що науково популяризує питання вирішення проблем екологічної безпеки Києва. 
Головні висновки. Укладена гіпергенезична (еколого-геодезична) карта м. Києва, яка показує геотектонічну активність на території міста. Визначена швидкість вертикальних та горизонтальних рухів земної поверхні під впливом природно-техногенного антропогенного навантаження на довкілля-простір. Запроваджений новий лік висот - гіпергенезичний. Розрахована швидкість формування «чаші опускання м. Києва».

За теоретико-експериментальними підрахунками визначений період екологічних катастроф на території міста. В досліджені застосовані космологічні закони та передові космічні технології, як наддовгобазисна радіоінтерферометрія. За основний об'єкт (космічний репер) було обрано Галактику із джерелом радіовипромінювання. Астронометрична обробка відповідних даних надала інформацію про потенційно небезпечні явища та процеси. Відповідно до їх часової амплітуди виникнення, сформульовані заходи попередження відповідних нетрадиційних надзвичайних ситуацій.

Визначений вплив геопатогенних геологічних зон на трансформацію довкілля-простору.
Укладена карта геоенергоаномальних зон м. Києва iз візуалізацією концентричних геопатогенних кіл. Запропоновано теоретичні аспекти виникнення геопатогенних зон і розташування на них потенційно небезпечних об'єктів.

Перспективи використання результатів дослідження. У першій чверті XXI ст. екологічні космогеодезичні дослідження набувають пріоритету у будівництві. Дані космології, екогеографії і геодезії формують новий науковий напрям - космоекодезію.

Новий напрям у прогнозі катастроф дає змогу зробити конкретний і точний прогноз. Він грунтується на моделюванні за даними статистичного аналізу. У майбутньому це стане документом, застосовуючи який, можна укладати детальні плани місцевості, космологічні закони та картографічні технології стануть у пригоді будівельним i проєктним організаціям. Вони акумулюватимуть геоінформацію про екологію, геологію, геофізичні поля, важливі знання під час розпланування відповідальних інженерних споруд і конструкцій систем життєзабезпечення суспільства та територіальної громади м. Києва.

1. Еніологія : навч. підручник. Київ, 2014. 783 с.

\section{Література}

2. Маркіна Л.М., Гіржева О.Л. Геоаномальні зони та біота. Миколаїв, 2010. 45 с.

3. Петрик М.П. Геофізична екологія : навч. посіб. Луцьк, 2005. 408 с.

4. Савчук С.Г. Вища геодезія : підручник. Житомир, 2005. 315 с.

5. Чудо I. Карта геопатогенных зон Киева. URL: http://www.bio-lavka.kiev.ua/fons/kiev2a.jpg.

6. Шевченко Р.Ю. Інструментарій моніторингу довкілля м. Києва : монографія. 2020. 324 с. 


\title{
ЕКОАОГІЯ ВОДНИХ РЕСУРСІВ
}

\author{
УДК 556.165 \\ DOI https://doi.org/10.32846/2306-9716/2020.eco.6-33.2
}

\section{НОРМА РІЧНОГО СТОКУ В БАСЕЙНI РІЧОК ПРИАЗОВ'Я}

\author{
Бурлуцька М.Е., Романчук М.Є., Погорелова М.П. \\ Одеський державний екологічний університет \\ вул. Львівська, 15, Одеса, 65016, Україна \\ viktoryb59@ukr.net,mromanchuk67@gmail.com,djoi84@ukr.net
}

\begin{abstract}
Об’єктом дослідження у цій роботі є басейни річок Приазов'я. Основною та найбільш важливою характеристикою стоку будь-якої річки є його середнє значення за багаторічний період - норма річного стоку. Для уточнення норми стоку в басейні річок Приазов'я необхідно виявити вплив на цю важливу характеристику місцевих факторів (висота місцевості, лісистість, заболоченість) і широтного положення водозбору, визначати норму річного стоку за допомогою побудованої карти ізоліній розглянутої території, якою можна керуватися при відсутності таких спостережень.

Для визначення параметрів були використані такі методи: метод моментів і найбільшої правдоподібності за програмою Stok Stat, перевірка на однорідність часових рядів річного стоку за критеріями Фішера, Стьюдента та Вілкоксона. Визначався вплив на норму річного стоку місцевих факторів та широтного положення водозборів, для чого були побудовані відповідні залежності. Узагальнення норми річного стоку виконано у вигляді карти ізоліній.

Для визначення норми стоку в басейні річок Приазов'я обрано 26 гідрологічних постів, на яких ведуться систематичні спостереження за стоком води. За цими даними виконана статистична обробка часових рядів середньорічних модулів річного стоку, отримані головні статистичні параметри: середнє значення ряду, коефіцієнт варіації та коефіцієнт асиметрії. Середня квадратична похибка для середньорічних модулів стоку, тобто для $\mathrm{q}_{\mathrm{cp}}$, у басейні річок Приазов'я дорівнює 8,1\%, а коефіцієнтів варіації - 13\%. Це відповідає вимогам нормативного документу СНіП 2.01.14.83. При перевірці на однорідність були виявлені 11 неоднорідних гідрологічних постів по басейну. За даними цих постів були побудовані хронологічні графіки та виявлені часові тренди.

Проаналізувавши можливий вплив різних чинників на розподіл норми річного стоку на розглянутій території, можна зробити висновок, що основним чинником $є$ лише широтне положення водозборів. Була розроблена методика узагальнення по території норми річного стоку у вигляді карти ізоліній для річок Приазов'я, на яких відсутні дані гідрометричних спостережень. Ключові слова: статистичні параметри, норма стоку, просторове узагальнення, географічна зональність.
\end{abstract}

Annual runoff rate in the basin of the rivers of the Azov Sea. Burlutska M., Romanchuk M., Pogorelova M.

The object of study of this work is the basin of the rivers of the Azov Sea. The main and practically are the most important characteristic of the runoff of any river is average value for a long period of time - the rate of annual runoff. To clarify the flow rate for the rivers of the Azov Sea, it's necessary to identify the impact on this important characteristic of local factors (altitude, forest cover, wetlands) and the latitudinal position of the catchment, as well as to determine the annual flow rate is using a map of isolines of the territory, which can be controlled in the absence of data observation.

The following methods were used to determine the parameters: the method of moments and the highest plausibility according to the Stok Stat program, checking for homogeneity of time series of annual runoff according to the criteria of Fisher, Student and Wilcoxon. The influence of local factors and the latitudinal position of catchments on the norm of annual runoff was determined, for which the corresponding dependences were constructed. The generalization of the annual runoff rate is made in the form of a map of isolines.

To determine the rate of runoff in the basin of the rivers of the Azov Sea, 26 hydrological posts were selected, where systematic monitoring of water runoff is conducted. According to these data, statistical processing of time series of average annual modules of annual runoff was performed, the main statistical parameters such as the average value of the series, the coefficient of variation and the coefficient of asymmetry were obtained. The root mean square error for the average annual runoff modules, ie for $\mathrm{q}_{\mathrm{sr}}$, in the Azov river basin is equal to $\sigma_{q}=8,1 \%$ and coefficients of variation $-C_{v}=13 \%$. This satisfies the requirements of the regulatory document SNIP 2.01.14-83. When checking for homogeneity, 11 inhomogeneous hydrological posts in the basin were found. According to these posts, chronological graphs were constructed and time trends were identified.

After analyzing the possible influence of various factors on the distribution of annual runoff in the area, we can conclude that the main factor is only the latitudinal position of the catchment. A method of generalization of the annual runoff norm on the territory in the form of a map of isolines for the rivers of the Azov Sea, on which there are no data of hydrometric observations, was developed. Key words: statistical parameters, runoff rate, spatial generalization, geographical zoning.

Постановка проблеми. Основною та практично найбільш важливою характеристикою стоку будь-якої річки є його середнє значення за багаторічний період - норма річного стоку. Поняття стійкості норми стоку є умовним, тому що при цьому враховується стійкість середніх багаторічних значень основних кліматичних чинників стоку (опадів і випаровування), а також незмінність фізико-географічних умов (рельєфу, грунтів, рослинності). Норма річного стоку має важливе значення при розрахун- 
ках стоку і водогосподарському проектуванні, тому що вона визначає потенційні водні ресурси певного району або басейну.

Актуальність дослідження. Розрахункові характеристики річного стоку відповідають вимогам нормативного документу СНіП 2.01.14-83 [1]. Однак цей нормативний документ грунтується на вихідних даних спостережень, проведених до 1980 року. За цей період ряди річного стоку суттєво поповнилися новими даними. Тому доцільним $\epsilon$ уточнення розрахункових характеристик, насамперед норми річного стоку.

Зв'язок авторського доробку з важливими науковими та практичними завданнями. Вчення про стік $\epsilon$ частиною річкової гідрології, у якій розглядаються процеси, що відбуваються в басейні річки та визначають їі водність. Більшість потреб галузей народного господарства до розрахунків річного стоку (запити гідроенергетики, водопостачання, залізничного та автомобільного транспорту, зрошення, осушення) насамперед зводиться до визначення об'ємів води, які підлягають використанню.

Особливо велика роль вчення про стік в умовах території України, яка має багато річок, але безпосередні вимірювання на яких гідрометричними методами не можливі. Тому важливого значення набуває вивчення законів формування та розподілу стоку у часі і просторі на основі узагальнення спостережень порівняно невеликої кількості опорних гідрометричних пунктів. Коли розглядається річний стік, вводиться поняття «норма стоку», яка є однією 3 основних характеристик водних ресурсів річок. Норма річного стоку має важливе значення при розрахунках річного стоку та водогосподарському проектуванні.

Аналіз останніх досліджень і публікацій. Дослідженням річкового стоку, його головних характеристик на сучасному етапі займаються вченігідрологи. Цій темі присвячено багато наукових робіт і статей. Вирішення цієї проблеми розпочато в останніх дослідженнях і публікаціях. Так, у статті «Районирование бассейна Верхнего Днестра по характеру колебаний годового стока на основе кластерного анализа» д.геогр.н. Н.С. Лобода та к.техн.н. С.В. Мельник виконали гідрологічне районування на основі аналізу розподілення річного стоку шляхом формалізації показників його мінливості й угрупування часових рядів спостережень середньорічних витрат води за допомогою кластерного аналізу [2]. Особливістю цього методу є те, що розподіл території по районах базується на аналізі коливань річного стоку як на великих річках, так і на усіх річках досліджуваного у статті району, що дає більш детальну картину.

Дослідженню річного стоку присвячена й стаття д.геогр.н. Н.С. Лободи «Оценка влияния атмосферных процессов Северной Атлантики на формирование полей годового стока рек Украины», метою якої є установа зв'язків між структурою полів річного стоку річок України і розлучним індексом атмосферної циркуляції [3].

Виділення не вирішених раніше частин загальної проблеми, котрим присвячусться означена стаття. Ця стаття присвячена розробці методики узагальнень характеристик річного стоку. Існують річки, на яких відсутні систематичні вимірювання стоку, тому уточнення головної розрахункової характеристики річного стоку - норми і іiі дослідження для невивчених річок $є$ важливим завданням. Раніше не визначалася норма річного стоку для невивчених річок басейну Приазов’я.

Новизна. За методикою, викладеною у роботі, можна визначати норму річного стоку за допомогою побудованої карти ізоліній розглянутої території для невивчених річок Приазов'я.

Методологічне або загальнонаукове значення. Запропоновану методику можна використовувати для визначення розрахункових характеристик річного стоку за відсутності систематичних вимірювань стоку і часових рядів для невивчених річок інших річкових басейнів.

Виклад основного матеріалу. Вказана вище територія розташована на півдні України, на північному узбережжі Азовського моря. До басейну північного узбережжя Азовського моря відносяться невеликі по протяжності і водності річки, які стікають із південних схилів Приазовської височини і Донецького кряжа. Це річки Молочна, Обитічна, Берда, Кальміус, Мiуc [4]. Грунтовий покрив у межах описуваного району неоднорідний, у його просторовій зміні спостерігається кліматична зональність [5].

Рослинність водозборів Приазов'я відображає фізико-географічні особливості досліджуваного регіону. Для цієї зони в минулому були характерні різнотравно-типчаково-ковилові степи. Нині ці степи суцільно розорані [6]. Територія Приазов'я вирізняється помірно-континентальним кліматом. За своїм географічним розташуванням досліджуваний район знаходиться під впливом повітряних мас, що прийшли з Атлантики, Арктичного басейну або сформувалися над значними континентальними територіями Євразії [7]. У період весняної повені досліджувана територія затоплюється водою шаром від 0,8-1,5 м до 2-3 м [8].

Спостереження за річним стоком досліджуваного району проводилася по 26 гідрологічних постах. Враховувалися спостереження від початку і по 2015 рік включно. Схема розташування гідрологічних постів у басейні річок Приазов'я наведена на рис. 1.

Відповідно до рекомендацій СНіП 2.01.14.83 середньорічні модулі стоку обчислювалися з використанням методів моментів і найбільшої правдоподібності [10; 11]. Визначалися стандартні параметри $\left(\mathrm{q}_{\mathrm{cp}}, \mathrm{C}_{\mathrm{v}}, \mathrm{C}_{\mathrm{s}} \mathrm{i} \mathrm{C}_{\mathrm{s}} / \mathrm{C}_{\mathrm{v}}\right)$ [9]. За результатами розрахунку середньорічні модулі стоку змінюються 


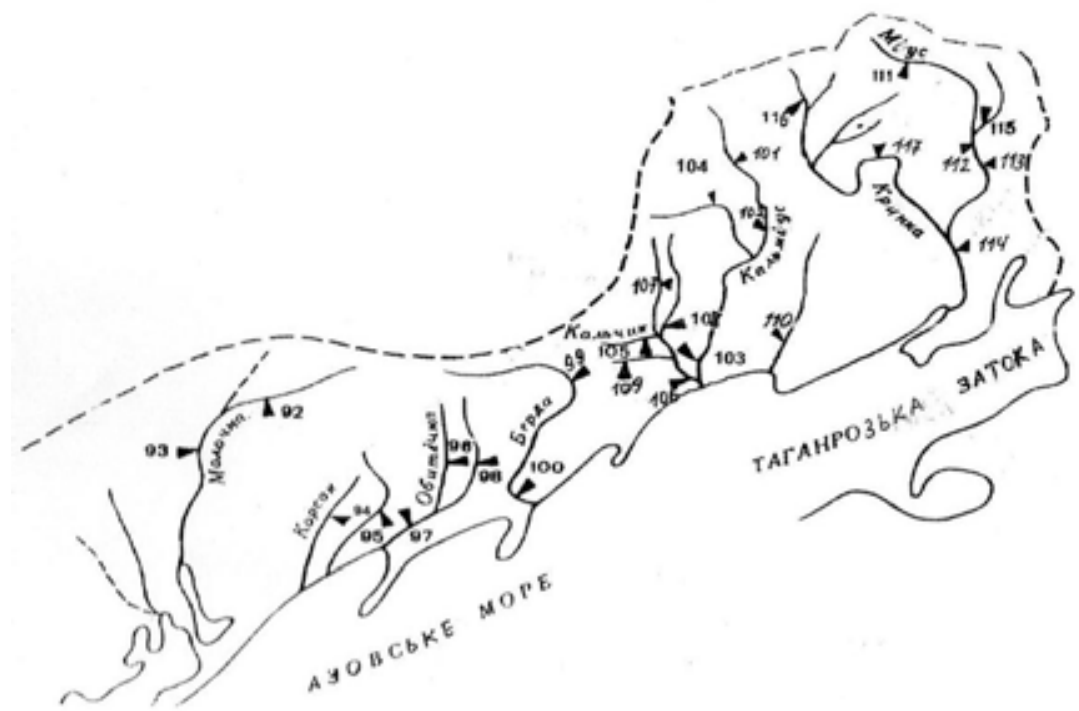

Рис. 1. Карта-схема розташування пунктів гідрологічних спостережень у басейні річок Приазов'я

від 0,58 л/с $\cdot \mathrm{\kappa м}^{2}$ до 11,4 л/с $\cdot \mathrm{\kappa M}^{2}$. Коефіцієнти варіації дають майже однакові результати за двома методами і змінюються в межах від 0,27 до 0,94 , що свідчить про невелику мінливість у рядах річного стоку розглянутої території.

По басейну середнє значення $\mathrm{C}_{\mathrm{v}}=0,49$. При $\mathrm{C}_{\mathrm{v}}<0,5$ методи найбільшої правдоподібності та метод моментів мають практично однакові результати, тому в подальших розрахунках можна використовувати будь-який із них. Коефіцієнти асиметрії змінюються від 0,05 до 1,71. Співвідношення $\mathrm{C}_{\mathrm{s}} / \mathrm{C}_{\mathrm{v}}$ в середньому знаходиться на рівні 1,73. Мірою точності статистичних розрахунків $\epsilon$ середня квадратична похибка. Середня квадратична похибка $n$-річних середніх рядів річного стоку, тобто для $\mathrm{q}_{\mathrm{cp}}$, у басейні річок Приазов'я дорівнює бq $_{\mathrm{cp}}=8,1 \%$, а коефіцієнтів варіаціï $-\mathrm{C}_{\mathrm{v}}=13 \%$ [12].

При встановленні норми річного стоку необхідно перевіряти статистичну однорідність часових рядів. Відомо, що ряди спостережень за стоком можуть бути неоднорідними у часі та просторі. Необлік цих обставин може призвести до неправильних висновків при визначенні норми річного стоку. Тому усі ряди річного стоку досліджуваної території були перевірені на однорідність. Перевірка виконувалася за критеріями Фішера, Ст'юдента і Вілкоксона на $5 \%$ рівні значущості [13]. За результатами перевірки неоднорідними виявилося 11 гідрологічних постів, інформацію про це наведено в табл. 1. Із вихідних даних не можна зробити однозначних висновків щодо причин такої неоднорідності, можливо, це наслідки інтенсивних водогосподарських перетворень. У разі, коли статистична неоднорідність ряду стоку встановлена, є сенс виявити у хронологічній послідовності стоку тренд, тобто зміну стокових величин у бік зростання або зменшення.
Для розв'язання цієї задачі можна використати критерій Аббе [14]. В його основі лежить порівняння дисперсії значень випадкової величини $\mathrm{X}$ із сумою квадратів їх послідовних різниць $\mathrm{S}^{2}$, яка менш чутлива до систематичної зміни математичного сподівання. Тому по неоднорідних постах були побудовані хронологічні графіки та виявлені часові тренди.

На розглянутих постах була зафіксована тенденція до збільшення та зменшення водності при зростанні років, що пов'язано 3 коливальними процесами. Наявні тренди на всіх неоднорідних постах чітко виражені. Одна група років є багатоводною, інша - маловодною. Це пояснює неоднорідність у цих гідрологічних рядах. Як приклад на рис. 2 і 3 наведені хронологічні графіки з часовими трендами по р. Кальміус - смт. Приморське та по р. Кальчик м. Маріуполь.

Після дослідження однорідності і отримання відповідних результатів можна приступати до визначення норми річного стоку для невивчених річок Приазов'я. Метод розрахунку річного стоку за відсутності гідрометеорологічної інформації в досліджуваному районі базується на методах, заснованих тільки на гідрологічній інформації у пунктах, де проводяться спостереження [15]. Формування гідрографічної мережі та режим поверхневого стоку річок Приазов'я здебільшого залежить від геолого-геоморфологічних особливостей території [16] (рис. 3).

Для узагальнення норми річного стоку по території спочатку необхідно виключити вплив на неї широтного положення водозборів. 3 цією метою будується залежність $\bar{q}=f\left(\phi^{\circ}\right)$, яка показана на рис. 4. Описує цю залежність таке рівняння:

$$
\bar{q}=3,04\left(\phi^{\circ}-47,6\right)+\bar{q}_{\phi=47,6},
$$


Перевірка часових рядів стоку на однорідність у басейні річок Приазов'я

\begin{tabular}{|c|c|c|c|c|c|c|c|c|c|c|c|}
\hline \multirow[t]{2}{*}{$\begin{array}{c}\text { № } \\
\text { ПI/I }\end{array}$} & \multirow[t]{2}{*}{ Річка - пост } & \multirow[t]{2}{*}{ 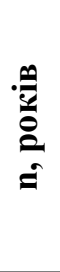 } & \multirow{2}{*}{ 总 } & \multicolumn{2}{|c|}{ 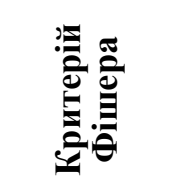 } & \multirow[t]{2}{*}{ 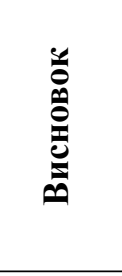 } & \multicolumn{2}{|c|}{ 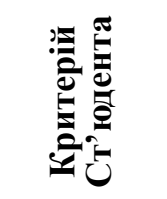 } & \multirow[t]{2}{*}{ 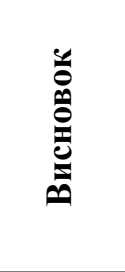 } & \multirow{2}{*}{ 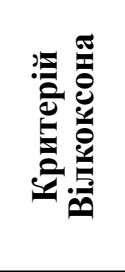 } & \multirow{2}{*}{ 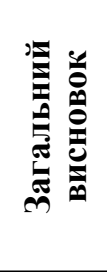 } \\
\hline & & & & $\mathbf{F}$ & $F_{\text {кр }}$ & & $\mathbf{t}$ & $t_{\text {кp }}$ & & & \\
\hline 1 & 2 & 3 & 4 & 5 & 6 & 7 & 8 & 9 & 10 & 11 & 12 \\
\hline 92 & $\begin{array}{l}\text { p. Молочна - } \\
\text { м. Токмак }\end{array}$ & 65 & 5 & 2,8 & 2,0 & неодн. & 1,9 & 2,0 & однор. & однор. & неодн. \\
\hline 93 & $\begin{array}{l}\text { p. Молочна - } \\
\text { с. Терпіння }\end{array}$ & 47 & 5 & 1,1 & 2,3 & однор. & 0,5 & 2,0 & однор. & однор. & однор. \\
\hline 94 & $\begin{array}{l}\text { p. Корсак - } \\
\text { с. Аннівка }\end{array}$ & 17 & 5 & & & & & & & & \\
\hline 95 & $\begin{array}{c}\text { р. Лозуватка - } \\
\text { с. Новоолексіївка }\end{array}$ & 57 & 5 & 2,4 & 2,2 & неодн. & 0,8 & 2,0 & однор. & однор. & неодн. \\
\hline 96 & $\begin{array}{l}\text { p. Обитічна - } \\
\text { с. Шевченко }\end{array}$ & 32 & 5 & 1,8 & 3,3 & однор. & 0,4 & 2,0 & однор. & однор. & однор. \\
\hline 97 & $\begin{array}{l}\text { p. Обитічна - } \\
\text { м. Приморськ }\end{array}$ & 49 & 5 & 1,5 & 2,4 & однор. & 2,0 & 2,0 & неодн. & неодн. & неодн. \\
\hline 98 & $\begin{array}{c}\text { p. Кільтичя - } \\
\text { с. Новотроїцьке }\end{array}$ & 33 & 5 & 2,2 & 3,2 & однор. & 0,2 & 2,1 & однор. & однор. & однор. \\
\hline 99 & $\begin{array}{l}\text { p. Берда - } \\
\text { с. Захарівка }\end{array}$ & 49 & 5 & 1,0 & 2,2 & однор. & 1,2 & 2,0 & однор. & однор. & однор. \\
\hline 100 & $\begin{array}{l}\text { p. Берда - } \\
\text { c. Осипенко }\end{array}$ & 61 & 5 & 1,8 & 2,1 & однор. & 2,7 & 2,0 & неодн. & неодн. & неодн. \\
\hline 101 & $\begin{array}{l}\text { p. Кальміус - } \\
\text { смт. Авдот'їно }\end{array}$ & 37 & 5 & 2,5 & 2,9 & однор. & 5,1 & 2,0 & неодн. & неодн. & неодн. \\
\hline 102 & $\begin{array}{l}\text { p. Кальміус - } \\
\text { с. Роздольне }\end{array}$ & 58 & 5 & 1,6 & 2,1 & однор. & 3,3 & 2,0 & неодн. & неодн. & неодн. \\
\hline 103 & $\begin{array}{c}\text { p. Кальміус - } \\
\text { смт. Приморське } \\
\text { (Сартана) }\end{array}$ & 77 & 5 & 1,5 & 2,0 & однор. & 4,4 & 2,0 & неодн. & неодн. & неодн. \\
\hline 104 & $\begin{array}{c}\text { р. Мокра } \\
\text { Волноваха - } \\
\text { с. Миколаївка }\end{array}$ & 63 & 5 & 1,1 & 2,1 & однор. & 0,8 & 2,0 & однор. & однор. & однор. \\
\hline 105 & $\begin{array}{l}\text { p. Кальчик - } \\
\text { c. Кременівка }\end{array}$ & 53 & 5 & 1,5 & 2,2 & однор. & 0,3 & 2,0 & однор. & однор. & однор. \\
\hline 106 & $\begin{array}{l}\text { p. Кальчик - } \\
\text { м. Маріуполь }\end{array}$ & 75 & 5 & 2,7 & 2,0 & неодн. & 3,5 & 1,9 & неодн. & неодн. & неодн. \\
\hline 107 & $\begin{array}{c}\text { p. балка Полкова - } \\
\text { с. Кременівка }\end{array}$ & 17 & 5 & & & & & & & & \\
\hline 108 & $\begin{array}{l}\text { p. М. Кальчик - } \\
\text { с. Кременівка }\end{array}$ & 51 & 5 & 1,8 & 2,2 & однор. & 0,5 & 2,0 & однор. & однор. & однор. \\
\hline 109 & $\begin{array}{c}\text { p. Калец - } \\
\text { х. Перемога }\end{array}$ & 18 & 5 & & & & & & & & \\
\hline 110 & $\begin{array}{c}\text { р. Грузській } \\
\text { Сланчик - } \\
\text { с. Гусельщикове }\end{array}$ & 26 & 5 & 5,2 & 3,6 & неодн. & 0,2 & 2,0 & однор. & однор. & неодн. \\
\hline 111 & $\begin{array}{c}\text { p. Мiус - } \\
\text { c. Стрюкове }\end{array}$ & 54 & 5 & 2,1 & 2,2 & однор. & 1,5 & 2,0 & однор. & однор. & однор. \\
\hline 112 & $\begin{array}{l}\text { p. Мiус - } \\
\text { с. Дмитрівка }\end{array}$ & 50 & 5 & 1,1 & 2,2 & однор. & 0,4 & 2,0 & однор. & однор. & однор. \\
\hline 113 & $\begin{array}{l}\text { p. Міус- } \\
\text { с. Куйбишеве }\end{array}$ & 18 & 5 & & & & & & & & \\
\hline 114 & $\begin{array}{c}\text { p. Мiус - } \\
\text { c. Матвіїв Курган }\end{array}$ & 25 & 5 & 1,2 & 3,6 & однор. & 0,2 & 2,0 & однор. & однор. & однор. \\
\hline
\end{tabular}


Закінчення табл. 1

\begin{tabular}{|c|c|c|c|c|c|c|c|c|c|c|c|}
\hline 1 & 2 & 3 & 4 & 5 & 6 & 7 & 8 & 9 & 10 & 11 & 12 \\
\hline 115 & $\begin{array}{c}\text { p. Крепенька- } \\
\text { х. Чугуно-Крепінка }\end{array}$ & 19 & 5 & 1,6 & 4,0 & однор. & 0,03 & 2,0 & однор. & однор. & однор. \\
\hline 116 & $\begin{array}{c}\text { p. Кринка - } \\
\text { с. Новоселівка }\end{array}$ & 64 & 5 & 1,3 & 2,1 & однор. & 3,4 & 2,0 & неодн. & неодн. & неодн. \\
\hline 117 & $\begin{array}{c}\text { р. Кринка - } \\
\text { смт Благодатне }\end{array}$ & 60 & 5 & 1,1 & 2,1 & однор. & 3,1 & 2,0 & неодн. & неодн. & неодн. \\
\hline
\end{tabular}

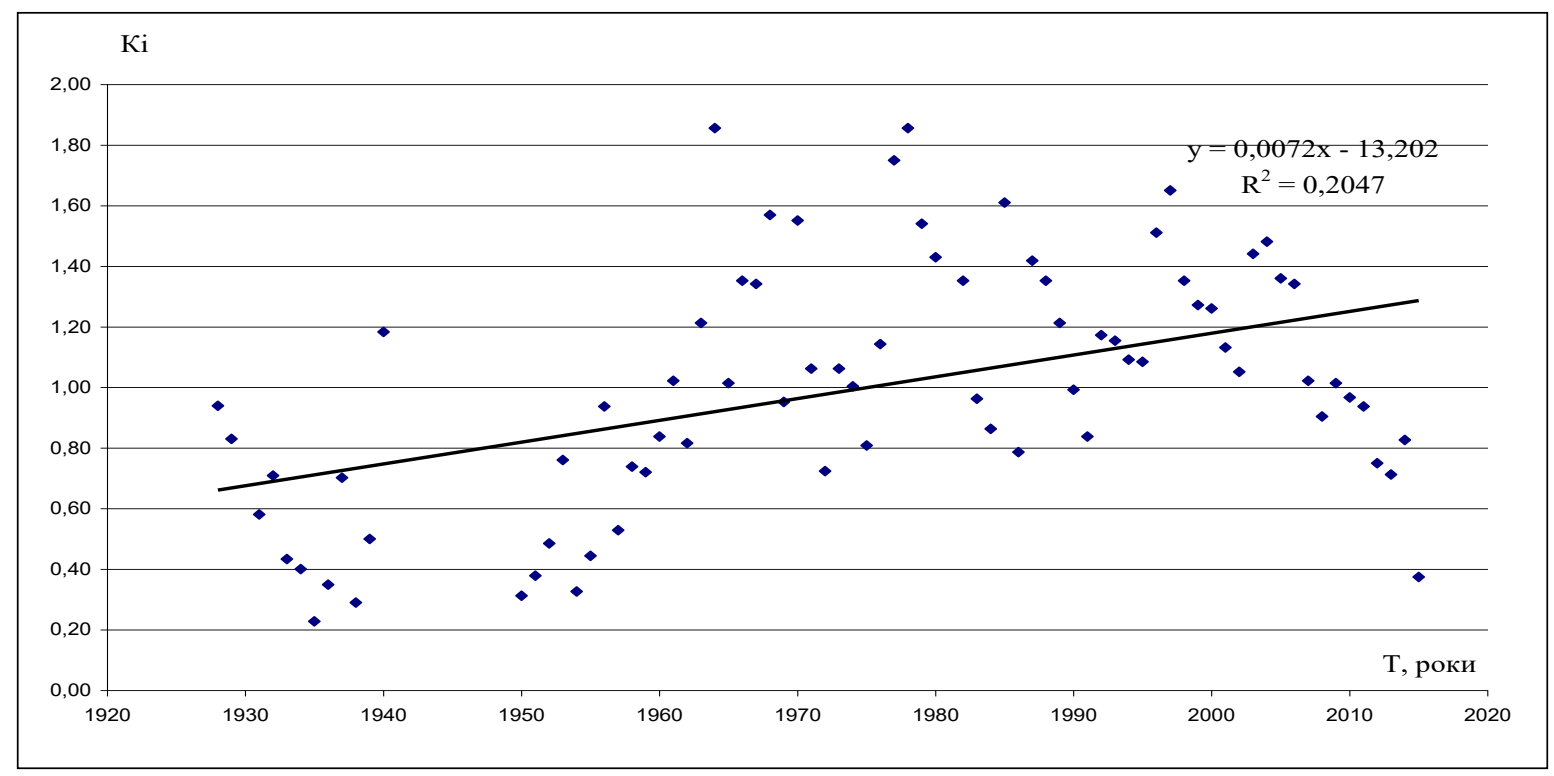

Рис. 2. Визначення тренду на р. Кальміус-смт. Приморське

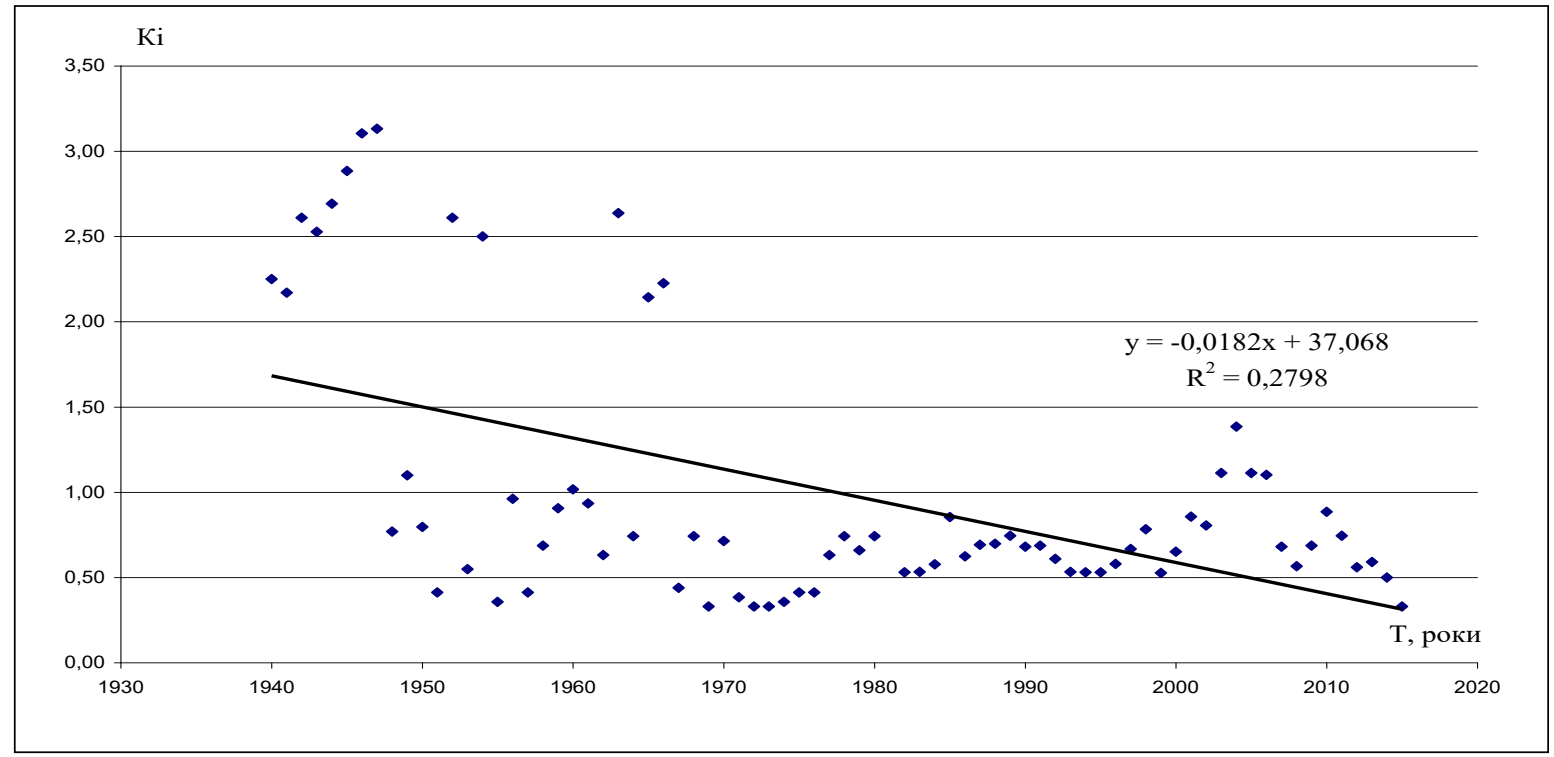

Рис. 3. Визначення тренду р. Кальчик-м. Маріуполь

Так, норма річного стоку підкорюється широтній закономірності, коефіцієнт кореляції $r \epsilon$ суттєво значимим і дорівнює 0,60 . На норму річного стоку можуть впливати і місцеві фактори (висота місцевості, лісистість, заболоченість). Тому були побудовані залежності $\bar{q}=f\left(f_{\eta}\right), \bar{q}=\mathrm{f}\left(H_{c p}\right)$, аналіз яких показав, що лісистість суттєво не впливає на норму річного стоку, коефіцієнт кореляції цієї залежності відноситься до незначущих $(r=0,36)$. 


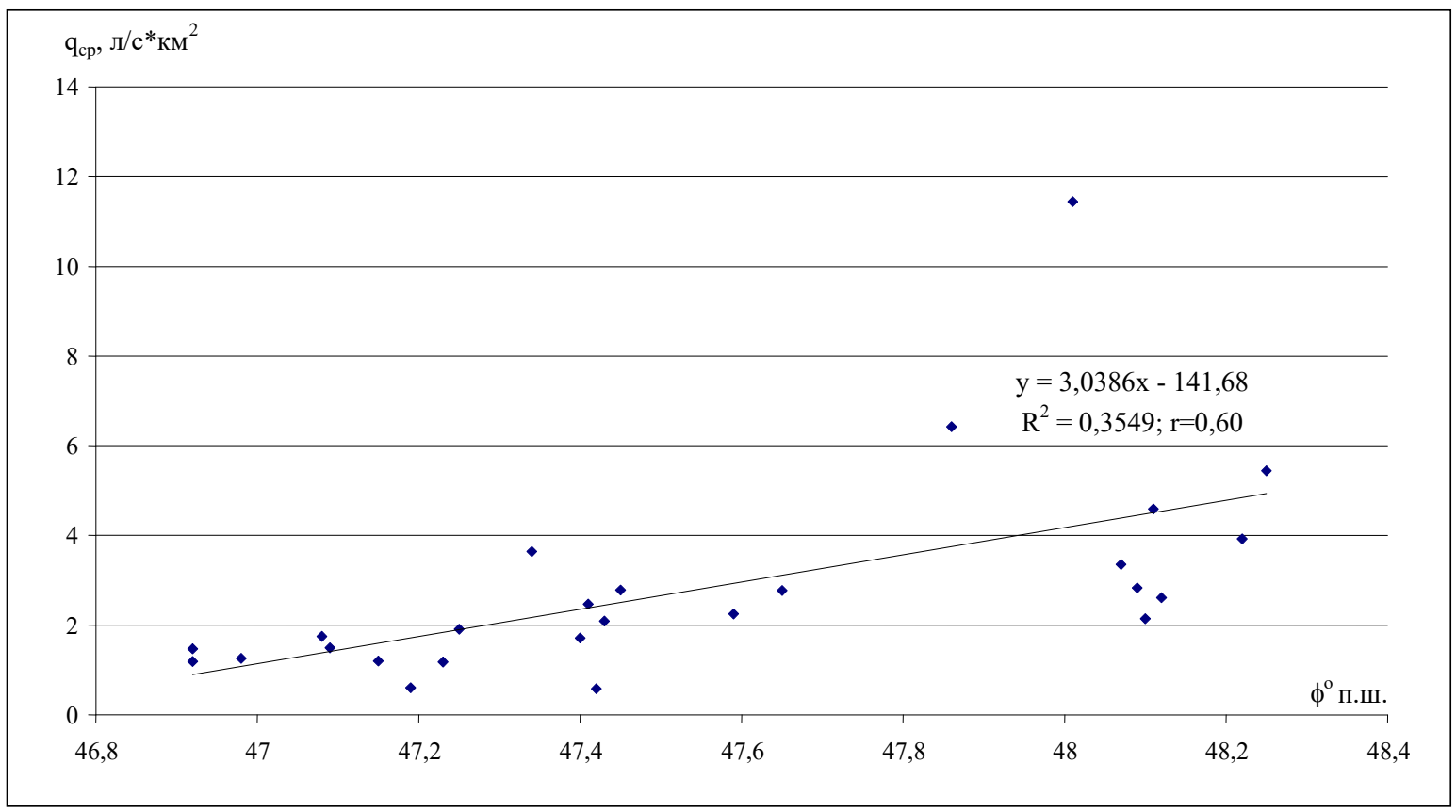

Рис. 4. Залежність середньорічних модулів річного стоку від иироти геометричних ијентрів тяжіння водозборів у басейні річок Приазов'я

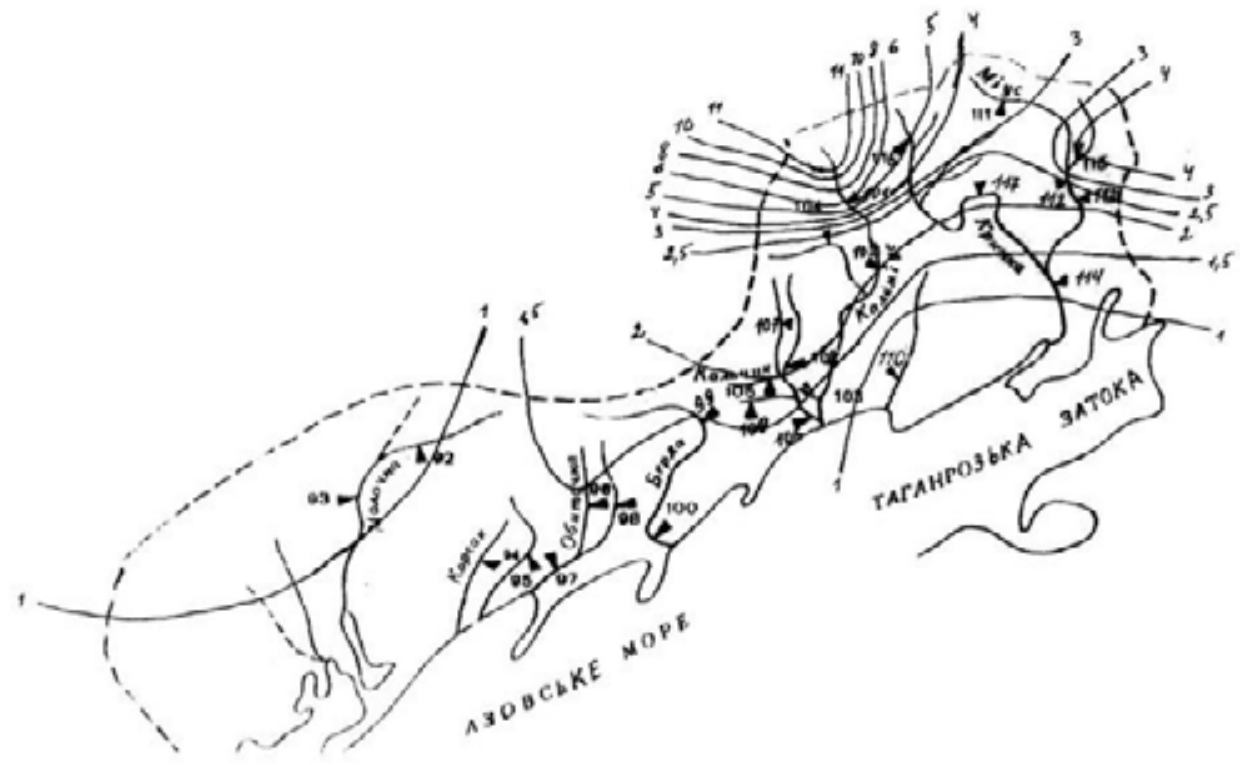

Рис. 5. Карта ізоліній розподілу норми річного стоку в басейні річок Приазов'я

Стосовно впливу висоти на норму річного стоку в басейнах річок Приазов'я, то коефіцієнт кореляції цієї залежності дорівнює 0,05 і теж є не значимим. Тому ці залежності можна не враховувати при узагальненні норми річного стоку досліджуваного району, через що ïx і не наведено у цій статті. Щодо заболоченості, то іï вплив на норму річного стоку дослідити не можливо, оскільки на розглянутій території вона майже відсутня.

Проаналізувавши можливий вплив різних факторів на розподіл по розглянутій території Приазов’я норми річного стоку, можна зробити висновок, що основним чинником впливу на цю характеристику $\epsilon$ лише широтне положення водозборів. Наявність залежності норми річного стоку від широти геометричних центрів водозборів (рис. 4) є підставою для картування значень $\bar{q}\left(\right.$ л/с $\left.\cdot \mathrm{KM}^{2}\right)$ досліджуваного району (рис. 5).

При побудові карти ізоліній середньорічні модулі стоку відносилися до геометричних центрів водозборів району досліджень. Ізолінії змі- 
нюються від 1,0 (л/с·км²) у районі р. Молочна до 11 (л/с·км²) біля р. Кальміус. Для перевірки адекватності отриманої карти ізоліній розподілу норми річного стоку по території басейну річок Приазов'я були виконані перевірочні розрахунки. Точність розрахунку визначається як відносне середнє відхилення розрахункових значень від фактичних за такою формулою:

$$
\Delta \overline{\mathrm{q}}=\frac{\left|\mathrm{q}_{\mathrm{p}}-\mathrm{q}_{\phi}\right|}{\mathrm{q}_{\phi}} 100 \%,
$$

де $\mathrm{q}_{\mathrm{p}} \%$ - розрахункові за методикою значення; $\mathrm{q}_{\phi} \%$ - фактичні значення.

За результатами перевірки встановлено, що в середньому по басейнах річок досліджуваної території відносне середнє відхилення дорівнює 11,0 , що відповідає точності вихідної інформації $\sigma_{\bar{q}}=8,1 \%$.

Головні висновки. Для визначення норми річного стоку в басейні річок Приазов'я було обрано 26 гідрологічних постів із початку спостережень за річним стоком і по 2015 рік включно.

Середньорічні модулі стоку змінювалися від 0,58 л/с·км² до 11,4 л/с·км². Коефіцієнти варіації давали майже однакові результати за двома методами. По басейну середнє значення $C_{v}=0,49$. Це свідчить про невелику мінливість у рядах річного стоку розглянутої території. Співвідношення $C_{s} / C_{v}$ в середньому знаходилося на рівні 1,73. Середня квадратична похибка n-річних середніх рядів річного стоку, тобто для $\bar{q}$, в басейні річок Приазов'я дорівнювала $\sigma_{\bar{q}}=8,1 \%$, а коефіцієнтів варіації $C_{v}=13 \%$, що відповідає вимогам СНіП 2.01.14.83.

За результатами перевірки на однорідність неоднорідними виявилося 11 гідрологічних постів. Для встановлення неоднорідності були побудовані хронологічні графіки та виявлені часові тренди. Наявні тренди на всіх неоднорідних постах чітко виражені, спостерігалася тенденція до збільшення та зменшення водності за роками. Кожний із неоднорідних постів мав групу багатоводних років і групу маловодних років. Це поясню неоднорідність розглянутих гідрологічних рядів.

На підставі отриманих розрахункових параметрів річного стоку річок Приазов'я здійснено узагальнення норми річного стоку у вигляді карти ізоліній. Для визначення точності отриманої карти виконані перевірочні розрахунки. Точність значень норми річного стоку, знятих із карти, дорівнює $\Delta \bar{q}=11,0 \%$ і відповідає точності вихідної інформації згідно нормативного документу СНіП 2.01.14.83, яка дорівнює $\sigma_{\bar{q}}=8,1 \%$. Тому запропоновану карту можна рекомендувати для визначення норми річного стоку для річок басейну Приазов'я за відсутності таких спостережень.

\section{Література}

1. Пособие по определению расчетных гидрологических характеристик. Ленинград : Гидрометеоиздат, 1984. 448 с.

2. Мельник С.В., Лобода Н.С. Районирование басейна Верхнего Днестра по характеру колебаний годового стока на основе кластерного анализа. Український гідрометеорологічний журнал. Одеса : Вид. «ТЕС», 2010. № 6. С. 180-189.

3. Лобода Н.С. Оценка влияния атмосферных процессов Северной Атлантики на формирование полей годового стока рек Украины. Украӥнський гідрометеорологічний журнал. Одеса : Вид. «ТЕС», 2008. № 3. С. 167-177.

4. Ресурсы поверхностных вод СССР. Т. 6. Украина и Молдавия. Вып. 3. Бассейн Северского Донца и реки Приазов’я / под ред. М.С. Каганера. Ленинград : Гидрометеоиздат, 1967. 492 с.

5. Почвы Украины и повышение их плодородия. Т. 2. Продуктивность почв, пути ее повышения, мелиорация, защита почв от эрозии и управление плодородием / под ред. Б.С. Носко, В.В. Медведева, Р.С. Трускавецкого. Киев : Урожай, 1988.176 с.

6. Генсірук С.А., Нижник М.С. Географія лісових ресурсів України. Львів : Світ, 1995. 123 с.

7. Клімат України / за ред. Ліпінського В.М., Дячуа В.А., Бабіченко В.М. Київ : Вид. Раєвського, 2003. 343 с.

8. Гребінь В.В. Сучасний водний режим річок України (ландшафтно-гідрологічний аналіз). Київ: Ніка-Центр, 2010. 316 с.

9. Гопченко С.Д, Овчарук В.А., Лобода Н.С. Гідрологічні розрахунки : підручник. Одеса : ТЕС, 2014. 483 с.

10. Gopchenko E.D., Romanchuk M.E., Pogorelova M.P. The influence of the afforestation and swampiness on the design characteristics of the spring flood peak flow in the river Pripyat basin. European science review. Premier Publishing s.r.o. Vienna, 2015. №№ 1-2. Р. 10-13.

11. Кучмент Л.С. Речной сток (генезис, моделирование, предвычисление) : монографія. Москва, 2008. 394 с.

12. Гопченко Е.Д., Гушля А.В. Гидрология с основами мелиорации : учебник. Ленинград : Гидрометеоиздат, 1989.302 с.

13. Рождественский А.В., Чеботарев А.И. Статистические методы в гидрологии. Ленинград : Гидрометеоиздат, 1973.424 с.

14. Горошков И.Ф. Гидрологические расчеты. Ленинград : Гидрометеоиздат, 1979. 432 с.

15. Вишневський В.І., Косовець О.О. Гідрологічні характеристики річок України. Київ : Ника-Центр, 2003. 324 с.

16. Лобода Н.С. Розрахунок та узагальнення характеристик річного стоку річок України в умовах антропогенного впливу : монографія. Одеса : Екологія, 2005. 208 с. 


\title{
ОЦІНКА СТАДІЙ ЖИТТЕВОГО ЦИКАУ ГІДРОБІОНТІВ У ТЕХНОАОГІЯХ ОЧИЩЕННЯ ПОВЕРХНЕВИХ ТА СТІЧНИХ ВОД
}

\author{
Мальований М.С. ${ }^{1}$, Афтаназів І.С. ${ }^{1}$, Тимчук І.С. ${ }^{1}$, Баландюх Ю.А. ${ }^{1}$, Жук В.М., Копій М.Л. ${ }^{2}$ \\ ${ }^{1}$ Національний університет «Львівська політехніка» \\ вул. Степана Бандери, 12, 79013, м. Львів \\ ${ }^{2}$ Національний лісотехнічний університет України \\ вул. Генерела Чупринки, 103, 79057, м. Львів
}

\begin{abstract}
Проведений огляд відомих технологій очищення поверхневих та стічних вод із використанням різних типів гідробіонтів (аеробного та анаеробного мікробіоценозу, мікроводоростей, макроводоростей, водоплавних рослин, гідробіонтів із розвинутою кореневою системою). Запропонована концепція відкритого біологічного конвеєра для технології біологічного очищення забруднених водних середовищ. Відкритий біологічний конвеєр відрізняється від замкнутого біологічного конвеєра періодичним відбором та утилізацією нарощеної біомаси. На основі аналізу життєвого циклу гідробіонтів в біологічних технологіях очищення забруднених водних середовищ виділено п’ять стадій, описано особливості реалізації кожної із цих стадій. Проведений аналіз особливостей реалізації стадії збору та концентрування нарощеної біомаси для різних типів гідробіонтів. Експериментально підтверджена ефективність гравітаційного реагентного (коагуляційно-флокуляційного) загущення суспензій мікроводоростей виду Microcystis aeruginosa. Найбільшу ступінь загущення досягнуто у випадку спільного використання коагулянта PAX-18 або PAX-XL19H разом із флокулянтом марки А100. Проведений аналіз відомих методів попередньої обробки біомаси гідробіонтів: реагентної, тонкого подрібнення та помелу, ультразвукової кавітації, гідродинамічної кавітації, віброгідродинамічної кавітації. Порівняльним аналізом із використанням як критерію кількості екстрагованих в подальшій утилізації біомаси ліпідів встановлено, що найбільш перспективним видом попередньої обробки біомаси $\epsilon$ віброкавітаційна обробка ціанобактерій перед реалізацією технологій їх утилізації. Технологічною перевагою такої обробки може бути можливість реалізації процесу обробки біомаси у безперервному режимі в потоці. Ключові слова: гідробіонти, кавітація, очищення, життєвий цикл, утилізація, ліпіди, біологічний конвеєр.
\end{abstract}

Hydrobionts life cycle stages assessment in surface and wastewater treatment technologies. Malovanyy V., Aftanaziv I., Tymchuk I., Balandiukh Ju., Zhuk V., Kopiy M.

A review of known technologies for surface and wastewater treatment using different types of hydrobionts (aerobic and anaerobic microbiocenosis, microalgae, macroalgae, floating aquatic plants, hydrobionts with a developed root system). The concept of an open biological conveyor for the technology of biological treatment of polluted aquatic environments is proposed. The open biological conveyor differs from the closed biological conveyor by periodic selection and utilization of the increased biomass. Based on the analysis of the hydrobionts life cycle of in biological technologies for the purification of polluted aquatic environments, five stages are identified, the features of the implementation of each of these stages are described. The analysis of application features of collecting and concentration stage of the increased biomass for various hydrobionts types is carried out. The effectiveness of gravitational reagent (coagulation-flocculation) thickening of the Microcystis aeruginosa species microalgae suspensions has been experimentally confirmed. The highest degree of thickening is achieved in the case of joint use of coagulant PAX-18 or PAX-XL19H with flocculant brand A100. The analysis of known methods of preliminary processing of hydrobionts biomass is carried out: reagent, fine grinding and grinding, ultrasonic cavitation, hydrodynamic cavitation, vibrohydrodynamic cavitation. Comparative analysis using as a criterion the amount of lipids extracted in the subsequent utilization of biomass found that the most promising type of pre-treatment of biomass is vibrocavitation treatment of cyanobacteria before the implementation of technologies for their utilization. The technological advantage of such treatment may be the ability to implement the processing biomass in a continuous mode in the stream. Key words: aquatic organisms, cavitation, purification, life cycle, utilization, lipids, biological conveyor.

Постановка проблеми. Використанню гідробіонтів для очищення стічних та поверхневих вод приділяється значна увага у дослідженнях цілого ряду дослідників. Зокрема поряд із величезною кількості досліджень в галузі використання для очищення водних середовищ аеробного чи анаеробного мікробіоценозу (так званого активного мулу) значна увага приділяється також дослідженню перспектив застосування для цих цілей мікро- та макроводоростей, водоплавних рослин (із яких найбільше відомі водний гіацинт та ряска), гідробіонтів із розвинутою кореневою системою, які найчастіше використовуються у технологіях очищення в складі побудованих штучних водно-болотних угідь. І у всіх випадках очищення супроводжується нарощенням додаткової біомаси як продукту використання рослинами забруднень, які для них $\epsilon$ елементами живлення. Проте залишається дискусійним питання поводження із цією біомасою. Ряд дослідників пропонує утилізувати іiі в трофічному ланцюгу, який необхідно організувати в системі очищення, що складається з ділянок 3 різних типів гідробіонтів $[1 ; 2]$. Інші пропонують вилучати іiі із системи очищення і використовувати у різних сільськогосподарських технологіях, не приводячи конкретних вимог та стратегій такого використання [3; 4]. Тому пошуки оптимальних стратегій 
та підходів шляхом оцінки стадій життєвого циклу гідробіонтів в технологіях очищення поверхневих вод і була предметом цього дослідження.

Актуальність дослідження. Технології біологічного очищення стічних та поверхневих вод, які широко досліджуються цілим рядом вчених, потребують детальних досліджень. Особливої актуальності ці дослідження набувають на сучасному етапі розвитку людства, який характеризується переоцінкою відносин до довкілля і поверненням в усіх галузях антропогенної діяльності та аспектах життєдіяльності до природних умов, природних продуктів, природних технологій. Як приклад можна навести стрімкий зріст популярності до органічних продуктів харчування, повернення (де це можливо) самоплинності річок, використання в адсорбційних технологіях природних дисперсних сорбентів і т.п. Тому останнім часом набувають широкої популярності і технології очищення забруднених водних середовищ із застосуванням гідробіонтів. За переконанням автора та популяризатора принципу біологічного конвеєра в Україні професора Петра Гвоздяка [1], майбутні біотехнології охорони довкілля, зокрема води, від хімічного та біологічного забруднення - у використанні якомога більшого розмаїття організмів у цих технологічних процесах. Різними групами дослідників встановлювались аспекти використання для очищення забруднених водних середовищ аеробного та анаеробного мікробіоценозу (ці технології найбільш широко досліджені в науковому плані, а в практичному отримали масове застосування), ряд досліджень присвячено використанню в технологіях біологічного очищення мікроводоростей та макроводоростей, водоплавних рослин, гідробіонтів із розвинутою кореневою системою. Тому оцінка оптимального комбінування стадій життєвого циклу для цих різних груп гідро біонтів є важливою та актуальною проблемою.

Зв'язок авторського доробку з важливими науковими та практичними завданнями. Тематика дослідження відповідає основним напрямам наукової діяльності кафедри екології та збалансованого природокористування Національного університету «Львівська політехніка».

Аналіз останніх досліджень і публікацій. Концепція біологічного конвеєра розроблена в Інституті колоїдної хімії та хімії води ім. А.В. Думанського за ініціативи і активної участі професора Петра Гвоздяка [1]. Технологічна суть біоконвеєра полягає в тому, що на шляху води, яку потрібно очистити, розміщені гідробіонти - анаеробні бактерії, аеробні мікроорганізми (копіотрофи, оліготрофи, найпростіші), фільтратори, хижаки. Перебуваючи на своїх «робочих місцях», вони «виїдають» із води розчинені у ній органічні сполуки і біомасу (тіла) організмів. На думку авторів, перевагами біоконвеєра є можливість очищення будь-яких (природних, зливових, побутових, промислових стічних) вод, що містять розчи- нені органічні сполуки, навіть гранично токсичні, канцерогенні чи мутагенні, за будь-яких їх концентрацій. Вважається, що біоконвеєр дає змогу доводити якість очищеної води до будь-якого заданого ступеня чистоти. він вирішує проблему надлишкової біомаси, оскільки вона споживається та мінералізується у трофічному ланцюгу. При цьому чим більша кількість трофічних рівнів задіяна у біоконвеєрі, тим менше біомаси залишається в очищеній воді. На думку автора, достатньо мати в очисній споруді трофічний ланцюг у 2-3 ланки, щоб зменшити кількість надлишкової біомаси у 100-1000 разів. Оскільки автор пропонує компонувати у біоконвеєрі трофічний ланцюг, то такий біоконвеєр повинен складати (або максимально наближатись) до замкнутої екобіологічної системи. Групи науковців, очолюваних П. Гвоздяком, розробили окремі варіанти біоконвеєрів для очищення токсичних стоків: токсичних відходів Чернігівського ВО «Хімволокно» (Україна), основним забруднювачем яких є гексаметилендіамін [1]; стічних вод АТ «Мотор Січ» (Україна), які забруднені нафтопродуктами та іонами нікелю [5]; стічних вод ВО «Лакофарба» (Білорусь), які забруднені токсичними органічними забрудненнями: ксилолом, толуолом, фталевим і малеїновим ангідридами, циклогексанолом, акролеїном тощо [1].

Слід зауважити, що окремі стадії біологічного конвеєра достатньою мірою досліджувались великою кількістю науковців, які в основному розглядали їх як окремі біологічні технології очищення: очищення стічних та поверхневих вод аеробним мікробіоценозом [6-8]; очищення цих об'єктів анаеробним методом [9-11]; дослідження систем очищення із застосуванням мікроводоростей [12-14]; перспектива використання водоплавних гідробіонтів ву технологіях водоочищення [15-16]; детально досліджували очищення поверхневих та стічних вод в умовах побудованих штучних водно-болотних угідь (які часто називають «біоплато») [17-19].

Виділення не вирішених раніше частин загальної проблеми, яким присвячусться означена стаття. Аналіз літературних джерел свідчить, що в життєвому циклі використання гідробіонтів в біологічних технологіях очищення водних середовищ основна увага приділялась самій технології очищення. Разом із тим інші стадії життєвого циклу (зокрема, такі важливі стадії, як відбір та утилізація нарощеної біомаси) не досліджувались. А як показує дослід масового забруднення довкілля продуктами розкладу біомаси ціанобактерій (які неконтрольовано розмножаються в літній період, очищаючи поверхневі водойми від забруднень, головним чином від сполук азоту та фосфору, що є їхніми елементами живлення) в акваторіях рік та водосховищ України, нехтувати цією стадію недопустимо. Тому аналіз життєвого циклу гідробіонтів в біологічних технологіях очищення поверхневих та стічних вод є важли- 
вим аспектом, невирішеним раніше, і аналізу цього аспекту присвячується стаття.

Новизна роботи полягає у проведенні оцінки стадій життєвого циклу гідробіонтів у технологіях біологічного очищення за їх участю та встановленні оптимальних стратегій та оптимальних технологічних підходів у реалізації цих стадій.

Методологічне або загальнонаукове значення. Основною ідеєю відомої концепції біологічного конвеєра [1] є побудова в технології очищення поверхневих та стічних вод трофічного ланцюга. Унаслідок цього, за переконанням автора, вдається реалізувати основну перевагу пропонованого методу - добитись відсутності накопичення додаткової біомаси - нарощена біомаса мінералізується та споживається у трофічному ланцюгу. Позаяк ціллю автора цієї стратегії була організація для очищення стічних та поверхневих вод самодостатньої замкнутої системи із трофічним ланцюгом, який був створений штучно, в подальшому будемо використовувати назву такої технології «біологічний конвеєр замкнутого типу». Загальний вигляд біологічного конвеєра замкнутого типу представлений на рис. 1 .

У загальному вигляді схема біоконвеєра замкнутого типу може бути представлена у вигляді (рис. 1):

На думку авторів цієї статті, не є цілком оправданим облаштування для біологічного конвеєра трофічного ланцюга. Основним завданням ділянки біологічного реактора є утилізація нарощеної біомаси, в очищенні стічної води ця ділянка практично не бере участі. Тому нами запропонована схема відкритого біологічно конвеєра, головною відмінністю якого від попередньої стратегії є відсутність трофічного ланцюга та значно розширена зона фітореактора за рахунок комбінування різних видів гідробіонтів. Нарощену біомасу пропону- ється відбирати із схеми очищення і відводити на стадію утилізації.

Виклад основного матеріалу. На основі аналізу життєвого циклу гідробіонтів, що застосовуються в біологічних технологіях очищення стічних та поверхневих вод, нами виділено 5 стадій (рис. 2).

Динаміка очищення забруднених середовищ на першій стадії життєвого циклу гідробіонтів визначається типом гідробіонтів, схемою компонування ділянок із різними типами гідробіонтів в технології очищення, факторами впливу навколишнього середовища (температура, освітленість, гідродинамічний режим, умови клімату, $\mathrm{pH}$ водного середовища та його хімічний склад, концентрація забруднень, від яких проходить очищення і т.п.) та відповідністю їх оптимальним умовам розвитку гідробіонтів. Тому оптимальні умови реалізації цієї стадії, ступінь очищення водного середовища та кількість нарощеної біомаси повинні визначатись для кожної конкретної схеми біологічного конвеєра виходячи із цих умов.

Оптимальні умови реалізації другої стадії - збору та концентрування гідробіонтів - значною мірою визначається типом гідробіонтів, біомаса яких вилучається із системи очищення. Для збору біомаси водоплавних водних рослин та водних рослини із розвинутою кореневою системою доцільно використовувати наявне технологічне обладнання: спеціалізовані водні комбайни та плаваючі косарки. Для збору та концентрування мікроводоростей доцільно використовувати двохстадійну технологію: первинний збір за допомогою переливних порогів та занурених викачувальних рукавів та концентрування у вертикальних концентраційних колонах [20]. Доцільним є забезпечити під час концентрування певний реагентний коагуляційно-флокуляційний режим, який дозволив би інтенсифікувати

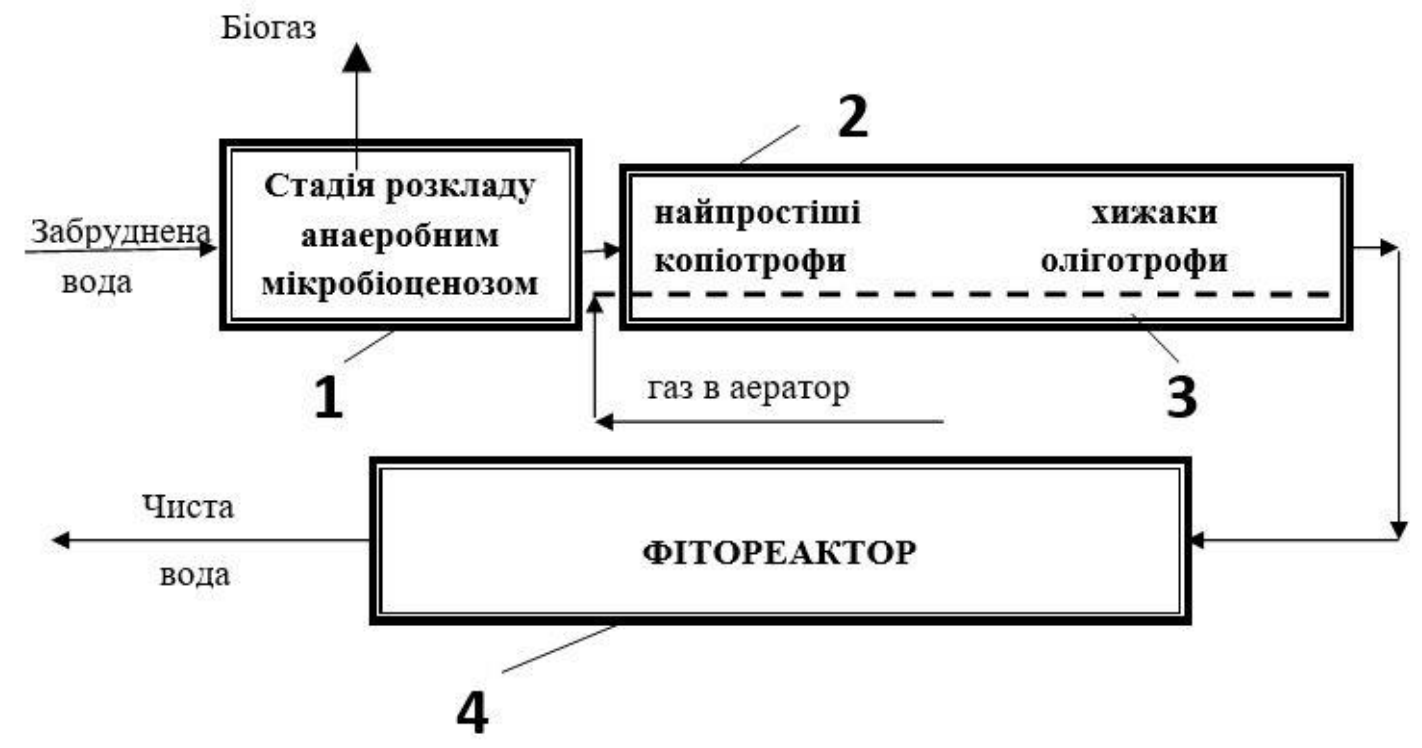

Рис. 1. Принципова схема біологічного конвеєра замкнутого типу: 1 - анаеробний біореактор, 2 -аеробний біореактор, 3 -зоореактор, 4-фітореактор 


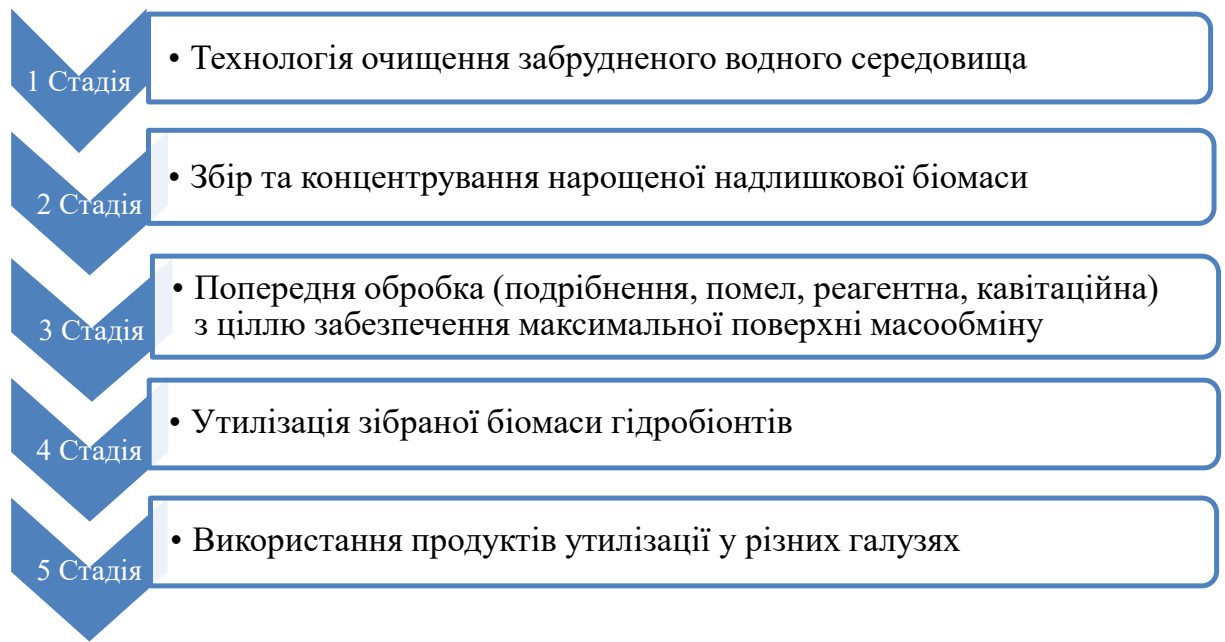

Рис. 2. Життєвий циикл гідробіонтів

у технологіях очищення стічних та поверхневих вод

згущення. Нами підтверджена експериментально ефективність гравітаційного коагуляційно-флокуляційного загущення суспензій мікроводоростей виду Microcystis aeruginosa [21]. У реагентному режимі коагуляційно-флокуляційного згущення суспензії мікроводоростей використовувались водні розчини полімер-алюмінієвих коагулянтів типів РАХ18 та PAX-XL19H, та флокулянтів типу A100 фірми P.P.H.U. WĘGLO-STAL. Застосовувані реагентні режими приведені у таблиці 1 , а результати досліджень наведені на рис. 3.

Таблиця 1

Реагентний склад коагуляційно-флокуляційного концентрування водної суспензії ціанобактерій

\begin{tabular}{|c|c|c|c|}
\hline \multirow{2}{*}{$\begin{array}{c}\text { Неагентног } \\
\text { складу }\end{array}$} & \multicolumn{3}{|c|}{ Концентрація реагентів, ppm } \\
\cline { 2 - 4 } & PAX-18 & PAX-XL19H & $\mathbf{A 1 0 0}$ \\
\hline 1 & - & - & - \\
\hline 2 & 10 & - & - \\
\hline 3 & 1 & - & - \\
\hline 4 & - & 10 & - \\
\hline 5 & - & 1 & - \\
\hline 6 & - & - & 10 \\
\hline 7 & - & - & 1 \\
\hline 8 & 10 & - & - \\
\hline 9 & - & 10 & 1 \\
\hline
\end{tabular}

Згідно із приведеною на рис. 3 інформацією, найбільшу ступінь загущення досягнуто у випадку спільного використання коагулянта РАХ-18 або PAX-XL19H разом із флокулянтом марки A100. За умов, коли початкова концентрація водорості Microcystis aeruginosa (за сухою речовиною) складає 500 ppm, а масова концентрація коагулянтів РАХ-18 i PAX-XL19H 10 ppm, концентрація флокулянта А100 складає 1 ppm, за часу відстоювання 30 хв після реагентної обробки ефект загущення суспензій складав відповідно в 11,8 та в 10,4 рази відносно об'єму. Масова концентрація біомаси водоростей Microcystis aeruginosa в об'ємі загущення після коагуляційно-флокуляційної обробки та розділення фаз збільшилася в порівнянні із початковою відповідно у 9,6 та у 9,0 рази, досягнувши значень 4800 ppm та 4500 ррт відповідно.

Як попередня обробка зібраної та зконцентрованої біомаси гідробіонтів залежно від типу гідробіонтів, технології та умов подальшої утилізації, може використовуватись реагентна обробка [22], тонке подрібнення та помел [22], ультразвукова кавітація [4], гідродинамічна кавітація [4], віброгідродинамічна кавітація [23]. Для кожного типу гідробіонтів доцільно застосовувати ті види попередньої обробки, які б давали найкращі результати у наступних процесах утилізації. Це вимагає окремих досліджень для кожного конкретного випадку. Нами проведена оцінка ефективності попередньої обробки біомаси на прикладі зміни кількості екстрагованих із біомаси ліпідів за методом [23] залежно від типу обробки. Результати приведені на рис. 4.

Приведені дані свідчить, що перспективною для практичного використання може бути обробка в полі гідродинамічної кавітації, але найбільш перспективною є віброкавітаційна обробка. Технологічною перевагою такої обробки може бути можливість реалізації процесу обробки біомаси у безперервному режимі в потоці.

Утилізація зібраної біомаси може реалізуватись шляхом отримання енергоносіїв (біогазу чи біодизелю), органічних чи органо-мінеральних добрив, протеїну, кормових добавок, фунгіцидів, інших необхідних для економіки продуктів. Біомаса гідробіонтів може застосовуватись як сировина у медицині, фармацевтиці, косметології, сільському господарстві, енергетиці. 


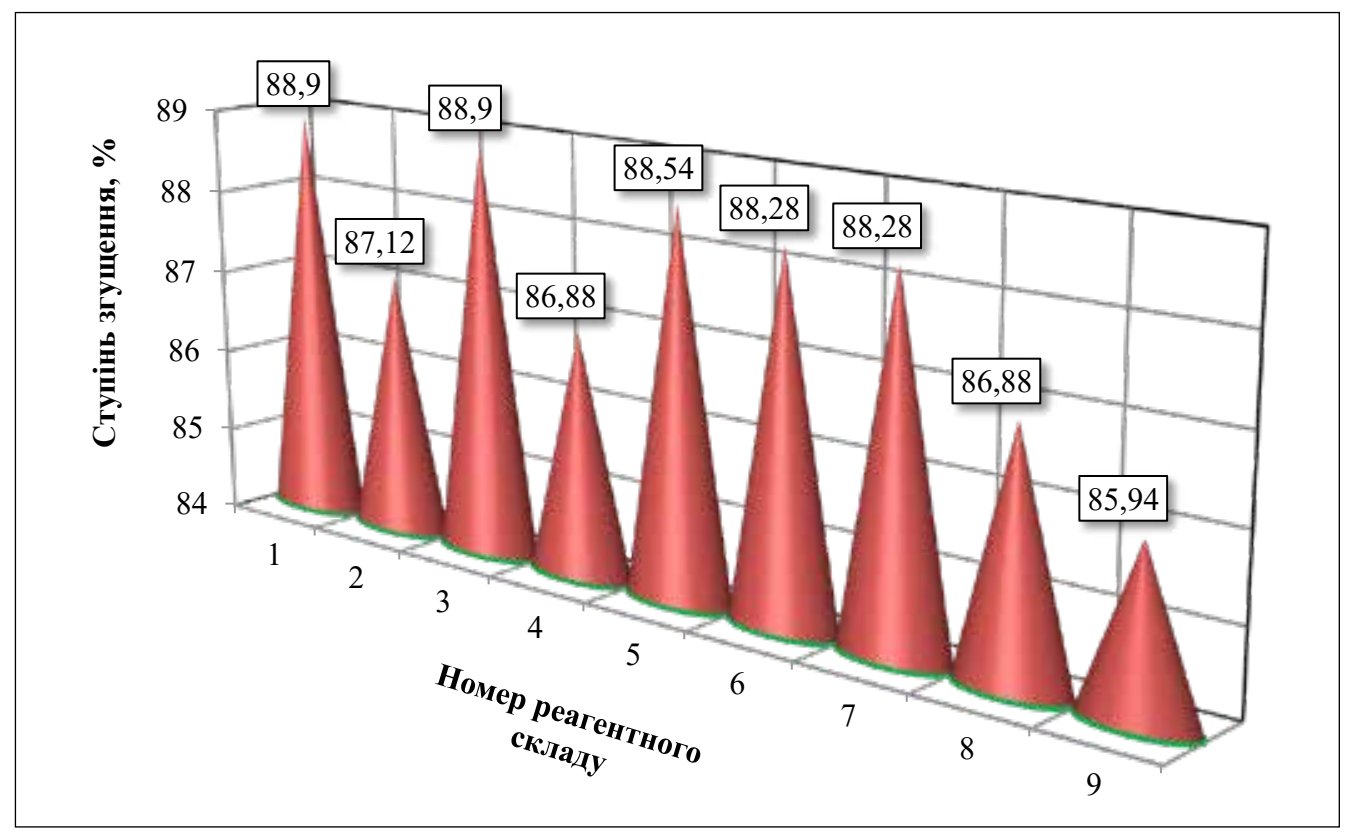

Рис. 3. Залежність ступеня згущення від реагентного складу коагуляційно-флокулячійного згущення суспензії мікроводоростей

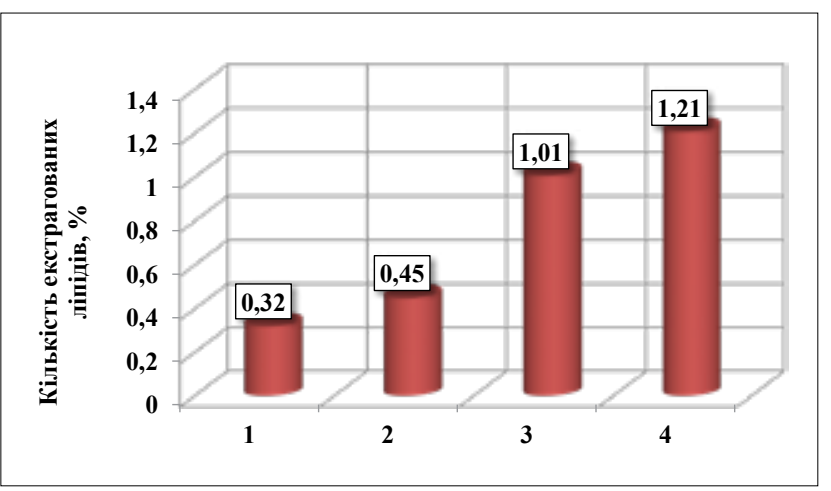

Рис. 4. Залежність кількості екстрагованих із иіанобактерій ліпідів (у\% від сухої маси) від виду попередньої обробки біомаси:

1 - без попередньої обробки; 2 - після обробки в акустичному кавітаційному полі; 3 - після обробки в полі гідродинамічної кавітації; 4 - після віброкавітаційної обробки

Головні висновки. Запропонована концепція відкритого біологічного конвеєра для технології біологічного очищення стічних та поверхневих вод із використанням гідробіонтів.
Проведений аналіз життєвого циклу гідробіонтів в біологічних технологіях очищення забруднених водних середовищ, в якому виділено п’ять стадій.

Проведений аналіз реалізації стадії збору та концентрування нарощеної біомаси для різних типів гідробіонтів. Підтверджено експериментально ефективність гравітаційного коагуляційно-флокуляційного загущення суспензій мікроводоростей виду Microcystis aeruginosa. Найбільшу ступінь загущення досягнуто у випадку спільного використання коагулянта PAX-18 або PAX-XL19H разом із флокулянтом марки А100.

Встановлено, що найбільш перспективною є віброкавітаційна обробка ціанобактерій перед реалізацією технологій їх утилізації. Технологічною перевагою такої обробки може бути можливість реалізації процесу обробки біомаси у безперервному режимі в потоці.

Перспективи використання результатів дослідження. Результати досліджень можуть використовуватись для впровадження технологій біологічного очищення стічних та поверхневих вод та технологій отримання енергоносіїв, нових цінних продуктів та матеріалів із використанням як сировини зібраної біомаси гідробіонтів.

\section{Література}

1. Гвоздяк П. За принципом біоконвеєра (Біотехнологія охорони довкілля). Вісник НАН України. Київ, 2003. № 3. С. $29-36$.

2. Гвоздяк П.І. Біоконвеєр в оживленні «мертвої води» в ставку - накопичувачі токсичних промислових стоків. Чиста Вода. Фундаментальні, прикладні та промислові аспекти: тези доповідей III міжнар. наук.-практ. конф., м. Київ, 28-30 жовтня 2015 p. C. $72-73$.

3. Мальований М.С. Оптимальні умови отримання енергії із ціанобактерій. Хімічна промисловість України. Київ. 2014. № 5. С. 39-43.

4. Мальований М.С. Раціональна технологія утилізації синьо - зелених водоростей. Науковий вісник НЛТУ Украйни. Львів. 2015. Вип. 25.10. С. 140-149. 
5. Крупєй К.С. Очистка стічних вод заводу АТ «Мотор Січ» мікроорганізмами, іммобілізованими на штучних носіях. Питання біоіндикації та екологї̈. Запоріжжя. 2014. Вип. 19, № 2. С. 224-236.

6. Жмур Н.С. Технологические и биохимические процессы очистки сточных вод на сооружениях с аеротенками. Москва : АКВАРОС, 2003. $512 \mathrm{c}$.

7. Шандрович В.Т. Моніторинг ефективності роботи аеротенків на Львівських очисних спорудах. Вісник Кременчуиького наиіонального університету імені Михайла Остроградського. Кременчук. 2015. Вип. 1, ч. 1 (90). С. 126-132.

8. Malovanyy M. Two-stage landfill leachate treatment in aerated lagoons and at a municipal wastewater treatment plant. EasternEuropean Journal of Enterprise Technologies. Kharkiv. 2018. № 1(10). P. 11-18.

9. Калюжный С.В. Высокоинтенсивные анаэробные биотехнологии очистки промышленных сточных вод. Катализ в промышиленности. Москва. 2004. № 6. С. 42-50.

10. Malovanyy A. Concentration of ammonium from municipal wastewater using ion exchange process. Desalination. London. 2013. 329. P. 93-102.

11. Khin T., Annachhatre A.P. Novel microbial nitrogen removal processes. Biotechnology Advances. London. 2004. № 225. P. 19-532.

12. Dogaris I. Study of landfill leachate as a sustainable source of water and nutrients for algal biofuels and bioproducts using the microalga Picochlorum oculatum in a novel scalable bioreactor. Bioresour Technol. V. 282. P. 18-27.

13. Sniffen K.D., Sales C.M., Olson M.S. Nitrogen removal from raw landfill leachate by an algae-bacteria consortium. Water Sci Technol. London. 2015. V. 73. P. 479-485.

14. Sardi Saavedra A. Grupos funcionales fitoplanctynicos en una laguna algal de alta tasa usada para la biorremediaciyn de lixiviados de rellenos sanitarios. Acta Biolyg Colombiana, Bogota. 2018. V. 23. P. 295-303.

15. Villamagna A. M., Murphy B. R. Ecological and socio-economic impacts of invasive water hyacinth (Eichhornia crassipes): a review. Freshwater Biology. London. V. 55. P. 282-298.

16. Flyurik E. Abramovich O., Zmitrovich A. Use of eichornia crassipes for sewage treatment and production feed additive. Tpydbl БГТУ. Минск. 4. С. 155-160.

17. Lapan O. Water Purification from Ions of Cadmium (II) Using a Bio-Plateau. Journal of Ecological Engineering. Lublin. 2019. 20(11). P. 29-34.

18. Marzec M. The Efficiency and Reliability of Pollutant Removal in a Hybrid Constructed Wetland with Common Reed, Manna Grass, and Virginia Mallow. Water. 2018. London. V. 10. 1445. P. 1-18.

19. Jozwiakowski K. Technological reliability of pollutant removal in different seasons in one-stage constructed wetland system with horizontal flow operating in the moderate climate. Separation and Purification Technology. 2020. London. 238. P. 1-23.

20. Nykyforov V. The biotechnological ways of blue-green algae complex processing. Eastern-European Journal of Enterprise Technologies. Kharkiv. 2016. № 5(10). P. 11-18.

21. Malovanyy M. Experimental investigation of Microcystis aeruginosa cyanobacteria thickening to obtain a biomass for the energy production. Journal of water and land development. Raszyn. 2019. V. 43(X-XII). P. 113-119.

22. Скляр О.Г. Скляр Р.В. Методи інтенсифікації процесів метанового зброджування. Науковий вісник Таврійського державного агротехнологічного університету. 2014. Херсон. В. 4. Т. 1. С. 3-9.

23. Nykyforov V.V. Developing a technology for treating blue-green algae biomass using vibro-resonance cavitators. Науковий вісник Начіонального гірничого університету. Дніпро. 2019. № 6. С. 181-188. 


\title{
СУЧАСНИЙ СТАН МЕРЕЖІ ПОВЕРХНЕВИХ ВОДОТОКІВ ПІВНІЧНО-ЗАХІДНОГО ПРИЧОРНОМОР'Я
}

\author{
Наконечна Ю.О., Чугай А.В. \\ Одеський державний екологічний університет \\ вул. Львівська, 15, 65016, м. Одеса \\ nakonechnayulya25@gmail.com
}

\begin{abstract}
Північно-Західне Причорномор'я являє собою цілісний природно-географічний регіон зі схожими характеристиками. Загально-рівнинний характер степового регіону порушується низкою понижень - азональних ділянок ландшафту, пов'язаних із потужними долинами річок Дунай, Дністер, Південний Буг, Дніпро та їхніми притоками, які зазвичай розташовані в розломах і міжблокових стиках. Останні разом із ерозійними врізами балок та ярами формують багаторівневу дренажно-стокову мережу водовідведення. Метою роботи є оцінка нинішнього стану мережі дренажно-поверхневих водотоків ПівнічноЗахідного Причорномор'я та їх функціонування в умовах кліматичної нестабільності. Вихідними матеріалами дослідження $\epsilon$ сучасні та ретроспективні картографічні дані, результати їхніх аналітичних узагальнень із застосуванням математичних моделей, дані польових обстежень територій Миколаївської та Одеської областей у 2014-2020 рр. Дані польових обстежень основних дренуючих водотоків свідчать, що тектонічним підняттям північної частини території Миколаївської області зумовлено домінування в цій місцевості процесів змиву та ерозії, які значно перевищують процеси акумуляції. Одночасно схили долин відрізняються і незначним розвитком акумулятивних терас завдяки їхньому інтенсивному ерозійному змиву. Такі картини загалом характерні для всіх водотоків північних і північно-східних ділянок Миколаївської області. Аналіз показав, що рельєф у межах адміністративної території Миколаївської області первинно зумовлений морфо-структурними особливостями та геологічними умовами місцевості. Інтенсивність неотектонічного підняття північної частини області значна й досить тривала, утримуючи провідну рельєфоутворювальну роль саме за процесами змиву та ерозії, активність яких у цій місцевості стабільно перевищує процеси акумуляції. Необхідна деталізація показників процесів змиву-акумуляції, які в наявний час мають прояв у зоні неотектонічного підняття, та оцінка їхньої можливої залежності від чинників кліматичної нестабільності. Ключові слова: Північно-Західне Причорномор'я, водотоки, дренажна мережа.
\end{abstract}

Current state of the surface water network of the North-Western Black Sea. Nakonechna Yu., Chugai A.

The North-Western Black Sea is an integral natural-geographical region with similar characteristics. The general plain character of the steppe region is disturbed by a number of depressions - azonal parts of the landscape associated with the powerful valleys of the Danube, Dniester, Southern Bug, Dnieper and their tributaries, which are usually located in faults and inter-block joints. The latter, together with the erosive cuts of beams and ravines form a multilevel drainage and drainage network. The aim of the work is to assess the current state of the network of drainage and surface watercourses of the North-Western Black Sea and their functioning in conditions of climate instability. The source materials of the study are modern and retrospective cartographic data, the results of their analytical generalizations using mathematical models, field survey data of Mykolaiv and Odesa regions in 2014-2020. Field survey data of the main drainage streams show that with tectonic uplift of the northern part due to the dominance of erosion processes in this area, which significantly exceed the accumulation processes. At the same time, the slopes of the valleys are characterized by insignificant development of accumulative terraces due to their intensive erosion. Such pictures in general are characteristic of all watercourses of northern and northeastern sites of the Mykolaiv area. The analysis showed that the relief within the administrative territory of the Mykolaiv area is primarily caused by morpho-structural features and geological conditions of district. The intensity of neotectonic uplift of the northern part of the region is significant and long enough, retaining the leading relief-forming role in the processes of erosion, the activity of which in this area consistently exceeds the processes of accumulation. It is necessary to detail the indicators of flushing-accumulation processes, which currently have a manifestation in the zone of neotectonic uplift and to assess their possible dependence on the factors of climatic instability. Key words: North-Western Black Sea, watercourses, drainage network.

Постановка проблеми. Північно-Західне Причорномор'я (далі - ПЗП) являс собою природногеографічний регіон зі схожими історичними, ландшафтними та кліматичними характеристиками. Межі ПЗП окреслені устям Дунаю на заході та долиною р. Молочної на сході, з півночі - відрогами Подільської та Придніпровської височин, а 3 півдня - Перекопом і морським узбережжям. Ця територія належить Причорноморському, або Понтичному, Степу. Регіон поєднує території Одеської, Миколаївської та Херсонської областей $[1 ; 2]$.

Актуальність дослідження. Загальнорівнинний характер степового регіону порушується низкою понижень - азональних ділянок ландшафту, пов'язаних із потужними долинами річок Дунай, Дністер, Південний Буг, Дніпро та їхніми притоками, які зазвичай розташовані в розломах і міжблокових стиках. Останні разом із ерозійними врізами балок та ярами формують багаторівневу дренажно-стокову мережу водовідведення 3 південних схилів Буджакської, Подільської та Придніпровської височин, а також із плакорів ПричорноморськоПриазовської низовини. За межами цієї системи розташовані тільки подові ділянки, кількість яких зростає зі зменшенням пересічних висот і вирівнюванням рельєфу місцевості, закономірно сягаючи 
значної присутності на території суто рівнинної Херсонської області [3].

Збережена донині потужність розроблення бортів річкових долин регіону та часта присутність глибоких балок із явними ознаками існуючих раніше водотоків вказує на значні рівні зволоженості приморських територій у кінцевому плейстоцені. Показово, що базис ерозії місцевих річкових водотоків у гирлових ділянках простежується до -80 м від сучасного рівня, відображаючи доголоценовий рівень Чорноморського басейну, підняття якого спричинило утворення Західного шельфу та виникнення лиманів у гирлі річок [4]. Пізньоголоценові процеси зміни стану поверхні території ПЗП, особливо в останні сторіччя, свідчать про неухильний процес вираженої денудаційної нівеляції рельєфу. Найбільш помітною сучасна денудація стала в долинах степових річок, тальвеги яких нині перетворені в лучно-степові рівнини, грунти яких відрізняє значна мінералізація. Проте інтенсивні денудаційні процеси на території регіону виявляють значне різноманіття, відображене у відмінних рівнях акумуляційних накопичень у тальвегах балок, що особливо виражено в місцевостях із пересічними висотами на межі 40-50 м.

Зв'язок авторського доробку 3 важливими науковими та практичними завданнями полягає в дослідженнях щодо розкриття закономірностей формування водного балансу поверхневих водойм ПЗП. Його територія в геологічному відношенні сформована на потужних осадових пластах юрських, крейдяних, палеогенових і значно розвинених неогенових та антропогенових відкладів, потужність яких поступово збільшується на південний схід. 3 півночі цей масив обмежений південними схилами Українського кристалічного щиту, з якими пов'язана зона підземних тріщинних вод, що охоплює 5,3\% загальної площі регіону. Тож більша частина території належить Причорноморському Артезіанському басейну підземних вод, розташованому на карстовій платформі з похилом у бік моря [5; 6].

Аналіз останніх досліджень і публікацій. Перші дослідження структури висот території ПЗП та ii дренажної мережі було виконано військовими топографами, гідрографами та інженерами ще на початку XIX ст. Оцінки коливань рівня моря та їхньої ролі в змінах базису ерозії річок Північного Причорномор'я належать І.Г. Авенаріусу (1979), інженерно-геологічні оцінки річкових долин регіону - Г.О. Бачинському (1974). Питання екологічних підходів до управління русловим стоком в умовах цієї місцевості опрацьовували К.М. Беркович зі співавторами [7], В.О. Мануколо [8] та О.Г. Ободовський [9], питання динаміки рельєфу та зміни ландшафтів опрацьовані групою дослідників під керівництвом В.П. Палієнка [10]. Значний обсяг новітньої інформації узагальнено в роботах Є.Д. Гопченко та Н.С. Лободи [11]. Загалом, провідну роль у переважанні денудаційного складника в динаміці сучасної орографічної картини регіону більшість авторів надають природним факторам: метеокліматичним, геоморфологічним, гідрологічним та їх поєднанням. Проте окремі дослідники заперечують провідну значимість природно-ініційованих факторів орографічної нівеляції, вказуючи на потужність явища площинного змиву грунту з розораних полів [12]. Тобто провідним і рушійним фактором цих процесів вважається антропогенний чинник - оранка Степу, яка впродовж тільки останніх двох сторіч призвела до панівної ролі ерозійно-денудаційних комплексів рельєфу.

Виділення не вирішених раніше частин загальної проблеми, котрим присвячується означена стаття. Враховуючи вказані досить різноспрямовані сприйняття факторів ініціації орографічних змін, метою роботи є оцінка нинішнього стану мережі дренажно-поверхневих водотоків ПЗП та їх функціонування в умовах кліматичної нестабільності. Обрання теми дослідження зумовлено його модельним потенціалом, що завдячує ландшафтно-кліматичній схожості місцевостей із загальновираженою тенденцією тих до рельєфної нівеляції в східному напрямку.

Методологічне або загальнонаукове значення. Питання щодо механізмів і закономірностей денудаційно-акумуляційних процесів та їхнього балансу для території Дунай-Дніпровського межиріччя є об'єктом досліджень упродовж останніх 200 років. Вони поєднують цілу низку проблем, які мають, зокрема, регіональне значення, поєднуючи науково-практичні питання фахівців різного профілю: гідрологів, геологів, екологів, фахівців водного та сільського господарств, а також будівельників, гідрографів, археологів тощо.

Вихідними матеріалами дослідження $є$ картографічні дані (сучасні та ретроспективні), результати їхніх аналітичних узагальнень, виконаних на основі новітніх математичних моделей і програм для розрахунків, дані польових обстежень територій Миколаївської та Одеської областей у 2014-2020 pp. Також для аналітичних узагальнень використано картографічні та звітні дані організації й установ, діяльність яких пов’язана з темою досліджень.

Облік і вторинну перевірку картографічних даних щодо рельєфу, орографії місцевості, пересічних і абсолютних висот місцевості виконували за допомогою порталу каталогізованих джерел геоданих GIS DATA [13], геоінформаційної системи gis Map Server i геопорталу комплексу ведення банку даних цифрових карт і даних дистанційного зондування землі gis Map Geo DBW eb [14]. Для картографування власних даних використовували кроссплатформену геоінформаційну систему QGIS ver.2.19.2 [15]. Методичне забезпечення аналітично-обчислювальних узагальнень фактичних матеріалів базували на пакетах рекомендованих програм ВМO [16]. 
Виклад основного матеріалу. Використання картографічних матеріалів із характеристиками рельєфу і висот у поєднанні з даними щодо глибин розчленування рельєфу для території Миколаївської області показує наявність у іiі межах двох височинних осередків. Саме останні започатковують водно-ерозійні явища в зоні Нижнього Побужжя, акцентуючи останні переважно в південному напрямку. Перший iз них представлений зоною південно-східних відрогів Подільської височини - 3 абсолютними висотами 203-189-166 м, які зменшуються на південний схід. Другий представлений зоною південно-західних відрогів Придніпровської височини з висотами від 255 м (найвища точка Миколаївщини) до 180-153 м, із ухилом на південний захід. Стиковою лінією між ними є долина Південного Бугу, розташована вздовж міжблокового глибинного розлому. Відповідно, перепади висот між вершинами височин, що ініціюють місцеві прояви водно-ерозійних явищ, i рівнем р. Південний Буг (сучасний рівень базису ерозії) в ділянці від м. Первомайськ до м. Вознесенськ перевищують 120 м. Через це річкові долини в північних районах області досить заглиблені (91-56 м), а задіяна на них мережа дренажу спричиняє значне розчленування рельєфу та зумовлює високу активність акумуляційних процесів.

Наведені дані є загальновідомими ще із середини XIX ст., тож, відповідно, їм треба очікувати постійного поглиблення ерозійних врізів і заповнення останніх акумуляціями. Окрім того, майже суцільна польова трансформація північно-степових грунтів у горбистій місцевості північних районів, які із середини XX ст. майже цілком розорані, є дуже потужним фактором посилення площинних ерозійно-змивних явищ. Усе це, разом із кліматичною нестабільністю останніх років, орієнтує на інтенсифікацію ерозійних процесів і посилений прояв акумуляційних явищ у середній і нижній частині місцевих водотоків завдяки седиментаційному грунтонакопиченню.

Проте виконані в 2014-2020 рр. польові обстеження мережі постійних і сезонно-проточних водотоків у північних районах Миколаївської області не підтверджують присутність у їхніх долинах потужних та явно «свіжих» алювіальних відкладів. Такі акумуляції у вигляді товщ, змитих із полів грунтів, наявні лише в неглибоких балках, які загалом рідкісні в цій місцевості. Хоча північні (лівобережно-бузькі) райони області розташовані в місцевості, яка дуже чутлива до стоково-схилових деструкцій грунтового покриву. Вона являє собою височинне плато з пологими схилами, глибоко покраяними вузькими каньйоноподібними долинами лівих притоків - Гарбузинки, Чорного і Мигійського Ташликів, Великої та Малої Корабельної, Мертвоводу, Кам'янувато-Костуватої, Комишуватої та інших малих річок (рис. 1). Показово, що витоки вказаних річок розташовані в межах Українського кристалічного щита та частково на відрогах Придніпровської височини. Абсолютні висоти витоків Чорного Ташлику-Мертвоводу-Гнилого Сланця становлять 200-240 м.

Повсюдно бортові схили їхніх долин і супутніх балок (особливо в межах Братського та частково Вознесенського районів) відкривають гранітні виходи, що формують великі ділянки петрофітного степу. Саме їхня наявність у Нижньому Побужжі [18] $\epsilon$ прямим свідченням тривалого переважання ерозійно-стокових явищ над акумуляційно-денудаційними процесами, що збережена навіть в умовах суцільної оранки схилових земель. Відповідно, височинно-дизюнктивальний рельєф, глибока та похила на південь дренажна мережа і достатній режим зволоження цих місцевостей забезпечують значні обсяги поверхневого стоку цілорічно проточних малих річок. Їхні

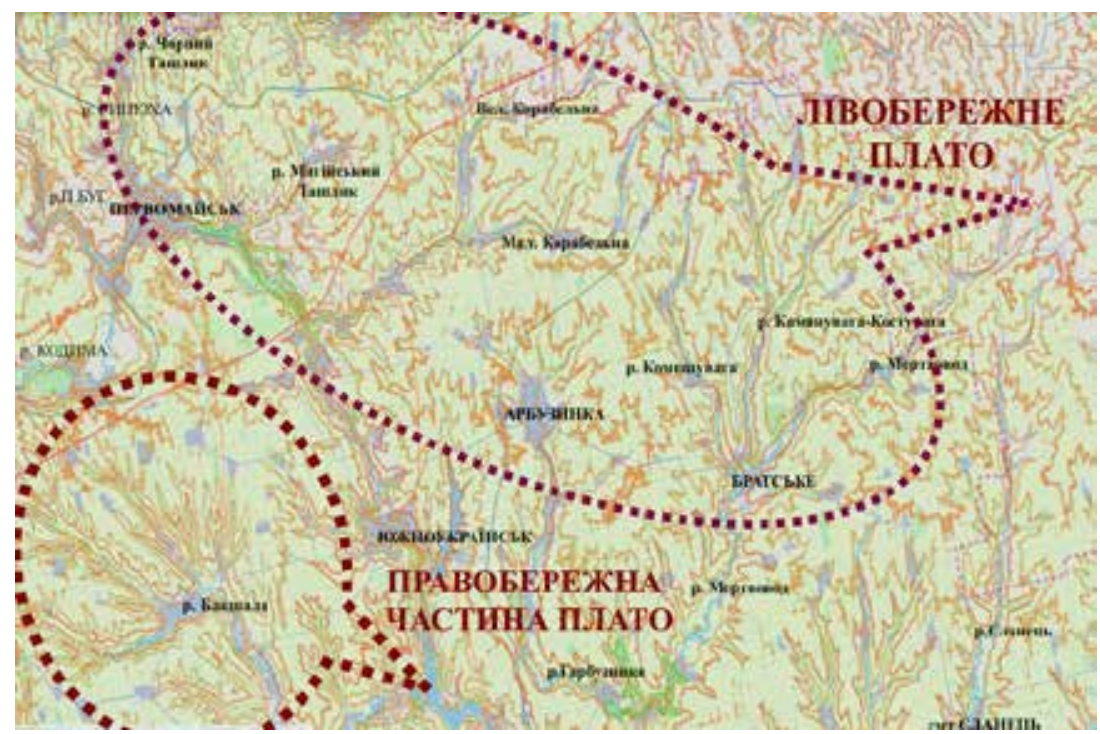

Рис. 1. Рельєф і річкова мережа на території північних районів Миколаӥвської області [17] 
притоки, які дренують місцевості з висотами, нижчими за 180 м, мають тільки сезонно-проточний режим завдяки недостатньому поверхнево-стоковому живленню влітку та восени.

Бузьке правобережжя поєднує Бузько-Кодимське, Бузько-Чичиклійське та Бузько-Тилігульське межиріччя, площі яких дренуються широкими і глибокими долинами Кодими, Тилігулу, Чичиклії, Бакшали, Чартали. Ці водотоки започатковані на південних відрогах Подільської височини і приймають увесь місцевий стік на південь від басейну Кодими. Перепади висот від їхніх витоків до рівня гирлових ділянок коливаються в межах 138-94 м і також забезпечують досить значні швидкості течії, але, на відміну від лівобережно-бузьких районів, обстежені долини містять більш об'ємні маси «свіжих» акумуляцій, які вже повністю нівелюють тальвеги. Такі ділянки явно пов'язані 3 фактором меандрування річкового русла і відсутні в зоні спрямленого русла. Відповідно, найбільш виражена денудація характерна для Бакшали та гирлової ділянки Чартали, яка формує єдину прибережно-рівнину частину правого берега Південного Бугу навпроти м. Вознесенськ. Водночас русло Бакшали значно меандроване, тоді як русло Чартали чітко випрямлене. Аналогічна прямизна русла характерна й для Чичиклії, яка набуває меандрованості тільки в пригирловій зоні.

Далі на південь від нижнього борту Українського кристалічного щита (нижче за лінію Доманівка Вознесенськ - Сланець - Казанка) починаються плакорні рівнини на висотах 130-102 м, а гранітні породи скельного фундаменту різко заглиблюються на 200-300 м під потужний шар осадочних відкладів кватеру [19]. Завдяки чутливості останніх до поверхнево-ерозійних і завдяки загальному похилу місцевості в південному напрямку набуває розвитку вторинно-ерозійна яружно-балочна мережа, яка відповідно до висот місцевості формує локальні водорозділи 3 крутими, сильно еродованими схилами (рис. 2).

Водороздільні ділянки, розширюючись на південь, зливаються у відносно вузькі плакори з рівнинно-хвилястим рельєфом поверхні, які поступово розвиваються і переходять у прибережні рівнини. Зокрема, початково невеликі плакорні площі межиріч Інгулу / Висуні / Інгульця демонструють стрімкий розвиток у південно-східному напрямку. У межах Єланецького і Новобузького районів вони займають до 27 \%, сягаючи в більш південних Баштанському, Березнегуватському та Снігурівському районах до $70 \%$ площі.

Вважається, що еволюція рельєфу сучасного типу всього ПЗП первинно пов' язана з формуванням осадових і лесових товщ кватеру, а також із тектонічними рухами Українського кристалічного щита [23]. Вторинна, явно циклічна динаміка дії водних потоків на лесові відклади кватеру виражена в сучасному поєднані ерозійних / акумуляційних процесів та здавна слугувала головним чинником ерозійної нівеляції поверхні регіону. Проте в Миколаївській області така ерозійно-стокова нівеляція понижень рельєфу характерна тільки для низинних південних районів. Для північних районів височинна нерівномірність базисної поверхні, розташованої в межах гранітного фундаменту Українського кристалічного щиту, під час поєднання зі специфікою його морфо-структурної неоднорідності спричинили виникнення увалисто-горбисто-хвилястого рельєфу,

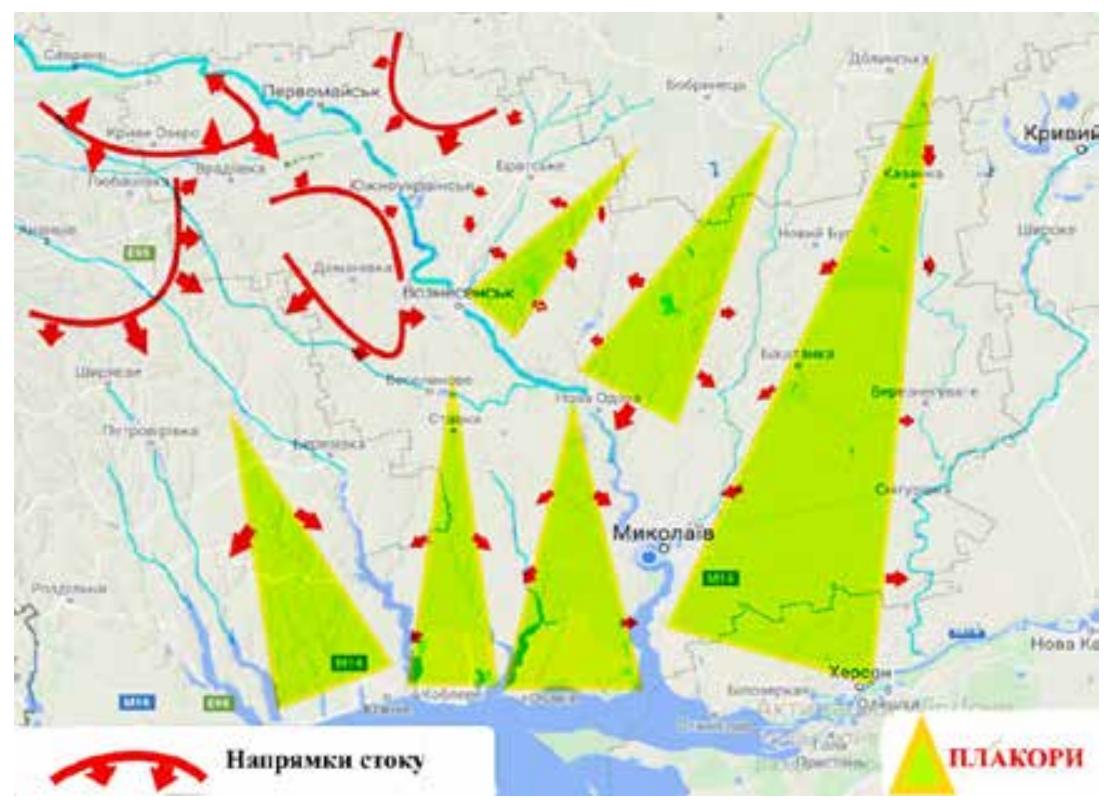

Рис. 2. Напрямки інтенсивного ерозійного врізу в зоні відрогів Подільської та Придніпровської височин і плакори рівнинних ділянок на території Миколаївської області [20] 
ускладненого ерозійними врізами (переважно пізньо-голоценового віку).

Відповідно, нинішня територія Миколаївської області являє собою нахилену в бік моря горбисту рівнину, яка меридіонально поділена долиною Південного Бугу, сформованою вздовж глибинного Південно-Бузького розлому [22]. За загальної тектонічної сталості цього розлому саме ним зумовлені сучасні неотектонічні рухи, спрямовані в бік підняття всієї південної зони Українського кристалічного щиту, розташованого на скельних фундаментах докембрійського походження. Вказане тектонічне підняття триває дотепер, тож території північної та центральної частини Миколаївської області проявляють тенденцію до підвищення [23]. Його темпи, судячи за глибиною та потужністю ерозійних врізів річкових долин, явно перевищують потужності акумулятивної нівеляції місцевості.

Вказана зона підняття морфологічно й гідрографічно пов'язана 3 Первомайською акумулятивно-денудаційною рівнинною, Подільською та Придніпровською височинами. Темпи їх підняття досить різні, але найбільш інтенсивними $є$ неотектонічні зростання в районі Придніпровської височини, що забезпечує там абсолютні висоти на межі +200-255 м. Водночас на захід (Ананьївський геоморфологічний район) та на південний схід (БузькоДніпровський геоморфологічний район) максимальні висоти місцевості не перевищують +120-180 м [24; 25], вказуючи на відсутність неотектонічних зростань. За їхньої відсутності (чи обмеженості) мережа дренажних водотоків Тилігуло-Бузького та БузькоДніпровського межиріч відрізняється інтенсивними ерозійно-акумулятивними явищами 3 вираженою нівеляцію долин місцевих річок (Тилігул і Березань на заході та Інгулець і Висунь на сході).

Зокрема, дані польових обстежень основних дренуючих водотоків степової зони Нижнього Побужжя, безперечно, свідчать, що саме тектонічним підняттям північної частини території Миколаївської області зумовлено домінування в цій місцевості процесів змиву та ерозії, які значно перевищують процеси акумуляції [26; 27]. Виражено це в глибоких ерозійних урізах долин річок і річково-балкових водотоків, які характеризуються відсутністю товщ новітніх алювіальних відкладів у руслових зонах (за переважання нівеляції давніх відкладів). Одночасно схили долин відрізняються й незначним розвитком акумулятивних терас завдяки їхньому інтенсивному ерозійному змиву. Такі картини загалом характерні для всіх водотоків північних, особливо для лівобережних, північно-східних ділянок Миколаївської області, вузько-каньйоні долини річок яких прямо вказують на давні тенденції підняття витоків і часткове вирівнювання базису ерозії в пониззі. На південь і південний захід ці закономірності поступово стираються, але завдяки загальному похилу території в бік моря залишкові явища інтенсивної водно-ерозійної діяльності поширюються до північних ділянок Причорноморської низовини.

Головні висновки. Узагальнюючи матеріали щодо перспектив розвитку рельєфу в межах адміністративної території Миколаївської області, закономірно вказати на його первинну зумовленість морфо-структурними особливостями та геологічними умовами місцевості. Вказаний комплекс умов підданий значним неотектонічно-позитивним змінам, одночасно з якими денна поверхня піддавалась впливу вивітрювання та ерозії, обсяги яких випереджають тектонічні явища.

Інтенсивність неотектонічного підняття північної частини області значна і досить тривала, утримуючи провідну рельєфоутворювальну роль саме за процесами змиву та ерозії, активність яких із кінця «Малого Льодовикового періоду» в цій місцевості стабільно перевищує процеси акумуляції.

Встановлений фактор стійкого неотектонічно-позитивного характеру поверхні Первомайської акумулятивно-денудаційної рівнини й південно-стикових відрогів Подільської та Придніпровської височин $\epsilon$ важливим у плані негативної оцінки проєктів щодо створення водосховищ на річках КодимськоЄланецького Побужжя. Нехтування цим фактором призведе до швидкого акумуляційного замулення новостворених водойм-накопичувачів i глибоких порушень еколого-гідрологічного режиму нижніх ділянок річкових долин із переважанням там штучно стимульованих акумулятивних явищ.

Перспективи використання результатів досліджень полягають у дрібно-басейновій деталізації показників процесів змиву-акумуляції, які нині мають прояв у зоні неотектонічного підняття, та оцінці їхньої можливої залежності від чинників кліматичної нестабільності.

\section{Література}

1. Базилевич Н.И. Биологическая продуктивность экосистем Северной Евразии. Москва : Наука, 1993. 248 с.

2. Барановський В.А. та ін. Україна. Еколого-географічний атлас. Київ : Варта, 2006. 220 с.

3. Географічна енциклопедія України / за ред. О.М. Маринич. Київ : Українська радянська енциклопедія ім. М.П. Бажана, 1993. T. 3. С. $422-427$.

4. Зайцев Ю.П., Александров Б.Г., Миничева Г.Г. Северо-Западная часть Черного моря: биология и экология. Киев : Наукова думка, 2006. $703 \mathrm{c}$.

5. Маринич О.М., Шищенко П.Т. Фізична географія України. Київ : Знання, 2005. 511 с.

6. Шестопалов В.М. та ін. Сучасні принципи гідрогеологічного районування. Збірник наукових праць УкрДГРІ. 2010. № 3-4. C. 147-157.

7. Беркович К.М., Чалов Р.С., Чернов А.В. Экологическое русловедение. Москва : ГЕОС, 2000. 331 с. 
8. Мануколо В.А. Расчет максимального стока малых рек степной зоны правобережной Украины и Молдавии. Tpyды УкрНИГМИ. 1991. Вып. 240. С. 3-16.

9. Ободовський О.Г. Гідролого-екологічна оцінка руслових процесів (на прикладі річок України). Київ : Ніка-Центр, 2001. $274 \mathrm{c}$.

10. Палієнко В.П. та ін. Сучасна динаміка рельєфу України. Київ, 2005. 268 с.

11. Гопченко Е.Д., Лобода Н.С. Водные ресурсы северо-западного Причерноморья (в естественных и нарушенных хозяйственной деятельностью условиях). Киев : Ніка-Центр, 2005. 188 с.

12. Екологія Миколаївської області / за ред. І.В. Наконечного. Миколаїв : НУК ім. адмірала Макарова, 2020. 320 с.

13. GIS DATA - портал каталогізованих джерел геоданих, багатошарових е-карт, їх застосування для управління громадами / регіонами. URL: https:/cid.center/gisdata/ (дата звернення: 5.09.2018).

14. Gis Map Server. Графический сервер для программы ГИС 6, Map Draw 2 и Gis Web Client. Геопортал комплексу ведення банку даних цифрових карт і даних дистанційного зондування Землі. URL: http:/globalgis.com.ua/products/ (дата звернення: 11.04.2020).

15. QGIS Desktop - настільна ГІС для створення, редагування, візуалізації, аналізу і публікації геопросторової інформації. URL: https://www.qgis.org/uk/site/about/features.html (дата звернення: 04.04.2020).

16. Всемирная метеорологическая организация. URL: https://public.wmo.int/en (дата звернення: 8.09.2020).

17. GIS File-Карта. Орографія та рельєф. Фрагмент. URL: https://gisfile.com/map/ (дата звернення: 15.08.2020).

18. Линдеманн Э. Очерк флоры Херсонской губернии. Одесса : Типография Л. Нитче, 1872. 229 с.

19. Стецюк В.В., Рудько Г.І., Ткаченко Т.І. Екологічна геоморфологія України. Київ : Вид. «Слово», 2010.367 с.

20. Это Место.ru - старые карты России и мира онлайн. URL: http://www.etomesto.ru/ukraine/ (дата звернення: 14.09.2020).

21. Рельєф України / за ред. В.В. Стецюка. Київ : Видавничий Дім «Слово», 2010. 688 с.

22. Палієнко В.П. та ін. Морфоструктурно-неотектонічний аналіз території України. Київ : Наукова думка, 2013. 264 с.

23. Геоморфология Украинской ССР / под ред. И.М. Рослого. Киев : Вища школа, 1990. 286 с.

24. Тектонічна карта України масштабу 1:1000000 (карта, легенда, поясн.зап.). Київ, 2007. Ч. 1. 95 с. (Інтерактивна карта). URL: http://supermaps.ukrdgri.gov.ua/tectonicsmap/default.aspx (дата звернення: 11.08.2020).

25. Тектоніка. Комплексний геоекологічний моніторинг впливу Ташлицької ГАЕС та Олександрівського водосховища 1998-2016 pp. / за ред. Г.В. Лисиченка. Київ : Наукова думка, 2017. С. 46-53.

26. Тектонічна карта України. Масштаб 1:1 000 000. Ч. 2. Тектоніка фундаменту Українського щита. Пояснювальна записка: Кирилюк В.П., Гурський Д.С. Київ : УкрДГРІ, 2007. 75 с.

27. Карта розломно-блоковой тектоники Украинского щита / под ред. Каляева Г.И. Киев : МинГео УCCP, 1984. 1 Л. URL: http://www.geokniga.org/maps/16264 (дата звернення: 6.12.2019). 


\title{
НАУКОВО-МЕТОДИЧНЕ ЗАБЕЗПЕЧЕННЯ РОЗРОБАЕННЯ ПААНІВ УПРАВАІННЯ РИЗИКАМИ ЗАТОПАЕННЯ В РІЧКОВИХ БАСЕЙНАХ
}

\author{
Петроченко О.В. ${ }^{1}$, Петроченко В.I. ${ }^{2}$ \\ ${ }^{1}$ Київський національний університет будівництва і архітектури \\ Повітрофлотський пр., 31, 03680, м. Київ \\ a_petr89@i.ua; \\ ${ }^{2}$ Інститут водних проблем і меліорації \\ Національної академії аграрних наук України \\ вул. Васильківська, 37, 03022, м. Київ \\ v_petr47@ukr.net
}

\begin{abstract}
Проблема паводків позначена як одна з глобальних проблем людської цивілізації. У статті зазначено, що основним документом із розв'язання проблеми паводків на міжнародному рівні є Директива 2007/60/ЄС Європейського Парламенту та Ради від 23 жовтня 2007 р. «Про оцінку і управління ризиками затоплення». Висвітлено основні заходи з імплементації Директиви 2007/60/ЄС до законодавства України в галузі водної політики. Здійснено аналіз методичних документів щодо впровадження в Україні Директиви 2007/60/ЄС, які розроблено Державною службою надзвичайних ситуацій України. Наголошено про брак необхідного для практичного використання універсального строго алгоритмізованого підходу до управління паводковими ризиками в річкових басейнах. У статті зроблено спробу створити на принципово новій концептуальній основі науково-методичне забезпечення впровадження Директиви 2007/60/СС. За результатами дослідження розроблено науково-методичний інструментарій оцінки ризиків затоплення й розроблення планів управління ризиками затоплення в річкових басейнах, який відповідає основним положенням Директиви 2007/60/СС та пропонується для іiі впровадження. Результати дослідження представлено в розділах, назви яких збігаються з назвами глав Директиви 2007/60/ЄС. Перший розділ «Загальні положення» містить терміни, які доповнюють список термінів, наведених у Директиві 2007/60/ЄС. У другому розділі «Попередня оцінка ризиків затоплення» розроблено науково-методичні основи оцінки ризиків затоплення, за якими передбачено використання статистики паводків за минулий період. Ризики затоплення запропоновано оцінювати за гідрологічними показниками паводків і показниками збитку від паводків, які представлено спадними гіперболічними функціями вірогідності паводків. Третій розділ «Карти небезпек затоплення і карти ризиків затоплення» містить методику розроблення для кожної зони паводкових ризиків карт небезпек затоплення і карт ризиків затоплення за сценаріями, які відповідають п’яти основним рівням інтенсивності паводків, що встановлюють за фіксованими значеннями вірогідності паводків. Для п'яти основних сценаріїв затоплення дано рекомендації з розроблення п'яти карт небезпек затоплення за гідрологічними показниками паводків і п’яти карт ризиків затоплення за показниками збитку від паводків. У четвертому розділі «Плани управління ризиками затоплення» заходи з управління ризиками затоплення запропоновано розділяти на ситуаційні, які виконують після короткострокового (3-7 діб) прогнозування паводків, і превентивні, які виконують після довгострокового прогнозування паводків. Наведено методичні основи розроблення планів управління ризиками затоплення як для окремих локальних зон паводкових ризиків, так і для всього річкового басейну, який може бути розташований на території кількох країн. Ключові слова: паводок, інтенсивність паводка, зона паводкових ризиків, зона затоплення, карти небезпек і ризиків затоплення, план управління ризиками затоплення.
\end{abstract}

Scientific and methodological support for the development of flood risk management plans in river basins. Petrochenko O., Petrochenko V.

The problem of floods is designated as one of the global problems of human civilization, which requires a solution at the international level. The article notes that the main document to address the problem of floods at the international level is Directive 2007/60/EU of the European Parliament and of the Council of 23.10.2007 "On flood risk assessment and management". The main measures for the implementation of Directive 2007/60/EU to the legislation of Ukraine in the field of water policy are highlighted. Methodical documents on the implementation of Directive 2007/60/EU in Ukraine, which were developed by the State Emergency Service of Ukraine, are analyzed. It is emphasized that there is no universal strictly algorithmic approach to flood risk management in river basins necessary for practical use. To eliminate this drawback, the article attempts to create scientific and methodological support for the implementation of Directive 2007/60/EU on a fundamentally new conceptual basis. Based on the results of the study, a fundamentally new scientific and methodological toolkit for assessing flood risks and developing plans for managing flood risks in river basins was developed, which complies with the main provisions of Directive 2007/60/EU and is proposed for its implementation. The results of the study are presented in sections whose names coincide with the titles of the chapters of Directive 2007/60/EU. The first section, General Provisions, contains terms that supplement the list of terms given in Directive 2007/60/EU. In the second chapter, "Preliminary assessment of flood risks", scientific and methodological foundations for assessing flood risks are developed, according to which the use of flood statistics over the past period is provided. It is proposed to assess the risks of flooding by hydrological indicators of floods and indicators of damage from floods, which are represented by descending hyperbolic functions of flood probability. The third section, "Flood hazard maps and flood risk maps", contains a methodology for developing flood hazard maps and flood risk maps for each flood risk zone according to the scenarios that correspond to the five main flood intensity levels, which are set based on fixed flood probability values. For the five main flood scenarios, recommendations are given on the development of five flood hazard maps 
for hydrological flood indicators and five flood risk maps for flood damage indicators. In the fourth section, "Flood Risk Management Plans", flood risk management measures are proposed to be divided into situational ones that perform after short-term (3-7 days) flood forecasting and preventive ones that follow after long-term flood forecasting. The methodological basis for the development of flood risk management plans for both individual local flood risk zones and the entire river basin, which can be located in several countries, is presented. Key words: flood, flood intensity, flood risk zone, flood zone, hazard and flood risk maps, flood risk management plan.

Постановка проблеми. Однією 3 глобальних проблем людської цивілізації є проблема паводків, яку з огляду на ії планетарне значення розглядають не тільки на внутрішньодержавному, а й на міжнародному рівнях. Однак ухвалені міжнародними організаціями декларації та директиви з глобальних проблем людства зазвичай потребують належного методологічного i науково-методичного забезпечення їх впровадження.

Актуальність дослідження. Основним законодавчим документом рішення на міжнародному рівні проблеми паводків є Директива 2007/60/ЄС Європейського Парламенту і Ради від 23 жовтня 2007 p. «Про оцінку і управління ризиками затоплення» [1]. Директиву 2007/60/ЄС було ухвалено для регулювання відносин між державами-членами ЄC у сфері запобігання і скорочення негативних наслідків паводків у постраждалих районах, а також для координації розроблення планів управління ризиками, пов'язаними зі стихійним лихом. Директива 2007/60/СС доповнює основні положення Директиви 2000/60/СС Свропейського Парламенту і Ради від 23 жовтня 2000 p. «Про встановлення рамок діяльності Співтовариства в галузі водної політики» [2].

Оскільки території багатьох європейських країн розташовані в басейнах транскордонних річок, то головним причинним фактором ухвалення міжнародних директив із водної політики $є$ потреба спільного впровадження Співтовариством (державами ЄC) басейнового принципу управління водними ресурсами (Директива 2000/60/СС), зокрема управління ризиками затоплення (Директива 2007/60/ $\mathrm{EC).} \mathrm{За} \mathrm{басейновим} \mathrm{принципом} \mathrm{управління} \mathrm{річковий}$ басейн визнають як цілісний природний гідрографічний об'єкт без його обмежень адміністративними чи державними кордонами.

Зв'язок авторського доробку 3 важливими науковими та практичними завданнями. Україна обрала курс на імплементацію Директиви 2007/60/ ЄC до законодавства України шляхом ухвалення Постанови Кабінету Міністрів України від 25 жовтня 2017 р. № 1106 «Про виконання Угоди про асоціацію між Україною, з однієї сторони, та Європейським Союзом, Європейським співтовариством з атомної енергії і їніми державами-членами, $з$ іншої сторони» [3]. Державну службу України 3 надзвичайних ситуацій (далі - ДСНС України) визначено відповідальним органом за впровадження Директиви 2007/60/ЄС за пунктами:

- 1713. Удосконалення законодавства України щодо оцінки та управління ризиками затоплення внаслідок паводків;
- 1743. Забезпечення проведення попередньої оцінки ризиків затоплення;

- 1777. Впровадження планів управління ризиками затоплення.

Аналіз останніх досліджень і публікацій. На виконання Постанови [3] відповідно до статей 4, 6 і 7 Директиви 2007/60/ЄС ДСНС України розробила й опублікувала такі документи:

- «Методика попередньої оцінки ризиків затоплення», затверджена Наказом МВС України від 17 січня 2018 р. № 30 [4];

- «Методика розроблення карт загроз і ризиків затоплення», затверджена Наказом МВС України від 28 лютого 2018 р. № 153 [5];

- «Порядок розроблення плану управління ризиками затоплення», затверджений Постановою Кабінету Міністрів України від 4 квітня 2018 р. № 247 [6].

Аналіз документів [4-6], а також публікацій [7; 8] за тематикою досліджень проблеми паводків свідчить про складність їхнього практичного використання під час оцінювання ризиків затоплення й розроблення планів управління ризиками затоплення. Ці документи містять комплекс посилань, загальних рекомендацій і пропозицій без викладення чіткого алгоритму здійснення цілісної багатоступеневої процедури оцінки ризиків затоплення і розроблення планів управління ризиками затоплення. Через брак універсального алгоритмізованого підходу до управління паводковими ризиками розробники змушені самі обирати принципові варіанти планів управління ризиками затоплення та процедуру їх розроблення. Через це ефективність планів управління ризиками затоплення та ступінь їхньої координованості значною мірою залежатиме від інтуїції та практичного досвіду розробників.

Виділення не вирішених частин загальної проблеми, котрим присвячусться означена стаття. Отже, ухваленням Постанови [3] Україна виявила бажання приєднатися до інших держав Свропи для спільного розв'язання проблеми паводків, а розробленням документів [4-6] здійснила перші кроки в напрямі імплементації Директиви 2007/60/ЄС до законодавства України з водної політики. Однак для ефективного впровадження Директиви 2007/60/СС виникла актуальна потреба вдосконалення методичних основ оцінки ризиків затоплення та процедури розроблення планів управління ризиками затоплення.

Мета дослідження - створити відповідно до Директиви 2007/60/ЄС науково-методичний інструментарій оцінки ризиків затоплення і розроблення 
планів управління ризиками затоплення в річкових басейнах.

Основним завданням дослідження $\epsilon$ аналіз і вдосконалення концептуальних і науково-методичних основ розв'язання проблеми паводків, викладених у міжнародних і вітчизняних законодавчих документах.

Методика дослідження. В основу методики дослідження покладено системний інтегрований підхід до аналізу комплексу складників паводкових загроз і обгрунтування ефективних заходів захисту від паводків.

Виклад основного матеріалу. Основним результатом дослідження $\epsilon$ науково-методичний інструментарій оцінки ризиків затоплення та розроблення планів управління ризиками затоплення в річкових басейнах, який не суперечить основним положенням Директиви 2007/60/€C і пропонується як методичне забезпечення їі впровадження. Результати дослідження викладено в розділах, назви яких обрано відповідно до назв глав Директиви 2007/60/€С.

1. Загальні положення. У дослідженні використано терміни, наведені в главі 1 [1], та додатково застосовано такі основні терміни й визначення:

- забезпеченість паводка - вірогідність перевищення статистично встановленої максимальної в певному році витрати води в річці;

- зона затоплення - територія в річковому басейні, яка затоплюється внаслідок проходження паводка певної забезпеченості;

- зона паводкових ризиків - територія в річковому басейні, контур якої збігається з контуром зони затоплення паводком найменшої забезпеченості;

- розрахунковий гідрометричний створ річки - гідрометричний створ річки, витрата паводкового потоку в якому найбільш адекватно відображає параметри зони затоплення і приймається за основний гідрологічний параметр паводка на стадії оцінки й управління ризиками затоплення;

- управління ризиками затоплення - здійснення комплексу заходів, призначених на зменшення або відвернення негативних наслідків затоплення;

- показник (індекс) ефективності управління ризиками затоплення - оцінений у грошових одиницях позитивний ефект заходів захисту від паводків, що випадає на одиницю вартості витрат на здійснення захисних заходів.

Інші терміни й визначення 3 обгрунтуванням доцільності їх застосування наведено в наступних розділах роботи.

2. Попередня оцінка ризиків затоплення. Під час попередньої оцінки ризиків затоплення здійснюють збір та аналіз статистичних даних проходження паводків у басейні річки та опис наслідків затоплень, що відбулися за минулий період. Попередню оцінку ризиків затоплення здійснюють за трьома критеріальними показниками: інтенсивність паводка; зона затоплення; наслідки затоплення (втрата і збиток від затоплення).

Першим критеріальним показником ризиків затоплення $є$ інтенсивність паводка. Цей показник $\epsilon$ визначальним, оскільки два інших критеріальних показники - зона затоплення та наслідки затоплення - функціонально залежать від нього й можуть бути визначені за його величиною шляхом виконання відповідних прогнозів і розрахунків. Інтенсивність паводка оцінюється перевищенням витрати паводкового потоку води в річці щодо витрати в меженний період i може бути визначена різними способами. У гідрології інтенсивність паводка заведено визначати забезпеченістю паводка [9]. Для визначення забезпеченості паводка в кожному $m$-му році спостережень минулого періоду враховують тільки максимальну за рік витрату води $Q_{m}$ в створі річки, яку розміщують у ряд (1) в порядку послідовного зменшення:

$$
Q_{1} \geq Q_{2} \geq Q_{3} \geq \ldots \geq Q_{m} \geq \ldots \geq Q_{n-1} \geq Q_{n},
$$

де $m$ - порядковий номер року в ряду; $n$ - кількість років спостережень.

Забезпеченість паводка $p_{m}$ в $m$-му році визначають як вірогідність (у відсотках) перевищення витрати води в річці значення $Q_{m}$ за формулою:

$$
p_{m}=\frac{m}{n+1} \cdot 100 \% \text {. [9] }
$$

Згідно 3 [1] інтенсивність паводків рекомендовано оцінювати показником вірогідності, за яким кожен паводок із витратою $Q_{m}$ оцінюють кількістю паводків, що на періоді часу в 100 років мають витрату $Q \geq Q_{m}$. Така оцінка логічно підтверджується, якщо припустити, що в кожному році минулого періоду тривалістю у 100 років було отримано низку емпіричних даних:

$$
Q_{1} \geq Q_{2} \geq Q_{3} \geq \ldots \geq Q_{m} \geq \ldots \geq Q_{99} \geq Q_{100} .
$$

Визначимо забезпеченість паводка $\overline{p_{m}} m$-го року в долях одиниці:

$$
\bar{p}_{m}=\frac{p_{m}}{100 \%}=\frac{m}{100+1} \cong \frac{m}{100} .
$$

За умови (3) згідно з (4) маємо: $p_{m}=m$. Оскільки $n=100$, то $m \in$ одночасно і порядковим номером ряду (3) і кількістю (частотою повторення) паводків, що в період часу у 100 років мають витрату $Q \geq Q_{m}$. Тобто частота паводка в період часу у 100 років відповідає його забезпеченості, визначеній у відсотках. Це належить також до паводків забезпеченістю $p<1 \%$. Наприклад, для паводка забезпеченістю $p=0,5 \%$ частота повторення становить 0,5/100=1/200.

У роботі [10] запропоновано паводки класифікувати за п'ятьма базовими рівнями їхньої інтенсивності (за забезпеченістю $p$ ): $p=100 \%$ (малий або щорічний); $p=25 \%$ (середній); $p=5 \%$ (великий); $p=2 \%$ (катастрофічний); $p \leq 1 \%$ (видатний). 
Оскільки основним причинним фактором затоплення є витрата води в гідрометричному створі річки, то для оперативного розроблення карт небезпек i карт ризиків затоплення паводками різної забезпеченості виникає потреба визначати для кожної зони паводкових ризиків функціональну залежність витрати води $Q$ від забезпеченості паводка $p$. Для цього, використовуючи статистичні дані гідрологічних вимірювань за попередні роки, за емпіричними точками $1\left(Q_{m}, p_{m}\right)$ спочатку будують емпіричну криву 2 (рис. 1), а потім визначають залежність $Q=f_{1}(p)$ у вигляді спадної гіперболічної функції:

$$
Q=\frac{k_{1}}{p}+k_{2} \cdot[11]
$$

Коефіцієнти $k_{1}$ i $k_{2}$ функції (5) знаходять, використовуючи множину емпіричних точок $\left(Q_{m}, p_{m}\right)$, за методом найменших квадратів із системи рівнянь:

$$
\left\{\begin{array}{l}
k_{1}=\frac{n \sum_{m=1}^{n} \frac{Q_{m}}{p_{m}}-\sum_{m=1}^{n} \frac{1}{p_{m}} \cdot \sum_{m=1}^{n} Q_{m}}{n \sum_{m=1}^{n}\left(\frac{1}{p_{m}}\right)^{2}-\left(\sum_{m=1}^{n} \frac{1}{p_{m}}\right)^{2}} ; \\
k_{2}=\frac{\sum_{m=1}^{n} Q_{m}-k_{1} \sum_{m=1}^{n} \frac{1}{p_{m}}}{n} .
\end{array}\right.
$$

Отже, маючи незначну кількість (4...7) емпіричних точок $\left(Q_{m}, p_{m}\right)$, отриманих за результатами гідрологічних вимірювань за минулі роки, можна, користуючись залежністю (5), визначати витрату води в річці в період походження паводка будь-якої забезпеченості, а отже оцінювати ризики затоплення для будь-якого сценарію надзвичайного випадку. За п. 3 ст. 6 [1] пропонується розроблювати карти небезпек для трьох сценаріїв надзвичайних випадків: затоплення низького, середнього і високого рівня вірогідності. Вважається, що так було запропоновано через недоцільність обміну між країнами ЄС тією інформацією про паводки, які не становлять загрози іншим країнам у басейнах транскордонних річок. Проте для досягнення високої ефективності управління ризиками затоплення в межах кожної країни варто розглядати більшу кількість сценаріїв, наприклад таких, що відповідають п'ятьом базовим рівням інтенсивності паводків (поз. 4...8 на рис. 1).

Другим критеріальним показником ризиків затоплення є зона затоплення. Її на стадії попередньої оцінки ризиків затоплення визначають за результатами спостережень за минулі роки за такими основними параметрами: контур затоплення, площа затоплення, максимальна і середня глибина затоплення.

Третім критеріальним показником ризиків затоплення є наслідки затоплення, або наслідки шкідливого впливу паводків на життєдіяльність людей у зонах затоплення та на прилеглих до них територіях. Наслідки затоплення визначають за величиною втрати від паводка й розміром збитку від паводка.

Втрату від паводка визначають у фізичних величинах за трьома іiі складовими: соціальна втрата втрата життя і здоров'я людей, а також втрата умов

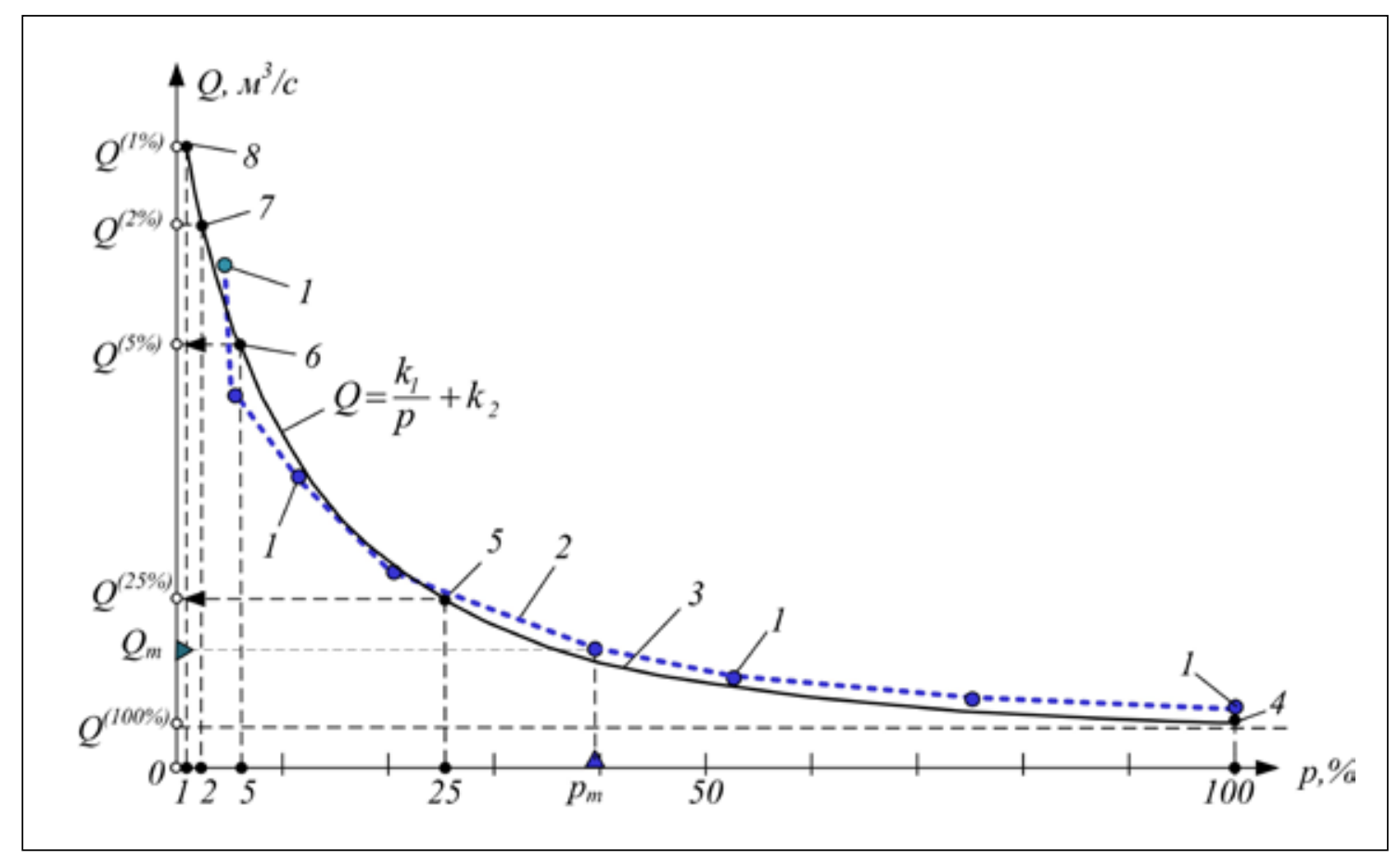

Рис. 1. Результати гідрологічних досліджень витрати води в річиі: 1 - емпіричні точки $\left(Q_{m}, p_{m}\right)$; 2 - емпірична крива; 3 - теоретична крива $Q=f_{1}(p) ; 4 \ldots 8$ - точки на кривій 3 , відповідні п'ятьом базовим рівням інтенсивності паводків 
комфортного проживання населення; екологічна втрата - втрата первинного екологічного стану навколишнього середовища, а також якісних і кількісних показників природних ресурсів; економічна втрата втрата споживчих та функціональних властивостей об’єктів виробничої сфери та господарської діяльності населення.

Під збитком від паводка розуміють оцінену в грошових одиницях втрату від паводка. Отже, відповідно до складників втрати від паводка, визначених у фізичних величинах, використовуючи методичні засади розрахунку складників збитків від паводків [12;13], розраховують у грошових одиницях: соціальний, екологічний і економічний збиток від паводка (табл. 1).

3. Розроблення карт небезпек затоплення i карт ризиків затоплення. Для кожної зони паводкових ризиків річкового басейну карти небезпек затоплення і карти ризиків затоплення розроблюють чотирма етапами.

Ha першому emani розроблюють інтегровану картосхему зон затоплення паводками різної забезпеченості (рис. 2), параметри яких були визначені на стадії попередньої оцінки ризиків затоплення паводком певного минулого року спостережень та занесені до таблиці 1. Оскільки основним причинним фактором ризику затоплення є підвищення витрати води в річці, то важливе значення має вибір гідрометричного створу річки, витрату води в якому слід враховувати як під час попередньої оцінки небезпек затоплення, так і при розробленні карт небезпек затоплення і карт ризиків затоплення. Якщо для короткострокового (3-7 діб) прогнозування наближення паводка до зони паводкових ризиків виникає необхідність вимірювати витрату води в руслі річки починаючи з їі верхів'я, то для оцінки та прогнозу- вання параметрів зон затоплення варто використовувати гідрометричні створи максимально наближені до зони паводкових ризиків. Один із таких створів приймають за розрахунковий.

У розрахунковому гідрометричному створі динаміка зміни гідрологічних показників повинна найбільш адекватно відображати динаміку зміни параметрів зони затоплення i наслідків проходження паводка [11]. Очевидно, що серед двох, представлених на рис. 2, гідрометричних створів 3 і 4 розрахунковим слід вважати створ 4, оскільки витрата води $Q_{m 2}$ в цьому створі більша ніж витрата $Q_{m l}$ у створі 3 і відображає реальну гідрологічну ситуацію в зоні паводкових ризиків 7 . Витрата води $Q_{m 2}$ функціонально залежить від стоку річки $1\left(Q_{m l}\right)$, стоку притоки $2\left(Q_{m}{ }^{n p}\right)$ і поверхневого стоку $\left(Q_{m}{ }^{\text {on }}\right)$ 3 інших площ басейну річки 1 , спрямованого до зони паводкових ризиків 5 в момент інтенсивних дощів та танення снігу.

Крім того, на відміну від створу 3, у створі 4 витрата води $Q_{m 2}$ адекватно відображає параметри зон затоплення і ризики затоплення також після здійснення превентивних протипаводкових заходів (рис. 3): локального захисту території в межах зони паводкових ризиків (поз. 12); захисту русла і берегів річки і притоки (поз. 13); захисту від затоплення за допомогою протипаводкового водосховища рівнинного типу (поз. 14); захисту за допомогою протипаводкового водосховища гірського типу (поз. 15).

Ha другому emani на основі інтегрованої картосхеми зон затоплення паводками минулих років (рис. 2), будують інтегровану карту небезпек затоплення (рис. 3) з зображенням контурів 6-10 зон затоплення паводками п'яти базових рівнів інтенсивності: $6(p=100 \%) ; 7(p=25 \%) ; 8(p=5 \%) ; 9(p=2 \%)$; $10(p=1 \%)$. Параметри зони затоплення паводком

Результати попередньої оцінки втрати і збитку від паводків у зоні ризиків

\begin{tabular}{|c|c|c|c|c|c|c|c|c|c|}
\hline \multirow{2}{*}{$\begin{array}{c}\text { Критеріальні } \\
\text { показники }\end{array}$} & \multicolumn{3}{|c|}{ Параметри } & \multicolumn{5}{|c|}{ Роки спостережень } & \multirow{2}{*}{$\begin{array}{c}\text { № } \\
\text { рядка }\end{array}$} \\
\hline & \multicolumn{2}{|c|}{ Назва } & Од. виміру & 1 & $\ldots$ & $\mathbf{m}$ & $\ldots$ & n & \\
\hline \multirow{2}{*}{$\begin{array}{c}\text { Інтенсивність } \\
\text { паводка }\end{array}$} & \multicolumn{2}{|c|}{ Витрата води } & $\mathrm{M}^{3} / \mathrm{c}$ & $Q_{1}$ & $\ldots$ & $Q_{m}$ & $\ldots$ & $\bar{Q}$ & 1 \\
\hline & \multicolumn{2}{|c|}{ Забезпеченість паводка } & $\%$ & $p_{1}$ & $\ldots$ & $p_{m}$ & $\ldots$ & $p_{n}$ & 2 \\
\hline \multirow{4}{*}{$\begin{array}{c}\text { Зона } \\
\text { затоплення }\end{array}$} & \multicolumn{2}{|c|}{ Контур зони затоплення } & *згідно картосхем & $*$ & $\ldots$ & $*$ & $\ldots$ & $*$ & 3 \\
\hline & \multicolumn{2}{|c|}{ Площа затоплення } & тис. $\mathrm{M}^{2}$ & $S_{1}$ & $\ldots$ & $S_{m}$ & $\ldots$ & $S_{n}$ & 4 \\
\hline & \multirow{2}{*}{$\begin{array}{c}\text { Глибина } \\
\text { затоплення }\end{array}$} & максимальна & M & $h_{1}^{\max }$ & $\ldots$ & $h_{m}^{\max }$ & $\ldots$ & $h_{n}^{\max }$ & 5 \\
\hline & & середня & M & $h_{1}^{c p}$ & $\ldots$ & $h_{m}^{c p}$ & $\ldots$ & $h_{n}^{c p}$ & 6 \\
\hline \multirow{8}{*}{$\begin{array}{c}\text { Наслідки } \\
\text { затоплення }\end{array}$} & \multirow{4}{*}{$\begin{array}{c}\text { Втрата від } \\
\text { паводка }\end{array}$} & соціальна & \multirow{4}{*}{$\begin{array}{c}\text { **у фізичних } \\
\text { одиницях згідно актів } \\
\text { обстеження } \\
\text { зон затоплення }\end{array}$} & $* *$ & $\ldots$ & $* *$ & $\ldots$ & $* *$ & 7 \\
\hline & & екологічна & & ** & $\ldots$ & $* *$ & $\ldots$ & $* *$ & 8 \\
\hline & & економічна & & $* *$ & $\ldots$ & $* *$ & $\ldots$ & $* *$ & 9 \\
\hline & & загальна & & $* *$ & $\ldots$ & $* *$ & $\ldots$ & $* *$ & 10 \\
\hline & \multirow{4}{*}{$\begin{array}{c}\text { Збиток від } \\
\text { паводка }\end{array}$} & соціальний & \multirow{4}{*}{ тис. грн./рік } & $3_{11}^{\mathrm{Cu}}$ & $\ldots$ & $3_{I m}{ }^{C u}$ & $\ldots$ & $3_{1 n}^{C u}$ & 11 \\
\hline & & екологічний & & 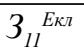 & $\ldots$ & $3_{1 m}^{E \kappa r}$ & $\ldots$ & $3_{1 n}^{\text {Eкr }}$ & 12 \\
\hline & & економічний & & $3_{11}^{\text {Екн }}$ & $\ldots$ & $3_{I m}^{E \kappa H ~}$ & $\ldots$ & $3_{I n}^{E \kappa H ~}$ & 13 \\
\hline & & загальний & & 311 & $\ldots$ & $3_{1 m}$ & $\ldots$ & $3_{1 n}$ & 14 \\
\hline
\end{tabular}




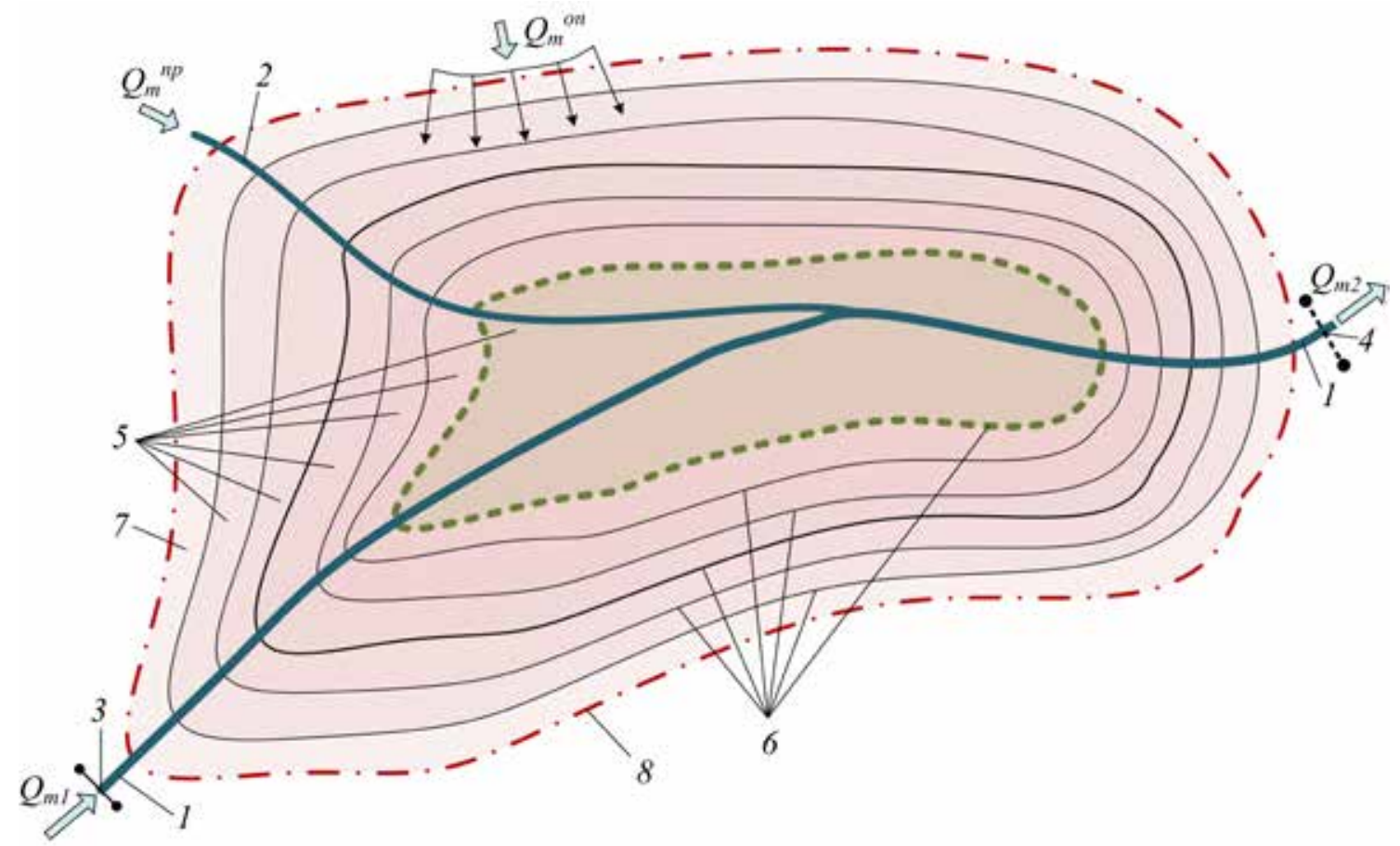

Рис. 2. Інтегрована картосхема зон затоплення паводками минулих років: 1 - річка;

2 - притока річки; 3 - гідрометричний створ перед зоною паводкових ризиків; 4 -розрахунковий гідрометричний створ; 5 - зони затоплення паводками різної забезпеченості $p\left(p_{\max } \geq p \geq p_{\min }\right)$;

6 - контури зон затоплення паводками забезпеченості р; 7 - зона паводкових ризиків; 8 - контур зони паводкових ризиків

$i$-го базового рівня інтенсивності $(i=1 \ldots 5)$ визначають у такій послідовності:

$$
p_{i} \rightarrow Q_{i} \rightarrow \Omega_{i} \rightarrow S_{i} \rightarrow h_{i}^{\max },
$$

де $p_{i}$ - забезпеченість паводка, \%; $Q_{i}$ - пікове значення витрати паводка, $\mathrm{M}^{3} / \mathrm{c} ; \Omega_{i}-$ контур зони затоплення; $S_{i}$ - площа зони затоплення, $\mathrm{M}^{2}, h_{i}^{\max }$ - максимальна глибина зони затоплення, м.

Витрату $Q_{i}$ визначають залежно від забезпеченості паводка $i$-го базового рівня інтенсивності за формулою (5). Контур $\Omega_{i}$ і параметри $S_{i}, h_{i}$ зони затоплення паводком $i$-го рівня інтенсивності визначають шляхом розрахунків із застосуванням методів інтерполяції [14], використовуючи наведені у таблиці 1 та на картосхемі (рис. 2) контури $\Omega_{m}$ i параметри $S_{m}, h_{m}$ зон затоплення паводком 3 витратою $Q_{m}$, найбільш наближеною до витрати $Q_{i}\left(Q_{m}=Q_{m 2} \rightarrow Q_{i}\right)$.

Ha mpembомy emani для кожної $j$-ї зони паводкових ризиків річкового басейну будують п'ять окремих карт небезпек затоплення, використовуючи інтегровану карту небезпек затоплення (рис. 3). В кожній 3 цих карт відповідно до п'яти базових сценаріїв надзвичайних випадків зображують контур тільки однієї зони затоплення паводком одного з п'яти базових рівнів інтенсивності.

Hа четвертому emani для кожної $j$-ї зони паводкових ризиків річкового басейну будують п'ять карт ризиків затоплення на основі п'яти карт небезпек затоплення. Карти ризиків зато- плення відрізняються від карт небезпек затоплення тим, що на них додатково символами зображують об'єкти затоплення (населені пункти, газопроводи, лісові насадження, сільгоспугіддя, рекреаційні зони, автотраси, підприємства тощо). До кожної карти ризиків затоплення додається інформація про об'єкти та наслідки потенційного затоплення у вигляді таблиці 2, а також розрахунки втрат і збитків від паводка.

Складові втрати $B m_{i}$ визначають за контуром $\Omega_{i}$ і параметрами $S_{i}, h_{i}$ зони затоплення паводком базового $i$-го рівня інтенсивності з урахуванням об'єктів, що знаходяться в межах зони затоплення, та потенційно можливого впливу паводка на зменшення корисних якісних і кількісних властивостей цих об'єктів.

Складові збитку $3_{i}$ визначають за фізичними величинами складових втрати $B m_{i}$ в індексованих на момент виконання розрахунків цінах.

Для кожного $i$-го сценарію затоплення основним показником наслідків є загальний (зональний) річний збиток $3_{i}$, який розраховують за формулою:

$$
3_{i}=\sum_{\eta=1}^{N} 3_{i \eta}=\sum_{\eta=1}^{N}\left(3_{i \eta}^{C \eta}+3_{i \eta}^{E \kappa r}+3_{i \eta}^{E k \mu}\right),
$$

де $3_{\text {i }}$ - локальний (об'єктний) збиток в зоні паводкових ризиків, який складається з соціального $3_{i \eta}{ }^{C u}$, екологічного $3_{i \eta}{ }^{E \kappa \imath}$ і економічного $3_{i \eta}{ }^{\text {Ек }}$ Збитків, завданих $\eta$-му об'єкту паводком базового $i$-го рівня інтенсивності, тис. грн./рік. 
Карти ризиків затоплення, таблиці 2 та додатки до них розроблюють для оцінки основного показника ризику затоплення - загального потенційно можливого річного збитку від паводка кожного 3 п'яти базових рівнів інтенсивності. Далі, маючи п’ять карт ризиків затоплення та п'ять таблиць 2 до них, виникає потреба визначення для певної $j$-ї зони паводкових ризиків функціональної залежності загального річного збитку 3 від паводка будь-якої забезпеченості $p$ та подальшого використання цієї залежності на стадії управління ризиками затоплення. Для цього згідно 3 [11] залежність $3_{j}=f_{2}(p)$ апроксимують (рис. 4) спадною гіперболічною функцією:

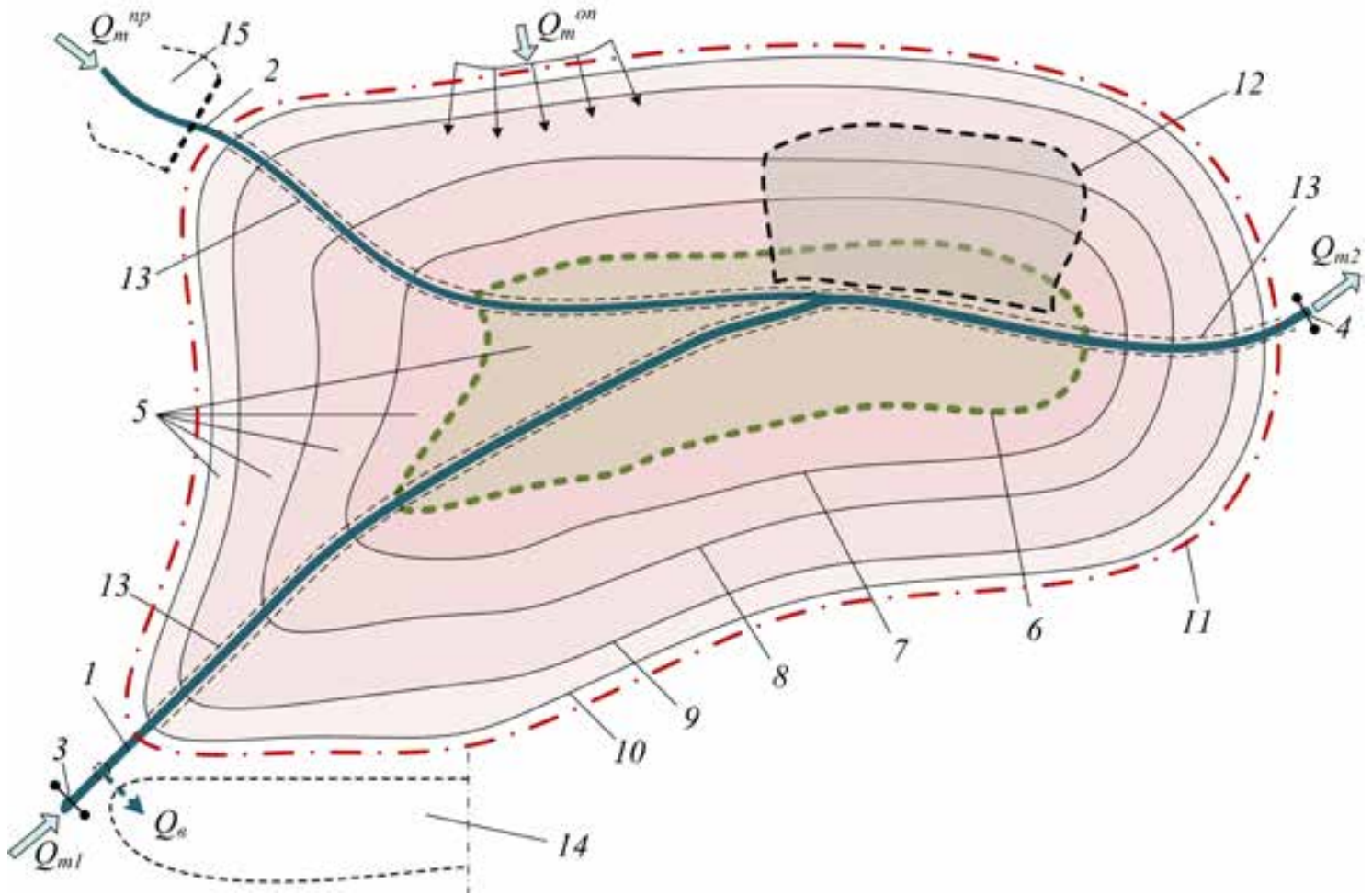

Рис. 3. Інтегрована карта небезпек затоплення, побудована за результатами прогнозування зон затоплення паводками базових рівнів інтенсивності: 1 - річка; 2 - притока річки;

3 - гідрометричний створ перед зоною паводкових ризиків; 4 -розрахунковий гідрометричний створ; 5 - зона паводкових ризиків з контурами зон затоплення паводками базових рівнів інтенсивності; 6, 7, 8, 9, 10 - контур зони затоплення паводком забезпеченості 100\%, 25\%, 5\%, 2\%, 1\%; 11 - контур зони паводкових ризиків ( $\leq \leq 1 \%) ; 12$ - локальний протипаводковий захист території в межах зони паводкових ризиків; 13 - протипаводковий захист русла річки та притоки; 14 - протипаводкове водосховище рівнинного (польдерного) типу; 15 - протипаводкове водосховище гірського типу

Таблиця 2

Об’єкти $j$-ї зони паводкових ризиків річкового басейну та потенційні наслідки їх затоплення паводком і-го базового рівня інтенсивності

\begin{tabular}{|c|c|c|c|c|c|c|c|c|}
\hline \multicolumn{2}{|c|}{ Об'єкти затоплення } & \multicolumn{7}{|c|}{ Наслідки затоплення паводком $i$-го рівня вірогідності } \\
\hline \multirow{2}{*}{$\begin{array}{c}\text { № на } \\
\text { карті } \\
\text { ризиків }\end{array}$} & \multirow[b]{2}{*}{ Назва } & \multicolumn{3}{|c|}{ *Втрата } & \multicolumn{4}{|c|}{ **Збиток, тис. грн./рік } \\
\hline & & $\begin{array}{c}\text { Соці- } \\
\text { альна }\end{array}$ & $\begin{array}{c}\text { Еколо- } \\
\text { гічна } \\
\end{array}$ & $\begin{array}{c}\text { Еконо- } \\
\text { мічна }\end{array}$ & $\begin{array}{c}\text { Соці- } \\
\text { альний }\end{array}$ & $\begin{array}{l}\text { Еколо- } \\
\text { гічний }\end{array}$ & $\begin{array}{l}\text { Еконо- } \\
\text { мічний }\end{array}$ & $\begin{array}{l}\text { Лока- } \\
\text { Льний }\end{array}$ \\
\hline 1 & Село Прирічне & $B m_{i 1}{ }^{C u}$ & 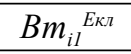 & $B m_{i l}^{\text {EкH }}$ & $3_{i 1} \mathrm{Cu}$ & 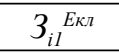 & $3_{i 1}^{\text {Екн }}$ & $3_{i 1}$ \\
\hline 2 & Сільгоспугіддя & $\mathrm{Bm}_{i 2}{ }^{\mathrm{Cu}}$ & $B m_{i 2}{ }^{\text {Eкл }}$ & $B m_{i 2}{ }^{E \kappa H}$ & $3_{i 2}{ }^{C u}$ & $3_{i 2}^{\text {Eкл }}$ & $3_{i 2}^{\text {Екн }}$ & $3_{i 2}$ \\
\hline 3 & Лісова смуга & $B m_{i 3}{ }^{C u}$ & $B m_{i 3}^{\text {Eкл }}$ & $B m_{i 3}^{\text {EкH }}$ & $3_{i 3}{ }^{C u}$ & $3_{i 3}^{\text {Екл }}$ & $3_{\text {iз }}^{\text {Екн }}$ & $3_{i 3}$ \\
\hline$\ldots$ & $\ldots$ & $\ldots$ & $\ldots$ & $\ldots$ & $\ldots$ & $\ldots$ & $\ldots$ & $\ldots$ \\
\hline \multirow[t]{3}{*}{$\mathrm{N}$} & Автотраса & $B m_{i N}{ }^{c u}$ & $B m_{i N}^{\text {Eкл }}$ & $B m_{i N}^{\text {Екн }}$ & $3_{i N} \mathrm{Cu}$ & $3_{i N}^{\text {Екл }}$ & $3_{i N}^{\text {Екн }}$ & $3_{i N}$ \\
\hline & Всього & $B m_{i}^{C u}$ & 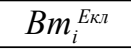 & $B m_{i}^{\text {Еки }}$ & $3_{i}^{C u}$ & $3_{i}^{\text {Екл }}$ & $3_{i}^{\text {Екн }}$ & $3_{i}$ \\
\hline & & \multicolumn{3}{|c|}{ Загальна втрата $B m_{i}$} & \multicolumn{4}{|c|}{ Загальний річний збиток 3} \\
\hline
\end{tabular}

* Складові втрат від паводків в таблиці наводять у вигляді символів, а фізичні величини втрат та їх розрахунки наводять в додатках. ** Кількісні показники збитків від паводків наводять в таблиці, а їх розрахунки в додатках 


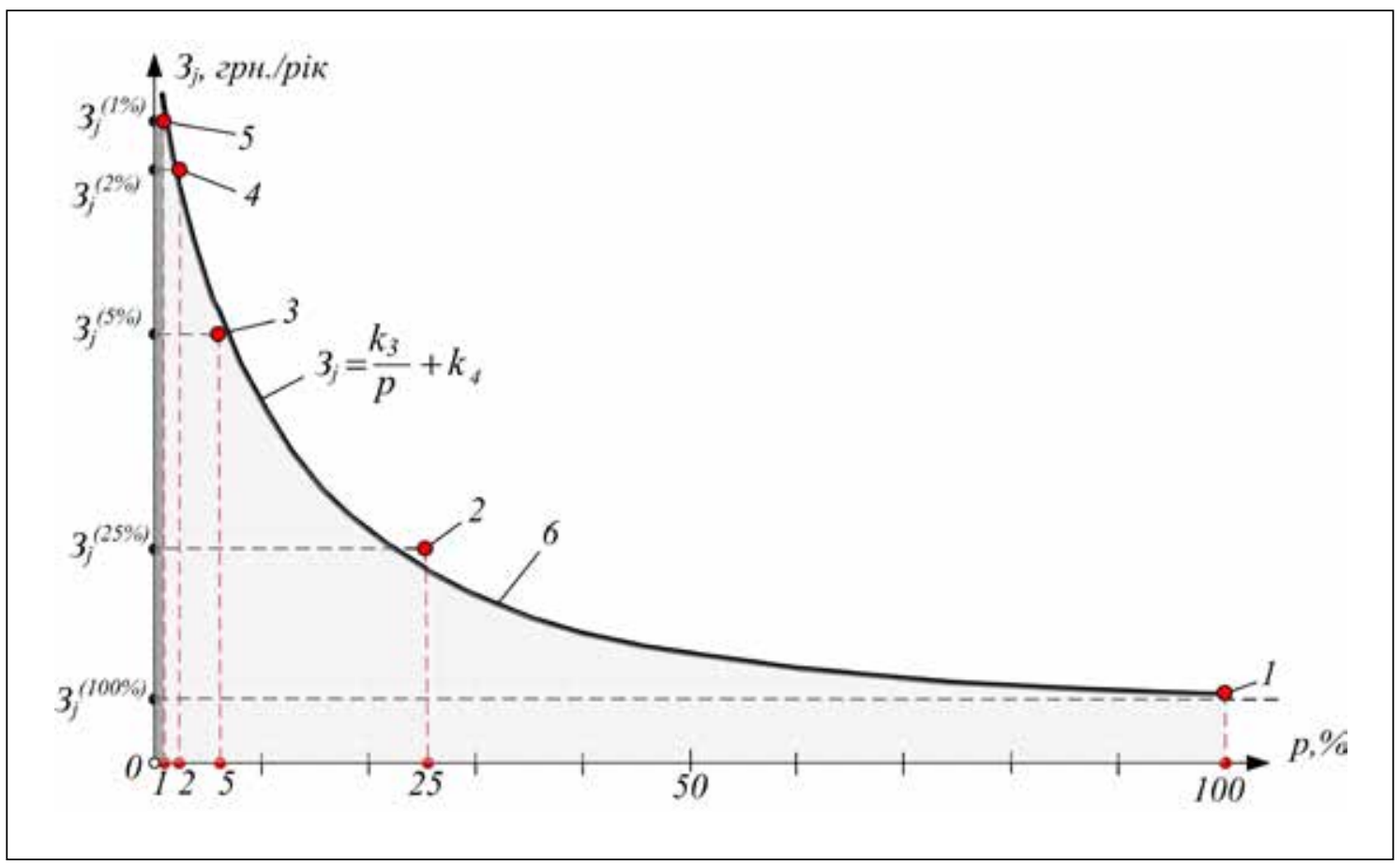

Рис. 4. Апроксимація гіперболічною залежністю загального річного збитку $3_{j}$ від забезпеченості паводка р в j-й зоні паводкових ризиків: 1-5 - розрахункові за формулою (9) точки ( $\left.3_{i}, p_{i}\right)$, відповідні n'ятьом базовим рівням інтенсивності паводка (i=1-5); 6 -графік функції $3_{j}=f_{2}(p)$

$$
3_{j}=\frac{k_{3}}{p}+k_{4} .
$$

За параметрами $\left(3_{i}, p_{i}\right)$ розрахункових точок 1-5 (рис. 4), використовуючи метод найменших квадратів, знаходять коефіцієнти $k_{3}$ і $k_{4}$ з системи рівнянь:

$$
\left\{\begin{array}{c}
k_{3}=\frac{5 \sum_{i=1}^{5} \frac{3_{i}}{p_{i}}-\sum_{i=1}^{5} \frac{1}{p_{i}} \cdot \sum_{i=1}^{5} 3_{i}}{5 \sum_{i=1}^{5}\left(\frac{1}{p_{i}}\right)^{2}-\left(\sum_{i=1}^{5} \frac{1}{p_{i}}\right)^{2}} \\
k_{4}=\frac{\sum_{i=1}^{5} 3_{i}-k_{3} \sum_{i=1}^{5} \frac{1}{p_{i}}}{5}
\end{array}\right.
$$

Визначення ризиків затоплення за гідрологічними показниками за формулою (5) і показниками збитку за формулою (9) дає змогу на основі статистичних даних відносно невеликої кількості паводків минулого періоду здійснювати довгострокове прогнозування паводків на майбутній період.

Зваживши на основний принцип дослідження паводків, який полягає у необхідності врахування протягом одного року тільки одного найбільш інтенсивного паводка [9], а також на те, що кількість паводків, які повторюються протягом 100 років, відповідає величині їх забезпеченості, визначеної у відсотках, довгострокове прогнозування паводків доцільно здійснювати на майбутній період часу у 100 років. У такому разі, замінивши параметр часу $t$ на параметр забезпеченості паводків $p$, довгострокове прогнозування паводків за гідрологічними показниками і показниками збитків можна здійснювати на періоді часу у 100 років шляхом інтегрування функцій (5) і (9). Важливими показниками оцінки ризику затоплення та рівня паводкової небезпеки в $j$-й зоні паводкових ризиків є середньорічна витрата паводка $Q_{j}^{c p}$ в розрахунковому гідрометричному створі і середньорічний збиток $3_{j}^{c p}$ від паводка. Для їх прогнозування застосовують формули:

$$
\begin{aligned}
& Q_{j}^{c p}=\frac{1}{100-p_{0}} \int_{p_{0}}^{100}\left(\frac{k_{1}}{p}+k_{2}\right) d p=\frac{\left.\left(k_{1} \ln p+k_{2} p\right)\right|_{p_{0}} ^{100}}{100-p_{0}}= \\
& =\frac{k_{1} \ln \left(100-p_{0}\right)}{100-p_{0}}+k_{2} ; \\
& 3_{j}^{c p}=\frac{1}{100-p_{0}} \int_{p_{0}}^{100}\left(\frac{k_{3}}{p}+k_{4}\right) d p=\frac{k_{3} \ln \left(100-p_{0}\right)}{100-p_{0}}+k_{4},
\end{aligned}
$$

де $Q_{j}^{c p}$ - середньорічна пікова витрата води в розрахунковому створі річки, $\mathrm{M}^{3} / \mathrm{c} ; 3_{j}^{c p}-$ середньорічний збиток від паводка в $j$-й зоні паводкових ризиків, тис. грн./рік (тис. грн./паводок); $p_{0}-$ мінімальна для $j$-ї зони паводкових ризиків величина забезпеченості паводка, яку встановлюють згідно статистики паводків в зоні паводкових ризиків за минулі роки, $\%$ (зазвичай приймають $p_{0} \cong 1 \%$ ).

4. Розроблення планів управління ризиками затоплення. У планах управління ризиками затоплення визначають комплекс заходів, призначених 
для зменшення або відвернення негативних наслідків затоплення, та порядок виконання цих заходів. Розрізняють два принципово відмінних типи захисту від паводків: ситуаційний і превентивний. Захист ситуаційного типу виконують шляхом короткострокового прогнозування паводків та здійснення захисних заходів в період від виникнення до завершення паводкової ситуації, а превентивний тип захисту виконують шляхом довгострокового прогнозування паводків та здійснення превентивних заходів, головним чином гідротехнічних. Отже, залежно від типу захисту, протипаводкові заходи поділяють на ситуаційні і превентивні. Їх ще розрізняють за видами, варіантами та порядком виконання (табл. 3) [10].

Захист від паводків потребує значних фінансових і матеріальних витрат, тому під час розроблення планів управління ризиками затоплення для кожної $j$-ї зони паводкових ризиків слід обирати оптимальний тип, вид та варіант протипаводкових заходів, використовуючи схему (табл. 3) та цільову функцію:

$$
I_{j}=\frac{B 3_{j}^{c p}}{B_{j}^{c p}} \rightarrow \max ,
$$

де $I_{j}-$ індекс ефективності плану управління ризиками затоплення; $B 3_{j}^{c p}-$ відвернені збитки, які за величиною відповідають середньорічним збиткам $\left(B 3_{j}^{c}=3_{j}^{c p}\right)$ і враховуються як позитивний ефект здійснення протипаводкових заходів, тис. грн./рік; $B_{j}^{c p}$ - середньорічні капітальні і поточні витрати на здійснення заходів, тис. грн./рік.

Встановлено, що в басейнах паводковонебезпечних річок превентивні заходи мають більший індекс ефективності $[10 ; 11]$. Проте, в основу розроблення планів управління ризиками затоплення слід закладати ситуаційні заходи, оскільки превентивні заходи виконують переважно із застосуванням захисних споруд, які на момент розроблення планів можуть бути ще не побудовані.
Для кожної $j$-ї зони паводкових ризиків річкового басейну розроблюють п'ять планів управління ризиками затоплення, поклавши в їх основу п'ять карт ризиків затоплення паводками п'яти базових рівнів інтенсивності. Плани управління ризиками затоплення $j$-ї зони паводкових ризиків повинні містити комплекс ситуаційних заходів, які спільні за їх видами (попереджувальні, аварійно-рятувальні, аварійно-відновлювальні), але відрізняються переліком та обсягом робіт, залежно від закладеного в їх основу одного $з$ п'яти базових сценаріїв затоплення. Плани управління ризиками затоплення також повинні містити заходи регулювання паводкового потоку за допомогою захисних споруд (огороджувальних дамб, берегозахисних покриттів, водосховищ та ін.), які були раніше побудовані на стадії здійснення превентивних заходів.

Оскільки гідрологічний стан в $j$-й зоні паводкових ризиків впливає на гідрологічний стан нижче розташованих зон паводкових ризиків, розроблення карт небезпек затоплення, карт ризиків затоплення та планів управління ризиками затоплення треба починати 3 верхів'я річки та іiі приток. Після здійснення кожного превентивного заходу в $j$-й зоні паводкових ризиків варто виконувати корегування карт небезпек затоплення, карт ризиків затоплення та планів управління ризиками затоплення як для $j$-ї, так і для всіх нижче розташованих зон паводкових ризиків гідрографічного басейну, який може бути розташований на території декількох країн.

Головні висновки. Проблему паводків розглянуто як одну 3 глобальних проблем людства, для рішення якої на міжнародному рівні була прийнята Директива 2007/60/ЄС «Про оцінку і управління ризиками затоплення». Проте встановлено, що основні положення цієї Директиви, а також розроблені методичні документи iï впровадження

Таблиця 3

Системна схема управління ризиками затоплення

\begin{tabular}{|c|c|c|c|c|c|c|c|c|c|c|c|}
\hline \multirow{5}{*}{ 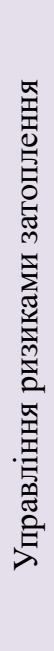 } & \multirow{2}{*}{\multicolumn{5}{|c|}{$\begin{array}{c}\text { Обгрунтування заходів } \\
\text { захисту від паводків }\end{array}$}} & \multicolumn{6}{|c|}{ Тип захисту від паводків } \\
\hline & & & & & & \multirow{2}{*}{\multicolumn{3}{|c|}{$\frac{\text { Ситуаційний }}{\text { Короткостроковий }}$}} & \multirow{2}{*}{\multicolumn{3}{|c|}{$\frac{\text { Превентивний }}{\text { Довгостроковий }}$}} \\
\hline & \multirow{3}{*}{ 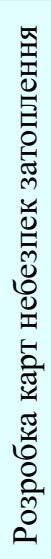 } & \multirow{3}{*}{ 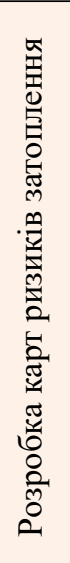 } & \multirow{3}{*}{ 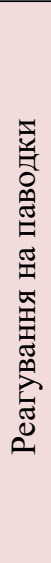 } & \multicolumn{2}{|c|}{$\begin{array}{l}\text { Прогноз } \\
\text { паводків } \\
\end{array}$} & & & & & & \\
\hline & & & & \multirow{2}{*}{ 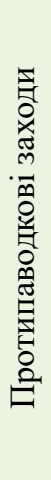 } & 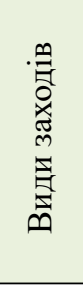 & 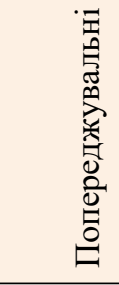 & 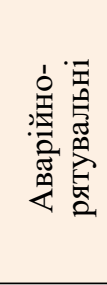 & 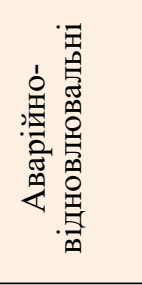 & 寻 & 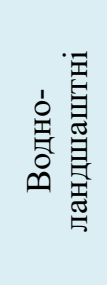 & 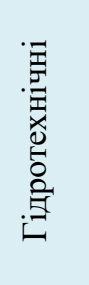 \\
\hline & & & & & 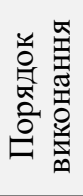 & \multicolumn{3}{|c|}{$\begin{array}{c}\text { Послідовне виконання всіх видів } \\
\text { ситуаційних заходів в єдиному } \\
\text { процесі в період наближення, } \\
\text { проходження і завершення паводків }\end{array}$} & \multicolumn{3}{|c|}{$\begin{array}{c}\text { Виконання одного з видів } \\
\text { превентивних заходів, обраного } \\
\text { за результатами обгрунтування } \\
\text { їх технічної надійності } \\
\text { і економічної ефективності }\end{array}$} \\
\hline
\end{tabular}


в Україні, не містять універсального строго алгоритмізованого підходу до управління паводковими ризиками, а мають загальний рекомендаційний характер, що зумовлює певні труднощі розробки планів управління паводковими ризиками в річкових басейнах.

Відповідно до основних положень Директиви 2007/60/СС створено принципово новий науково-методичний інструментарій оцінки ризиків затоплення та розроблення планів управління ризиками затоплення, за яким у річковому басейні виділяють зони паводкових ризиків, у межах яких розрізняють п'ять зон затоплення паводками п'яти базових рівнів інтенсивності, визначених за фіксованими рівнями вірогідності паводків.

Ризики затоплення запропоновано оцінювати за гідрологічними показниками паводків і показниками збитку від паводків, які представлено у вигляді спадних гіперболічних функцій забезпеченості паводків.

Запропоновано системну схему управління ризиками затоплення, за якою заходи захисту від паводків запропоновано ділити на ситуаційні і превентивні, а також розрізняти заходи за видами, варіантами та порядком виконання.

В основу розроблення планів управління ризиками затоплення запропоновано закладати ситуаційні заходи 3 урахуванням раніше виконаних превентивних заходів, а після здійснення кожного наступного превентивного заходу плани запропоновано корегувати.

Розроблення та корегування планів управління ризиками затоплення запропоновано починати з вищерозташованих по течії річки зон затоплення.

Перспективи використання результатів дослідження. Створений за результатами дослідження новий науково-методичний інструментарій оцінки ризиків затоплення та розроблення планів управління ризиками затоплення містить більш досконалу алгоритмізовану процедуру управління паводковими ризиками, використання якої забезпечить підвищення ефективності заходів протипаводкового захисту в річкових басейнах, а також прискорить процес впровадження Директиви 2007/60/СС в Україні та країнах ЄC.

\section{Література}

1. Директива 2007/60ЄС Європейського Парламенту і Ради від 23 жовтня 2007 року «Про оцінку і управління ризиками затоплення».

2. Директива 2000/60/ЄС Європейського Парламенту і Ради від 23 жовтня 2000 року «Про встановлення рамок діяльності Співтовариства в галузі водної політики».

3. Постанова Кабінету Міністрів України від 25 жовтня 2017 р. № 1106 «Про виконання Угоди про асоціацію між Україною, з однієї сторони, та Європейським Союзом, Свропейським співтовариством з атомної енергії і їхніми державами-членами, 3 іншої сторони».

4. Наказ МВС України від 17 січня 2018 р. № 30 «Про затвердження Методики попередньої оцінки ризиків затоплення».

5. Наказ МВС України від 28 лютого 2018 р. № 153 «Про затвердження Методики розроблення карт загроз і ризиків затоплення».

6. Постанова Кабінету Міністрів України від 4 квітня 2018 р. № 247 «Про затвердження Порядку розроблення плану управління ризиками затоплення».

7. Козицький О.М., Шевчук С.А., Шевченко І.А. Моніторинг і управління гідрологічними ризиками в басейнах річок України. 36. матер. Міжнар. наук.-практ. конф. «Природа для води», присвяченої Всесвітньому дню води (22 березня 2018 р.). Київ : НААН України, ІВПіМ НААН, Глобальне водне партнерство. 2018. С. 87-88.

8. Козицький О.М., Шевчук С.А., Шевченко І.А. Визначення рівнів паводкового ризику в басейнах річок України. Меліорація i водне господарство. 2019. Вип. 110. С. 157-166.

9. СНиП 2.01.14-83. Определение расчетных гидрологических характеристик. Госстрой СССР. Москва : Стройиздат, $1985.36 \mathrm{c}$.

10. Петроченко А.В. Классификация паводков и систематизация противопаводковых мероприятий. Мелиорация. Минск, 2019. № 3 (89). С. 30-37.

11. Петроченко В.И., Петроченко А.В. Научно-методическое обоснование систем превентивной противопаводковой защиты территорий в бассейнах рек. Вестник Брестского государственного технического университета. 2018. № 2 (110): Водохозяйственное строительство и теплоэнергетика. С. 44-48.

12. Методика оцінки збитків від наслідків надзвичайних ситуацій техногенного і природного характеру. Затверджена Постановою Кабінету Міністрів України від 15 лютого 2002 р. № 175.

13. Петроченко В.І., Сташук В.А. Еколого-економічна ефективність протипаводкових заходів. Київ : ДІУЕВР. 2009.62 с.

14. Методические указания к решению задач по интерполяции функций. Составители: Калашников А.Л., Потёмин Г.В., Федоткин А.М., Фокина В.Н. Учебно-методическое пособие. Нижний Новгород : Нижегородский госуниверситет, $2016.35 \mathrm{c}$. 


\title{
ДАТЧИК ДАЯ ВИМІРЮВАННЯ ТЕМПЕРАТУРИ В ПРІСНИХ ВОДОЙМАХ
}

\author{
Пількевич Ю.Г. ${ }^{1}$, Розорінов Г.М. ${ }^{2}$ \\ ${ }^{1}$ Київський національний університет будівництва і архітектури \\ Повітрофлотський пр., 31, 03680, м. Київ \\ y.rozorinova@gmail.com; \\ ${ }^{2}$ Національний технічний університет України \\ «Київський політехнічний інститут імені Ігоря Сікорського» \\ пр. Перемоги, 37, 03056, м. Київ \\ hnroz@ukr.net
}

\begin{abstract}
Майже всі водні ресурси України в останні роки інтенсивно забруднюються внаслідок збільшення впливу антропогенних чинників. Фактично в кожній із водойм можна легко зафіксувати перевищення допустимих норм забруднення. Для поліпшення стану водойм потрібно постійно проводити їхній екологічний моніторинг. Теплове забруднення належить до основних видів забруднення вод. Тепла вода змінює термічний і біологічний режими водойм і шкідливо впливає на їхніх мешканців. Вимірюють температуру води у водоймах переважно за допомогою переносних термометрів, що мають обмежений діапазон і невисоку точність.

Розроблений високоточний датчик для вимірювання температур у водних шарах прісних водойм, вимірювальний перетворювач якого $\epsilon$ схемою автогенератора, а як чутливий елемент використана високочастотна індуктивна котушка. Переваги датчика температури - точність $0,01^{\circ} \mathrm{C}$; надійність; стійкість до обростання; довговічність; зручність в експлуатації; стійкість до зовнішнього тиску; відсутність регулювання; відсутність випадкової похибки.

Високочастотна котушка індуктивності має стрижневе осердя. Осердя виконане з термомагнітного матеріалу - кальмаллоя, який має лінійну характеристику перемагнічування. Для оцінки роботи електричної схеми датчика в діапазоні зміни інформативного параметра встановлено залежності вихідної напруги на виході випрямляча від індуктивності котушки щонайменше в трьох точках значень індуктивності: максимального, середнього і мінімального. Водночас суттєвим чином використано пакет графічного програмування LabView. Для роботи в діапазоні температур $0 \ldots 60^{\circ} \mathrm{C}$ вимірювальна схема повинна реагувати на зміну індуктивності в діапазоні $100 \ldots 200$ мкГн.

Для найкращого контакту датчика 3 навколишнім середовищем його покривають теплопровідною пастою типу КПТ-8 і поміщають в алюмінієвий балончик. Ключові слова: водойма, датчик температури, екологічний моніторинг, теплове забруднення.
\end{abstract}

A sensor for measuring of temperature in fresh reservoirs. Pilkevych Yu., Rozorinov $\mathrm{H}$.

Practically all Ukraine water resources in the last years are intensively contaminated as a result of increase of influence of anthropogenic factors. Actually in each of reservoirs it is possible easily to fix exceeding of possible norms of contamination. For the improvement of the state of reservoirs it is necessary constantly to conduct them ecological monitoring. Thermal contamination behaves to the basic types of water contamination. Warm water changes the thermal and biological modes of reservoirs and harmful influences on their inhabitants. Measure the temperature of water in reservoirs mainly by portable thermometers which have the limited range and low exactness.

A high-fidelity sensor is developed for measuring of temperatures in the water layers of fresh reservoirs, a measuring transformer of which is the chart of self-contained generator, but as pickoff a high-frequency inductive spool is utillized. Advantages of temperature sensor are exactness $0,01^{\circ} \mathrm{C}$; reliability; firmness to becoming overgrown; longevity; a exploitation comfort; firmness to external pressure; absence of adjusting; absence of random error term.

A high-frequency inductive spool has rod-type core. The core is executed from thermomagnetic material - calmalloy what has linear description of magnetization reversal.

For the estimation of work of electric chart of sensor in a turn-down informing parameter dependences of initial tension are set on the output of rectifier from inductance of spool minimum in three points of inductance values: maximal, middle and minimum. Thus a substantial rank the Labview package of the graphic programming is utillized. For work in the range of temperatures of $0 \ldots 60^{\circ} \mathrm{C}$ a measuring chart must react on changing of inductance in a range $100 \ldots .200 \mu \mathrm{H}$.

For the best contact of sensor with an environment, it is covered heat-conducting paste as KPT-8 and place in an aluminium bulb. Key words: reservoir, sensor of temperature, ecological monitoring, thermal contamination.

Постановка проблеми. Теплове забруднення належить до основних видів забруднення поверхневих та підземних вод. Тепла вода змінює термічний i біологічний режими водойм і шкідливо впливає на їхніх мешканців $[1 ; 2]$.

Аналіз фізичних параметрів води, особливостей сприйняття рибою деяких фізичних дій і їхній вплив на зростання й розвиток риби показали, що екологічний моніторинг біоти прісного водоймища повинен передбачати вимірювання одного 3 найважливіших параметрів води - температури з точністю до $0,01^{\circ} \mathrm{c}$.

У більшості видів риб вона на $0,5 \ldots 1^{\circ} \mathrm{C}$ вища за температуру води. У тунців під час швидкого руху різниця температур може досягати $10^{\circ} \mathrm{C}$. Діапазон 
переношуваних температур води у риб - від $+52^{\circ} \mathrm{C}$ до $-2^{\circ} \mathrm{C}$. Кожному виду властиві граничні й оптимальні температури води. Для карася нижня гранична температура води становить $0^{\circ} \mathrm{C}$, верхня $-+30^{\circ} \mathrm{C}$, оптимальна $-+25^{\circ} \mathrm{C}$. Стенотермні риби (тропічні, субтропічні, арктичні, антарктичні і глибоководні) мешкають у воді за вузького діапазону коливань iii температури $-5 \ldots 7^{\circ} \mathrm{C}$. Евритермні риби (риби помірних широт: щука, сазан, карась, окунь, тюлька) витримують значні коливання температури, до кількох десятків градусів.

Ба більше, у риб нерест наступає за певної температури, наприклад у судака - за температури $+17 \ldots 18^{\circ} \mathrm{C}$, у миня - за температури $+0,2 \ldots 4^{\circ} \mathrm{C}$. Виживання ікри для багатьох видів риб відбувається в діапазоні температур близько $+10 \ldots 15^{\circ} \mathrm{C}[3 ; 4]$.

Вимірюють температуру води у водоймах переважно за допомогою переносних індикаторів - термометрів, що мають обмежений діапазон і невисоку точність $[5 ; 6]$.
Метою роботи $є$ розроблення простого в експлуатації датчика для вимірювання температури у водних шарах прісних водойм із підвищеною точністю.

Виклад основного матеріалу. Враховуючи необхідність вимірювання температури води з точністю не нижче ніж $0,01^{\circ} \mathrm{C}$, тривале знаходження датчика у воді, що приводить до його заростання, зручного і надійного знімання даних, як чутливий елемент датчика використано котушку індуктивності із стрижневим осердям. Осердя виконане 3 термомагнітного матеріалу. На рис. 1 показано температурні залежності для деяких термомагнітних матеріалів [7].

3 огляду на те, що температура води в прісних водоймах зазвичай не виходить за межі діапазону $0 \ldots 30^{\circ} \mathrm{C}$, найбільш відповідним термомагнітним матеріалом є кальмаллой (сплав $\mathrm{Ni}-\mathrm{Cu}$ за 30-40\% змісту $\mathrm{Cu}$ ). У кальмаллоя залежність магнітної проникності від температури в цьому діапазоні майже лінійна.

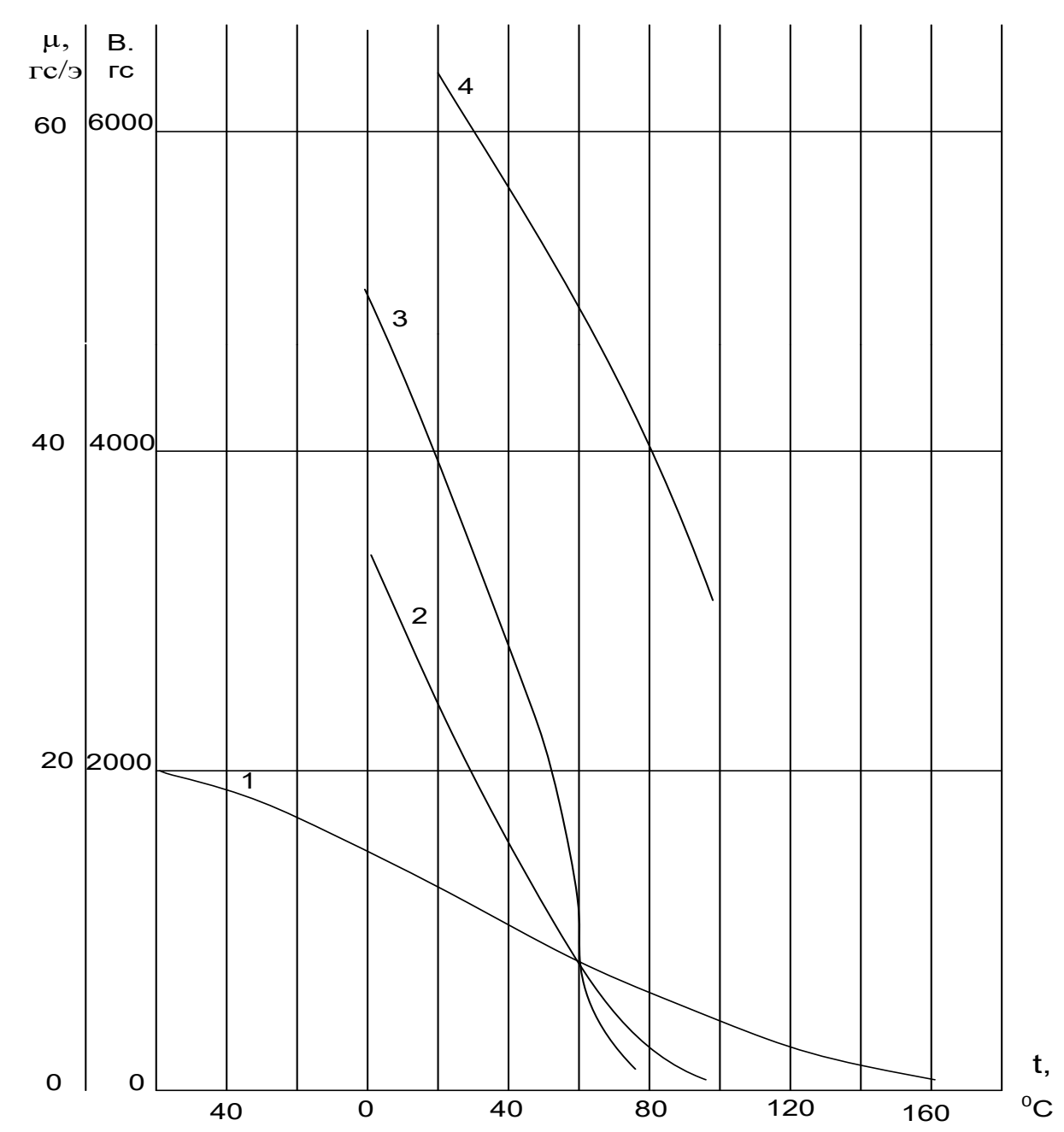

Рис. 1. Температурна залежність індукиії та магнітної проникності термомагнітних матеріалів за H=100 е: 1 - кальмаллой; 2 - термаллой; 3 - сплав компенсатор (7 \% Cr); 4 - сплав компенсатор $(10,5 \% \mathrm{Cr})$ 
Під час проведення експериментальних досліджень геометричні розміри осердя становили: діаметр $-d_{k}=5$ мм, довжина $-l_{k}=30$ мм, індуктивність котушки за температури $60^{\circ} \mathrm{C}-L_{k} \approx$ 100 мкГн. Товщина дроту обмотки вибрана рівною 0,1 мм. Число витків обмотки може бути визначене за формулою

$$
w=\sqrt{\frac{L_{k}}{L_{0}}} \cdot d_{k}
$$

де $L_{0}-$ коефіцієнт, який визначається за графіком, що показаний на рис. 2.

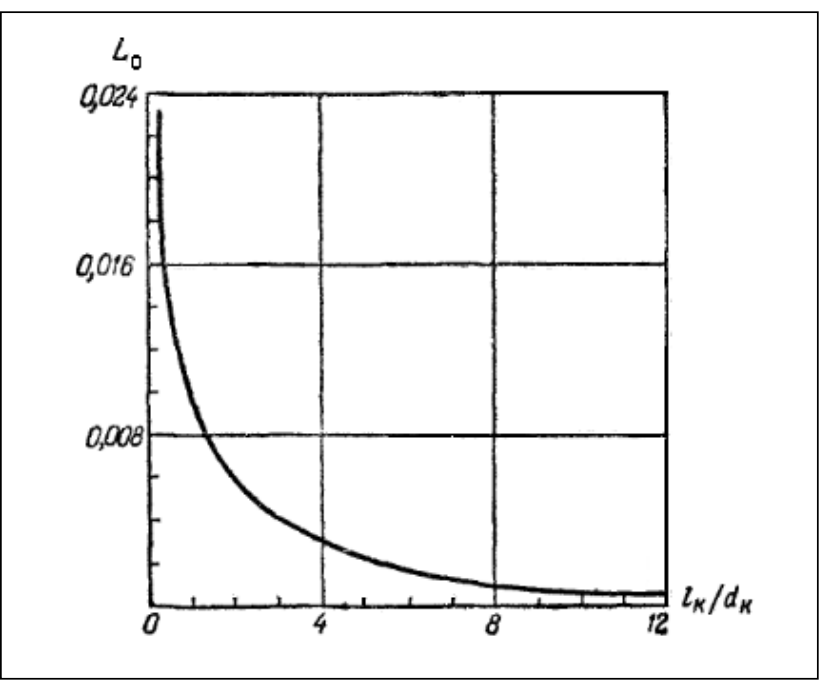

Рис. 2. Залежність коефіиієнта $L_{0}$ від відношення $l_{k} / d_{k}$

За $60^{\circ} \mathrm{C}$ ефективне значення магнітної проникності (близьке до магнітної проникності матеріалу, рис. 1) $\mu_{\text {еф }}=7$ гс/е, і кількість витків рівне: $w=\sqrt{\frac{100}{0,002}} \cdot 0,5=112$. Залежність індуктивності котушки від температури показано на рис. 3 .

Отже, для роботи в діапазоні температур $0 \ldots 60^{\circ} \mathrm{C}$ вимірювальна схема повинна реагувати на зміну індуктивності в діапазоні 100...200 мкГн.

Для забезпечення якнайкращого контакту датчика 3 навколишнім середовищем його покривають теплопровідною пастою, наприклад КПТ-8, і поміщають в алюмінієвий балончик. Індуктивну котушку включають у вимірювальну схему автогенераторного типу [8]. Вибір такої схеми пояснюється тим, що вона має найбільшу чутливість. Структурну схему вимірювальної частини датчика показано на рис. 4.

Під час зміни індуктивності котушки $L_{k}$ від температури змінюється вихідна напруга автогенератора, яка потім посилюється, випрямляється однонапівперіодним активним випрямлячем і відображається покажчиком середнього значення напруги. Використання активного випрямляча розширює динамічний діапазон схеми, оскільки дає можливість усунути падіння напруги на діодах.

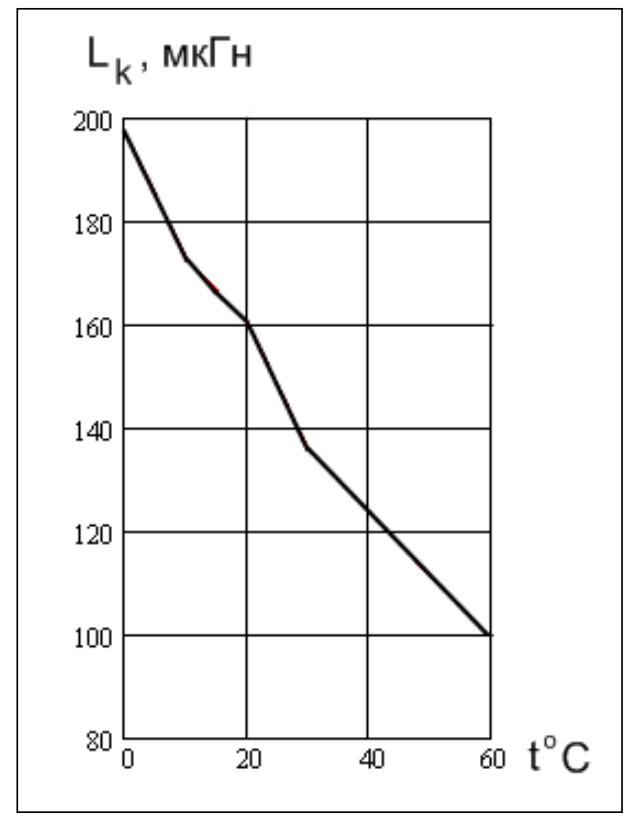

Рис. 3. Залежність індуктивності котушки від температури

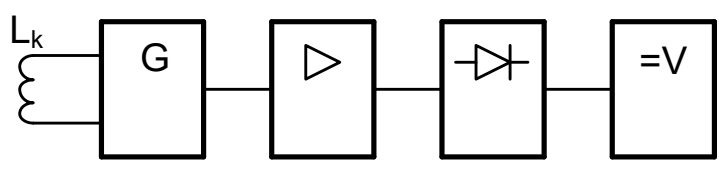

Рис. 4. Структурна схема вимірювальної частини датчика

Принципову схему вимірювального автогенератора показано на рис. 5 .

У схемі генератора режим роботи транзистора задається струмом бази, що протікає через резистор R1. У ланцюзі емітера встановлено коливальний контур, настроєний на частоту 159,235 мГц і активний опір R2, з якого знімається вихідний сигнал і завдяки якому підвищується еквівалентна добротність контуру. Резонансна частота цього контуру визначається за формулою:

$$
\omega=\frac{1}{\sqrt{L_{1} \cdot C_{3}}} .
$$

У ланцюзі бази встановлено інший контур, виконаний за схемою Колпітца [9], у який увімкнено обмотку індуктивної котушки. Спочатку цей контур за допомогою конденсатора С1 також настроюється на частоту 159,235 мГц.

Оскільки $C_{o}=\frac{C 1 \cdot C 2}{C 1+C 2}$, то $\omega_{o}=\frac{1}{\sqrt{L_{k} \cdot C_{o}}}$. Позитивний зворотний зв'язок у схемі забезпечується 3'єднанням емітера 3 контуром у ланцюзі бази транзистора.

Під час увімкнення живлення в контурі L1C3 завдяки обміну енергій електричного і магнітного полів виникає перехідний процес у вигляді синусоїдальних коливань із частотою 159,235 мГц. Оскільки 


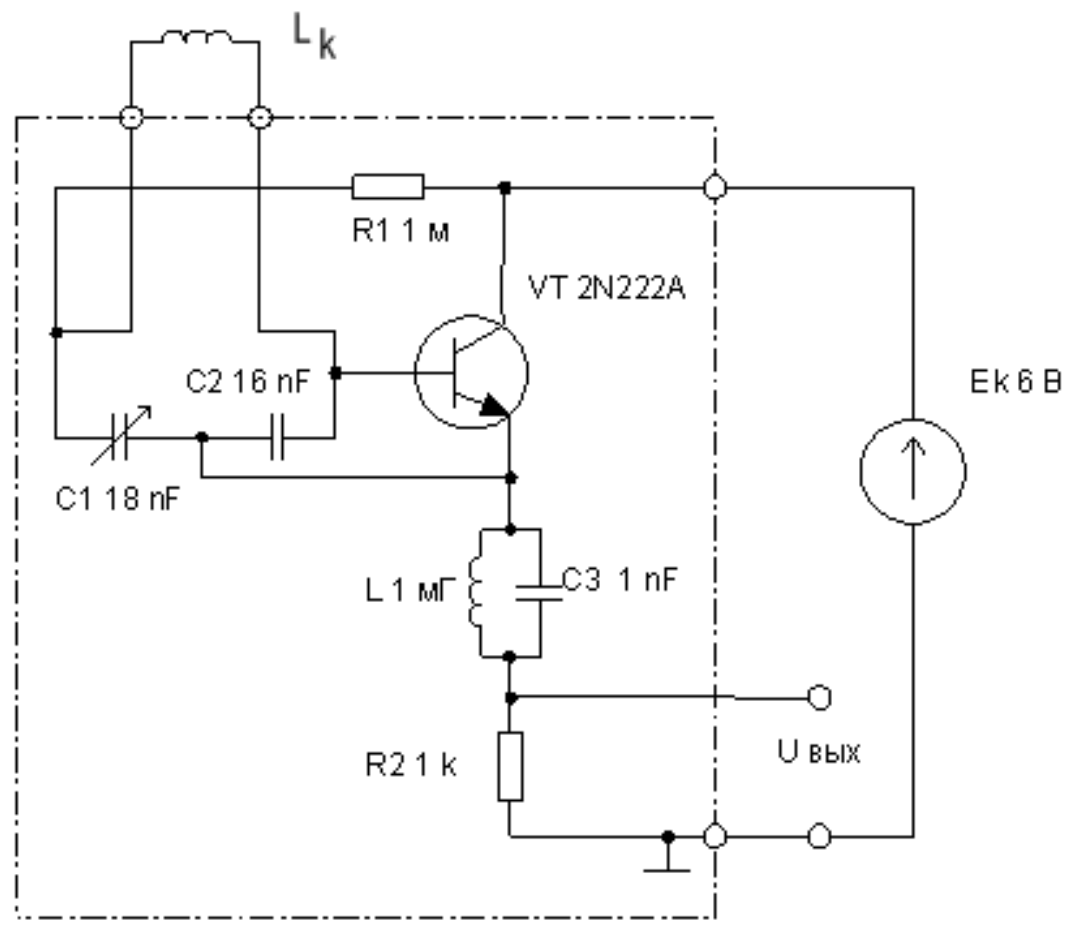

Рис. 5. Схема вимірювального автогенератора

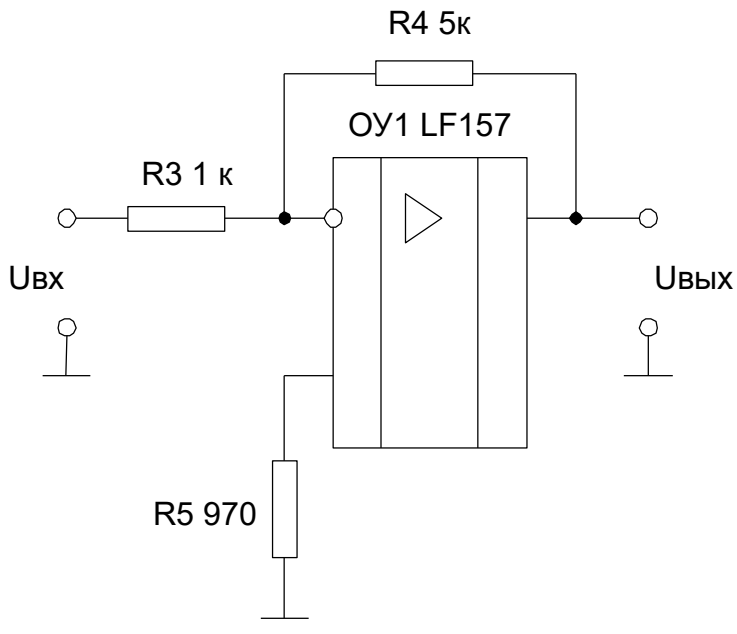

Рис. 6. Схема підсилювача постійного струму

транзистор працює в нелінійному режимі, то через його електроди протікає несинусоїдальний струм, який створює падіння напруги на резисторі R2.

Під час зменшення індуктивності котушки змінюється резонансна частота базового коливального контуру, унаслідок чого змінна напруга на базі зменшується й під час значення індуктивності 0,09 мГн повністю зникає. Це пов'язано зі зменшенням глибини позитивного зворотного зв'язку на частоті 159,235 мГц. Та сама ситуація має місце під час збільшення індуктивності котушки. Під час значення 0,25 мГн коливання також зриваються.

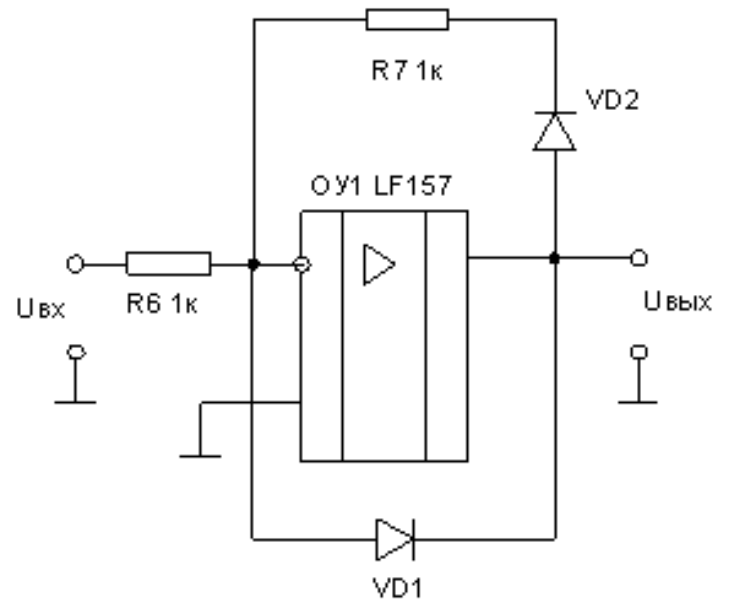

Рис. 7. Схема однонапівперіодного активного випрямляча

Підсилювач побудовано на швидкодіючому операційному підсилювачі ОУ 13 малими вхідними струмами (рис. 6). Коефіцієнт передачі задається резисторами R4 i R5 i рівний п'яти. Резистор R5 використовується для урівноваження струмів інверсного і прямого входів ОУ1 для зменшення зсуву нуля. Схему однонапівперіодного активного випрямляча також виконано на операційному підсилювачі (рис. 7). Як діоди можна використовувати будь-які діоди Шоттки.

Повну схему вимірювальної частини датчика було промодельовано в програмі Electronics Workbench Professional (рис. 8). 


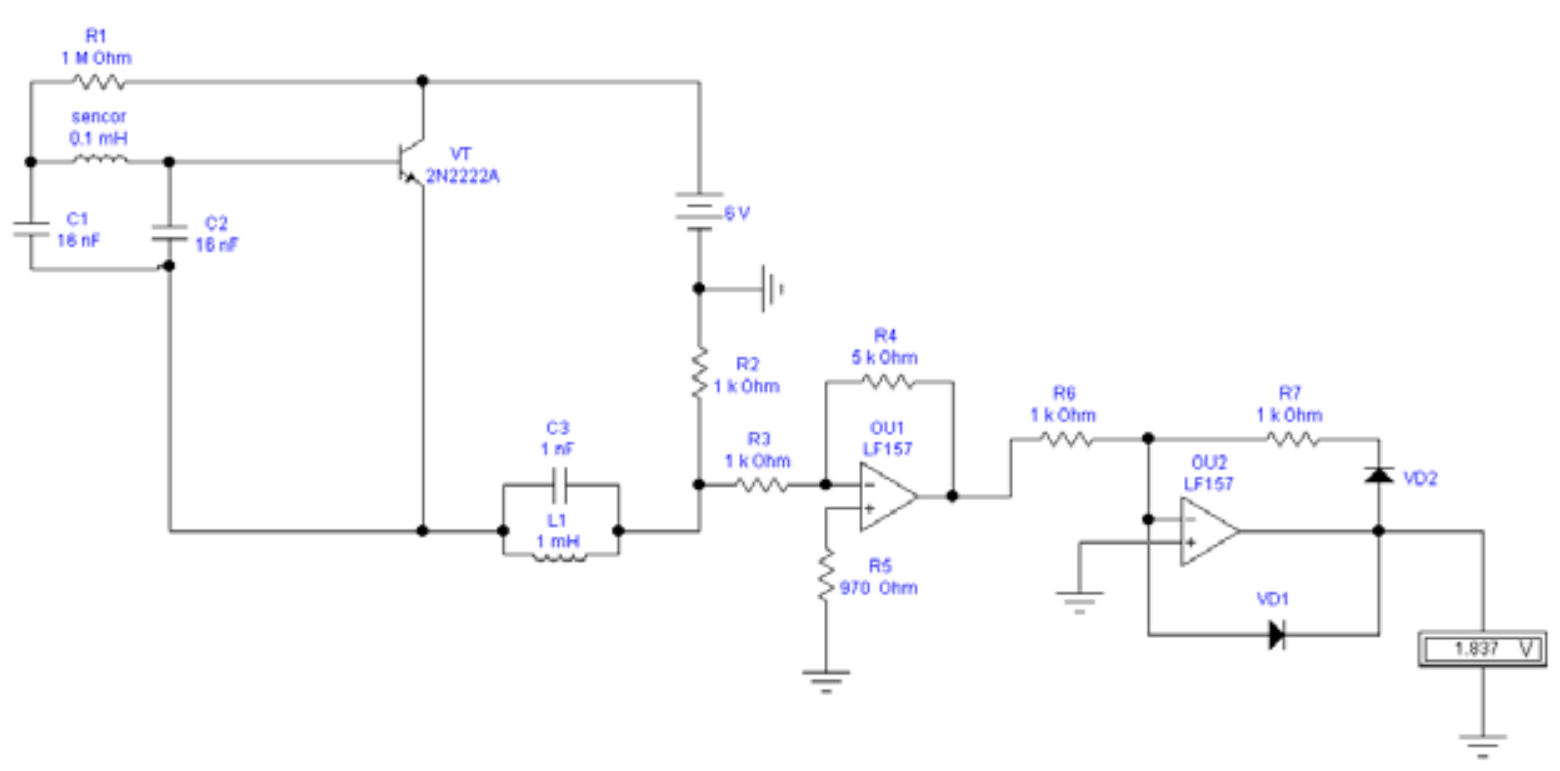

Рис. 8. Модель схеми вимірювальної частини датчика

Для оцінки роботи схеми в діапазоні зміни інформативного параметра встановлено залежності вихідної напруги на виході випрямляча від індуктивності датчика щонайменше в трьох точках значень індуктивності: максимального, середнього і мінімального. Водночас суттєвим чином використано пакет графічного програмування LabView.

Форми сигналу на виході генератора (темний колір) і випрямляча (світлий колір) за значень індуктивності $0,12 \mathrm{мГн;} 0,15$ мГн і 0,2 мГн показано на рис. 9, а-в.

Для найкращого контакту датчика 3 навколишнім середовищем його покривають теплопровідною пастою на зразок КПТ-8 і поміщають в алюмінієвий балончик.

Висновки. Розроблено й випробувано простий в експлуатації датчик для вимірювання температури у водних шарах прісних водойм із точністю $0,01^{\circ} \mathrm{C}$.

Як чутливий елемент датчика використано котушку індуктивності із стрижневим осердям із термомагнітного матеріалу на зразок кальмаллоя.

Для підвищення чутливості датчика котушку індуктивності ввімкнено у вимірювальну схему автогенераторного типу.

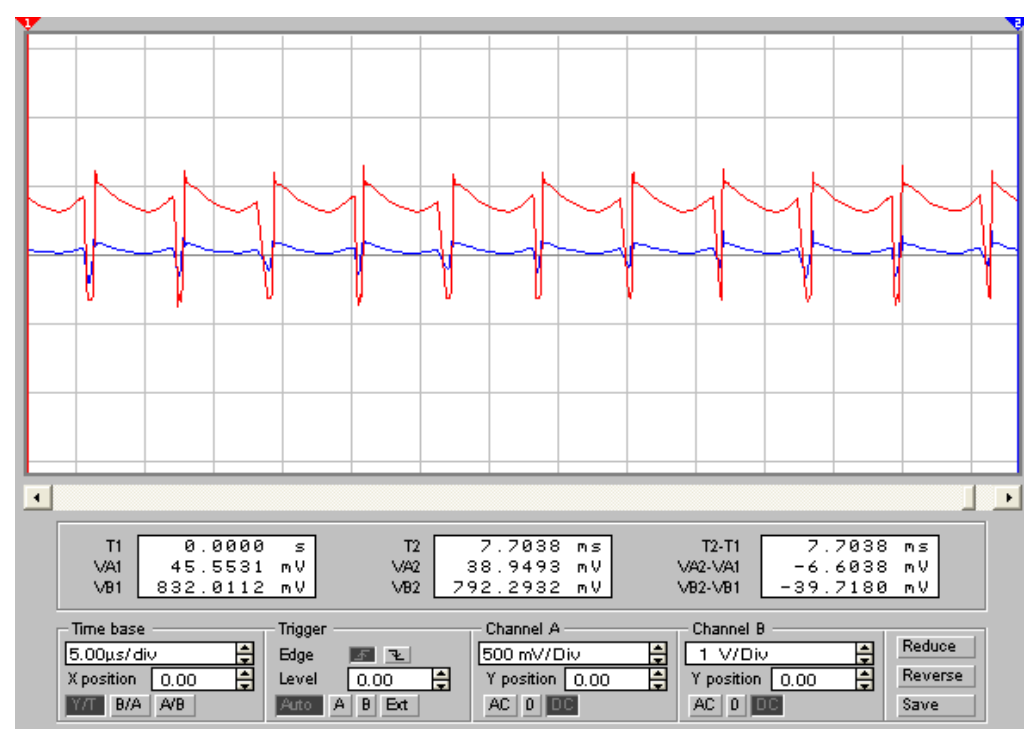

a)

Рис. 9. Форми сигналів на виході генератора й випрямляча за значень індуктивності: $a-0,12 м Г$; б-0,15 мГн; в-0,2 мГн 


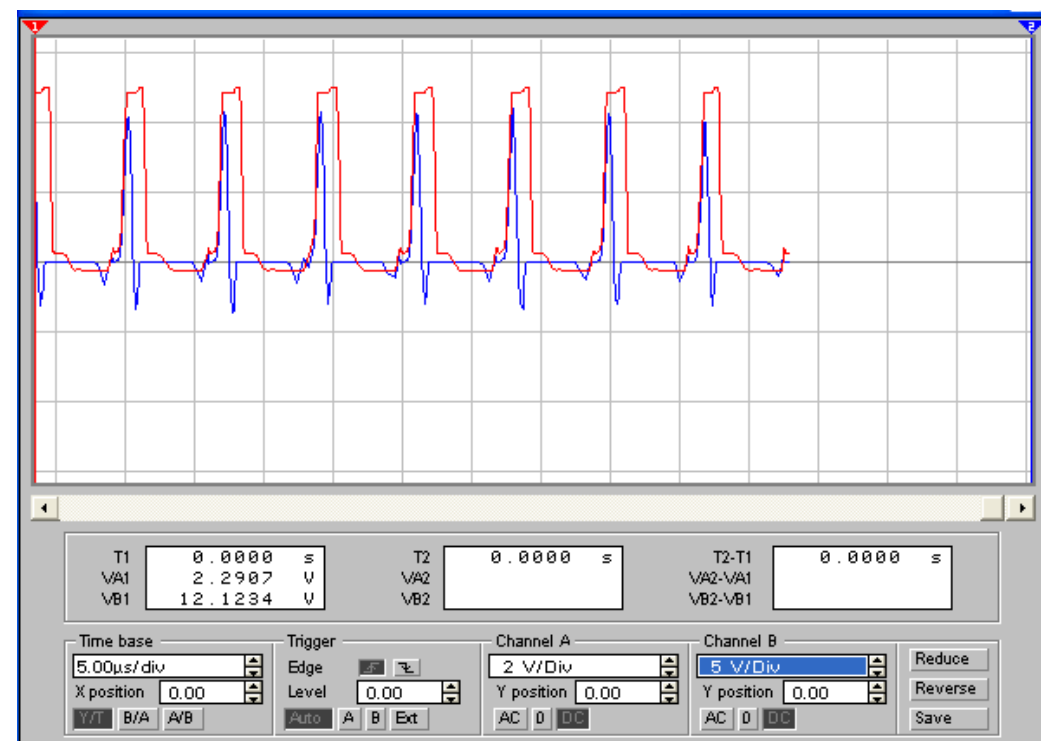

б)

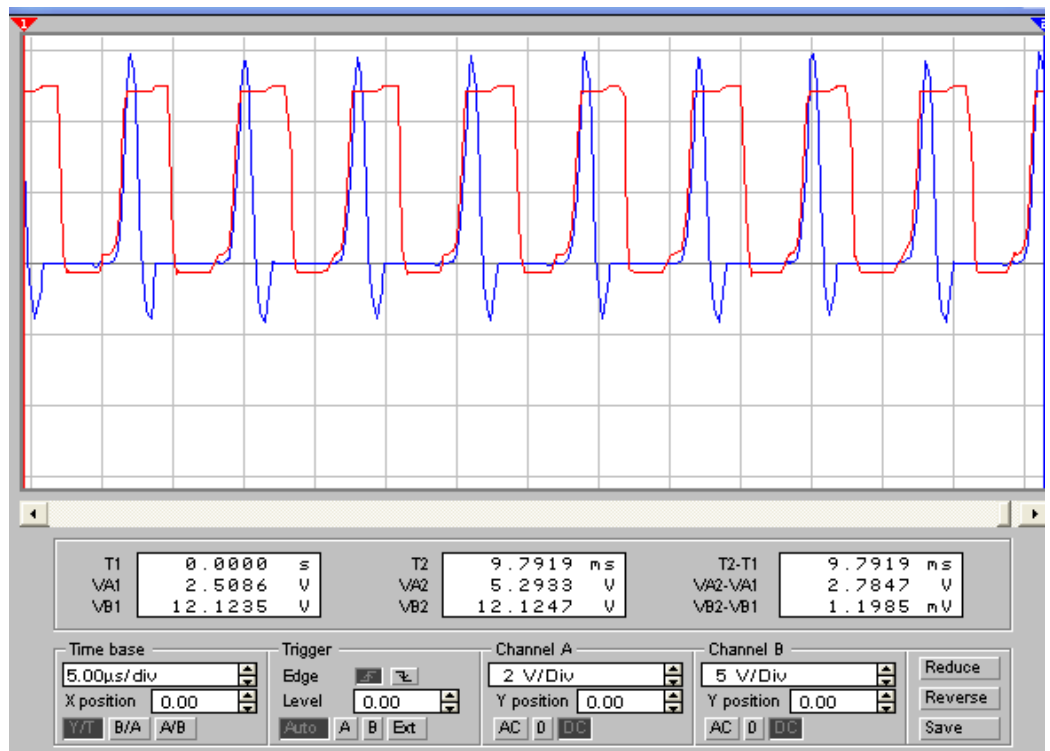

в)

Pис. 9. (Закінчення)

\section{Література}

1. Воронцов А.И., Николаевская Н.Г. Вопросы экологии и охраны водной среды. Москва : Инфра-М, 2011. 98 с.

2. Исмагилов Р.Р. Проблема загрязнения водной среды и пути ее решения. Молодой ученый. 2012. № 11 (46). С. $127-129$.

3. Фундаментальные основы управления биологическими ресурсами: стат. сб. Товарищество научных изданий КМК. Москва, 2005. $592 \mathrm{c}$.

4. Черняев Ж.А. Воспроизводство сиговых рыб. Эколого-физиологические особенности размножения и развития. Товарищество научных изданий КМК. Москва, 2017. 329 с.

5. Фрайден Дж. Современные датчики. Справочник. Москва : Техносфера, 2005. 592 с.

6. Датчики : справочное пособие / под общ. ред. В.М. Шарапова, Е.С. Полищука. Москва : Техносфера, 2012. 624 с.

7. Конструкционные электротехнические материалы : учеб. пособие / В.П. Горелов, С.В. Горелов, В.С. Горелов, Е.А. Григорьев ; под ред. В.П. Горелова. 5-е изд. стер. Москва : Берлин: Директ-Медиа, 2016. 340 с.

8. Михлин Б.З. Высокочастотные емкостные и индуктивные датчики. Москва : Государственное энергетическое издательство, 1960. 72 с.

9. Карлащук В.И. Электронная лаборатория на IBM РС. Москва : СОЛОН-Пресс, 2003. 736 с. 


\title{
СУЧАСНI МЕТОДИ АНАМІЗУ НАПРУЖКНО-ДЕФОРМОВАНОГО СТАНУ ДОРОЖНЬОГО ОДЯГУ
}

\author{
Салій І.В. ${ }^{1}$, Кияшко В.Т. ${ }^{1}$, Косарчук В.В. ${ }^{2}$, Агарков О.В. ${ }^{2}$, Ковальчук В.В. ${ }^{2}$, Чаусов М.Г. ${ }^{3}$ \\ ${ }^{1}$ Державна екологічна академія післядипломної освіти та управління \\ вул. Митрополита Василя Липківського, 35, корп. 2, 03035, м. Київ \\ deaohoronapraci@gmail.com; \\ ${ }^{2}$ Державний університет інфраструктури та технологій \\ вул. Кирилівська, 9, 04071, м. Київ \\ kosarchuk_vv@gsuite.duit.edu.ua, agarcov@gmail.com,kovalchuk_vv@gsuite.duit.edu.ua; \\ ${ }^{3}$ Національний університет біоресурсів і природокористування України \\ вул. Героїв оборони, 15, 03041, м. Київ \\ m.g.chausov@gmail.com
}

\begin{abstract}
Мета роботи - аналіз основних напрямів використання чисельних методів механіки деформованого твердого тіла, зокрема методу скінченних елементів для розрахунку напружено-деформованого стану елементів конструкції дорожнього одягу. У нормативних документах, що регламентують порядок указаних розрахунків, використовують занадто спрощені розрахункові схеми, які не відображають особливості структури, взаємодії та механічної поведінки елементів дорожнього одягу різних типів. Тому результати таких розрахунків суттєво залежать від великої кількості емпіричних поправочних коефіцієнтів. Під час використання методу скінченних елементів можна за однією розрахунковою схемою розглядати одночасний вплив усіх складників напружено-деформованого стану й брати до уваги водночас реальні геометричні форми досліджуваних об'єктів. Актуальність роботи зумовлена тим, що цей метод останнім часом дедалі частіше стали використовувати в практиці проєктування автомобільних доріг. Визначено основні напрями використання методу скінченних елементів для проєктування дорожнього одягу, а саме: розрахунки теплового і напружено-деформованого стану складових елементів дорожнього одягу за різних умов температурно-силового навантаження; верифікація чисельних розрахунків за результатами експериментальних досліджень моделей дорожнього одягу на спеціальних лабораторних стендах; створення спеціального програмного забезпечення для проведення багатоваріантних розрахунків. Аналіз опублікованих результатів досліджень, проведений у роботі, дає змогу стверджувати, що під час правильного вибору розрахункової схеми метод скінченних елементів забезпечує доволі точні оцінки для напружень і деформацій у такій складній конструкції, як багатошаровий дорожній одяг. Використання чисельних методів розрахунку напружено-деформованого стану елементів конструкції дорожнього одягу має великі перспективи для практичного використання. Тому в Україні є необхідність систематизувати відповідні дослідження і скоординувати роботи науковців у цьому напрямі. Ключові слова: напружено-деформований стан, дорожній одяг, метод скінченних елементів.
\end{abstract}

Modern methods of analysis of stress-strain state of road pavement. Salii I., Kiyashko V., Kosarchuk V., Agarcov O., Kovalchuk V., Chausov M.

The aim of this article is to analyze the main ways of using numerical methods of mechanics of deformed solids, in particular, the method of finite elements to calculate the stress-strain state of structural elements of road pavement. The normative documents, that regulate the order of the specified calculations, use too simplified calculation schemes, which do not reflect features of structure, interaction and mechanical behavior of elements of road pavement of different types. Therefore, the results of such calculations significantly depend on a large number of empirical correction factors. When using the finite element method, it is possible to consider the simultaneous influence of all components of the stress-strain state according to one calculation scheme and to take the real geometric shapes of the studied objects into account. The relevance of this study is that recently usage of this method in the practice of road design increased significantly. The main directions of using the finite element method for designing pavement are determined, namely: calculations of thermal and stress-strain state of components of pavement under different conditions of temperature and power load; verification of numerical calculations based on the results of experimental studies of road clothing models on special laboratory stands; creation of special software for multivariate calculations. The analysis of the published research results carried out in this work allows us to state that with the correct choice of the calculation scheme the finite element method provides quite accurate estimates for stresses and strains in such a complex structure as multilayer road pavement. The use of numerical methods for calculating the stressstrain state of construction elements road pavement has great prospects for practical use. Therefore, in Ukraine there is a need to systematize relevant research and coordinate the work of scientists in this direction. Key words: stress-strain state, road pavement, finite element method. 
Постановка проблеми. Конструювання багатошарового дорожнього одягу жорсткого типу полягає в розробленні кількох варіантів конструкції для подальшого визначення товщини шарів і вибору оптимального варіанта. Водночас потрібно забезпечити міцність конструкції завдяки використанню матеріалів з оптимальними фізичними властивостями для заданих умов експлуатації. Розрахунок напружено-деформованого стану (НДС) є одним із найважливіших етапів проєктування конструкції дорожнього одягу. Точність і надійність таких розрахунків залежить від вибраних методів розрахунку та відповідних розрахункових схем. Розрахунки дорожнього одягу з використанням чисельних методів механіки деформованого твердого тіла потребують досить високої кваліфікації дослідника та спеціального вартісного програмного забезпечення. Тому вітчизняні проєктні організації використовують застарілі напівемпіричні нормативні методики. Нормативні документи [1-3] для аналізу НДС елементів дорожнього одягу регламентують використання доволі спрощених розрахункових схем. Це зумовлено тим, що для конструкцій дорожнього одягу складові елементи є структурно неоднорідними, мають різну механічну поведінку й водночас ще й контактують між собою. За таких вихідних умов задача розрахунку НДС є надзвичайно складною й поки що не має теоретичного розв'язання. Тому нормативні розрахунки як вихідні дані потребують великої кількості емпіричних коефіцієнтів. Це, зі свого боку, суттєво впливає на узгодженість отриманих результатів із даними практичних спостережень.

Перспективним напрямом для розрахунку НДС елементів конструкції дорожнього одягу є використання чисельних методів механіки деформованого твердого тіла, наприклад методу скінченних елементів (MCE) [4]. Проте сьогодні поки ще немає єдиної методики розрахунку напружено-деформованого стану елементів конструкції дорожнього одягу за допомогою МСЕ, яка була б регламентована в Україні або в інших країнах. Для вказаної складної конструкції (з погляду математичного моделювання) розрахунки доцільно виконувати з поступовим ускладненням розрахункової моделі з огляду на відповідний аналіз результатів. Саме за такого підходу можна визначити суттєві чинники й параметри розрахункової схеми, що впливають на результати розрахунків.

У роботі розглянуто основні напрями використання МСЕ для розрахунку НДС елементів дорожнього одягу.

Актуальність дослідження. Як і будь-яка інженерна споруда, конструкція дорожнього одягу має бути міцною, надійною, довговічною й відповідати певним експлуатаційним вимогам. Розвиток сучасних технологій спонукає науковців приділяти велику увагу розробленню нових і оптимізації наявних методів розрахунку дорожніх конструкцій. Використання
MCE для розрахунку напружено-деформованого і теплового стану конструктивних елементів дорожнього одягу донедавна було предметом тільки дисертацій [5; 6]. Проте останнім часом завдяки стрімкому розвитку обчислювальної техніки інтерес до таких досліджень значно зріс, особливо в розвинених країнах. Оскільки в нашій країні $є$ тільки поодинокі спроби використання МСЕ для розрахунку дорожніх покриттів, розгляньмо можливі напрями досліджень на прикладі публікацій у міжнародних журналах. Водночас зауважимо, що 3 огляду на обмежений обсяг статті будемо розглядати тільки деякі роботи, на матеріалі яких проілюструємо поступовий розвиток методики чисельних розрахунків стосовно аналізу НДС дорожнього покриття та перспективи використання цих результатів у практиці вітчизняних проєктних організацій.

Дослідження проведені в межах виконання етапу «Аналітичні та теоретичні дослідження основ проєктування дорожнього одягу жорсткого типу з використанням відходів гірничодобувної промисловості» НДР «Розроблення екологічно прийнятних технологій поводження 3 відходами гірничорудної та металургійної промисловості», номер Державної реєстрації 0120U101148.

Виклад основного матеріалу. Використанню МСЕ для розрахунку конструкцій дорожнього одягу присвячено чимало робіт, у більшості з яких розглянуто нежорсткі типи покриття. Перші роботи вказаного спрямування з'явилися в середині 60-х років минулого століття після розроблення універсальних пакетів прикладних програм, які реалізували MCE. Розглядалися доволі прості розрахункові схеми, у яких дорожній одяг моделювався плитою скінченного розміру, що складалася 3 кількох шарів із різними механічними властивостями $[7 ; 8]$. Транспортне навантаження моделювали вертикальними силами, рівномірно розподіленими по відбитку колеса. За такої постановки задачі плита перебувала у плоскому напруженому стані. Задача розв'язувалась у пружній осесиметричній постановці. Хоча така розрахункова схема суттєво відрізнялася від реальної конструкції дороги, результати розрахунків дали можливість перевірити точність самого методу скінченних елементів (на початку впровадження методики чисельних розрахунків у практику проєктно-конструкторських робіт у інженерів виникали сумніви щодо точності цього чисельного методу).

На рис. 1 порівнюються дані чисельних розрахунків із теоретичними (аналітичними) розрахунками плит методами теорії пружності (до речі, останні використовувались у відповідних нормативних документах того часу). Штриховими лініями показано результати розрахунку прогинів і вертикальних нормальних напружень багатошарової плити методом скінченних елементів, суцільними лініями результати розрахунків за аналітичними формулами теорії пружності. 


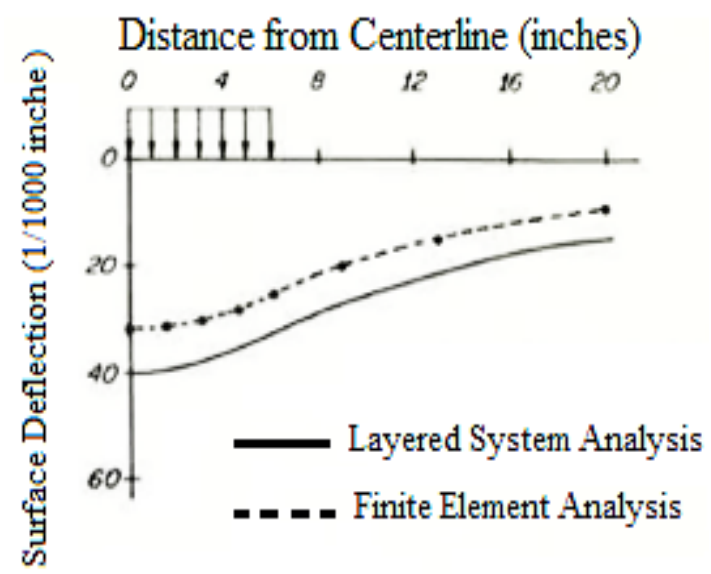

a)

\section{Vertical Normal Stress $\left(\mathrm{lb} / \mathrm{in}^{2}\right)$}

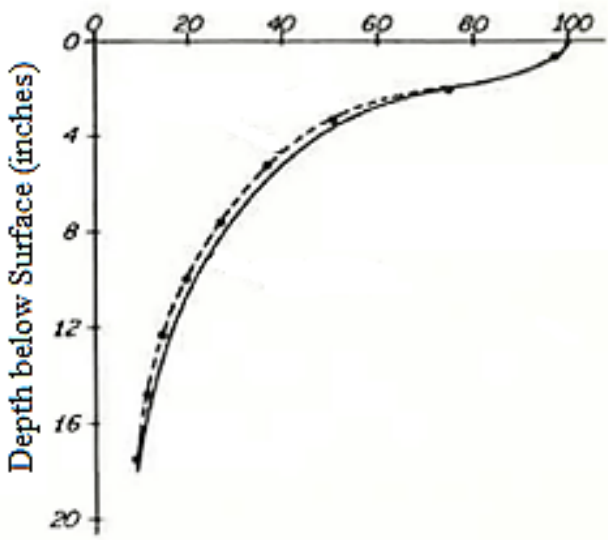

б)

Рис. 1. Порівняння теоретичних і чисельних розрахунків прогинів (а) і нормальних напружень (б) [8]

Як бачимо, величини напружень (рис. 1, б), розраховані МСЕ, у цьому випадку доволі точно відповідають теоретичним значенням. Проте точність моделювання прогинів була значно меншою (рис. $1, a$ ). Тут варто зауважити, що такий результат не дивує, оскільки розрахункові скінченноелементні моделі мали доволі розріджену сітку, а точність визначення переміщень безпосередньо пов'язана 3 густиною сітки скінченних елементів. На той час обчислювальні можливості комп'ютерів були обмеженими, тому отримати більш точні результати було неможливо.

Розвиток обчислювальних потужностей комп'ютерів і розроблення нових програмних систем, що реалізують MCE, таких як ANSYS, ABAQUS, ADINA, NASTRAN та інші, надали інженерам-проєктувальникам можливість уточнити розрахункові схеми, наблизити їх до схем реальних конструкцій. Стало можливим враховувати нелінійну механічну поведінку окремих шарів багатошарового дорожнього одягу, 3 більшою точністю розраховувати контактні напруження на межі розділу шарів, враховувати нелінійний характер розподілу температур у шарах конструкції тощо [9-16]. Останні досягнення в розв'язанні проблеми взаємодії транспортних засобів із дорожнім одягом стосуються розрахунків довговічності покриття з огляду на циклічність режиму навантаження й моделювання процесу руйнування покриття методами теорії тріщин. Проте ці роботи поки що залишаються дослідницькими і в практику роботи конструкторських бюро досі не впроваджені. Хоча в деяких державах уже розробляють відповідні нормативні документи [17]. Тому і в Україні $\epsilon$ потреба систематизувати відповідні дослідження і скоординувати роботи науковців у цьому напрямі.

Розгляньмо більш докладно результати досліджень НДС дорожнього одягу, що було опубліковано останнім часом.
Аналіз механічної поведінки двошарової гнучкої конструкції автомобільної дороги, що складається iз зернистої основи 3 поверхневим шаром асфальту, проведений у роботі [18]. Залишкова деформація або колійність на поверхні асфальту спостерігається як основна проблема в тонкому шарі твердої поверхні. У вказаному дослідженні запропоновано нову методику визначення прогинів поверхні двошарової автомобільної дороги для двох випадків передачі навантаження від транспортного засобу: через вісь з одним і з двома колесами. Представлену методику було розроблено на основі розв'язання задачі теорії пружності у тривимірній постановці, для розв'язання якої методом скінченних елементів було використано програмний комплекс ABAQUS. Особливостями розрахункової схеми (рис. 2) є: передача навантаження через відбиток шини прямокутної форми, проведення серії розрахунків для різних співвідношень характеристик пружності гранульованого шару основи й асфальтного покриття, а також для різних товщин шарів покриття та основи.

Встановлено, що співвідношення коефіцієнтів Пуассона покриття та основи мало впливає на механічну поведінку двошарової конструкції. На нашу думку, такий результат був очікуваний і пов'язаний із тим, що основа моделювалась суцільним матеріалом, тоді як насправді вона $є$ зернистим, тобто неоднорідним, середовищем. 3 інших результатів цієї роботи вкажемо на встановлені залежності прогинів i напружень від співвідношення модулів пружності покриття та основи, від співвідношення товщин шарів дороги, а також від ширини відбитка шин.

Важливим питанням впровадження чисельних методів у практику розрахунку доріг залишається верифікація результатів розрахунків, особливо під час використання нелінійних моделей поведінки матеріалів. Зазначимо, що аналітичних результатів 

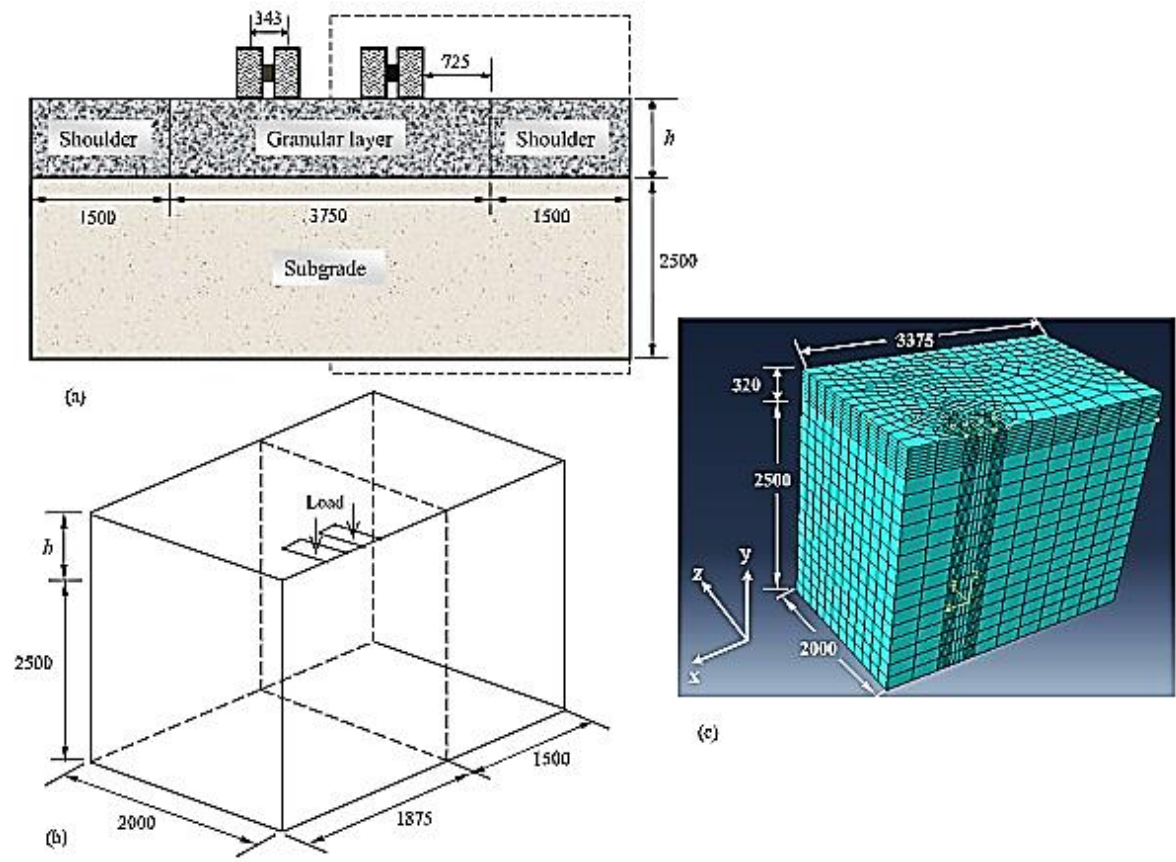

(c)

Рис. 2. Розрахункова схема дорожнього одягу [18]

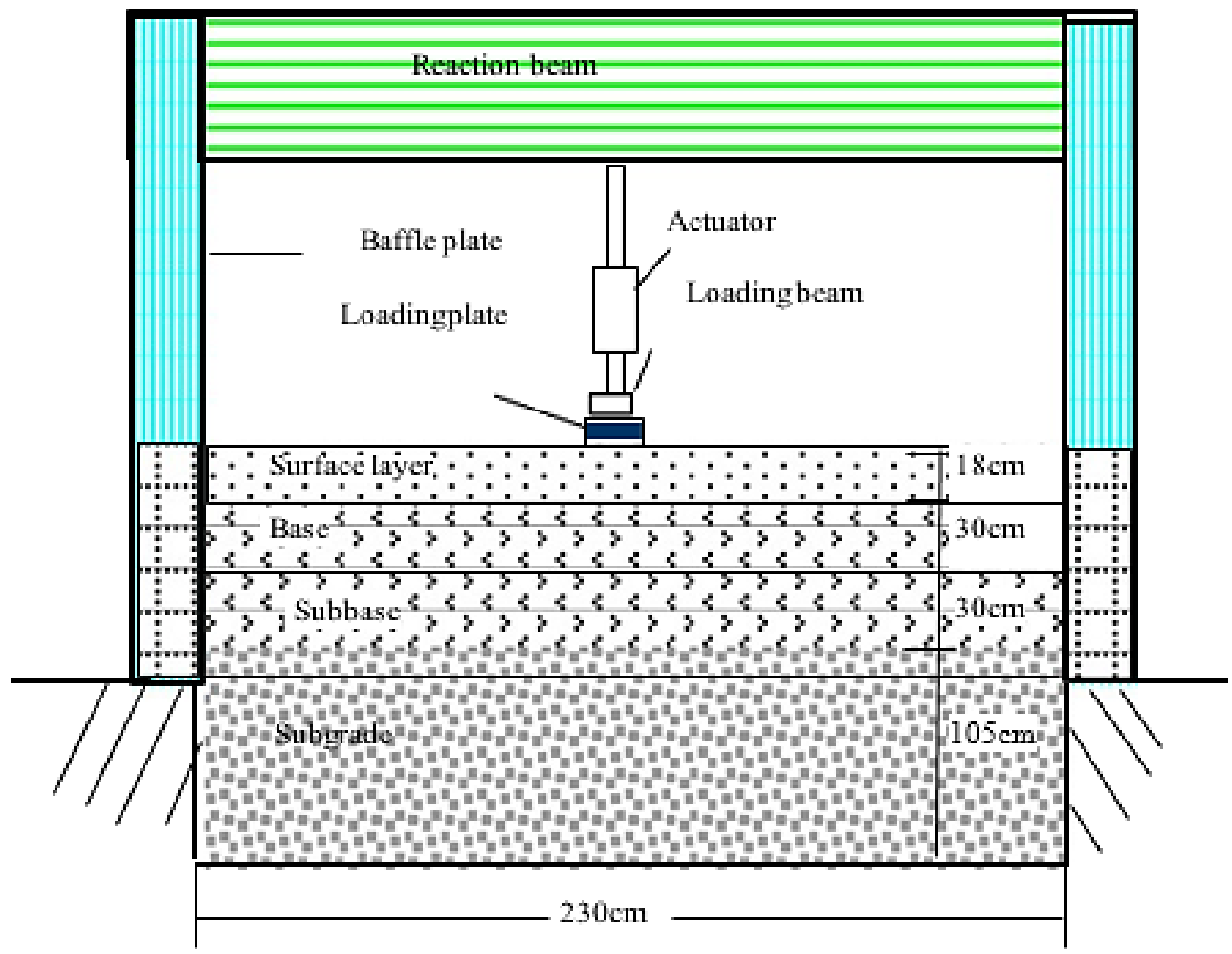

Рис. 3. Схема стенду для лабораторних досліджень [19]

розв'язання таких задач немає, тому єдиною можливістю перевірити точність розрахунків $є$ співставлення їхніх результатів із даними експериментальних досліджень. У роботі [19] розглянуто схему проведення експериментальних досліджень меха- нічної поведінки моделі дороги 3 багатошаровим дорожнім одягом (рис. 3).

Динамічне циклічне навантаження моделі дорожнього одягу здійснювали за допомогою штампу. Реакцію моделі на навантаження визначали шляхом 
вимірювання (за допомогою спеціальних датчиків) переміщень у різних точках моделі, зокрема на межі розділу шарів. Така сама модель використовувалась як розрахункова схема під час чисельних експериментів, які проводили 3 використанням комерційної програмної системи, що реалізує МСЕ. Порівняння результатів розрахунків 3 експериментальними даними показало їхню добру узгодженість навіть під час оцінювання залишкових деформацій, для чого в розрахунках використовували нелінійні моделі деформування матеріалів.

Результати, отримані в роботі, дають підстави стверджувати, що під час правильного вибору розрахункової схеми (геометричної моделі конструкції, моделі граничних умов i моделей деформування матеріалів) метод скінченних елементів дає доволі точні результати визначення напружень і деформацій у такій складній конструкції, як багатошаровий дорожній одяг.

Заслуговує уваги ще одна робота, яка присвячена питанням автоматизації проєктних розрахунків конструкцій доріг різного типу [20]. Тут варто зазначити, що для проведення якісних розрахунків за допомогою сучасних спеціалізованих програмних систем, таких яких ABAQUS або ANSYS, користувач повинен мати грунтовні знання з таких розділів механіки деформованого твердого тіла, як теорії пружності, пластичності, повзучості, тріщиностійкості, а також добре володіти чисельними методами вищої математики, розумітися на програмуванні, знати основи матеріалознавства й низки інших галузей науки. Звичайний інженер у галузі проєктування доріг зазвичай має великий практичний досвід, але не має грунтовної теоретичної підготовки. Тому доволі актуальним є питання автоматизації проєктних робіт із використанням універсальних програмних систем, що реалізують МСЕ. Така автоматизація є можливою, якщо застосувати так звані параметричні обчислення, суть яких полягає в тому, що на етапі підготовки розрахункової схеми деякі їі характеристики задають у вигляді параметрів (наприклад, кількість шарів дорожнього одягу або відношення величин модулів пружності шарів, відношення ширини відбитку колеса до ширини проїзної частини тощо). Тоді з результатів розрахунку, беручи до уваги конкретні значення цих параметрів, можна отримати результати для інших значень параметрів. Тут варто зауважити, що діапазон зміни вказаних параметрів має бути таким, щоб фізична суть задачі не змінювалася (скажімо, замість пружної поведінки матеріалу за невеликих навантажень можна спостерігати його пружно-пластичну поведінку за більших навантажень).

Головні висновки і перспективи використання результатів дослідження. У короткому огляді методів проєктування й розрахунку дорожніх покриттів ми проаналізували основні, на нашу думку, проблеми та способи їх розв'язання. Використання чисельних методів розрахунку напружено-деформованого стану елементів конструкції дорожнього одягу має великі перспективи для практичного використання.

\section{Література}

1. ГБН В.2.3-37641918-557:2016. Автомобільні дороги. Дорожній одяг жорсткий. Проєктування. Київ, 2016.71 с.

2. ДБН В.2.3-4:2015. Автомобільні дороги. Частина І. Проєктування. Частина IІ. Будівництво. Київ, 2015. 104 с.

3. ГБН В.2.3-37641918-559:2019. Дорожній одяг нежорсткий. Проєктування. Київ, 2019. 59 с.

4. Zienkiewicz O.C., Taylor R.L. The Finite Element Method. Vol. 1-3. Oxford, Auckland, Boston, Johannesburg, Melbourne, New Delhi, 2000. $1482 \mathrm{p}$.

5. Корочкин А.В. Элементы теории и практика повышения технико-эксплуатационных показателей жёсткой дорожной одежды с асфальтобетонным покрытием : автореф. дисс. ... докт. техн. наук : 05.23.11 «Проектирование и строительство дорог, метрополитенов, аэродромов, мостов и транспортных тоннелей». Москва, 2014. 49 с.

6. Александров А.С. Развитие теоретических положений комплексного расчета дорожных конструкций по сопротивлению сдвигу и пластическому деформированию : дисс. ... докт. техн. наук : 05.23 .11 «Проектирование и строительство дорог, метрополитенов, аэродромов, мостов и транспортных тоннелей». Омск, 2017. 377 с.

7. Monismith C.L. Asphalt Mixture Behaviour in Repeated Flexure. University of California, Berkeley, 1966. Rep. No. TE 66-6.

8. Duncan J.M., Monismith C.L., Wilson E.L. Finite Element Analyses of Pavements. Highway Research Record, 1968. 228. P. 18-33.

9. Мерзликин А.Е., Капустников Н.В. Моделирование упругого однородного и двухслойного полупространства применительно к задачам по расчету дорожных одежд методом конечных элементов. Дороги и мосты. 2011. № 1 (25). С. 63-72.

10. Демьянушко И.В., Носов В.П., Стаин В.М., Стаин А.В. Конечноэлементные модели для расчета плиты жесткого дорожного покрытия. Транспортное строительство. 2012. № 4. С. 5-8.

11. Попов А.Н., Волков В.В., Хатунцев А.А., Шашков И.Г., Кочетков А.В. Численное моделирование напряженно-деформированного состояния аэродромных покрытий в условиях физической нелинейности грунтового основания. Вестник евразийской науки. 2013. № 5 (18). URL: https://naukovedenie.ru/PDF/108tvn513.pdf.

12. Прогнозування та оцінка залишкових деформацій асфальтобетонного покриття з використанням методу скінченних елементів / А.М. Онищенко, С.М. Худолій, М.В. Гаркуша, О.М. Лещук. Вісник Національного транспортного університету. 2017. Вип. 1 (37). С. 308-320.

13. Мельникова И.С. Моделирование воздействия температуры и транспортных нагрузок на возникновение и развитие трещин в асфальтобетонных дорожных покрытиях. Наука и техника. 2012. № 4. С. 44-52.

14. Gupta A., Kumar A. Comparative structural analysis of flexible pavements using finite element method. International Journal on Pavement Engineering \& Asphalt Technology. 2014. 15 (1). P. 11-19. DOI: 10.2478/ijpeat-2013-0005. 
15. Mulungye R.M., Owende P.M.O., Mellon K. Analysis of Response of Flexible Pavements Using Finite Element Method. The ITB Journal. 2005. 6 (2): 5. DOI: 10.21427/D71T8T.

16. Ястремский Д.А., Чепур П.В., Абайдуллина Т.Н. Численное моделирование напряженно-деформированного состояния дорожного покрытия из ЩМА с применением стабилизирующей добавки «Армидон». Фундаментальные исследования. 2016. № 7-2. С. 277-281.

17. ОДМ 218.3.051-2015. Рекомендации по определению напряженно-деформированного состояния многослойных дорожных одежд. Отраслевой дорожный методический документ. Росавтодор. Москва, 2015. 147 с.

18. Singh A.K., Sahoo J.P. Analysis and design of two layered flexible pavement systems: A new mechanistic approach. Computers and Geotechnics. (2020). 117. 103238. doi.org/10.1016/j.compgeo.2019.103238.

19. Zheng L., Hai-lin Y., Wan-ping W., Ping C. Dynamic stress and deformation of a layered road structure under vehicle traffic loads: Experimental measurements and numerical calculations. Soil Dynamics and Earthquake Engineering. 2012. 39. $100-112$. https://doi.org/10.1016/j.soildyn.2012.03.002.

20. Tang F., Ma T., Guan Y., Zhang Z. Parametric modeling and structure verification of asphalt pavement based on BIM-ABAQUS. Automation in Construction. 2020. 111, 103066. doi.org/10.1016/j.autcon.2019.103066. 


\title{
АНАМІЗ РЕЗУИЬТАТІВ ДОСАІДЖЕНЬ ТЕХНОГЕННОГО ЗАБРУДНЕННЯ ДОВКІММЯ ТЕРИТОРІЙ НАВКОАО ВУГАЕВИДОБУВНИХ ПІДПРИЕМСТВ
}

\author{
Горобей М.С., УЛицький О.А., Бойко К.Є., Клименко О.О. \\ Державна екологічна академія післядипломної освіти та управління \\ вул. Митрополита Василя Липківського, 35, корп. 2, 03035, м. Київ \\ marina.dea@ukr.net
}

\begin{abstract}
У статті розглянуто еколого-технічні показники діяльності вугільних підприємств України, техногенне навантаження на навколишнє природне середовище, пов'язані з цим екологічні зміни, вплив на природу й здоров'я населення внаслідок інтенсивного видобутку вугілля. Велика концентрація підприємств вугільної галузі на порівняно невеликих територіях Донбасу істотно впливає на довкілля, порушуючи його екологічну рівновагу.

Сучасні проблеми екологічного стану навколо вугільних шахт України згубно впливають на екосистеми та природні території. Так, відбувається руйнація промислових та екологічно небезпечних об'єктів; забруднення джерел питної води, земель, атмосферного повітря; порушення геологічного середовища. Серед негативних наслідків, які супроводжують процеси планової діяльності вугільних підприємств, найбільш розповсюдженим практично для усіх вуглевидобувних регіонів $є$ погіршення (досить часто значне) гідрогеологічного стану територій їх розташування.

Процеси видобутку та переробки вугілля істотно впливають не лише на всі компоненти навколишнього природного середовища, а й на здоров'я населення, яке мешкає на територіях кам'яно-вугільних басейнів. Тому однією 3 найважливіших проблем у вугледобувній галузі України є забезпечення екологічної безпеки довкілля навколо вугільних шахт. Для ії ефективного розв'язання необхідно здійснювати розрахунки рівня величини питомих викидів забруднюючих речовин відповідно до кількості видобутих корисних копалин. Постійний контроль за кількісними та якісними показниками впливу на навколишнє середовище дозволить своєчасно розробляти рекомендації та приймати управлінські рішення по вжиттю заходів щодо поліпшення (виправлення) екологічної ситуації та наслідків техногенного забруднення територій навколо вуглевидобувних підприємств. Ключові слова: техногенне забруднення, екологічна безпека, екосистема, забруднюючі речовини, питомі викиди.
\end{abstract}

Analysis of the results of research on man-made pollution of the territories around coal mining enterprises. Horobei M., Ulytskyi O., Boiko K., Klymenko O.

Ecological and technical indicators of coal enterprises of Ukraine are considered in the paper, man-made environmental impact, related environmental changes, impacts on nature and public health due to intensive coal mining. The high concentration of coal industry enterprises in relatively small areas of Donbass causes a significant impact on the environment, disturbing its ecological balance.

Modern problems of the ecological condition around the coal mines of Ukraine have a detrimental effect on ecosystems and natural areas, in particular, it is the destruction of industrial and environmentally hazardous facilities; pollution of drinking water sources, lands, atmospheric air; disturbance of the geological environment. Among the negative consequences that accompany the processes of planned activities of coal enterprises, the most common, characteristic factor for almost all coal-mining regions is the deterioration (often significant) of the hydrogeological condition of their territories.

Coal mining and processing have a significant impact not only on all components of the environment, but also on the health of the population living in the coal basins. Thus, one of the most important problems in the coal mining industry of Ukraine is to ensure environmental safety around coal mines. To solve it effectively, it is necessary to calculate the level of specific emissions of pollutants in accordance with the amount of extracted minerals. Continuous control over quantitative and qualitative indicators of environmental impact will allow timely development of recommendations and management decisions to take measures to improve (correct) the environmental situation of man-made pollution of areas around coal mining enterprises. Key words: men-made pollution, environmental safety, ecosystem, pollutants, specific emissions.

Постановка проблеми. Постійне зростання обсягів видобутку та споживання кам'яного вугілля призвело до загострення екологічної ситуації в регіонах інтенсивного і тривалого використання надр України. Разом зі зростанням виробництва сировини збільшується й антропогенне забруднення атмосфери, літосфери, гідросфери та біосфери. Із 1996 року тривають процеси реструктуризації вугільної промисловості, зокрема закриття вуглевидобувних підприємств.
Найбільш проблемними напрямами структурної перебудови вугільної промисловості стали соціально-економічні та екологічні наслідки. Експлуатація шахт призводить до просторово-часових змін геомеханічної рівноваги і оточуючого територіального ландшафту внаслідок видобутку вугілля та нагромадження гірничих мас. Процеси видобутку і переробки вугілля впливають не лише на всі компоненти навколишнього природного середовища, а й на здоров'я населення [1]. 
Мета статті - контроль за кількісними та якісними показниками впливу на довкілля, аналіз негативних наслідків функціонування та ліквідації шахт в Україні, розробка рекомендацій і заходів щодо плану виправлення наслідків техногенного забруднення територій навколо вугільних підприємств та оперативного реагування на зміни екологічної ситуації.

Об'єктом дослідження є сучасний стан екосистеми територій гірничодобувної промисловості.

Актуальність дослідження. Сучасна вугільна галузь України нараховує сотні підприємств - діючих шахт, збагачувальних фабрик, відомчих ТЕЦ, котелень, заводів різного профілю, шахтобудівних підприємств, які сконцентровані на порівняно невеликих територіях. Діяльність гірничо-промислових підприємств призводить до техногенного забруднення довкілля та спричиняє низку небезпечних природно-антропогенних процесів: порушення земель і деградація ландшафтів, зміна геологічного, гідрологічного та гідрохімічного режимів територій, на яких розташовані вугледобувні підприємства, забруднення повітряного i водного середовища, збіднення флори та фауни, екологічні загрози життю i здоров'ю населення. Отже, питання підвищення рівня екологічної безпеки функціонування і закриття вугільних шахт, зменшення техногенного забруднення у вуглевидобувних регіонах набуло виняткової актуальності.

Виклад основного матеріалу. Постійне зростання обсягів видобутку та споживання кам'яного вугілля призвело до загострення екологічної ситуації в регіонах інтенсивного і тривалого використання надр України [2]. Разом зі зростанням виробництва сировини збільшувалося й антропогенне забруднення атмосфери, літосфери, гідросфери та біосфери, тобто геологічного середовища у широкому його розумінні. Процеси видобутку і переробки вугілля впливають не лише на всі компоненти навколишнього природного середовища, а й на здоров'я населення, яке проживає на територіях кам'яно-вугільних басейнів. Охорона атмосферного повітря також $\epsilon$ важливою проблемою поліпшення природного середовища, оскільки більшість населення вуглевидобувних регіонів живе в районах, де концентрація забруднюючих речовин регулярно перевищує гранично допустимі рівні [3].

Моніторинг поточного впливу вугільних підприємств на довкілля складається із кількох напрямів, які представляють усі важливі компоненти навколишнього природного середовища (далі - НПС):

- атмосферне повітря;

- водні та земельні ресурси;

- відходи;

- витрати на охорону природи [4].

Саме тому об'єктом моніторингових досліджень за сучасним станом екосистеми територій організованого розвитку гірничодобувної промисловості виступають еколого-технічні показники (далі - ЕТП) планової діяльності вугільних підприємств (далі ПДВП) під час видобутку вугілля.

Запаси кам'яного вугілля, які розробляються державними та самостійними вугільними підприємствами, належать до Донецького та ЛьвівськоВолинського кам'яновугільних басейнів і до 8 різних геолого-промислових районів, кожен із яких має відмінності в тектонічному, літологічному, гідрогеологічному сенсі, у стадії вуглефікації (в марочному складі вугілля), у газових (метанових) ресурсах, глибині залягання вугленосних пластів.

Донецький кам'яно-вугільний басейн розташований на північному сході України на територіях Дніпропетровської (Західний Донбас), Донецької (Червоноармійський, Північно-Донбаський, Центральний геолого-промислові райони), Луганської (Алмазно-Мар'євський, Лисичанський геолого-промислові райони) областей. ЛьвівськоВолинський кам'яно-вугільний басейн (Нововолинський, Червоноградський геолого-промислові райони) розташований на заході України, у верхній течії річки Буг (рис. 1).

Шахти Львівсько-Волинського басейну і Західного Донбасу дуже спотворюють русла рік Західний Буг і Самара та їхніх притоків. У результаті експлуатації червоноградської групи шахт ВАТ «Львіввугілля» утворилося осідання земної поверхні на 0,5-4 м, понад 600 га землі стали заболоченими.

Щорічно шахти та вуглезбагачувальні фабрики видають біля 700 тисяч тонн вугільних відходів, iз яких 400-500 тисяч тонн складають у відвали. Загальна площа відведення земельних ресурсів усіма підприємствами вуглевидобувної галузі у першій половині 2020 року складала 9651,59 га. Аналіз результатів моніторингових досліджень за екологічною ситуацією дозволив виявити перелік реальних чинників (табл. 1), які характеризують негативний вплив на екосистеми навколо вугільних шахт, оцінити їхні параметри.

Відкачування шахтної води здійснюється як окремими вугільними шахтами, так і державними підприємствами-об'єднаннями (рис. 2, а). На рис. 1, б зображено обсяги викидів парникових газів. Так, було проведено підрахунок викидів забруднюючих речовин (далі - 3Р) і парникових газів (далі - ПГ) у повітря від діяльності усіх шахт.

Отримана в результаті моніторингу статистична інформація за кожним показником дозволяє визначити розміри відшкодування збитків, заподіяних державі в результаті наднормативних викидів ЗР в атмосферне повітря або значного навантаження на земельні ресурси (ставки-освітлювачі, шламонакопичувачі та хвостосховища, породні відвали).

Подібний підхід дозволяє оцінити надходження в НПС загального обсягу ЗР і пайову участь окремої шахти або об'єднання [5]. При цьому оцінка комплексного впливу на навколишнє середовище економічно ефективного використання природних ресур- 


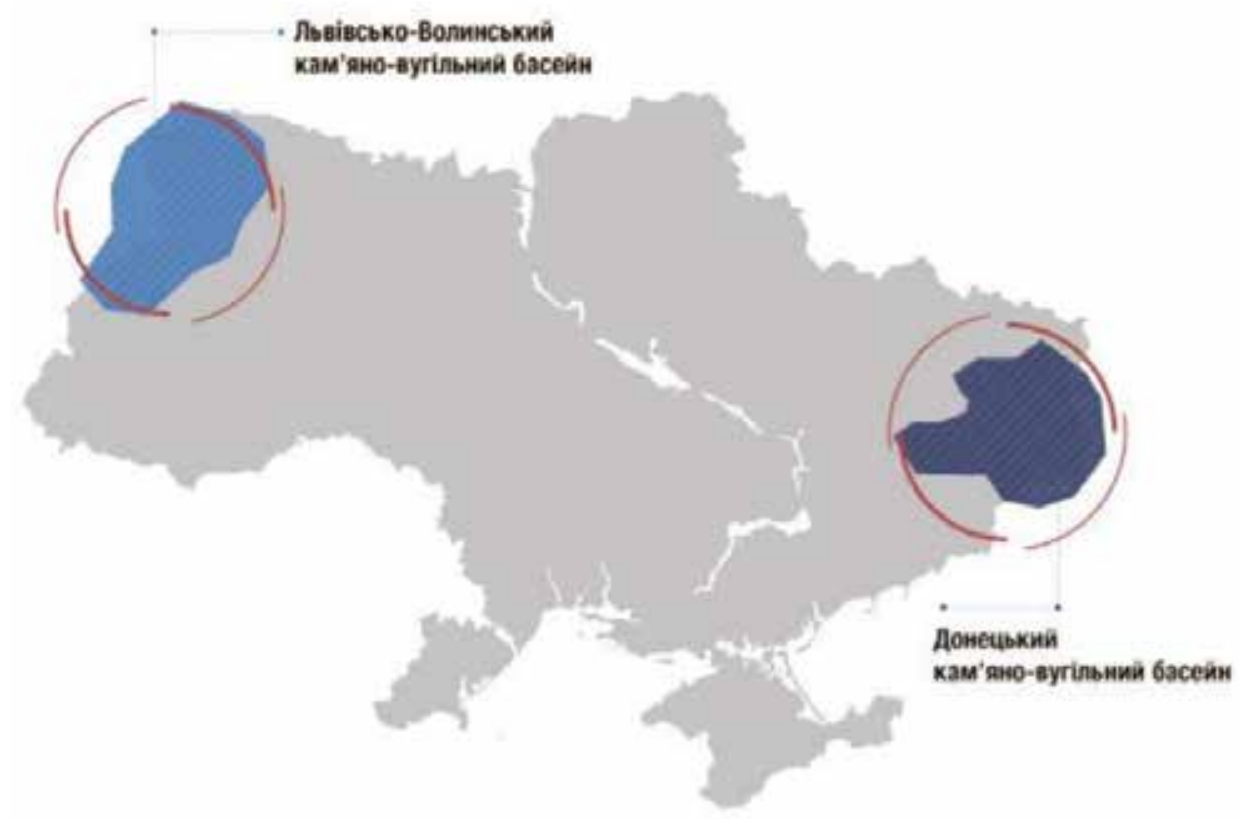

Рис. 1. Кам'яно-вугільні басейни України

Основні чинники негативного впливу вугільних шахт України на довкілля

\begin{tabular}{|c|c|c|}
\hline Виробниче об'сднання & Вугільна шахта & Фактори екологічної небезпеки \\
\hline \multirow{4}{*}{ «Лисичанськвугілля» } & «Новодружська» & $\begin{array}{l}\text { Горіння териконів, шахтні води, } \\
\text { санітарні стоки. }\end{array}$ \\
\hline & «Капустіна» & $\begin{array}{l}\text { Горіння териконів, шахтні води, } \\
\text { санітарні стоки. }\end{array}$ \\
\hline & шахта ім. Д.Ф. Мельникова & $\begin{array}{l}\text { Горіння териконів, шахтні води, } \\
\text { санітарні стоки. }\end{array}$ \\
\hline & «Привольнянська» & $\begin{array}{l}\text { Горіння териконів, шахтні води, } \\
\text { санітарні стоки. }\end{array}$ \\
\hline \multirow{3}{*}{ «Селидіввугілля» } & № 1-3 «Новогродівська» & \multirow{3}{*}{$\begin{array}{l}\text { Горіння териконів, шахтні води, санітарні } \\
\text { стоки, деформування земної поверхні. }\end{array}$} \\
\hline & «Курахівська» & \\
\hline & «Україна», «Котляревська» & \\
\hline Незалежна вугільна шахта & «Південнодонбаська № 1» & $\begin{array}{c}\text { Горіння териконів, шахтні води, утилізація } \\
\text { метану, деформування земної поверхні. }\end{array}$ \\
\hline \multirow{3}{*}{ «Торецьквугілля» } & «Центральна» & \multirow{3}{*}{$\begin{array}{l}\text { Горіння териконів, деформування } \\
\text { земної поверхні. }\end{array}$} \\
\hline & «Північна», «Торецька» & \\
\hline & «Південна» & \\
\hline \multirow{4}{*}{ «Мирноградвугілля» } & «Капітальна» & \multirow{4}{*}{$\begin{array}{l}\text { Горіння відвалів, шахтні води, просідання } \\
\text { грунту, санітарні стоки, утилізація метану, } \\
\text { деформування земної поверхні. }\end{array}$} \\
\hline & «Родинська» & \\
\hline & «Центральна» & \\
\hline & «Шахта № 5/6» & \\
\hline \multirow{3}{*}{ «Добропіллявугілля» } & «Алмазна», «Білицька» & \multirow{3}{*}{$\begin{array}{c}\text { Горіння відвалів, шахтні води, утилізація } \\
\text { метану, деформування земної поверхні. }\end{array}$} \\
\hline & $\begin{array}{l}\text { «Добропільська», } \\
\text { «Піонер» }\end{array}$ & \\
\hline & «Новодонецька» & \\
\hline «Львіввугілля» & $\begin{array}{c}\text { «Великомостівська», } \\
\text { «Межирічанська», } \\
\text { «Відродження», «Лісова», } \\
\text { «Червоноградська», } \\
\text { «Степова» } \\
\end{array}$ & $\begin{array}{l}\text { Горіння териконів, шахтні води, } \\
\text { деформування земної поверхні. }\end{array}$ \\
\hline «Укршахтгідрозахист» & $\begin{array}{l}\text { ВВК «Кремінна» } \\
\text { ВВК «Чорноморка» }\end{array}$ & Відкачування води, утилізація води. \\
\hline
\end{tabular}


Об'єм шахтної води, що відкачано за 2019 рік

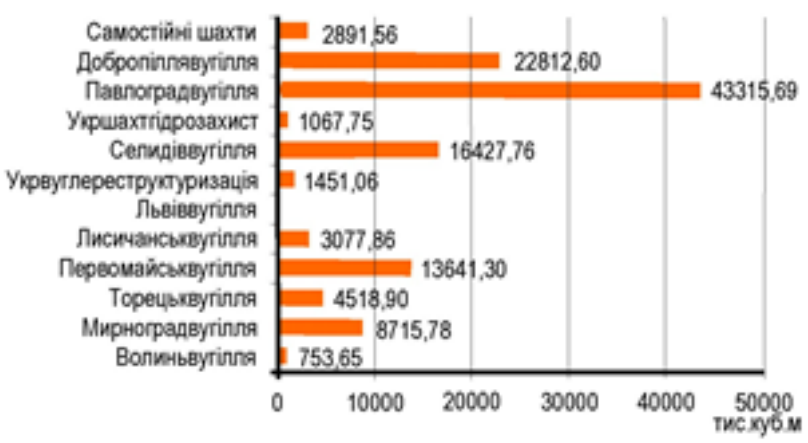

a)
Обсяг викидів парникових газів за 2019 рік, \%

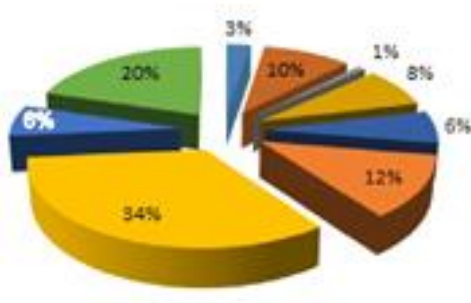

"Boniviseyrinna - Мирноградвугілn n Topeubkgyring

"Переомайськвутіпля - Лисичамсыхвугілn m ภเeieeyrinn

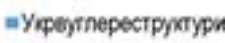
"Cenugiesyrinna

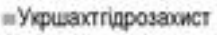

Рис. 2. Аналіз результатів моніторингових досліджень щчодо статистичних річних еколого-технічних показників

Об'єм шахтної води, що відкачано за рік на тону видобутого вугілля
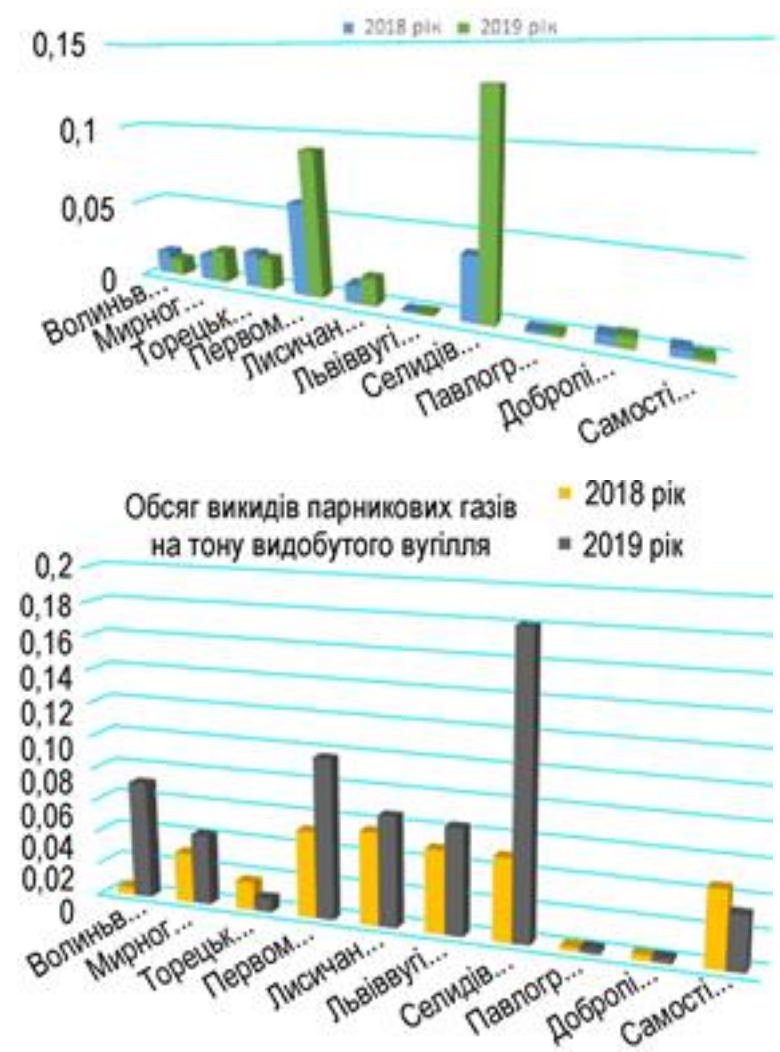
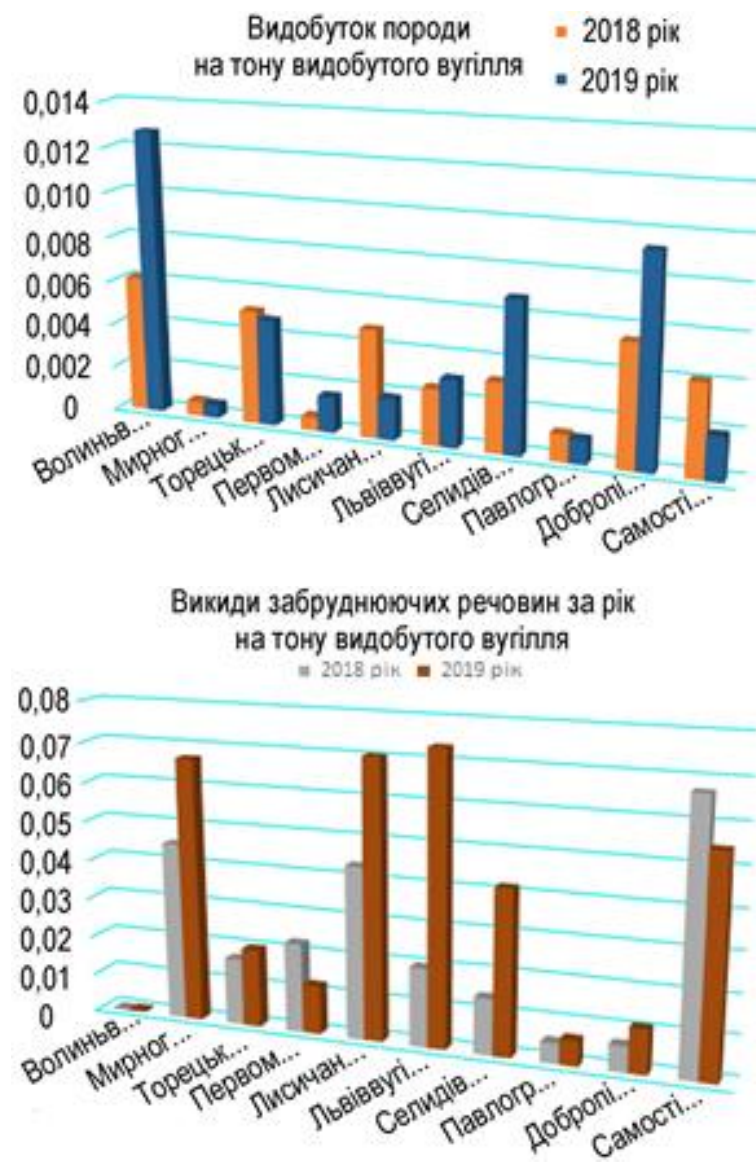

Рис. 3. Визначення величини питомих викидів об'єднань та самостійних шахт України

сів і витрат на охорону природи внаслідок діяльності вуглевидобувних підприємств залишається недопрацьованою. Беручи до уваги той факт, що за останні 10 років дуже змінилися не тільки обсяги видобутку вугілля, а й структура видобутку в розрізі «держава приватний бізнес», а окремі державні гірничі підприємства тривалі періоди простоювали, то порівняння
ЕТП забруднення навколишнього природного середовища між окремими підприємствами або об'єднаннями не зовсім коректне [6].

Якщо шахта не працює в режимі видобутку, вона працює в режимі «відкачки» та «вентиляції». Саме тому внаслідок дії водозабору і шахтного водовідливу виявляються зміни в області живлення, руху 
і розвантаження підземних вод, утворюються досить великі за площею депресійні лійки, зростає мінералізація [7; 8]. Вентиляційні системи також продовжують викид метану. Для розв'язання цих питань має бути запроваджено визначення величини питомих викидів (далі - ПВ) ЗР, що пов’язано з кількістю видобутих корисних копалин, а не тільки з кількістю і якістю забруднювачів, тобто [9] по кожній ЗР по виробництву та від кожного джерела викиду. Так, порівняння ПВ по окремих позиціях (рис. 3) за різні роки допускає практичну можливість об'єктивного контролю за фактичними викидами ЗР і встановлює залежність між кількістю ЗР, що викидається, та діяльністю або бездіяльністю, пов'язаною з цим викидом.

Аналіз результатів розрахунку ПВ за даними моніторингових спостережень свідчить про те, що при однакових щорічних показниках якості вугілля та експлуатаційних характеристик (зольність, гли- бина, марка вугілля, вихід летких речовин, газоносність) значення ПВ у 2019 році порівняно із 2018 роком на багатьох об'єднаннях зросли у кілька разів. Особливо це стосується ГП «Селидіввугілля», ГП «Первомайськвугілля» та ГП «Волиньвугілля». Це свідчить про неефективне управління відходами на регіональному рівні, відсутність обладнання для використання метану, відсутність екологічно-безпечних технологій проведення гірничих робіт, які призводять до значного, невиправданого економічно навантаження на навколишнє середовище.

Головні висновки. Проведений у роботі ефективний аналіз результатів моніторингу за ЕТП роботи вугільних підприємств стосовно екологічно збалансованого природокористування свідчить про те, що останніми роками зниження видобутку кам'яного вугілля призвело до невиправданого збільшення викидів забруднювачів на багатьох державних підприємствах.

\section{Література}

1. Вплив вуглевидобувного підприємства на урбоекосистеми України / О.І. Бондар, О.А. Улицький, В.М. Срмаков, О.В. Луньова : збірник матеріалів 5-го Міжнародного конгресу «Захист навколишнього середовища. Енергоощадність. Збалансоване природокористування». Львів : Львівська політехніка, 2018.79 с.

2. Gorobei M. Environmental sustainability and pollution prevention: the negative impact of carbon-containing dust on the environment and humans and effective measures for its reducing. International Journal of Advanced Research (IJAR). Technical science. Vol. 8, June 2020. Issue 06. ISSN 2320-5407. P. 1489-1496.

3. Горобей М.С. Екологічна шкода карбоновмісного пилу та зменшення його негативного впливу на довкілля як складник сталого розвитку гірничовидобувної галузі. Екологічні науки. Науково-практичний журнал. 2020. Вип. 30. С. 98-103.

4. Екологізація вуглевидобувного виробництва: розробка управлінських рішень на основі методу "seven new tools" / О.А. Улицький, О.М. Сухіна, М.В. Кротинова. Економіка України. 2016. № 5. С. 64-77.

5. Екологічні ризики та загрози на шахтах Донецької та Луганської областей України. О.А. Улицький, В.М. Єрмаков, О.В. Луньова, О.В. Буглак. Форум гірняків : зб. наук. праџь. Дніпро : Середняк Т.К., 2018. С. 282-289.

6. Кузін Ю.С. Охорона навколишнього природного середовища на підприємствах вугільної галузі. Щорічні показники природоохоронних робіт. Ю.С. Кузін: фонди УкрНДІпроект. Київ, 2010. 28 с.

7. Дьяченко Н.А. Особенности формирования региональных воронок депрессии в отложениях палеогена под влиянием шахтоосушения и водозабора (Западный Донбасс). Наукові праці УкрНДМІ НАН України. 2013. № 1. С. 291-305.

8. Дятел О.О. Розрахунки та прогнозування впливу розробки родовища «Хотиславське» на гідродинаміку грунтових і підземних вод Західного Полісся. Екологічна безпека та природокористування. 2018. Вип. 2(26). С. 65-76.

9. Типова методика визначення питомих викидів від основних виробництв по галузях промисловості. Д. № 0002556-00, затверджено 25.12.2000 : офіційний сайт Верховної Ради України. URL: https://zakon.rada.gov.ua/rada/show/n0002556-00\#Text (дата звернення: 15.11.2020). 


\title{
ДОСАІДЖЕННЯ ТЕХНОАОГІЧНИХ ПАРАМЕТРІВ ГІДРОХІМІЧНОГО ВИАУЧЕННЯ СПОАУК ВАНАДІЮ ІЗ ТЕХНОГЕННИХ ВІДХОДІВ
}

\author{
Гринь Г.І., Кузнєцов П.В., Гринь С.О. \\ Національний технічний університет \\ «Харківський політехнічний інститут» \\ вул. Кирпичова, 2, 61002, м. Харків \\ griinsvetlana@ukr.net
}

\begin{abstract}
У статті розглянуто та досліджено процес гідролітичного вилучення сполук ванадію із твердих продуктів спалювання мазуту. Показано, що ванадій і його сполуки можна вилучати переробкою твердих продуктів спалювання мазуту трьома основними способами: металургійним, гідрохімічним, пірогідрохімічним.

3'ясовано, що для переведення ванадію в розчинну форму у технологію переробки ванадійвмісної сировини вводять процес окиснювального обпалу із реакційноздатними добавками. Як добавки є можливість використовувати солі лужних i лужноземельних металів. Це дозволяє перевести оксиди ванадію у вищу форму валентності та одержати розчинні ванадати. Проаналізовано хімічний склад основних компонентів вторинної ванадійвмісної сировини, яка містить сполуки ніколю, заліза, хрому, алюмінію, кальцію, кремнію.

Встановлено, що тривалість процесу вилуговування оксидів ванадію із твердих продуктів спалювання позитивно впливає на ступінь вилучення ванадію із зольних залишків. Показано, що активне перемішування сприяє більш глибокому розкриттю зольних залишків. Доведено, що збільшення часу процесу на понад 2 години не дуже впливає на ступінь вилучення ванадію. Показано, що поліванадати добре розкриваються суспензіями гідрооксиду кальцію при тиску кисню 1,0 МПа та відношенні Ж:Т $=7: 1$. Проаналізовано вплив $\mathrm{pH}$ розчину на утворення розчинних сполук ванадію. Встановлено залежність ступеня вилучення оксиду ванадію (V) суспензією гідрооксиду кальцію від рН розчину.

3'ясовано, що найбільшу розчинність мають метаванадати кальцію в інтервалі $\mathrm{pH}=5,5-7,2$. Досліджено вплив температури вилуговування твердих продуктів спалювання та підтверджено позитивний вплив на процес вилучення сполук ванадію вище 373 К. Встановлено термін часу процесу вилучення сполук ванадію із техногенних відходів і показано, що при максимальному ступені утилізації термін складає 90-120 хв. Проведені дослідження дозволили з'ясувати оптимальні технологічні параметри гідрохімічного способу вилучення оксидів ванадію із промислових відходів. Ключові слова: оксид ванадію, гідрохімічний метод, розчини, концентрація, ступінь вилучення.
\end{abstract}

Research of technological parameters of hydrochemikal extraction of vanadium composition from technological waste. Gryn G., Kuznetsov P., Gryn S.

In this work the process of hydrolytic withdrawal of vanadium compounds from solid fuel oil combustion products was studied. It is shown that vanadium and its compounds can be extracted by processing solid combustion products of fuel oil in three main ways: metallurgical, hydrochemical, pyrohydrochemical.

It was found that the process of oxidative roasting with reactive additives is introduced to convert vanadium into a soluble form into the technology of processing vanadium-containing raw materials. As additives it is possible to use salts of alkali and alkaline earth metals. This makes it possible to convert vanadium oxides to a higher valence form and to obtain soluble vanadates. The chemical composition of the main components of the secondary vanadium-containing raw material, which additionally contains compounds of nickel, iron, chromium, aluminum, calcium, silicon, etc., is analyzed.

It was found that the duration of the process of leaching of vanadium oxides from solid combustion products has a positive effect on the degree of extraction of vanadium from ash residues. It is shown that active mixing promotes deeper disclosure of ash residues. It is proved that increasing the process time by more than 2 hours has little effect on the degree of extraction of vanadium. It is shown that polivanadates well removed by suspensions of calcium hydroxide at a pressure of $1.0 \mathrm{MPa}$ and oxygen ratio $\mathrm{F}: \mathrm{R}=7: 1$. Of Concentrational influence of a $\mathrm{pH}$ and formation of soluble vanadium compounds was analyzed.

It was established dependence vanadium oxide (V) degree of extraction by the suspension of calcium hydroxide from the $\mathrm{pH}$ of the solution. It was defined that the most solubility of calcium meta-vanadates is in the $\mathrm{pH}$ range 5.5-7.2. Temperature influence on leaching of combustion solid products was studied and confirmed its positive impact on the process of extracting vanadium compounds above $373 \mathrm{~K}$. It is defined period of time the process of extracting vanadium compounds from technogenical waste and shown that in the maximum degree of utilization it is 90-120 minutes. The conducted researches allowed to find out the optimal technological parameters for the hydrochemical method of extracting vanadium oxides from industrial waste. Key words: vanadium oxide, hydrochemical method, solutions, concentration, degree of extraction.

Постановка проблеми. Світова промисловість все більше використовує марки сталей, при виготовленні яких додаються сполуки ванадію. Завдяки цим сполукам сталь набуває міцності, пружності та зносостійкості при одночасному збереженні ї пластичності та здатності зварюватися. Нині велику увагу приділяють ванадію та його сполукам з можливістю виплавки нових сталей із заданими властивостями для електро-, радіо- та СВЧ техніки. Основним джерелом ванадію є титаномагнетитові руди, кон- 
векторні шлами, тверді продукти спалювання мазуту на електростанціях. У світі ванадій виробляють із ванадійвмісного шлаку (68\% від загального об'єму виробництва), ванадієвих руд (23\%), нафтових та інших матеріалів $(9 \%)[1 ; 2]$.

У різних країнах збільшується роль техногенної сировини для одержання ванадію та його сполук із продуктів нафтопереробки, шлаків і золи. Ця проблема знаходиться в центрі уваги науковців ПАР, Австралії, США, Канади, Китаю, Росії, оскільки ці країни є лідерами 3 виробництва ванадію із природних запасів. У Європі великими виробниками $\epsilon$ Німеччина, Австрія, Бельгія, Швеція. У невеликих об'ємах ванадієва продукція виробляється в Чехії, Бразилії, Індії, Україні [2].

Актуальність дослідження. Ванадій і його сполуки можна вилучати переробкою твердих продуктів спалювання (далі - ТПС) мазуту трьома основними способами: металургійним, гідрохімічним, пірогідрохімчним, які здійснюються по аналогії із традиційним шляхом вилучення ванадію із природної залізорудної сировини.

Металургійний спосіб переробки ТПС дозволяє на існуючому обладнанні без капітальних витрат одержувати сплав або лігатуру з ванадієм. Однак він має значні недоліки, до яких відносять низький ступінь вилучення ванадію, забруднення продукту сульфуром і виділення в газову фазу диоксиду сірки $[3 ; 4]$.

Пірогідрохімічний спосіб вилучення ванадію із ТПС включає окиснювальне випалювання в суміші iз кальцинованою содою або хлористим натрієм, а вилучення ванадію проводять водою чи сірчанокислим розчином.

Для осадження ванадію із розчинів та одержання ванадійвмісного концентрату використовують гідролітичний спосіб. Для переведення ванадію в розчинну форму у технологію переробки ванадійвмісної сировини вводять процес окиснювального обпалу iз реакційноздатними добавками. Як добавки використовують солі лужних і лужноземельних металів, що дозволяє перевести оксиди ванадію у вищу форму валентності та одержати розчинні ванадати.

Зв'язок авторського доробку 3 важливими науковими та практичними завданнями. 3 огляду на актуальність проблеми збільшення виробництва ванадію та велику кількість проблем, пов'язаних із дослідженням вилучення ванадію із ТПС органічної сировини, проблема одержання розчинних ванадатів потребує більш глибокого вивчення. Незважаючи на високий ступінь вилучення ванадію із обпалювального матеріалу, введення у технологію окиснювального обпалу твердих продуктів згоряння (далі - ТПЗ) недоцільне за таких причин [4; 5]:

- перебільшений вміст у зольних залишках дрібнодисперсійної фракції ( 0,1 мм), який призводить до спікання шихти та збільшення втрат ванадію в результаті виносу матеріалу димовими газами;
- високий вміст сульфуру в ТПЗ та його надходження в атмосферу у вигляді оксиду сірки в результаті обпалу, що погіршує екологічну безпеку технології та ускладнює апаратурне оформлення технологічної схеми в результаті використання дорогоцінної системи очищення вихідних газів.

Тому доцільно проаналізувати гідрохімічну технологічну схему вилучення ванадію із ТПС мазуту, виключивши процес енергоємного високотемпературного обпалу. Метою досліджень $є$ визначення оптимальних технологічних параметрів гідрохімічного методу.

Аналіз останніх досліджень і публікацій. Токсичні сполуки ванадію забруднюють навколишнє середовище у вигляді твердих частинок (пил, шлами, шлаки, зола) і рідких стоків. Комплексні заходи з ліквідації ванадійвмісних речовин із метою вилучення сполук ванадію і покращення стану навколишнього середовища повинні включати [6; 7]:

1) зневоднення і пресування твердих речовин у брикети, що дозволяє запобігати проникненню сполук ванадію у довкілля, більш економно і безпечно транспортувати їх, компактно і безпечно зберігати з подальшою утилізацією відходів;

2) високотемпературні способи переробки твердих ванадійвмісних сполук із подальшим одержанням товарної продукції;

3) автоклавні способи знешкодження сполук ванадію 3 одержанням $\mathrm{V}_{2} \mathrm{O}_{5}$ у вигляді готової продукції;

4) гідролітичне вилучення сполук ванадію зі складних рідких стоків з одержанням оксидів ванадію (V).

Такий комплексний підхід до процесу вилучення токсичних сполук ванадію із техногенних відходів дозволить вирішити проблему забруднення довкілля, зменшити економічні втрати для промисловості.

Актуальність проблеми вилучення сполук із техногенних відходів спонукає багатьох науковців проводити численні дослідження. Так, у роботах $[2 ; 8 ; 10]$ розглядаються питання початкової техногенної сировини, вивчається склад і пропонується технологія одержання ванадієвої продукції 3 відходів промислового виробництва. Науковці $[3 ; 5 ; 6 ; 11]$ детально аналізують існуючі промислові схеми і технології переробки ванадійвмісних відходів, їх позитивні і негативні складники, звертають увагу на ресурсозбереження та екологічні проблеми кожного способу.

У роботі [4] автори вивчали процес гідролітичного осадження сполук ванадію із розчинів, не розглядаючи тверду фазу. Гідрохімічній технології вилучення сполук ванадію присвячена праця науковців [5], у якій вперше розглянуто використання тиску, додаткового кисню та запропоновано методику використання автоклавного способу. Однак проведені дослідження і отримані результати не дозволили запропонувати оптимальні технологічні параметри для перевірки в дослідно-промислових умовах. 
Виділення не вирішених раніше частин загальної проблеми, котрим присвячусться означена стаття. Аналіз літературних джерел показав, що у промисловій практиці гідролітичне осадження ванадію здійснюють із суміші водних і кислих розчинів, одержуваних при вилуговуванні ТПС, обпалених з реагуючою добавкою, або при їхній роздільній нейтралізації. При цьому відсутня інформація про осадження ванадію із суміші лужних і кислих розчинів, які утворюються при високотемпературній обробці зольних залишків в автоклаві. У зв'язку з цим було поставлено завдання визначити раціональні умови осадження ванадію із розчинів, одержуваних при окисному вилуговуванні ТПС у закритому апараті.

Новизна. У статті досліджено та встановлено процес взаємодії компонентів та оптимальні технологічні параметри для перевірки в дослідно-промислових умовах; запропоновано модель процесу, яка дозволяє прогнозувати умови його проведення.

Методологічним і загальнонауковим значенням $\epsilon$ розробка фізико-хімічних основ технології отримання сполук ванадію із техногенних відходів 3 метою покращення екологічної ситуації.

Виклад основного матеріалу. У дослідженнях розглядалися проблеми 3 метою визначення оптимальних технологічних параметрів при температуpax 373-623 К з окисненням сполук ванадію (III, IV) до п'ятивалентного стану та вилучення сполук ванадію із відходів промислового виробництва. Хімічний склад основних компонентів вторинної ванадійвмісної сировини наведено у табл. 1 .

Попередньо було проведено дослідження з вилуговування зольних залишків розчинами $\mathrm{Ca}(\mathrm{OH})_{2}$ i $\mathrm{H}_{2} \mathrm{SO}_{4}$ та вилучення оксидів ванадію із отриманих розчинів на лабораторній установці. Лабораторні дослідження з вивчення впливу технологічних параметрів на переведення $\mathrm{V}_{2} \mathrm{O}_{5}$ у розчин при температурі вище 373 К проводили на дослідній автоклавній установці періодичної дії ємністю 3 л $з$ електрообігріванням (рис. 1).

До досліду залучали автоклав (7) із механічною мішалкою (4), обладнанням для відбору проб (5), манометром для виміру тиску всередині автоклава (6), впускним клапаном (3) для подачі $\mathrm{O}_{2}$ iз балона (1) в автоклав. Контроль і регулювання температури й тиску пари в автоклаві забезпечували за допомогою системи СТОСІВ і автоматики, які включали вимір, запис і регулювання температури пульпи й тиску в автоклаві.
Для експериментальних досліджень були відібрані проби зольних залишків на Київській ТЕЦ-5, Углегірській і Запорізькій ГРЕС, склад яких представлено в табл. 1. Відібрані проби для досліджень мали розмір часток близько 0,1 мм, щільність же становила 3400-3700 кг/м³ [5]. На першій стадії досліджень навіску зольних залишків Запорізької ГРЕС розміром часток менше 0,1 мм завантажували в автоклав, у який заливали воду до 1 л і суспензію лужної добавки реагенту при співвідношенні рідкої фази до твердої (2-20):1.

Розчин в автоклаві нагрівали до заданої температури за допомогою електронагрівника. Потім в автоклав подавали кисень у кількості 20 л $(\mathrm{P}=1,0 \mathrm{MПа)}$ на 2 л вільного простору, що становило 12-13 г $\mathrm{O}_{2}$ на 100 г ТПС. При досягненні заданої температури досліду вели відлік тривалості процесу. Дослідження процесу вилуговування ТПС проводили за температури 373-563 К, активному перемішуванні й тривалості 60-240 хв.

Після завершення досліду автоклав охолоджували до 323-343 К. Тиск в автоклаві знижували до 0,5-0,7 МПа. Після вирівнювання тиску з атмосферним автоклав розгерметизовували, вивантажували й фільтрували пульпу. Твердий залишок промивали гарячою водою, сушили й визначали в ньому вміст оксидів ванадію, нікелю, хрому, марганцю, заліза [10]. Маточний розчин змішували 3 основним розчином і аналізували його на вміст $\mathrm{V}_{2} \mathrm{O}_{5}, \mathrm{NiO}, \mathrm{Fe}_{2} \mathrm{O}_{3}$, $\mathrm{Cr}_{2} \mathrm{O}_{3}, \mathrm{CaO}$ та інших речовин $[4 ; 5 ; 10]$.

3 метою більш повного вилучення ванадію із твердого залишку після першої стадії вилуговування його обробляли в автоклаві $3-10 \%$ розчином $\mathrm{H}_{2} \mathrm{SO}_{4}$ за температури 423-523 K й активного перемішування без кисню. Після закінчення досліду осад від розчину відокремлювали фільтруванням. Отриманий розчин і твердий залишок піддавали хімічному аналізу [10].

Відомо [4-7], що окиснення нижчих оксидів ванадію у вищі відбувається в лужному середовищі, тому як реагенти використовували розчини $\mathrm{NaHCO}_{3}, \mathrm{Na}_{2} \mathrm{CO}_{3}, \mathrm{Na}(\mathrm{OH}), \mathrm{Ca}(\mathrm{OH})_{2}$, а також їхні суміші. Результати досліджень по вилученню ванадію залежно від умов представлено в табл. 2 .

Так, найбільший ступінь вилучення оксиду ванадію (V) із твердих продуктів спалювання забезпечують розчини гідроксиду кальцію й натрію. У зв'язку з більшою доступністю в практичних умовах, меншою вартістю й більш високим ступе-

Таблиця 1

Хімічний склад ТПС [5]

\begin{tabular}{|l|c|c|c|c|c|c|c|c|c|c|}
\hline \multirow{2}{*}{$\begin{array}{c}\text { Найменування } \\
\text { проби }\end{array}$} & \multicolumn{10}{|c|}{ Масовий вміст основних компонентів \% } \\
\cline { 2 - 12 } & $\mathbf{V}_{\mathbf{2}} \mathbf{O}_{\mathbf{5}}$ & $\mathbf{N i O}$ & $\mathbf{F e}_{\mathbf{2}} \mathbf{O}_{\mathbf{3}}$ & $\mathbf{M n O}$ & $\mathbf{C r}_{\mathbf{2}} \mathbf{O}_{\mathbf{3}}$ & $\mathbf{A l}_{\mathbf{2}} \mathbf{O}_{\mathbf{3}}$ & $\mathbf{C a O}$ & $\mathbf{S i O}_{\mathbf{2}}$ & $\mathbf{N a}_{\mathbf{2}} \mathbf{O}+\mathbf{K}_{\mathbf{2}} \mathbf{O}$ & $\mathbf{S}$ \\
\hline Углегірська ГРЕС & 34,4 & 4,7 & 21,4 & 0,2 & 3,6 & 3,1 & 2,2 & 5,7 & 6,8 & 4,5 \\
\hline Київська ТЕЦ-5 & 12,3 & 2,6 & 15,1 & 0,2 & 2,5 & 1,9 & 6,2 & 8,9 & 8,2 & 5,8 \\
\hline Запорізька ГРЕС & 26,7 & 4,4 & 18,7 & 0,1 & 0,9 & 1,5 & 7,6 & 8,5 & 7,8 & 3,2 \\
\hline
\end{tabular}


нем розкриття зольних залишків подальші дослідження проводили 3 використанням розчинів гідроксиду кальцію.

Дослідження показало, що при гідролітичному вилученні сполук ванадію утворюються метаванадати, розчинність яких досягає 460 г/л. Процеси, які відбуваються при утворенні метаванадату кальцію, можна представити так:

$$
\begin{gathered}
\mathrm{V}_{2} \mathrm{O}_{5}+\mathrm{H}_{2} \mathrm{O} \leftrightarrow \mathrm{HVO}_{3}(\mathrm{pH} 2,2-2,4) \\
\mathrm{CaO}+\mathrm{H}_{2} \mathrm{O} \leftrightarrow \mathrm{Ca}(\mathrm{OH})_{2}(\mathrm{pH} 10,5-12,0) \\
2 \mathrm{HVO}_{3}+\mathrm{Ca}(\mathrm{OH})_{2} \leftrightarrow \mathrm{CaV}_{2} \mathrm{O}_{6}+2 \mathrm{H}_{2} \mathrm{O}(\mathrm{pH} 5,5-7,2)
\end{gathered}
$$

Зі збільшенням $\mathrm{pH}$ розчину збільшується й утворення спочатку пірованадату, а потім ортованадату кальцію - сполук, малорозчинних у воді:

$$
\begin{aligned}
& \mathrm{CaV}_{2} \mathrm{O}_{6}+\mathrm{Ca}(\mathrm{OH})_{2} \leftrightarrow \mathrm{Ca}_{2} \mathrm{~V}_{2} \mathrm{O}_{7}+\mathrm{H}_{2} \mathrm{O} \\
& \mathrm{Ca}_{2} \mathrm{~V}_{2} \mathrm{O}_{7}+\mathrm{Ca}(\mathrm{OH})_{2} \leftrightarrow \mathrm{Ca}_{3} \mathrm{~V}_{2} \mathrm{O}_{8}+\mathrm{H}_{2} \mathrm{O}
\end{aligned}
$$

Встановлено, що найбільшу розчинність має метаванадат кальцію, максимальна розчинність якого перебуває в інтервалі рН 5,5-7,2. Тому можна припустити, що максимальний ступінь вилучення ванадію із зольних залишків суспензією гідрооксиду кальцію буде досягнутий при вказаних вище значен-

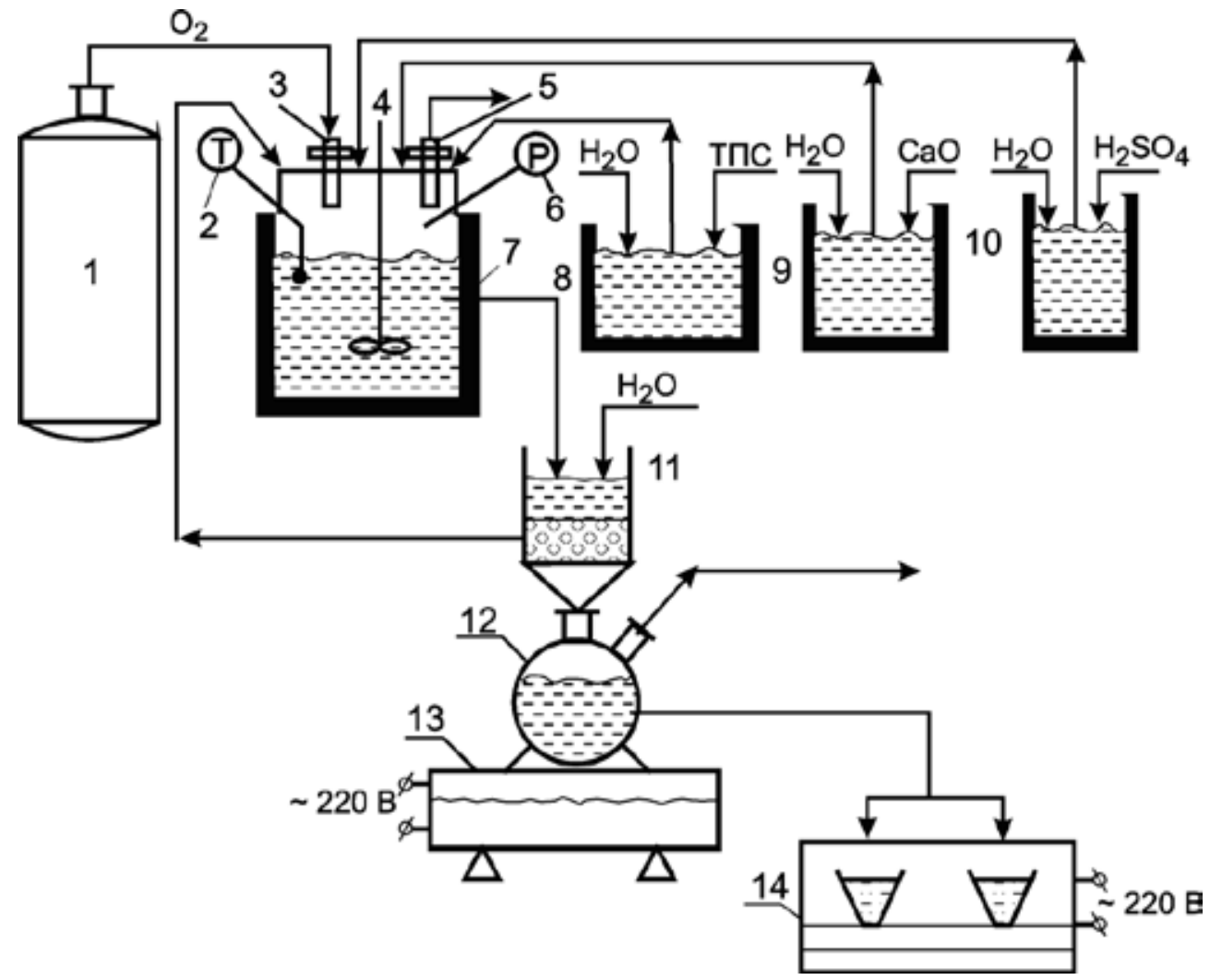

Рис. 1. Схема лабораторної установки гідрохімічної переробки ТПС: 1 - балон із $O_{2}$; 2 - контактний термометр із термореле; 3 - впускний клапан подачі $\mathrm{O}_{2}$; 4 -мімалка; 5 - обладнання для відбору проб; 6 - манометр; 7 - автоклав з електрообігріванням; 8 - посудина для готування водної суспензї ТПС; 9 - посудина для готування $\mathrm{Ca}(\mathrm{OH})_{2}$; 10 - посудина для готування розчину $\mathrm{H}_{2} \mathrm{SO}_{4} ; 11$ - фільтр; 12 - колба; 13 - електроплита; 14 - муфельна піч

Таблиця 2

Залежність ступеня вилучення оксиду ванадію (V) при $P_{02}=1,0$ МПа, Ж:T = 7:1, маса зразка - 100 г

\begin{tabular}{|c|c|c|c|c|}
\hline \multicolumn{2}{|c|}{ Склад пульпи } & \multicolumn{2}{|c|}{ Умови досліду } & $\begin{array}{c}\text { Стпінь вилучення } \\
\text { ванадію, \% }\end{array}$ \\
\hline Розчинник & Концентрація, г/л & Температура, К & Час, хв & 62,3 \\
\hline $\mathrm{NaOH}$ & 250 & 523 & 120 & 74,8 \\
\hline $\mathrm{NaOH}$ & 300 & 523 & 240 & 27,2 \\
\hline $\mathrm{NaHCO}_{3}$ & 250 & 523 & 120 & 63,1 \\
\hline $\mathrm{Ca}(\mathrm{OH})_{2}$ & 100 & 523 & 120 & 69,2 \\
\hline $\mathrm{Ca}(\mathrm{OH})_{2}$ & 200 & 523 & 120 & 58,1 \\
\hline $\mathrm{H}_{2} \mathrm{SO}_{4}$ & 50 & 473 & 120 & \\
\hline
\end{tabular}


Залежність ступеня вилучення $\mathrm{V}_{2} \mathrm{O}_{5}$ із ТПС суспензією Са(OH)

\begin{tabular}{|c|c|c|c|c|c|}
\hline \multicolumn{2}{|c|}{ Склад суспензії } & \multicolumn{2}{|c|}{ Значення рН розчину } & \multirow[b]{2}{*}{$\begin{array}{c}\text { Концентрація } \mathrm{V}_{2} \mathrm{O}_{5} \\
\text { у розчині, г/л }\end{array}$} & \multirow[b]{2}{*}{$\begin{array}{l}\text { Ступінь вилучення } \\
\mathbf{V}_{2} \mathbf{O}_{5}, \%\end{array}$} \\
\hline Вода, мл & Зола, г & вихідного & $\begin{array}{l}\text { наприкінці } \\
\text { досліду }\end{array}$ & & \\
\hline 1000 & 200 & 12,0 & 7,1 & 22,7 & 45,4 \\
\hline 1050 & 150 & 11,4 & 6,4 & 17,1 & 41,7 \\
\hline 1050 & 150 & 12,4 & 7,3 & 14,3 & 37,4 \\
\hline 1000 & 200 & 11,6 & 6,7 & 33,1 & 65,6 \\
\hline 1000 & 200 & 12,5 & 8,1 & 0,28 & 0,8 \\
\hline 1000 & 200 & 10,3 & 7,6 & 4,8 & 12,8 \\
\hline
\end{tabular}

нях $\mathrm{pH}$. Ця думка підтверджена результатами досліджень, представлених у табл. 3 .

Раніше проведені дослідження [8; 9] із вилуговування зольних залишків розчинами $\mathrm{Ca}(\mathrm{OH})_{2} \mathrm{i}_{2} \mathrm{SO}_{4}$ при атмосферному тиску показали, що збільшення температури процесу вилуговування ТПС сприяє підвищенню ступеня витягу ванадію в розчин. Вивчення процесу вилуговування ТПС розчинами $\mathrm{Ca}(\mathrm{OH})_{2}$ при температурах вище 373 К підтвердили позитивний вплив температури на ступінь вилучення ванадію. Встановлено, що на першій стадії вилуговування ТПС гідрооксидом кальцію та окисненням киснем максимальний ступінь вилучення ванадію в розчин досягається за температури 523-573 К. При цьому концентрація $\mathrm{V}_{2} \mathrm{O}_{5}$ у розчині становила $15,8-21,3$ г/л.

$\mathrm{У}$ практиці автоклавного вилуговування рідких металів освоєні автоклави, конструкція яких дозволяє вести процес за температури 493-503 К. Лабораторний автоклав, на якому проводилися дослідження, розраховано на температуру 563 К. Досліди із зольним залишком показали, що зі збільшенням температури вилуговування із 423 до 563 К ступінь вилучення ванадію збільшується з 45,8 до $64,7 \%$. $Є$ теоретичні дані, що за температури 623 К вона може досягти $80-85 \%$.

Як показали дослідження, тривалість процесу вилуговування оксидів ванадію із твердих продуктів спалювання позитивно впливає на ступінь вилучення ванадію із зольних залишків. При вилуговуванні протягом 90-120 хвилин і активному перемішуванні досягається максимальний ступінь розкриття ТПС, який становить $63,9 \%$. Досліджено, що активне перемішування сприяє більш глибокому розкриттю зольних залишків. Збільшення часу на понад 2 години не дуже впливає на ступінь вилучення ванадію.
Визначальним фактором при виборі оптимального відношення Ж:T була концентрація $\mathrm{V}_{2} \mathrm{O}_{5}$ у розчині. Експериментально встановлено, що при Ж:T = (5-7):1 забезпечується необхідна концентрація $\mathrm{V}_{2} \mathrm{O}_{5}$ у розчині $15-20$ г/л і ступінь витягу ванадію $60-65 \%$ у розчин.

Головні висновки. У результаті проведених досліджень визначено оптимальні параметри процесу автоклавного вилуговування ТПС гідроксидом кальцію, які забезпечують максимальний ступінь витягу ванадію в розчин: масова концентрація $\mathrm{V}_{2} \mathrm{O}_{5}$ у вихідній сировині - не менше $26 \%$; відношення Ж:Т = (3-7):1; температура процесу вилуговування - 423-493 К; тривалість процесу - 90-120 хвилин; $\mathrm{pH}$ розчину, обробленого $\mathrm{Ca}(\mathrm{OH})_{2}$ вихідної суміші, - 9,5-12,5; pH розчину по закінченню процесу вилуговування - 5,5-7,5; тиск $\mathrm{O}_{2}$ на початку досліду - 1,0 МПа. Отримані експериментальні дані добре узгоджуються 3 оцінкою термодинамічної ймовірності взаємодії відповідних ванадатів із гідроксидом кальцію, представленою у роботах $[4 ; 5 ; 9]$. Проведені експериментальні дослідження дозволили видати рекомендації для проведення дослідно-промислових випробувань способу переробки ванадійвмісних техногенних відходів промисловості.

Перспективи використання результатів дослідження. На підставі проведених досліджень встановлено вплив основних технологічних параметрів на процес вилучення ванадію, що дозволяе знижувати витрату енергії у промисловості, досягати високого ступеню утилізації. Отримані експериментальні дані процесу можуть бути використані для розрахунків оптимальних умов проведення способу переробки ванадійвмісних техногенних відходів у промислових умовах.

Література

1. Цыганкова М.В. Экстракция ванадия азотсодержащими экстрагентами фенольного типа : дисс. канд. хим. наук: 05.17.02. М. : МИСИ, 2010. $136 \mathrm{c.}$

2. Обзор рынка ванадия и ванадийсодержащей продукции в СНГ. ИнфоМайн. Исследовательская группа. М., 2009. Издание 5-е. 17 c.

3. Жуковский Т.Ф., Гринь С.А. Разработка способов и мероприятий по уменьшению загрязнений окружающей среды токсичными соединениями ванадия. Вестник НТУ «ХПИ». 2001. № 23. С. 95-99.

4. Жуковский Т.Ф., Гринь С.А. Исследование процесса гидролитического осаждения соединений ванадия из растворов. Вестник НТУ «ХПИ». 2002. № 9, т. 9. С. 55-60. 
Гринь Г.І., Кузнєцов П.В., Гринь С.О.

5. Гринь Г.И., Жуковский Т.Ф., Гринь С.А. Энергосберегающая автоклавная гидрохимическая технология извлечения ванадия из твёрдых продуктов сжигания мазута на энергетических установках. Интегрированные технологии и энергосбережение. 2002. № 3. С. 3-8.

6. Черноусов П.И. Ванадий: производство, потребление, структура рынка. П.И. Черноусов, И.Н. Монахов. Снабжение. 2005. № 11(461). С. 124-129.

7. Гринь Г.И., Жуковский Т.Ф., Гринь С.А. Экологические аспекты использования ванадиевой продукции в машиностроении. Високі технології в машинобудуванні : збірник наукових пращь НТУ «ХПI». 2005, Вип. 2(11). С. 138-141.

8. Гринь С.А, Звягинцева Ю.Ю., Цалина Д.С. Загрязнение окружающей среды газообразными, жидкими и твёрдыми соединениями ванадия. Молодий вчений. № 11(38), жовтень 2016 року. С. 1-5.

9. Гринь С.А, Питак И.В., Цалина Д.С. Термодинамические условия протекания реакций извлечения ванадия из твёрдых продуктов сжигания. Молодий вчений. № 1(41), січень 2017 року. С. 186-189.

10. Сирина Т.П., Мизин В.Г., Рабинович Е.М. Извлечение ванадия и никеля из отходов теплоэлектростанций. Екатеринбург : УрО РАН, 2001. $237 \mathrm{c}$.

11. Жуковский Т.Ф. Ресурсосберегающая и экологически ориентированная технология получения ванадиевой продукции из отходов производства. Вестник НТУ «ХПИ». 2010. № 13. С. 29-35. 
УДК 65.012.123

DOI https://doi.org/10.32846/2306-9716/2020.eco.6-33.10

\title{
МЕТОДОАОГІЧНІ АСПЕКТИ ЕКОАОГІЧНОГО АУДИТУ СИСТЕМИ МЕНЕДХМЕНТУ ПІДПРИЕМСТВ
}

\author{
Машков О.А. ${ }^{1}$, Іващенко Т.Г. ${ }^{1}$, Тупкало В.М. ${ }^{2}$ \\ ${ }^{1}$ Державна екологічна академія післядипломної освіти та управління \\ вул. Митрополита Василя Липківського, 35, 03035, м. Київ \\ ${ }^{2}$ Київський інститут інтелектуальної власності та права \\ Національного університету «Одеська юридична академія» \\ вул. Харківське шосе, 210, 02121, м. Київ \\ mashkov_oleg_52@ukr.net,tvn.prof@gmail.com
}

\begin{abstract}
У статті розглянуті елементи науково-методичного апарату екологічного менеджмент-аудиту процесно-орієнтованих підприємств на основі контролінгових правил виділення, композиції та наочного (графічного) визначення системи бізнес-процесів з використанням мови процесного моделювання. Запропоновані такі визначення: «екологічний аудит бізнес-процесів», «екологічний менеджмент-аудит», «екологічний процесно-орієнтований менеджмент-аудит», «екологічний менеджмент-аудит бізнес-процесів».

Проведений аналіз вітчизняних і зарубіжних праць засвідчив недостатню сформованість на одних методологічних засадах методології менеджмент-аудиту процесно-орієнтованих підприємств та організаційних систем. Запропонований науково-методологічний підхід до створення такої методології грунтується на моделі повної бази даних об'єкту менеджмент-аудиту процесно-орієнтованого підприємства. Аудит бізнес-процесів визначається як оцінка відповідності їх наочного (відчутного) відображення правилам графічної (наочної) композиції, прийнятих у вживаній мові процесного бізнес-моделювання. Обгрунтована доцільність пошуку теоретичних методів структурно-композиційного менеджмент-аудиту ефективності системи бізнес-процесів підприємств на основі дотримання базових системо-утворюючих принципів теорії організаційних систем.

Перспектива подальших досліджень пов'язується із розробкою базової множини правил структурно-композиційного аудиту системи бізнес-процесів. Зазначається, що за умови розширення компанією бізнесу за рахунок інвестицій екологічний аудит необхідний, особливо, якщо інвестор іноземний. Наявність нефінансової звітності, до якої відносять і екологічний аудит, дозволяє компанії бути стабільною і впевненою у завтрашньому дні, привабливою для інвесторів. Ключові слова: бізнес-інжиніринг, екологічний аудит, менеджмент-аудит, модель, організаційна система, процесно-орієнтоване управління.
\end{abstract}

Methodological aspects of environmental audit of enterprise management system. Mashkov O., Ivashchenko T., Tupkalo V.

The elements of the scientific and methodical apparatus of ecological management-audit of process-oriented enterprises on the basis of controlling rules of selection, composition and visual (graphic) representation of the system of business processes with the use of process modeling language are stated in the work. The definition is offered: "ecological audit of business-processes", "ecological management-audit", "ecological process-oriented management-audit", ecological management-audit of business-processes".

The analysis of existing domestic and foreign works has determined that the methodology of management-audit of process-oriented enterprises and organizational systems in general has not yet developed on a single methodological basis. The scientific novelty of the obtained results is that the proposed scientific and methodological approach to the creation of this methodology is based on the model of a complete database of the object of management-audit of process-oriented enterprise. Thus audit of business processes is defined as an estimation of conformity of their visual (tangible) display to the established rules of a graphic (visual) composition which are accepted in the used language of process business-modeling. The expediency of search of theoretical methods of structuralcompositional management-audit of efficiency of system of business-processes of the enterprises on the basis of observance of basic system-forming principles of the theory of organizational systems is substantiated in the work.

The prospect of further research may be related to the development of a basic set of rules for structural and compositional audit of the business process system. If the company is going to expand the business by investing from the outside, the environmental audit will not hurt, especially if the investor is foreign. The presence of non-financial reporting, which includes an environmental audit, allows the company to look stable and confident in the future and therefore-attractive to investors. Key words: business engineering, ecological audit, management audit, model, organizational system, process-oriented management.

Постановка проблеми. Законом України «Про екологічний аудит» (далі - Закон) визначаються основні правові та організаційні засади проведення екологічного аудиту, покликаного підвищити екологічну обгрунтованість та ефективність підприємств незалежно від форми власності і виду діяльності. Згідно Закону екологічний аудит - це документально оформлений системний незалежний процес оцінювання об'єкта екологічного аудиту, який передбачає збирання і об'єктивне оцінювання доказів для встановлення відповідно- сті визначених видів діяльності, заходів, умов, системи екологічного управління та інформації 3 цих питань вимогам законодавства України про охорону навколишнього природного середовища, іншим критеріям екологічного аудиту.

Нині розрізняють добровільний та обов'язковий екологічний аудит. Перший проводиться за ініціативи власника підприємства або за його згоди, другий є результатом замовлення зацікавлених державних органів, коли вид діяльності або об'єкт екологічного аудиту становить екологічну небезпеку. 
Доцільність проведення екологічного аудиту для суб'єкта господарської діяльності виникає під час розв'язання актуальних проблем, які зумовлюють необхідність визначити відповідність діяльності підприємства чинним нормам законодавства; перевірити об'єктивність висновків екологічної інспекції (щодо платежів і штрафних санкцій); зменшити затрати підприємства; використати на підприємстві додаткові сировинні та ресурсні резерви; мінімізувати ризик забруднення навколишнього природного середовища; підвищити інвестиційну привабливість, конкурентоздатність суб'єкта господарювання та наблизитися до міжнародних стандартів; розробити екологічну стратегію підприємства.

Зв'язок авторського доробку 3 важливими науковими та практичними завданнями. У науково-практичній діяльності часто під екологічним аудитом мають на увазі комплекс заходів, які дозволяють оцінити об'єкт на предмет відповідності встановленим законодавчим нормам. Він включає збір i аналіз даних, що вказують на характер діяльності господарського підприємства і ступінь його впливу на навколишнє середовище. В Україні основним нормативним актом, який відповідає на питання, що таке екологічний аудит, $є$ Закон «Про екологічний аудит». На міжнародному рівні процедура оцінки впливу об'єкта господарювання на навколишне середовище регламентується стандартом ISO 14001 (один із критеріїв системи екоменеджменту).

У сучасних наукових розробках 3 аудиторської тематики здебільшого висвітлені аспекти аудіювання економічних суб'єктів на предмет достовірності їх фінансової звітності. Проте, на думку авторів, мають висвітлюватися і питання управлінського аудіювання 3 огляду на актуальність тенденції переходу сучасних підприємств на процесно-орієнтовану систему організаційного управління. Нині така тенденція є фактором, який визначає конкурентоздатність підприємств з точки зору їх взаємодії із зовнішнім бізнес-середовищем. Тому актуалізується пошук теоретично обгрунтованих методів структурно-композиційного менеджмент-аудиту ефективності системи бізнес-процесів підприємств на основі дотримання базових системоутворюючих принципів теорії організаційних систем.

Екологічний аудит - це незалежна оцінка дотримання підприємством законодавства в галузі охорони навколишнього середовища або вимог міжнародних стандартів. На підставі такої оцінки готуються рекомендації щодо усунення недоліків у природоохоронній діяльності компанії і визначаються оптимальні шляхи їх вирішення. Поняття «екологічний аудит» для України не нове, адже Закон «Про екологічний аудит» був прийнятий у 2004 році. Він передбачає два види екологічного аудиту: добровільний та обов'язковий. Добровільний аудит ініціюється і фінансується керівництвом самої компанії або (за погодженням із компанією) третьою особою, наприклад, інвестором.
Поняття «екологічний аудит» запозичене з фінансової сфери, тому основними характеристиками екологічного аудиту є незалежність; 100\% конфіденційність оброблюваної інформації; спрямованість на результат; об'єктивність і неупереджене ставлення; високий професіоналізм і наявність дозволу у осіб, які проводять перевірку; широкий перелік напрямів аналізу; впровадження програми, яка дозволяє підвищити рівень економічного менеджменту; виявлення потенційної економічної вигоди для замовника; порівняння діяльності організації і діючих стандартів законодавства.

Аналіз останніх досліджень і публікацій. Вивченню методів проведення менеджмент-аудиту присвячена значна кількість публікацій [1-5]. Вони засвідчують, що домінуюче тлумачення поняття «менеджмент-аудит» здебільшого зводиться до оцінки відповідності діяльності окремих структурних підрозділів підприємства та його загалом встановленим критеріям і формальним вимогам, наприклад вимогам стандарту ISO 9001 до системи менеджменту якості (далі - СМЯ) процесно-орієнтованого підприємства. При цьому в контексті декларованої цим стандартом процесно-орієнтованої парадигми побудови системи менеджменту підприємства результативність функціонування процесів та їх відповідність контролінговим правилам виділення, композиції та наочного представлення не розглядаються.

Варто зазначити, що дослідники здебільшого приділяють увагу лише способам збору аудиторської інформації. При цьому методам оцінки спостережень процесного менеджмент-аудиту присвячена незначна кількість досліджень. Так, у роботах $[1 ; 5]$ пропонується підхід до визначення значущості відхилень процесів від норми, який базується на експертних оцінках за розробленою бальною шкалою. Автори запропоновали таку систему оцінки, яка не враховує локалізацію невідповідності в бізнес-процесах системи менеджменту. Тому проблема оцінки значущості невідповідності не вирішується. Процедура прийняття рішення за спостереженнями менеджмент-аудиту є евристичним процесом, заснованим на досвіді, інтуїції, думці експертів. Через це однакові невідповідності класифікуються аудиторами за ступенем їх значущості по-різному, тому і результати менеджмент-аудиту відрізняються.

Виділення не вирішених раніше частин загальної проблеми, котрим присвячусться означена стаття. Діючий стандарт ISO 9001:2015 у розділі 9.2.2 висуває низку вимог до планування внутрішніх аудитів системи менеджменту якості:

1) планувати, розробляти i підтримувати програми аудиту, включаючи частоту, методи відповідальності, вимоги до планування і звітності, в яких повинна враховуватися важливість обраних для перевірки процесів, зміни, що впливають на організацію, і результати попередніх аудитів; 
2) для кожного аудиту встановлювати критерії та області;

3) відбирати аудиторів і проводити аудит так, щоб була забезпечена об'єктивність і неупередженість цього процесу.

Загалом ці вимоги до планування і проведення внутрішніх аудитів здатні забезпечити виконання встановлених у стандарті вимог і успішне проходження сертифікації. Однак метод організації аудитів «діяльність підрозділів» має підвищений ризик не виконати вимогу стандарту «визначити результативність системи управління якістю», оскільки зібрані дані будуть характеризувати стан діяльності окремих підрозділів, тобто фрагменти діяльності системи менеджменту. Тому на основі таких даних практично не можливо зробити надійні висновки про систему загалом.

Якщо підприємство задовольняється лише формальним існуванням СМЯ згідно з вимогами стандарту ISO 9001 як інструментом забезпечення ефективності (досконалості) системи менеджменту на якомусь «мінімально сертифікованому» рівні, то метод планування і проведення внутрішніх аудитів системи менеджменту «діяльність підрозділів» може бути прийнятним. Але якщо підприємство зацікавлене в отриманні точних даних про роботу своєї системи менеджменту, то у нього практично немає альтернативи: тільки аудит системи бізнес-процесів на основі науково обгрунтованої методики може забезпечити досягнення таких цілей. Для цього парадигма функціювання створеної СМЯ повинна грунтуватися на методології, що чітко визначає механізм контролінгових правил виділення, композиції та наочного (графічного) представлення системи управлінських та технологічних бізнес-процесів на всіх рівнях піраміди процесного менеджменту підприємства [6; 7-11] за умови дотримання базових системоутворюючих принципів теорії організаційних систем. Тобто виникає дилема: аудит системи бізнес-процесів чи аудит структурних підрозділів? 3 цього приводу в табл. 1 наведена оцінка щодо переваг і недоліків кожного з розглянутих методів аудиту.

Мета дослідження полягає у викладі нових елементів науково-методичного апарату менеджмент-аудиту процесно-орієнтованих підприємств на основі контролінгових правил виділення, композиції та наочного (графічного) представлення системи бізнес-процесів 3 використанням мови процесного моделювання [6;11].

Виклад основного матеріалу. Керуючись критерієм табл. 1 щодо методу менеджмент-аудиту бізнес-процесів як повною базою даних моделі системи бізнес-процесів підприємства (концептуальна модель об'єкту менеджмент-аудиту підприємства), яка дозволяла б оперативно визначати порушення (відхилення) протікання бізнес-процесів, пропонується модель, подана на рис. 1. При цьому контролінговими правилами інжинірингу / реінжинірингу статичних і динамічних моделей мають бути відповідні правила їх композиції.

Керуючись таким твердженням, пропонуємо такі визначення:

Визначення 1. Екологічний аудит бізнес-процесів - це оцінка відповідності їх наочного відображення відповідним правилам графічної (наочної) композиції, які прийняті у використовуваній мові процесного бізнес-моделювання. У практичному сенсі цільове призначення менеджмент-аудиту процесно-орієнтованого підприємства пропонується розглядати в контексті вирішення трьох типових управлінських задач:

Таблиця 1

Оцінка методів менеджмент-аудиту

\begin{tabular}{|c|c|c|}
\hline \multirow{2}{*}{$\begin{array}{c}\text { Метод } \\
\text { менеджмент- } \\
\text { аудиту } \\
\end{array}$} & \multicolumn{2}{|c|}{ Критерії оцінки } \\
\hline & $\begin{array}{c}\text { Цінність результатів аудиту } \\
\text { для менеджменту }\end{array}$ & Ступінь складності проведення аудиту \\
\hline $\begin{array}{c}\text { Аудит } \\
\text { бізнес-процесів }\end{array}$ & $\begin{array}{l}\text { Висока. Дозволяє зібрати свідчення для } \\
\text { обгрунтованого рішення про поліпшення } \\
\text { процесів і системи менеджменту загалом }\end{array}$ & $\begin{array}{c}\text { Досить висока. Вимагає ретельної } \\
\text { попередньої роботи щодо створення повної } \\
\text { бази даних бізнес-моделі системи бізнес- } \\
\text { процесів підприємства у наочній (графічній) } \\
\text { формі, яка б дозволяла оперативно } \\
\text { визначати порушення (відхилення) } \\
\text { протікання бізнес-процесів. Створення такої } \\
\text { бази даних вимагає високих витрат }\end{array}$ \\
\hline $\begin{array}{c}\text { Аудит } \\
\text { діяльності } \\
\text { підрозділів }\end{array}$ & $\begin{array}{c}\text { Невисока. Дозволяє отримати } \\
\text { фрагментарні дані, на основі яких } \\
\text { можна прийняти управлінське рішення } \\
\text { лише про локальні поліпшення } \\
\text { (з ризиком порушення цілісності } \\
\text { системи менеджменту). Вона не } \\
\text { сприяє актуальному в сучасних } \\
\text { умовах ведення бізнесу переходу від } \\
\text { структурно-функціонального управління } \\
\text { підприємством до процесно-орієнтованого }\end{array}$ & $\begin{array}{c}\text { Істотно простіше. Не потребує } \\
\text { попередньої ідентифікації (виділення, } \\
\text { композиції та опису) системи бізнес- } \\
\text { процесів і їх прив’язки до організаційної } \\
\text { структури. Спрощується організація і } \\
\text { координація проведення аудиту. Такий } \\
\text { метод менеджмент-аудиту може бути } \\
\text { рекомендований, коли на перший план } \\
\text { висувається вимога щодо зниження витрат } \\
\text { на планування та проведення аудитів }\end{array}$ \\
\hline
\end{tabular}




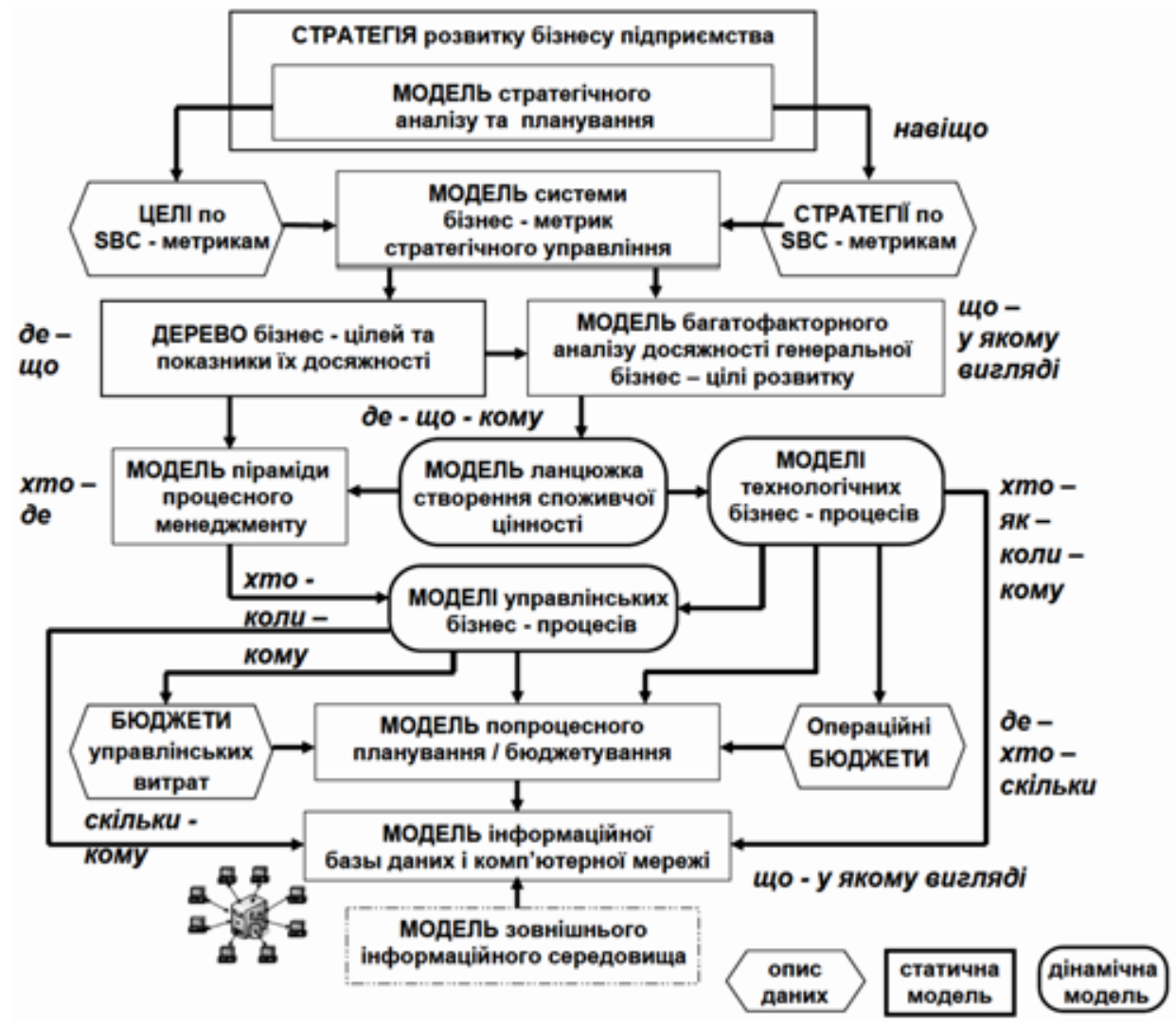

Рис. 1. Концептуальна модель повної бази даних об 'єкту менеджмент-аудиту прочесно-орієнтованого підприємства

Джерело: складено авторами

1) оцінка ефективності системи бізнес-процесів управління підприємством для досягнення поставленої генеральної (стратегічної) цілі, наприклад 3 метою максимізації економічної доданої вартості;

2) визначення «вузьких місць», тобто ризиків або недоліків у бізнес-процесах різних видів операційної діяльності з метою розроблення запобіжних механізмів внутрішнього контролю, які мінімізують негативні наслідки;

3) внесення рекомендацій, що стосуються удосконалення системи процесного менеджменту загалом, наприклад залежно від зміни стратегії взаємодії підприємства із зовнішнім бізнес-середовищем.

Варто зазначити, що запропонована методологія менеджмент-аудиту i оптимізації бізнес-процесів грунтується на концептуальному визначенні про те, що система бізнес-процесів є підлеглою функцією бізнес-стратегії підприємства і системоутворюючим інструментом менеджмент-аудиту стратегії розвитку бізнесу процесно-орієнтованого підприємства, базою для виконання численних консалтингових проектів матриці стратегічного планування "SBC-MМ" (рис. 2).

Визначення 2. Екологічний менеджмент-аудит - це дослідження усіх видів (напрямів) операційної діяльності підприємства згідно бізнес-метрик підприємства, спрямоване на формування рекомендацій зі зміни практики менеджменту тими видами діяльності, за яких є можливість у скороченні витрат виробництва. В контексті моделі (рис. 1) та визначення об'єктами аудиту (менеджмент-діагностики) процесно-орієнтованого підприємства доцільно розглядати систему з чотирьох груп (видів) бізнес-процесів згідно піраміди процесного менеджменту:

- бізнес-процеси стратегічного планування і маркетингу;

- бізнес-процеси фінансово-економічного управління;

- бізнес-процеси управління основними та допоміжними видами операційної діяльності;

- технологічні бізнес-процеси створення споживчої бізнес-цінності (рис. 3 ).

Основна мета комплексного менеджмент-аудиту зазначених вище груп бізнес-процесів управління це виявлення логічних і процедурних невідповідностей у діловодстві та системах документообігу, які $\epsilon$ причинами збоїв у системі управління та недостатньої ефективності роботи підприємства. Отже, документообіг необхідно аналізувати так:

- стан і застосування реєстраційних процедур у системі внутрішнього документообігу і діловодства;

- стан опису маршрутів руху документів, умов їх виникнення, місць архівації; 


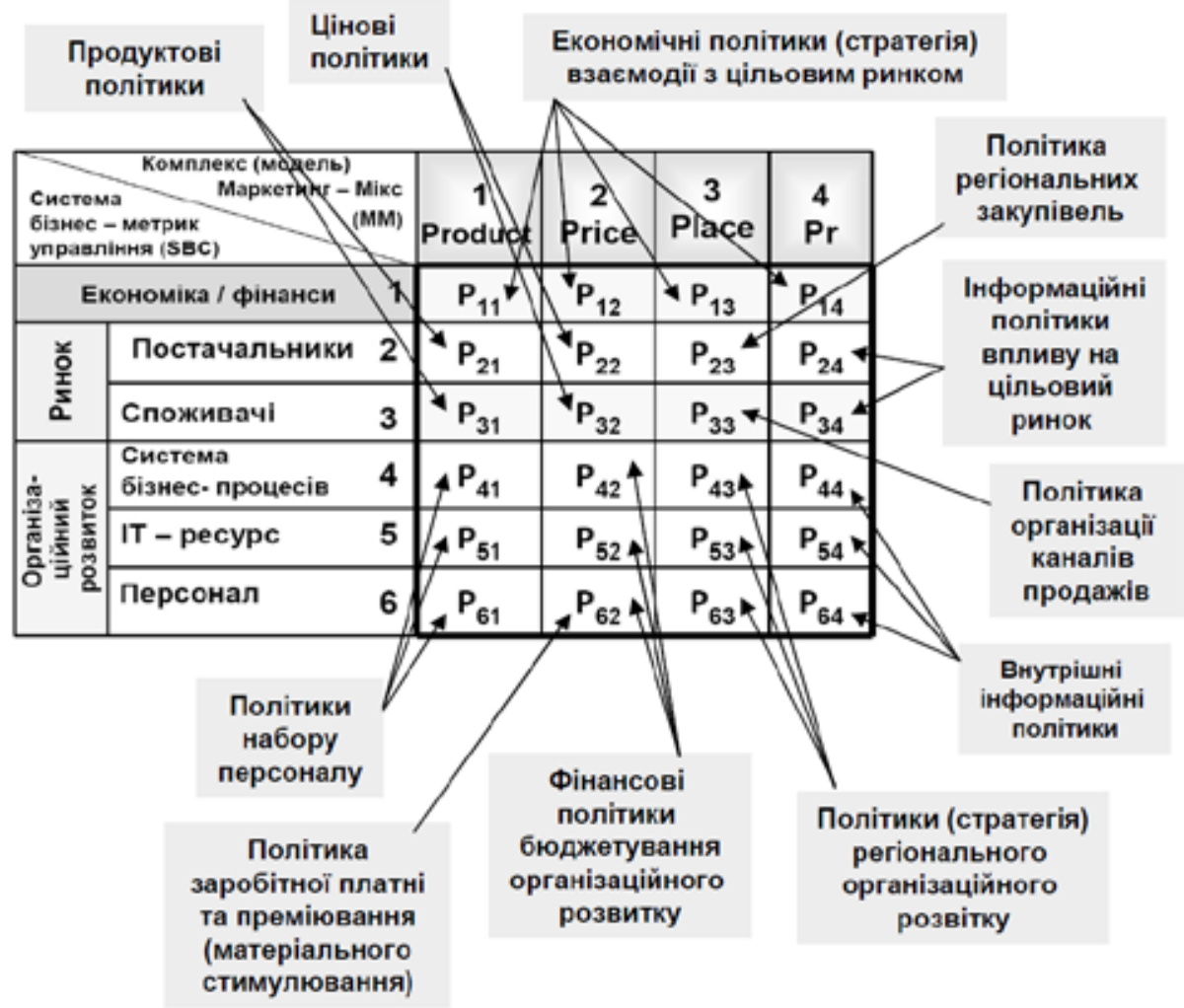

Рис. 2. Матриця стратегічного планування "SBC-MM"

Джерело: складено авторами

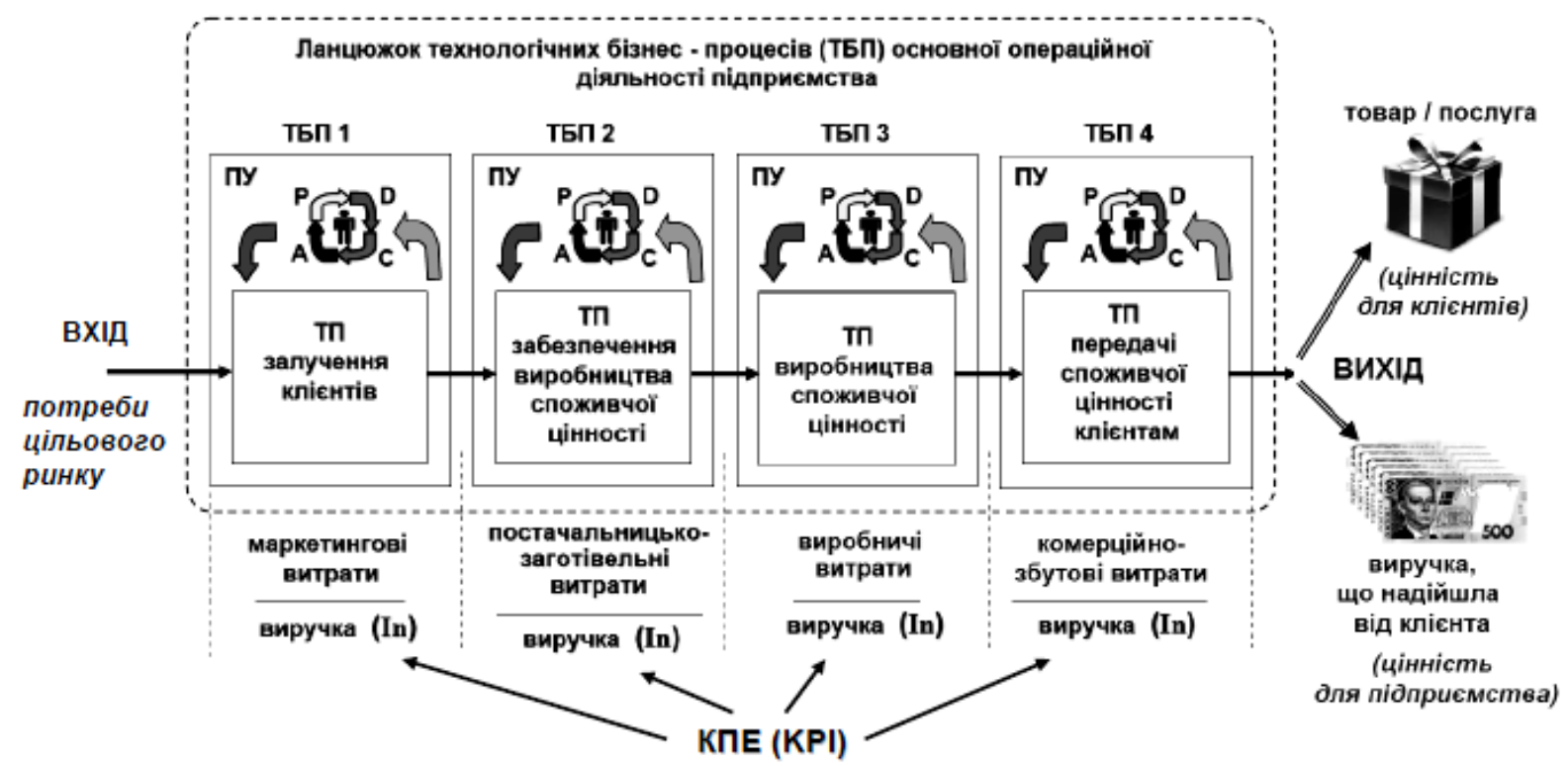

Рис. 3. Модель ланцюжка технологічних бізнес-процесів створення бізнес-иінності підприємства: ПУ - індивідуальний процес управління власника технологічного бізнес-процесу згідно управлінського циклу PDCA (англ. "Plan-Do-Check-Act”); ТП- технологічний процес створення бізнес-иінності; КПЕ (KPI) - ключові показники ефективності (англ. “Key Performance Indicators”)

Джерело: складено авторами

- наявність логічної зв’язаності між джерелами даних у системі документообігу та їх значеннями (характеристиками);
- наявність безперервності ланцюжка управлінської інформаційної взаємодії (управлінського документообігу) між центрами управлінської відпо- 
відальності по кожній окремій гілці піраміди процесного менеджменту підприємства.

Основна мета аудиту другого, третього та четвертого технологічного бізнес-процесів створення споживчої бізнес-цінності підприємства (рис. 3) полягає у знаходженні та усуненні «розривів» у ланцюжку матеріальної відповідальності посадових осіб, дозволяє визначити так звані «мовчазні» в інформаційному сенсі функціональні операції в ТП і знайти «розриви» в безперервності ланцюжка інформаційної відповідальності посадових осіб ТП. Зазначена вище мета комплексного аудиту технологічних бізнес-процесів буде досягнута, якщо композиція будьякого ТП відбувається відповідно до поданої на рис. 4 моделі та будуть отримані відповіді на базові аудит-питання відповідно до запропонованої концепції діагностики виробничих процесів підприємства (рис. 5).

Визначення 3. Екологічний процесно-орієнтований менеджмент-аудит - це дослідження системи бізнес-процесів видів операційної діяльності підприємства згідно з визначеною системою бізнес-метрик підприємства, спрямоване на формування рекомендацій зі зміни практики менеджменту тими видами діяльності, за яких є можливість підвищити ефективність і основна увага яких спрямовується не на функції, що виконують окремі структурні підрозділи підприємства, а на бізнес-процеси, які об'єднують окремі функції у відповідний ланцюжок технологічних бізнес-процесів створення бізнес-цінності підприємства відповідно до його моделі (рис. 3).
Можна стверджувати, що визначальна перевага запропонованої концепції процесно-орієнтованого менеджмент-аудиту згідно моделі (рис. 1) - це його спрямованість на створення i зміцнення горизонтальних зв' язків як між функціональними підрозділами по їх ланцюжку створення бізнес-цінностей, так і вертикальних зв'язків бізнес-взаємодії між центрами управлінської відповідальності у всій піра-

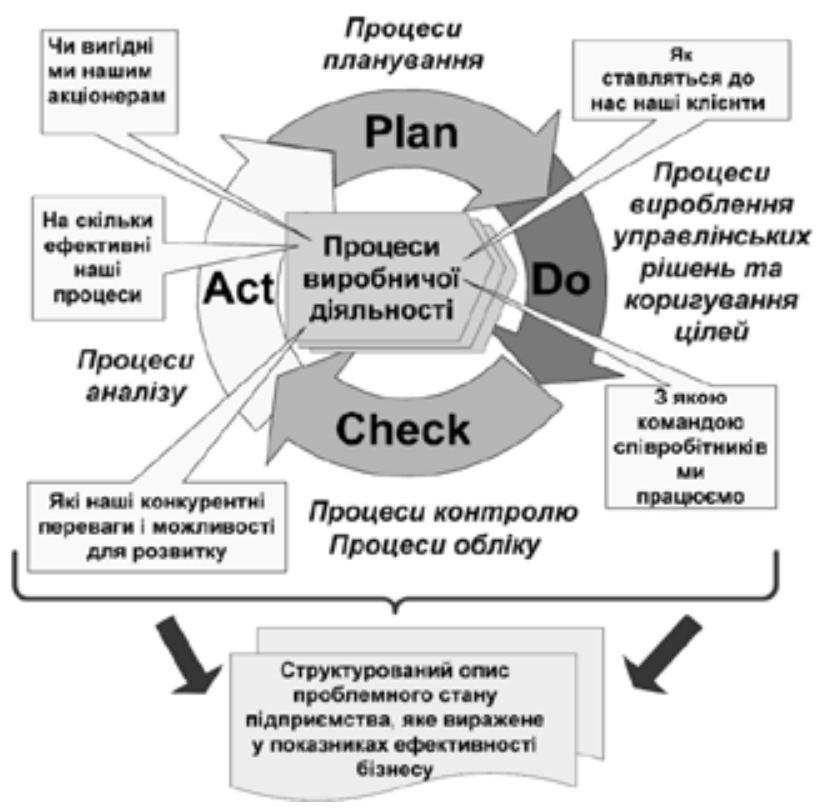

Рис. 5. Система базових аудит-питань діагностики прочесів виробничої діяльності підприємства

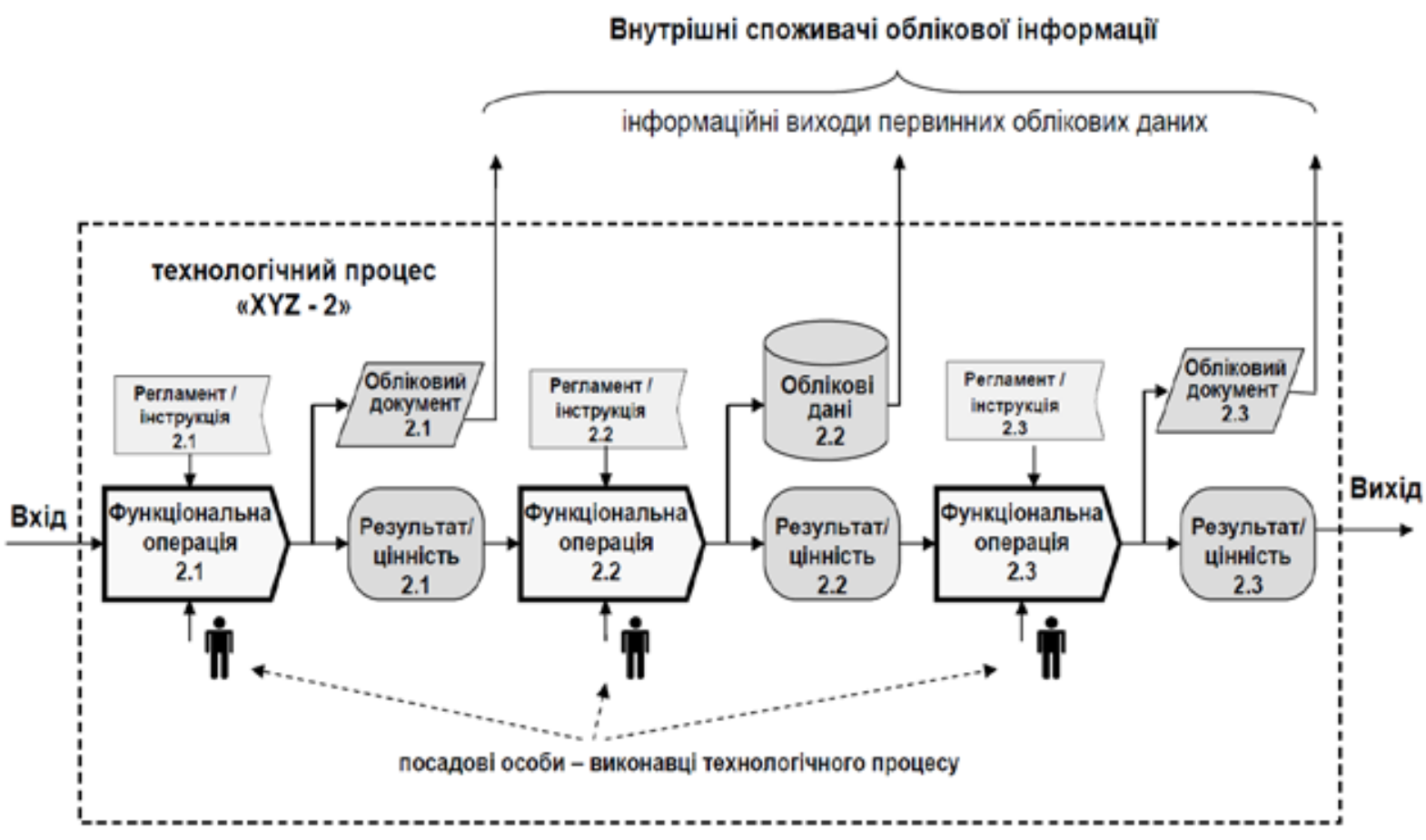

Рис. 4. Модель структури графічного опису

потокових workflow моделей (діаграм) технологічних процесів

Джерело: складено авторами 
міді процесного менеджменту підприємства (його бізнес-метриках). Тому менеджмент-аудит процесно-орієнтованого підприємства можна розглядати як комплексний аудит у просторовому вимірі: горизонтальний менеджмент-аудит; вертикальний менеджмент-аудит; менеджмент-аудит у прямому напрямі; менеджмент-аудит у зворотному напрямі.

Горизонтальний менеджмент-аудит - це аудит окремого технологічного (далі - ТП) або управлінського (далі -ПУ) процесу від його початку й до завершення, не відволікаючись на суміжні процеси. Під час горизонтального аудиту здійснюється детальна послідовна перевірка кожної функціональної операції процесу. Переваги такого аудиту пов'язані з тим, що $\epsilon$ змога детально перевірити всі операції (дії) одного процесу, супровідну документацію, ресурси, рольові функції усіх співробітників, задіяних саме в цьому процесі. Модель проведення горизонтального структурно-композиційного менеджмент-аудиту технологічного бізнес-процесу (далі - ТБП) та індивідуального процесу управління (далі - ПУ) керівника 3 управлінським статусом, власника бізнес-процесу наведені на рис. 6 і 7, система аудит-питань моделі (рис. 5) наведена в табл. 2.

Вертикальний менеджмент-аудит - це структурно-композиційний аудит системи бізнес-проце-

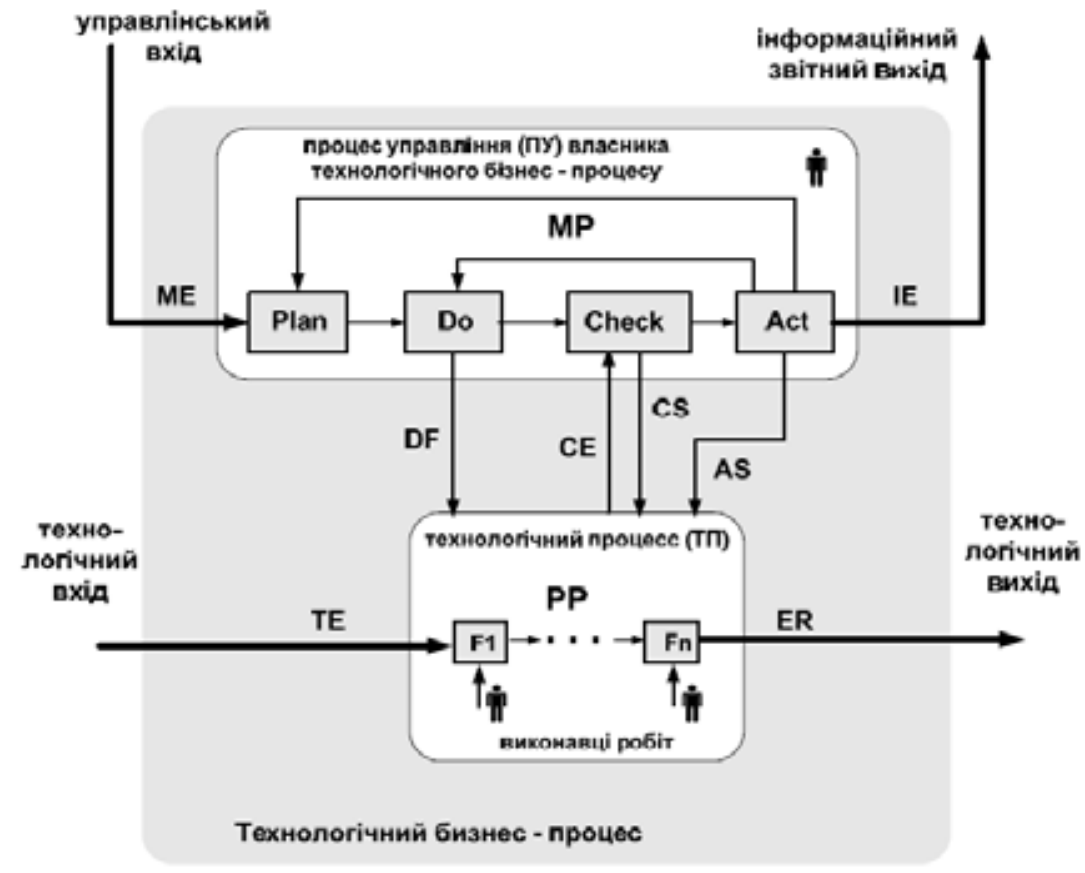

Pис. 6. TML-модель проведення горизонтального

структурно-композиційного менеджмент-аудиту технологічного процесу

Джерело: складено авторами

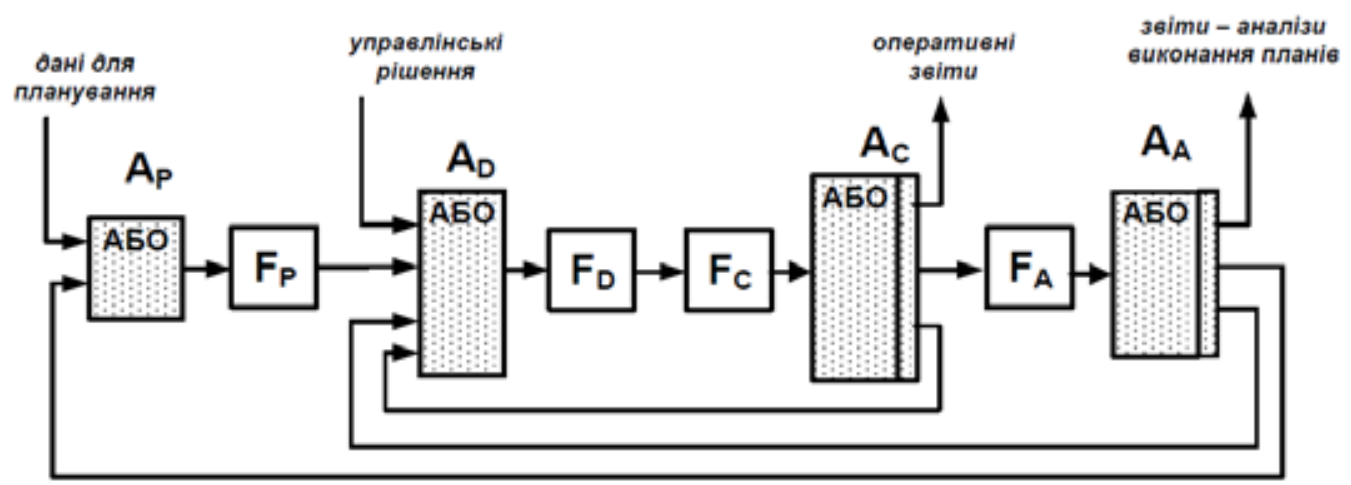

Puc. 7. TML-модель проведення горизонтального структурно-композиційного менеджмент-аудиту проиесу управління власника бізнес-проиесу:

$F_{P}, F_{D}, F_{C}, F_{A}$ - функиіональні операциї управлінського ициклу "Plan-Do-Check-Act”;

$A_{P}, A_{D}, A_{C}, A_{A}-$ логічні оператори (перетини) «АБО»

Джерело: складено авторами 
Система аудит-питань горизонтального структурно-композиційного менеджмент-аудиту технологічного процесу

\begin{tabular}{|c|c|c|}
\hline $\begin{array}{l}\text { Бізнес-зв'язок } \\
\text { ТБП }\end{array}$ & $\begin{array}{c}\text { Ланцюжок питань } \\
\text { управління }\end{array}$ & Управлінський сенс бізнес-зв'язку ТБП \\
\hline ME & $\begin{array}{c}\text { Хто-коли-навіщо - } \\
\text { цио-скільки }\end{array}$ & $\begin{array}{c}\text { Xmo, коли і яка (навіщц) мета (щщо) ставиться власникові ТБП і якими } \\
\text { кількісними показниками (скільки) оцінювати її досягнення }\end{array}$ \\
\hline MP & Як - скільки - навіщцо & $\begin{array}{c}\text { Яка послідовність дій (як) управління необхідна власникові ТБП для } \\
\text { досягнення запланованого кількісного показника (cкільки) досягнення } \\
\text { встановленої цілі (навіщь) виду операційної діяльності ТБП }\end{array}$ \\
\hline IE & $\begin{array}{c}\text { Коли - щио- } \\
\text { у якому вигляді }\end{array}$ & $\begin{array}{c}\text { Коли, щцо і в якому вигляді подавати звіти-аналізи } \\
\text { керівникові власника ТБП }\end{array}$ \\
\hline $\mathrm{DF}$ & $\begin{array}{c}\text { Кому - навіщо - щео- } \\
\text { скільки }\end{array}$ & 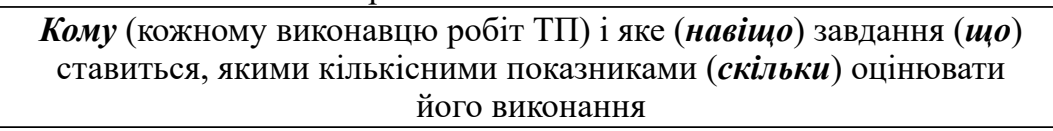 \\
\hline $\mathrm{CE}$ & $\begin{array}{l}\text { Коли-щцо-де- } \\
\text { в якому вигляді }\end{array}$ & 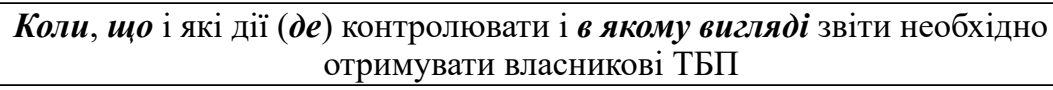 \\
\hline $\mathrm{CS}$ & \multirow{2}{*}{$\begin{array}{l}\text { Навіщцо - щео-коли - } \\
\text { кому -в якому вигляді }\end{array}$} & \multirow{2}{*}{$\begin{array}{l}\text { Які (навіщо) управлінські рішення власника ТБП (щцо), коли, кому } \\
\text { (кожному виконавцю робіт ТП) і в якому вигляді доводяться }\end{array}$} \\
\hline $\mathrm{AS}$ & & \\
\hline $\mathrm{TE}$ & $\begin{array}{l}\text { Хто-шцо-в якому } \\
\text { вигляді - коли }\end{array}$ & $\begin{array}{c}\text { Від кого (xmo) і який за своїми характеристиками вхідний потік (щцо) } \\
\text { і в якому вигляді та коли має надходити для створення потрібної } \\
\text { споживчої цінності (продукту) }\end{array}$ \\
\hline PP & Коли - що -хто - як & $\begin{array}{c}\text { Коли яку цінність (щсо) і хтоо (кожний виконавець робіт ТП) у якій } \\
\text { послідовності встановлених дій (як) робить }\end{array}$ \\
\hline ER & $\begin{array}{c}\text { Коли - кому - що - } \\
\text { в якому вигляді }\end{array}$ & Коли, кому передається зроблена цінність (цио) і в якому вигляді \\
\hline
\end{tabular}

сів підприємства, який проводиться за всіма суміжними (взаємопов'язаними) ТП і ПУ по кожній гілці піраміди процесного менеджменту підприємства. Коли під час аудиту ТП або ПУ виявляється, що будь-яка операція цього процесу пов'язана з операцією іншого процесу, то аудит переходить на інший процес і так далі. Перевага цього аудиту полягає в тому, що він дозволяє перевірити усі взаємозв'язки процесів і затребуваність входів і виходів процесів. Модель проведення вертикального структурно-композиційного менеджмент-аудиту суміжності процесів наведена на рис. 8.

Менеджмент-аудит у прямому напрямі - це аудит ланцюжка бізнес-процесів створення споживчої цінності (бізнес-цінності) 3 його початку до кінця виробництва продукції або послуги. Аудит починається 3 першої функціональної операції першого ТП, а далі відбувається послідовна перевірка усіх його функціональних операцій. Якщо зустрічаються взаємозв'язки такого ТП з ПУ його безпосереднього керівника або іншими ТП ланцюжка, то аудит переходить на ці суміжні процеси в частині контролю операційної релевантності взаємодії із першим ТП. Потім аудит обов'язково повертається до тієї функціональної операції першого ТП, звідки стався перехід. Перевагою цього типу аудиту $є$ те, що він дозволяє перевірити повноту і доцільність операційних зовнішніх зв'язків, ефективність управління, забезпечення і обслуговування ТП. Приклад цього виду менеджмент-аудиту наведений на рис. 9.
Менеджсмент-аудит у зворотному напрямі-це аудит ланцюжка бізнес-процесів створення споживчої цінності (бізнес-цінності), який перевіряє виконану роботу зі створення цінності. За початок аудиту приймається момент завершення роботи усього ланцюжка або приймання продукції, потім аналізується, що зроблено перед тим, як робота була завершена (прийнята продукція). Цей аудит дозволяє визначити, яка робота дійсно була виконана у процесах ланцюжка, яка облікова та управлінська документація (звітність) виникла під час їі виконання.

Переваги цього аудиту полягає у можливості виявити пропущені або «мовчазні» в інформаційному сенсі функціональні операції в ТП, знайти «розриви» ланцюжка матеріальної та інформаційної відповідальності посадових осіб ТП, а також розбіжності між відомостями облікових документів, які виникають після виконання операцій. 3 цього витікає принципове твердження: при графічному (наочному) описі потокової workflow моделі ТП має бути використана така нотація мови процесного моделювання, яка б давала можливість оперативного контролю (обліку) руху товарно-матеріальних цінностей (далі - ТМЦ) по всьому їх маршруту у виробництві шляхом створення безперервного ланцюжка матеріально відповідальних осіб.

Повертаючись до розгляду моделі об'єкту менеджмент-аудиту процесно-орієнтованого підприємства в частині ії динамічних складників - «моделі технологічних бізнес-процесів» і «моделі управлінських бізнес-процесів» (рис. 1), необхідно вказати на 


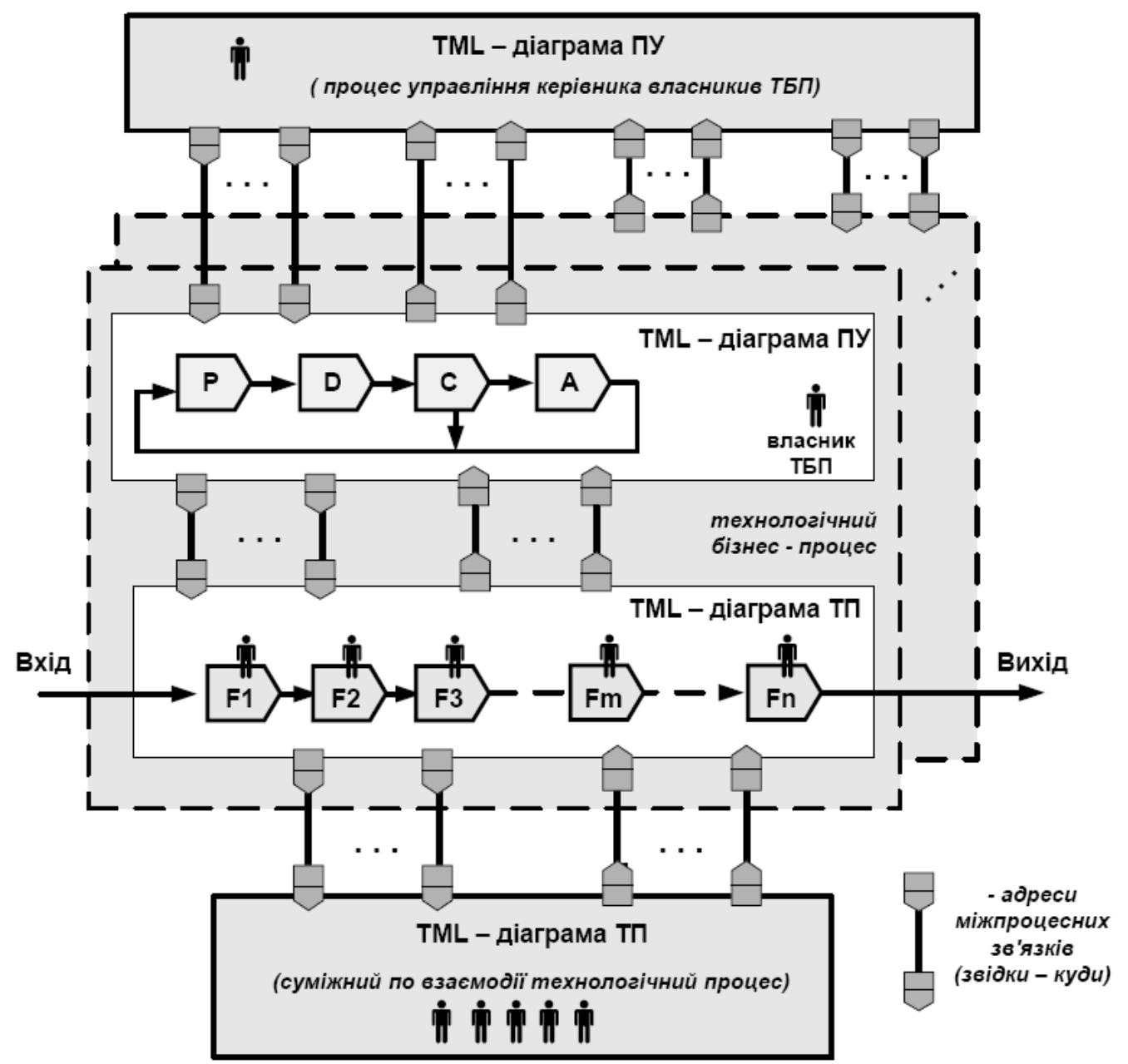

Рис. 8. Модель проведення вертикального структурно-композиційного менеджмент-аудиту суміжності процесів

Джерело: складено авторами

необхідність визначення відповідних правил структурної композиції моделей наочного графічного опису бізнес-процесів. Сутність правил відносно обраної форми графічного (наочного) представлення (опису) бізнес-процесів пропонуємо сформулювати визначенням, наведеним нижче.

Визначення 4. Екологічний менеджмент-аудит бізнес-процесів - це оцінка відповідності їх наочного відображення усталеним правилам наочної графічної композиції в рамках відповідної використовуваної мови процесного бізнес-моделювання. Можна стверджувати, що запропонована авторами мова процесного бізнес-моделювання - це системне об'єднання трьох базових методів:

- метод виділення системи бізнес-процесів на основі композиції SBC-графи і ланцюжка створення управлінської інформаційної цінності по піраміді процесного менеджменту;

- метод композиції управлінських бізнес-процесів відповідно до системи РDCA-діаграм піраміди процесного менеджменту;
- метод композиції технологічних (операційних) процесів потокового типу workflow на основі виділення ланцюжків створення цінності для внутрішніх споживачів підприємства і зовнішніх клієнтів.

Головні висновки. Аналіз існуючих вітчизняних і зарубіжних робіт засвідчує, що на єдиних методологічних засадах практично не склалася методологія менеджмент-аудиту процесно-орієнтованих підприємств і взагалі організаційних систем. Наукова новизна отриманих результатів полягає в тому, що запропонований науково-методологічний підхід до створення цієї методології грунтується на моделі повної бази даних об'єкту менеджмент-аудиту процесно-орієнтованого підприємства. При цьому аудит бізнес-процесів визначається як оцінка відповідності їх наочного (відчутного) відображення встановленим правилам графічної (наочної) композиції, який використовуються у вживаній мові процесного бізнес-моделювання.

Перспективи використання результатів дослідження. Перспектива подальших досліджень пов'я- 


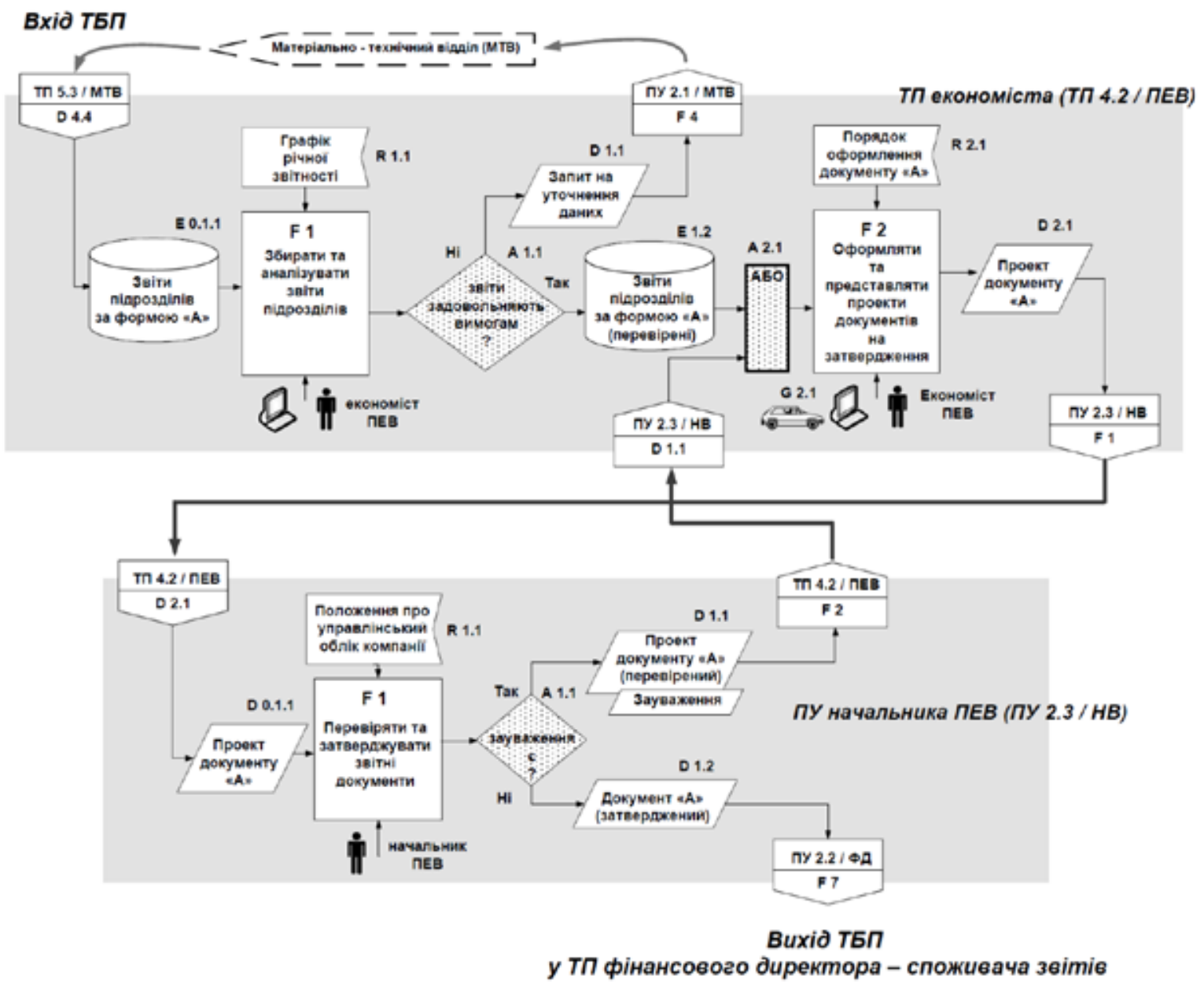

Рис. 9. Приклад менеджмент-аудиту технологічного бізнес-процесу (ТБП) «Підготовка звітних документів планово-економічним відділом»

Джерело: нотація графічного опису складена авторами

зана з розробкою базової множини правил структурно-композиційного аудиту системи бізнес-процесів. Якщо компанія розширюватиме бізнес за рахунок інвестицій, то екологічний аудит необхідний, осо- бливо, якщо інвестор іноземний. Наявність нефінансової звітності, до якої відносять і екологічний аудит, дозволяє компанії бути стабільною і впевненою у завтрашньому дні, привабливою для інвесторів.

\section{Література}

1. Трофимов А.В. Проведение внутреннего аудита системы менеджмента качества машиностроительного предприятия с серийным типом производства / А.В. Трофимов, С.С. Пекина. Тамбов : ТГТУ, 2007. 53 с. Деп. в ВИНИТИ № 239. В 2007 году от 12.03.2007.

2. Горбунов А.В. Аудит процессов или аудит подразделений? / А.В. Горбунов. ММК. 2007. № 1. С. 15-18.

3. Емелин В.Н., Кузнецова А.Ю. Опыт стандартизации внутреннего аудита менеджмента качества и безопасности пищевой продукции / Актуальные вопросы экономики и управления : материалы II междунар. науч. конф. (г. Москва, октябрь 2013 года). М. : Буки-Веди, 2013. С. 86-91.

4. Кучеров А.В., Салина К.А. Проблемы организации внутреннего и внешнего контроля качества аудита. Молодой ученый. 2013. № 6. C. 365-369.

5. Местецкая Е.В. Методики осуществления внутреннего контроля качества в аудиторской организации / Молодой ученый. 2012. № 6. C. 191-195.

6. Тупкало В.М. Основи методології процесного бізнес-моделювання / Тупкало В.М. Економіка. Менеджмент. Бізнес : зб. наук. пр. К. : ДУТ. Вип. 2 (12), 2015. С. 5-15.

7. Бондар O.І., Машков О.А., Міхеєв В.С. Системний підхід щодо створення системи підтримки екологічних рішень для забезпечення екологічної безпеки держави / Екологічні науки : науково-практичний журнал. К. : ДЕА, 2020. № 3(30), 2020. C. $30-38$. 
8. Бондар O.І., Машков О.А. Формалізація наукових підходів для забезпечення захисту довкілля та природних ресурсів / Актуальні питання техногенної безпеки України : материали II Всеукраїнської наукової конференції. Миколаїв : Видавець Topyбара B.B., 2020. C. 111-117.

9. Mashkov O., Zhukauskas S., Nigorodova S., Kosenko V. Innovative approaches of using the metods for remote sensing of the earth for monitoring the ecological-technical condition jf water ecosystems / Екологічні науки : науково-практичний журнал / К. : ДЕА, 2019. № 3(26), 2019. Р. 115-125.

10. Бондар О.І., Машков О.А., Жукаускас С.В., Нігородова С.А. Інноваційний підхід щодо інтеграції освіти, науки та бізнесу в галузі екології: створення Академії наук природокористування України / Інтеграція освіти, науки та бізнесу в сучасному середовищі: літні диспути : тези доп. І Міжнародної науково-практичної інтернет-конференції, 1-2 серпня 2019 року. Дніпро. 2019. С. 57-68.

11. URL: http://www.investgazeta.net/praktika/ekologicheskij-audit.-ne-tolko-imidzha-161171/. 


\title{
ДИНАМIКА ПIГМЕНТІВ ФОТОСИНТЕЗУ В РОСАИНАХ НА ТЕРИТОРІї НАФТОВИДОБУВНИХ РАЙОНІВ

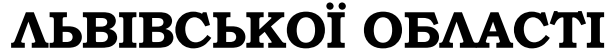

\author{
Поліщук О.І., Лесів М.С., Антоняк Г.Л. \\ Львівський національний університет імені Івана Франка \\ вул. Саксаганського, 1, 79005, м. Львів, Україна \\ alex1994pol@gmail.com,mlesivmarta@gmail.com, halyna.antonyak@gmail.com
}

\begin{abstract}
Нафтовидобувна діяльність створює ризик забруднення компонентів довкілля нафтою, вуглеводнями та іншими небезпечними речовинами, які шкідливо впливають здоров'я людей і біоту у природних екосистемах. 3 метою вивчення впливу нафтовидобувної діяльності на фотосинтетичний апарат рослин і з'ясування їхнього адаптаційного й біоіндикаційного потенціалу проведено дослідження вмісту хлорофілу в дикорослих рослинах Taraxacum officinale, Urtica dioica, Plantago major, Scirpus sylvaticus, Equisetum arvense і Pylaisia polyantha, зібраних у районах Східницького і Старосамбірського нафтових родовищ на території Львівської області. Відбір наземних рослин здійснювали на ділянках, розташованих на віддалі 10 і 100 м від нафтових видобувних свердловин; рослини S. sylvaticus збирали у прибережних ділянках водойм, розміщених на території досліджень. Як контроль використовували рослини, зібрані в парковій зоні м. Львова, яка не зазнає техногенного впливу. У процесі досліджень встановлено відмінності в концентрації хлорофілу $a$ і $b$ та їхнього загального вмісту в рослинах, які ростуть на територіях видобування нафти, порівняно з рослинами, зібраними на контрольній ділянці. Здебільшого у проаналізованих видах рослин, зібраних на території нафтовидобування, виявлено зменшення концентрації хлорофілу в клітинах, що вказує на пригнічення функцій фотосинтетичного апарату. Зазначено пряму залежність між концентрацією пігментів фотосинтезу в листках T. officinale і віддаллю ділянок збору рослин від нафтових видобувних свердловин. У листках $P$. major і бічних гілочках $E$. arvense не виявлено зменшення вмісту хлорофілу за умов росту рослин поблизу видобувних свердловин, що вказує на здатність цих рослин адаптуватися до змін у стані компонентів довкілля, зумовлених видобуванням нафти. Водночас отримані результати свідчать про біоіндикаційний потенціал рослин T. officinale, S. sylvaticus i P. polyantha й придатність цих видів рослин до використання під час досліджень екологічного стану довкілля в районах, які зазнають техногенного навантаження внаслідок нафтовидобувної діяльності. Ключові слова: рослини, мохоподібні, гідрофіти, хлорофіл, фотосинтез, біоіндикація, екосистеми, видобування нафти, Львівська область.
\end{abstract}

Dynamics of photosynthetic pigments in plants growing in oil-producing areas of Lviv region. Polishchuk A., Lesiv M., Antonyak H.

Petroleum production is a source of environmental pollution with crude oil, hydrocarbons and other hazardous substances that adversely affect human health and biota in natural ecosystems. In order to study the effect of oil production on the photosynthesis system in plant cells and to clarify the adaptive and bioindication potentials of terrestrial and aquatic plants, the chlorophyll content in wild plants growing in oil-producing areas of Lviv region has been analyzed. Six plant species have been collected in the territory of the oil fields located in the vicinity of Skhidnytsia and Staryi Sambir in Lviv region, including Taraxacum officinale, Urtica dioica, Plantago major, Scirpus sylvaticus, Equisetum arvense, and the moss Pylaisia polyantha. Terrestrial plants were collected at sites located at a distance of 10 and 100 meters from the oil drilling rigs; S. sylvaticus plants were collected in water bodies located in the study area. For comparison, the plants of the mentioned species were collected in the park zone of the city of Lviv. The concentrations of photosynthetic pigments in plant material from this site were taken as control. The results obtained indicate differences in the concentration of chlorophylls $a$ and $b$ and their total content in plants that grow in oil production areas compared with the plants collected from the control plot. In plant species collected from oil-producing areas, a decrease in chlorophyll content was mainly observed, which indicated the suppression of the function of the photosynthetic apparatus. A direct relationship was observed between the concentration of photosynthetic pigments in the leaves of $T$. officinale plants and the distance of collecting sites from oil drilling rigs. No decrease in chlorophyll concentration was observed in the leaves of $P$. major and lateral branches of $E$. arvense plants growing in the immediate vicinity of drilling rigs, which may indicate the high ability of these plant species to tolerate oil-related environmental pollution. At the same time, the results of this study demonstrate the bioindication potential of T. officinale, S. sylvaticus and $P$. polyantha plants and their suitability for use in biomonitoring the state of the environment in areas exposed to anthropogenic pressure related to oil production. Key words: plants, bryophytes, hydrophytes, chlorophyll, photosynthesis, bioindication, ecosystems, oil production, Lviv region.

Постановка проблеми. Видобування й переробка нафти належать до найважливіших галузей промислового виробництва. Однак ці види виробничої діяльності зумовлюють екологічний ризик через забруднення навколишнього середовища внаслідок утворення відходів і викидів шкідливих речовин [1-3]. Функціонування видобувних сверд-

ловин і нафтопереробних заводів супроводжується утворенням стічних вод, нафтошламів і газоподібних забруднювачів; окрім того, на кожному етапі виробничого процесу i транспортування розливи та витоки нафти можуть забруднювати довкілля, що впливає на стан абіотичних і біотичних компонентів екосистем [3; 4]. 
Актуальність дослідження. У багатьох дослідженнях встановлено, що забруднення компонентів навколишнього середовища нафтою, нафтопродуктами або вуглеводневими інгредієнтами палива шкідливо впливає на наземну й водну біоту та погіршує загальний екологічний стан територій i акваторій [5-7]. Розливи нафти на суші завдають шкоди наземним екосистемам, спричиняють зменшення родючості грунту, пригнічують проростання насіння, ріст і продуктивність рослин [7; 8]. Водночас вивільнення летких вуглеводнів та інших шкідливих сполук під час добування і переробки нафти спричиняє забруднення атмосфери, несприятливо впливає на природні екосистеми і створює загрозу здоров'ю людей. Тому актуальні дослідження екологічного стану навколишнього середовища та пошук видів рослин-біоіндикаторів якості компонентів довкілля на територіях, де здійснюють нафтовидобувну діяльність.

Зв'язок авторського доробку з важливими науковими та практичними завданнями. Виконане наукове дослідження є фрагментом науково-дослідної роботи кафедри екології Львівського національного університету імені Івана Франка «Екологічний моніторинг абіотичних і біотичних компонентів середовища в умовах антропогенно-техногенного впливу на довкілля» (№ державної реєстрації 0119U002396).

Аналіз останніх досліджень і публікацій. Основними компонентами нафти і нафтопродуктів $\epsilon$ різні групи вуглеводнів, які характеризуються різною стійкістю в компонентах навколишнього середовища і неоднаковим впливом на біоту [1]. Ароматичні вуглеводні належать до найстабільніших, токсичних i канцерогенних сполук [9]. За умов потрапляння нафти або нафтопродуктів у навколишнє середовище леткі вуглеводні випаровуються в атмосферне повітря, інші - розкладаються під впливом мікроорганізмів, проте частина складників нафти впродовж тривалого часу залишається в компонентах довкілля [10]. Це призводить до змін структури і фізико-хімічних властивостей грунту, пригнічення росту рослинного покриву і погіршення якості води в поверхневих водоймах. В експериментах встановлено, що забруднення грунту компонентами нафти спричиняє морфологічні й анатомічні зміни в рослинах, руйнування мембранних структур і розладів внутрішньоклітинного метаболізму [11-13].

Виділення не вирішених раніше частин загальної проблеми, котрим присвячусться означена стаття. Сьогодні більшість досліджень впливу нафти і нафтопродуктів на метаболізм у рослинах здійснено з використанням модельних експериментів. Однак показники метаболізму, зокрема вміст пігментів фотосинтезу в рослинах, які ростуть у складі природних екосистем на території нафтовидобувних районів, вивчено недостатньою мірою. Водночас не досить 3'ясовано біоіндикаційний потенціал рослин, які населяють грунт і водойми в районах видобування нафти. Зокрема, це стосується території
Львівської області, яка є одним із важливих нафтовидобувних регіонів України.

Мета дослідження. Метою роботи було з'ясувати динаміку вмісту хлорофілу та його фракцій (хлорофіл $a \mathrm{i} b$ ) як основних компонентів фотосинтетичного апарату в клітинах судинних рослин і мохоподібних, зібраних на території Східницького і Старосамбірського нафтових родовищ Львівської області, й проаналізувати зв' язок між концентрацією пігментів фотосинтезу в рослинах різних видів і рівнем техногенного впливу на довкілля, зумовленого нафтовидобувною діяльністю.

Новизна. У дослідженнях з'ясовано зміни вмісту хлорофілу в рослинах, що населяють природні екосистеми в районах видобування нафти на території Львівської області. Встановлено видові особливості динаміки концентрації фотосинтетичних пігментів у рослинах і біоіндикаційний потенціал рослин Taraxacum officinale L., Scirpus sylvaticus L. i Pylaisia polyantha (Hedw.) Schimp., які ростуть на територіях, де здійснюють нафтовидобувну діяльність; 3'ясовано стійкість рослин Plantago major L. і Equisetum arvense L. до техногенного впливу, зумовленого нафтовидобувною діяльністю.

Методологічне та загальнонаукове значення. Отримані результати щодо динаміки пігментів фотосинтезу в рослинах важливі для екологічної оцінки стану компонентів довкілля в районах видобування нафти, а також для наукового аналізу метаболізму й адаптаційних можливостей рослин за умов росту в екосистемах, які зазнають антропогенного навантаження.

Виклад основного матеріалу. У дослідженнях використовували дикорослі судинні рослини: кульбабу лікарську (Taraxacum officinale (L.) Weber ex F.H. Wigg), кропиву дводомну (Urtica dioica L.), подорожник великий (Plantago major L.), комиш лісовий (Scirpus sylvaticus L.), хвощ польовий (Equisetum arvense L.) і представника мохоподібних - пілезію багатоквіткову (Pylaisia polyantha (Hedw.) Schimp.). Дослідження проведені впродовж 2020 р. на території, прилеглій до м. Старий Самбір (Старосамбірське нафтове родовище) і смт Східниця (Східницьке нафтове родовище) Львівської області, у яких вибрано ділянки відбору рослинного матеріалу поруч із активними нафтовими видобувними свердловинами (координати розташування свердловин,

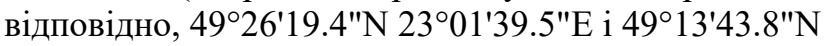
$\left.23^{\circ} 20^{\prime} 01.9^{\prime \prime} \mathrm{)}\right)$. Для збору наземних судинних рослин (T. officinale, U. dioica, P. major, E. arvense) було вибрано чотири ділянки: № 1 і № 2 - на території Східницького родовища, відповідно, на віддалі 10 м і 100 м від нафтової свердловини; № 3 і № 4 - на території Старосамбірського родовища на віддалі 10 м i 100 м від свердловин відповідно. Mox P. polyantha збирали на ділянках № 2 i № 4 (на віддалі 100 м від свердловин Східницького і Старосамбірського родовищ відповідно). Для порівняння досліджу- 
вали рослини вказаних видів, зібрані в парковій зоні м. Львова, які позначали як контроль. Рослини S. sylvaticus збирали у прибережних ділянках водойм на території Східницького родовища (ділянка № 5) і Старосамбірського родовища (ділянка № 6). Як контроль використовували рослини, зібрані у прибережних ділянках водойм на території м. Львова, віддалених від джерел техногенного впливу.

Підготовку рослинного матеріалу до аналізу здійснювали за допомогою стандартних методів. 3 метою ідентифікації моху $P$. polyantha, який збирали зі стовбурів листяних дерев, зразки аналізували за допомогою стереоскопічного мікроскопа XS 6220. Вміст пігментів фотосинтезу визначали в листкових пластинках рослин $U$. dioica, $T$. officinale, $P$. major i S. sylvaticus, у бокових гілочках вегетативних пагонів E. arvense і в гаметофітах $P$. polyantha. Пігменти фотосинтезу екстрагували з використанням $96 \%$ етанолу; концентрацію фракцій хлорофілу $a$ і $b$ та їхній загальний вміст (хлорофіл $a+b$ ) визначали спектрофотометрично й обчислювали, використовуючи молярні коефіцієнти екстинкції [14]. Дослідження здійснювали у 3-5-кратній повторності. Отримані результати опрацьовували методами варіаційної статистики.

Результати дослідження та їх обговорення. Результати досліджень вмісту хлорофілу в рослинному матеріалі, зібраному на територіях Східницького i Старосамбірського нафтових родовищ, свідчать про зміни у стані системи фотосинтезу рослин, які ростуть у зоні впливу нафтовидобувної діяльності. Зокрема, загальний вміст хлорофілу та концентрація хлорофілу $a$ і $b$ в листках $T$. officinale, зібраних на ділянках № 1 і № 3 (на віддалі 10 м від нафтових свердловин), менша в 2,18-2,74 раза $(\mathrm{p}<0,01-0,001)$ від значень цих показників у листках рослин, зібраних на контрольній ділянці (рис. 1). Натомість, у рослин, зібраних на віддалі 100 м від нафтових свердловин, зниження концентрації хлорофілу $a$ i $b$ та загального вмісту хлорофілу виявляється меншою мірою на ділянці № 2 (різниця порівняно 3 контролем становить $1,51-1,38$ раза, $\mathrm{p}<0,05)$ і не виявляється на ділянці № 4. Отримані результати вказують на прямий зв'язок між вмістом пігментів фотосинтезу в листках T. officinale і віддаллю ділянок збору рослин від нафтових свердловин, які є потенційним джерелом забруднення компонентів довкілля [3]. Зміни вмісту хлорофілу виявлено і в інших видах рослин на досліджуваних ділянках. Однак зв'язок між розташуванням ділянок збору матеріалу й концентрацією пігментів фотосинтезу в рослинах менш виразний, ніж у T. officinale.

Зокрема, у листках рослин $U$. dioica значне зменшення загального вмісту хлорофілу та концентрації хлорофілу $a$ і $b$ (відповідно, в 2,44, 2,48 і 2,24 раза, $\mathrm{p}<0,05-0,001)$ виявляється в листках рослин iз ділянки № 2, а в рослинах із ділянки № 3 виявлено менший вміст фракції $a$ і загального вмісту хлорофілу, відповідно, в 1,63 і 1,59 раза (р<0,05) (рис. 2). У листках $U$. dioica 3 інших ділянок концентрація хлорофілу вірогідно не відрізняється від значень, характерних для рослин із контрольної ділянки.

У листках рослин $P$. major вірогідно менший вміст хлорофілу та обох його фракцій, порівняно 3 контролем $(\mathrm{p}<0,05-0,01)$, виявляється тільки на ділянці № 2 (рис. 3). Натомість у рослин з інших ділянок значних змін концентрації хлорофілу порівняно 3 контролем не встановлено. Такі результати вказують на стійкість метаболізму рослин $P$. major до змін хімічного складу компонентів довкілля,

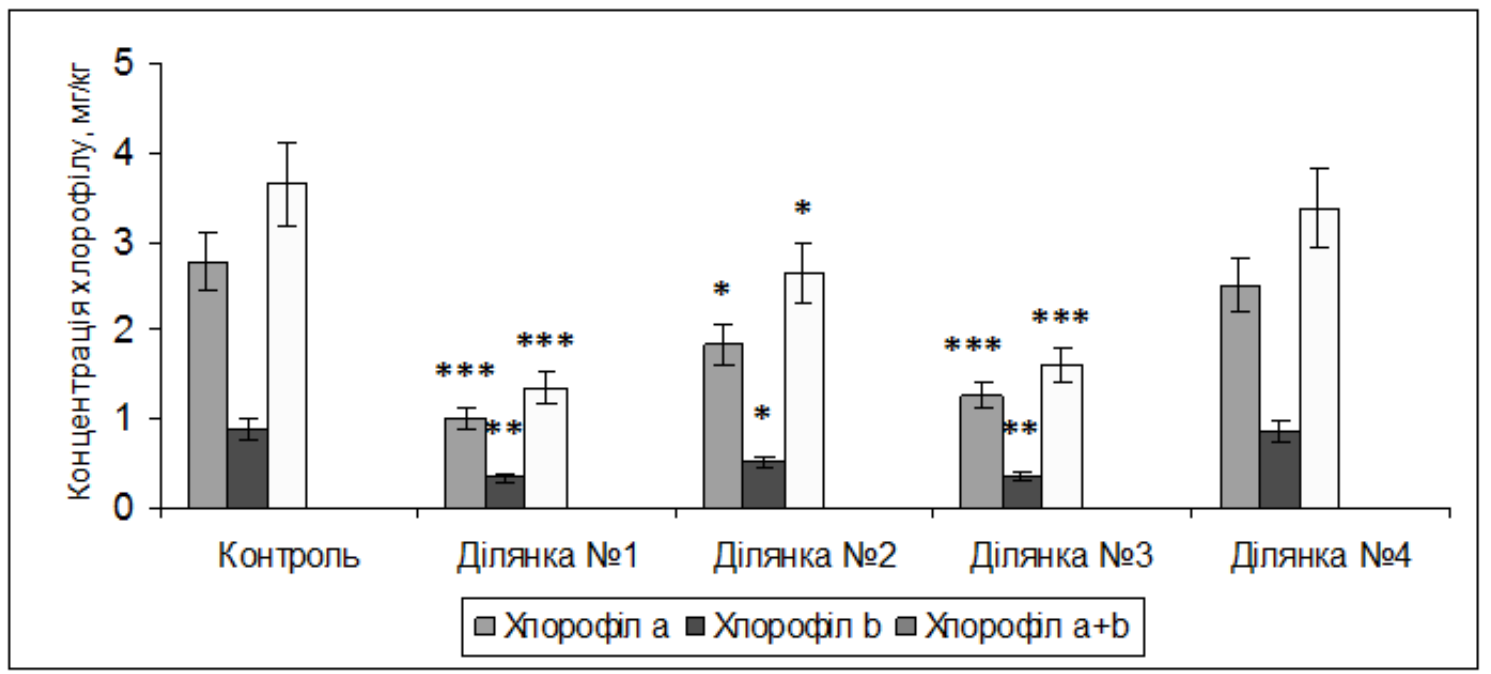

Рис. 1. Кониентрація хлорофілу в листках рослин Taraxacum officinale, зібраних на контрольній ділянці і в районах видобування нафти

Примітка: на цьому і наступних рисунках *, **, *** - вірогідність різниць у показниках порівняно з контролем $(*-p<0,05 ; * *-p<0,01 ; * * *-p<0,001)$ 


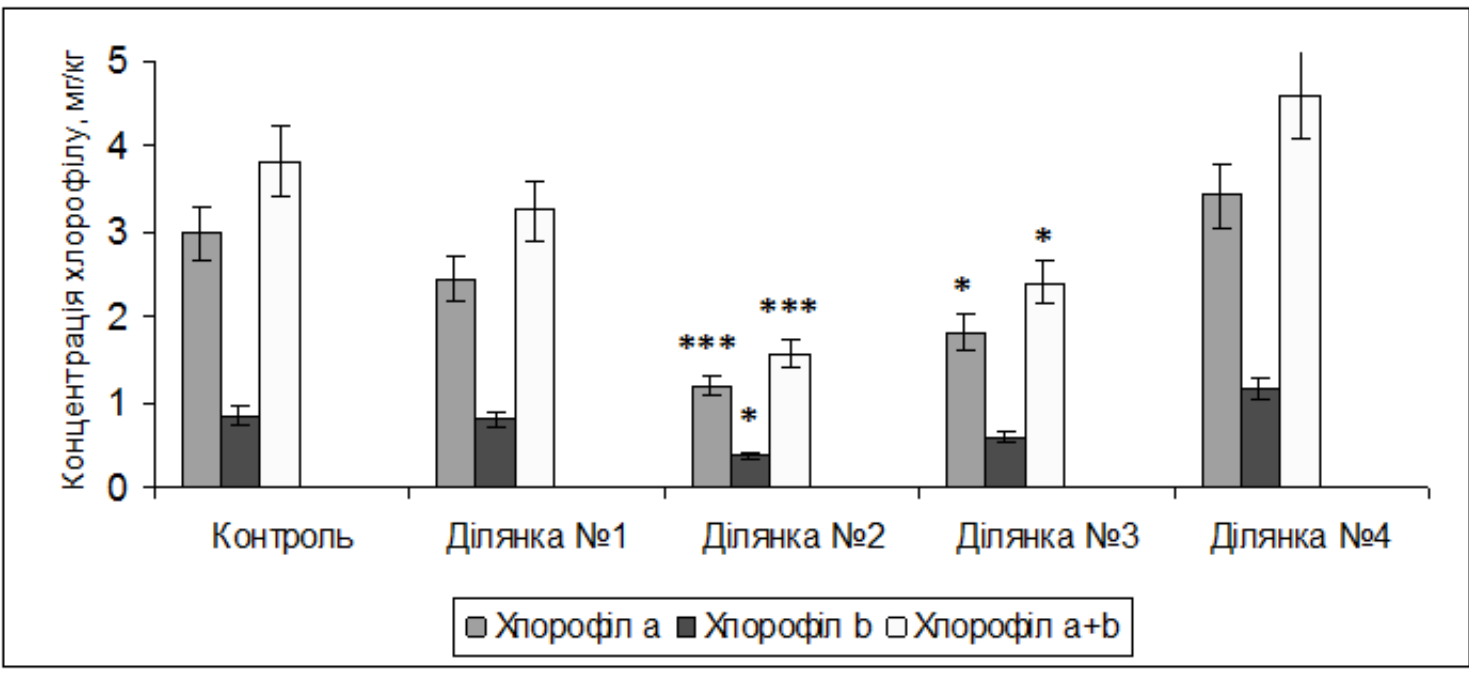

Рис. 2. Коничентрація хлорофілу в листках рослин Urtica dioica, зібраних на контрольній ділянці і в районах видобування нафти

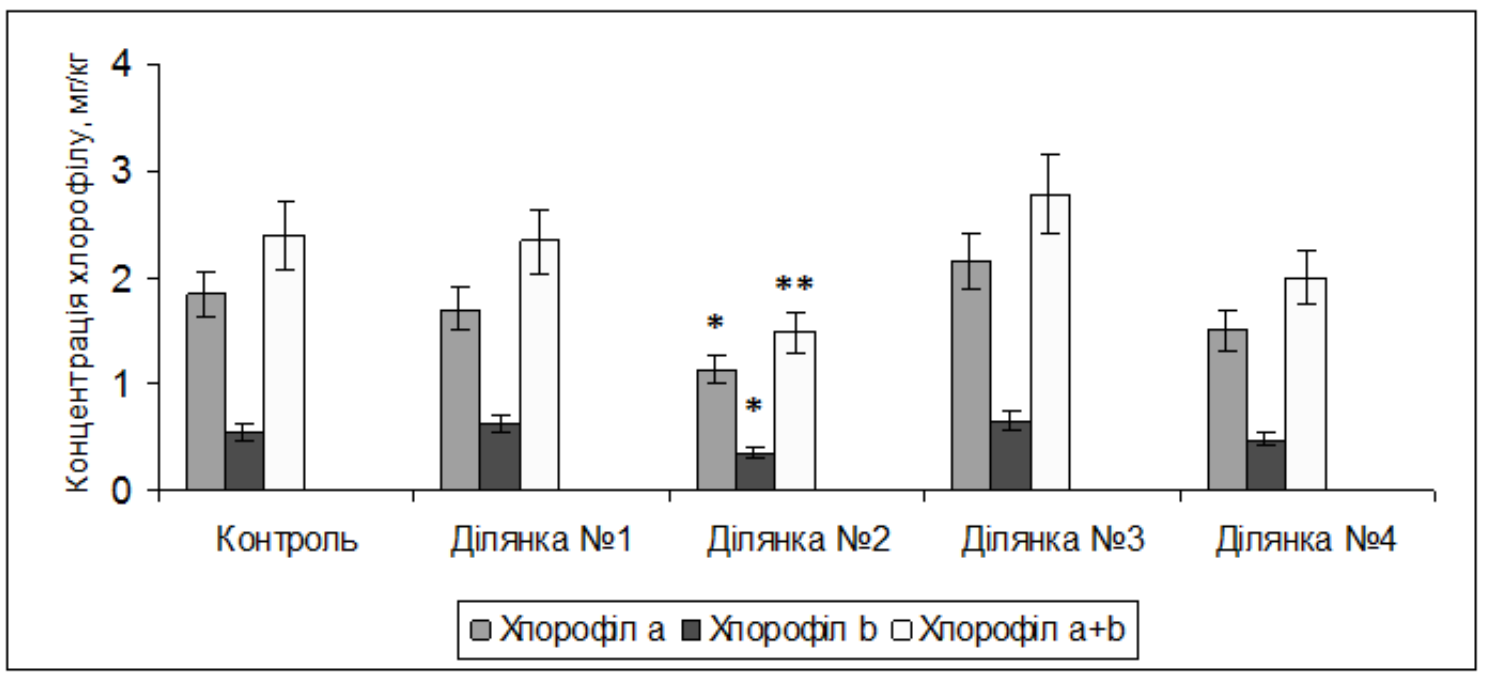

Рис. 3. Концентрація хлорофілу в листках рослин Plantago major, зібраних на контрольній ділянці і в районах видобування нафти

зумовлених нафтовидобувною діяльністю. 3 наукових джерел відомо, що деякі види рослин мають високу здатність адаптуватись до наявності вуглеводнів у середовищі росту $[15 ; 16]$. Значною мірою це зумовлюється формуванням у ризосфері рослин специфічного складу мікроорганізмів, здатних розкладати компоненти нафти [16]. Вірогідно, що такі чинники можуть зумовлювати толерантність рослин $P$. major до техногенного впливу на ділянках, прилеглих до нафтових свердловин.

Своєрідний характер змін у системі фотосинтетичного апарату виявлено під час аналізу рослин E. arvense, зібраних на досліджуваних ділянках (рис. 4). Зокрема, загальний вміст хлорофілу та концентрація хлорофілу $a$ i $b$ в бічних гілочках вегетативних пагонів $E$. arvense 3 ділянок № 2 i № 4 значно менші порівняно з контролем (у 2,3-2,9 раза, $\mathrm{p}<0,01-0,001)$. Натомість немає вірогідних відмінностей вмісту пігментів у рослинах із ділянки № 1 та концентрації хлорофілу $a$ й загального вмісту хлорофілу в рослинах із ділянки № 3. Такі дані свідчать про здатність системи фотосинтезу рослин $E$. arvense, як і рослин $P$. major, адаптуватися до умов середовища на близькій віддалі від нафтових свердловин. На адаптаційну здатність рослин E. arvense може вказувати й підвищення концентрації хлорофілу $b$ у рослинах, зібраних на ділянці № 3 (в 1,80 раза, $\mathrm{p}<0,05)$, оскільки збільшення вмісту цього типу хлорофілу вважають одним із фізіологічних пристосувань фотосинтетичного апарату рослин до несприятливих умов довкілля $[17 ; 18]$.

Під час досліджень моху Pylaisia polyantha, який збирали на віддалі 100 м від нафтових свердловин, встановлено, що на ділянці № 4 (Старосамбірське 


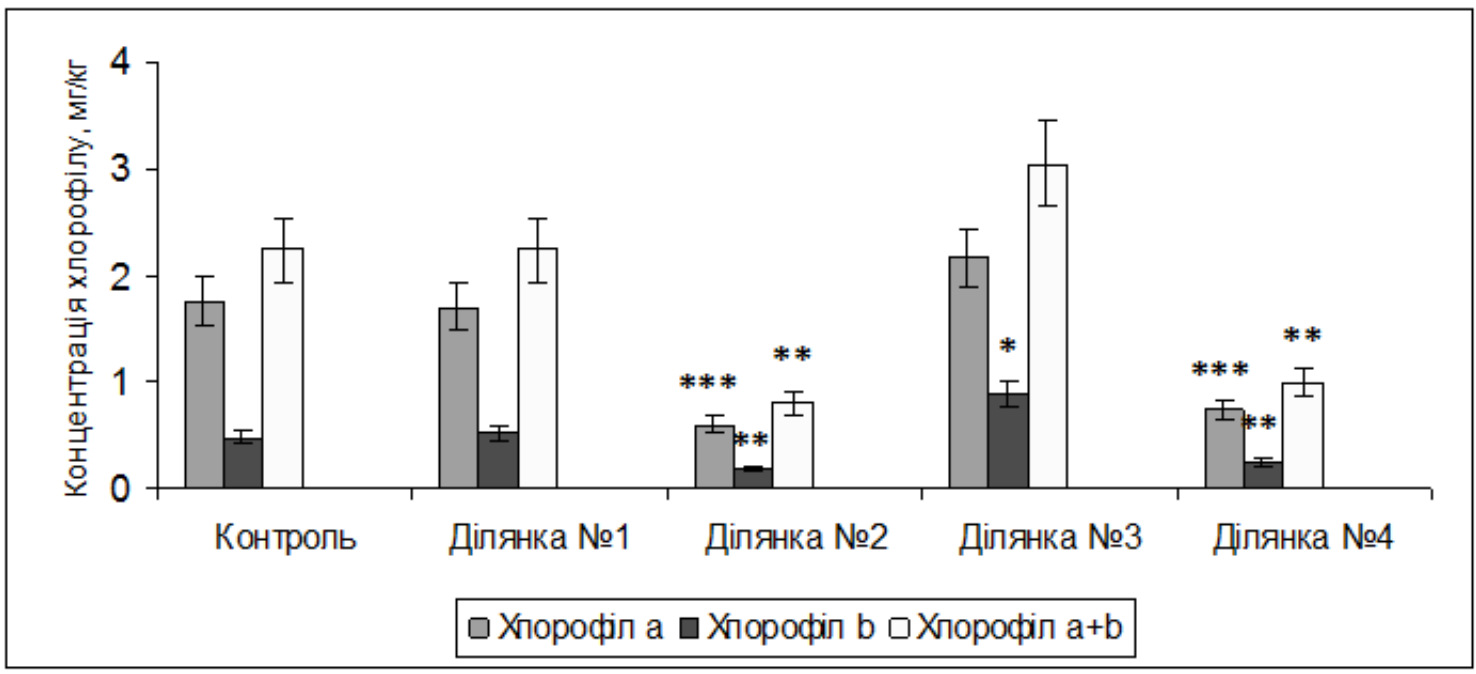

Рис. 4. Концентрація хлорофілу в бічних гілочках вегетативних пагонів Equisetum arvense, зібраних на контрольній ділянці і в районах добування нафти

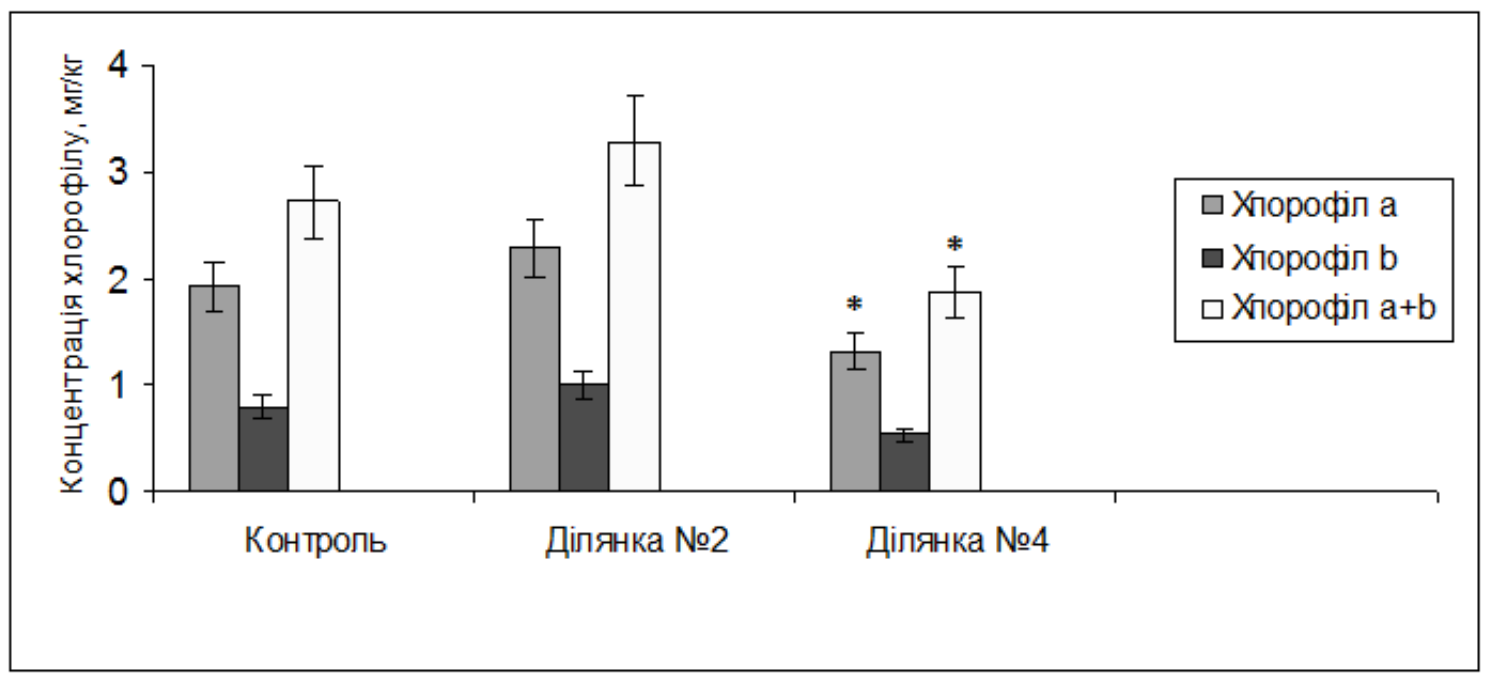

Puс. 5. Кониентрація хлорофілу в гаметофіті моху Pylaisia polyantha, зібраного на контрольній діляниі і в районах видобування нафти

родовище) вміст хлорофілу $a$ і загальна концентрація хлорофілу в гаметофіті досягають менших значень порівняно 3 контролем $(\mathrm{p}<0,05)$, але в рослинах, зібраних на ділянці № 2 (Східницьке родовище), ці показники не відрізняються від контролю (рис. 5). Варто зауважити, що, на відміну від інших аналізованих у роботі рослин, P. polyantha - це переважно епіфітний вид, метаболізм якого реагує на зміни складу атмосферного повітря [19-21]. У попередніх працях встановлено придатність цього виду мохопоподібних до використання в біоіндикаційних дослідженнях стану атмосфери в районах, які зазнають техногенного навантаження [22; 23]. Отримані результати щодо зменшення вмісту хлорофілу в гаметофіті $P$. polyantha можуть вказувати на погіршення стану атмосферного повітря внаслідок нафтовидобувної діяльності на території Старосамбірського родо- вища. Такий висновок узгоджується 3 результатами інших досліджень стану навколишнього середовища на цій території [7].

Поряд із аналізом впливу техногенного навантаження на компоненти фотосинтетичного апарату у клітинах наземних рослин важливим $є$ вивчення впливу нафтовидобувної діяльності на пігменти фотосинтезу в рослинах-гідрофітах, які населяють водні та прибережні екосистеми. 3 метою 3'ясування цього питання проведено дослідження 3 використанням гідрофіта Scirpus sylvaticus, який дуже поширений у прибережних ділянках водойм на території України. Отримані результати свідчать про зменшення загального вмісту хлорофілу в листках рослин S. sylvaticus, зібраного у водоймах на ділянках № 5 і № 6, в 1,35 раза $(\mathrm{p}<0,05)$ і 1,87 раза $(\mathrm{p}<0,01)$ відповідно, порівняно з контролем (рис. 6). 


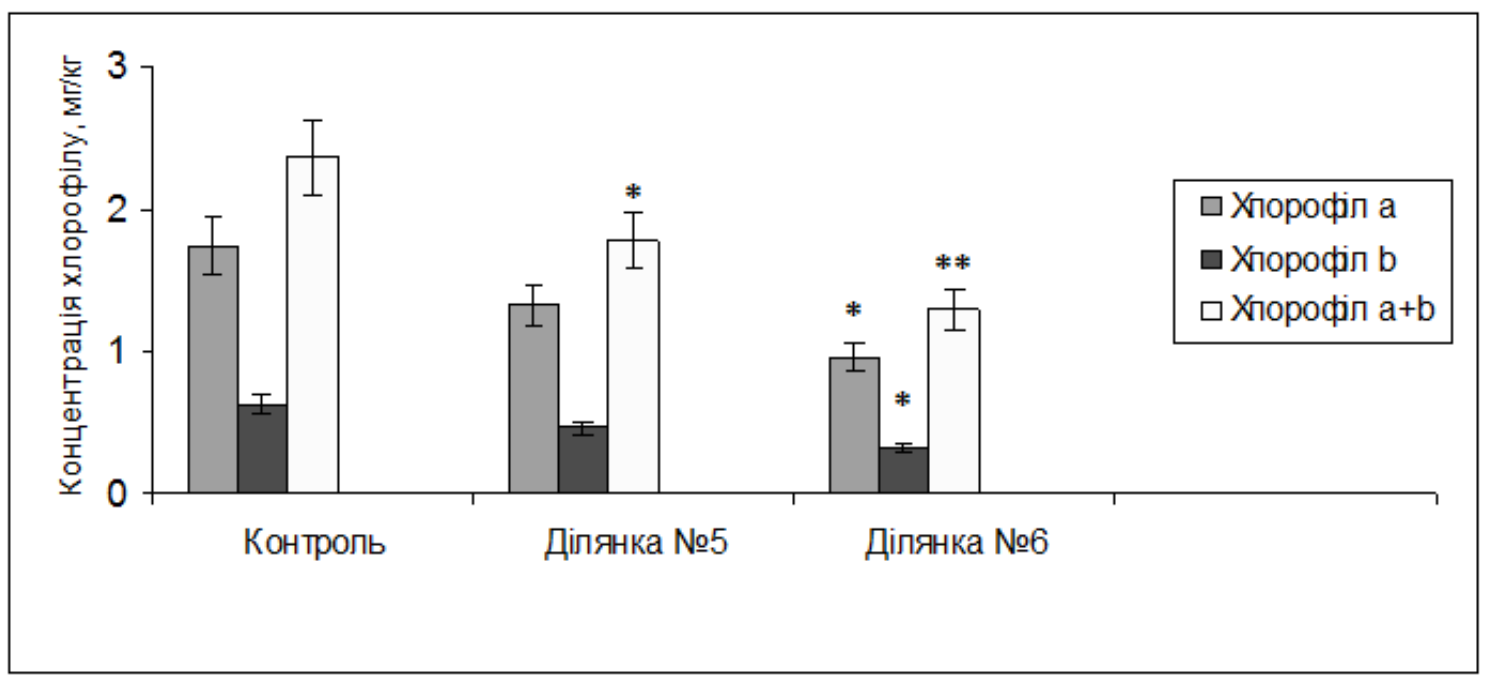

Рис. 6. Конщентрація хлорофілу в листках рослин Scirpus sylvaticus, зібраних у водоймах на контрольній ділянці і в районах видобування нафти

Важливо зауважити, що в листках рослин із ділянки № 6 (Старосамбірське родовище) виявлено зменшення вмісту обох фракцій хлорофілу (хлорофілу $a$ в 1,81 раза і хлорофілу $b$ в 1,91 раза, $\mathrm{p}<0,05)$. Такі дані свідчать про пригнічувальний вплив нафтовидобувної діяльності в досліджуваних районах на процес фотосинтезу в клітинах S. sylvaticus, до того ж виразніше цей ефект виявляється на території Старосамбірського родовища.

Головні висновки. Результати досліджень свідчать про відмінності в концентрації фотосинтетичних пігментів у рослинах, які ростуть у природних екосистемах у районах видобування нафти у Львівській області, порівняно 3 контрольною ділянкою, яка не зазнає техногенного впливу. Загалом, в аналізованих у нашій роботі рослинах ріст на ділянках, прилеглих до нафтових свердловин, супроводжується зменшенням вмісту хлорофілу, що свідчить про погіршення екологічного стану грунту, водного середовища й атмосферного повітря під впливом нафтовидо- бувної діяльності. Водночас спостерігається пряма залежність між концентрацією пігментів фотосинтезу в листках T. officinale і віддаллю ділянок збору рослин від джерел забруднення. Проте в листках рослин $P$. major і бічних гілочках вегетативних пагонів $E$. arvense, зібраних на віддалі 10 м від свердловин на території Східницького і Старосамбірського нафтових родовищ, зменшення концентрації хлорофілу не виявлено. Такий ефект може зумовлюватись особливостями метаболізму й високим адаптаційним потенціалом рослин, а також складом мікробних популяцій, який формується в їхній ризосфері на територіях, де здійснюють видобування нафти.

Перспективи використання результатів дослідження. Отримані результати свідчать про біоіндикаційний потенціал рослин $T$. officinale, гідрофіта S. sylvaticus і бріофіта $P$. polyantha й придатність цих видів рослин до використання під час біомоніторингу стану навколишнього середовища на територіях, де здійснюють нафтовидобувну діяльність.

\section{Література}

1. Spight J.G. The chemistry and technology of petroleum. $4^{\text {th }}$ ed. Taylor \& Francis Group, 2007. 954 p.

2. Rajabi H., Mosleh M.H., Mandal P., Lea-Langton A., Sedighi M. Emissions of volatile organic compounds from crude oil processingGlobal emission inventory and environmental release. Sci. Total Environ. 2020. 727:138654. doi: 10.1016/j.scitotenv.2020.138654.

3. Chand J. Environmental pollution monitoring in oil exploration and exploitation. Condition Monitoring and Diagnostic Engineering Management. Rao R.B.K.N., Au J., Griffiths B. (Eds). Springer, Dordrecht. 1990. P. 218-224. doi: 10.1007/978-94-009-0431-6_34.

4. Гринчишин Н.М. Причини та наслідки витоків нафти і нафтопродуктів на трубопровідному транспорті у Львівській області. Науковий вісник НЛТУ Украӥни. 2015. Вип. 25.8. С. 178-185.

5. McCoy M.A., Salerno J.A. Assessing the effects of the Gulf of Mexico oil spill on human health. National Academies Press, 2010. $206 \mathrm{p}$.

6. Udebuani A.C., Okoli C.I., Nwigwe H., Ozoh P.T. Effects of spent engine oil pollution on arable soil of Nekede Mechanic Village Owerri, Nigeria. International Journal of Natural and Applied Sciences. 2011. Vol. 7. N 3. P. 257-260.

7. Джура Н.М., Подан I.I. Екологічні наслідки довготривалого нафтовидобутку на Старосамбірському родовищі Львівської області. Вісник Львівського університету. Серія біологічна. 2017. Вип. 76. С. 120-127.

8. Yahaya I.H., Lami R.S.M., Alkali A.I., Farouq A.A., Abakwak C.S. Biostimulation potentials of Vigna species (L.) in hydrocarbon impacted soil. American Journal of Bioscience and Bioengineering. 2019. Vol. 7. P. 22-27. doi: 10.11648/j.bio.20190701.15.

9. Purcaro G., Barp L., Moret S. Determination of hydrocarbon contamination in foods. A review. Analytical Methods. 2016. Vol. 8. P. 5755-5772. DOI: 10.1039/c6ay00655h. 
10. Fowzia A., Fakhruddin A.N.M. A review on environmental contamination of petroleum hydrocarbons and its biodegradation. International Journal of Environmental Sciences and Natural Resources. 2018. Vol. 11. N 3. 555811. doi: 10.19080/ IJESNR.2018.11.555811.

11. Shukry W., Al-Hawas G., Al-Moaikal R., El-Bendary M. Effect of petroleum crude oil on mineral nutrient elements, soil properties and bacterial biomass of the rhizosphere of jojoba. Br. J. Environ. Clim. Change. 2013. Vol. 3. P. 103-118.

12. Baruah P., Saikia R.R., Baruah P.P., Deka S. Effect of crude oil contamination on the chlorophyll content and morpho-anatomy of Cyperus brevifolius (Rottb.) Hassk. Environ. Sci. Pollut. Res. 2014. Vol. 21. P. 12530-12538. DOI: 10.1007/s11356-014-3195-y.

13. Подан I.I., Джура Н.М. Вплив нафтового забруднення і гуматів на ріст рослин міскантусу. Екологічні науки. 2019. № 2 (25). C. 182-186. DOI: 10.32846/2306-9716-2019-2-25-30.

14. Knudson L.L., Tibbits T.W., Edwards G.E. Measurements of ozone injury by determination of leaf chlorophyll concentration. Plant Physiol. 1977. Vol. 60. P. 606-608.

15. Fattah Q.A., Wort D.J. Effect of light and temperature on stimulation of vegetative and reproductive growth of bean plants by naphthenates. Agronomy Journal. 1970. Vol. 62. N 5. P. 576-577. doi: 10.2134/agronj1970.00021962006200050007x.

16. Odokuma L.O., Ubogu M. 2014. Quantitative assessment of hydrocarbon utilizing microflora of the rhizosphere of some plants in the rainforest and mangrove swamp in the Niger Delta. Australian Journal of Biology and Environment Research. 2014. Vol. 1. N 2. P. 31-42.

17. Cantabella D., Piqueras A., Acosta-Motos J.R., Bernal-Vicente A., Hernández J.A., Díaz-Vivancos P. Salt-tolerance mechanisms induced in Stevia rebaudiana Bertoni: Effects on mineral nutrition, antioxidative metabolism and steviol glycoside content. Plant Physiol. Biochem. 2017. Vol. 115. P. 484-496. doi: 10.1016/j.plaphy.2017.04.023.

18. Hoivanovych N., Antonyak H., Petriv M. Analysis of biochemical parameters of Persicaria bistorta in different ecosystems. Sustainable Development and Human Health. Krynski A., Tebug G.K., Voloshanska S. (Eds.). Czestochowa : Educator, 2020. P. 123-132.

19. Stringer P., Stringer M. Air pollution and the distribution of epiphytic lichens and bryophytes in Winnipeg, Manitoba. Bryologist. 1974. Vol. 77. P. 405-427.

20. Маєвський К.В Розподіл бріофлори м. Київ в умовах урбанізації. Агробіологія. 2012. № 8. С. 105-109.

21. Поліщук О.І., Панченко В.О., Гілецька І.Б., Антоняк Г.Л. Еколого-біохімічні особливості моху Pylaisia polyantha (Hedw.) Schimp. Матеріали XIV Конференції молодих вчених «Наукові, прикладні та освітні аспекти фізіології, генетики, біотехнології рослин і мікроорганізмів», м. Київ, 23-24 жовтня 2019 р. Київ, 2019. С. 51-52.

22. Антоняк Г.Л., Мамчур 3.І., Поліщук О.І. Біоіндикація стану атмосферного повітря у місті Львові з використанням моху Pylaisia polyantha (Hedw.) Schimp. 5-й Міжнародний конгрес «Захист навколишнього середовища. Енергоощадність. Збалансоване природокористування», м. Львів, 26-29 вересня 2018 р. Львів : Видавництво Львівської політехніки, 2018. C. 65.

23. Поліщук O.І., Антоняк Г.Л., Першин О.І. Акумуляція металів у гаметофітах деяких видів мохів на території міста Львова (Україна). Вісник проблем біологіï і медищини. 2019. Вип. 3 (152). С. 58-62. 


\title{
ОЧИЩЕННЯ ПІЩАНИХ ГРУНТІВ ВІД НАФТОЗАБРУДНЕНЬ ЗАСТОСУВАННЯМ БІОСОРБЦІЙНИХ КОМПАЕКСІВ
}

\author{
Хохлов А.В., Хохлова Л.Й. \\ Інститут сорбції та проблем ендоекології \\ Національної академії наук України \\ вул. Генерала Наумова, 13, 03164, м. Київ \\ ispe@ispe.kiev.ua, techsorb@ukr.net
}

\begin{abstract}
Очищення грунтів, забруднених нафтою і нафтопродуктами, має особливості, тому що через велику адсорбувальну здатність грунт накопичує забруднювач. Одним із найбільш проблемних є метод очищення піщаних грунтів із бідним біоценозом від застарілих нафтозабруднень. Перспективним напрямом в очищенні грунтів від забруднення нафтою $\epsilon$ мікробіологічні технології. Застосування спеціальних мікробних препаратів дає змогу пришвидшити деструкцію нафти. Наявні препарати мають свої особливості застосування й хиби. Вони втрачають деструктивну активність із часом і малоефективні під час ліквідації застарілих нафтозабруднень із великою концентрацією. Об'єктом досліджень є створений біосорбційний комплексний препарат для очищення забруднених нафтою піщаних грунтів. Біосорбційний комплекс (біосорбент) на основі екологічного матричного сорбенту світлого кольору й іммобілізованих на його поверхні активних мікроорганізмів-деструкторів нафти природного походження дає змогу очищати світлі піщані грунти від застарілих концентрованих забруднень. Введення до складу біосорбенту аеробних і анаеробних мікроорганізмів дає змогу здійснювати біодеструкцію нафти як на поверхні в аеробних умовах, так і в глибині. Іммобілізовані на сорбційному матеріалі мікроорганізми володіють великим потенціалом деструктивної дії. Під час іммобілізації зберігається життєздатність клітин мікроорганізмів і значно підвищується ефект їх застосування. Встановлено оптимальні параметри отримання олеофільної сорбційної матриці з різних типів сировини та отримання мікробної біомаси з високою деструктивною активністю до вуглеводнів нафти. Вивчено деструктивні характеристики отриманих біоактивних сорбентів світлого кольору на основі носіїв різного типу. Як носії використано рослинні матеріали та мінеральні сорбенти - глауконіт, смектоніт. Проведеними дослідженнями показано зміну концентрації нафтового забруднення піщаного грунту від 30-40 \% до 1-5 \% нафти в процесі біодеструкції через 140 діб. Проведені випробування біосорбенту світлого кольору на промислових умовах нафтобази із застарілим нафтозабрудненням показали ефективність очищення до $90 \%$. Ключові слова: піщані грунти, нафта, мікроорганізми-деструктори, глауконіт, смектоніт, сорбція, деструкція.
\end{abstract}

Purification of sandy soils from oil with the use of biosorption complexes. Khokhlov A., Khokhlova L.

Cleaning of soils contaminated with oil and oil products has features. Due to the high adsorption capacity of the soil accumulates contaminants. One of the most problematic is the method of cleaning sandy soils with poor biocenosis from obsolete oilpollution. A promising area in the purification of soils from oil pollution is microbiological technology. The use of special microbial drugs can accelerate the destruction of oil. Existing drugs have their own peculiarities and disadvantages. They lose destructive activity over time and are ineffective in eliminating obsolete oil pollution with a high concentration. The object of research is a biosorption complex preparation for cleaning oil-contaminated sandy soils. The biosorption complex (biosorbent) on the basis of ecological matrix sorbent of light color and the active microorganisms-destructors of oil of natural origin immobilized on its surface allows to clear light sandy soils of outdated concentrated pollution. The object of the study is a biosorption complex preparation for cleaning oil-contaminated sandy soils. Biosorption complex (biosorbent) on the basis of ecological matrix sorbent of light color and active microorganismsdestructors of oil of natural origin, immobilized on its surface, allows to clear light sandy soils from outdated concentrated pollution. The introduction of aerobic and anaerobic microorganisms into the biosorbent allows the biodegradation of oil both on the surface under aerobic conditions and at depth. Microorganisms immobilized on the sorption material have a great potential for destructive action. Immobilization preserves the viability of cells of microorganisms and significantly increases the effect of their use. The optimal parameters for obtaining oleophilic sorption matrix from different types of raw materials and obtaining microbial biomass with high destructive activity to petroleum hydrocarbons have been established. The destructive characteristics of the obtained light-colored bioactive sorbents based on carriers of different types have been studied. Plant materials and mineral sorbents - glauconite, smectonite were used as carriers. Studies have shown a change in the concentration of oil pollution of sandy soil from $30-40 \%$ to $1-5 \%$ of oil in the process of biodegradation after 140 days. Tests of light biosorbent in industrial conditions of the oil depot with obsolete oil pollution of the soil showed a cleaning efficiency of up to $90 \%$. Key words: sandy soils, oil, microorganisms-destructors, glauconite, smectonite, sorption, destruction.

Постановка проблеми. На сучасному етапі історичну перспективу людства визначає екологічний фактор. Нафта є складним і стійким забруднювачем. Вуглеводні нафти доступні для засвоєння тільки спеціалізованим бактеріям. Така вибірковість щодо нафти лягла в основу бактеріальних методів нейтралізації нафтового забруднення. Бактерії - це високоактивні мікроорганізми, які містять ферменти, тобто біологічні каталізатори, що можуть діяти на велику кількість субстрату за одиницю часу. Біосорбенти, побудовані на основі адсорбційного матеріалу 3 іммобілізованими нафтоокислюючими мікроорганізмами, здатні локалізувати та руйнувати нафтопродукти. Руйнування нафти може здійснюватися до завершальних стадій, коли залишаються тільки продукти розпаду нафти, які інертні $\left(\mathrm{CO}_{2}, \mathrm{H}_{2} \mathrm{O}\right.$, асфаль- 
тени) до довкілля. Залишкова частина біосорбенту є початковою основою сорбційного носія.

Актуальність дослідження. Для розв'язання цієї проблеми доцільним є застосування сорбенту, що забезпечує швидку локалізацію забруднення, а мікроорганізми-деструктори, іммобілізовані на його поверхні, здатні здійснювати подальшу ремедіацію забрудненої території. Розроблення принципів спільного використання сорбентів і мікроорганізмів-деструкторів для очищення грунту, забрудненого ксенобіотиками, встановлення параметрів одержання біосорбційного комплексу та його застосування в біотехнології сприятиме ефективному та якісному відновленню забруднених грунтів. Окрім того, відновлення забруднених грунтів біологічними методами вимагає набагато менше витрат для свого застосування, ніж відомі небіологічні технології. Отже, проведення досліджень із розроблення й застосування на практиці біосорбційного комплексу для очищення піщаного грунту від застарілих нафтозабруднень є надзвичайно важливо.

Аналіз останніх досліджень і публікацій. $€$ різноманітні технології та методи очищення грунтів від забруднення нафтою. У роботі [1] представлено результати досліджень 3 очищення забруднених однорідних і різнорідних грунтів шляхом промивання їх водою. Ефективність та актуальність такої технології викликають сумніви, хоча це твердження може бути суперечливим. Питання деструкції нафтозабруднення грунтів становлять значну частину зарубіжних і вітчизняних досліджень у галузі грунтової мікробіології. Технології очищення нафтозабруднених грунтів, як зазначається в роботах авторів [2; 3], передбачають активацію процесів самоочищення завдяки індукуванню мікроорганізмів, що руйнують забруднення. Численні дослідження визначили технологічні особливості виробництва та методи використання біоактивних матеріалів для очищення грунту від забруднення нафтою для різних об'єктів навколишнього середовища. Як показано [4], очищення грунтів, забруднених нафтою та нафтопродуктами, має особливості. Внесення мікроорганізмів доцільно в тому разі, коли активність природного біоценозу невисока, а окислення нафти відбувається вкрай повільно. Через велику адсорбувальну поверхню грунту в ньому накопичується забруднювач. Сорбційна здатність залежить від властивостей грунту, насамперед від капілярних сил, які визначаються гранулометричним складом грунту та вмістом вологи. Насичені водою грунти зв'язують тільки залишкову кількість нафти у вигляді рідкої фази. Природний біокомплекс (природний біоценоз), що існує в грунті, активний там, де більше бактеріальних клітин утримується на грунтовій поверхні. Автори [5; 6] показують, що введення в грунт адаптованих мікроорганізмів із високою руйнівною активністю пришвидшує розкладання нафти. Однак під час використання мікробних препаратів, як зазна- чають автори [7], існує суперечність у результатах. Іммобілізовані на різних матеріалах, мікроорганізми мають більший потенціал руйнівної дії. Тому створення й дослідження біоактивних сорбційних комплексів, що сорбують рухливий забруднювач (нафту) та розкладають нафту в локалізованому стані, є актуальним, особливо для конкретних піщаних грунтів. На основі аналітичного огляду наукової літератури обгрунтовано необхідність і перспективність проведення досліджень зі створення біосорбційних комплексів, у яких мікроорганізми-деструктори іммобілізовані на носіях, що сорбційно активні до нафти та мікроорганізмів. Іммобілізація підвищує життездатність клітин мікроорганізму. Вибір оптимальних адсорбентів для іммобілізації мікроорганізмів може значно збільшити ефект їх використання. Переваги використання іммобілізованих мікроорганізмів-деструкторів наведено в статтях [8; 9]. Практика показує, що очищення піщаних грунтів становить особливу складність, і вказує на необхідність досліджень на місцях. Розроблення технології очищення забрудненого нафтою грунту повинна визначити необхідні методи, основані на наукових та експериментальних дослідженнях. Оцінка стану забрудненої території після застосування технології визначає можливість використання тієї чи іншої технології. У значній кількості біосорбентів, відмінною рисою яких є різноманітність використовуваних носіїв (сорбентів) та іммобілізованих на них культур мікроорганізмів. Однак питання їх використання для очищення піщаних грунтів залишається відкритим через специфіку. Отже, результати аналізу дають змогу зробити висновок, що розроблення біоактивного сорбенту світлого кольору з підвищеною руйнівною здатністю іммобілізованих мікроорганізмів $\epsilon$ актуальним і необхідним.

Мета роботи. Метою дослідження є розроблення ефективної технології очищення піщаних грунтів від застарілих нафтових забруднень за допомогою спеціалізованих біосорбційних комплексів світлого кольору. Для досягнення цієї мети потрібно вибрати 3 наявних природних мінеральних і рослинних сорбційних матеріалів світлого кольору сорбент-носій, що володіє сорбційною активністю щодо вуглеводнів нафти та біосумісністю 3 нафтоокислювальними мікроорганізмами; виділити із забруднених нафтою природних об'єктів консорціум мікроорганізмів-деструкторів вуглеводнів широкого спектра діiі, який володіє синергізмом і $є$ стійким під час повернення в навколишнє середовище; визначити ефективність біосорбційного комплексу на зразках модельного піску, забруднених нафтопродуктами різного походження, та на зразках, відібраних на промислових об'єктах; випробовувати біосорбентний комплекс (біосорбент) у промислових умовах; комплексне дослідження сорбційних, деструктивних (щодо нафтозабруднення) та інших фізико-хімічних властивостей біологічно модифікованих сорбентів. 
Матеріали й методи досліджень. Як методологічну базу досліджень було використано праці вітчизняних і зарубіжних дослідників із питань виділення 3 аборигенної мікрофлори довготривало забруднених нафтою грунтів мікроорганізмів-деструкторів і оцінки їхніх деструктивних властивостей. Вивчено умови вирощування мікробної біомаси та іммобілізації клітин на сорбентах різного типу. Застосування зазначених методів, а також аналіз фактичного матеріалу дали змогу забезпечити об'єктивність отриманих висновків і результатів. Проведено комплексне дослідження сорбційних, деструктивних (щодо нафти) та інших фізико-хімічних властивостей біологічно модифікованих сорбентів різного складу. Об'єктами досліджень були рослинні відходи, вуглецеві матеріали, природні мінеральні сорбенти (глауконіт, смектоніт), біосорбційні комплекси, нафтопродукти різного походження, піщані грунти.

Серед сорбційних матеріалів світлих кольорів природний мох, глауконіт і смектоніт мають найкращі показники сорбційної активності як для нафти, так i для мікроорганізмів-деструкторів нафти. Глауконіт дуже поширений в осадових породах мілководного морського походження та в сучасних морських відкладах. Однак у природі він не утворює великих мономінеральних агрегатів, а трапляється лише у вигляді суміші з іншими мінералами глинистих або піщаних шарів. Тобто глауконіт споріднений із піщаними грунтами. Смектоніт- чи смектит - загальна назва для ді- тріоктаедричних шаруватих мінералів до групи монтмориллонит. Відома здатність цих сорбентів пов'язувати бактеріальні клітини. Завдяки унікальній кристало-хімічній структурі природні смектити володіють колоїдними, адсорбційними, іонообмінними й вологоутримувальними властивостями.

Нафтоокислювальна група мікроорганізмів природного походження дуже різноманітна. Ідентифікація показала, що виділені мікроорганізми належать до родів: Pseudomonas, Arthrobacter, Rhodococcus, Acinetobacter, Flavobacterium, Corynebacterium, Xanthomonas, Alcaligenes, Nocardia, Brevibacterium, Candida, Mycobacterium, Beijerinkia, Bacillus, Enterobacteriaceae, Klebsiella, Micrococcus, Sphaerotilus. Streptomyces. Вони характеризуються здатністю до засвоєння широкого спектра вуглеводнів, зокрема й ароматичних, мають високу швидкість зростання, активно утилізують нафту i нафтопродукти різноманітного складу, зокрема важкі фракції нафти.

Кількість закріпленої біомаси (абсолютно суха вага = а.с.в.) розрахували за різницею ваги зразка до та після обробки сорбента біомасою (вага в мг на 1 г ваги зразка). Результати дослідження показали, що сорбція біомаси на носії становить від 100 до 400 мг сухої біомаси на г сорбенту. Відомо, що під час «мономолекулярної» адсорбції (один шар клітин) питома сорбція біомаси куль- тури становить 80-120 мг/г матеріалу. Як показали результати досліджень, найвища величина питомої сорбції у вуглецевого носія та перевищує рівень клітинного закріплення в 3-4 рази, що свідчить про наявність у матеріалі додаткового утримання клітин завдяки фізичному введенню в макропори. Серед сорбційних матеріалів світлого кольору найкращі показники щодо сорбційної активності як до нафти, так і до нафтоокислювальних мікроорганізмів мають смектит і глауконіт. Сорбційна здатність носія щодо мікробної культури дуже важлива під час створення біосорбційного комплексу та визначається адсорбційною взаємодією між біоносієм і біокультурою. Одним із важливих параметрів процесу іммобілізації, що характеризує можливість функціонування іммобілізованих клітин в умовах підвищеної гідродинамічної дії, $\epsilon$ міцність їх утримання на поверхні носія. Тому нами було досліджено здатність до десорбції клітин із поверхні носіїв. У середньому 76 \% клітин $\epsilon$ в іммобілізованому стані на поверхні носія.

Виклад основного матеріалу. Дослідження процесу деструкції нафтозабруднення здійснювали на забруднених грунтах під час внесення мікроорганізмів-деструкторів у вигляді культуральної рідини та іммобілізованих на сорбенті. Біодеструктивну спроможність сорбенту з іммобілізованими мікроорганізмами-деструкторами контролювали за зниженням концентрації забруднювальної речовини (нафти) та накопиченням біомаси в системі. Іммобілізація консорціуму мікроорганізмів-деструкторів на носії $\epsilon$ одним з ефективних прийомів підвищення активності мікроорганізмів й інтенсифікації процесу біодеструкції нафтопродуктів. Основними вимогами до таких носіїв $є$ пориста структура й високорозвинена поверхня носія, здатного добре акумулювати поживні речовини, вологу. Сутність іммобілізації мікробних клітин - це прикріплення їх в активній формі до нерозчинної основи-матриці. Іммобілізація мікроорганізмів на поверхні сорбентів захищає їх від несприятливих факторів, збільшує біологічну активність мікробіоти й активізує процес розкладання нафти Проведені дослідження показали, що іммобілізація МО на поверхні сорбційної матриці повинна бути частковою, щоб не знизити сорбційну ємність матеріалу щодо нафти. Достатня кількість іммобілізованих клітин на сорбент $120-200 \times 10^{4-6}$ кл / г.

Як показали дослідження, потенціал нафтоокислювальних мікроорганізмів значно вищий, якщо вони іммобілізовані на поверхні сорбенту. Згідно 3 результатами досліджень вуглецевий сорбент (чорний колір) утримує на своїй поверхні достатню кількість нафтоокислювальних мікроорганізмів, що пояснюється наявністю на його поверхні різних за хімічною природою центрів: полярних і неполярних.

У табл. 1 надано порівняльні показники деструктивної активності біосорбційних комплексів на основі біомодефікованих носіїв. Під час застосу- 
Сорбційні властивості нафтопоглинальних матеріалів щодо мікроорганізмів-деструкторів і деструктивна активність біосорбційного комплексу

\begin{tabular}{|c|c|c|c|}
\hline Тип носія & $\begin{array}{l}\text { Питома сорбція } \\
\text { Мг а.с.в./г }\end{array}$ & 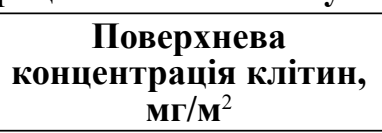 & $\begin{array}{c}\text { Деструктивна } \\
\text { активність } \\
\% 100 \text { діб }\end{array}$ \\
\hline $\begin{array}{l}\text { Деревне вугілля б/м } \\
\text { (чорний колір) }\end{array}$ & 12,7 & 65,94 & 91 \\
\hline $\begin{array}{l}\text { Вугілля із стрижнів кукурудзи, б/м } \\
\text { (чорний колір) }\end{array}$ & 10,3 & 46,8 & 72 \\
\hline Глауконіт б/м & 11,1 & 28,9 & 65 \\
\hline Монтморилоніт б/м & 20,1 & 35,04 & 51 \\
\hline Смектоніт б/м & 21,1 & 35,94 & 65 \\
\hline
\end{tabular}

Таблиця 2

Динаміка очищення грунту від нафти під час обробки біосорбційним комплексом

\begin{tabular}{|c|c|c|c|c|c|c|}
\hline \multirow{2}{*}{$\begin{array}{c}\text { Термін від початку } \\
\text { очищення, доба }\end{array}$} & \multicolumn{3}{|c|}{$\begin{array}{c}\text { Вміст залишкової нафти, \% (суглинок) } \\
\text { Вуглецевий носій- } \\
\text { носій глауконіт- смектоніт }\end{array}$} & \multicolumn{3}{|c|}{$\begin{array}{c}\text { Вміст залишкової нафти, \% (пісок) } \\
\text { Вуглецевий носій- } \\
\text { носій глауконіт- смектоніт }\end{array}$} \\
\hline & 40 & - & - & 40 & - & - \\
\hline 10 & 24 & 29 & 31 & 26 & 18 & 14 \\
\hline 30 & 10,5 & 11 & 12 & 14 & 13 & 15 \\
\hline 60 & 9,8 & 9 & 10 & 10,1 & 12 & 11 \\
\hline 91 & 8,4 & 10 & 9 & 9,1 & 8 & 6 \\
\hline 100 & 7,6 & 6 & 7 & 8,4 & 7 & 6 \\
\hline 120 & 5,2 & 4 & 7 & 6 & 5 & 7 \\
\hline 140 & 0,4 & 2,1 & 1,9 & 2,8 & 2,9 & 1,8 \\
\hline
\end{tabular}

вання препарату на основі біомодифікованих глауконіту та смектоніту для обробки нафтозабрудненого піщаного грунту механізм дії його полягає не тільки в біохімічній деструкції нафти, але й в активізації бідних природних мікробних біоценозів. Вони можуть бути рекомендовані як світлі біосорбенти деструктивного типу для очищення нафтозабруднених піщаних грунтів.

Проведеними дослідженнями показано зміну концентрації нафти в процесі біодеструкції в промислових зразках грунту: чорнозем, суглинок, пісок. Через 140 діб відбувалося зниження концентрації нафтового забруднення від 30-40 \% до 1-5\%. Дослідження процесів біодеструкції нафти в піщаному грунті під дією біосорбційних комплексів на основі сорбційних матричних матеріалів різного типу, активізованих ідентичною композицією нафтоокислювальних мікроорганізмів природного походження, показали можливість застосування світлих композицій сорбент-мікробного складника на основі глауконіту та смектоніту (рис. 1, табл. 2).

У композицію вводили мікроелементи в кількості, яка необхідна для розвитку та життєдіяльності мікроорганізмів, суміш сполук для підтримки $\mathrm{pH}=6-8$ та стартовий концентрат мікроорганізмів-деструкторів. Дослідження адсорбційних і деструктивних властивостей нафтопоглинальних біосорбційних комплексів щодо очищення піщаних грунтів із

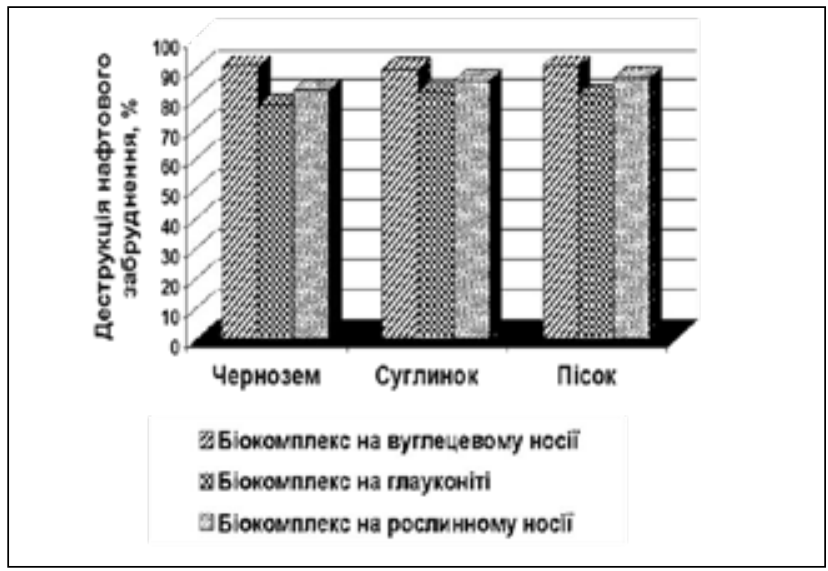

Рис. 1. Біодеструкиія нафтового забруднення трунтів різного типу після обробки біосорбичійним комплексом (через 140 діб)

застарілим нафтозабрудненням визначать напрями практичного впровадження технології отримання й застосування ефективних екологічно чистих біоактивних нафтосорбентів деструктивного типу.

Головні висновки. Створено світлий біосорбційний препарат деструктивного типу для очищення специфічних піщаних грунтів від нафти та застарілих нафтозабруднень. Як носій використано біологічно активний смектоніт світлого кольору, який має задовільну нафтоємніть (4 г нафти / 1 г сорбенту) 
та біосумісний із нафтоокислювальними мікроорганізмами. Вивчено умови одержання біосорбційного комплексу, запропоновано новий підхід до розв'язання проблем біоочищення забруднених грунтових середовищ, що полягає у створенні біосорбційних комплексів, у яких мікроорганізми-деструктори закріплюються на носіях не інертних, а сорбційно-активних до забруднювача та мікроорганізмів. Результати досліджень підтверджують, що комплексний підхід до детоксикації забруднення - сорбція + мікробна деструкція - гарантує очищення нафтозабруднених піщаних грунтів.

\section{Література}

1. Полициклические ароматические углеводороды в почвах техногенных ландшафтов / Д.Н. Габов, В.А. Безносиков, Б.М. Кондратенок, Е.В. Яковлева. Геохимия. 2010. № 6. С. 606-617.

2. Поиск микроорганизмов, разрушающих нефть в различных природных зонах / М.Б. Куплетская, Л.И. Лопатина, Е.В. Породенко, А.И. Нетрусов. Экология и промышиенность России. 2009. № 7. С. 32-33.

3. Ананьева Н.Д. Микробиологические аспекты самоочищения и устойчивости почв. Москва : Наука, 2003.223 с.

4. Пашаян А.А. Проблемы очистки загрязненных нефтью вод и пути их решения / А.А. Пашаян, А.В. Нестеров. Экология $u$ промышленность. 2008. № 5. С. 32-35.

5. Другов Ю.С. Экологические анализы при разливах нефти и нефтепродуктов : практ. руководство. Санкт-Петербург, 2000. 249 c.

6. Jurgensen K.S., Puustinen J., Suortti A.-M. Bioremediation of petroleum hydrocarbon-contaminated soil by composting in biopiles. Environmental Pollution. 2000. Vol. 107. No. 2. P. 245-254. DOI: https://doi.org/10.1016/s0269-7491(99)00144-x.

7. Analysis of bacterial diversity and community structure in forest soils contaminated with fuel hydrocarbon / Ahn J.H. et al. Journal of Microbiology and Biotechnology. Vol. 16. P. 704-715.

8. Wagner-Dobler I., Bennasar A., Vancanneyt M., Strompl C., Brummer I., Eichneer C., Grammel I., Moore E.R.B. Micro-cosm Enrichment of Biphenyl-Degrading Microbial Communities from Soils and Sediments. Applied and Environmental Microbiology. 1998. Vol. 64. № 8. P. 3014-3022.

9. Киреева Н.А. и др. Микробиологическая рекультивация нефтезагрязненных почв. Москва : ОАО «ВНИИОЭНГ», $2001.40 \mathrm{c}$.

10. Khokhlov A., Strelko V., Khokhlova L. Physico-chemical features of bioactive carbon sorbents for oil. Chemistry and Chemical Technology. 2018. Vol. 12. № 3. P. 337-340. https://doi.org/10.23939/chcht12.03.337. 


\title{
ЗАГАМЬНІ ПРОБАЕМИ ЕКОАОГIЧНОї БЕЗПЕКИ
}

УДК 620.9

DOI https://doi.org/10.32846/2306-9716/2020.eco.6-33.13

\section{АНАМИЗ ОСОБЕННОСТЕЙ ШУМОВОГО ЗАГРЯЗНЕНИЯ ПРИ ИСПОАЬЗОВАНИИ ВЕТРОГЕНЕРАТОРОВ В УСАОВИЯХ ЮГА УКРАИНЫ}

\author{
Боженко А.Л., Кубов В.И. \\ Черноморский национальный университет имени Петра Могилы \\ ул. 68 Десантников, 10, 54000, г. Николаев \\ voodoo@chmnu.edu.ua
}

\begin{abstract}
Статья посвящена недостаточно изученному фактору шумового загрязнения при внедрении ветроустановок на юге Украины и определению способов управления этим фактором. Негативное влияние ветровых установок затрагивает как человека, так и окружающую среду. Оно проявляется в акустических явлениях (магнитные, механические и аэродинамические шумовые эффекты), вибрации, электромагнитном излучении. Также высока вероятность аварийных ситуаций с отлетанием повреждённых частей ветроколеса. Для нас наиболее актуальным является вопрос негативного влияния ВЭУ на человека.

Авторами произведена оценка диапазона шумового ветрового загрязнения, которое может быть создано существующими и потенциальными ветропарками в Николаевской области. Показано, что с точки зрения шумового загрязнения заметно отличаются ВЭУ, классифицируемые по направлению горизонтально и вертикально осевые, поскольку эта разница наиболее существенно сказывается на уровне генерируемого шума. Предоставлены рекомендации по уменьшению шумового загрязнения от ветровых энергетических установок. Показано, что сегодня на украинском рынке доступны и широко используются ветроустановки, чей фактический рабочий шум ниже допустимого по санитарным нормам Украины в 80 дБ.

На данный момент использование ветроэнергетики на юге Украины может рассматриваться как перспективное в некоторых пределах роста. В то же время на современном техническом уровне ВЭУ способны вызывать ощутимый дискомфорт у человека в широком спектре звуковых волн. Также при планировании размещения ветропарков необходимо учитывать, что акустический шум ВЭУ увеличивается из-за поверхностных и акустических процессов отражения от окружающих конструкций, в которых находится человек. В связи с этим настоятельно рекомендуется размещать ветроустановки в местах, максимально удалённых от населённых пунктов. Ключевые слова: ветровая энергетика, типы ветроустановок, шумовое загрязнение.
\end{abstract}

Аналіз особливостей шумового забруднення при використанні вітрогенераторів в умовах півдня України. Боженко А.Л., Кубов В.І.

Стаття присвячена не досить вивченому фактору шумового забруднення при впровадженні вітроустановок на півдні України й визначенню способів управління цим фактором. Негативний вплив вітрових установок стосується як людини, так і навколишнього середовища. Воно виявляється в акустичних явищах (магнітні, механічні та аеродинамічні шумові ефекти), вібрації, електромагнітному випромінюванні. $Є$ також ймовірність аварійних ситуацій, пов'язаних із відлітанням пошкоджених частин вітроколеса. Для нас найбільш актуальним $є$ питання негативного впливу ВЕУ на людину.

Автори провели оцінку діапазону шумового вітрового забруднення, яке може бути створене існуючими й потенційними вітропарками у Миколаївській області. Показано, що з точки зору шумового забруднення помітно відрізняються ВЕУ, які класифікуються за напрямом горизонтально й вертикально осьові, оскільки ця різниця найістотніше позначається на рівні генерованого шуму. Надано рекомендації щодо зменшення шумового забруднення від вітрових енергетичних установок. Показано, що нині на українському ринку доступні й широко використовуються вітроустановки, фактичний робочий шум яких нижчий допустимого за санітарними нормами України у 80 дБ.

Нині використання вітроенергетики на півдні України може розглядатися як перспективне в деяких межах зростання. В той же час на сучасному технічному рівні ВЕУ здатні викликати відчутний дискомфорт у людини в широкому спектрі звукових хвиль, Також при плануванні розміщення вітропарків необхідно враховувати, що акустичний шум ВЕУ збільшується через поверхневі й акустичні процеси відображення від оточуючих конструкцій, у яких знаходиться людина. У зв'язку з цим рекомендується розміщувати вітроустановки в місцях, максимально віддалених від населених пунктів. Ключові слова: вітрова енергетика, типи вітроустановок, шумове забруднення.

Analysis of the noise pollution caused by wind turbines in the south of Ukraine. Bozhenko A., Kubov V.

The article is devoted to the insufficiently studied factor of noise pollution during the operation of wind turbines in the south of Ukraine and finding ways to control this factor. The negative impact of wind turbines affects both humans and the environment. It manifests itself in acoustic phenomena (magnetic, mechanical and aerodynamic noise effects), vibration and electromagnetic radiation. There is also the likelihood of accidents with damaged parts of the wind turbine flying off. For us, the most relevant issue is the negative impact of wind turbines on humans. 
The authors estimated the range of wind noise pollution that can be created by existing and potential wind farms in the Mykolaiv region. It is shown that from the perspective of noise pollution, horizontal and vertical axial wind turbines differ significantly, this difference significantly affects the level of generated noise. Recommendations for reducing noise pollution from wind power plants are provided. It is shown that today in the Ukrainian market wind turbines are available and widely used whose actual operating noise is lower than the permissible one according to sanitary standards of Ukraine at $80 \mathrm{~dB}$.

At the moment, the use of wind energy in the south of Ukraine can be considered promising within some growth limits. At the same time, at the modern technical level, wind turbines are capable of causing significant discomfort in a person in a wide range of sound waves. Also, when planning the placement of wind farms, it is necessary to take into account that the acoustic noise of wind turbines increases due to surface and acoustic processes of reflection from the surrounding buildings (where people live or work). In this regard, it is strongly recommended to place wind turbines in places as far as possible from settlements. Key words: wind energy, types of wind turbines, noise pollution.

Постановка проблемы. В условиях перехода к максимально диверсифицированным источникам энергии возникает необходимость изучать все побочные явления, которые возникают при их эксплуатации. В то время как использование углеродного топлива приводит к загрязнению атмосферы продуктами сгорания, гидроэлектростанции нарушают баланс бассейнов рек, атомная энергетика создаёт проблему накопления отработанных радиоактивных отходов, альтернативные источники энергии тоже имеют свои специфические недостатки. Так, использование ветровых установок предполагает отчуждение значительных площадей, пригодных для других нужд, опасность для некоторых местных представителей фауны. В этой статье проводится анализ одного из вышеупомянутых негативных явлений - изменения шумового фона.

Актуальность исследования. Сегодня всё большее значение принимает повсеместное внедрение источников альтернативной энергетики, к которым относятся и ветроустановки разного типа. В перспективе это решит часть энергетических проблем разных стран. Очевидно, что непосредственно ветровая энергия будет занимать лишь узкую нишу, но полезно изучать её на практике, включая её влияние на человека для принятия оптимальных решений на перспективу.

Негативное влияние ветровых установок затрагивает как человека, так и окружающую среду. Безусловно, вред, нанесённый среде проживания человека, можно автоматически считать вредом, нанесённым самому человеку, но для нас наиболее актуальным является вопрос негативного влияния ВЭУ непосредственно на организм человека. Оно проявляется в акустических явлениях (механические, магнитные и аэродинамические шумовые эффекты), вибрации, электромагнитном излучении. Есть также вероятность аварийных ситуаций с отлетанием повреждённых частей ветроколеса [1].

Реакция на шум нередко выражается в повышенной возбудимости и раздражительности, охватывающих всю сферу чувственных восприятий. Люди, которые подвергаются постоянному воздействию шума, часто становятся трудными в общении, что можно расценивать как социальные последствия функционирования ветропарков для местного сообщества.
Связь авторских наработок с важными научными и практическими задачами. Эта работа связана с двумя важными научными задачами: задачей внедрения в местную энергетическую систему альтернативных источников энергии и задачей снижения негативного шумового влияния ветроустановок на человека.

Анализ последних исследований и публикаций. При анализе шумового загрязнения следует учитывать, что оно отличается для установок разных типов. В целом все ветровые установки разделяют по области применения, направлению оси, виду вырабатываемой энергии, мощности, принципу работы, способу управления, структуре системы генерирования энергии.

По виду вырабатываемой энергии ВЭУ делятся на механические (ветросиловые, ветронасосные) и электрические (постоянного, переменного тока). По принципу работы установки могут иметь постоянную и переменную частоту вращения лопастей. Тот факт, что ветряные турбины взаимодействуют с окружающей средой, которая распространяет звук, генерируемый ими, делает этот источник шума уникальным среди других автономных механических источников шума, поскольку возникает несколько разных видов шумов, широко изученных в $[2 ; 3 ; 4 ; 5]$.

C точки зрения шумового загрязнения нас в первую очередь интересуют ВЭУ, классифицируемые по направлению как горизонтально и вертикально осевые, поскольку эта разница наиболее существенно сказывается на уровне генерируемого шума. Преимуществом вертикально-осевых ВЭУ является возможность размещения генератора и мультипликатора на фундаменте установки. В результате при их работе все уровни аэродинамических и инфрашумов, иногда теле- и радиопомехи, электромагнитные колебания практически отсутствуют [6].

Выделение не решенных ранее частей общей проблемы, которым посвящается данная статья. Статья посвящена недостаточно изученному фактору шумового загрязнения при внедрении ветроустановок на юге Украины и определению способов управления этим фактором.

Новизна. Авторами осуществлён анализ локальных особенностей ветровых условий Николаевской области и шумового загрязнения, которое может 
возникать в этом регионе от ветроустановок разных производителей.

Методологическое или общенаучное значение. Методологическое или общенаучное значение работы заключается в определении, уточнении и теоретическом обосновании комплекса вопросов, связанных с совершенствованием учета и анализом фактора шумового загрязнения при принятии решений об установке ветрогенераторов на выбранной местности. Дальнейшее развитие получила методика экстраполяции данных о шумовом загрязнении для ВЭУ, близких по характеристикам.

Изложение основного материала. В Николаевской области ветровая энергетика представлена ветропарком «Очаковский», расположенным между Днепро-Бугским лиманом и автомобильной дорогой «Николаев-Очаков» в пределах территорий сельсоветов Солончаковский, Дмитровский, Парутинский. Этот промышленный комплекс состоит из трех полей, общая площадь которых составляет 5436 га. На каждом поле планируется в перспективе установить по 50 ветроэнергетических установок. Первые 15 ВЭУ были установлены компанией ООО «Фурлендер Виндтехнолоджи» в тесном сотрудничестве с Fuhrlander AG. На данный момент ООО «ФВТ» является самостоятельным производителем ВЭУ мощностью 2,0/2,5/3,0 МВт по лицензии немецкой компании [7].

Производителем турбины "Fuhrlander" позиционируются как современные, относительно комфортные для человеческого уха ветроустановки с пороговым шумом до 60 дБ. Детальных таблиц о шумовой нагрузке, характерной для этих установок, найти не удалось, поэтому для анализа авторы обратили своё внимание на другого активного в Украине производителя - ООО «Украинская альтернативная энергетика».
Допустимый рабочий шум установки по санитарным нормам Украины должен составлять до 80 дБ. В [8] приведены уровни шума разных моделей ветрогенераторов марки Euro Wind на расстоянии 12 метров от источника. Уровень шума ветрогенератора также включает в себя уровень шума природного ветра и посторонние фоновые шумы, которые возникали при замерах (гул проводов, шелест деревьев). Авторы этой статьи построили график по данным [8] (рис. 1), а также его модификацию для диапазона среднегодовых скоростей ветра для региона Николаева согласно ДБН Украины (рис. 2). На этих графиках, особенно на рис. 2, видно, что связь между скоростью ветра и производимым установкой шумом в дБ близка к прямолинейной.

Можно предположить, что данные [8] не являются результатом многочисленных измерений, поскольку кривые для разных моделей марки Euro Wind отличаются не только в силу реальных технических характеристик, но и по величине погрешности. В связи с этим мы не будем на основании полученных данных давать рекомендации по выбору конкретного типа установки из указанного ряда.

Также важно учитывать, что уровень шума часто измеряют в дБ при помощи шумомера с коррекцией А и выражают это в единицах дБА. Недостаток шкалы дБА заключается в том, что при этом недооценивается чувствительность человека к звукам низкой частоты и не учитывается чувствительность уха к громкости чистых тонов. Удобство шкалы дБА состоит в том, что удвоение громкости примерно соответствует увеличению уровня шума на 10 дБА.

На рис. 3 представлен график зависимости уровня шума в дБА для ветрогенераторов марки Vesta V90-3.0MW, построенный авторами по данным [4]. По наблюдениям [4], когда турбина работает при скоростях ветра примерно 4 м/с и 30 м/с при

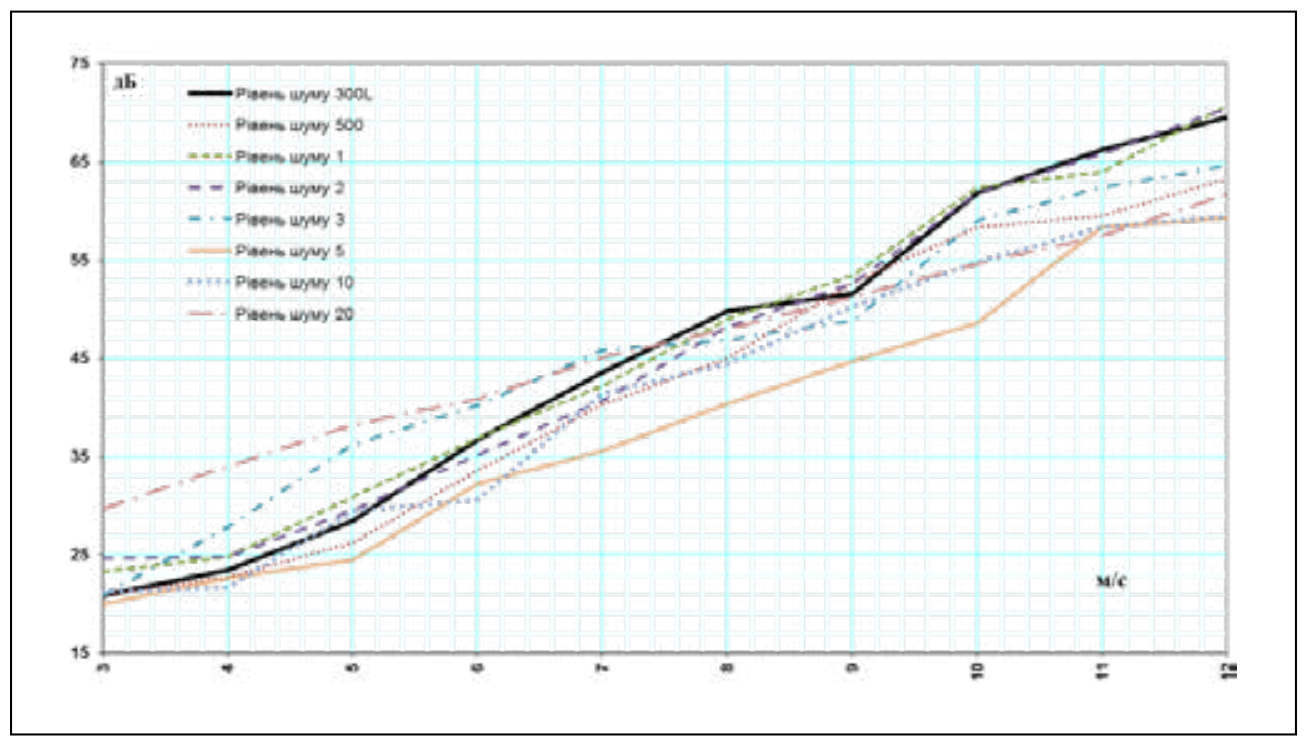

Pис. 1. Уровень шума ветрогенераторов марки Eиго Wind в дБ 


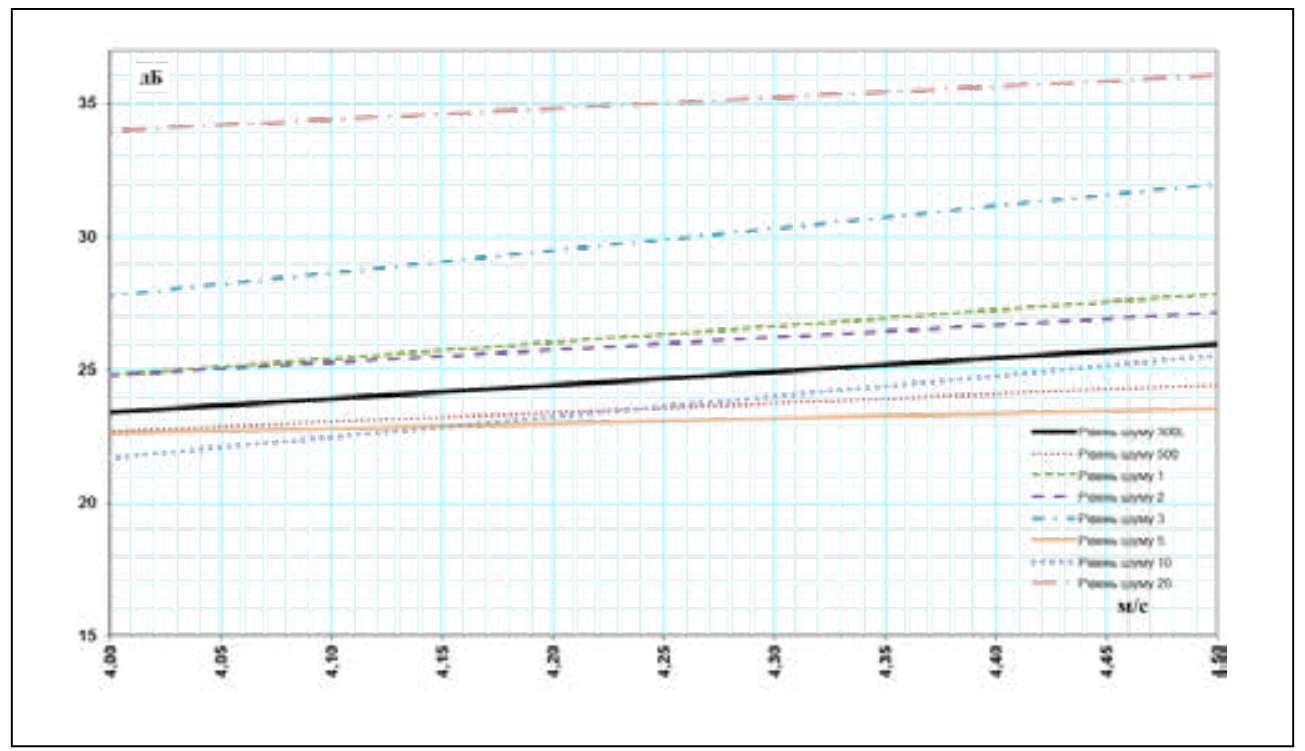

Pис. 2. Уровень шума ветрогенераторов марки ЕигоWind в дБ на промежутке скоростей ветра, среднегодовых для региона Николаева согласно ДБН

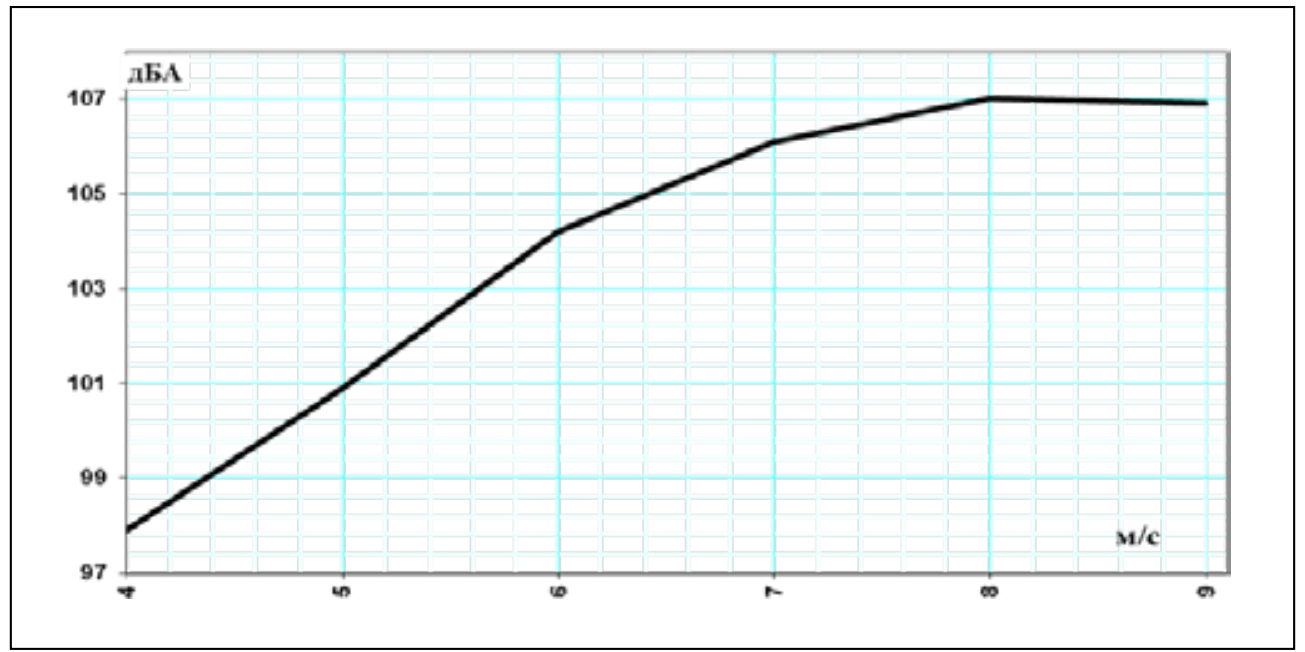

Рис. 3. Уровень шума ветрогенераторов марки Vesta V90-3.0MW в дБА

измерении на высоте ступицы, то уровень звуковой мощности монотонно возрастает, типичный пример чего показан на рис 3. Тем не менее, можно утверждать о прямолинейной зависимости только в диапазоне 4-6 м/с, а дальше кривая заметно отличается от графиков в дБ, изображённых на рис. 1 .

Все описанные в этом разделе ветроустановки относятся к горизонтально осевым. Из вышеперечисленного можно сделать вывод, что на рынке ветрогенераторов Украины представлен выбор разных марок и видов ВЭУ, соответствующих местным требованиям по шуму [6; 8; 9].

К нерешённым задачам в этом контексте относится недостаточное количество данных о конкретных измерениях в полевых условиях в шкалах дБ и дБА. Также необходимо учитывать, что шум нескольких генераторов не равен шуму от одного генератора, хотя и не воспринимается человеком как арифметическая сумма отдельных уровней шума [10]. Поэтому исследования в этой области необходимо продолжать.

Главные выводы. Со временем производителям ветрогенераторов удаётся снизить шумовое загрязнение, оказываемое их продукцией на окружающую среду. Сегодня на украинском рынке доступны и широко используются ветроустановки, чей фактический рабочий шум ниже допустимого по санитарным нормам Украины в 80 дБ. Если ВЭУ производит более высокие скачки, то это может быть связано с проектированием или отсутствием тестирования при производстве установки. В таком случае рекомендуется связаться с поставщиком или производителем для устранения или смягчения таких проявлений. 
Пока на современном техническом уровне ВЭУ способны вызывать ощутимый дискомфорт у человека в широком спектре звуковых волн, настоятельно рекомендуется размещать ветроустановки в местах, максимально удалённых от населённых пунктов. Во избежание локального уменьшения скорости ветра оптимальным является расположение ВЭУ на расстоянии от зданий и других объектов инфраструктуры. Это ещё одна причина, почему такие генераторы наиболее целесообразны на хуторах, околицах сёл.

Больше внимания следует уделять вертикально осевым ВЭУ, которые легко найти в интернет-магазинах. Их преимуществом является возможность размещения генератора и мультипликатора на фундаменте установки, что упрощает требования к монтажу оборудования и условиям эксплуатации (отсутствие толчков и вибраций). Вертикально осевые ВЭУ с точки зрения воздействия на окружающую среду имеют и другие преимущества: при их работе ниже все уровни аэродинамических и инфрашумов, меньше теле- и радиопомехи, электромагнит- ные колебания, меньше радиус разброса обломков лопастей в случае их разрушения, ниже вероятность столкновения лопастей с птицами.

Что касается уменьшения уровней шумов, проникающих в помещение от внешних источников, то оно должно обеспечиваться рациональным планированием помещения, соблюдением мер по звукоизоляции ограждающих конструкций (стен, потолка и пола), санитарно-технического и инженерного оборудования зданий.

Перспективы использования результатов исследования. В перспективе развитие ветровой энергетики в Украине зависит от наличия зелёного тарифа и других экономических условий (в том числе и на мировом рынке углеводородного топлива). Шумовое загрязнение в этой ситуации является второстепенным фактором принятия решений. При благоприятном развитии отрасли материалы статьи могут использоваться как методическое пособие по шумовому загрязнению в условиях юга Украины и борьбе с ним.

\section{Литература}

1. Серіков Я.О., Діденко О.М., Лісіцин В.Е. Інформаційні технології у вирішенні завдань забезпечення безпеки життєдіяльності людини, ергономіки, охорони праці і навколишнього середовища : монографія: у 2-х ч. / за ред. Я.О. Сєрікова. Х. : ХНАМГ. 2013. Ч. 2. Вітроелектричні станції / Х. : ХНУМГ ім. О.М. Бекетова. 2014. 183 с.

2. A laboratory study on the effects of wind turbine noise on sleep: results of the polysomnographic WiTNES study Sleep / Michael G Smith and others. Volume 43. Issue 9. September 2020. DOI: https://doi.org/10.1093/sleep/zsaa046.

3. Пляцук Л.Д., Афанасьєва Н.О. Поле звукових коливань довкола вітрових електростанцій. Імпульсний низькочастотний шум. Вісник ЖДТУ. Технічні науки. 2014. № 1(68). С. 74-81.

4. Tonin Renzo. Sources of wind turbine noise and sound propagation. Acoustics Australia. № 40. 2012. C. $20-27$.

5. Боженко А.Л., Кубов В.Л. Аналіз впливу вітрових установок на здоров'я людини. Матеріали науково-практичної конференції «Могилянські читання - 2019: досвід та тенденції розвитку суспільства в Україні: глобальний, національний та регіональний аспекти: XXII Всеукр. наук.-метод. конф. : тези доповідей: Екологія і сучасні екологічні проблеми. Миколаїв, 11-16 листопада 2019 року, ЧНУ ім. Петра Могили. Миколаїв : Вид-во ЧНУ ім. Петра Могили, 2019. С. 26-27.

6. Статья по материалам специалистов по ветроэнергетике КБ «Южное»: д.т.н. М.И. Галась, инж. Ю.П. Дымковец, H.А. Акаева, И.Ю. Костюкова. URL: http://vetrogenerator.com.uа (дата обращения: 10.12.2020).

7. Анализ эффективности работы промышленной ВЭС Очаковского ветропарка / Подгуренко В.С., Никитенко Е.Ф., Терехов В.Е. Матеріали міжнародної науково-технічної конференції «Суднова енергетика: стан та проблеми», жовтень 2013 року. Миколаїв. URL: http://conference.nuos.edu.ua/catalog (дата обращения: 10.12.2020).

8. Официальный сайт ООО «Украинская альтернативная энергетика». URL: http://wind.ae.net.ua/index.php/main/index/0/520 (дата обращения: 10.12.2020).

9. Burdelna H., Bozhenko A. Energy security management at the regional level: economic and environmental aspects / Markina I., Aranchiy V., Safonov Y., Zhylinska O. and other. Security of the XXI century: national and geopolitical aspects : collective monograph / in edition I. Markina. Prague. Nemros s.r.o. 2019. Czech Republic. P. 261-267.

10. Wolniewicz K., Kuczyński W., Zagubien A. Method for wind turbine selection basing on in-field measurements. Journal of Mechanical and Energy Engineering. Vol. 3(43), № 1, 2019. P. 77-84. 


\title{
ЕКОАОГІЧНА ОЦІНКА СТАНУ СІАЬСЬКИХ НАСЕАЕНИХ ПУНКТІВ ЖИТОМИРСЬКОЇ ОБААСТІ
}

\author{
Валерко Р.А., Герасимчук Л.О. \\ Житомирський національний агроекологічний університет \\ бульв. Старий, 7, 10008, м. Житомир \\ valerko_ruslana@ukr.net,gerasim4uk@ukr.net
}

\begin{abstract}
Сучасний екологічний стан сільських населених пунктів як Житомирської області, так і України загалом характеризується як кризовий, що безпосередньо впливає на економічний і соціальний розвиток сільської території. Причинами погіршення стану навколишнього природного середовища сільських населених пунктів є інтенсивне ведення сільського фермерського та особистого господарств, низька якість екологічної освіти і виховання місцевого населення.

Протягом 2019 року у районах Житомирської області викинуто в атмосферне повітря 9439,9 тонн забруднюючих речовин, найбільша їх кількість (1558,68 тонн) зафіксована у Новоград-Волинському районі, найменша - у Народицькому районі (5,82 тонни). Динаміка скидів зворотних вод у поверхневі водні об’єкти Житомирської області в розрізі районів свідчить, що протягом 2010-2017 років спостерігалася чітка тенденція до їх зниження. Найбільші обсяги зворотних вод $(9,3 \text { млн м })^{3}$ скинуто у поверхневі водні об'єкти на території Ружинського району, взагалі не зафіксовано скидів у Брусилівському районі.

Нині в області зареєстровано 845 об'єктів місць видалення відходів, у тому числі 6 полігонів для зберігання твердих побутових відходів, загальна площа яких становить близько 632 га. Найбільша кількість сміттєзвалищ у 2019 році була в Овруцькому районі - 108 шт., найменша - у Народицькому районі - 18 шт. Розрахунок коефіцієнту антропогенного навантаження дозволяє згрупувати райони Житомирської області на 4 категорії антропогенного навантаження. До незначного рівня навантаження відносяться 4 райони, до середнього - 2 , до значного - 9 , до великого -8 , що свідчить про досить високий рівень навантаження в межах сільських населених пунктів Житомирщини. Ключові слова: атмосферне повітря, сільські населені пункти, стічні води, відходи, навколишнє середовище, комплексна оцінка.
\end{abstract}

Ecological assessment of the condition of rural settlements of Zhytomyr region. Valerko R., Herasymchuk $\mathbf{L}$.

The current ecological condition of rural settlements, both Zhytomyr region and Ukraine as a whole, is characterized as a crisis that directly affects the economic and social development of rural areas. The reasons for the deterioration of the natural environment of rural settlements are: intensive management of rural farms and personal farms and low quality of environmental education and upbringing of the local population.

During 2019 9439,9 tons were released into the atmosphere in the districts of Zhytomyr region, on average the largest amount, which is 1558,68 tons, was recorded in Novohrad-Volynskyi district, and the smallest amount - in Narodytskyi district, which averages $5,82 \mathrm{t}$. The dynamics of discharges of return waters into surface water bodies of Zhytomyr region in terms of districts showed that during 2010-2017 there is a clear tendency to reduce discharges of return waters. The largest amount of return water 9,3 million $\mathrm{m}^{3}$ was discharged into surface water bodies in the territory of Ruzhyn district, no discharges were recorded in Brusyliv district.

Currently, 845 waste disposal sites are registered in the region, including 6 landfills for solid waste storage, the total area of which is about 632 hectares. The largest number of landfills in 2019 was in Ovruch district - 108 units, the smallest number was set for Narodytskyi district - 18 units. The calculation of the anthropogenic load factor allows to group the districts of Zhytomyr region into 4 categories of anthropogenic load: 4 districts belong to the insignificant level of loading, 2 to the medium level, 9 to the significant one and 8 to the large one, which indicates a rather high level of load within rural settlements Zhytomyr region. Key words: atmospheric air, rural settlements, sewage, waste, environment, complex assessment.

Постановка проблеми. Розвиток сільських селітебних територій як одна із проблем, 3 якою останнім часом стикається людство, звертає на себе особливу увагу у світі, оскільки захист довкілля сільських територій має важливе значення для їх стійкого розвитку. Особливе місце у забезпеченні сталого розвитку сільських територій займає екологічний фактор, який забезпечує збереження навколишнього середовища. Відповідно до стратегії сталого розвитку України до 2030 року необхідною умовою сталого розвитку сільських територій є забезпечення їх екологічної безпеки шляхом розвитку раціонального природокористування та своєчасного впровадження заходів щодо запобігання негативному впливу антропогенних процесів на середовище.
Актуальність дослідження. Екологічні проблеми, які виникли в останні десятиліття, є одним із аргументів проти економічного зростання та сталого розвитку держави, зокрема й сільських селітебних територій. Сучасна екологічна ситуація сільських територій свідчить про необхідність впровадження цілей сталого розвитку для подальшого безпечного функціонування у сільській місцевості.

Житомирська область не входить до переліку регіонів із несприятливою екологічною ситуацією, проте наявне антропогенне навантаження на значній території сформувало тенденцію до деградації екосистем, екотипів і зменшення біорізноманіття, що й спонукало нас до проведення досліджень, які стосуються оцінки стану навколишнього середовища у сільських селітебних територіях Житомирської 
області. Ця область $є$ однією із найбільш постраждалих від аварії на Чорнобильській АEC, що також підвищує актуальність таких досліджень.

Зв'язок авторського доробку з важливими науковими та практичними завданнями. Дослідження виконувалося в рамках науково-дослідної роботи «Еколого-соціальна оцінка стану сільських селітебних територій у контексті сталого розвитку» (державний реєстраційний номер 0120U104233). Отримані результати можуть бути використані представниками сільських, селищих рад та об'єднаних територіальних громад при формуванні звітів, програм і стратегій розвитку, а також для інформування населення про стан навколишнього середовища сільських селітебних територій Житомирської області.

Аналіз останніх досліджень і публікацій. Нині моніторингом і вирішенням екологічних проблем сільських селітебних територій займається багато вітчизняних і зарубіжних учених, серед них Н.В. Палапа, О.В. Устименко, І.О. Сігалова [1-3], О.І. Фурдичко, Н.А. Макаренко [4; 5], Е.Е. Афанасьева, О.В. Корева, В.І. Тихий [6; 7] та інші.

Більшість досліджень присвячені оцінці окремих компонентів навколишнього середовища сільських територій: питна вода, грунтовий покрив, продукти харчування. Лише невелика їх кількість висвітлюють питання комплексної оцінки стану довкілля сільських населених пунктів з урахуванням викидів, скидів забруднюючих речовин і розміщення відходів.

Виділення не вирішених раніше частин загальної проблеми, котрим присвячусться означена стаття. Оскільки екологічний складник розвитку сільських територій безпосередньо пов'язаний 3 економічним і соціальним становищем, то актуальним $є$ постійний моніторинг стану навколишнього середовища сільської місцевості та проведення його комплексної оцінки, що має бути основою для прийняття управлінських рішень щодо покращення стану екологічної безпеки як регіону, так і держави загалом.

Загальнонаукове значення. Емпіричну основу дослідження складають узагальнення статистичних матеріалів, опублікованих на офіційних інтернет-ресурсах Головного управління статистики у Житомирській області, Управління екології та природних ресурсів ЖОДА, Державної екологічної інспекції Поліського округу. Для комплексного оцінювання стану довкілля сільських населених пунктів Житомирського регіону використовували методику, наведену у науковому дослідженні Національного інституту стратегічних досліджень [8].

Коефіцієнт антропогенного навантаження визначали за такою формулою:

$$
m_{i}=\frac{M_{i}-M_{\min }}{M_{\max }-M_{\min }},
$$

де $\mathrm{M}_{\mathrm{i}}$ - показник питомої щільності досліджуваного фактору впливу на довкілля (щільність насе- лення, кількість викидів в атмосферне повітря, скиди у водні об’єкти та кількість сміттєзвалищ).

Сумарний показник рівня антропогенного навантаження адміністративно-територіальних утворень Житомирської області $\gamma$ визначали за формулою:

$$
\gamma=\sum_{i=1}^{n} \frac{M_{i}-M_{\min }}{M_{\text {max }}-M_{\text {min }}},
$$

Виклад основного матеріалу. Станом на 01.01.2019 у Житомирській області налічується 1613 сільських населених пунктів, що на 77 населених пунктів менше порівняно із 1993 роком. Найбільша кількість сільських населених пунктів (далі - НП) знаходиться на території Овруцького району - 135 НП, найменша - у Брусилівському (36 СНП). Щільність населення коливається від 7,4 осіб/км² у Народицькому районі до 39,4 у Хорошівському (рис. 1).

Стосовно кількості населення, то, починаючи з 1995 року, спостерігається зниження чисельності населення як по області загалом, так і сільського населення зокрема. Кількість сільського населення області протягом 1995-2020 років знизилася на 26\%. Загалом же сільське населення становить 40,1\% від загальної кількості населення регіону (рис. 2).

Протягом 2019 року в районах Житомирської області було викинуто в атмосферне повітря 9439,9 тонн, що становить 74\% від загальної кількості викидів по області. У середньому найбільша кількість викидів, що становить 1558,68 тонн, зафіксована у Новоград-Волинському районі, основними забруднювачами у якому, згідно даних управління екології та природних ресурсів ЖОДА, є ПП «Галекс-Агро» і ТОВ «Церсаніт Інвест». Друге місце за величиною викидів в атмосферне повітря займає Бердичівський район (у середньому 1045,22 тонн), основним забруднювачем у якому є філія Управління магістральних газопроводів «Київтрансгаз» ПАТ «Укртрансгаз» Житомир.

НайбільшимизабруднювачамиуПопільнянському районі, середня кількість викидів на території якого становить 1029 тонн, є ТОВ «Сігнет-Мілк» і ТОВ «Сігнет-Центр». На території Коростенського району функціонують ПАТ Транснаціональна корпорація «Граніт» і ТОВ «Бехівський гранітний кар'єр», які $\epsilon$ основними забруднювачами атмосферного повітря району, середня кількість викидів на території якого протягом 2015-2019 років становила 715,24 тонн. Найменша кількість викинутих забруднюючих речовин зафіксована у Народицькому районі, що в середньому становить 5,82 тонни (рис. 3) [9].

Із загальної кількості викидів викиди діоксиду вуглецю, який впливає на зміну клімату, становлять 0,7 млн тонн. Основними забруднювачами атмосферного повітря області за видами економічної діяльності залишається сільське, лісове та рибне господарство; переробна промисловість; добувна промисловість і розроблення кар'єрів; транспорт 


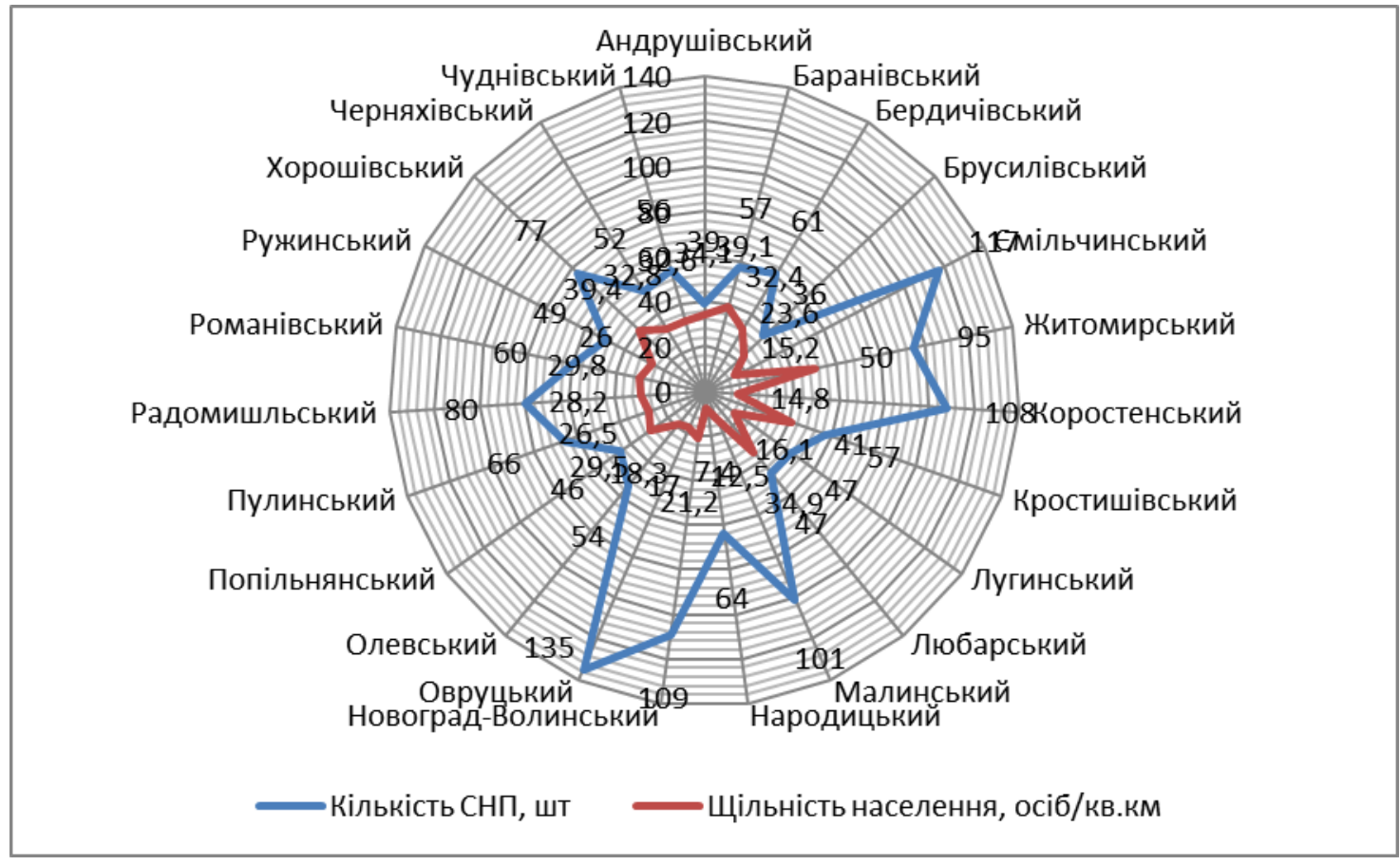

Рис. 1. Кількість сільських населених пунктів і щільність населення в розрізі районів Житомирської області станом на 01.01.2019

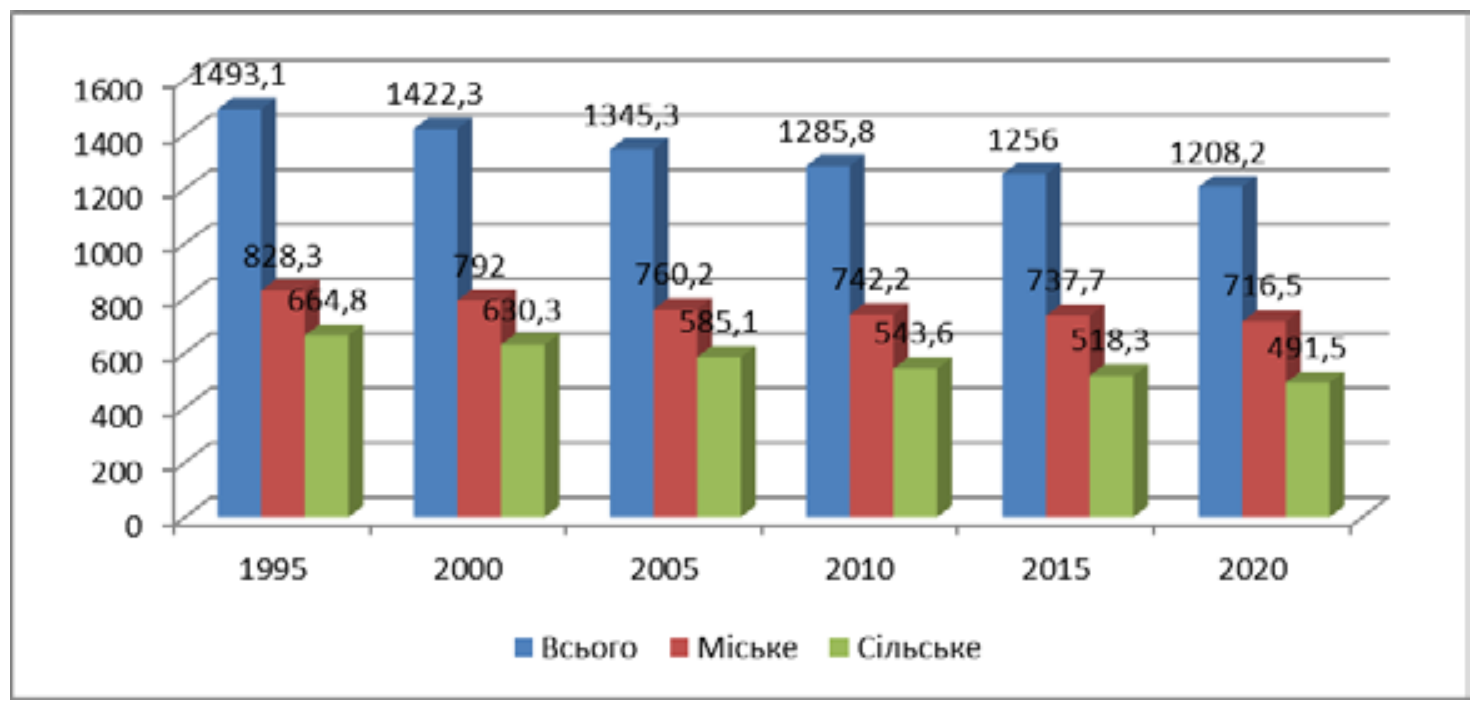

Рис. 2. Динаміка кількості населення Житомирської області, тис. осіб

[11], викиди забруднюючих речовин яких у 2019 році склали понад 80\% від загального обсягу викидів в атмосферне повітря у Житомирській області.

На стан атмосферного повітря Житомирської області, особливо сільських селітебних територій, впливають пожежі в екосистемах, зокрема лісові та торфові пожежі. Особливо небезпечними є торфові пожежі, оскільки їх дуже важко загасити, а дим від них містить велику кількість вуглецю, сірки та азоту. Найнебезпечнішим є виділення чадного газу.

За даними Державної служби України з надзвичайних ситуацій, протягом 2018 року на терито- рії Житомирської області зафіксовано 31 торфову пожежу, що становило 9\% від загальної кількості торфових пожеж в Україні. Протягом 2019 року в екосистемах Житомирської області сталося 2357 пожеж, а $з$ початку 2020 року - 1489, зокрема й на торфовищах. Найбільш постраждалими є Олевський, Овруцький і Лугинський райони області.

Фактором забруднення атмосферного повітря на території сільських населених пунктів $\epsilon$ і спалювання побутового сміття, яке містить пластик, поліетилен та інші токсичні речовини, при спалюванні яких у повітря виділяються важкі метали, бром, 


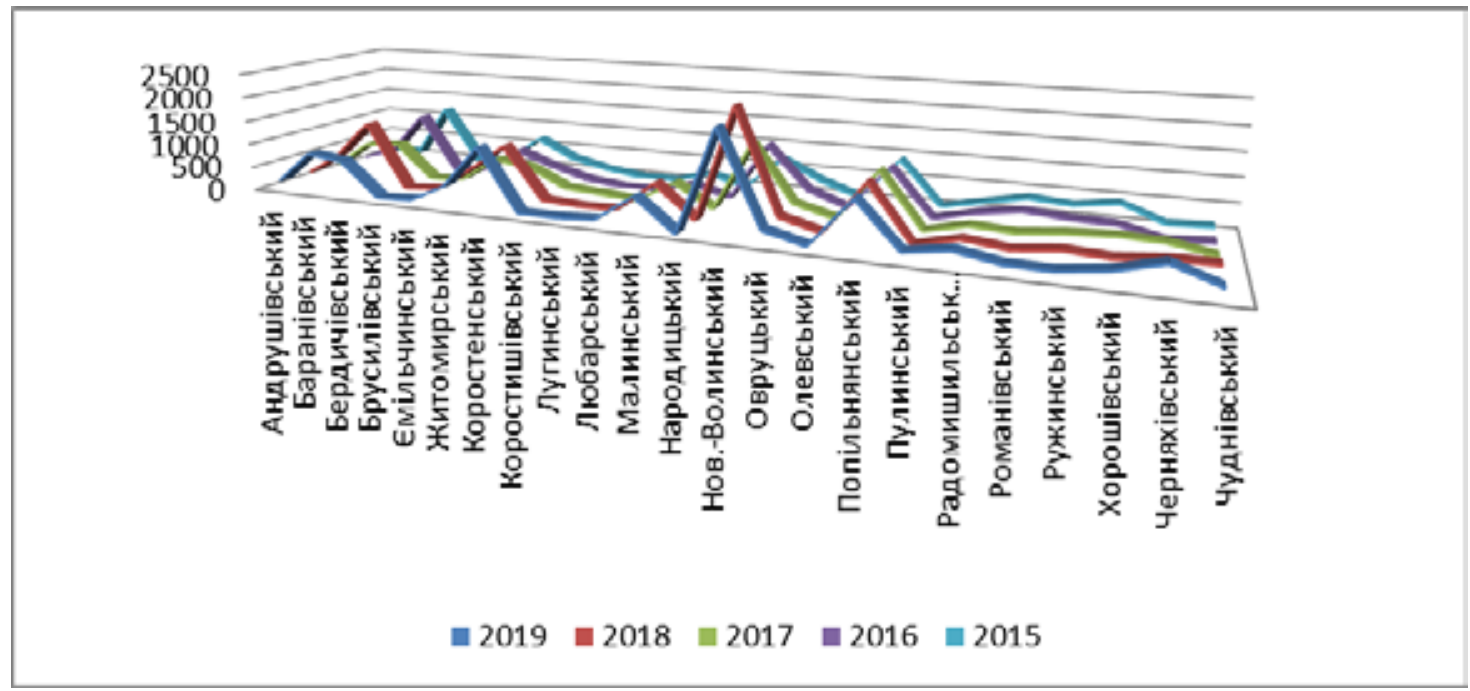

Рис. 3. Динаміка викидів забруднюючих речовин в атмосферне повітря у розрізі районів області, $m$

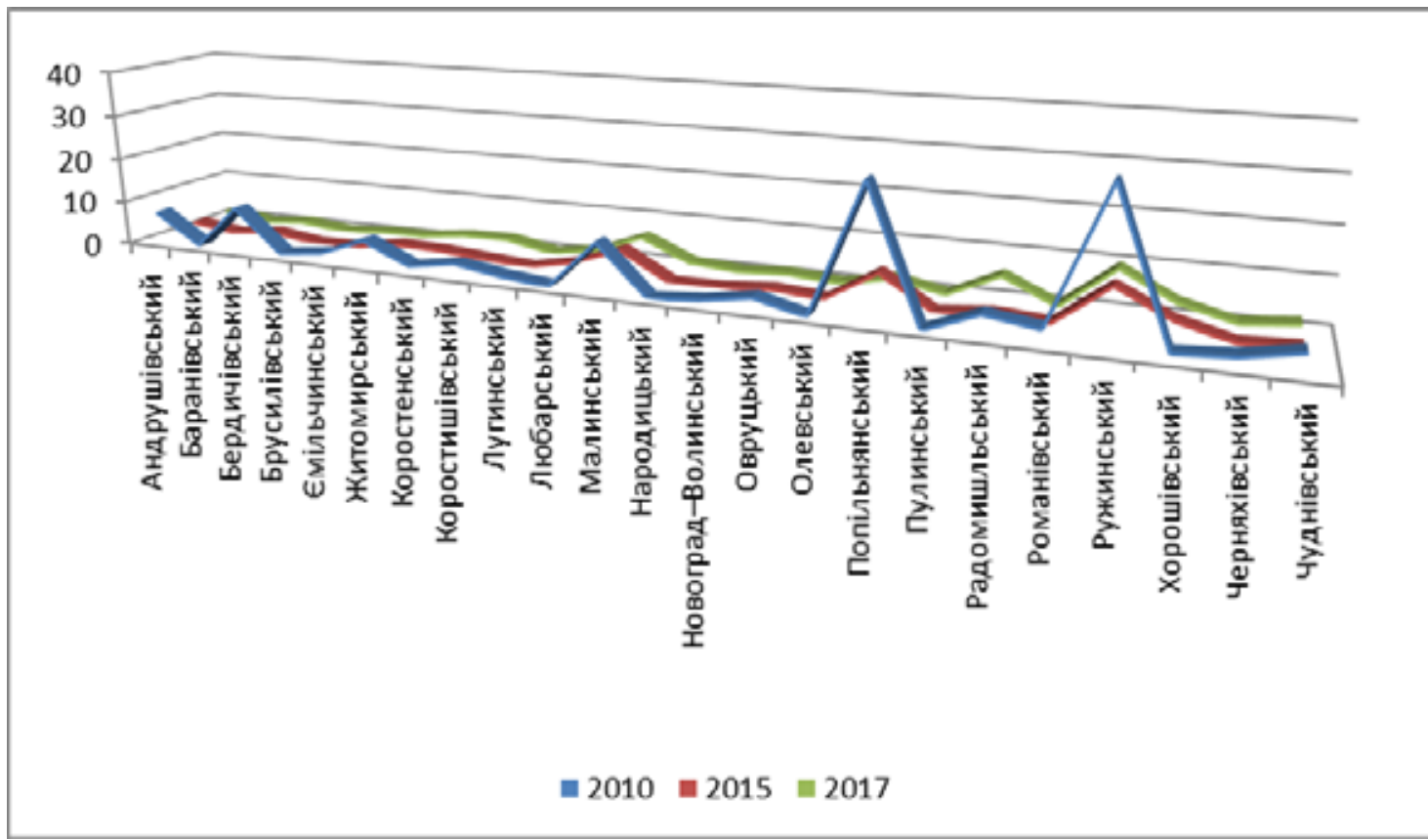

Рис. 4. Динаміка скидів зворотних вод у поверхневі водні об 'єкти сільських територій Житомирської області, млн $м^{3}$

фтор, діоксини, які є найнебезпечнішими забруднювачами атмосферного повітря.

Небезпеку забруднення атмосферного повітря викликає спалювання рослинних решток і стерні, що досить часто практикується сільськими мешканцями. Такі дії призводять до підвищення рівня вуглекислого газу в атмосфері, що насамперед впливає на зміну клімату. Спалювання рослинних решток також призводить до утворення смогу, підвищує ризик лісових і торфових пожеж.

Складною залишається ситуація із водопостачанням, водовідведенням та якістю питної води на території сільських населених пунктів Житомирської області, у якій лише 13,7\% сіл мають централізоване водопостачання, а тому сільські жителі змушені використовувати альтернативні джерела водопостачання, зокрема й для питних потреб. Такими джерелами є криниці, свердловини та природні джерела, якість води у яких дуже часто є незадовільною [10].

На якість питної води централізованого та нецентралізованого водопостачання впливає стан поверхневих водних об'єктів, які є джерелами водопостачання. Динаміка скидів зворотних вод у поверхневі водні об'єкти Житомирської області в розрізі районів показала, що протягом 2010-2017 років спостерігалася чітка тенденція до зменшення їхніх обсягів (рис. 4). 
У 2017 році найбільшу кількість зворотних вод (9,3 млн м $)$ було скинуто у поверхневі водні об’єкти на території Ружинського району, взагалі не зафіксовано скидів у Брусилівському районі. У Баранівському, Олевському і Пулинському районах встановлено скид на рівні 0,2 млн м².

За даними Управління екології та природних ресурсів ЖОДА, до найбільших точкових джерел забруднення у суббасейні річки Прип'ять відноситься Любарське комунальне підприємство «Добробут»; комунальне підприємство «Водоканал» Першотравневої селищної ради Овруцького району та комунальне підприємство «Водоканал» Смільчинської селищної ради [9].

Утворення та розміщення відходів $є$ актуальною проблемою особливо для сільських населених пунктів, де місцеве населення часто створює стихійні сміттєзвалища, які впливають на якість атмосферного повітря, грунту, водних об'єктів. Крім того, на території області відсутній сміттєпереробний завод, що значно ускладнює проблему переробки сміття. Так, лише у 2018 році на території домогосподарств області утворено 105 612,4 тонн відходів, що становить 22\% від їх загальної кількості (рис. 5).

Станом на 01.01.2019 в обласному реєстрі зареєстровано 845 об'єктів місць видалення відходів, із яких 6 полігонів для зберігання твердих побутових відходів. Площа, зайнята цими відходами, складає близько 632 га [9]. Найбільша кількість сміттєзвалищ у 2019 році була в Овруцькому районі - 108 шт., найменша - у Народицькому районі (18 шт.). Крім зазначених вище екологічних проблем, на стан сільських населених пунктів Житомирської області вплинула і аварія на Чорнобильській АЕС.
Проведення моніторингу стану навколишнього природного середовища сільських населених пунктів Житомирщини спонукало нас до проведення комплексної оцінки стану довкілля шляхом розрахунку коефіцієнту антропогенного навантаження за такими показниками: щільність населення, кількість викидів в атмосферне повітря, кількість скидів зворотних вод у водні об’єкти, кількість сміттєзвалищ. Отримані дані узагальнено в табл. 1.

Розрахунок коефіцієнту антропогенного навантаження дозволяє згрупувати райони Житомирської області на 4 категорії антропогенного навантаження:

- незначний рівень навантаження $(\gamma<0,75)$. Сюди віднесено 4 райони: Брусилівський, Смільчинський, Лугинський, Олевський;

- середній рівень (0,75-1) - 2 райони: Пулинський, Романівський;

- значний рівень (1-1,5) - 9 районів: Андрушівський, Бердичівський, Коростенський, Коростишівський, Любарський, Малинський, Народицький, Черняхівський, Чуднівський;

- високий рівень $(1,5-2,5)-8$ районів: Баранівський, Житомирський, Новоград-Волинський, Овруцький, Попільнянський, Радомишльський, Ружинський, Хорошівський, що свідчить про досить високий рівень навантаження в межах сільських населених пунктів Житомирщини.

Головні висновки. У результаті проведеного дослідження встановлено райони Житомирської області із найбільшою кількістю викидів забруднюючих речовин - це Новоград-Волинський, Бердичівський, Попільнянський i Коростенський. Найменша середня кількість викидів зафіксована у Народицькому районі. Основним забруднювачем атмосферного повітря за видом економічної діяль-

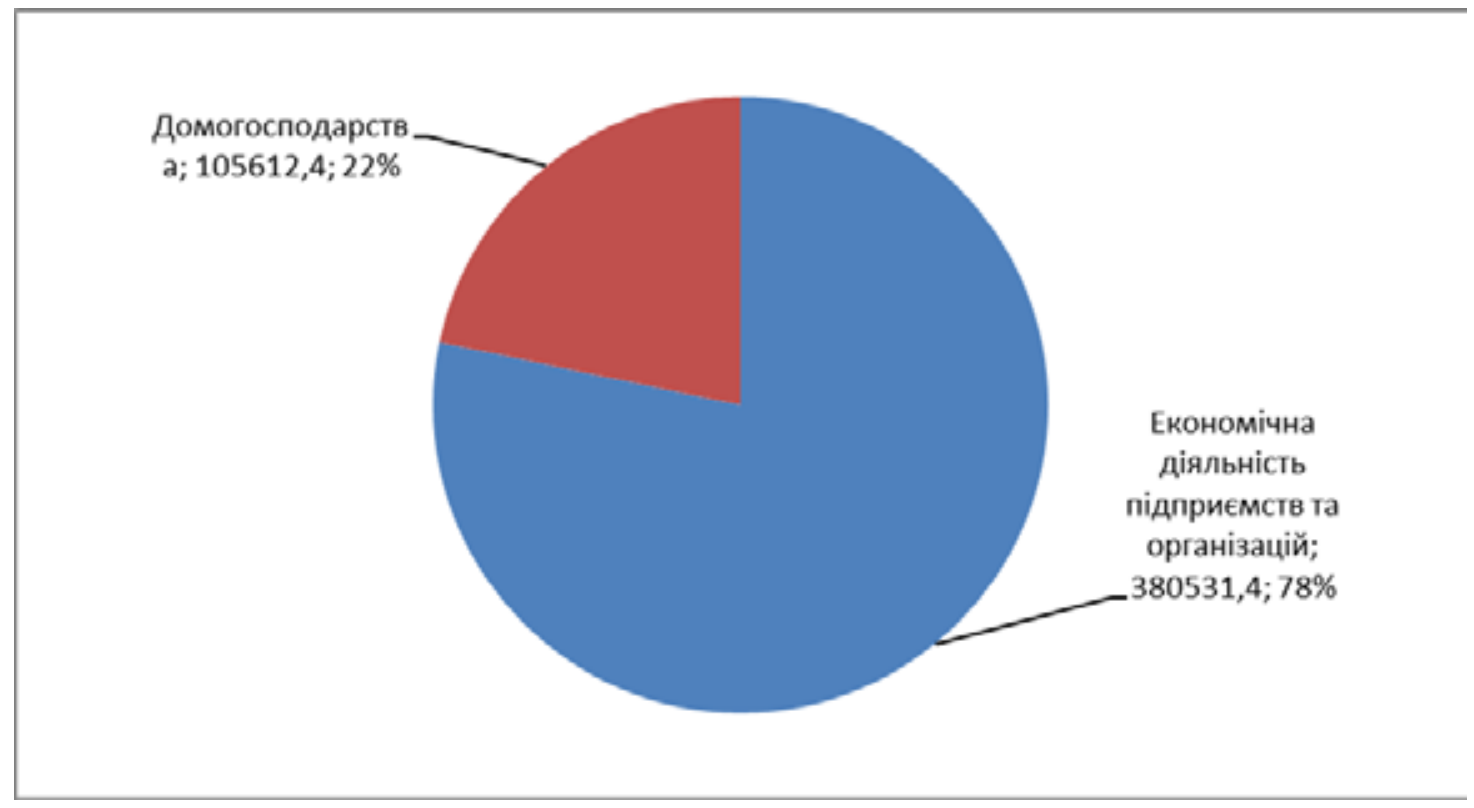

Рис. 5. Утворення відходів по Житомирській області у 2018 роиі, $m$ 


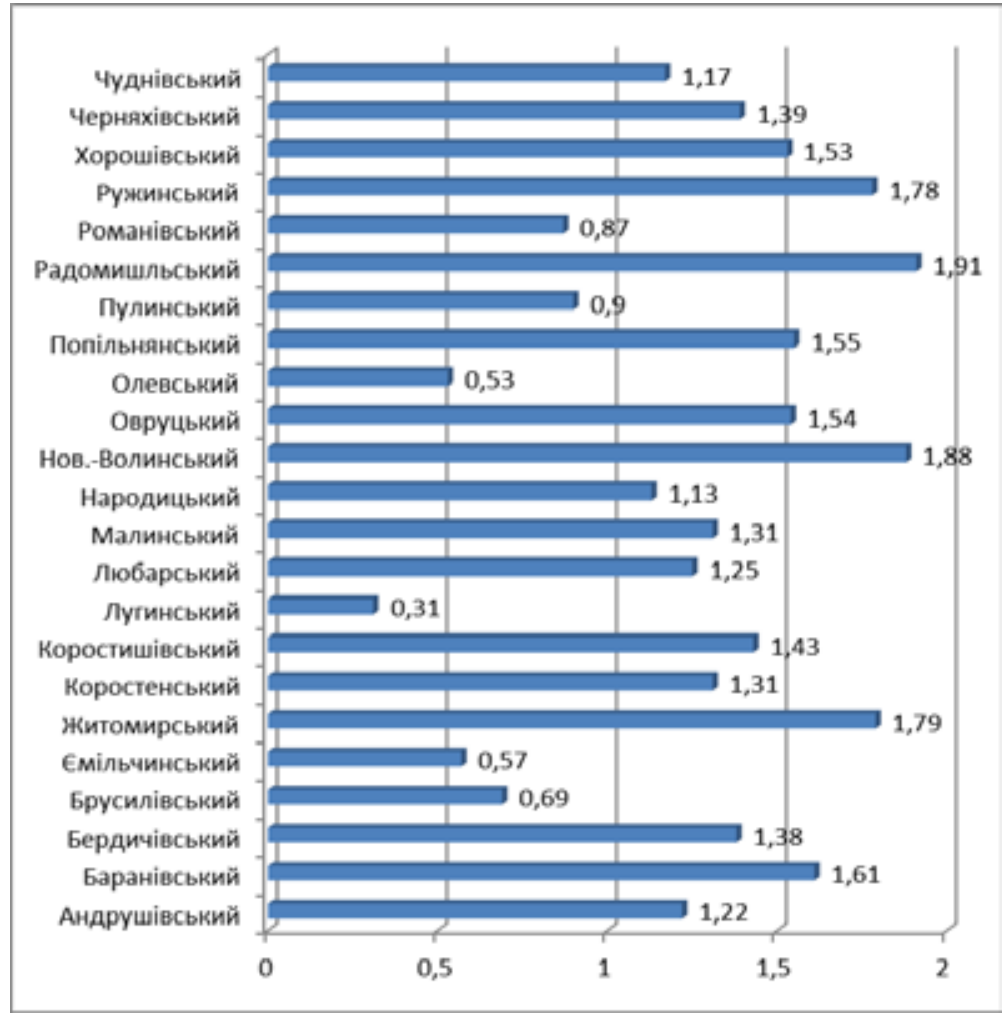

Рис. 6. Результати оцінки рівня антропогенного навантаження Житомирської області

Таблиця 1

Показники антропогенного навантаження

\begin{tabular}{|l|c|c|c|c|c|}
\hline \multicolumn{1}{|c|}{ Назва району } & $\mathbf{M}_{\mathbf{1}}{ }^{*}$ & $\mathbf{M}_{\mathbf{2}}$ & $\mathbf{M}_{\mathbf{3}}$ & $\mathbf{M}_{\mathbf{4}}$ & $\boldsymbol{\gamma}^{* *}$ \\
\hline Андрушівський & 0,83 & 0,08 & 0,18 & 0,13 & 1,22 \\
\hline Баранівський & 0,99 & 0,39 & 0,02 & 0,21 & 1,61 \\
\hline Бердичівський & 0,78 & 0,35 & 0,12 & 0,13 & 1,38 \\
\hline Брусилівський & 0,51 & 0,02 & 0 & 0,16 & 0,69 \\
\hline Смільчинський & 0,24 & 0,04 & 0,08 & 0,21 & 0,57 \\
\hline Житомирський & 1,42 & 0,21 & 0,09 & 0,07 & 1,79 \\
\hline Коростенський & 0,23 & 0,62 & 0,22 & 0,24 & 1,31 \\
\hline Коростишівський & 1,05 & 0,02 & 0,23 & 0,13 & 1,43 \\
\hline Лугинський & 0,27 & 0,02 & 0,01 & 0,01 & 0,31 \\
\hline Любарський & 0,86 & 0,05 & 0,18 & 0,16 & 1,25 \\
\hline Малинський & 0,16 & 0,31 & 0,62 & 0,22 & 1,31 \\
\hline Народицький & 0 & 0 & 0,13 & 1 & 1,13 \\
\hline Новоград-Волинський & 0,43 & 1 & 0,04 & 0,41 & 1,88 \\
\hline Овруцький & 0,3 & 0,13 & 0,11 & 1 & 1,54 \\
\hline Олевський & 0,34 & 0,03 & 0,02 & 0,14 & 0,53 \\
\hline Попільнянський & 0,69 & 0,49 & 0,26 & 0,11 & 1,55 \\
\hline Пулинський & 0,6 & 0,07 & 0,02 & 0,21 & 0,9 \\
\hline Радомишльський & 0,65 & 0,14 & 0,58 & 0,54 & 1,91 \\
\hline Романівський & 0,7 & 0,07 & 0,02 & 0,08 & 0,87 \\
\hline Ружинський & 0,58 & 0,06 & 1 & 0,14 & 1,78 \\
\hline Хорошівський & 1 & 0,12 & 0,38 & 0,03 & 1,53 \\
\hline Черняхівський & 0,79 & 0,23 & 0,06 & 0,31 & 1,39 \\
\hline Чуднівський & 0,79 & 0,08 & 0,19 & 0,11 & 1,17 \\
\hline
\end{tabular}

Примітка: ${ }^{*} M_{i}-$ показник питомої щільності досліджуваного фактору впливу на довкілля (щільність населення, кількість викидів в атмосферне повітря, скиди у водні об'єкти, кількість сміттєзвалищ); ** - сумарний показник рівня техногенного навантаження 
ності $є$ сільське, лісове та рибне господарство. На стан атмосферного повітря Житомирської області, особливо сільських селітебних територій, впливають також лісові і торфові пожежі, спалювання побутових відходів, рослинних залишків і стерні. Комплексна оцінка стану довкілля сільських населених пунктів Житомирщини показала, що до знач- ного і високого рівня навантаження відноситься 9 і 8 районів відповідно.

Перспективи використання результатів дослідження. Перспективами подальших досліджень має стати оцінка соціально-демографічного складника розвитку сільських населених пунктів Житомирської області.

\section{Література}

1. Палапа Н.В. Економічна розбалансованість і соціально-екологічні проблеми сільських поселень. Таврійський науковий вісник. № 83. С. 350-353.

2. Палапа Н.В., Колесник Ю.П. Агроекологічні проблеми сільських селітебних територій і шляхи їх розв'язання. Агроекологічний журнал. 2009. № 1. С. 30-36.

3. Палапа Н.В., Устименко О.В., Сігалова І.О. Екологічна оцінка сільських селітебних територій. Агроекологічний журнал. 2017. № 2. C. 89-95.

4. Методика оцінки агроекологічного стану селітебних територій з метою попередження негативних впливів антропогенних і природних чинників на умови проживання сільського населення / За ред. Н.А. Макаренко, Н.В. Палапи. К., 2010.44 с.

5. Фурдичко О.І., Макаренко Н.А., Палапа Н.В. Екологічний стан сільських селітебних територій України. Вiсник аграрноі науки. 2009. № 8. С. 5-9.

6. Тихий В.И., Корева О.В. Проблемы устойчивого развития сельских территорий региона: экологический и социально-экономический анализ. InterCarto / ИнтерГИС. 2017. № 23. С. 50-70.

7. Afanasieva E.E., Koreva O.V., Kondrashova I.N., Kondykova N.N., Tikhii V.I. Monitoring the current state of rural territories ecology in the Oryol region and some areas of their environmental development. Journal of Physics: Conference Series. 2019. 1399. 055056. doi:10.1088/1742-6596/1399/5/055056.

8. Іванюта С.П. Оцінка рівня техногенного навантаження в Україні: регіональний вимір. Стратегічні пріоритети. 2015. № 2(35). С. 157-163.

9. Регіональні доповіді про стан навколишнього природного середовища Житомирської області. URL: http://ecology.zt.gov.ua.

10. Валерко Р.А., Герасимчук Л.О. Екологічна оцінка якості питної води джерел нецентралізованого водопостачання у сільських населених пунктах Житомирської області. «Наукові читання-2020» : науково-теоретичний збірник. Житомир : Житомирський національний агроекологічний університет, 2020. С. 11-16.

11. Валерко Р.А., Герасимчук Л.О. Оцінка рівня техногенного навантаження Житомирської області. Вісник ЖНАEУ. 2017. № 1(58), т. 1. C. 39-48. URL: http://ir.znau.edu.ua/handle/123456789/8052. 


\title{
ЕФЕКТИВНІСТЬ ВИКОРИСТАННЯ ПРЕПАРАТУ "АНТИСТРЕС" НА ВРОЖАЙНІСТЬ РІЗНИХ ЗА СТІЙКІСТЮ ГІБРИДІВ КУКУРУДЗИ НА ГРУНТАХ ЗА НАДИИШКОВОГО ВМІСТУ XPOMY I HIKE $\Lambda$ Ю
}

\author{
Гришко В.М., Лисенко О.I. \\ Криворізький ботанічний сад Національної академії наук України \\ вул. Маршака, 50, 50089, м. Кривий Ріг, Дніпропетровська обл. \\ vitgryshko@i.ua, olyalis080991@gmail.com
}

\begin{abstract}
Сьогодні досить актуалізована проблема високого рівня надходження полютантів у навколишнє середовище, яке призводить до незбалансованого розвитку агроекосистем в Україні. Обгрунтовану тривогу викликає зростання забруднення важкими металами, пов'язане із промисловою діяльністю людини та агротехногенним навантаженням. У статті розглянуто результати дрібноділяночного польового досліду із впливу надлишкового вмісту в чорноземах звичайних сполук хрому і нікелю на показники врожайності різних гібридів кукурудзи, районованих у степовій частині України, та можливості використання вітчизняного регулятора росту рослин «Антистрес» для пом'якшення негативної дії забруднення. Схема варіантів польового досліду: контроль (не забруднений грунт); 5ГДК $\mathrm{Ni}^{2+}+5 Г Д К С \mathrm{Cr}^{3+} ; 20 Д К \mathrm{Ni}^{2+}+20 Г Д К С \mathrm{r}^{3+} ; 5 Д К \mathrm{Ni}^{2+}+5 Г Д К С \mathrm{Cr}^{3+}+$ «Антистрес» i 20ГДК $\mathrm{Ni}^{2+}+20$ ГДК $\mathrm{Cr}^{3+}+«$ Антистрес». У досліді використовували сполуки $\mathrm{NiSO}_{4} \mathrm{Cr}_{2}\left(\mathrm{SO}_{4}\right)_{3}$ ГДК для $\mathrm{Cr}$ розраховували як 6,0 i $\mathrm{Ni}-4,0$ мг/кг грунту в перерахунку на глибину 0-15 см. За умов мінімального надлишкового вмісту хрому і нікелю (5 ГДК) в чорноземі звичайному зафіксовано зменшення кількості рядів зерен у качані та зерен у качані для гібриду Євро 401 СВ по відношенню до контролю на 8-11\%, у порівнянні з гібридом Премія 190 МВ. За максимального надлишкового рівня внесених елементів (20 ГДК) в останнього гібриду спостерігалось на 23-34\% менше зниження всіх досліджених показників, ніж у рослин Свро $401 \mathrm{CB}$. Використання регулятора росту має певні особливості в гібридів як різних строків стиглості насіння, так і металочутливості. У більш резистентного до надлишкового вмісту іонів металів в грунті гібриду Премія 190 МВ, який відноситься до ранньостиглої групи, позитивний ефект препарату «Антистрес» у варіанті за мінімального внесення надлишку металів призводить до збільшення усіх показників на 13-28\% по відношенню до варіанту без регулятора росту За максимального внесення надлишку металів найсуттєвіше зростала кількість зерен у качані (на $31 \%$ ). Для менш металостійкого гібриду (Свро $401 \mathrm{CB}$ ) підвищення значень досліджених показників на тлі дії хрому і нікелю в максимальній концентрації коливалось в межах 28-40\%. Доведено, що за мінімальної концентрації хрому і нікелю відбувається зниження урожайності гібриду Премія 190 МВ на 33,2, а у Євро 401 СВ 58,8 ц/га. Використання регулятора росту підвищує врожайність гібридів кукурудзи на 28-33\%. Ключові слова: хром, нікель, забруднення грунтів, кукурудза; гібриди регулятор росту, врожайність.
\end{abstract}

The effectiveness of the preparation "Antistres" for the yield of children for the stiffness of corn hybrids on the soil for excess chromium and nickel. Gryshko V., Lysenko $O$.

Today, the problem of high levels of pollutants in the environment, which leads to unbalanced development of agroecosystems in Ukraine, is quite relevant. There is a well-founded concern about the increase in heavy metal pollution associated with human industrial activities and agro-man-made loads. The article considers the results of a small-scale field experiment on the effect of excess content of common chromium and nickel compounds in chernozems on yields of various maize hybrids located in the steppe part of Ukraine and the possibility of using native plant growth regulator "Antistress" to mitigate the negative impact of pollution. Scheme of variants of field experiment: control (not contaminated soil); $5 \mathrm{MPC} \mathrm{Ni}^{2+}+5 \mathrm{MPC} \mathrm{Cr}^{3+} ; 20 \mathrm{MPC} \mathrm{Ni}^{2+}+20 \mathrm{MPC} \mathrm{Cr}^{3+} ; 5 \mathrm{MPC} \mathrm{Ni}^{2+}+5 \mathrm{MPC} \mathrm{Cr}^{3+}+$ "Antistress" and 20MPC Ni ${ }^{2+}+20 \mathrm{MPC} \mathrm{Cr}^{3+}+$ "Antistress". In experiments using compound NiSO4 $\mathrm{Cr} 2$ (SO4) $3 \mathrm{MAC}$ for Cr was calculated as 6.0 and $\mathrm{Ni}-4,0 \mathrm{mg} / \mathrm{g}$ of soil in terms of depth of $0-15 \mathrm{~cm}$. Under conditions of minimal excess content of chromium and nickel (5 MPC) in ordinary chernozem, a decrease in the number of rows of grains in the cob and grains in the cob for the hybrid Euro $401 \mathrm{SV}$ was recorded compared to the control by $8-11 \%$, compared to the hybrid Premium $190 \mathrm{MV}$. At the maximum excess level of introduced elements (20 MPC) in the last hybrid there was a 23-34\% smaller decrease in all studied indicators than in Euro $401 \mathrm{SV}$ plants. The use of growth regulator has certain features in hybrids with different maturity of seeds and metal sensitivity. The use of growth regulator has certain features in hybrids with different maturity of seeds and metal sensitivity. In more resistant to excessive content of metal ions in the soil hybrid Premium $190 \mathrm{MW}$, which in addition belongs to the early group, the positive effect of the preparation "Antistress" in the variant with the minimum excess metal leads to an increase in all indicators $13-28 \%$ compared to the variant without growth regulator for maximum excess metal making the most significant increase in the number of grains in the cob (31\%). For a less metal-resistant hybrid (Euro $401 \mathrm{JI})$, the increase in the values of the studied parameters against the background of the action of chromium and nickel in the maximum concentration ranged from $28-40 \%$. It is proved that at the minimum concentration of chromium and nickel there is a decrease in the yield of the hybrid Premium 190 MV by 33.2 , and in Euro $401 \mathrm{SV} 58,8 \mathrm{c} / \mathrm{ha}$. The use of growth regulator increases the yield of maize hybrids by $28-33 \%$. Key words: chromium, nickel, soil pollution, maize; hybrids growth regulator, yield.

Постановка проблеми. Зважаючи на високий потенціал продуктивності сучасних гібридів кукурудзи та середню врожайність в Україні, яка колива- лась у 2018 році в областях від 29,4 (Донецька) до 104,3 ц/га (Волинська), можна констатувати низьку реалізацію потенціалу продуктивності культури. 
Ураховуючи, що рослини кукурудзи засвоюють значну кількість мікроелементів і досить чутливі до їх нестачі на певних етапах росту і розвитку, актуальною $є$ оптимізація живлення та застосування комплексу заходів хімізації, зокрема макро- та мікродобрив $[1 ; 2]$. Поряд із позитивними моментами використання добрив треба враховувати і можливе підвищення в грунтах, іноді до критичного рівня, вмісту рухомих форм деяких елементів, особливо коли добрива або інші засоби хімізації використовуються систематично. Так, за внесення нітроамофоски в дозі 109 кг/га у грунт надходить 4,22 г нікелю та до 5 г-хрому. Особливо таке може бути небезпечним у грунтах $з$ підвищеною кислотністю [3; 4].

Іншим чинником, який призводить до акумуляції надлишкової кількості іонів металів в едафотопах, може бути функціонування промислових об'єктів гірничометалургійного комплексу та теплових електростанцій, де якості як паливо використовується вугілля [5; 6]. Зокрема, щорічно в атмосферне повітря Кривого Рогу сумарно надходить близько 6 т сполук нікелю і хрому в перерахунку на відповідний елемент [7]. Враховуючи, що така кількість хрому та нікелю у вигляді аерозолей та пилових часток осідає на грунти, як урболандшафтів, так і земель сільськогосподарського призначення, які часто безпосередньо межують 3 підприємствами, виникає потенційна загроза забруднення останніх.

Актуальність досліджень та аналіз останніх досліджень і публікацій. На сьогодні актуальним $\epsilon$ не тільки вивчення екологічних та фізіологічних ефектів, зумовлених збалансуванням умісту в грунті доступних для рослин елементів, зокрема важких металів, а також пошук можливості пом'якшення негативної їх дії за підвищеного рівня. Таке може вирішуватися не лише селекційно-генетичними методами [8; 9] а й застосуванням регуляторів росту рослин [10], мікродобрив та бактеріальних препаратів [11], які все більше стають невід'ємними елементами інтенсивних технологій вирощування кукурудзи [12]. Серед таких засобів останнім часом все більше використовуються вітчизняні плівкоутворюючі препарати біологічно-активних речовин iз підвищеними кріопротекторними і адаптогеними властивостями, до яких належить «Антистрес» [13]. У більшості публікацій показано позитивний ефект цього препарату на зернових культурах. Так, в умовах Дніпропетровщини інкрустація насіння ячменю озимого «Антистресом» підвищувала до 10\% виживаності рослин після перезимівлі та зростання на 0,2 т/га врожайності [14]. Обробка рослин озимої пшениці в фазу кущіння призводила до поліпшення біометричних параметрів їх органогенезу та елементів структури посівів: збільшувалась кількість стебел на одній рослині до $12,5 \%$, вузлових коренів до $12 \%$ та вузол кущіння розташовувався глибше на 0,5 см. Також спостерігалось збільшення на 9,4\% маси надземної частини рослин після перезимівлі та кількості рослин і продуктивних стебел із розрахунку на м² посівів на 8 і 4\% відповідно, а також на 4\% маси 1000 насінин та урожайності (залежно від попередника) до 0,53 т/га [15]. Комплексне використання препаратів «Деймос» (інкрустація насіння) та «Антистрес» (обробка вегетуючих посівів восени) в господарствах Київщини сприяло підвищенню відсотку виживаності рослин озимої пшениці після перезимівлі на 16-21\% [16]. Автори пояснюють такий ефект препарату підвищенням у вузлах кущіння вмісту цукрів, які є кріопротекторами. Проте можливість їх застосування для зменшення негативної дії надлишкового вмісту хрому і нікелю майже не досліджена. Тому метою роботи було з'ясування впливу надлишкових концентрацій нікелю і хрому на врожайність кукурудзи та ефективність реалізації захисної функції препарату «Антистрес» для пом’якшення негативної сумісної дії цих важких металів.

Зв'язок авторського доробку 3 важливими науковими та практичними завданнями. Однією iз причин незбалансованого розвитку агроекосистем в Україні вітчизняні вчені вважають високий рівень техногенного забруднення навколишнього природного середовища. Найбільш поширеними полютантами $є$ важкі метали, які здебільшого відносяться до класів підвищеної небезпеки. Робота є продовженням наукових досліджень, що виконувалися в Криворізькому саду НАН України, а саме: «Роль антиоксидантних ферментних систем у формуванні адаптаційного синдрому рослин за сумісної дії ксенобіотиків та біологічні процеси трансформації сполук азоту в техногенних едафотопах» (0111U005106); «Фізіолого-біохімічні і цитогенетичні особливості адаптації рослин до стресової дії важких металів та процеси біологічної мобілізації сполук карбону і нітрогену в техноземах» (0116U003465), і виконуються в установі зараз: «Фізіологічний сигналінг у трав'янистих рослин за стресової дії важких металів» (0121U100358).

Новизна. Уперше встановлені залежності зменшення господарсько-цінних ознак гібридів кукурудзи від рівня надлишкового сумісного внесення сполук хрому і нікелю в грунти. В умовах дрібноділяночних польових дослідів на чорноземі звичайному доведено, що в різних за термінами стиглості гібридів найсуттєвіше (на 50-85\%) знижується кількість рядів зерен у качані, зерен в ряду, зерен у качані та врожайність. Вплив забруднення суттєвіше проявляється у середньопізнього гібриду кукурудзи (Євро 401 СВ). Використання регулятора росту «Антистрес» призводить до пом'якшення негативної дії забруднення на елементи структури врожаю та врожайність кукурудзи (урожайність зростає на 27-33\%).

Методологічне або загальнонаукове значення. Під час виконання роботи використовували як загальнонаукові, так і спеціальні методи досліджень: польовий експеримент та камеральну обробку результатів. Об'єктами досліджень були рослини 
гібридів кукурудзи Премія 190 МВ (ФАО 190) і Євро 401 СВ (ФАО 400), районованих у степовій зоні України, насіння яких надала Науково виробнича фірма «Компанія Маїс» (м. Синельникове, Дніпропетровської області) [17]. Дослідження проводили в дрібноділяночному польовому досліді за методикою Доспехова [18], який було закладено на дослідному полі навчально-наукового центру Дніпровського державний аграрно-економічного університету (с. Олександрівка, Дніпропетровської області). Грунт - чорнозем звичайний малогумусний важкосуглинковий на лесі. Основні його агрохімічні показники наступні: глибина гумусового горизонту 60-65 см, вміст гумусу в орному шарі $3,5-4,0 \%$, валового азоту $0,23-0,26 \%$, фосфору $0,11-0,12 \%$ і калію $-2,0-2,5 \%$. Реакція грунтового розчину близька до нейтральної (рН водної витяжки 6,5-7,0).

Трифакторний дослід проводився в зернопаропросапній сівозміні з чергуванням культур: чистий пар - озимий ячмінь - кукурудза - соняшник: перший фактор - гібриди різної групи стиглості та стійкості до сполук хрому і нікелю (Премія 190 МВ ранньостиглий і Євро $401 \mathrm{CB}$ - середньопізній) [17; $19 ; 20]$; другий - різні рівні забруднення грунту водними розчинами $\mathrm{Cr}_{2}\left(\mathrm{SO}_{4}\right)_{3}$ та $\mathrm{NiSO}_{4}$ і третій - використання регулятору росту «Антистрес».

Схемапольовогодосліду:контроль(незабруднений грунт); 5ГДК $\mathrm{Ni}^{2+}+5 Г Д К С \mathrm{Cr}^{3+} ; 20 Д К \mathrm{Ni}^{2+}+20 Г Д К \mathrm{Cr}^{3+}$; 5ДК $\mathrm{Ni}^{2+}+5 Г Д К С \mathrm{Cr}^{3+}+$ «Антистрес» і 20ГДК $\mathrm{Ni}^{2+}+20$ ГДК $\mathrm{Cr}^{3+}+$ «Антистрес» 3 розрахунку ГДК для $\mathrm{Cr}-$ 6,0 i Ni $-4,0$ мг/кг грунту (та перерахунку на глибину боронування 0-15 см). Ділянки польового досліду розташовувалися на вирівняних за природною родючістю і рельєфом клинах сівозміни. Водні розчини сульфатних солей хрому та нікелю вносилися після проведення вирівнювання дослідної ділянки боронами і розбивки дослідного поля на окремі ділянки відповідно до схеми польового досліду. Посівна площа ділянки $50 \mathrm{~m}^{2}$, облікова $20 \mathrm{M}^{2}$, повторність в польовому досліді триразова.

Висівання гібридів кукурудзи проводили в оптимальні строки при стійкому прогріванні грунту на глибині загортання насіння до $+10-12{ }^{\circ} \mathrm{C}$. Для вивчення можливої протекторної дії на рослини кукурудзи використовувався регулятор росту «Атистрес» у рекомендованій виробником ПП «ВКФ «Імпторгсервіс» (м. Дніпро, Дніпропетровська область) дозі - 0,68кг/т насіння при інкрустації. Завдяки тому, що до його складу входять монофосфат калію (сприяє інтенсивному росту кореневої системи на початку онтогенезу рослин), димитилсульфоксид (забезпечує інтенсивне проникнення дегідрофосфат аніону через біологічну мембрану), спиртова витяжка з гриба-ендофіта та гумінові кислоти (сприяють інтенсифікації поділу меристемних клітин проростків та забезпечує фунгіцидну активність) і багатокомпонентний препарат «Mapc EL» (утворює міцну, прозору, еластичну та проникну для води плівку на поверхні насіння), препарат має кріопротекторні і адаптогенні властивості [21].

Збирання врожаю качанів кукурудзи проводили вручну $з$ кожної ділянки окремо. Із них відбирали по дві проби масою 5 кг кожна. Після висушування до повітряно-сухого стану проби зважували і обмолочували. Після їх обмолоту на лабораторній молотарці ЛКМ 2-61 та висушування проводили розрахунок урожайності зерна за стандартної 14\% вологості. Для структурного аналізу врожаю відбиралися 10 качанів з облікової ділянки, на яких після висушування вимірювали довжину та діаметр качана, кількість рядів зерен і зерен у ряду, масу 1000 зерен [22; 23]. Статистичну обробку результатів аналітичних, біометричних та врожайності проводили на основі статистичної вибіркової сукупності за методикою [18] і пакетів програм MicrocoftExcel i Agrostat.

Виклад основного матеріалу. Отримані результати показали, що внесення сполук хрому і нікелю у грунт призводить до неоднозначного впливу на морфометричні показники качанів. У ранньостиглого гібриду Премія 190 МВ, довжина качана статистично достовірно ( $\mathrm{T}_{\mathrm{st}}-$ фактичне значення t-критерію Стьюдента) зменшується під час внесення до грунту сполук хрому та нікелю в концентрації 5 ГДК на 32\%, а 20 ГДК - на 55\% до контролю, тоді як діаметру качана - на 11 і 28\% відповідно (табл. 1, рис. 1). Тоді як качани середньопізнього гібриду Євро 401 СВ формуються більшою мірою меншими за діаметром (до 8\% під впливом внесених сполук в концентрації 5 ГДК) порівняно з їх довжиною, або вплив більш високих концентрацій іонів призводив до зменшення в однаковій мірі як діаметру, так і довжини качанів. Проте необхідно констатувати, що загальною закономірністю вирощування гібридів кукурудзи під час внесення надлишку іонів хрому і нікелю $є$ формування менших за розмірами качанів при підвищеному (до 20 ГДК) рівні важких металів у грунті. Наприклад, у гібриду Премія 190 МВ довжина качана зменшується від 64,4 до 45,2 \% відносно контролю, а діаметр від 89,4 до 72,5 відповідно.

Передпосівна інкрустація насіння препаратом «Антистрес» сприяє зменшенню негативного впливу хрому і нікелю на розміри качанів обох гібридів кукурудзи (табл. 1, рис. 1). Проте необхідно підкреслити, що в рослин ранньостиглого гібриду, який, крім того, проявляє себе як стійкий до сумісного впливу хрому і нікелю гібрид, під впливом обох концентрацій сполук металів діаметр качанів статистично достовірно не відрізняється від контрольного варіанту, тоді як у менш стійкого гібриду (Євро $401 \mathrm{CB})$ вона статистично достовірно зменшується за максимального внесення іонів металів до грунту. Наведені в таблиці 1 результати свідчать, що обробка насіння регулятором росту сприяє суттєвішому збільшенню довжини качанів у гібриду Премія 190 МВ на тлі максимальної концентрації важких металів (від 45,2 до $78,4 \%$ до контролю), тоді як у рослин гібриду Свро 
401 CВ воно становить лише 16\%. Kaliyan та Morey показали, що до основних складових елементів продуктивності кукурудзи, які впливають на формування врожайності та швидкості втрати вологи зерном, належать такі морфометричні ознаки, як довжина та діаметр качана і стрижня, кількість рядів зерен і кількість зерен у ряду [24]. Тому можна припустити, що стабілізація розмірів качанів на рівні контрою за дії регулятора росту «Антистрес» є позитивною реакцією гібридів при надлишку сполук хрому і нікелю. Встановлене є важливим особливо для ранньостиглих гібридів під час вирощування кукурудзи на зерно, тому що використання сучасних комбайнів із прямим обмолотом зерна потребує раннього дозрівання і сухого насіння [25].
Результати визначення кількісних ознак зерен у качані, які належать до господарсько-цінних характеристик гібридів кукурудзи при визначенні як фактичної, так і потенційної врожайності, представлені в таблиці 2. За умов мінімального надлишкового вмісту хрому і нікелю в чорноземі звичайному зафіксовано зменшення таких показників, як кількість рядів зерен у качані та зерен у качані для гібриду Євро 401 СВ по відношенню до контролю на 8-11\%, в порівнянні з гібридом Премія 190 МВ.

Тоді як за максимального надлишкового рівня внесених елементів у останнього гібриду спостерігалось на 23-34\% менше зниження всіх досліджених показників (відносно контролю), ніж у рослин Свро $401 \mathrm{CB}$. Використання регулятора росту має певні

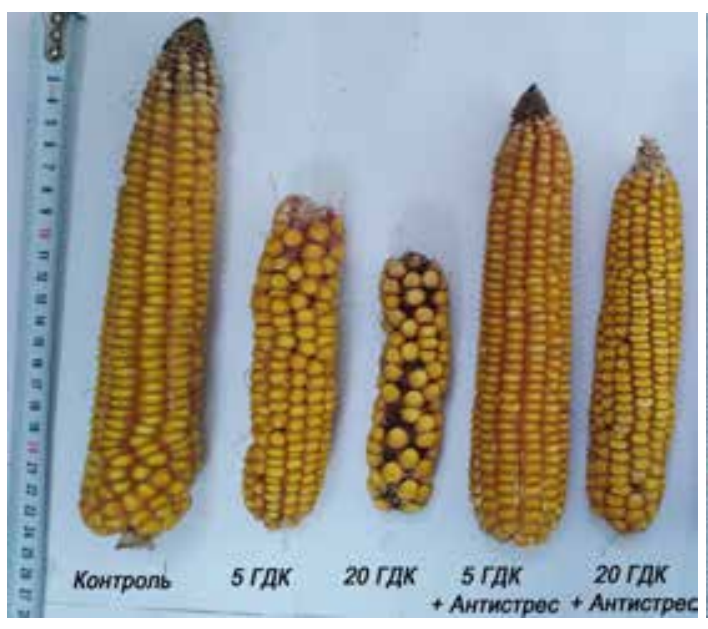

a)

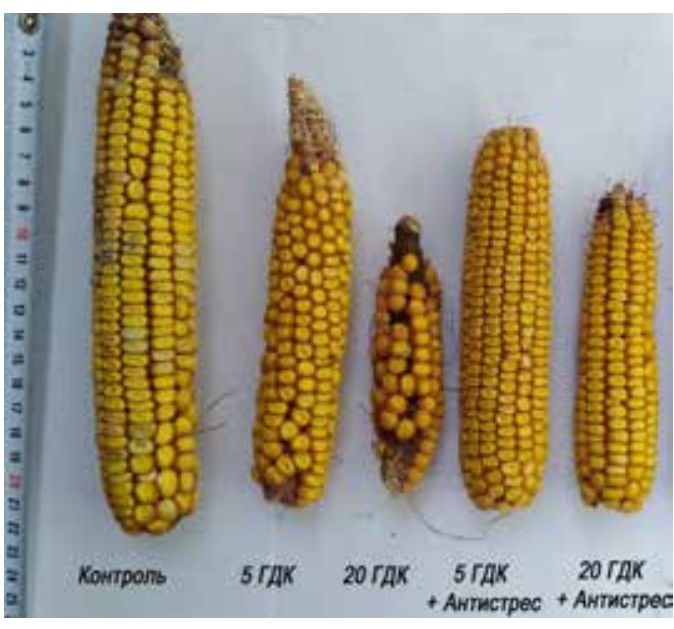

б)

Рис. 1. Качани гібридів кукурудзи у варіантах дрібноділяночного досліду: а) Премія 190 МВ $і$ б) Евро $401 \mathrm{CB}$

Таблиця 1

Морфометричні параметри качанів гібридів кукурудзи, см, $\mathbf{n = 3 0}$

\begin{tabular}{|c|c|c|c|c|c|c|c|c|}
\hline \multirow[b]{2}{*}{ Варіанти досліду } & \multicolumn{4}{|c|}{ Діаметр } & \multicolumn{4}{|c|}{ Довжина } \\
\hline & $M \pm m$ & $\mathbf{V}, \%$ & $\begin{array}{c}\text { \% до } \\
\text { контролю }\end{array}$ & Tst & $M \pm m$ & $\mathrm{~V}, \%$ & $\begin{array}{c}\text { \% до } \\
\text { контролю } \\
\end{array}$ & Tst \\
\hline \multicolumn{9}{|c|}{ Премія 190 МВ } \\
\hline Контроль & $6,2 \pm 0,2$ & 8,4 & - & - & $23,6 \pm 0,3$ & 3,6 & - & - \\
\hline 5ГДК $\mathrm{Ni}^{2+}+5 Г Д К С \mathrm{r}^{3+}$ & $5,5 \pm 0,2$ & 11,6 & 89,4 & 2,2 & $16,2 \pm 0,5$ & 7,2 & 68,4 & 12,6 \\
\hline 20ГДК $\mathrm{Ni}^{++}+20 Г Д К С \mathrm{Cr}^{3+}$ & $4,5 \pm 0,3$ & 18,0 & 72,5 & 4,3 & $10,7 \pm 0,4$ & 10,1 & 45,2 & 23,2 \\
\hline $\begin{array}{l}\text { 5ГДКNi }{ }^{2+}+5 Г Д К С \mathrm{C}^{3+} \\
+ \text { Антистрес }\end{array}$ & $5,6 \pm 0,8$ & 27,5 & 90,4 & 0,7 & $21,0 \pm 1,1$ & 12,0 & 88,2 & 2,2 \\
\hline $\begin{array}{l}\text { 20ГДКNi²+20ГДКСr }{ }^{3+} \\
+ \text { Антистрес }\end{array}$ & $5,5 \pm 0,4$ & 13,4 & 88,8 & 1,6 & $18,5 \pm 0,8$ & 9,9 & 78,4 & 5,7 \\
\hline \multicolumn{9}{|c|}{ Свро 401 СВ } \\
\hline Контроль & $7,1 \pm 0,7$ & 25,9 & - & - & $21,8 \pm 0,4$ & 4,5 & - & - \\
\hline 5ГДК $\mathrm{Ni}^{2+}+5 Г Д К С \mathrm{r}^{3+}$ & $4,4 \pm 0,2$ & 9,8 & 62,2 & 3,7 & $15,3 \pm 0,6$ & 9,2 & 70,0 & 8,8 \\
\hline 20ГДК $\mathrm{Ni}^{++}+20 Г Д К С \mathrm{Cr}^{3+}$ & $4,2 \pm 0,3$ & 20,7 & 59,8 & 3,7 & $11,4 \pm 0,6$ & 13,5 & 61,7 & 16,5 \\
\hline $\begin{array}{l}\text { 5ГДК } \mathrm{Ni}^{2+}+5 Г Д К С \mathrm{C}^{3+} \\
+ \text { Антистрес }\end{array}$ & $5,9 \pm 0,5$ & 21,2 & 82,8 & 1,5 & $14,5 \pm 0,5$ & 7,9 & 66,5 & 11,2 \\
\hline $\begin{array}{l}\text { 20ГДК } \mathrm{Ni}^{2+}+20 Г Д К С \mathrm{Cr}^{3+} \\
\text { + Антистрес }\end{array}$ & $5,3 \pm 0.3$ & 15,5 & 75,4 & 2,3 & $16,8 \pm 0,4$ & 5,0 & 77,3 & 9,2 \\
\hline
\end{tabular}


Господарсько-цінні ознаки гібридів кукурудзи, шт., n=30

\begin{tabular}{|c|c|c|c|c|c|c|c|c|c|}
\hline \multirow[b]{2}{*}{ Варіанти досліду } & \multicolumn{3}{|c|}{ Рядів у качані } & \multicolumn{3}{|c|}{ Зерен у ряду } & \multicolumn{3}{|c|}{ Зерен у качані } \\
\hline & $M \pm m$ & $\begin{array}{l}\% \text { до } \\
\text { конт- } \\
\text { ролю }\end{array}$ & $T s t$ & $M \pm m$ & $\begin{array}{l}\text { \% до } \\
\text { конт- } \\
\text { ролю }\end{array}$ & $T s t$ & $M \pm m$ & $\begin{array}{l}\text { \% до } \\
\text { конт- } \\
\text { ролю }\end{array}$ & $T s t$ \\
\hline \multicolumn{10}{|c|}{ Премія 190 МВ } \\
\hline Контроль & $14,2 \pm 0,4$ & - & - & $36,8 \pm 1,6$ & - & - & $515,5 \pm 36,2$ & - & - \\
\hline 5ГДК $\mathrm{Ni}^{2+}+5 Г Д К С \mathrm{Cr}^{3+}$ & $11,2 \pm 0,4$ & 78,6 & 5,5 & $23,7 \pm 1,7$ & 64,3 & 5,7 & $264,3 \pm 21,4$ & 51,3 & 6,0 \\
\hline $20 Г Д К \mathrm{Ni}^{2+}+20 Г Д К \mathrm{Cr}^{3+}$ & $10,2 \pm 0,8$ & 71,8 & 4,5 & $19,0 \pm 2,0$ & 51,6 & 6,9 & $194,8 \pm 6,4$ & 37,8 & 8,7 \\
\hline $\begin{array}{l}5 Г Д К С r^{3+} \\
\text { c }\end{array}$ & $13,2 \pm 0,5$ & 93,0 & 1,6 & $\pm 1,0$ & 84,2 & 3,1 & $\pm 23,6$ & 79,5 & 2,4 \\
\hline 20ГДКС ${ }^{3+}$ & $12,0 \pm 0,4$ & 84,5 & 4,0 & $29,8 \pm 1,7$ & 80,8 & 3,1 & $356,8 \pm 21,9$ & 69,2 & 3,7 \\
\hline \multicolumn{10}{|c|}{ Євро $401 \mathrm{CB}$} \\
\hline $\mathrm{KOH}$ & $16 \pm 0,6$ & - & - & $35,0 \pm 1,1$ & - & - & $572,0 \pm 32,3$ & - & - \\
\hline 5ГД & $10,8 \pm 0,3$ & 67,7 & 7,9 & $23,0 \pm 1,1$ & 65,7 & 7,8 & $248,5 \pm 18,4$ & 43,4 & 8,7 \\
\hline 20ГДК $\mathrm{Ni}^{2+}+20 Г Д К С \mathrm{r}^{3+}$ & $7,3 \pm 0,9$ & 45,3 & 8,5 & $11,5 \pm 1,8$ & 32,9 & 11,0 & $84,3 \pm 10,9$ & 14,7 & 14,3 \\
\hline $\begin{array}{l}\text { 5ГДКNi }{ }^{2+}+5 Г Д К С \mathrm{C}^{3+} \\
+ \text { Антистрес }\end{array}$ & $13,2 \pm 0,6$ & 82,3 & 3,4 & $29,0 \pm 1,9$ & 82,9 & 2,7 & $389,3 \pm 37,1$ & 68,0 & 3,7 \\
\hline $\begin{array}{l}20 Г Д К \mathrm{Ni}^{2+}+20 Г Д К С \mathrm{r}^{3+} \\
+ \text { Антистрес }\end{array}$ & $11,8 \pm 0,8$ & 73,7 & 4,4 & $26,1 \pm 1,4$ & 74,7 & 5,0 & $313,4 \pm 26,4$ & 54,8 & 6,2 \\
\hline
\end{tabular}

особливості в гібридів як різних строків стиглості насіння, так і металочутливості (табл. 2, рис. 1). Так, у більш резистентного до надлишкового вмісту іонів металів у грунті гібриду Премія 190 МВ, який відноситься до ранньостиглої групи позитивний ефект препарату «Антистрес» у варіанті за мінімального внесення надлишку металів призводить до збільшення усіх показників на 13-28\% по відношенню до варіанту без регулятора росту. Тоді як за максимального внесення надлишку металів найсуттєвіше зростала кількість зерен у качані (на 31\%), тоді як інші - на 13-29\% відповідно. Для менш металостійкого гібриду (Свро 401 CВ) підвищення значень досліджених показників на тлі дії хрому і нікелю в мінімальній концентрації було аналогічне як і для попереднього гібриду, тоді як за максимальної-коливалось в межах 28-40\%. Тобто за дії високих концентрацій іонів металів позитивний ефект регулятора росту проявляється більшою мірою в середньопізнього гібриду з меншою металотолерантністю.

Формування високої та якісної урожайності зерна кукурудзи зумовлюється головними структурними елементами, до яких, крім вищезазначених, відноситься і маса 1000 зерен (табл. 3). Отримані результати свідчать, що в гібрида Премія 190 МВ формуються зернівки 3 масою меншою лише на 4,8\%, тоді як у гібрида Євро $401 \mathrm{CB}$ - на 33,2\% від контрольного варіанту. Підвищення надлишкового вмісту важких металів, які вносились до чорнозему звичайного до 20 ГДК, лише робило більш виразною встановлену закономірність. Так, у рослин гібриду Свро 401 СВ маса 1000 зерен зменшувалась на половину, а у гібриду Премія 190 MB - на $14,5 \%$.
Отримані дані добре узгоджуються з результатами урожайності різних гібридів кукурудзи (табл. 3). Вони дозволяють констатувати, що вже за мінімальної концентрації хрому і нікелю відбувається зниження урожайності, яке становить для гібриду Премія 190 МВ 33,2, а у Свро 401 СВ 58,8 ц/га. Про посилення негативної дії забруднення грунтів сполуками хрому і нікелю свідчить зростання до $67 \%$ втрати врожаю зерна у ранньостиглого гібриду, тоді як у середньопізнього - на 90\%. Проте використання регулятора росту позитивно впливає на пом'якшення негативного впливу надлишкового вмісту важких металів. Вже у варіанті за їх мінімального надлишкового внесення відбувається підвищення врожайності обох гібридів на 28-30\%. Використання препарату «Антистрес» на тлі максимального надлишкового надходження іонів металів до грунту дещо більшою мірою сприяє підвищенню зернової продукції в середньопізнього гібриду (на $33 \%$ ), тоді як у ранньостиглого воно лишається на попередньому рівні (зростає на 28\%).

Головні висновки. Проведені дослідження свідчать про наявність пропорційної залежності зменшення госодарсько-цінних ознак гібридів кукурудзи від рівня надлишкового сумісного внесення сполук хрому і нікелю в грунти. В умовах дрібноділяночних польових дослідів на чорноземі звичайному доведено, що в різних за термінами стиглості гібридів найсуттєвіше (на 50-85\%) знижується кількість рядів зерен у качані, зерен в ряду, зерен у качані та врожайність. Вплив забруднення суттєвіше проявляється в середньопізнього гібриду кукурудзи (Свро 401 $\mathrm{CB}$. Використання регулятора росту «Антистрес» призводить до пом'якшення негативної дії забруд- 
Таблиця 3

Вплив забруднення грунту на елементи структури врожаю та врожайність кукурудзи на зерно

\begin{tabular}{|c|c|c|c|c|c|c|c|c|}
\hline \multirow[b]{2}{*}{ Варіанти досліду } & \multicolumn{4}{|c|}{ Урожайність ц/га } & \multicolumn{4}{|c|}{ Маса 1000 зерен, г } \\
\hline & $M \pm m$ & $\mathrm{~V}, \%$ & $\begin{array}{c}\% \text { до } \\
\text { контролю }\end{array}$ & $T s t$ & $M \pm m$ & $\mathrm{~V}, \%$ & $\begin{array}{c}\% \text { до } \\
\text { контролю }\end{array}$ & $T s t$ \\
\hline \multicolumn{9}{|c|}{ Премія 190 МВ } \\
\hline Контроль & $64,3 \pm 2,8$ & 9,8 & $\begin{array}{llll}- & \\
\end{array}$ & $\begin{array}{llll}- & \\
\end{array}$ & $278,0 \pm 4,1$ & 3,3 & $\begin{array}{llll}- & \\
\end{array}$ & - \\
\hline 5ГДК $\mathrm{Ni}^{2+}+5 Г Д К С \mathrm{r}^{3+}$ & $31,1 \pm 2,3$ & 18,2 & 48,3 & 9,1 & $264,6 \pm 6,2$ & 5,3 & 95,2 & 2,2 \\
\hline 20ГДК $\mathrm{Ni}^{2+}+20 Г Д К С r^{3+}$ & $20,8 \pm 7,7$ & 7,7 & 32,4 & 15,0 & $237,6 \pm 1,3$ & 1,3 & 85,5 & 9,3 \\
\hline $\begin{array}{l}\text { 5ГДКNi }{ }^{2+}+5 Г Д К С \mathrm{Cr}^{3+} \\
+ \text { Антистрес }\end{array}$ & $50,2 \pm 2,8$ & 12,6 & 78,1 & 3,5 & $273,9 \pm 7,4$ & 3,8 & 98,5 & 0,5 \\
\hline $\begin{array}{l}\text { 20ГДКNi }{ }^{2+}+20 Г Д К С r^{3+} \\
+ \text { Антистрес }\end{array}$ & $38,2 \pm 2,2$ & 11,6 & 59,3 & 7,3 & $262,8 \pm 25,3$ & 19,2 & 94,5 & 0,6 \\
\hline \multicolumn{9}{|c|}{ Свро $401 \mathrm{CB}$} \\
\hline Контроль & $83,1 \pm 4,7$ & 14,0 & - & - & $323,3 \pm 1,4$ & 0,9 & - & - \\
\hline 5ГДК $\mathrm{Ni}^{2+}+5 Г Д К С \mathrm{r}^{3+}$ & $24,3 \pm 2,2$ & 21,8 & 29,2 & 11,3 & $216,1 \pm 6,7$ & 5,3 & 66,8 & 15,8 \\
\hline 20ГДКNi²+ & $6,2 \pm 0,7$ & 25,4 & 7,4 & 16,0 & $162,3 \pm 6,3$ & 6,7 & 50,2 & 25,1 \\
\hline $\begin{array}{l}5 \text { 5ГДК } \mathrm{Ni}^{2+}+5 Г Д К С \mathrm{Cr}^{3+} \\
+ \text { Антистрес }\end{array}$ & $47,3 \pm 4,9$ & 25,6 & 56,9 & 5,2 & $269,0 \pm 7,0$ & 5,2 & 83,2 & 7,6 \\
\hline $\begin{array}{l}\text { 20ГДК } \mathrm{Ni}^{2+}+20 Г Д К С \mathrm{Cr}^{3+} \\
+ \text { +Антистрес }\end{array}$ & $33,9 \pm 3,0$ & 23,8 & 40,8 & 8,7 & $242,1 \pm 3,8$ & 3,5 & 74,9 & 20,1 \\
\hline
\end{tabular}

нення на елементи структури врожаю та врожайність кукурудзи (урожайність зростає на 27-33\%).

Перспективи використання результатів дослідження. Результати польових досліджень показують перспективність використання регулятору росту «Антистрес» для зменшення негативної дії на рослини гібридів кукурудзи різних груп стійкості, районованих у степовій зоні України.

\section{Література}

1. Статистичний збірник «Рослинництво України» 2018, Київ : Державна служба статистики України, 2019. 220 с.

2. Єрмакова Л.М., Крестьянова Є.В. Урожайність кукурудзи залежно від удобрення та гібриду на темно-сірих опідзолених грунтах. Вісник Полтавської державної аграрної академії. 2016. № 4. С. 63-65

3. Безуглов В.Г., Гогмачадзе Г.Д. Минеральные удобрения и свойства почвы. Ел. Журнал «АгроЭкоИнфо», 2009. № 2. URL : http://agroecoinfo.narod.ru/journal/TEXT/RUSSIAN/2009/st_12_annot.html. (дата звернення: 19.03.2020).

4. Овчаренко М.М. Тяжелые металлы в системе почва-растение-удобрение. Москва : Пролетарский светоч, 1997.290 с.

5. Поворотня М.М. Еколого-фізіологічний аналіз стійкості роду Acer в техногенних умовах теплових електростанцій Дніпропетровщини : автореф. дис. ... канд. біологіч. наук : 03.00.16. Житомир, 2016. 24 с

6. Миленка М.М. Біоіндикаційна оцінка екологічного стану Бурштинської урбоекосистеми. Екологічний вісник. 2016. № 1. C. 19-22.

7. Важкі метали: надходження в грунти, транс локація у рослинах та екологічна небезпека / В.М. Гришко та ін., Донецьк : Донбас. 2012. 303 с.

8. Відпрацювання інструментарію та алгоритмів корегування селекційних програм по кукурудзі. / М.В. Капустян та ін. Селекиія і насінництво. 2018 Вип. 113. С. 77-84.

9. Якимчук Р.А. Генетичні наслідки забруднення навколишнього середовища природними і техногенними мутагенними чинниками Київ : Логос, 2019. 379 с.

10. Артюшенко Т.А., Гришко. В.М. Вплив регуляторів росту на рівень фізіологічної адаптації гороху до стресового впливу кадмію та нікелю. Физиология растений и генетика. 2013. Т. 45. № 5. С. 417-424.

11. Мікробні препарати у землеробстві. Теорія і практика : монографія. / Волкогон В.В., Надкернична О.В. та ін.; за ред. В.В. Волкогона. Київ, 2006. 312 с.

12. Інтенсифікація технологій вирощування кукурудзи на зерно - гарантія стабілізації урожайності на рівні 90-100 ц/га: практ. рек./ Держ. установа Ін-т сільс. госп-ва степової зони. Дніпропетровськ. 2012. 88 с.

13. Лисенко O.I. Використання препарату «Антистрес» для зменшення негативного впливу сполук хрому та нікелю на початкових стадіях онтогенетичного розвитку кукурудзи. Сучасний стан родючості чорноземних трунтів $і$ шляхи підвищення продуктивності сільськогосподарських культур: матеріали міжнар. наук.-практ. конф. (Дніпро 25 листопада. 2016 р.) Дніпро, 2016. С. 172-175.

14. Інкрустація ячменю озимого препаратами Антистрес та Мapc ELBi / I.I. Ярчук та ін. Вісник Дніпропетровського державного аграрно-економічного університету. 2015. № 4(38). С. 55-58.

15. Позняк, В.В. Влияние комплексных росторегулирующих препаратов на урожайность пшеницы озимой (Triticum aesitivum L) выращиваемой после разных предшественников. Известие Наџиональной академии наук Беларуси. Серия аграрних наук. 2019 Т. 57. № 1. С. 63-73. 
16. Гончар Л.Н, Пустовит Я.А. Повищение морозостойкости пшеницы озимой под влиянием предпосивной обработки семян. Hаучные труды SWorld. 2015. 23(1). C. 42-46.

17. Сайт компанії MAIS. URL : http://i.maize.com.ua/catalog/price.htm (дата звернення 29.09.19).

18. Доспехов Б.А. Методика полевого опыта (с основами статистической обработки результатов исследований). 5-е изд., доп. и перераб. Москва : Агропромиздат. 1985. 351 с.

19. Гришко В.М., Лисенко О.І. Стійкість гібридів кукурудзи до стресового впливу хрому і нікелю на початку ювенільного етапу розвитку рослин. Агроекологічний журнал. 2017. № 3. С. 82-89.

20. Гришко В.М., Лисенко О.І. Фітотоксичність хрому і нікелю на початковому етапі онтогенетичного розвитку кукурудзи. Вісник Харківського національного університету імені В.Н. Каразіна. Серія «Біологія». 2019. Т. 33. С. $123-132$.

21. Сайт ПП «ВКФ «Імпторгсервіс». Електронний ресурс. URL : https://imptorgservis.uaprom.net. (дата 3вернення: 26.05.18).

22. Методика державного випробування сільськогосподарських культур / за. ред. В.В. Волкодава. Київ, 2001. Вип. 2. 65 с.

23. ДСТУ 4138:2002. Насіння сільськогосподарських культур. [Чинний від 2004-01-01]. Вид. офіц. Київ, 2003.148 с. (Інформація та документація).

24. Kaliyan N., Morey R.V Densification characteristics of corn cobs. Fuel Processing Technology. 2010. Vol. 91. Iss. 5. P. $559-565$.

25. Науково-практичні рекомендації з технології вирощування кукурудзи в умовах зрошення Південного Степу України / Р.А. Вожегова та ін. Херсон : Грінь Д.С., 2015. 104 с. 


\title{
FERRITES AS ADSORBENTS: REVIEW
}

\author{
Ivanenko I.M., Fedenko Yu.M., Lesik S.M., Kutsan N.V. \\ National Technical University of Ukraine \\ "Igor Sikorsky Kyiv Polytechnic Institute" \\ 37, Peremohy ave., 03056, Kyiv \\ fedenkoyura@ukr.net
}

Different methods are used to remove toxic dyes and synthetic substances from wastewater, such as adsorption, decomposition, photocatalysis, precipitation, coagulation, filtration, etc. Among the known removal methods, adsorption combined with the method of magnetic separation is promising due to its ease of operation, high efficiency and low cost.

A literary review on the synthesis of ferrite spinels and the study of their photocatalytic and sorption properties is presented. It has been established that in recent years, to further enhance the adsorption capacity of ferrite adsorbents in relation to chemical pollutants, research has mainly focused on the following two points: synthesis of ferrite nanomaterials different in morphology to increase the specific surface area, such as nanospheres, nanowires and nanostructures; synthesis of surface-modified ferrite composites, such as polymer-coated ferrite nanocomposites.

The influence of the ratio of ferrite: carbon carrier on the photocatalytic and sorption properties of the formed composites has been analyzed from the considered works. It is revealed that the chemical composition of ferrite spinel largely determines their ability to sorption of heavy metals, in particular of dime and synthetic dyes (methylene blue), due to the high value of their specific surface area, economy, high removal efficiency and the unique advantage of easy separation. magnetic field. The adsorption efficiency of ferrite spinels and alkaline-activated paligorskite was compared on the example of a methyl blue dye.

The effect of $\mathrm{pH}$ of the investigated solutions on the adsorption capacity of magnetic nanocomposites in relation to copper ions, as well as the dependence of the adsorption of methylene blue on the duration of contact with magnetic composites $\mathrm{Fe}_{3} \mathrm{O}_{4} @ \mathrm{C}$ was analyzed. It is established that the efficiency of adsorption by magnetic composites increases with increasing pH of adsorbate solutions in all studied cases. It has been found that magnetic adsorbents have indisputable advantages over traditional ones not only due to their high adsorption capacity, but also due to the possibility of their separation from the purified solutions by the method of magnetic separation. Key words: composite, nanoparticles, sorption, ferrite, photocatalysis, spinel.

Ферити як адсорбенти: огляд. Іваненко І.М, Феденко Ю.М., Лесік С.М., Куцан Н.В.

Для видалення токсичних барвників і синтетичних речовин зі стічних вод застосовуються різні методи, такі як адсорбція, розкладання, фотокаталіз, осадження, коагуляція, фільтрація. Відомим методом видалення є адсорбція, поєднана $з$ методом магнітного розділення. Вона є перспективною завдяки простоті ії експлуатації, високій ефективності і низькій вартості.

Представлено літературний огляд, присвячений синтезу феритних шпінелей і дослідженню їх фотокаталітичних і сорбційних властивостей. Встановлено, що останніми роками для подальшого підвищення адсорбційної здатності феритних адсорбентів щодо хімічних забруднювачів дослідження здебільшого зосереджені на двох таких моментах: синтез різних за морфологією феритних наноматеріалів для збільшення питомої поверхні (наносфери, нанопроволоки, наностержні і нанолисти); синтез модифікованих на поверхні феритних композитів, таких як нанокомпозити з полімерним покриттям фериту.

Проаналізовано вплив співвідношення ферит-вуглецевого носія на фотокаталітичні та сорбційні властивості утворюваних композитів. Виявлено, що хімічний склад феритових шпінелей здебільшого визначає їхню здатність до сорбції важких металів, зокрема йонів купруму та синтетичних барвників (метиленовий синій), завдяки високому значенню питомої площі їх поверхні, економічності, високій ефективності видалення і унікальній перевазі легкого розділення під впливом зовнішнього магнітного поля.

Проведено порівняння адсорбційної ефективності феритових шпінелей та лужно-активованого палигорськіту на прикладі полютанта - барвника метиленового синього. Проаналізовано вплив $\mathrm{pH}$ досліджуваних розчинів на адсорбційну ємність магнітних нанокомпозитів по відношенню до йонів купруму, а також залежність адсорбції метиленового синього від тривалості контакту 3 магнітними композитами $\mathrm{Fe}_{3} \mathrm{O}_{4} @ \mathrm{C}$. Встановлено, що ефективність адсорбції магнітними композитами зростає при збільшенні рН розчинів адсорбатів в усіх досліджених випадках. 3'ясовано, що магнітні адсорбенти мають безперечні переваги перед традиційними завдяки не тільки високій адсорбційній ємності, а й можливості їх відділення від очищуваних розчинів методом магнітної сепарації. Ключові слова: композит, наночастинки, сорбція, ферит, фотокаталіз, шпінель.

Introduction. Today, there is a growing interest in the studying and usage a new sorption materials. The advantage of the latter is the ability of the adsorbent to regenerate and work without the formation of sediment [1], and the process of adsorption purification of water is a simple and convenient method.

Many researchers are developing a series of new adsorption materials and new methods of water purification. Different methods are used to remove toxic dyes and synthetic substances from wastewater, such as adsorption, decomposition, photocatalysis, precipitation, coagulation and filtration, etc. [2-4]. Among them, adsorption based on the method of magnetic separation has been found to be excellent due to its ease of operation, high efficiency and low cost [5].

Spinel ferrite (SF) is one of the most famous classes of magnetic materials. The general formula of spinel ferrites is $\mathrm{MFe}_{2} \mathrm{O}_{4}$. In this formula, $\mathrm{M}$ is a cation of a diva- 
lent metal such as $\mathrm{Co}^{2+}, \mathrm{Zn}^{2+}, \mathrm{Ni}^{2+}, \mathrm{Fe}^{2+}, \mathrm{Mn}^{2+}, \mathrm{Mg}^{2+}$ etc [6-9]. Spinel ferrites have excellent properties due to their structural properties, high electrical resistance, low conductivity and low dielectric losses [10-12].

The exceptional properties of SFs make them promising materials for use as adsorbents [13-15], sensors [16-19], magnetic devices [20], rechargeable batteries [21], photocatalysts [22-23], etc. The usage of SFs in water treatment as adsorbents for the purification of toxic contaminants from the aquatic environment is of particular interest. BF has been widely studied as adsorbents because their unique physicochemical properties differ from their analogues. SFs can be made with variable size and shape, versatility of the surface (easy to operate with different ligands), high surface-to-volume ratio and tuned magnetic properties. These wonderful properties of SFs can guarantee their durability.

Investigation of photocatalytic properties. The authors of [10] synthesized mixtures of ferrite nanoparticles of various sizes, which were investigated for potential use as photocatalysts and biological catalysts. In determining the practical and relevant structure-property correlations, the authors used a combination of SQUID and Mesbauer methods to explain this data to systematically correlate the size and composition of nanoparticles with the observation of the magnetic behavior of nanoparticles. In doing so, they found that superparamagnetism is only present in ultra-small nanoparticles $(\leq 4,0 \mathrm{~nm})$ with very low magnetic saturation values. The presence of spin slopes, uncompensated surface spins and magnetic anisotropy was observed for most samples; freezing temperatures and freezing temperatures associated with these systems were also discussed.

Silica-modified cobalt ferrite magnetic nanostructured composite, the authors of [11], obtained by wet chemical method. The silica-modified $\mathrm{CoFe}_{2} \mathrm{O}_{4}$ composite (CZFS) was studied in terms of its adsorption properties (with respect to $\mathrm{MC}$ and $\mathrm{Mn}^{+}$model solutions) in comparison with CZF and CF samples prepared without modification of silica and $\mathrm{Zn}^{2+}$ silica, respectively. A higher surface area of SBET = $59,8 \mathrm{~m}^{2} / \mathrm{g}$ CZFS (mesopores with $\mathrm{D}=8,5 \mathrm{~nm}$ ) compared to $\mathrm{CZF}$ and $\mathrm{CF}$ together with a high $\zeta=-35,4 \mathrm{mV}$ leads to improved MS adsorption capacity compared to $\mathrm{CZF}$ and $\mathrm{CF}$. The adsorption of MS by CZFS (for $\mathrm{C}_{0}=5-25 \mathrm{mg} / \mathrm{dm}^{3}$ ) is well in line with the Langmuir model, supporting an almost homogeneous CZFS surface with predominantly equivalent sites for MS adsorption. CZFS can be effectively used as an adsorbent of MS and $\mathrm{Mn}^{+}$up to three cycles.

The authors of [18] found that cobalt ferrite nanoparticles aggregated with schwertmannite (CNSh) is a potential adsorbent for the removal of arsenic from water. It has been found that arsenic sorption by CNSh is strongly $\mathrm{pH}$ dependent. More than $95 \%$ of arsenic was adsorbed at initial arsenic concentrations up to $200 \mathrm{~g} / \mathrm{dm}^{3}$ with using a dosage of adsorbent of $1 \mathrm{~g} / \mathrm{dm}^{3}$ during 240 minutes. The percentage of adsorption gradually decreased with increasing initial concentration of arsenic. Thermodynamic studies have shown that the process of adsorption of arsenic is spontaneous and endothermic with a value of $\mathrm{H} 5,3 \mathrm{~kJ} / \mathrm{mol}$, which confirms the physicochemical process of adsorption.

It was found that the second-order pseudo-kinetic model is in best agreement with the experimental data for arsenic adsorption. The equilibrium study showed the correspondence of the Langmuir isotherm model and not the Freundlich isotherm model with an adsorption capacity of $10-11 \mathrm{~g} / \mathrm{g}$, indicating the adsorption of the monolayer on the surface of the nano-adsorbent. The spent adsorbents were recovered by $\mathrm{NaOH}$ solutions, and the recovered adsorbents showed very good adsorption efficiency. The prepared adsorbent can be selected as an alternative to the existing one used to remove arsenic.

Compared to other sorbents, nanoscale magnetic materials have a high ability to adsorb $\mathrm{Cu}$ (II) ions due to their large surface area, cost-effectiveness, high removal efficiency, and the unique advantage of easy separation under the influence of an external magnetic field [24-26]. Magnetic nanoparticles attract close attention when removing heavy metals from wastewater [27], such as arsenic, lead, mercury, chromium, cadmium and copper, which are known to cause serious damage to living organisms and the environment [28-29].

In recent years, to further enhance the adsorption capacity of ferrite adsorbents in relation to chemical pollutants, research has focused mainly on the following two points: synthesis of various morphological ferrite nanomaterials to increase the specific surface area, such as nanospheres, nanowires, nanorods and nanostructures; synthesis of surface-modified ferrite composites, such as polymer-coated ferrite nanocomposites. Here, the polymer coating on the surface of the ferrite is used to remove certain classes of contaminants, and the ferrite nanoparticles are used to complete the magnetic separation. The authors of [30] synthesized modified polylysine nanoparticles of $\mathrm{Fe}_{3} \mathrm{O}_{4}$ and indicated that the adsorption capacity of the modified adsorbent for the anionic dye increased significantly.

Maine et al. chitosan-modified manganese ferrite nanoparticles were synthesized and used for adsorption of $\mathrm{Cu}^{2+}$ ions from wastewater [31]. However, only a few studies address the micro-mechanisms of the polymer coating to change the microstructure of the ferrite nanoparticles and the physical nature of the polymer coating to enhance the adsorption capacity of the ferrite nanoparticles.

The authors of [31] also studied the effect of $\mathrm{pH}$ solution on the efficiency of the adsorption process. $\mathrm{pH}$ is an important operating parameter in the adsorption process because it affects the solubility of metal ions, the concentration of counterions on the functional groups of the adsorbent and the degree of ionization of the adsorbent during the reaction. Fig. 1 shows the effect of solution $\mathrm{pH}$ on the efficiency of adsorption 
of $\mathrm{Cu}^{2+}$ ions on magnetic nanoparticles at $27^{\circ} \mathrm{C}$ with initial concentrations of $\mathrm{Cu}^{2+} 100$ and $50 \mathrm{mg} / \mathrm{dm}^{3}$.

The adsorption efficiency increases with increasing $\mathrm{pH}$ of the solution in all three cases. It is noteworthy that the adsorption efficiency increases markedly with an increase in the $\mathrm{pH}$ of the solution from 3,5, and then gradually increases to a $\mathrm{pH}$ of 6,5 , especially for a solution with an initial concentration of $\mathrm{Cu}^{2+} 50 \mathrm{mg} / \mathrm{dm}^{3}$ ions. As shown in Fig. 1, the adsorption efficiency can reach $99,1 \%$ at the initial concentration of $\mathrm{Cu}^{2+} 50 \mathrm{mg} / \mathrm{dm}^{3}$ ions, $\mathrm{pH} 6,5$ and contact duration of 3 hours. When the $\mathrm{pH}$ is above 6,5 , a blue precipitate of $\mathrm{Cu}(\mathrm{OH})_{2}$ is formed, so no adsorption experiments were performed.

Methylene blue (MB) is the main dye used for histological, microbiological and tissue staining. When MB is exposed to ultraviolet, water and many chemicals, fading and decomposition are almost impossible due to its complex aromatic structures and sufficient water solubility. Thus, much effort was devoted to the removal of $\mathrm{MB}$ before discharge into the natural environment.

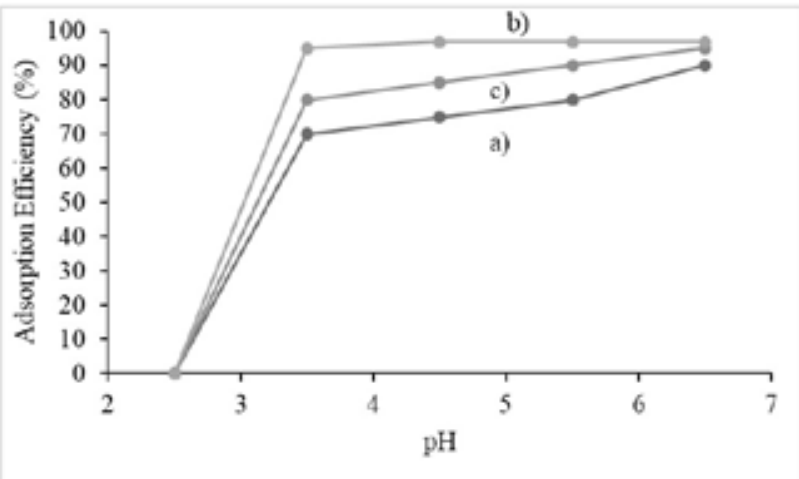

Fig. 1. Effect of solution $\mathrm{pH}$ on the efficiency of adsorption of $\mathrm{Cu}^{2+}$ ions by magnetic nanocomposites, with initial concentration of $\mathrm{Cu}^{2+}$ ions and contact duration: $a-100 \mathrm{mg} / \mathrm{dm}^{3}, 3$ years; $b-50 \mathrm{mg} / \mathrm{dm}^{3}$, 3 years; $c-50 \mathrm{mg} / \mathrm{dm}^{3}, 30 \mathrm{~min}[31]$

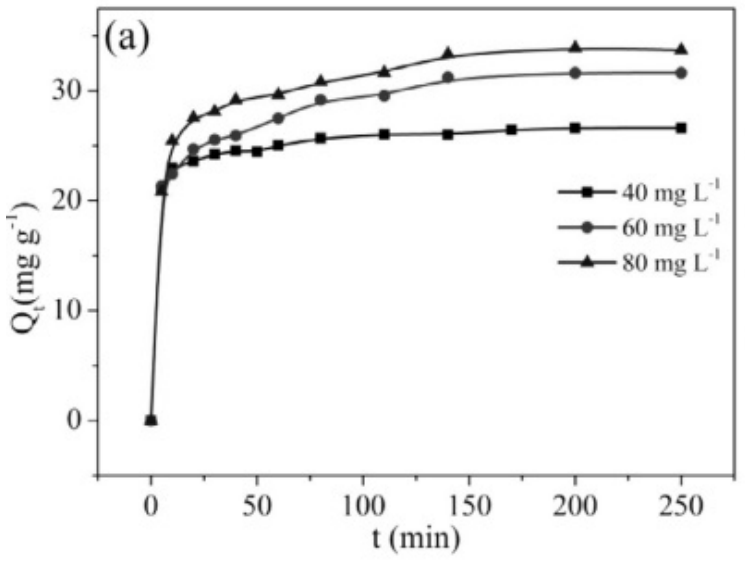

The authors of [32] made magnetic beads-type carbon nanospheres to remove methylene blue.

The adsorption properties of $\mathrm{Fe}_{3} \mathrm{O}_{4} @ \mathrm{C}$ composites were demonstrated by the choice of MS as a model pollutant. To understand the kinetics of adsorption, the effect of contact duration on the adsorption of $\mathrm{MB}$ by the $\mathrm{Fe}_{3} \mathrm{O}_{4} @ \mathrm{C}$ composite was first investigated by adding $10 \mathrm{mg}$ of sample to $10 \mathrm{ml}$ of MB solution $\left(40-80 \mathrm{mg} / \mathrm{dm}^{3}\right)$. After shaking for a predetermined interval, the magnetic particles were separated by magnetic separation and the corresponding concentrations of the dyes in the solutions were measured by UV-visible spectrometry. As can be seen in Fig. 2 a, the same tendency is observed on the adsorption curves, and all samples reach $>90 \%$ of the adsorption capacity at equilibrium for $30 \mathrm{~min}$. The amount of adsorbed MB increased significantly along with the initial concentration of $\mathrm{MB}$, which implies favorable adsorption even at high dye concentration.

The graph of the dependence of $\mathrm{t} / \mathrm{Qt}$ on the adsorption of $\mathrm{MB}$ at different initial concentrations was linear (Fig. 2b). These results demonstrated that the pseudo-second order model exhibits kinetic properties well $\left(\mathrm{R}_{2}>0,99\right)$ and indicates typical chemical adsorption. Adsorption progressed when the MS molecules first adsorbed the $\mathrm{Fe}_{3} \mathrm{O}_{4} @ \mathrm{C}$ carbon shell and then diffused into the cavity through the porous channel. MS was adsorbed on the surface of $\mathrm{Fe}_{3} \mathrm{O}_{4}$ by electrostatic gravity, since $\mathrm{MB}$ is a cationic dye, and some carboxyl groups derived from dehydrate trisodium citrate exist on the surface of $\mathrm{Fe}_{3} \mathrm{O}_{4}$. This process is similar to the diffusion of small molecules into cells through cell membranes.

Quote by others have proposed a photoelectron catalytic oxidation method for the removal of $\mathrm{MB}$ using $\mathrm{SnO}_{2} / \mathrm{Fe}_{2} \mathrm{O}_{3}$ electrodes [33].

As can be seen in Fig. 3, the decrease in $\mathrm{Cu}^{2+}$ content at the cathode was more influenced by the current density than the deterioration of the $\mathrm{MC}$ at the anode. Initially, the removal rates of $\mathrm{Cu}^{2+}$ and $\mathrm{MB}$ increased

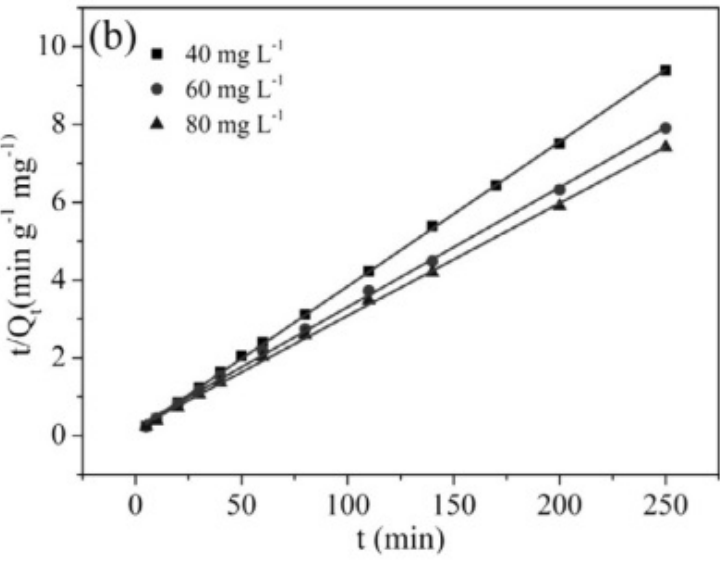

Fig. 2. Influence of contact duration and initial $M B$ concentration on $M B$ adsorption by $\mathrm{Fe}_{3} \mathrm{O}_{4} @ \mathrm{C}$ composite (a) and pseudo-second order MB kinetics adsorption on $\mathrm{Fe}_{3} \mathrm{O}_{4} @ C$ composite (b) [32] 


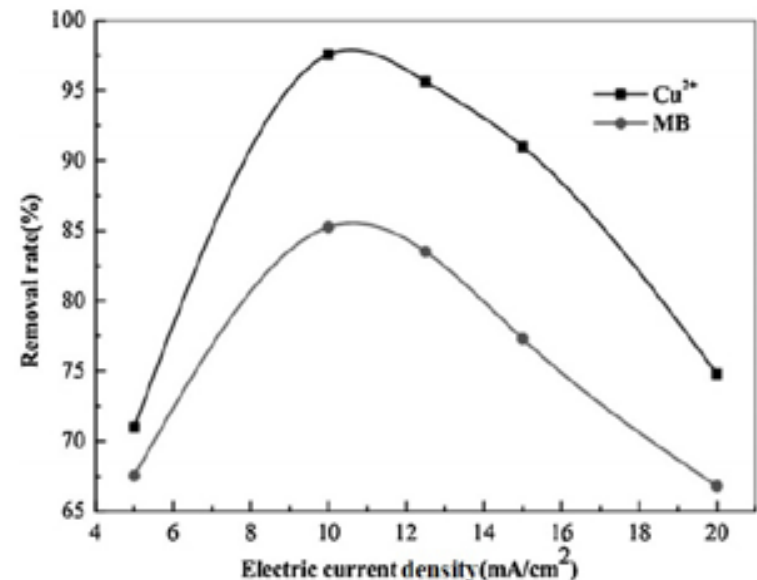

Fig. 3. Effect of electric current density on the removal of $\mathrm{MC}$ and $\mathrm{Cu}^{2+}[33]$

with increasing current density from $5 \mathrm{~mA} / \mathrm{cm}^{2}$ to $10 \mathrm{~mA} / \mathrm{cm}^{2}$, reaching maximum removal rates of $97,57 \%$ and $85,26 \%$ for $\mathrm{Cu}^{2+}$ and $\mathrm{MB}$, respectively. However, with a further increase in current density up to $20 \mathrm{~mA} / \mathrm{cm}^{2}$, the removal rate of both $\mathrm{Cu}^{2+}$ and $\mathrm{MB}$ decreased dramatically, since the limiting current density for this process is $20 \mathrm{~mA} / \mathrm{cm}^{2}$. In addition, when the current density exceeds $10 \mathrm{~mA} / \mathrm{cm}^{2}$, the reduction of $\mathrm{Cu}^{2+}$ at the cathode is limited due to interference from adverse reactions. Therefore, the removal rate of $\mathrm{Cu}^{2+}$ is affected. Therefore, $10 \mathrm{~mA} / \mathrm{cm}^{2}$ was chosen as the optimal current density for the subsequent studies.

The authors of [34] found enhanced adsorption removal of $\mathrm{MB}$ from an aqueous solution of alkaline-activated paligorskite (PAL). Alkaline activation was successfully introduced to enhance the adsorption capacity of PAL with respect to MB. It was found that metal ions in the crystalline PAL framework can be selectively removed by controlling the concentration of alkali solution. Interestingly, in addition to acid activation, the $\mathrm{Si}-\mathrm{O}-\mathrm{M}$ and $\mathrm{Si}-\mathrm{O}-\mathrm{Si}$ bonds were moderately broken in the alkaline activation process, which led to the creation of new adsorption centers. This effectively increases the surface negative potential of PAL and improves the adsorption properties for MB.

The PAL nanoparticle became shorter after alkaline activation at a lower concentration $\left(<5 \mathrm{~mol} / \mathrm{dm}^{3}\right)$. The rod-like morphology and specific surface area of BET PAL practically disappeared, with activation of a higher concentration of $\mathrm{NaOH}$ solution $\left(5,0 \mathrm{~mol} / \mathrm{dm}^{3}\right)$, which means that the pore structure was destroyed. Although the specific surface area of the PAL activated by $5 \mathrm{~mol} / \mathrm{dm}^{3} \mathrm{NaOH}$ solution is almost zero, it still has a much better adsorption capacity than the untreated PAL. From the above analysis, we can conclude that the adsorption is primarily affected not by the specific surface area, but by the interaction, such as electrostatic, complexing and hydrogen bonds. Activated PAL can decolorize MB in solution $\left(200 \mathrm{mmol} / \mathrm{dm}^{3}\right)$, which is far superior to untreated PAL. Another invention is that the PAL absorbed by MB exhibits higher stability and can be used to produce Mayan blue pigment, which provides a new approach to the sustainable usage of PAL adsorbents.

Dyes are widely used as colorants in industries such as textile, paper, food, printing, leather, plastic, pharmaceutical, and the like. To date, pollution of surface and groundwater by many species of dyes is a global environmental problem and a threat to humans and aquatic organisms [35]. Many treatments have been developed and applied, including electrochemical methods, oxidation or ozonation, membrane separation, photochemical decomposition, reverse osmosis, flocculation, coagulation, aerobic or anaerobic treatment and adsorption [34-36] have been developed and applied worldwide.

Conclusions. A literary review on the synthesis of ferrite spinels and the study of their photocatalytic and sorption properties is presented. It has been established that in recent years, to further enhance the adsorption capacity of ferrite adsorbents in relation to chemical pollutants, research has mainly focused on the following two points: synthesis of various morphological ferrite nanomaterials to increase the specific surface area, such as nanospheres, nanowires, nanorods, nanorods; synthesis of surface-modified ferrite composites, such as polymer-coated ferrite nanocomposites.

The influence of the ratio of ferrite: carbon carrier on the photocatalytic and sorption properties of spinels has been analyzed from the considered works. It is revealed that the chemical composition of ferrite spinels largely determines their ability to sorption of heavy metals, in particular dime, and synthetic dyes (methylene blue), due to the high value of their specific surface area, economy, high removal efficiency and the unique advantage of easy separation. magnetic field. A comparison of the sorption efficiency of ferrite spinels and alkaline-activated paligorskite is made on the example of a pollutant-methylene blue dye.

\section{References}

1. Y.-J. Chu, S.-Y. Hsiao, C.-C. Weo, C.-W. Liu, C.-M. Liao, F.-J. Chang, V.-C. Liao, W.-C. Shen, Arsenici Geosphere and Human Diseases; Arsenic 2010, CRCPress, Taylor\&Francis Group, Boca Raton. New-York, 2010. P. 556-557.

2. A. Mittal, A. Malviya, D. Kaur, J. Mittal, L. Kurup, Studies on the adsorption kinetics and isotherms for the removal and recovery of Methyl Orange from wastewaters using waste materials. J. Hazard. Mater. 2007. Vol. 148. P. 229-240.

3. N. Mohan, N. Balasubramanian, C. Ahmed Basha. Electrochemical oxidation of textile wastewater and its reuse. J. Hazard. Mater. 2007. Vol. 147. P. 644-651.

4. S.Y. Kim, J.Y. An, B.W. Kim. The effects of reductant and carbon source on the microbial decolorization of azo dyes in an anaerobic sludge process. Dyes Pigments. 2008. Vol. 76. P. 256-263. 
5. Y.J. Tu, C.F. You. Phosphorus adsorption onto green synthesized nano-bimetal ferrites: equilibrium, kinetic and thermodynamic investigation. Chem. Eng. J. 2014. Vol. 251. P. 285-292.

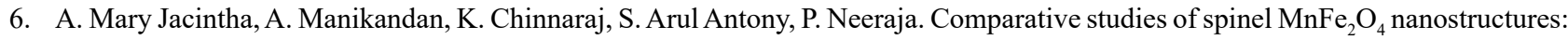
structural, morphological, optical, magnetic and catalytic properties. J. Nanosci. Nanotechnol. 2015. Vol. 15. P. 9732-9740.

7. E. Hema, A. Manikandan, M. Gayathri, M. Durka, S.A. Antony, B.R. Venkatraman. The role of $\mathrm{Mn}^{2+}$-doping on structural, morphological, optical, magnetic andcatalytic properties of spinel $\mathrm{ZnFe}_{2} \mathrm{O}_{4}$ nanoparticles. J. Nanosci. Nanotechnol. 2016. Vol. 16. P. 5929-5943.

8. M.M.L. Sonia, S. Anand, V.M. Vinosel, M.A. Janifer, S. Pauline, A. Manikandan. Effect of lattice strain on structure, morphology and magneto-dielectric propertiesof spinel $\mathrm{NiGd}_{x} \mathrm{Fe}_{2-\mathrm{x}} \mathrm{O}_{4}$ ferrite nano-crystallites synthesized by sol-gel route. J. Magn. Magn. Mater. 2018. Vol. 466. P. 238-251.

9. M. Amiri, M. Salavati-Niasari, A. Akbari. Magnetic nanocarriers: evolution of spinelferrites for medical applications. Adv. Colloid Interface Sci. 2019. Vol. 265. P. 29-44.

10. A.L. Tiano, G.C. Papaefthymiou, C.S. Lewis, J. Han, C. Zhang, Q. Li, C. Shi, A.M. Abeykoon, S.J. Billinge, E. Stach. Correlating size and composition-dependent effects with magnetic, mossbauer and pair distribution function measurements in afamily of catalytically active ferrite nanoparticles. Chem. Mater. 2015. Vol. 27 P. 3572-3592.

11. A. Sengupta, R. Rao, D. Bahadur. $\mathrm{Zn}^{2+}-$ Silica modified cobalt ferrite magnetic nanostructured composite for efficient adsorption of cationic pollutants from water. ACS Sustain. Chem. Eng. 2017. Vol. 5. P. 1280-1286.

12. E. Jaberolansar, P. Kameli, H. Ahmadvand, H. Salamati. Synthesis and characterization of PVP-coated $\mathrm{Co}_{0} \cdot 3 \mathrm{Zn}_{0} \cdot \mathrm{Fe}_{2} \mathrm{O}_{4}$ ferrite nanoparticles. J. Magn. Magn.Mater. 2016. Vol. 404. P. 21-28.

13. T.G. Glover, D. Sabo, L.A. Vaughan, J.A. Rossin, Z.J. Zhang. Adsorption of sulfur dioxide by $\mathrm{CoFe}_{2} \mathrm{O}_{4}$ spinel ferrite nanoparticles and corresponding changes in magnetism. Langmuir. 2012. Vol. 28. P. 5695-5702.

14. T.G. Glover, J.B. DeCoste, D. Sabo, Z.J. Zhang. Chemisorption of cyanogen chloride by spinel ferrite magnetic nanoparticles. Langmuir. 2013. Vol. 29. P. 5500-5507.

15. A. Dey, R. Singh, M.K. Purkait. J. Cobalt ferrite nanoparticles aggregated schwertmannite: a novel adsorbent for the efficient removal of arsenic. Water Process Eng. 2014. Vol. 3. P. 1-9.

16. Y.-L. Liu, Z.-M. Liu, Y. Yang, H.-F. Yang, G.-L. Shen, R.-Q. Yu. Simple synthesis of $\mathrm{MgFe}_{2} \mathrm{O}_{4}$ nanoparticles as gas sensing materials. Sensor. Actuat. B-Chem. 2005. P. 600-604.

17. R.H. Vignesh, K.V. Sankar, S. Amaresh, Y.S. Lee, R.K. Selvan. Synthesis and characterization of $\mathrm{MnFe}_{2} \mathrm{O}_{4}$ nanoparticles for impedometric ammonia gas sensor. Sensor. Actuat. B-Chem. 2015. P. 50-58.

18. A. Šutka, K.A. Gross. Spinel ferrite oxide semiconductor gas sensor. Sensor. Actuat. B-Chem. 2016. Vol. 222. P. 95-105.

19. J.Y. Patil, D.Y. Nadargi, J.L. Gurav, I.S. Mulla, S.S. Suryavanshi. Synthesis of glycine combusted $\mathrm{NiFe}_{2} \mathrm{O}_{4}$ spinel ferrite: a highly versatile gas sensor. Mater. Lett. 2014. Vol. 124. P. 144-147.

20. Y. Suzuki, Epitaxial Spinel Ferrite Thin Films. Annu. Rev. Mater. Res. 2001. Vol. 31. P. 265-289.

21. B.P. Hahn, J.W. Long, A.N. Mansour, K.A. Pettigrew, M.S. Osofsky, D.R. Rolison. Nanosized Mo-substituted cobalt ferrite $\mathrm{CoFe}_{2 \mathrm{x}} \mathrm{Mo}_{\mathrm{x}} \mathrm{O}_{4}$. Energ. Environ. Sci. 2011. Vol. 4. P. 1495-1502.

22. E. Casbeer, V.K. Sharma, X.-Z. Li. Synthesis and photocatalytic activity of ferrites under visible light: a review. Sep. Purif. Technol. 2012. Vol. 87. P. 1-14

23. D. Hong, Y. Yamada, M. Sheehan, S. Shikano, C.-H. Kuo, M. Tian, C.-K. Tsung, S. Fukuzumi. Mesoporous nickel ferrites with spinel structure prepared by an aerosol spray pyrolysis method for photocatalytic hydrogen evolution. Acs. Sustain. Chem. Eng. 2014. Vol. 2. P. 2588-2594.

24. I. Ali, Z.A. Alothman, A. Al-Warthan. Synthesis of composite iron nano adsorbent and removal of ibuprofen drug residue from water. J. Mol. Liq. 2016. Vol. 219. P. 858-864.

25. I. Ali, Z.A. Alothman, A. Al-Warthan. Green synthesis of functionalized iron nano particlesand molecular liquid phase adsorption of ametryn from water. J. Mol. Liq. 2016. Vol. 221. P. 1160-1174.

26. I. Ali, Z.A. Alothman, O.M.L. Alharbi. Uptake of pantoprazole drug residue from water using novel synthesized composite iron nano adsorbent. J. Mol. Liq. 2016. Vol. 218. P. 465-472.

27. H.A. Patel, J. Byun, C.T. Yavuz. Arsenic removal by magnetic nanocrystalline bariumhexa ferrite. J Nanopart Res. 2012. Vol. 14. P. 881.

28. N.V. Solenkova, J.D. Newman, J.S. Berger, G. Thurston, J.S. Hochman, G.A. Lamas. Metalpollutants and cardiovascular disease: mechanisms and consequences of exposure. AM Heart J. 2014. Vol. 168. P. 812-822.

29. J. Byun, H.A. Patel, C.T. Yavuz. Magnetic $\mathrm{BaFe}_{12} \mathrm{O}_{19}$ nanofiber filter for effective separation of $\mathrm{Fe}_{3} \mathrm{O}_{4}$ nanoparticles and removal of arsenic. J Nanopart Res. 2014. Vol. 16. P. 1-12.

30. Y.R. Zhang, P. Su, J. Huang, Q.R. Wang, B.X. Zhao. A magnetic nanomaterial modified with poly-lysine for efficient removal of anionic dyes from water. Chem.Eng. J. 2015. Vol. 262. P. 313-318.

31. Y.Y. Meng, D.Y. Chen, Y.T. Sun, D.L. Jiao, D.C. Zeng, Z.W. Liu. Adsorption ofCu ${ }^{2+}$ ions using chitosan-modified magnetic Mn ferrite nanoparticles synthesized by microwave-assisted hydrothermal method. Appl. Surf. Sci. 2015. Vol. 324. P. 745-750.

32. Y.M. Shao, L.C. Zhou, C. Bao, J.J. Ma. A facile approach to the fabrication ofrattle-type magnetic carbon nanospheres for removal of methylene blue in water. Carbon. 2015. Vol. 89. P. 378-391.

33. J.Q. Qi, X.C. Liu, H. Zheng, P.Q. Li, H.Y. Wang. Simultaneous removal of methylene blue and copper (II) ions by photoelectron catalytic oxidation using stannic oxide modified iron (III) oxide composite electrodes. J. Hazard. Mater. 2015. Vol. 293. P. 105-111.

34. N. Mohammadi, H. Khani, V.K. Gupta, E Amereh, S. Agarwal. Adsorption process of methyl orange dye onto mesoporous carbon material-kinetic and thermodynamic studies. J. Colloid Interface Sci. 2011. Vol. 362. P. 457-462.

35. V.K. Gupta, R. Kumar, A. Nayak, T.A. Saleh, M.A. Barakat. Adsorptive removal of dyes from aqueous solution onto carbon nanotubes: a review. Adv. Colloid Interface Sci. 2013. Vol. 193-194. P. 24-34.

36. P. Sharma, M.R. Das. Removal of a Cationic Dye from Aqueous Solution Using Graphene Oxide Nanosheets: investigation of Adsorption Parameters. J. Chem. Eng. Data. 2013. Vol. 58. P. 151-158. 


\title{
ЕНЕРГОЕФЕКТИВНІСТЬ МОРСЬКИХ СУДЕН ЯК ВАЖАИВИЙ ЕАЕМЕНТ ДЕКАРБОНІЗАЦІї АТМОСФЕРИ
}

\author{
Кірсанова В.В. ${ }^{1}$, Биковець Н.П. ${ }^{1}$, Бражник І.Д. ${ }^{2}$ \\ ${ }^{1}$ Дунайський інститут \\ Національного університету «Одеська морська академія» \\ вул. Фанагорійська, 9, 68607, м. Ізмаїл, Одеська обл. \\ ${ }^{2}$ Національний університет «Одеська морська академія» \\ вул. Дідріхсона, 8, 65000, м. Одеса \\ vvkirsanova@ukr.net, bnp.di2017@gmail.com,ig.brazhnik@gmail.com
}

Провівши аналіз змін кліматичної системи Землі в результаті глобального потепління, було з'ясовано, що ця екологічна проблема не вирішена. У статті досліджено сучасний стан екологічної проблеми загалом і надлишкове накопичення парникових газів в атмосфері зокрема. Розкрито вплив діоксиду карбону на підвищення температури атмосфери внаслідок його накопичення. 3'ясовано, що стабілізація клімату передбачає скорочення його викидів до обсягів, які може абсорбувати біосфера. Проаналізовано сучасні технології та інновації в судноплавстві, які дають змогу використовувати енергію вітру для скорочення викидів $\mathrm{CO}_{2}$ в атмосферу.

У статті розглянуто додаткові можливості підвищення енергоефективності судноплавства на суднах дедвейтом 50000 реєстр. тонн за рахунок реконструкції системи інертних газів, яка є обов'язковою для танкерів і хімовозів. При розробці технології з накопичення димових газів головного двигуна у призначених ємностях можлива економія палива. При накопиченні діоксиду карбону і його збереженні в зрідженому стані на судні роль газогенератора може виконувати головний двигун.

Найбільш оптимальною для цієї мети є система уловлювання діоксиду карбону, запропонована Швейцарським центром енергетичних досліджень SCCER EIP, який розробив технологію уловлювання діоксиду карбону з вихлопних газів двигуна внутрішнього згоряння з використанням адсорбції при коливаннях температури. За такої реконструкції економія палива в судноплавстві складе 2839200 тонн у рік. Запропонована реконструкція зменшить не лише витрати при експлуатації суден, але й викиди $\mathrm{CO}_{2}$ на 6000000 тонн.

Отримані результати вказують на можливу економію великих обсягів викопного палива, однак вона частково є зниженою, оскільки можлива економія палива і зменшення викидів діоксиду карбону в судноплавстві визначені без урахування наявності аналогічних інертних систем на балкерах. Ключові слова: декарбонізація атмосфери, енергоефективність транспорту, енергія вітру, інертні системи судна, система акумуляції діоксиду карбону.

Energy efficiency of sea vessels as an important element of decarbonization of the atmosphere. Kirsanova V., Bykovets N., Brazhnik I.

When analyzing the changes in the Earth's climate system as a result of global warming, we came to the conclusion that this ecological problem is unsolved. These phenomena are caused by the excessive accumulation of greenhouse gases in the atmosphere as a result of anthropogenic influence. Among greenhouse gases, carbon dioxide plays a major role in climate change. Climate stabilization implies reducing its emissions to volumes that the biosphere can absorb. Modern technologies and innovations make it possible to use wind energy as an element of efficiency in shipping industry.

Additional possibilities for increasing the energy efficiency of navigation on ships with a deadweight of 50000 registered tones at the expense of the inert gas system's reconstruction, which is mandatory for tankers and chemical carriers, are considered. While developing a technology for the accumulation of the main engine's flue gases in designated containers, fuel saving is possible. The role of the gas generator can be performed by the main engine, when carbon dioxide accumulates and is kept in a liquefied form on the ship.

The most optimal for this purpose is the carbon dioxide capture system was suggested by the Swiss Center of Energy Research SCCER EIP. The above mentioned center developed a technology for capturing carbon dioxide from the exhaust gases of an internal combustion engine using adsorption at temperature fluctuations. With such reconstruction, the savings in shipping industry will be 2839200 tons per year. The proposed reconstruction will reduce not only the expenses in ships' operating but also CO2 emissions by six million tons.

The obtained results point to possible savings in large volumes of fossil fuels, but are partially reduced, as the possible fuel economy and reduction of carbon dioxide emissions in shipping industry are determined without taking into account the presence of similar inert systems on bulk carriers. Key words: decarbonization of the atmosphere, energy efficiency of transport, inert systems of the ship, carbon dioxide capture system.

Постановка проблеми. Зміна кліматичної системи Землі в результаті глобального потепління $\epsilon$ не вирішеною екологічною проблемою. Це явище зумовлене надлишковим накопиченням парникових газів в атмосфері в результаті антропогенного впливу [1-2]. Серед парникових газів у зміні клімату головна роль відведена діоксиду карбону [3-4].
Стабілізація клімату передбачає скорочення викидів діоксиду карбону до обсягів, які зможе абсорбувати біосфера. Щоб уникнути хаотизації кліматичних процесів, наш економічний уклад повинен стати карбононейтральним не пізніше 2050 року [5-6].

Економічні показники і тенденції у використанні природного газу і нафти у світі вказують на подальше 
зростання викидів діоксиду карбону у 2020 році [7]. Транспорт є найбільшим джерелом викидів діоксиду карбону і фактором кліматичних змін. На глобальному рівні на транспорт припадає приблизно 26\% сумарного споживання енергії, серед якого найчисленнішим $\epsilon$ автомобільний транспорт. Морський транспорт також входить до складу десяти найбільших забруднювачів атмосфери [8-9].

Скорочення викидів $\mathrm{CO}_{2}$ у транспортному секторі $\epsilon$ найбільш складним процесом. Електрифікація транспортних засобів $є$ перспективним рішенням для заміни викопного палива для транспорту. Однак така альтернатива обмежена щільністю накопичення електрики в батареях і накопиченням великої кількості утилізованих акумуляторів. Викопні види палива не можна повністю замінити на біопаливо, оскільки для обробки великих обсягів біомаси олійних культур потрібні значні площі родючої землі.

Фіксація $\mathrm{CO}_{2}$ також запропонована як спосіб декарбонізації атмосфери. Однак фіксація діоксиду карбону з метою його нагромадження вимагає великих витрат на його зберігання. Нині проводяться численні дослідження, присвячені методам фіксації і переробки діоксиду карбону, багато з них перебувають на стадії лабораторних досліджень. Зменшити кількість викидів карбону в атмосферу також можливо шляхом збільшення енергоефективності транспортних засобів.

Актуальність дослідження. Екологічні проблеми, пов'язані 3 накопиченням діоксиду карбону в атмосфері, набувають особливого значення, оскільки їх наслідки зумовлюють зміну кліматичної системи планети. Ці явища призводять до людських та екологічних катастроф [10-12]. Останніми роками реєструється підвищення концентрації парникових газів і збільшення середньорічної температури кліматичної системи Землі [7].

При підвищенні температури на два градуси відбудеться переломний момент у процесі зміни клімату, що, ймовірно, вивільнить гігантські маси метану внаслідок танення вічної мерзлоти в Канаді, Росії, льодовиків у Заполяр'ї та на Гімалаях. Земля почне абсорбувати більше сонячного тепла, що може призвести до підвищення рівня моря до кількох метрів. Також можливе випаровування діоксиду карбону, розчиненого у Світовому океані. Усі ці явища можуть призвести до знищення живої матерії на Землі [10-12].

У Парижі в 2015 році відбулася ХХІ Конференція OOH зі зміни клімату (COP21), під час якої було підписано угоду щодо обмеження рівня глобального потепління. Вказана угода зобов'язала країни стримувати підвищення температури нижче двох градусів Цельсія (3,6 Фаренгейта) [13].

Проблемі глобального потепління на планеті приділили увагу й на Мадридській конференції зі зміни клімату, яка відбулася у грудні 2019 року. Учасники заходу зазначали, що сучасний спосіб життя людства ставить під загрозу саме життя на планеті. Не існує єдиного рішення, яке вирішило б проблему кліматичної кризи, тому необхідно сприяти дослідженням не лише в галузі поновлюваних джерел енергії і фіксації діоксиду карбону, а й при розробці методів більш ефективного використання енергії, оскільки до 2050 року необхідно скоротити викиди діоксиду карбону на 50\% [14].

До десяти найбільших забруднювачів повітря належить морський транспорт, тому були розроблені вимоги до енергоефективності цього виду транспорту. На 62-й нараді (липень 2011 року) Комітет із захисту морського середовища (далі - МЕРС) Міжнародної морської організації (далі - IMO) прийняв поправку щодо захисту атмосфери від забруднення суднами, долучивши Додаток VI МАРПОЛ 73/78, зробивши і1і обов'язковою. Був розроблений індекс проектування енергоефективності (далі - EEDI) для нових суден, а також план управління енергоефективністю суден (далі - SEEMP) для усіх суден.

Резолюцією МЕРС 70 був затверджений план із розробки дорожньої карти для стратегії IMO щодо скорочення викидів парникових газів із суден. Вказаний план включав короткострокові, середньострокові і довгострокові заходи. Завершення етапу впровадження стратегії планується у 2023 році. Первісна стратегія IMO щодо скорочення викидів парникових газів із суден викладена в резолюції МЕРС 72, а в резолюції МЕРС 73 опубліковані програми відповідно до первісної стратегії скорочення викидів парникових газів IMO.

Досягнення оптимальної енергоефективності при використанні та управлінні судна можливе за наявності комплексного підходу до вирішення цієї проблеми. Автори Плану управління енергоефективністю судна рекомендують судновласникам і морським транспортним організаціям зосередити увагу на низці таких ключових моментів: ефективному витрачанні палива, дизайні корпусу і рухової установки, обслуговуванні та експлуатації механізмів і обладнання, управлінні судном і флотом, оптимізації вантажних операцій, енергопостачанні та кадровій підготовці. Міжнародна шипінгова палата до головних умов зменшення викидів діоксиду карбону відносить зниження швидкості руху, оптимізацію водного баласту і маршрутів з урахуванням погодних умов, своєчасність заходу судна в порт, застосування нових видів палива. Такі заходи, за оцінками експертів, до 2050 року зможуть скоротити викид газів на 50\% [15].

Зв'язок авторського доробку 3 важливими науковими та практичними завданнями. Енергоефективність судноплавства $є$ важливою умовою декарбонізації атмосфери, вона відповідає стратегії Міжнародної морської організації щодо зниження викидів парникових газів із суден. Тому вдосконалення технологічних процесів 3 метою під- 
вищення енергоефективності в судноплавстві є важливим науковим і практичним дослідженням.

Аналіз останніх досліджень і публікацій. Нині у судноплавстві використовуються альтернативні джерела енергії, які можуть підвищити енергоефективність судна, серед них особливий інтерес викликає енергія вітру. Сучасні технології та інновації в галузі морського транспорту дають змогу використовувати енергію вітру як елемент ефективності роботи судна.

У 2016 році була опублікована доповідь незалежної науково-дослідницької консалтингової організації "CE Deifi”, яка спеціалізується на розробці інноваційних рішень екологічних проблем. Наукові співробітники організації досліджували чотири види сучасних вітряних установок: жорсткі вітрила, буксирувальні кайти, ротори і вітрові турбіни. Найкращих показників економії палива для великих суден було досягнуто при застосуванні ротора Флеттнера, а для малих суден - Кайт-вітрила.

Установка системи Кайт-вітрила не потребує виводу судна з експлуатації і може бути встановлена незалежно від року побудови судна. Для експлуатації та обслуговування установки немає необхідності в збільшенні кількості екіпажу. При використанні системи Кайт-вітрила економія палива становить від 10 до 20\%, при цьому вона не впливає на остійність судна. Це означає, що Кайт-вітрило не впливає на безпеку плавання, не провокує крен і не змінює габаритів судна. Ми вважаємо, що, враховуючи небезпеку глобального потепління, систему Кайт-вітрила необхідно більш широко впроваджувати та проводити дослідження з ії удосконалення [16].

На великогабаритних суднах нині встановлюються ротори Флеттнера, засновані на використанні ефекту Магнуса. На судні E-SHIP 1, побудованому у 2010 році на замовлення німецької компанії Enerkocon, на верхній палубі встановлено чотири ротора типу Флеттнер висотою 27 метрів і діаметром 4 метри. Двигунами слугують дев'ять силових установок Mitsubishi, ротори обертаються за допомогою парової турбіни виробництва Siemens, яка працює від відпрацьованих газів. Нині така технологія дозволяє зекономити паливо до $15 \%$. Передбачається, що роторні вітрила можуть досягти до $30-40 \%$ економії.

Під час аналізу даних було з'ясовано, що застосування технології ефекту Магнуса доцільно використовувати на нових суднах, конструкція яких буде це передбачати. Це пов'язано з тим, що діючі судна будуть вимагати серйозних конструктивних змін і великих капіталовкладень, що є економічно недоцільним [17].

Виділення не вирішених раніше частин загальної проблеми, котрим присвячусться означена стаття. У статті розглянуто можливість скорочення викидів парникових газів при реконструкції та вдосконаленні процесів інертизації танків нафто- наливних танкерів / продуктовозів і хімовозів з установкою інертного газу.

Виклад основного матеріалу. Система інертних газів може застосовуватися як основний засіб пожежогасіння в суховантажних трюмах, а також як засіб попередження виникнення пожежі шляхом створення і постійного підтримання у вантажних танках атмосфери, яка не запалюється.

Згідно з вимогами Конвенції SOLAS-74, система інертних газів є обов'язковою для танкерів дедвейтом 20000 реєстр. тонн і більше. Система повинна підтримувати в будь-якій частині вантажного танка атмосферу із вмістом кисню не більше $8 \%$ за обсягом, а також надлишкового тиску не більше 20 кПа, який перешкоджає надходженню повітря. Згідно 3 Правилами Регістру, у вантажні танки повинен подаватися інертний газ з умістом кисню не більше $5 \%$ за обсягом.

Система забезпечує подачу інертного газу у вантажні танки в кількості 125\% від максимальної продуктивності розвантаження судна. Таким чином здійснюється заповнення обсягів танків, які вивантажуються 3 урахуванням можливості випаровування деякого об' єму інертного газу. Як інертний газ можуть використовуватися димові гази, що пройшли обробку від головних або допоміжних котлів.

Нині набули поширення спеціальні генератори інертних газів різного типу, які включають у себе джерело інертного газу, скрубер, магістральний трубопровід із відгалуженнями в захищені обсяги, вентилятори, захисні пристрої і арматуру, пристрої контролю та сигналізації. Джерелами інертного газу можуть слугувати головні або допоміжні котли і спеціальні газогенератори.

Проведено численні дослідження, присвячені оптимізації обладнання, що забезпечує безпеку вантажних перевезень, в результаті яких було розроблено покращену технологію виробництва інертних газів у судноплавстві. Лідером за виробництвом $\epsilon$ компанія Альфа Лаваль. При вдосконаленні технології виробництва інертних газів насамперед враховуються вимоги пожежної безпеки для різних типів суден, має значення і оптимізація процесу горіння та зменшення утворення сажі. В усіх системах головним елементом $\epsilon$ газогенератор, у якому спалюють певну кількість палива [18].

Паралельно на суднах працює головний двигун, який забезпечує рух судна і виділяє достатню кількість інертних газів. При розробці технології з накопичення димових газів головного двигуна у призначених ємностях можлива економія палива. Роль газогенератора може виконувати головний двигун при накопиченні діоксиду карбону і його зберіганні в зрідженому стані на судні. Найбільш оптимальною для цієї мети є система уловлювання діоксиду карбону, запропонована Швейцарським центром енергетичних досліджень SCCER EIP. Він розробив технологію уловлювання діоксиду карбону з вихлопних 
газів двигуна внутрішнього згоряння з використанням адсорбції при коливаннях температури.

Система поглинає діоксид карбону з вихлопних газів двигуна і дозволяє його накопичувати в зрідженому стані. Адсорбенти, леговані аміном, демонструють високі показники ефективності у водному середовищі, основним завданням яких є акумуляція $\mathrm{CO}_{2}$ [19]. Система акумуляції $\mathrm{CO}_{2}$ володіє енергетичною автономністю і не вимагає зовнішнього живлення. Технологія адсорбції зі зміною температури (далі - ТАЗТ) із турбокомпресорами є оптимальним вибором для $\mathrm{CO}_{2}$, що акумулюється $з$ транспортних засобів без будь-яких енергетичних втрат.

Потік вихлопних газів охолоджується до $25^{\circ} \mathrm{C}$, а вода конденсується і видаляється. У цьому випадку $\mathrm{CO}_{2}$ акумулюється, стискається, зріджується і зберігається в резервуарі-сховищі. Критична точка $\mathrm{CO}_{2}$ становить $31,1^{\circ} \mathrm{C}$ i 73,8 бар. Щоб зберігати рідкий $\mathrm{CO}_{2}$ влітку за температури близько $25^{\circ} \mathrm{C}$, буде потрібна ефективна система охолодження для роботи системи акумулювання та зберігання $\mathrm{CO}_{2}$. Запропонована система накопичення діоксиду карбону розроблена для вантажного автотранспорту. Дизельний двигун таких автомобілів споживає 6,25 л дизельного палива на годину. Це означає, що утворюється 13,19 кг $\mathrm{CO}_{2}$. Тобто система захоплення $\mathrm{CO}_{2}$ потребує 131,88 кг/год (163,8 л/ч) адсорбенту. Тривалість циклу ТАЗТ становить 1 годину, а регенерований адсорбент може бути використаний у наступному циклі ТАЗТ.

Запропонована система може бути використана для накопичення діоксиду карбону з метою інертизації вантажних приміщень, що дозволить заощадити певні обсяги палива. 3 метою визначення обсягів передбачуваної економії палива в судноплавстві у статті проаналізовано економію палива при реконструкції установки інертного газу на танкерах i хімовозах дедвейту 50000 реєстр. тонн, яка спалює за годину 350 кг палива. Припустили, що судно експлуатувалося на лінії, на якій вивантаження відбувається раз на тиждень, протягом 24 годин. За цих умов при одній вантажній операції витратиться 350 кг пального на годину. Витрата палива за одну добу на одному судні складатиме 8400 кг, а за рік -
436800 кг. Якщо витрату палива за рік помножити на кількість суден 3 аналогічною водотоннажністю, то можна визначити приблизні можливості економії палива у судноплавстві загалом.

У світі 7444 нафтоналивних танкери і 5734 хімовози [20]. Припустимо, що така система інертного газу встановлена на 6500 суден. При реконструкції цих систем у судноплавстві можлива економія палива обсягом 2839200 тонн викопного палива за рік. Отримані результати вказують на можливу економію великих обсягів викопного палива, проте вони $\epsilon$ частково зниженими, оскільки можлива економія палива у судноплавстві визначена без урахування наявності аналогічних інертних систем на балкерах. Якщо 6,25 л дизельного палива утворюють 13,19 кг діоксиду карбону, то при спалюванні 2839200 тонн в атмосферу викидається 5991848 тонн $\mathrm{CO}_{2}$. Проведене дослідження показало, що цих викидів можна уникнути.

Головні висновки. До десяти найбільших забруднювачів атмосфери входить морський транспорт. Згідно з вимогами Конвенції SOLAS-74, система інертних газів $\epsilon$ обов'язковою для танкерів дедвейтом 20000 реєстр. тонн і більше. Як інертний газ використовуються димові гази, що пройшли обробку від допоміжних котлів або спеціальних газогенераторів.

У статті проаналізовано конструкцію і роботу газогенераторів суден із водотоннажністю до 50000 тонн. При їх реконструкції з метою накопичення i подальшого використання димових газів головного двигуна для інертизації танків можливе зменшення викидів діоксиду карбону в атмосферу на шість мільйонів тонн за рік. Запропонована реконструкція зменшить не тільки викиди $\mathrm{CO}_{2}$, але і витрати при експлуатації суден.

При реконструкції системи інертних газів суден доцільно використовувати системи акумулювання діоксиду карбону, запропоновану Швейцарським центром енергетичних досліджень SCCER EIP. Biн розробив технологію акумулювання діоксиду карбону з вихлопних газів двигуна внутрішнього згоряння 3 використанням адсорбції при коливаннях температури.

\section{Література}

1. Білявський Г.О. Техногенний вплив на атмосферу. Основи екології. К. : Лібра, 2006. С. 170-176.

2. Джигирей В.С. Забруднення атмосфери. Екологія та охорона навколишнього середовища. К. : Знання, 2007. С. 170-176.

3. Джигирей В.С. Екологія та охорона навколишнього природного середовища. К. : Знання, 2007. С. 174-176.

4. О переломных моментах в истории климата Земли см. Spiegel Online. URL: http://www.spiegel.de/flash/0,5532,17184,00.html (дата звернення: 03.12.2020).

5. Ruth Lorenz, Zélie Stalhandske Erich M. Fischer. Detection of a Climate Change Signal in Extreme Heat, Heat Stress and Cold in Europe From Geopheysical Research Letters, 17 July 2019. URL: https://doi.org/10.1029/2019GL082062 (дата звернення: 11.11.2020).

6. UN report on oceans, frozen zones: the facts (2019, August 29) retrieved 20 November 2019. URL: https://phys.org/news/2019-08oceans-frozen-zones-facts (дата звернення: 10.11.2020).

7. Сергей Коленов. Выбросы $\mathrm{CO}_{2}$ в 2019 году вновь достигли рекорда. URL: https:/hightech.plus/2019/12/16/vibrosi-co2-v2019-godu-vnov-dostigli-rekorda (дата звернення: 06.11.2020). 
8. Глобальный транспортный сектор: выбросы $\mathrm{CO}_{2}$ растут. URL: https://www.planete-energies.com/en/medias/close/globaltransportation (дата звернення: 03.11.2020).

9. Топливо в авиации и судоходстве. URL: https://www.planete-energies.com/en/medias/close/fuels-aviation-and-shippingsectorco2-emissions-rise (дата звернення: 03.11.2020).

10. Donaldi S. Permana et al, Disappearance of the last tropical glaciers in the Western Pacific Warm Pool (Papua, Indonesia) appears imminent National Academy of Sciences. December 26, 2019116 (52) 26382-26388; first. URL: https://doi.org/10.1073/ pnas.1822037116 (дата звернення: 25.11.2020)

11. Holland, p.r., bracegirdle, t.j., dutrieux, p. Et al. West antarctic ice loss influenced by internal climate variability and anthropogenic forcing Nature Geoscience. Volume 12. 2019. P. 718-724. URL: https://doi.org/10.1038/s41561-019-0420-9 (дата звернення: 25.11.2020).

12. Maya K. Buchanan, Michael Oppenheimer, Robert E. Kopp. Amplification of flood frequencies with local sea level rise and emerging flood regimes Published 7 June 2017. IOP Publishing Ltd Environmental Research Letters. Volume 12, Number 6. URL: https://doi.org/10.1088/1748-9326/aa6cb3 (дата звернення: 22.11.2020).

13. Рогинко С.А. Итоги Парижской конференции ООН по климату 2015 года. Современная Европа. 2016. C. 42-52. URL: http://dx.doi.org/10.15211/soveurope320164252 (дата обращения: 20.11.2020).

14. В Мадриде открылась 25-я климатическая конференция OOH. URL: https://p.dw.com/p/3U5Eg (дата звернення: 02.12.2020).

15. Горб С. Новые правила энергоеффективности для судов. Порты Украины. № 1(123). 2013. С. 34-35.

16. Ветряные фрахтовщики. URL: https://phys.org/news/2015-01-wind-powered-freighters.html (дата звернення: 11.11.2020).

17. Максимов С.Б. Использование энергии ветра - один из потенциальных путей повышения энергоэффективности морских судов // VIII Міжнародна науково-практична конференція «Сучасні підходи до високоефективного використання засобів транспорту» : матеріали VIII Міжнародної науково-практичної конференції. Ізмаїл : ДІ НУ «ОМА», 2017. С. 172-176.

18. Система инертных газов. Морская библиотека. URL: http://sea-library.ru/bezopasnost-plavanija/195-inertnie-gazi.html (дата звернення: 11.11.2020).

19. Shivom Sharma, François Maréchal. Carbon Dioxide Capture From Internal Combustion Engine Exhaust Using Temperature Swing Adsorption, Front. Energy Res., 16 December, 2019. URL: https://doi.org/10.3389/fenrg.2019.00143 (application Date: 21.11.2020).

20. Number of ships in the world merchant fleet as of January 1, 2019. URL: https://www.statista.com/statistics/264024/number-ofmerchant-ships-worldwide-by-type/ (application Date: 20.11.2020). 


\title{
ICTOPIЯ ЕКОАОГIЧНИХ КАТАСТРОФ У MICTI КИСВI
}

\author{
Шевченко Р.Ю. ${ }^{1}$, Шевченко 3.М. ${ }^{2}$ \\ ${ }^{1}$ Державна екологічна академія післядипломної освіти та управління \\ вул. Митрополита Василя Липківського, 35, корп. 2, 03035, м. Київ \\ azimut90@ukr.net; \\ 23аклад загальної середньої освіти № 210 Оболонського району м. Києва \\ вул. Йорданська, 22А, 04210, м. Київ \\ 0980710374@ukr.net
}

\begin{abstract}
Історія екологічних катастроф у м. Києві - новітній напрям сучасного екологічного та історико-краєзнавчого києвознавства. Це інтегральна наука, що вивчає особливості трансформації ландшафтного комплексу м. Києва під впливом фізичних та антропогенних факторів. Одним із головних наукових завдань екологічного києвознавства є розроблення прикладних тематичних маршрутів туристичних та екскурсійних подорожей по місту та забезпечення екологічної безпеки туристів під час відвідування природних рекреаційних комплексів столиці України. Уперше складено класифікаційну схему екстремальних природних явищ на забудованій території міста. Доповнені класифікаційні ознаки надзвичайних ситуацій природного та техногенного характеру: екологічна небезпека, аномальні аерокосмічні явища та загрози, астроблеми. До гібридних надзвичайних ситуацій на території міста віднесено: потужність електромагнітного смогу, стан природної течії р. Дніпро, катастрофічна евтрофікація, замулення та обміління ріки внаслідок техногенних забруднень, діяльності закладів торговельно-розважальної сфери тощо. Вдосконалено систему класифікації надзвичайних ситуацій суспільно-політичного та воєнного характеру з урахуванням фактора перманентних екологічних небезпек. За проведеними науковими дослідженнями складено геохронологічний літопис основних екологічних і природно-техногенних катастроф у м. Києві. Уперше розглянуто історію виникнення та документація аномальних аерокосмічних явищ, метеорологічних і синоптичних процесів. Проведено хронометраж відповідних неоекологічних небезпек. Стаття супроводжується літописними гравюрами та архівними фотографічними матеріалами, а також унікальними світлинами пам'ятних знаків, розміщених у місцях екстремальних природних явищ. За підсумками аналізу історичних матеріалів виникнення екологічно-небезпечних ситуацій у м. Києві створено картографічну модель ексклюзивних надзвичайних природно-техногенних небезпек та екологічних катастроф у м. Києві від найдавніших часів до сьогодення. Бібліотека умовних позначень представлена ексклюзивними авторськими умовними позначеннями таких природних ексклюзивів: епідемії, астрономічні явища (комети та боліди) та повітряні аномалії. Вдосконалено систему картографічних знаків екологічних і природних катастроф: обміління річок, ареали геологічних катастроф, пилові буревії. Отримані результати наукових досліджень сприятимуть формуванню альманаху історії природних і техногенних катастроф у м. Києві. Ключові слова: екологічна історія м. Києва, класифікатор катастроф м. Києва, літописи, землетруси, повені, пожежі, пандемії, туризм.
\end{abstract}

History of ecological catastrophe in the city of Kyiv. Shevchenko R., Shevchenko Z.

The history of ecological catastrophes of Kyiv is the newest direction of modern ecological and historical-local lore Kyiv studies. It is an integral science that studies the peculiarities of the transformation of the landscape complex of Kyiv under the influence of physical and anthropogenic factors. One of the main scientific tasks of ecological Kyiv studies is the development of applied thematic routes of tourist and excursion trips around the city and ensuring the ecological safety of tourists when visiting the natural recreational complexes of the capital of Ukraine. From the methodological point of view, for the first time a classification scheme of extreme natural phenomena in the built-up area was compiled. The classification features of natural and man-made emergencies have been supplemented: eniological danger, anomalous aerospace phenomena and threats, astroblems. Hybrid emergencies in the city include: the power of electromagnetic smog, cessation of the natural flow of the Dnieper, catastrophic eutrophication, siltation and shallowing of the river due to man-made pollution from road transport, shopping and entertainment facilities. The system of classification of emergencies of socio-political and military nature has been improved, taking into account the factor of permanent ecological dangers. As a result of the conducted scientific researches the geochronological chronicle of the basic ecological and naturaltechnogenic catastrophes in Kyiv is made. For the first time the history of origin and documentation of anomalous aerospace phenomena, meteorological and synoptic processes is mentioned. The relevant neo-ecological hazards were timed. The article is accompanied by chronicle engravings and archival photographs, as well as unique photographs of memorials erected at the site of extreme natural phenomena. An important result of the accumulation and analysis of historical material on the occurrence of ecological disasters in Kyiv is the created cartographic model of exclusive natural and man-made emergencies and ecological catastrophes of Kyiv from ancient times to the present. The library of symbols is represented by the exclusive author's symbols of the following natural exclusives: epidemics, astronomical phenomena (comets and fireballs) and air anomalies. The system of cartographic signs of ecological and natural catastrophes has been improved: shallowing of rivers, areas of geological catastrophes, dust storms. The obtained results of scientific research should be useful for the formation of a further almanac of the history of natural and man-made disasters in Kyiv. Key words: ecological history of Kyiv, classifier of catastrophes of Kyiv, chronicles, earthquakes, floods, fires, pandemics, tourism.

Постановка проблеми. В екологічній історії м. Києва (зафіксовані в літописах, документах та на картах) природні та техногенні надзвичайні ситуації та катастрофи, серед яких - війни, пожежі, землетруси, повені та епідемії.
Зміна кліматичних поясів в Україні, абсолютне зношення основних фондів промислових підприємств, значна кількість занедбаних промислових майданчиків закритих підприємств із неконтрольованим рівнем залишкових забруднюючих речовин, 
будівництво високо-поверхових конструкцій та споруд без урахування інженерного стану грунтів, гідрогеологічних умов створюють сумарну потенційну небезпеку та підвищують ймовірність виникнення надзвичайних ситуацій природного та техногенного характеру.

Еколого-туристична та екскурсійно-рекреаційна діяльність у м. Києві донедавна була найбільш прибутковим видом економічної діяльності.

Науковою проблемою сучасної екологічної географії м. Києва $є$ вивчення історії передумов виникнення екологічних надзвичайних ситуацій природного та техногенного характеру, розробити класифікацію екологічних катастроф у м. Києві, провести геохронологічний та геопросторовий аналіз екстремальних явищ та інтерпретувати їх у вигляді спеціалізованої еколого-географічної карти, що матиме відповідне призначення у системі генерального планування м. Києва, організації системи еколого-природоохоронних обмежень у транспортному, житловому та промисловому будівництві, туризмі, рекреації, екскурсійній справі та природозаповіданні.

Актуальність дослідження. Ландшафт м. Києва це трансформовані компоненти фацій, змінені під впливом антропогенних навантажень. Фактично на території міста відсутні автохтонні компоненти природного комплексу. Навіть площі НПП «Голосіївський» та інша переважна кількість об'єктів ПЗФ столиці є деградованими $з$ точки зору геоботанічної, ландшафтно-грунтознавчої, еколого-природоохоронної цінностей.

Найбільшою еколого-туристичною та природно-антропогенною дестинацією України $є$ місто Київ. Атрактивними центрами муніципального туризму є природно-заповідні території та історичні місця. Він поєднує природно-територіальний комплекс та розгалужену мережу об'єктів природно-заповідний фонду.

Сучасною проблемою міста $є$ безпрецедентна розбалансованість територіальної структури природного та антропогенного ландшафтів. Нещадно знищуються яри, урочища, сквери, старі дерева, які потребують санітарного нагляду та внесення їх до переліку пам'яток природи міста. Втрачаються об'єкти рекреаційної спадщини столиці. Під ймовірність знищення підпадають історико-ландшафтні комплекси Батиєвої гори, Протасового яру, зелений пояс Труханового острову та усього архіпелагу РЛП «Дніпровські острови» [8].

Патогенним наслідком постає знищення біогеоценозів, зміна мікроклімату в бік підвищення метеорологічних показників парникового ефекту, катастрофічна концентрація $\mathrm{CO}_{2}$ у повітрі міста, що вже має медико-географічні наслідки. Все це знижує туристичну та рекреалогічну привабливість міста, перетворює урбаністичний простір столиці України у суцільні квартальні забудови. У плановому положенні відповідне будівництво $є$ хаотичним, де гібридно поєднуються заповідні природні урочища НПП «Голосіївський» та хмарочосні комплекси у Мишоловці, Теремках, Китаєвому, Деміївці. Вони завдають непоправної шкоди навколишньому середовищу міста. Робота котелень, сотні квадратних метрів несанкціонованих сміттєзвалищ навколо будівельних майданчиків у природних зонах, псують краєвиди. Створюються перешкоди у ревіталізації територій, наприклад, Почайнинської промзони в районі оз. Йорданського та Почайнинського меліоративного каналу неподалік однойменної станції кільцевої залізниці [2].

У результаті вищезазначених проблем місто втрачає свій еколого-туристичний, рекреаційний та екскурсійний потенціал, а мешкання у місті вже має деякі фактори екологічної небезпеки. Експерти вже зазначають, що життєдіяльність населення міста в повсякденних умовах характеризується екологічною катастрофою.

Це ставить під загрозу екологію довкілля міста та безпеку життєдіяльності населення, економічні втрати в галузі екологічного туризму та природоохоронних екскурсій. Насамперед це зменшення прибутків у бюджет міста від відповідної маловитратної сфери обслуговування, закриття малих туристичних фірм та екскурсійних бюро, що спеціалізуються на місцевих екологічних туристичних подорожах природно-заповідним фондом столиці України.

Зв'язок авторського доробку 3 важливими науковими та практичними завданнями. Наукове дослідження виконане у рамках докторського дисертаційного дослідження «Наукові основи управління екологічним моніторингом для оперативного визначення ризиків антропогенного впливу» (затверджена Вченою радою ДЗ «ДЕА» 14.12.2017 р., прот. № 13) та наступних науково-дослідних робіт: «Методологія обсерваційного моніторингу довкілля-простору» (2019-2020 р.) та «Методологія моніторингу екологічної безпеки туристичних подорожей та екскурсійної діяльності на території м. Києві» (2020р.).

Викладений науковий доробок грунтується на авторських еколого-природоохоронних рекогностувальних експедиційних дослідженнях природно-територіального комплексу реалізованих останнім часом.

Аналіз останніх досліджень і публікацій. Єдиного систематизованого наукового твору з питань історії, географії та екології надзвичайних ситуацій у м. Києві не існує.

Вишукування, що присвячені екологічним катастрофам у м. Києві, описано переважно в літописних джерелах Н. Літописця, Радзивіловського литопису та монографії києвознавців: М. Берлинського «Краткое описание Киева, содержащее историческую перечень сего города, так же показание достопамятностей и древностей оного» (1820р.) [1], А. Муравйова «Письмо из Киева» (1859 р.) [6], Л. Похилевича «Сказания о населенных местностях Киевской губернии» (1864р.) [7]. Важливим 
джерелом даних стали київські газети періоду 1920-1990 pp. [2; 4].

Виділення не вирішених раніше частин загальної проблеми, котрим присвячусться означена стаття. В Україні розроблений національний класифікатор надзвичайних ситуацій та катастрофічних явищ. Але в масштабах мегаполісу не всі його компоненти присутні, а деякі поки що не знайшли свого місця в системі ранжувальних ознак небезпечних явищ навколишнього природного середовища. Це передусім аномальні аерокосмічні явища та загрози, еніологічні та еніогеографічні особливості території міського середовища, медико-географічні та нозологічні потенційно-небезпечні зони. Гіпотетично вони $\epsilon$ джерелом екологічних небезпек, що провокують виникнення екологічних катастроф. Це необхідно перевірити шляхом геохронометричного аналізу вивчення історико-географічних джерел київських катастроф від найдавніших часів до сьогодення.

Новизна. Інноваційним у дослідженні $\epsilon$ розроблення методології вивченя історії катастрофічних явищ на території м. Києва. Водночас алгоритм дослідження має різночасову геопросторову територіальну характеристику, яка залежить від зміни площі м. Києва у плині часу. Вивчається трансформація соціо- та еколого-культурного ландшафту під впливом природних та техногенних факторів: військових конфліктів, природних катастроф, епідемій, зміни статусу міста.

Методологічне або загальнонаукове значення. 3 погляду екологічних наук уперше розроблена класифікаційна схема надзвичайних ситуацій та екологічних загроз й катастроф у м. Києві як мегалополісу, що перманентно трансформує природно-територіальний комплекс та перетворює міський ландшафт на ареал перманентних екологічних загроз. Відповідні загрози моделюються та прогно- зуються картографічно із застосуванням технології геохронологічного оверлейного аналізу сучасних та стародавніх планів, карт, серії карт та атласів м. Києва. Відповідна методологія апробована в процесі експедиційних досліджень польового (полігонного) вивчення потенційно небезпечних екологічних об'єктів м. Києва із застосуванням геоінформаційних та аерокосмічних технологій.

Виклад основного матеріалу. Місто Київ має особливий ареал надзвичайних ситуацій та екологічних загроз які сформувалися історично та під впливом сучасних глобальних трансформацій навколишнього природного середовища геосфери планети. Класифікаційна схема автентичних екологічних катастроф м. Києва представлена на рис. 1. Складена на основі національного класифікатора надзвичайних ситуацій.

Подамо історичний зріз задокументованих екологічних катастроф та надзвичайних ситуацій та їх територіальний розподіл. Найбільше описів в джерелах присвячено природним та техногенним надзвичайним ситуаціям від яких м. Київ потерпав найчастіше. Значна частина описів присвячена пожежам.

Печерські літописні патерики інформують, що у 1017 р. за великої пожежі в місті згоріло 700 будинків. Наслідком стала зміна системи розселення містян на суміжних до Старого Міста територіях: Перевісища - Євсейкової долини (сучасна Європейська площа), Києво-Подолу. Тоді не існували системи пожежного оповіщення та попередження, технічних вимог до поводження із вогнем. Особливо це стосувалося ковальських майстерень на території сучасних урочищ Гончарів-Кожум'як. Не менш важливий фактор пожежної небезпеки того часу було жертовне капище Велеса на Подолі та вогняне капище Сонця-Ярила на сучасні горі Киянці [3].

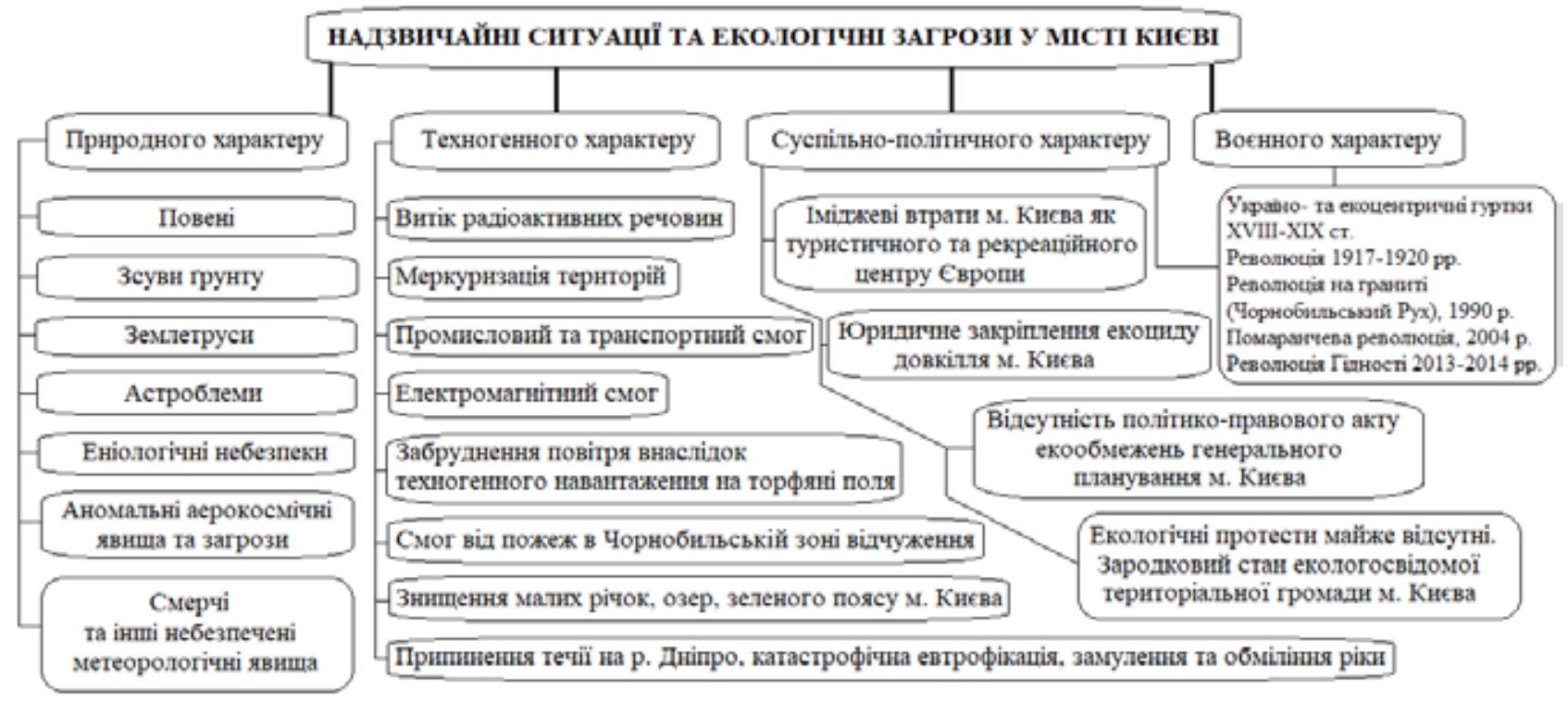

Рис. 1. Муніципальний класифікатор екстремальних явищ на території м. Києва 
По-перше, задокументоване аномальне аерокосмічне явище зафіксоване у «Повісті Временних Літ» Нестора Літописця. $Є$ такий запис: «... в рік 6573 (1065 рік н.е.) було знамення на Заході, зірка велика з променями як би кривавими. 3 вечора сходила вона на небо після заходу Сония, $і$ так було сім днів. Пізніше в Сетомль було знайдено істоту (ия річка протікала біля Києва, по луках Оболоні, впадала в річку Почайну). Ї̈ витягли рибалки в невід і розглядали його до вечора і знову кинули в воду. Був же він такий: на обличчі у нього були сороміцькі частини, а іншого не можна і сказати сорому ради. Перед тим часом $і$ Сонце змінилося, $і$ не стало світлим, але було як Місящь...» (рис. 2) [6].

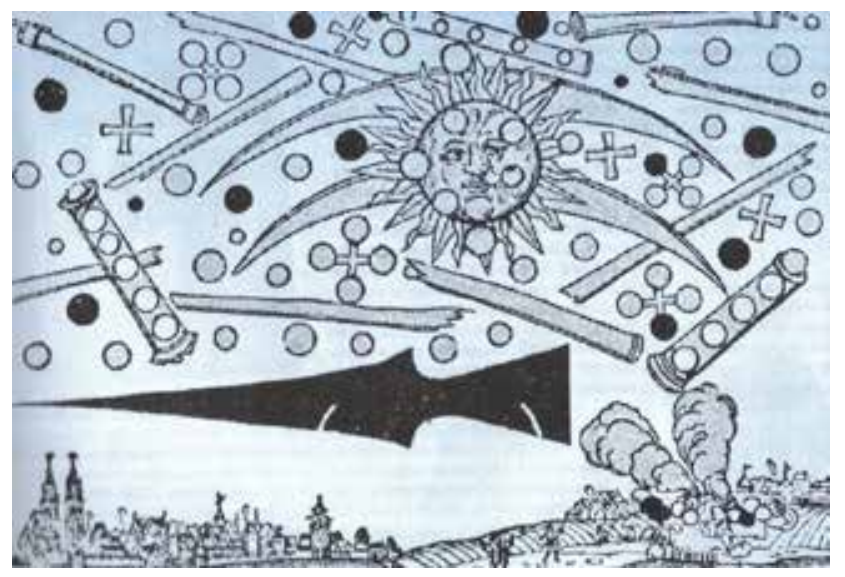

Рис. 2. Явище на Києвом 1065 р.

Медико-бактеріологічна надзвичайна ситуація у м. Києві сталася у кінці ХІ ст. Це була пандемія бубонної чуми, яка прийшла з Європи. У 1092 р. м. Київ був охоплений хворобою, від якої померло більше семі тисяч киян.

Відомо, що м. Київ знаходиться у переважно стійкій частині Українського кристалічного щита. Відповідна геологічна структура зазнає впливу руху тектонічних плит та розломів 3 боку Українських Карпат та гір Вранча у Румунії. Це тектонічне навантаження триває вже більше тисячі років. Це зумовлено ростом молодої гірської країни карпатської зони складчастості. У історичних джерелах ми знаходимо, що у 1100 р. від м. Києва до м. Володимира Волинського спостерігався сильний землетрус. У матеріалах Печерських літописів є запис «...ледве церкви встояли, а шкоди багато учинилося, хрести із бань попадали...» [4].

Незвичайне метеорологічне та сейсмологічне явище спостерігалося 5 лютого 1108 р. над КиєвоПечерською Лаврою. З'явився «вогняний стовп» та був землетрус. Це надзвичайно налякало киян того часу. Сучасні еніогеографи відносять відповідне спостереження до другої документації аномальних аерокосмічних явищ та загроз у м. Києві.

Землетруси у м. Києві відчуваються із не рідкою періодичністю. Кожен десятий $з$ них є сильним або катастрофічним. Так, у вересні 1122 р. у м. Києві відчувався землетрус силою 8 балів. Збереглися лише культові споруди та сакральні місця у природних урочищах. Ці місцини стали місцями першого паломництва та чудодійності. Це сучасні території масивів та урочищ Китаїв, Самбурки, Голосіїв, Церківщина, Кирилівські висоти, Старокиївська гора, лисі гори.

На початку XII ст. у м. Києві сталася друга величезна, надзвичайно сильна пожежа у липні 1124 р. Катастрофа тривала дві доби. Вона перетворила більшу частину міста на попіл. На Подолі згоріло 600 будинків. У цьому ж році трапилося два землетруси та сонячне затемнення, що викликало жах серед киян. Кияни стали надзвичайно містичними та забобонними [1].

Майже через двадцять років в м. Києві у 1145 р. катастрофічна пожежа повторилася. Суздальський літопис стверджує, що пожежею було знищено пів Подолу. Це передмістя було переважно дерев'яним, одноповерховим. Верхнє місто - кам'яне, поверхове. Це й врятувало містян кварталу від знищення. Окремо Поділ навіть не входив до складу Києва. Він іменувався Києво-Подолом та мав свою окрему систему управляння.

У 1224 р. зафіксовано появу над містом комети: «...це була зірка надзвичайної величини, яка показувалася на Заході міста протягом тижня, освітлюючи небо яскравим сяйвом. У той же рік трапилася неслихана посуха ... ліси, болота горіли полум'ям, клуби диму закривали Сонце, імла затягнуло повітря та мертві птахи падали на землю...» [1].

У 1346 р. Київ був охоплений другою пандемією моровою язви (бубонної чуми), «...від якої тодi майже все місто спорожнів...».

У 1424 р. У м. Києві зафіксовано третій спалах морової язви.

Запис про четвертий спалах морової язви датований 1603 р.: «...у той час Київ та вся Україна була охоплена надто сильною моровою язвою, так й замок київський внаслідок пожежею був охоплений...».

У 1710 р. Київ повторно спіткала п’ята епідемія чуми.

У 1770 р. місто ледве вижило після шостої епідемії чуми. У місті з 20 тис. мешканців 4 тис. померло.

26 березня 1790 р. трапився сильний землетрус. Вистояли кам'яні церкви та монастирі.

27 листопада 1793 р. у м. Києві знову був землетрус.

9 липня 1811 р. серед доби трапилася катастрофічна пожежа на Подолі. Він увійшов у трійку наймасштабніших у XIX ст. Очевидцем трагічних подій став директор гімназії Я. Мишковський, який доповідав своєму керівництву наступне: «...nеред незгасаючим вогнем не змогло встояти ніякий кам'яний будинок, ні склеп, ні ичерква, хоча й криті залізом та були вимощені; погреби з залізними дверима та рамами, якщо мали хоча щуо-небудь 
дерев'яне або самий малий отвір, вигоріли також. Протягом шістнадчяти годин поглинання незвичним полум'ям важлива частина м. Києва, щзо відома під назвою Поділ згорів. Це 1176 будинків, Духовна Академія із Братським монастирем, Греизкий монастир, Флорівський монастир, 11 кам'яних иерков та 4 дерев'яних приходських, обидві пошти, Магістрат, Контрактовий будинок та запаси різної деревини та інших товарів на березі ставали здобиччю вогню ... більша частина Подолу вигоріла, лише невелика Північна сторона за Нижнім Валомвулиці Костянтинівська, Введенська та Волоська визілили...» [4].

Постраждалі подоляни вимушені були тулитися у куренях на Оболоні. Серед них мешкав відомий проповідник протиєрей Іван Леванда. Він писав до однієї своєї знайомої: «... Ви дуже пам'ятаєте нам чудовий Києво-Поділ. Але тепер його не має. Його не існує. 9 липня його знищила страшна пожежа, не жалкуючи у ньому нічого при посусі, вітрі та плам'яному вихорі. Церкви, монастирі, будинки зруйнувалися в огні та попелі. Навколо жах, але вигляд Флорівського монастиря, після спалених до фундаментів келій, в яких загинуло 30 з лишком тіл монахинь та послушниць, які задихнулися та обгоріли, перевершували інші жахи...».

Наступна надзвичайна ситуація трапилася вночі 39 на 10 лютого 1821 р. протягом 15 хвилин був сильний землетрус.

У 1831 р. за свідками географа, історика та києвознавця Миколи Закревського (1805-1871рр.), «...у перший раз з'явилася у багатьох місиях Росї страшна хвороба Холера, проникла в Київ та призвела велике спустошення...» [3].

11 січня 1838 р. трапився землетрус. Ректор університету Св. Володимира М. Максимович, що мешкав на Печерську, згадував: «...nочувся дивний гул, шуо схожий на літній шум екіпажів по бруківиі. Дивлюся: на стіні у мене захитався, як маятник, nортрет нашого пріснопам'ятного професора Данилевича, а на столі моєму захитався великий підсвічник. Це продовжувалося біля трьох хвилин...».

Річка Дніпро, окрім того, що була транспортною артерією від найдавніших часів та джерелом водопостачання міста, постійно несла екологічні лиха та катастрофи. У 1845 р. повінь на Подолі повністю знищила будинки та був пошкоджений 451 дім. Рівень води в р. Дніпро склав 779 см.

Відсутність системи очищення та знезараження водогону спричиняла постійні спалахи черевних захворювань. Так, під час епідемії холери 1847 р., що продовжувалася до 1 серпня, померли 990 киян.

Через рік, 4 та 5 липня 1848 р., у місті йшов такий сильний дощ, що «...Хрещзатищька вулищя до того наповнилася водою, шуо між будинками перервалося будь-яке сполучення; вода стояла у пів зросту людського...». Це вийшла з берегів р. Хрещата, що протікала по самісінькому центрі вулиці.
6 червня 1849 р. трапилася сильна буря. Вона згинала та ламала хрести на банях багатьох церков, пошкодила багато будов, завалила паркани та вирвала 3 коренями фруктові дерева у садах.

У 1853 р. місто вкотре було охоплено епідемією холери: захворіли 1437 мешканців, з яких померли 813 осіб [3].

С інформація, що р. Дніпро мав періодичні гідрологічні феномени від катастрофічних повеней до повного висихання русла. Так, 1901 р. в Україні були дуже спекотні весна і літо, кілька місяців не було жодних опадів, постраждали врожаї, обміліли річки й озера, а в Києві русло Дніпра цілком пересохле. Внаслідок цих природних катаклізмів навіть дно Дніпра місцями потріскалося і було настільки рівним, що там влаштовувалися перегони диліжансів, а деякі велосипедисти навіть організовували велозабіг «Київ - Канів». Російський уряд намагався поглибити русло, але й там, на глибині, води не було. Подивитися на висохлу річку приїжджали фахівці із сусідніх країн. Залишилися фотографії пересохлого Дніпра проти Видубицького монастиря (рис. 3) [5]. Були й аномалії 3 надзвичайними повенями, що засвідчують пам'ятні знаки на Подолі та Трухановому острові та на опорах київських мостів.

Аномальні метеорологічні та аерокосмічні явища та небезпеки періодично спостерігаються у місті. Увесь липень 1908 р. спостерігалося полярне сяйво, що було викликано падінням Тунгуського метеориту (30.06.1908 р.).

Після цієї аномалії 23 вересня 1908 р. трапився землетрус. Газета «Киянин» писала: «...y величезному n'ятиповерховому будинку А.П. Слінко на Андріївському узвозі серед мешканців трапилася справжня паніка. Квартиранти, особливо із верхніх поверхів, в переляку повискакували та кинулися вниз, я вирішив, щуо будинок повзе та валиться. Один пан, шео сидів за письмовим столом, явно відчував, як його та стіл декілька разів підкинуло, при чому двері та стільці стукали, шпалери тріщали, штукатурка дала трішинуу...» [4].

До побудови Київської ГЕС 1968 р. та Великої кам'яної набережної на Подолі його постійно заливало. У весняну повінь 1917 р рівень води у р. Дніпро піднявся до позначки $785 \mathrm{~cm}$.

326 квітня по 10 травня 1931 р. трапився небувалий розлив Дніпра. 2 травня був зафіксований рівень води 853 см. Була затоплена вся прибережна смуга обох берегів Дніпра. На лівому: Труханів острів, Передмістна, Микільська, Кухмістерська Слобідки. На правому: Теличка, всі набережні вулиці та деякі райони Подолу до Кирилівської вулиці. Під водою виявилися Ігорівська, Андріївська, Борисоглібська, Ільїнська, Нижній та Верхній Вали, Ярославська, Щекавицька, Юрківська, Оболонська та Введенська вулиці. Про що свідчить гідрологічний історичний ландмарк на вулиці Юрківській 34-А, коп. А (рис. 4). 


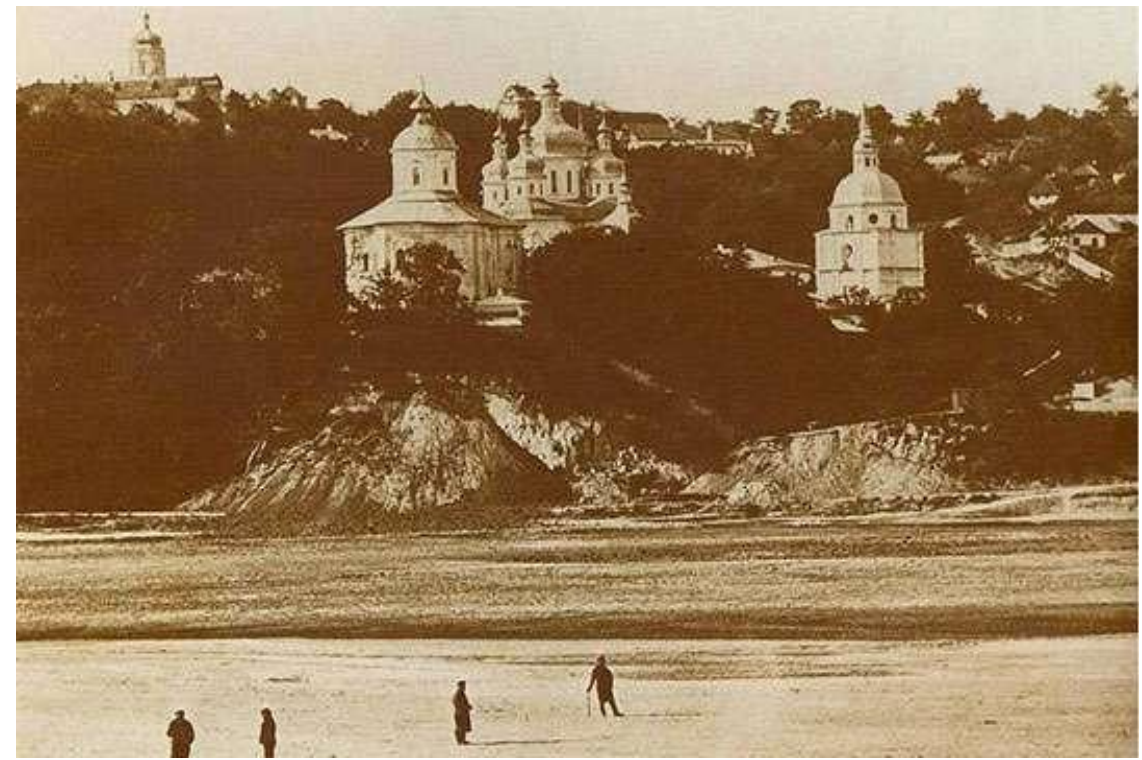

Рис. 3. Світлина пересохлого русла р. Дніпро у 1901 р.

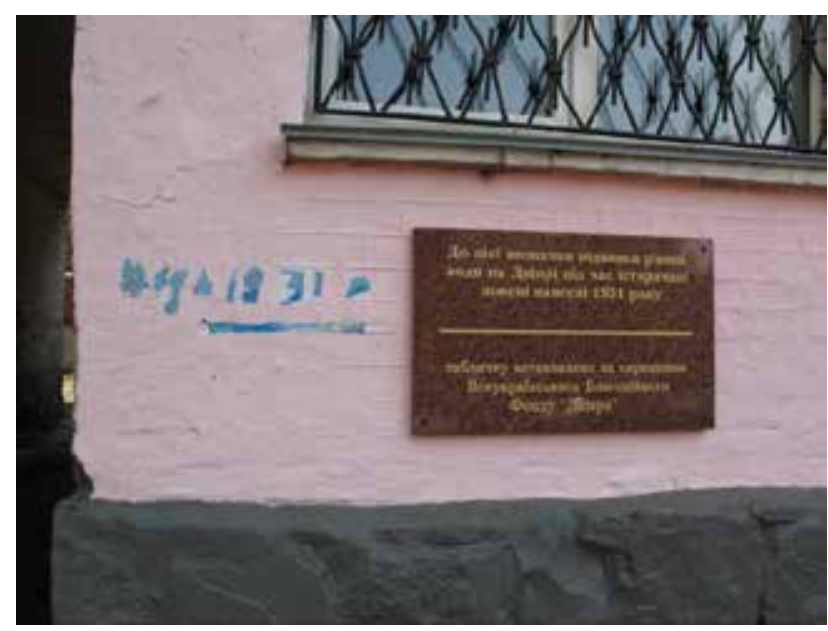

Рис. 4. Пам'ятна дошка про відмітку рівня води в 1931 p.

Для захисту промислових підприємств були зведені заслони висотою до двох метрів із цегли, щебеню, мішків із піском. На Подолі та Лівому березі у загальній кількості було знищено та пошкоджено 2700 будинків.

Техногенна катастрофа, що стала величезною за обсягами та надзвичайною за таємничістю трапилася 13 березня 1961 р. Прорвало земляну дамбу у Бабиному Яру. У повідомленні урядової комісії від 31 березня говорилося, що загинули 145 осіб та 143 доставлені до лікарні. Висота потоку рідкої земляної маси, рухалася зі швидкістю 5,16 м/сек., склала на окремих ділянках більше 10 м/сек. За 30 хвилин потік змив все, що було на його шляху. Було зруйновано 163 будинки (248 квартир), де мешкали 1228 громадян.

Значене коливання земної поверхні в районі м. Києва зафіксовано 4 березня 1977 р. Це був землетрус силою 3-4 бали. Спостерігалася паніка серед

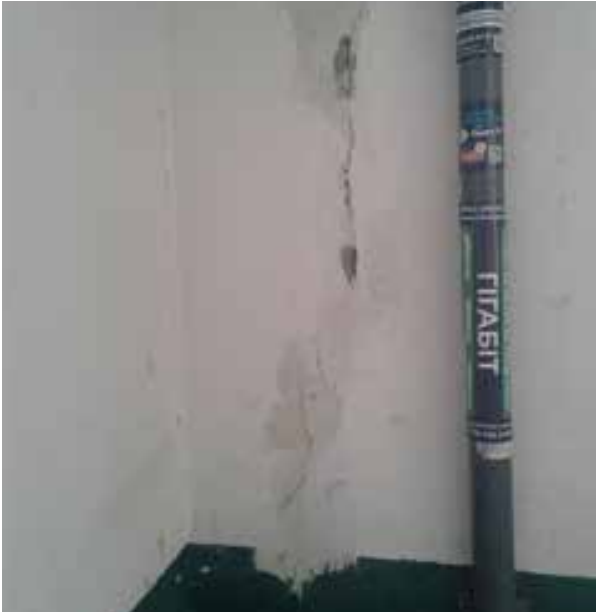

Рис. 5. Стан залізобетонної стіни у будинку на Оболоні після землетрусу 1977 р. Фото 2020 р.

киян, але ніяких людських втрат не було. Але в багатьох будинках міста до теперішнього часу залишилися вертикальні тріщини, які навіть після шпаклювання знову з'являються (рис. 5). Вони визнані аварійними. Значна ї кількість розташована на Оболоні. Епіцентр, як завжди знаходився у горах Вранча Румунських Карпат.

Планетарна техногенна катастрофа майже не знищила поселення на берегах Дніпра назавжди 26 квітня 1986 р. Тоді сталася Чорнобильська катастрофа у 130 км. від міста Києва. Напередодні над м. Буча спостерігалося гало у вигляді хреста. Це перше задокументоване аномальне аерокосмічне явище на Київщині, що тоталітарна влада не мала змоги засекретити.

Значна паніка серед киян прокотилася 30 травня 1990 р., коли стався землетрус силою 4-5 балів за шкалою Ріхтера. 
Останній значний за силою черговий землетрус силою 4 бали стався 27 жовтня 2004 р.

Зі зміною кліматичних поясів періодично спостерігаються аномальні метеорологічні та синоптичні явища, температурні «гойдалки», надзвичайна кількість твердих снігових опадів (квітень 2013 р.), смерчі на Оболоні (1995, 2000, 2010, 2019 рр.). Апогеєм аномальності став «холодний» період 2019-2020 pp. Вперше за 140 років метеорологічних спостережень у м. Києві не наступила зима.

Із 12 березня 2020 р. по теперішній час у м. Києві оголошений безпрецедентний карантин через пандемічне поширення гострої респіраторної інфекції, зумовленої коронавірусом (COVID-19). Оголошено надзвичайну ситуацію природного характеру медико-бактеріологічного походження. На два 3 половиною місяці із березня по червень у місті фактично була зупинена повноцінна робота громадського транспорту. Громадянам було заборонено без нагальних потреб виходити 3 дому. 3 часом карантин дещо послабили, але це призвело до другої хвилі пандемії, що розпочалася із жовтня 2020 р.

Авторами складено електронну карту ексклюзивних надзвичайних природно-техногенних ситуацій та екологічних катастроф м. Києва від найдавніших часів до сьогодення (рис. 6). Модель демонструє локалізацію повеней, техногенних аварій, небезпечних метеорологічних явищ, ізосейсти землетрусів.

Головні висновки. Геохронологічний аналіз катастрофічних явищ довів, що м. Київ перманентно знаходиться у «жовтій» - потенційно-небезпечній зоні екологічної безпеки. Географічне, топографічне, гідролого-гідрографічне та геолого-літологічне розташування м. Києва визначається таким, що поселення територіально знаходиться у значній віддалені від епіцентрів можливих глобальних екологічних катастроф. Потенційна ймовірність локальних техногенно-екологічних ризик-факторів зменшені в рази. Наприклад, катастрофічні повені на Дніпрі. Але поряд 3 цим виникає техногенна небезпека гіпотетичної руйнації греблі Київської ГЕС, що будувалася як стратегічний військово-оборонний об'єкт на випадок Третьої світової війни. Ії призначення - руйнування та ліквідація великим тиском об'єму води інфраструктури противника уздовж нижньої течії р. Дніпра.

Визначено основні компоненти системи екологічної безпеки м. Києва. Проведено хронологічний аналіз основних природних i техногенних катастроф у м. Києва починаючи з XII ст. до сьогодення. Відкрито нові сторінки екологічної історії м. Києва.

Перспективи використання результатів дослідження. Відповідне дослідження доповнює тематич-

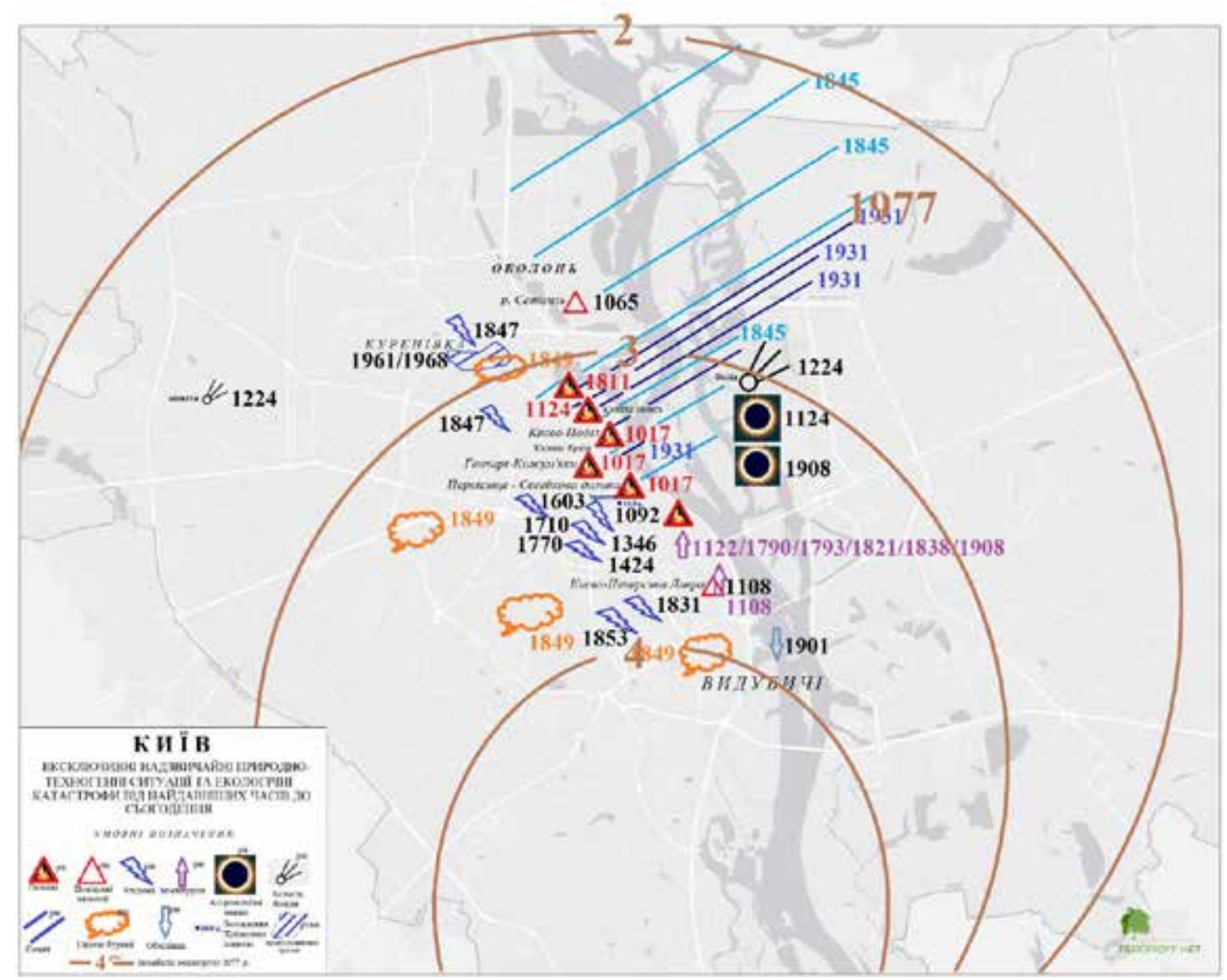

Рис. 6. Карта ексклюзивних надзвичайних природно-техногенних ситуацій та екологічних катастроф м. Києва від найдавніших часів до сьогодення 
ний зміст організації нових маршрутів екологічних туристичних подорожей м. Кисвом, а саме - новим контентом про історичні особливості виникнення природних та техногенних загроз у м. Києві.
Необхідно зазначити, що розроблений історичний хронограф екологічних небезпек у м. Києві потрібно враховувати при генеральному плануванні антропогенного ландшафту міста.

\section{Література}

1. Берлинский М. Краткое описание Киева, содержащее историческую перечень сего города, так же показание достопамятностей и древностей оного. Санкт-Петербург, 1820. 221 с.

2. Вечірній Київ. Підшивка газети 1930-1991 рр.

3. Закревский Н. Летопись и описание Киева. Москва, 1858. Т. ІІ. 301 с.

4. Кіевлянинъ. Підшивка газет за 1900 год.

5. Как 1901 г. в Киеве полностью пересох Днепр. URL: http://profidom.com.ua/mnenija/blogi/22928-kak-1901-godu-vkievepolnostyu-peresokh-dnepr.

6. Муравьев А. Письмо из Киева. Москва, 1859. 26 с.

7. Похилевич Л. Сказания о населенных местностях Киевской губернии. Киев, 1865.73 с.

8. Шевченко Р.Ю. Космологічні закони та передові космічні технології у моніторингу та прогнозі екологічних катастроф у м. Києві. Інженерна геодезія. № 43. 2000. С. 283-294. 


\title{
ЗБЕРЕЖЕННЯ БІОАОГІЧНОГО ТА МАНДШАФТНОГО РІЗНОМАНІТТЯ
}

\author{
УДК 634.662+631.527 \\ DOI https://doi.org/10.32846/2306-9716/2020.eco.6-33.19
}

\section{СЕАЕКЦІЯ КРУПНОПАІДНИХ ФОРМ УНАБІ СПРАВЖКЬОГО (ZIZYPHUS JUJUBA MILL.) У ХОРОАЬСЬКОМУ БОТАНІЧНОМУ САДУ}

\author{
Красовський В.В. \\ Хорольський ботанічний сад \\ вул. Кременчуцька, 1/79, оф. 46, 37800, м. Хорол \\ horolbotsad@gmail.com
}

\begin{abstract}
У статті наведено особливості селекції місцевих крупноплідних форм Z. jujuba у Хорольському ботанічному саду. Зазначається, що основне використання Z. Jujuba, заради якого здійснюється його інтродукція та акліматизація в Лісостеп України, - отримання плодів. Однак попри численні дослідження широке поширення Z. jujuba у Лісостеповій зоні України стримується через недостатню кількість посадкового матеріалу. Тому завдання селекціонерів полягає у виведенні адаптованих до змінених умов середовища крупноплідних форм, які можуть у перспективі стати сортами, оскільки саме їхні плоди відповідають потребам ринку.

Показано, що в період глибокого зимового спокою інтродуковані у Лісостеп України дрібно- та середньоплідні форми унабі переносять без пошкоджень зниження температури до мінус 28-30 градусів морозу. У крупноплідних сортів без виконання агротехнічних прийомів захисту при сильних морозах і зростанні на земельних ділянках з пронизливими вітрами спостерігається відпад рослин або значне пошкодження крони.

Зазначено, що агротехнічні прийоми захисту крупноплідних сортів Z. jujuba, інтродукованих перенесенням вегетативного матеріалу, можуть бути ефективними лише для рослин із невеликими габітуальними розмірами. Тому в основу подальших наукових досліджень ставилося завдання створити в умовах інтродукції гібридне насіння унабі, яке змогло б передати нащадкам гени, що контролюють зимостійкість рослин і їхню крупноплідність.

У процесі пошуку запропоновано спосіб отримання гібридного насіння для виведення місцевих крупноплідних зимостійких форм, який включає вільне перезапилення батьківських компонентів виду і полягає у тому, що схрещувалися ізольовано поряд зростаючі добре адаптовані зимостійкі місцеві середньоплідні форми, створені в результаті кількох репродуктивних циклів та з яких заготовляли гібридне насіння і сорти з крупними плодами, які в умовах Лісостепу України потребують обов'язкового захисту від низьких температур у зимовий період виконанням прийомів агротехніки. Як джерела крупноплідності до гібридизації залучали генотипи сортів Та-Ян-Цзао та Вахшський. У результаті селекційних досліджень у 2019 році серед рослин, вирощених із гібридного насіння, були виявлені зимостійкі зразки Z. jujuba, перспективні для поширення в Лісостеповій зоні України, серед яких і два крупноплідні. Ключові слова: Лісостеп України, інтродукція, унабі справжній, селекція.
\end{abstract}

Big fruitage selection of jujube in Khorol botanical garden. Krasovsky V.

The special features of jujube big fruitage selection growing in Khorol botanical garden are given. It is remarked that basic using of $Z$. jujuba and its aim of introduction and acclimatization in the forest-steppe zone of Ukraine is getting fruitage. While as detailed research the spreading of $Z$. jujuba in the forest-steppe zone of Ukraine is being retarded because of planting stock lack. The aim of selectors is to develop adopted big fruitage sorts which are on market demands.

The current study investigates that introduced small- or big fruitage jujubes are able to survive in the conditions of temperature lowering to 28-30 degrees below zero. In the conditions of hard frost and strong wind without agricultural technologies of protection it's difficult to resist for the plants and its crown may be damaged.

The study defines that agricultural protection methods of big fruitage sorts of Z. jujube may be effective only for the small-size plants. The further aim of research is to grow hybrid seed of jujube with strong genetic fund for improving and controlling of winter resistance and getting big fruitage.

It is suggested getting hybrid seed for selecting of big fruitage and winter-resistant sorts including free cross-pollination of parent components. The main concern is pollination of adopted and selected mid-sized fruitage plants selected after several reproductive cycles their seed was selected. They need protection from low temperature in winter. Ta-Yan-Zao and Vahshsky sorts were involved into hybridization. As a result of selection research in 2019 among hybrid plants there were found winter resistant $\mathrm{i} Z$. jujuba individuals which are perspective for spreading in the forest steppe zone of Ukraine. There are two big fruitage ones among them. Key words: the forest-steppe zone of Ukraine, introduction, zizyphus jujuba, selection.

Постановка проблеми. До переліку інтродукованих видів плодових культур Лісостепу України можна додати ще один вид - унабі справжній, оскільки результати досліджень, проведених у Національному ботанічному саду імені академіка М.М. Гришка НАН України та в м. Хорол Полтавської області, де згодом 
був заснований ботанічний сад загальнодержавного значення, суттєво доповнили існуючі уявлення щодо можливості та доцільності вирощування цієї культури в Лісостеповій зоні України [4].

Унабі справжній (Zizyphus jujuba Mill.) із родини жостерові (Rhamnaceae R. Br.) - субтропічна деревовидна листопадна плодова рослина, ще має назву китайський фінік. Таксономічно унабі справжній із фініковою пальмою (Phoenix dactylifera L.) не пов'язаний, а таку назву він отримав за зовнішню схожість зав'ялених плодів крупноплідних сортів Z. jujuba iз плодами $P$. dactylifera. На продовольчих ринках України сухофрукти унабі справжнього здебільшого реалізують під назвою китайський фінік.

Рослини Z. јuјuba вирізняються високою посуховитривалістю, вони стійкі до вірусних і грибкових хвороб, бактеріозів, ракових уражень, не пошкоджуються комахами-шкідниками сільського господарства, а отже не потребують захисту спеціальними хімічними препаратами для саду. Основна цінність цієї рослини - іiі плоди, які використовуються в харчуванні людини. Вони за вмістом сухих речовин перевершують багато інших плодових культур, мають багатий і своєрідний хімічний склад.

За вмістом вітаміну С плоди унабі конкурують iз шипшиною звичайною (Rosa canina L.), актинідією (Actinidia kolomikta Maxim, A. arguta (Siebold et Zucc.) Plansh. ex Mig., A. polygama (Siebold et Zucc.) Mig.), смородиною чорною (Ribes nigrum L.), а за вмістом цукрів, кислот і мінеральних речовин плоди Z. juјuba схожі з інжиром. Унабі справжній здавна відомий своїми лікувальними властивостями через те, що при вживанні його плодів знижується артеріальний тиск, зміцнюються судини, прискорюється відновлення організму після захворювань $[2 ; 3 ; 10 ; 11]$.

Залежно від форми чи сорту рослини Z. јuјuba мають свої параметри за усередненою масою плоду. Умовно їх поділяють на дрібноплідні, середньо- та крупноплідні з масою плоду до 5 г, від 5 до 10 та більше 10 г [9]. Виду властива генеративна та вегетативна репродукція. У культурі підщепи здебільшого вирощують шляхом посіву насіння дрібноплідних форм, рідше використовують прикореневу порість дорослих рослин, а прищепою є вегетативний орган сортової рослини $[10 ; 11]$.

У Лісостепу України Z. јuјuba здебільшого культивують у ботанічних садах, інколи - на присадибних ділянках. Варто зазначити, що основне використання Z. Jujuba, заради якого здійснюється його інтродукція та акліматизація в Лісостеп України, отримання плодів. Незважаючи на численні дослідження, широке поширення Z. jujuba в Лісостеповій зоні України стримується через відсутність належного місцевого посадкового матеріалу, адже здебільшого культивують дрібноплідні, рідше - середньоплідні форми або сорти, що $є$ невирішеною практичною проблемою. Завдання селекціонерів полягає у виведенні адаптованих до змінених умов середовища крупноплідних форм, які у перспективі можуть стати місцевими сортами, тому що саме рослини 3 крупними плодами відповідають потребам ринку. Велика роль у розв'язанні цієї проблеми відведена ботанічним садам, покликаним проводити інтродукцію рослин, що має важливе екологічне та наукове значення.

Зв'язок авторського доробку 3 важливими науковими та практичними завданнями. Метою статті є узагальнення досліджень щодо схрещування різних за спадковістю особин унабі справжнього 3 такими закріпленими фізіологічними та морфологічними ознаками як висока зимостійкість в одних і крупноплідність в інших та створення гібридів, серед яких відбирали місцеві зимостійкі крупноплідні форми рослин.

Аналіз останніх досліджень і публікацій. Під час польових досліджень, які з 1998 року проводилися на присадибній земельній ділянці та земельній ділянці прибудинкової території автора статті i мешканця Хорола, а 32014 року і на території Хорольського ботанічного саду, встановлено, що в період глибокого зимового спокою інтродуковані у Лісостеп України способом перенесення насіння дрібно- та середньоплідні форми Z. jujuba витримують без пошкоджень зниження температури до мінус 28-30 градусів морозу. У крупноплідних сортів, які зростають на земельних ділянках із пронизливими вітрами, без виконання агротехнічних прийомів захисту при сильних морозах спостерігається відпад рослин або значне пошкодження крони, що позначається на урожаї.

Агротехнічні прийоми захисту крупноплідних сортів Z. Јијиba, інтродукованих перенесенням вегетативних органів, можуть бути ефективні лише для молодих рослин, які мають невеликі габітуальні розміри. Наші дослідження підтвердили літературні дані щодо утворення неповноцінного насіння у плодах крупноплідних сортів Z. jujuba через не досить виповнений ендосперм [10].

Z. juјиbа є ксеногамною ентомофільною рослиною. На одному дорослому дереві утворюється досить велика кількість квіток (близько 250 тисяч штук), тому зав'язування 0,8-3,2\% квіток достатнє для формування урожаю на рівні 250-325 ц/га. При самозапиленні утворюється не більше 0,5-1\% плодів, лише перехресне запилення забезпечує нормальне плодоношення. Фаза цвітіння відбувається не одним етапом. Вона розтягнена у часі, оскільки бутони закладаються по мірі росту пагонів. Суцвіття цимозне, клубочковидне, складається із 3-20 квіток. У межах суцвіття формується не більше одного-двох плодів [4; 10].

У процесі підготовки до захисту дисертації ми ретельно вивчали складники квіток та їхні розміри [4]. Вимірювання квіток форми Мореджер проводили мікрометром типу МК 3 діапазоном 
вимірювань 0-25 мм, класом точності - 2, ціною поділки - 0,01 мм, межею похибки - 0,004 мм.

Описуючи результати дослідження, необхідно зазначити, що квітконос дуже короткий, квітки - двостатеві, дрібні (4-5,5 мм у діаметрі), духмяні, п'ятипелюсткові, зірковидні, вони неодночасно розпускаються у суцвітті. Базальні частини 5 чашолистиків, 5 пелюсток і 5 тичинок утворюють квіткову трубку, в якій у верхній частині приростає округло-п' ятикутний нектарний диск. Чашолистики, довжина яких становить 3 мм, широко трикутні або овальні жовтувато-зелені, розгалужені. Пелюстки, довжина яких становить 2 мм, мало примітні, значно менші за чашолистики, широколожковидні, зеленкувато-жовті або кремові, вони охоплюють тичинки. Гінецей синкарпний, зав'язь - м'ясиста, жовта, блискуча, напівнижня, двогніздна рідко три- або чотиригніздна. Стовпчик, довжина якого становить 1-2 мм, двохроздільний, короткий.

3 огляду на те, що квітки досить дрібні і їх велика кількість, фаза цвітіння відбувається не в один етап. У Лісостепу України достатня ентомофауна для здійснення перехресного запилення квіток, тому ми дійшли висновку, що при гібридизації унабі справжнього штучне видалення андроцею виконувати недоцільно, як і штучне запилення.

Виклад основного матеріалу. Науково доведено, що інтродукція південних плодових культур у північні регіони найкраще здійснюється способом перенесення насіння з подальшим його пересівом в умовах змінених факторів середовища, адже насінне розмноження має вирішальний вплив на єдиний по своїй суті акліматизаційний процес. Отримане гібридне насіння - цінний матеріал для подальшої селекції за різними ознаками, оскільки серед великої кількості сіянців можна відібрати форми, плоди яких за масою дещо поступаються батьківським рослинам, залученим у гібридизаційний процес, але за морозостійкістю перевершують їх $[1 ; 8 ; 13]$. Тому в основу подальших наукових і практичних досліджень ставилося завдання створити в умовах інтродукції гібридне насіння унабі, яке змогло б передати нащадкам гени, що контролюють закріплений адаптивний потенціал зимостійкості в одних рослинах і закріплений господарський ресурс, а саме крупноплідність, в інших.

Селекційний процес здебільшого триває довго i на різних етапах його застосування вимагає тих чи інших способів їх вдосконалення. У процесі пошуку запропоновано спосіб отримання гібридного насіння унабі справжнього для виведення місцевих крупноплідних зимостійких форм, що включає вільне перезапилення батьківських компонентів виду і полягає у тому, що схрещувалися ізольовано поряд зростаючі добре адаптована зимостійка місцева середньоплідна форма, створена в результаті кількох репродуктивних циклів та 3 якої й заготовляли гібридне насіння, i сорти 3 крупними плодами, але неповноцінним насінням, які в умовах Лісостепу України потребують обов'язкового захисту від низьких температур у зимовий період виконанням прийомів агротехніки.

Як джерела крупноплідності до гібридизації залучали цінні генотипи Z. јujuba - сорти Та-Ян-Цзао та Вахшський, інтродуковані перенесенням вегетаційного матеріалу у вигляді живців. Для того, щоб створювані гібриди успадкували домінантні ознаки батьківських особин, тобто пилок інших рослин, за винятком крупноплідних, не переносився на середньоплідну форму, витримували ізоляцію до масових дослідних насаджень середньо- та дрібноплідних форм і сортів Z. јuјuba.

Висіяне отримане гібридне насіння дало значне розщеплення ознак з утворенням нових гібридних форм першого покоління з цінними ростовими показниками, з яких у 2014 році в Хорольському ботанічному саду була закладена колекція із 50-ти 3-річних сіянцевих рослин, висаджених рядами 3 кроком у ряду 2 м. У результаті селекційних досліджень у 2019 році серед плодоносних рослин колекції були виявлені форми Z. јuјuba, перспективні для поширення в Лісостеповій зоні України, серед яких і дві крупноплідні, позначені номерами 4-5-11 та 5-5-17. На рис. 1 зображено кісточки середеньоплідної зимостійкої форми, залученої до гібридизації, та вилучене з них анатомічно повноцінне насіння.

Крупноплідний сорт Та-Ян-Цзао, який перенесено в Лісостеп України у вигляді вегетативних органів, має плоди 3 середньою масою 16 г (рис. 2), але насіння в кісточках через невиповнений ендосперм неповноцінне (рис. 3). Форма Z. јuјuba 4-5-11 має такі цінні господарські ознаки: дерево з прямою формою крони, сильноросле, нині висота сформованого дерева становить 2,5 м, плід при вигляді з боку грушоподібний великих розмірів (висота 39 мм, діаметр 30 мм), середня маса плода 14,0 г (рис. 4). Шкірка плода коричневого кольору, м'якуш біло-зелена, помірно-твердої консистенції з середньою соковитістю, кісточка вузькоеліптична - середня довжина 2,3 см, діаметр - 0,9 см. Урожайність у 2020 році склала 1,8 кг із дерева, період дозрівання плодів третя декада вересня - перша декада жовтня.

Форма 5-5-17 - дерево із напіврозлогою формою крони, висота 2,2 м, плід округлий великих розмірів (висота $31 \mathrm{мм}$, діаметр 27 мм), середня маса 12,0 г, шкірка плода коричнева, м'якуш біло-зелена помірно-твердої консистенції з середньою соковитістю, кісточка вузько- еліптична (середня довжина 1,9 см, середній діаметр 0,8 см). Урожайність 2,4 кг із дерева, період дозрівання плодів - третя декада вересня. Обидві форми вирізняються підвищеною посухостійкістю (9 балів) та зимостійкістю (1 бал) [5; 6].

Головні висновки. Основним методом селекції є відбір і гібридизація двох груп Z. јuјuba, критеріями їх оцінки була зимостійкість і крупноплідність. Запропонований спосіб отримання гібридного 


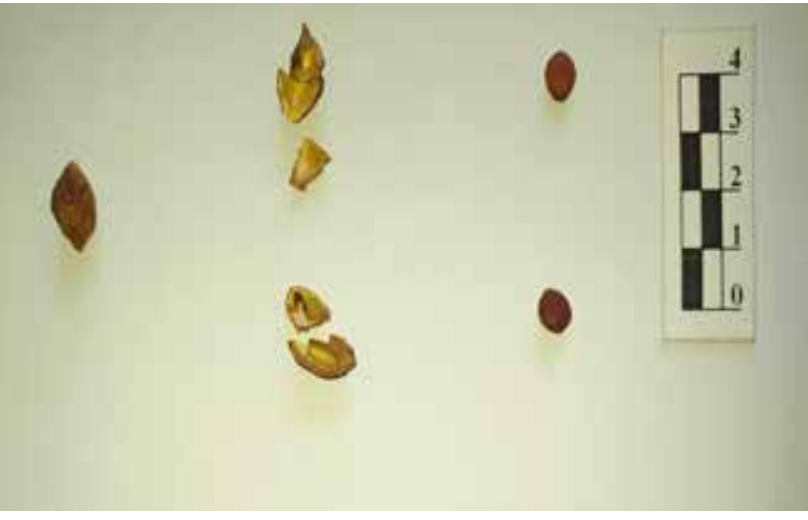

Рис. 1. Кісточки середньоплідної зимостійкої форми унабі та вилучене з них повноцінне насіння

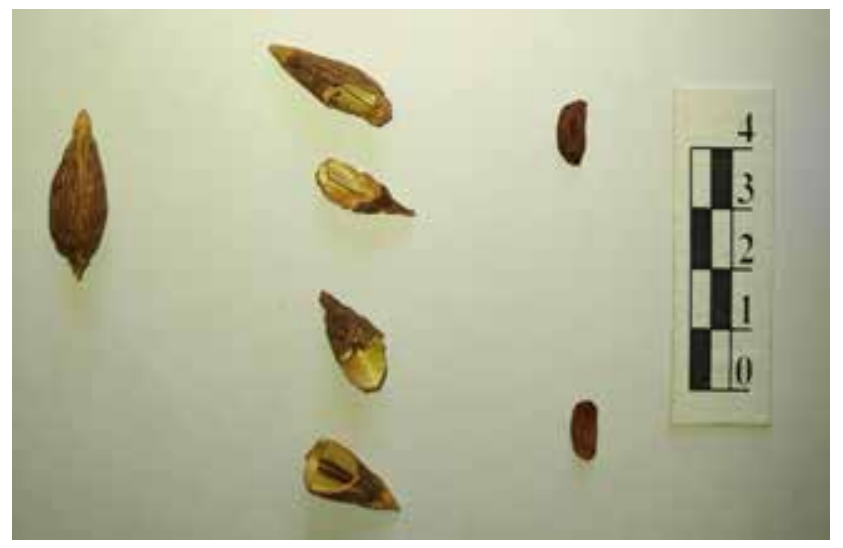

Рис. 3. Кісточки унабі сорту Та-Ян-Цзао та вилучене з них неповноцінне насіння

насіння унабі справжнього вирізняється новою суттєвою ознакою, яка полягає у тому, що схрещували ізольовано поруч зростаючі середньоплідну форму, адаптовану до місцевих факторів навколишнього середовища, та крупноплідні, які в умовах інтродукції можуть виживати лише при виконанні запобіжних заходів захисту, причому їх не можливо буде виконати при збільшенні габітуальних розмірів рослин.

Ділянка контрольованої схеми гібридизації містила лише набір рослин, призначених для простого схрещування при близькому їх розміщенні.
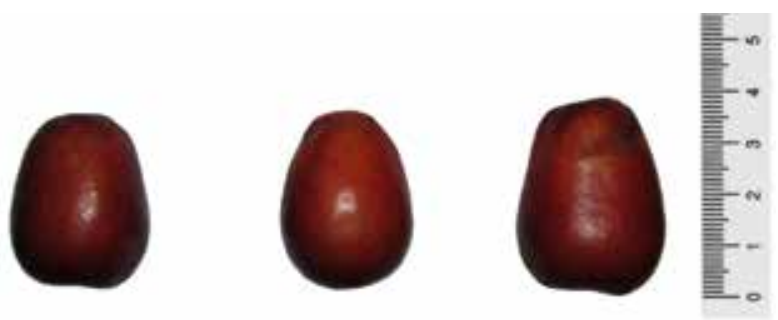

Рис. 2. Плоди унабі сорту Та-Ян-Цзао, середня маса плода - 16 г

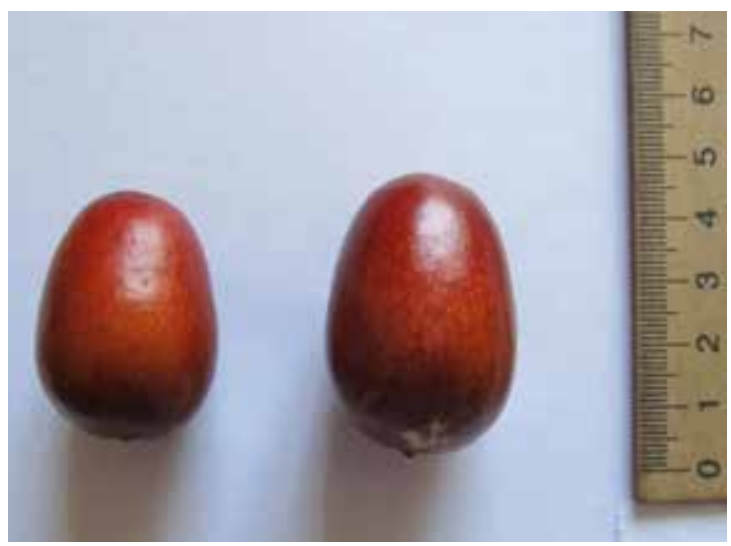

Рис. 4. Плоди унабі форми 4-5-11, середня маса плода - 14 г

Донором ознак крупноплідності були сорти Та-ЯнЦзао та Вахшський. Як материнський компонент використано зимостійку середньоплідну форму. У Хорольському ботанічному саду в польових умовах серед сіянцевих рослин, вирощених зі створеного гібридного насіння, відібрано зимостійкі крупноплідні форми, що мають позитивні ознаки батьківських особин. Ці форми придатні для поширення в Лісостеповій зоні України, на них $є$ попит, оскільки саме такі рослини цікавлять чимало садівників-аматорів.

\section{Література}

1. Гель І.М. Практикум із прикладної селекції плодових і овочевих культур / ІІ частина. Плодові, ягідні та горіхоплідні культури. Львів, 2015. 320 с.

2. Грабовецька О.А. Споживчі та цінні властивості малопоширених плодових: азиміна, зізіфус, хурма. Досягнення та концептуальні напрями вирощування малопоширених плодово-ягідних культур і переробки їх сировини : матеріали I Всеукраїнської наук.-практ. конф. (с. Новосілки, 18-19 грудня 2018 року). Київ, 2019. С. 21-24.

3. Казас А.Н., Литвинова Т.В., Мязина Л.Ф. и другие. Субтропические плодовые и орехоплодные культуры : научно-справочное издание. Симферополь : ИТ «Ариал», 2012. 304 с.

4. Красовський В.В. Інтродукція унабі (Zizyphus jujuba Mill.) у Лісостепу України (біоекологічні особливості, розмноження, вирощування). Автореферат дисертації на здобуття наукового ступеня кандидата біологічних наук. Київ, 2007, 19 с.

5. Методика проведення експертизи сортів рослин групи плодових, ягідних, горіхоплідних, субтропічних і винограду на придатність до поширення в Україні / За ред. Ткачик С.О. 2-ге вид., випр. і доп. Вінниця : ФОП Корзун Д.Ю., 2016.85 с.

6. Положення про реєстрацію колекцій зразків генофонду рослин у Національному центрі генетичних ресурсів рослин України. Харків, 2012. 23 с. 
7. Рахметов Д.Б. Адаптація інтродукованих рослин в Україні : монографія / [Д.Б. Рахметов, М.Б. Гапоненко, Т.М. Черевченко та інші]; відп. за ред. Д.Б. Рахметов. К. : Фітосоціоцентр, 2017. 516 с.

8. Рябчун В.К., Кузимишина Н.В., Задорожна О.А. Стан і проблеми формування банку генетичних ресурсів плодових, ягідних, горіхоплідних, малопоширених і декоративних культур в Україні. Досягнення та концептуальні напрями вирощування малопоширених плодово-ягідних культур і переробки їх сировини : матеріали I Всеукраїнської наук.-практ. конф. (с. Новосілки, 18-19 грудня 2018 року). Київ, 2019. С. 15-17.

9. Синько Л.Т. Зизифус - Zizyphus jujuba Mill. // Каталог видов, сортов и гибридных форм субтропических плодовых культур, произрастающих в государственном Никитском ботаническом саду. Ялта : ГНБС, 1975. С. 22-32.

10. Соловьева М.Ф. Малораспространенные плодово-ягодные растения. Кишинев : Картя Молдовеняскэ, 1987. 184 с.

11. Чебан С.Д., Долід А.В., Сіленко В.О., Чередниченко Л.І. Цитрусові та субтропічні плодові культури. Кам'янецьПодільський, 2013. 198 с.

12. Черевченко Т.М. Збереження та збагачення рослинних ресурсів шляхом інтродукції, селекції та біотехнології : монографія / [Т.М. Черевченко, Д.Б. Рахметов, М.Б. Гапоненко та інші]; відп. за ред. Т.М. Черевченко. К. : Фітосоціоцентр, 2012. $432 \mathrm{c}$.

13. Шайтан И.М., Мороз П.А., Клименко С.В. Интродукция и селекция южных и новых плодовых растений. К. : Наукова думка, 1983. 216 с. 


\title{
ПОВОДЖЕННЯ З ВІДХОДАМИ
}

\author{
УДК 504.064.4 \\ DOI https://doi.org/10.32846/2306-9716/2020.eco.6-33.20
}

\section{ПОВОДЖЕННЯ З ВІДХОДАМИ У МІСТІ КРЕМЕНЦІ (ТЕРНОПІАЬСЫКА ОБААСТЬ)}

\author{
Галаган О.К., Дух О.І., Ковалевич О.В. \\ Кременецька обласна гуманітарно-педагогічна академія імені Тараса Шевченка \\ вул. Ліцейна, 1, 47003, м. Кременець, Тернопільська область \\ bukowska.ok@gmail.com
}

\begin{abstract}
У статті розкрито питання поводження з відходами у місті Кременці Тернопільської області. Наведено інформацію про Закон України «Про відходи» та останні поправки до нього.

Місто Кременець є освітнім, релігійним і туристичним містом із населенням понад 20 тисяч осіб. Сміттєзвалище Кременця розташоване за 1 км від міста в урочищі «Ганушівка», воно має площу 4,0 га і потужність 521,8 тис. м³. Полігон ліцензований і призначений для складування відходів. Щотижня сюди привозять до 400 тонн різного сміття. Поводження з відходами у місті Кременці здебільшого зводиться до того, що відходи збираються у контейнери і вивозяться на сміттєзвалище.

Зроблено перші кроки у сортуванні - ПЕТ-пластик збирається окремо. За підтримки ГО «Кременецька екологічна ліга» було встановлено окремі контейнери для скла, паперу, пластику та металу у НПП «Кременецькі гори», Кременецькій обласній гуманітарно-педагогічній академії ім. Тараса Шевченка та деяких школах міста. Відсортовані відходи зберігаються на складах, проводяться пошуки його переробників, щоб здача вторинної сировини не була збитковою. Серед небезпечних відходів окремо збираються батарейки. У місті майже немає пунктів прийому вторинної сировини, окремі підприємці приймають лише скло, папір і метал. Вважаємо за доцільне впроваджувати окремий збір органіки і розташовувати сортувальні баки по всьому місту.

Згідно проєкту Регіонального плану поводження з відходами Тернопільської області місто Кременець має бути віднесене до Кременецького кластеру, куди входять міста Шумськ і Ланівці. Поблизу Кременця (в селі Білокриниця) передбачена сміттєсортувальна лінія, а також установка біоферментації органічних твердих побутових відходів для виробництва органічних добрив, куди можна буде відвозити органіку. Запропоновано практичні рекомендації щодо зменшення утворення відходів, особливу увагу приділено окремому збору органіки. Заплановано створення регіонального еколого-просвітницького центру 3 навчальною та просвітницькою метою. Екохаб має ознайомити студентів і містян із філософією “Zero Waste”, або «Нуль втрат». Ключові слова: поводження з відходами, Кременець, полігон, сортування, органіка, свідоме споживання.
\end{abstract}

The waste management in the city Kremenets (Ternopil region). Halahan O., Duch O., Kovalevich O.

The article reveals the issue of waste management in the town of Kremenets, Ternopil region. The information on the Law of Ukraine "On Waste" and the latest amendments to it is provided.

The town of Kremenets is an educational, religious and tourist town with a population of more than 20 thousand people. The Kremenets landfill is located $1 \mathrm{~km}$ from the town in the Hanushivka tract, has an area of 4.0 hectares and a capacity of 521.8 thousand $\mathrm{m}^{3}$. The landfill is licensed and designed for waste storage, up to four hundred tons of various garbage are brought here every week. Waste management in Kremenets is mainly reduced to the fact that waste is collected in containers and taken to the landfill.

The first steps in sorting have been made: PET plastic is being collected separately. With the support of the Kremenets Ecological League, separate containers for glass, paper, plastic and metal were installed at the Kremenets Mountains National Park and the Kremenets Regional Humanitarian and Pedagogical Academy named after Taras Shevchenko and some schools in the town. Sorted waste is kept in the warehouses and searches are conducted for its processors so that the delivery of secondary raw materials is not unprofitable. Among hazardous wastes, batteries are collected separately. There are almost no recycling points in the town, only glass, paper and metal are accepted by individual entrepreneurs. We consider it expedient to introduce a separate collection of organics and to place sorting tanks throughout the town.

According to the Draft Regional Waste Management Plan of the Ternopil Region, the town of Kremenets should be assigned to the Kremenets cluster, which also includes the towns of Shumsk and Lanivtsi. Near Kremenets (in the village of Bilokrynytsia) there is a waste sorting line, as well as a biofermentation plant for organic solid waste for the production of organic fertilizers, where organic matter can be transported. Practical recommendations for waste reduction are offered, special attention is paid to separate collection of organics. It is planned to create a regional ecological and educational center for educational and educational purposes. The ecohub should introduce students and citizens to the philosophy of Zero Waste, or "Zero Losses". Key words: waste management, Kremenets, landfill, sorting, organic, conscious consumption.

Постановка проблеми. Утилізація відходів $\epsilon$ однією із нагальних екологічних проблем, адже за статистикою житель міста щорічно виробляє від 280 до 600 кг відходів і з кожним роком ця цифра збільшується [1]. Кожна держава вирішує це питання по-своєму: спалювання, захоронення, переробка, впровадження нових законів і правил. Найбільш екологічним методом вирішення цієї проблеми $є$ сортування з подальшою переробкою. Роздільний збір відходів для європейців та мешканців інших розви- 
нених країн - така ж повсякденна справа, як похід до магазину за продуктами. Чим розвиненіша країна, тим більше різнокольорових контейнерів для відходів, які можуть бути використані для збору вторинної сировини.

Актуальність дослідження. В Україні 94\% відходів не переробляються, в той час як Польща захоронює на сміттєзвалищах близько 44\%, а Швеція лише $0,8 \%$. Метал, пластик роками лежать у землі, не втрачаючи первісного вигляду. Тонкому поліетиленовому пакету потрібно не менше 15 років, а одноразовому посуду - 500 років, щоб повністю розкластися.

Сміттєзвалища в Україні займають площу понад 9 тис. га. Перший пріоритет, який Європейський Союз застосовує у законодавстві та на практиці із поводження з відходами, - це запобігання утворенню відходів, а на останньому місці - захоронення відходів. Основна директива у сфері управління відходами, яку повинна впровадити Україна відповідно до Угоди про асоціацію із СС, - це Директива 2008/98/ ЄС про відходи [2].

Аналіз останніх досліджень іпублікацій. Усі відходи поділяють на органічні та неорганічні. До органічних відносять залишки продуктів, шкірку овочів і фруктів, чайні пакетики, до неорганічних - відходи, які складаються зі штучних матеріалів: папір, метал, пластик. Ці матеріали при правильному сортуванні й переробці можуть не тільки очистити планету від сміття, а й слугувати матеріалом для нового товару.

Розрізняють два варіанти сортування відходів: 1) збирати вдома усі неорганічні відходи в одному контейнері або пакеті, а потім сортувати відходи безпосередньо на станції. Цей варіант зручніший для людей, які живуть у невеликих квартирах; 2) збирати їх удома в кілька контейнерів для роздільного збору відходів: контейнер для пластику, скла, металу, паперу та органічних відходів. Це практичніше [3]. Відходи сортують за категоріями: папір, скло, пластик, метал і органіка. На станції для сортування сміття здають усі категорії, крім органіки, яка збирається в окремі контейнери. Перша в Україні станція компостування органічних відходів запрацювала цього року у Львові.

В Україні діє Закон «Про відходи», в якому чітко регламентовано обов'язки громадян у сфері поводження 3 твердими побутовими відходами (далі ТПВ) [4]. Власники або наймачі, користувачі, у тому числі орендарі, джерел утворення побутових відходів, земельних ділянок укладають договори з юридичною особою (у Кременці - КП «Міськводгосп» Кременецької міської ради), яка визначена виконавцем послуг на вивезення побутових відходів, здійснюють оплату таких послуг. Також прописано заборони та відповідальність за порушення. Винні в порушенні законодавства про відходи несуть дисциплінарну, адміністративну, цивільну чи кримінальну відповідальність.
Із 1 січня 2018 року набула чинності правка до цього закону про обов'язкове сортування сміття приватними особами та підприємствами. Згідно зі змінами органам місцевого самоврядування заборонено захоронення неперероблених побутових відходів на полігонах, у містах і селах вони мають забезпечити сортування сміття за видами для переробки та утилізації. Проте на практиці жодне місто України не готове повноцінно виконувати цей закон через брак інфраструктури для роздільного збирання сміття та його переробки. 28 жовтня 2020 року Кабмін України вніс зміни до Закону «Про відходи» щодо запровадження окремого тарифу на сортування відходів як для тих осіб, які до цього часу платили лише за вивезення і знешкодження ТПВ, так і для тих, які вивозили сміття на полігон.

Багато екологічних громадських організацій вимагають внести поправки до закону про розширену відповідальність виробника, яка діє в багатьох європейських країнах. Розширена відповідальність виробника означає, що виробник упаковки та товарів в упаковці несе відповідальність за весь цикл життя продукту навіть після його використання. Згідно цього закону виробники зобов'язуються збирати відходи (упаковки), переробляти чи утилізувати їх.

Виклад основного матеріалу. Місто Кременець, як і інші міста України, має проблеми із вивозом і захороненням сміття, а особливо із його сортуванням і переробкою. Щороку збільшується ділянка землі, яку відведено під сміттєзвалище. Кількість мешканців Кременця становить 21239 осіб, із них 9839 мешканців живе у 84 багатоквартирних будинках, 11400 мешканців - у 3800 індивідуальних будинках, які є житловим фондом міста [5].

Кременець $є$ освітнім (Кременецька гуманітарно-педагогічна академія ім. Тараса Шевченка, Кременецький педагогічний коледж, Кременецький медичний фаховий коледж імені Арсена Річинського, Кременецький лісотехнічний коледж, 7 загально-освітніх шкіл і 3 садочки, музична та спортивна школи), релігійним (Кременецький жіночий монастир, поблизу міста розташована відома в усьому світі Почаївська Лавра, в межах міста $\epsilon$ єврейський цвинтар, костел і польське товариство, в місті народився Юліуш Словацький - відомий польський поет) і туристичним (Почаївсько-Кременецький державний історико-архітектурний заповідник, Національний парк «Кременецькі гори», Кременецький ботанічний сад, гора Бона (Замкова), яка є візитівкою міста, Кременецький краєзнавчий музей, музей Юліуша Словацького, санна траса, розвинений парапланеризм, армрестлінг, є центр вільного часу «Панорама», численні готелі та кафе) центром свого регіону.

У місті є лише три промислових підприємства: ТОВ «Фабрика «Ватин», ТОВ «Укркрейда» та комунальне підприємство Кременецької міської ради «Міськводгосп», численні заклади торгівлі. Благоустрій на вулицях Кременця забезпечують два 
комунальні підприємства Кременецької міської ради: КП «Кременецька оселя» та КП «Міськводгосп», понад 600 сміттєвих контейнерів, два сміттєвози.

Сміттєзвалище Кременця розташоване за 1 км від міста в урочищі «Ганушівка» на території Чугалівської сільської ради. Полігон має площу 4,0 га, потужність 521,8 тис. м $^{3}$, його наповнюваність станом на 2010 рік складала 68,2 тис. м³ ${ }^{3}$ Полігон ліцензований і призначений для складування відходів. Щотижня сюди привозять до 400 тонн різного сміття: пластикові пляшки, пакети, металеві відходи. Цінна вторсировина тут гниє, забруднюючи грунти і підземні води. Процес сортування не налагоджений, оскільки захоронити відходи удесятеро дешевше, ніж відправити їх на переробку, а міська влада не наважується підняти ціну для населення.

Нині вивезення твердих побутових відходів (з ПДВ) за $1 \mathrm{~m}^{3}$ для населення і бюджетних організацій становить 56,40 грн, а для інших споживачів - 59,42 грн. Знешкодження твердих побутових відходів (з ПДВ) за $1 \mathrm{~m}^{3}$ для населення і бюджетних організацій коштує 65,40 грн, а для інших споживачів $-68,14$ грн [5].

Використовується метод захоронення усіх відходів на полігоні зі всіма його недоліками, через що система поводження 3 ТПВ потребує переходу на більш прогресивні методи вирішення проблеми. Тому в перспективі оптимальною схемою поводження з ТПВ є роздільний збір ресурсоцінних матеріалів із подальшим їх сортуванням на сміттєсортувальному комплексі і утилізацією невідсортованого залишку на сучасному полігоні з перспективою поетапного впровадження новітніх технологій.

Для вивезення будівельних і побутових великовантажних відходів мешканець або юридична особа повинні укласти додаткову угоду 3 підприємством, яке обслуговує житловий фонд, або з перевізником ТПВ. Існують особливі види відходів, які утворюються населенням, проте поводження 3 ними не здійснюється в рамках системи поводження з ТПВ. До них відносяться побутові миючі та інші хімічні засоби; батареї та акумулятори; фарби та хімікати побутового призначення; продукти садівництва (пестициди, добрива); протерміновані медикаменти та медичні відходи; відходи електричного та електронного обладнання; відпрацьовані транспортні засоби або їх складники; інші небезпечні відходи. Щодо цих відходів розроблено або планується розробити окремі програми.

Нині ці види відходів збираються разом з іншими ТПВ та захоронюються на полігоні, де вони становлять серйозну небезпеку для довкілля та здоров’я населення. Це $\epsilon$ екологічно неприпустимо, тому у населених пунктах необхідно створювати альтернативні методи збирання та переробки небезпечних побутових відходів. Створення та запровадження єдиної системи збору та утилізації відходів побутового електронного та електричного устаткування є запорукою реалізації повного циклу збору та утилізації відповідних відходів 3 метою їх зменшення їх впливу на довкілля.

У Кременці, як і в багатьох містах нашої держави, гостро стоїть питання сортування сміття, зокрема пластику, адже він природнім шляхом розкладається понад сотню років. Окрім того, спалювати поліетилен не можна, тому що при горінні він виділяє шкідливі для організму людини речовини. Нині у Кременці роблять перші кроки до сортування сміття. Так, у місті вже встановлені контейнери для збору ПЕТ-пляшок. Комунальне підприємство «Міськводгосп» Кременецької міської ради сортує зібраний пластик за кольором і пресує його з метою майбутньої переробки. За 40 хв. пресується 1 тюк вагою 22 кг. Окремо сортуються кришечки (рис. 1).

Вперше у Кременці окремі контейнери для збору скла, металу, паперу та пластику були встановлені за підтримки ГО «Кременецька екологічна ліга». На початку 2018 року відбулося засідання представників цієї організації та органів місцевого самоврядування, на якому вирішували питання можливості закупівлі контейнерів для роздільного збирання ТПВ для шкіл, садочків та інших організацій міста.

Було вирішено придбати їх для Національного природного парку «Кременецькі гори» та НВК «Кременецька загальноосвітня школа I-III ступенів № 5 - дошкільний навчальний заклад». Контейнери були закуплені у запорізької екоорганізації «Кольорові відра», яка практикує розділене збирання відходів у Запоріжжі, Дніпрі та Одесі. Вартість контейнерів становила 90 гривень за одиницю, нині ж вона зросла до 150 грн. Контейнери були виготовлені із цупкого екокартону і могли вмістити сміттєві мішки вагою на 120 літрів. Згодом члени ГО «Кременецька екологічна ліга» встановили ще 8 контейнерів для сортування ТПВ у двох навчальних корпусах Кременецької обласної гуманітарно-педагогічної академії ім. Тараса Шевченка.

Незважаючи на контейнери, встановлені організацією, значна кількість сміття не відсортовується. Якщо ж вона і сортується, то це не завжди відбувається за встановленими правилами. Люди не завжди дивляться, що й у якому вигляді вони кидають до контейнера. Це свідчить про те, що громадяни не знають основних правил сортування сміття або не усвідомлюють, для чого це робити. Нині це відсортоване сміття зберігається на складах, проводяться пошуки його переробників, які були б географічно близько розташовані, щоб здача вторинної сировини не була збитковою.

ГО «Кременецька екологічна ліга» проводила інформаційні кампанії щодо збору батарейок у супермаркетах міста. Також вона спільно 3 Кременецькою обласною гуманітарно-педагогічною академією ім. Тараса Шевченка кілька років поспіль проводить еко-пікніки, які популяризують екологічну свідомість містян і мають просвітницьку мету. Відбуваються еко-пікніки в рамках реаліза- 


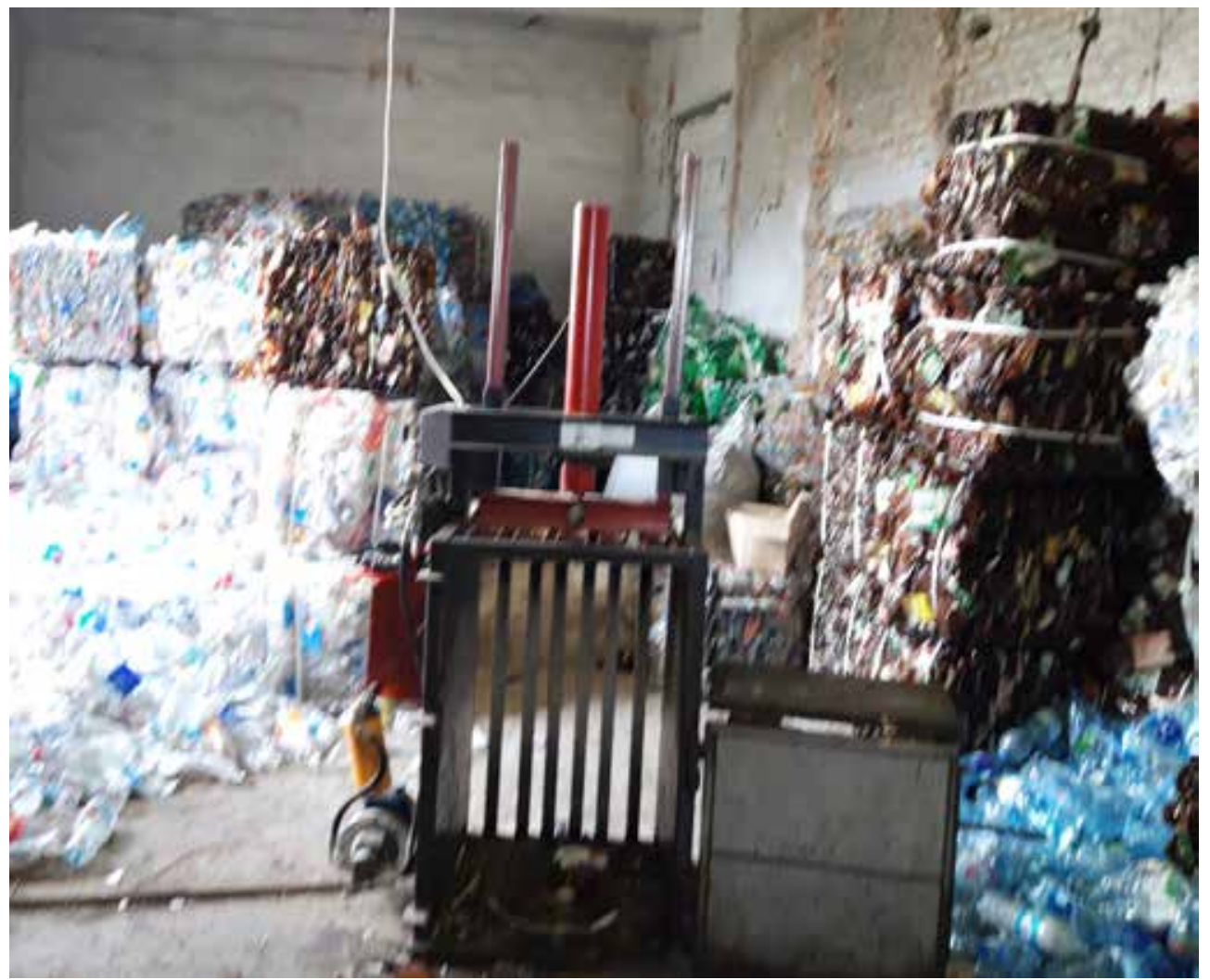

Рис. 1. Склад КП «Міськводгоспу», в якому пресують ПЕТ-пляшки

ції міжнародної грантової програми «Культура, освіта та громада: шляхи до об'єднання» від DVV Internationale та за сприяння Кременецької міської ради у Кременецькому парку культури і відпочинку, під час яких проводиться багато дослідів, експериментів, демонстрацій і майстер-класів.

Гарним прикладом поводження з відходами серед шкіл Кременця є Кременецька спеціалізована школа I-III ступенів № 2. У школі розвивають екологічну грамотність учнів, просто і наочно вчать дітей сортувати сміття, разом беруть участь в масштабних екологічних проєктах. Нині у школі існує повноцінна система сортування відходів, за якої учні окремо утилізують пластик, папір, метал, використані батарейки і скло. Рух до такої системи був поступовим, а почався він із окремого контейнеру для відпрацьованих елементів живлення.

Навесні 2019 року команда Кременецької спеціалізованої школи I-III ступенів № 2 брала участь у проєкті Zero Waste School. Учні цієї школи потрапили до п’ятірки освітніх закладів Тернопільщини, які стали учасниками проекту. Після повернення 3 першої частини проєкту “Zero Waste School” учасники провели тренінг для школярів, батьків і шкільного персоналу, на якому навчали їх правильному сортуванню сміття в рамках Всеукраїнського проекту Zero Waste School Kremenets. У подарунок навчальний заклад отримав прес для пластикових пляшок.

Нині триває розробка Регіонального плану управління відходами у Тернопільській області до 2030 року. Замовником є Управління екології та природних ресурсів Тернопільської ОДА, розробником - Тернопільський національний економічний університет. План мають завершити до лютого 2021 року. Зі слів членів робочої групи, в області планується 4 кластери щодо управління поводження 3 твердими побутовими відходами: Тернопільський, Чортківський, Бережанський i Кременецький, до останнього відноситься і громада Кременця.

Кременецький кластер охоплюе три міста: Кременець, Шумськ i Ланівці. Поблизу міста Кременець (у селі Білокриниця) вже відведено місце під полігон для відходів, закладається сміттєпереробне підприємство потужністю 160 тонн на добу, є сортувальна лінія, але вона ще не працює. Планується біоферментація органічних ТПВ для виробництва органічних добрив [6].

Рекомендуємо практичні поради щодо зменшення побутових відходів:

1. Виділіть окреме місце для відсортованого сміття. Необов'язково мати окремі контейнери для кожного виду сировини - відсортувати можна і перед здаванням сміття на станцію.

2. Підготуйте сировину: помийте іiі від залишків їжі та висушіть. Відокремлюйте частини пакування з різних матеріалів. Знімайте металеві кришки 3 пляшок, кришки 3 фольги, 3 йогуртів чи сметани. Зменшіть об'єм пакувального матеріалу: випустіть повітря з пляшок і скрутіть їх, розкладіть коробки та упаковки Tetra Pak, спресуйте залізні бляшанки. 
Це допоможе підвищити ефективність збору сортованого сміття та заощадить місце.

3. Уникайте пластику. По можливості відмовтеся від пластикової тари на користь дерев'яної, скляної, порцелянової або металевої.

4. Уважно слідкуйте за маркуванням пластикової продукції. Не купуйте тару, якщо на ній відсутнє маркування, або віддавайте перевагу пластиковому пакуванню з маркуванням 1 або 2.

5. Компостуйте органіку. Якщо ви живете у приватному будинку і маєте ділянку землі, то органіку можна компостувати і перетворювати на натуральне добриво. Якщо у багатоквартирному, то можна використовувати спеціальні або саморобні компостери, хробачків чи ЕМ-препарати.

6. Будьте свідомими та відмовтеся від одноразових речей, ходіть до магазину зі своєю екоторбинкою, каву з собою беріть у свою чашку. Багато кав'ярень роблять знижки, коли люди замовляють каву у свою кружку. Одне із кафе міста Кременець ("Black and White") робить саме таку знижку.

7. Користуйтеся мобільним додатком «Сортуй».

8. Дотримуйтеся 5 принципів філософії "Zero Waste", або «Нуль втрат».

Вважаємо за доцільне встановлення контейнерів для окремого збору органічних відходів поблизу багатоповерхівок міста Кременця, оскільки в них проживає половина кременчан. У приватних будинках і селах із цим проблем немає, адже там споконвіку окремо сортували органіку, яка потім використовувалася на удобрення полів.

Згідно досліджень, 1/4 (26\%) сміттєвого відра середньостатистичного жителя міста займають харчові відходи [7]. Ця органіка утворює метан (парниковий газ), вона потрапляє на полігон, де взаємодіє із важкими металами, батарейками, люмінесцентними лампами і формує фільтрат - дуже отруйну речовину, яка, потрапляючи у грунтові води, спричиняє онкозахворювання у людей. Вирішивши проблему 3 харчовими відходами, ми на чверть вирішимо проблему сміття. Тим паче, що поблизу Кременця (в селі Білокриниця) передбачена сміттєсортувальна лінія, а також установка біоферментації органічних твердих побутових відходів для виробництва органічних добрив, куди можна буде відвозити органіку.
Головні висновки. Поводження 3 відходами у місті Кременці зводиться до того, що відходи збираються в контейнери і вивозяться на сміттєзвалище. Однак вже зроблено перші кроки у сортуванні. Так, нині окремо збирається ПЕТ-пластик, у деяких освітніх і наукових закладах міста $€$ сортувальні баки для скла, металу, паперу та пластику. У місті майже немає пунктів прийому вторинної сировини, скло, папір і метал приймають лише окремі підприємці. Вважаємо за доцільне впроваджувати окремий збір органіки і розташовувати сортувальні баки по всьому місту.

Перспективи використання результатів дослідження. Велику кількість відходів, які продукує кожен житель міста, можна скоротити, якщо знати як. Плануємо розробити проєкт на громадський бюджет щодо закупівлі контейнерів для роздільного збору ТПВ і створити Регіональний еколого-просвітницький центр «ЕКОХАБ KREMENETS» на базі Кременецької обласної гуманітарно-педагогічної академії ім. Тараса Шевченка. Мета центру: просвітницька, навчальна та надихаюча. Завдання екохабу: формування екологічних звичок серед молоді, впровадження навчального курсу «Екологічний стиль життя» серед вибіркових дисциплін студентів КОГПА ім. Тараса Шевченка, ознайомлення із філософією «Нуль втрат», роздільне збирання ТПВ у навчальному закладі та збір батарейок, створення бібліотеки сучасних екологічних видань, виставка еко-товарів, дружніх до навколишнього середовища, як альтернатива одноразовим речам, майстер-класи із сортування відходів, проведення просвітницьких кампаній та екологічних акцій, консультування бізнесу.

Причини нагромадження великої кількості відходів: низька екологічна свідомість людей, нестача елементарних знань про сортування відходів, недостатня обізнаність про альтернативні продукти, якими можна замінити одноразові речі, недостатній рівень екологічної освіти і екологічного виховання у дитсадках, школах і вузах, недостатня увага до екологічних проблем з боку влади на різних рівнях. Свідоме споживання та сортування відходів має стати не тільки модним, стильним і молодіжним, а й життєво необхідним для довкілля, економічно вигідним.

\section{Лiтература}

1. Проблема побутових відходів і сміттєзвалищ в Україні. URL: https://ns-plus.com.ua/2017/08/15/tonemo-problemapobutovyh-vidhodiv-ta-smittyezvalyshh-v-ukrayini-2/.

2. Войціховська А., Кравченко О., Мелень-Забрамна О., Панькевич М. Кращі європейські практики управління відходами [за заг. ред. О. Кравченко]. Львів, 2019. 64 с.

3. Я хочу сортувати сміття. URL: https://nv.ua/ukr/spec/ya-hochu-sortuvati-smittya-ce-skladno-z-chogo-meni-pochati-50035473.html.

4. Закон України «Про відходи». URL: https://zakon.rada.gov.ua/laws/show/187/98-\%D0\%B2\%D1\%80\#Text.

5. Програма поводження з ТПВ у м. Кременці, Кременецькому районі на 2018-2022 роки (№ 1045, додаток). URL: https://drive.google.com/drive/folders/1u2GjOVX_xEWCUG2TXJLA4RUBDZk4VTbN.

6. Програма поводження з ТПВ у Тернопільській області на 2018-2020 роки. URL: http://www.oda.te.gov.ua/data/upload/ publication/main/ua/855/1285.pdf.

7. Кропівний В.М., Медведева О.В., Кропівна А.В. Утилізація та рекуперація відходів [за заг. ред. В.М. Кропівного]. Кропивницький : КОД, 2019. 243 с. 


\title{
ПРОБАЕМИ ЕКОАОГО-ЗБАМАНСОВАНОГО POЗBИTKY
}

\author{
УДК 378+502/504 \\ DOI https://doi.org/10.32846/2306-9716/2020.eco.6-33.21
}

\section{ФОРМУВАННЯ ЕКОСВІДОМОСТІ СТУДЕНТСЫКОЇ МОАОДІ КРІЗЬ ПРИЗМУ ЕКОАОГІЗАЦІї ТУРИЗМУ}

\author{
Борущька Ю.З., Дудяк Р.П., Бугіль С.Я. \\ Львівський національний аграрний університет \\ вул. В. Великого, 80381, м. Дубляни, Львівська обл. \\ borutska_yulya@ukr.net,dudiak_roman@i.ua,s_bugil@ukr.net
}

Серед основних передумов виникнення екологічного туризму провідну роль відіграє наростання протиріч між задоволенням туристичного попиту та раціональним використанням природних ресурсів. Тому екологізація туристичної діяльності нині посідає одне $з$ чільних місць.

У найважливіших міжнародних документах останніх десятиліть, присвячених проблемам навколишнього середовища і гармонійного розвитку людства, особлива увага приділяється екологічній освіті, культурі та свідомості, інформованості людей про екологічні ситуації, їхній обізнаності 3 можливими шляхами вирішення різних екологічних проблем. Центрами організації еколого-освітньої діяльності, цілеспрямованого впливу на світогляд, поведінку населення повинні бути природно-заповідні установи, профільні освітні заклади.

Екологізація свідомості населення відбувається досить повільними темпами. Тому для розробників туристичного продукту повинно діяти «золоте» правило: надання туристичних послуг не має супроводжуватися погіршенням характеристик стану природного довкілля (засміченням території, витоптуванням рослинного покриву, пошкодженням і випалюванням чагарників і дерев). Низький рівень екологічної свідомості туристів $є$ причиною багатьох варварських вчинків і свідчить про неготовність населення займатися екологічними видами туризму.

Як казав Іван Павло II: «При кожному втручанні в певну сферу екологічної системи не можемо відмовитися від зважування наслідків цього втручання в інші сфери і його наслідків на благостановище майбутніх поколінь. Екологічний туризм приводить людей до місць, країв чи регіонів, природня рівновага яких потребує постійного догляду, щоб не бути пошкодженою. Тому необхідно сприяти проведенню досліджень і суворого контролю, щоб привести у відповідність повагу до природи і право людини використовувати ії для власного розвитку».

Тому стає дедалі очевиднішим, що мешканці, особливо міських територій, починають усвідомлювати потребу людини абстрагуватися від щоденного побуту, відпочити в інших умовах, поліпшити власний психоемоційний стан поза урбанізованим середовищем. Завдяки своїм величезним рекреаційним і пізнавальним можливостям екологічний туризм, окрім відпочинку, має за мету ще й сформувати суспільну свідомість щодо охорони та раціонального використання природних багатств, донести до людей нагальність і важливість питань захисту навколишнього середовища. Ключові слова: екологічна освіта, екологічна свідомість, екологічний туризм, студентська молодь, раціональне використання природних ресурсів.

Formation of eco-consciousness of student young people through the prise of environmental tourism. Borutska Yu., Dudiak R., Bugil S.

Among the main prerequisites for the emergence of ecological tourism the leading role is played by the growing contradictions between the pleasure of tourist demand and the rational use of natural resources. Despite this, the greening of tourist activity now occupies one of the leading places.

At the same time, in the most important international documents of recent decades, devoted to environmental problems and the harmonious development of mankind, special attention is paid to environmental education, culture and awareness, informing people about the environmental situation, their awareness of possible ways to solve various environmental problems. And the actual centers of the organization of environmental education, purposeful impact on the outlook, behavior and activities of the population should be natural-reserve institutions, specialized educational institutions.

Ecologization of consciousness of the population is going on, but at a slow pace. Therefore, the developers of tourist product should follow the "golden" rule: provision of tourist services should not be accompanied by deterioration of characteristics of natural environment (littering of territory, trampling of vegetation cover, damage and burning of bushes and trees, etc.). Such a factor as the low level of ecological consciousness of tourists is the cause of many barbaric acts and indicates the unreadiness of the population to engage in ecological forms of tourism.

As John Paul II says: "With every intervention in a certain sphere of the ecological system we cannot refuse to weigh the consequences of this intervention in other spheres and, in general, its consequences on the welfare of future generations. Ecological tourism leads people to places, edges or regions whose natural equilibrium requires constant care not to be damaged. Therefore, it is necessary to promote research and strict control, in order to reconcile the respect for nature and the human right to use it for their own development". 
So, it is becoming increasingly evident that the inhabitants of especially urban areas are beginning to realize the human need to abstract from everyday life, to rest in a different environment, to improve their psycho-emotional state outside the urbanized environment. And thanks to its enormous recreational and educational opportunities, eco-tourism, except for recreation, is also intended to form a social consciousness of the protection and rational use of natural resources, to make people aware of the relevance and importance of environmental protection issues. Key words: environmental education, ecological consciousness, ecological tourism, students, rational use of natural resources.

Постановка проблеми. Реальне загострення екологічних проблем в останні десятиліття змусило людство уважніше ставитися до аналізу сценаріїв нашого майбутнього розвитку. Діяльність людини набула форм, не притаманних для природи, що призводить до різних видів забруднення, механічного перетворення природних об'єктів та їхньої деградації. Усе це спричинило загрозу здоров'ю людини та залишило на межі виживання-вимирання багато видів флори і фауни. Зворотним боком господарської діяльності є й виснаження тих видів природних ресурсів, які використовуються подекуди украй нераціонально.

Сучасна екологічна криза - час неминучих роздумів і пошуків виходу. Народжуються нові бачення, методики, інноваційні технології, здатні хоча б пом'якшити глобальні протиріччя між природою і суспільством. Ідеї загальної екологізації проникають і в сучасну еколого-туристичну індустрію, починаючи від м'якших форм екоінновацій підприємницької діяльності і аж до імперативних вимог сталих форм туризму, зокрема екологічного. Одними iз найефективніших засобів екологічного розвитку $\epsilon$ сталі форми туризму, оскільки громадяни зацікавлені у збереженні максимально непорушених природних і природно-антропогенних систем, у рамках яких можна з успіхом здійснювати еколого-освітню, рекреаційну та природоохоронну функції.

Екологічний туризм - це один із найефективніших засобів екологічного виховання, тому що він надає широкі можливості будь-яким категоріям туристів для формування і розвитку цілісного ставлення до навколишнього світу з паралельним отриманням знань у різних галузях (біології, екології, географії, краєзнавства, загальної історії). 3 розвитком суспільства туризм набув різних значень і розгалужень, проте саме екологічний туризм включає усі його види, орієнтовані на збереження природи, налагодження доброзичливих стосунків із місцевим населенням та органами самоврядування. Саме тому цей напрям туризму добре виконує функцію екологічної освіти [1-3].

Актуальність дослідження. Формування екологічної свідомості повинно розпочинатися значно раніше, ніж дитина переступає шкільний поріг, iз раннього дитинства. Перші слова про велич природи, iii дивну різноманітність, беззахисність і вичерпність вона має почути від своїх батьків, у дитячому садочку, а потім - на перших шкільних уроках. Саме тут екологічне виховання повинно бути продуманим, ненав'язливим, а форми роботи підібрані таким чином, щоб уся інформація проходила крізь душу дитини, залишаючи в ній чітке уявлення про чуйне ставлення до усього живого.

Важливо, щоб діти усвідомили, що людина - не лише природокористувач, а й частина природи, іiі майбутнє. Цьому значно сприятиме дослідницька робота студентів, оскільки вона поєднує теоретичні знання із життям, навчання - 3 працею, підвищуючи якість знань, нівелюючи теоретично-практичний бар'єр в освітньому процесі. Недарма у найважливіших міжнародних документах останніх десятиліть, присвячених проблемам навколишнього середовища і гармонійного розвитку людства, особлива увага приділяється екологічній освіті, культурі і свідомості, поінформованості людей про екологічні ситуації, їхній обізнаності з можливими шляхами вирішення різних екологічних проблем. Центрами організації екологічної освіти, цілеспрямованого впливу на світогляд, поведінку і діяльність населення повинні бути природно-заповідні установи, профільні навчальні заклади [3].

Зв'язок авторського доробку 3 важливими науковими та практичними завданнями. На нашу думку, на сучасному етапі особливо важливо знівелювати «теоретично-практичний бар'єр» між класичним навчальним процесом і практичним його застосуванням або виявом у конкретних ситуаціях. Вважаємо, що саме такі механізми є передумовою для впровадження дуальної освіти в українських освітніх закладах.

Так, і у Львівському національному аграрному університеті, і в Екологічному фаховому коледжі ЛНАУ протягом тривалого часу значна кількість годин відведена на практичне навчання, а саме на навчальні, виробничо-технологічні, виробничо-переддипломні практики, серед яких «Екологічні маршрути», «Екологічні стежки» для студентів спеціальностей «Туризм», «Екологія». Ми стверджуємо, що така філософія освіти може бути реалізована через екологічні маршрути та стежки як втілення освітньої, туристичної і природоохоронної діяльності. Адже екологічна стежка (маршрут) водночас i $є$ базовою основою туристичного продукту (рис. 1).

На основі набутих теоретичних знань і практичних навичок студенти-випускники вміло застосовують основні положення законодавства України, зокрема, екологічного; аналізують природоохоронні території, землі природно-заповідного фонду з точки зору туристичного потенціалу; організовують екологічні маршрути на природоохоронних територіях; проєктують екологічні стежки; використовують основні пріоритети діяльності у сфері екологізованих форм туризму; започатковують еколого-про- 


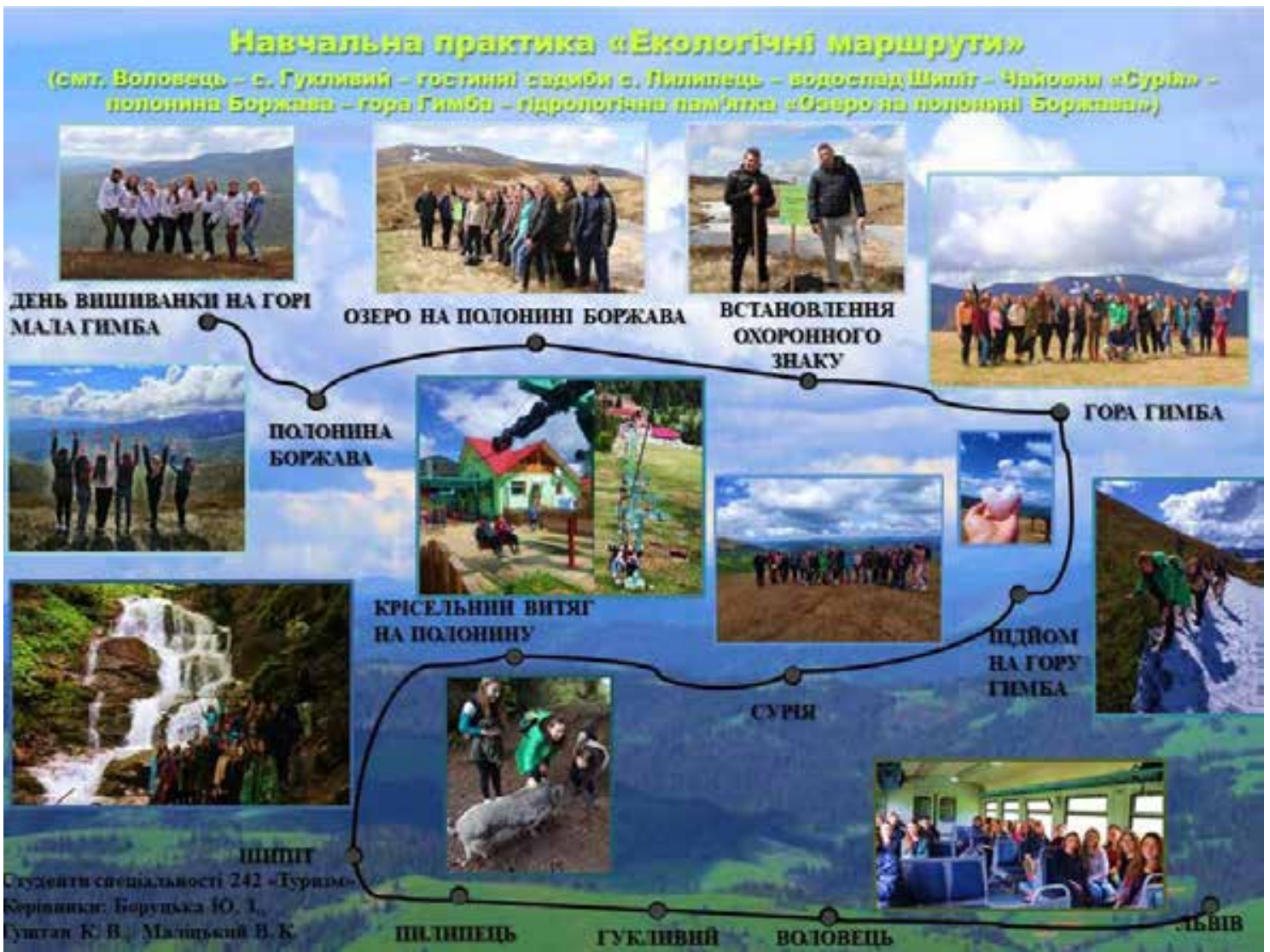

Рис. 1. Студенти III курсу спеціальності 242 «Туризм» Екологічного фахового коледжу ЛНАУ під час проходження навчальної практики «Екологічні маршрути»

світницькі заходи та здійснюють виховну діяльність серед студентів і молоді. Багаторічні напрацювання щодо цієї проблематики і висвітлені у публікаціях авторів $[1 ; 4 ; 5]$.

Аналіз останніх досліджень і публікацій. Необхідно зазначити, що в розвинених державах розроблені та вдосконалюються різні концепції розвитку екологічної освіти, програми й плани підготовки спеціалістів-екологів сучасного рівня. Поняття екології й охорони довкілля стали обов'язковими поняттями і навіть дисциплінами у закладах освіти усіх рівнів, проводяться сотні екологічних національних і міжнародних семінарів, конференцій, з’іздів. Еколого-просвітницьку роботу забезпечують організації «зелених», громадські об'єднання, товариства з охорони природи.

Ці важливі для цивілізації процеси екологізації свідомості населення, формування нового екологічного світогляду, нової екологічної культури цілком характерні й для України. Останніми роками у нашій державі розроблено програми й концепції розвитку екологічної освіти й виховання, видано посібники й підручники $з$ екології, створено десятки кафедр і факультетів екологічного профілю у закладах вищої освіти, започатковано багато журналів загально-екологічного, еколого-економічного, еколого-географічного змісту.
Так, період із 2005 по 2015 роки на Всесвітньому Саміті в Йоганнесбурзі було рекомендовано оголосити десятиліттям освіти для еколого-збалансованого розвитку. В Україні відбулася низка важливих подій, пов'язаних із розвитком екологічної освіти: наприкінці 2001 року було затверджено Концепцію екологічної освіти України, на початку 2002 року план заходів з іiі реалізації, того ж року до Верховної Ради було подано проєкт Закону України про екологічну освіту, який, на жаль, так і не був прийнятий.

Науковий доробок українських вчених щодо питань екологічної освіти дуже насичений. Це грунтовні праці Г. Білявського, Н. Пустовіт, Н. Гудкової, В. Пестунова, О. Стеценка, О. Головко, К. Кликової, В. Гуляєвої, О. Проценко. Щодо досліджень у контексті екологічного туризму, то тут необхідно згадати, що вагомий внесок зробили науковці О. Бейдик, В. Вишневський, О. Дмитрук, Т. Сорокіна, В. Борейко, В. Кекушев, В. Храбовченко [6-8].

Виділення не вирішених раніше частин загальної проблеми, котрим присвячується означена стаття. 3 огляду на концепцію екологічної освіти України їі основною метою $є$ формування екологічної культури окремих осіб і суспільства загалом, професійних навичок, фундаментальних екологічних знань, екологічного мислення і свідомості, які грунтуються на ставленні до природи як уні- 
версальної, унікальної цінності. Екологічна освіта повинна бути самостійним елементом загальної системи освіти і виконувати інтегративну роль у цій системі. Така мета досягається шляхом вирішення освітніх і виховних завдань і вдосконалення практичної діяльності в контексті сталих екологізованих форм туризму [9; 10].

Необхідно брати до уваги думку Папи Римського Івана Павла II про те, що «екологічний туризм $\epsilon$ ключем до сталого розвитку, доброю нагодою для роздумів про явище людської мобільності, яке в минулих десятиліттях суттєво розвинулося і нині стосується мільйонів людей. Туризм дає можливість використовувати частину нашого вільного часу для споглядання Божої доброти і краси у його створінні. Завдяки контактам із ближніми, він також допомагає поглибленню діалогу і взаємному пізнанню. У такий спосіб дозвілля і практика туризму можуть заповнити прогалини людськості, які ми так часто досвідчуємо у повсякденному житті» [11].

На думку авторів, увагу необхідно звернути саме на реалізацію освітньої функції сталих екологізованих форм туризму за безпосереднього перебування студентсько-викладацького колективу на лоні природи, під час практичних занять, навчальних, навчально-виробничих і навчально-переддипломних практик.

Новизна. Екологізація свідомості населення відбувається досить повільними темпами. Тому для розробників туристичного продукту повинно діяти «золоте» правило: надання туристичних послуг не має супроводжуватися погіршенням характеристик стану природного довкілля (засміченням території, витоптуванням рослинного покриву, пошкодженням і випалюванням трави, чагарників, дерев). Низький рівень екологічної свідомості туристів часто є причиною багатьох варварських вчинків і свідчить про неготовність населення займатися екологічними видами туризму. Зі слів Папи Римського Івана Павла II, «нині поширюється нова екологічна свідомість, відома під назвою «екологічний туризм». Її основні передумови є добрими. Однак необхідно зважати на те, щоб вона не була викривлена і не стала інструментом експлуатації та дискримінації. Коли захист довкілля стає самоціллю, ми стаємо перед загрозою виникнення нових форм колоніалізму, що порушують права місцевих спільнот, які проживають на певній території. Це могло б призвести до перешкод на шляху подальшого існування і розвитку місцевих культур, до позбавлення місцевих урядів, які є відповідальними за екологічні системи і багате біологічне різноманіття у відповідних регіонах, економічних ресурсів» [11].

Методологічне або загальнонаукове значення. Сфера туризму має широкі можливості для формування науково-освітнього та культурного рівня соціуму, адже саме в вільний час у процесі туристично-рекреаційної діяльності ефективніше відбу- вається засвоєння нових понять, фактів, інформації. Сучасний туризм сприяє вихованню осіб, які прагнуть володіти екологічною культурою, біосферним світоглядом, науковими знаннями, екологічною свідомістю, готові приймати рішення і відповідати за них. У цьому і полягає, на нашу думку, головна роль еколого-освітньої функції щодо формування екосвідомості в контексті сталих екологізованих форм туризму.

Іван Павло II казав: «При кожному втручанні в певну сферу екологічної системи ми не можемо відмовитися від зважування наслідків цього втручання в інші сфери і його впливу на становище майбутніх поколінь. Екологічний туризм приводить людей до місць, країв чи регіонів, природна рівновага яких потребує постійного догляду, щоб не бути пошкодженою. Тому необхідно сприяти проведенню досліджень i суворого контролю, щоб привести у відповідність повагу до природи і права людини використовувати iї для власного розвитку» [11].

Виклад основного матеріалу. Можна стверджувати, що екологічна освіта $є$ украй важливою для сталого розвитку туризму у світі та нашого спільного майбутнього. Проте існує низка запитань щодо змісту екоосвіти, іiі головної мети, масштабів, ефективності, законодавчо-правової бази. Отже, екологічна освіта в сучасному розумінні - це постійний процес наслідування та поглибленого відтворення людиною екологічної культури, покликаної протистояти віковому імперативу підкорення природи.

Завданням екологічної освіти є формування екологічної свідомості особистості. Вона конкретизується на рівні трьох основних завдань:

- формування адекватних екологічних уявлень, відповідальних суспільних позицій щодо навколишнього середовища;

- формування навичок кваліфікованих, професійних дій щодо навколишнього середовища;

- формування системи вмінь і навичок (технологій) взаємодії з природою.

Екологічна освіта передбачає створення системи екологічної освіти, підготовки кадрів і підвищення кваліфікації для всіх вікових і професійних категорій населення; удосконалення координації між зацікавленими органами виконавчої влади та навчальними закладами у сфері екологічної освіти; створення інформаційно-методичних центрів екологічної освіти; включення у необхідному обсязі екологічних знань до стандартів освіти, кваліфікаційних вимог, паспортів спеціальностей; введення до навчальних програм усіх освітніх закладів як однієї з базових дисциплін курсу «Основи екологічних знань»; гармонізацію програм екологічних дисциплін закладів вищої освіти України з програмами провідних європейських вищих наукових закладів, які приєдналися до Болонського процесу; забезпечення систематичного ведення у засобах масової інформації еколого-виховних та освітянських програм $з$ питань захи- 
сту довкілля; розроблення організаційних механізмів локального, регіонального та національного рівнів для активного залучення громадянського суспільства у процес екологічної освіти; впровадження програми підтримки на конкурсних засадах проєктів екологічних неурядових організацій з інформаційної та освітньо-просвітницької діяльності.

У Законі України «Про Основні засади (стратегію) державної екологічної політики України на період до 2030 року» освіта в інтересах сталого розвитку дасть змогу встановити методологічні основи та запровадити безперервну екологічну освіту. Випереджаючими темпами має розвиватися всеохоплююча екологічна просвіта та виховання підростаючого покоління шляхом підтримки діяльності позашкільних закладів освіти, еколого-натуралістичних центрів і природничих секцій центрів дітей та юнацтва, профільних громадських організацій $[9 ; 10]$.

Екологічна освіта та виховання спрямовані на формування світогляду, мислення поведінки людини в усьому багатоманітті іiі стосунків із довкіллям. Однією 3 найважливіших умов екологічної освіти є необхідність закріпити у суспільстві усвідомлення того, що природні багатства не безмежні. Моделлю збалансованого використання природних ресурсів i компромісною формою наближення дикої при- роди до сучасної людини стають сталі екологізовані форми туризму, зокрема й екологічного, який насамперед здійснюється на територіях та об'єктах природно-заповідного фонду [1;2].

Саме природоохоронні території володіють величезним екоосвітнім потенціалом, а екологічна освіта входить до переліку основних завдань, покладених на ці об'єкти. По-перше, вони мають змогу демонструвати людям красу і багатство збереженої природи, залучати населення до безпосередньої природоохоронної діяльності. По-друге, там працює велика кількість кваліфікованих фахівців в області біології, екології, лісового господарства. По-третє, у заповідниках, національних парках, музеях наявна або створюється матеріально-технічна база для проведення еколого-просвітницьких туристичних заходів (рис. 2, 3).

Головні висновки. Нині стає дедалі очевиднішим, що мешканці, особливо міських територій, починають усвідомлювати потребу людини абстрагуватися від щоденного побуту, відпочити в інших умовах, поліпшити свій психоемоційний стан поза урбанізованим середовищем. Тому завдяки своїм величезним рекреаційним і пізнавальним можливостям екологічний туризм, окрім відпочинку, має за мету ще й сформувати суспільну свідомість щодо охорони та раціонального використання природних

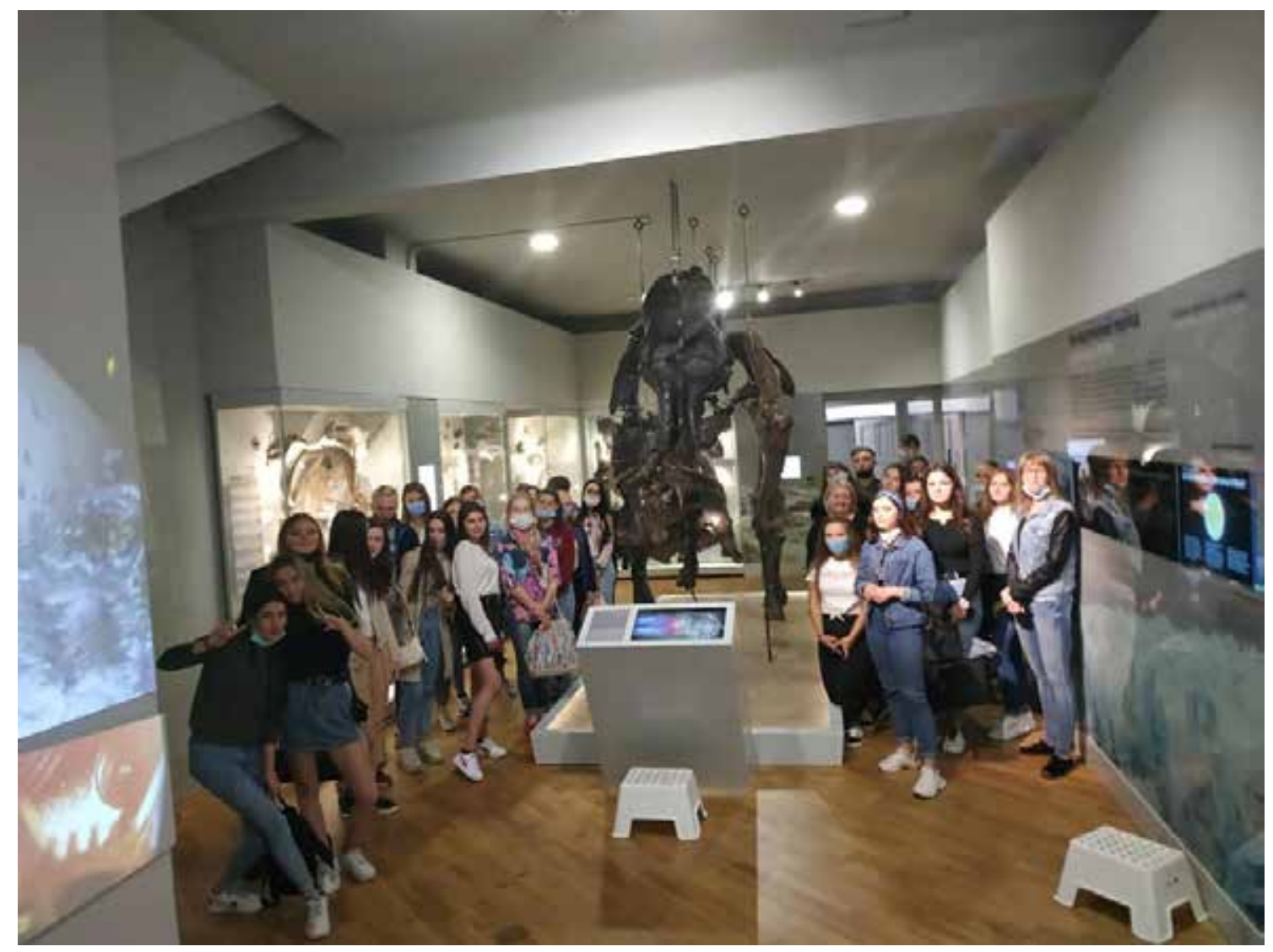

Рис. 2. Зі студентами Львівського національного аграрного університету у Державному природознавчому музеї НАН України (м. Львів) 


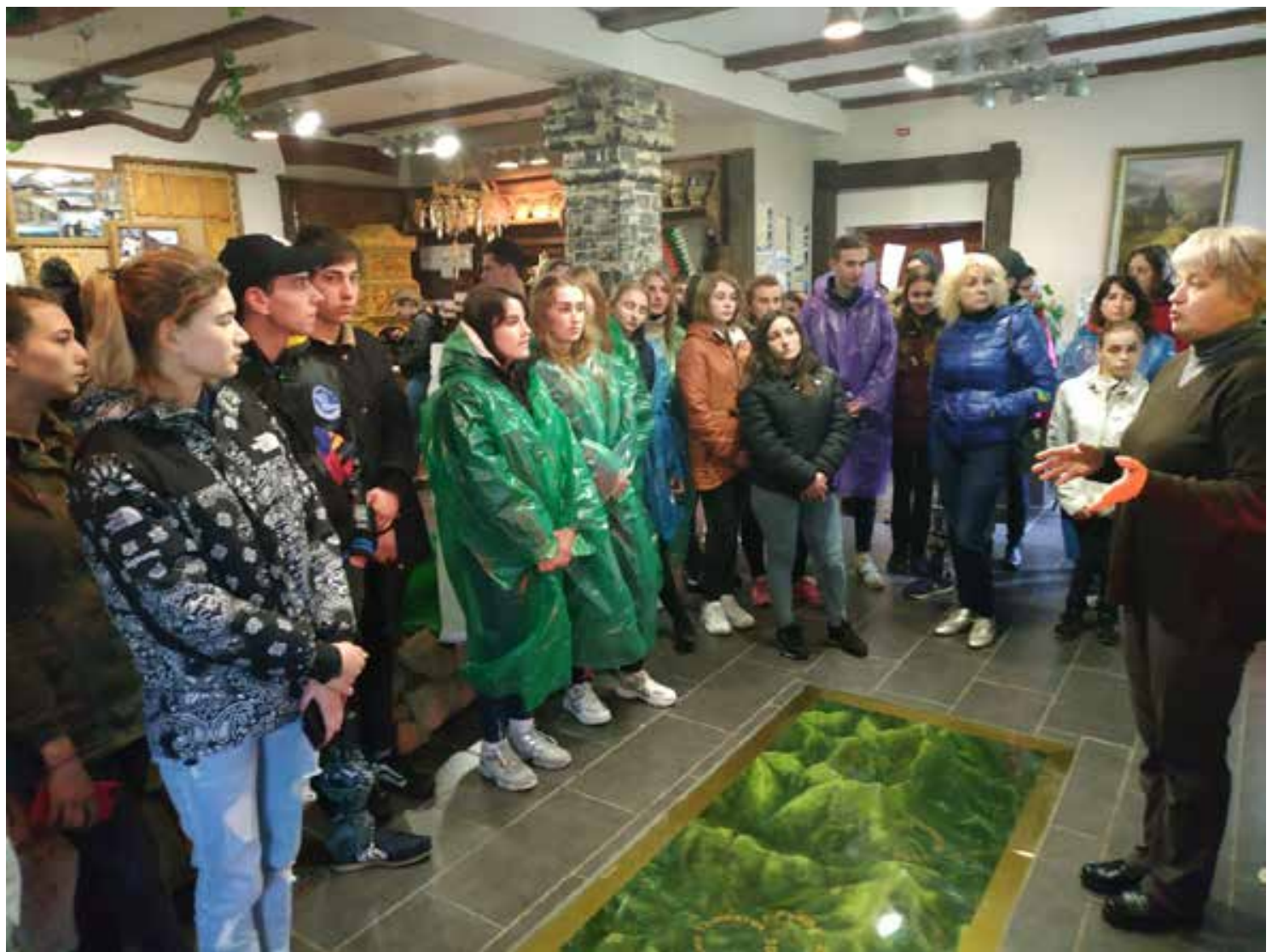

Рис. 3. Зі студентами Екологічного фахового коледжу ЛНАУ під час проходження навчальної практики «Екологічні стежки» в екотуристичному візитцентрі

Карпатського національного природного парку

багатств, донести до людей важливість питань захисту навколишнього середовища.

На думку Папи Римського Івана Павла II, «внутрішня екологія» дійсно сприяє «зовнішній екології» iз позитивними наслідками не лише для боротьби проти бідності та голоду, а й для власного здоров'я і доброго самопочуття. Формування цієї внутрішньої позиції необхідне для того, щоб перемогти культуру смерті і створити культуру життя» [11].

Перспективи використання результатів дослідження. Варто наголосити, що головні перспективи використання результатів дослідження полягатимуть саме у практичному застосуванні отриманих знань під час освітнього процесу. Найбільшого ефекту в питанні зростання екосвідомості під час підго- товки студентів природничого напряму, зокрема його еколого-туристичних аспектів, і у Львівському національному аграрному університеті, i в Екологічному фаховому коледжі ЛНАУ можна досягнути завдяки практичним особливостям освіти, тобто спостерігаючи-вивчаючи-пізнаючи «симбіоз» природних туристичних ресурсів (ландшафтних, орографічних, гідролого-гідрогеологічних, клімато-терапевтичних, бальнеологічних) з історико-культурними, архітектурними, сакральними пам'ятками, безпосередньо перебуваючи на тих територіях, де вони гармонійно поєднуються і вдало «співіснують» завдяки екосвідомому, раціональному впливу людини, збалансованому природокористуванню, підпорядковуючись законам сталого розвитку.

\section{Література}

1. Боруцька Ю.3. Практикум із методики створення еколого-туристичних стежок і маршрутів (з елементами сільського зеленого туризму) : навч.-метод. посібник. Львів : Екологічний коледж Львівського національного аграрного університету, 2020. $166 \mathrm{c}$.

2. Сорокіна Г.О. Екологічний туризм : навч. посібник. Луганський національний університет імені Тараса Шевченка. Луганськ, 2013. 206 с.

3. Максимів Л.І. Екологічна освіта в контексті парадигми сталого розвитку. Матеріали міжнародного науково-практичного семінару. Львів : Видавничий центр ЛНУ імені Івана Франка, 2009. 124 с.

4. Доценко Н.В., Боруцька Ю.З. Перспективність екологічного маршруту «Геологічна пам'ятка природи «Медова печера» лісовий заказник «Чортові скелі» у формуванні еколого-освітнього потенціалу учнівсько-студентської молоді. Біологічні дослідження - 2018 : збірник наук. праць. Житомир : ПП «Рута», 2018. С. 383-385. 
5. Боруцька Ю.З., Доценко Н.В. Деякі аспекти розвитку сільського туризму в Україні. Біологічні дослідження - 2019 : збірник наукових праць. Житомир : «Полісся», 2019. С. 311-313.

6. Шевченко Р.Ю., Доценко К.О. Диференційність рівнів екологічної освіти та екосвідомості при оцінці впливу сучасного ресурсо-природокористування на довкілля. Науково-практичний журнал. Екологічні науки. 2019. № 4(27). С. $215-221$.

7. Бобро О.В. Інформація природничо-наукового напряму як спосіб розвитку екологічної свідомості людини. Науковопрактичний журнал. Екологічні науки. 2019. № 4(27). С. 222-225.

8. Посохов І.С., Сагайдачна А.В. Перспективи розвитку екологічного туризму в Україні. Bicник ХНУ імені B.H. Каразіна. Серія «Міжнародні відносини. Економіка. Краӥнознавство. Туризм». 2019. Вип. 9. С. 203-212.

9. Закон України «Про Основні засади (стратегію) державної екологічної політики України на період до 2030 року». Київ, 2019. URL: https://zakon.rada.gov.ua/laws/show/2697-19\#Text (дата звернення: 20.12.2020).

10. Закон України «Про Стратегію національної екологічної політики України на період до 2020 року». Київ, 2011. URL: https://zakon.rada.gov.ua/laws/show/2818-17\#Техt (дата звернення: 21.12.2020).

11. Папа Іван Павло II на тему створіння та екології: пер. $з$ нім., допов. та упорядкув. / за ред. В. Шеремета. Івано-Франківськ : Екол. центр Івано-Франківської єпархії УГКЦ, 2006. 99 с. 


\title{
ДЕМОГРАФІЧНІ ПРОЦЕСИ ТА СТАН ЗДОРОВ'Я НАСЕАЕННЯ ЯК СТРИМУЮЧИЙ ФАКТОР СТАМОГО РОЗВИТКУ ЧЕРНІГІВЩИНИ
}

\author{
Єрмішев О.В., Бацилсва О.В., Кученко Т.А. \\ Донецький національний університет імені Василя Стуса \\ вул. 600-річчя, 21, 21021, м. Вінниця \\ o.yermishev@donnu.edu.ua
}

Сталий розвиток регіону тісно пов'язаний як із наявністю ресурсів, так і з певним їх поєднанням. Розвиток не можливий за відсутності одного з цих ресурсів, навіть якщо $є$ їх надлишок. До стратегічних ресурсів відноситься і «людський капітал», який включає не тільки вроджені здібності, таланти, отриману освіту і придбану кваліфікацію, але й загальний ресурс здоров'я населення, який безпосередньо впливає на його чисельність і працездатність.

Мета - виявлення регіональних особливостей демографічних, медико-статистичних процесів і захворюваності населення Чернігівщини.

Матеріали і методи. Для дослідження були використані щорічні статистичні звіти державних установ України та Чернігівської області із загальної захворюваності, захворюваності за видами, щодо демографічних змін складу та кількості населення. Використовували методи медичної та демографічної статистики, ретроспективний аналіз здоров'я населення за демографічними та медико-статистичними показниками, бібліосемантичний метод і метод системного аналізу.

Результати. Під час дослідження було виявлено та проаналізовано особливості демографічних і медико-статистичних процесів Чернігівської області: збільшення показників смертності, від’ємний природний приріст населення, порівняно високу смертність чоловіків і рівень демографічної старості населення, зниження сумарного коефіцієнту народжуваності.

За останні 20 років чисельність населення Чернігівської області зменшилася на $26,44 \%$, в той час як населення України за цей період зменшилося на $18,1 \%$. На 25,02\% знизився загальний коефіцієнт народжуваності, спостерігається підвищення загального коефіцієнту смертності на 1,76\%. За статистичними даними, основними причинами смертності у 2019 році були хвороби органів кровообігу - 73,65\%; травми, отруєння та інші наслідки зовнішніх факторів - 15,39\% та новоутворення (загальна кількість) - 10,96\%. За цей період загальна чисельність населення дитячого віку в області зменшилася на $45 \%$ при зниженні динаміки показника смертності дітей до одного року удвічі. Спостерігається регресивний тип вікової структури за рахунок збільшення населення похилого віку, яке сумарно збільшилося до 19,44\%.

Висновки. Стан стійкості Чернігівщини значно погіршується через сучасні тенденції розвитку народонаселення. Проблемою залишається загальне падіння народжуваності і зростання смертності населення (в тому числі і у працездатному віці), що зумовлює інтенсифікацію процесів депопуляції населення в більшості регіонів України і Чернігівщини зокрема. Виявлені демографічні процеси стану народонаселення України свідчать про глибоку демографічну кризу, яка 31991 року супроводжується загальним зменшенням чисельності населення, яке в Україні зменшилося на 9,7 млн осіб, а у Чернігівській області - на 361,5 тис.

Нині існує низка об'єктивних і суб'єктивних передумов для подальшої депопуляції, омолодження показників смертності від більшості зареєстрованих хвороб, високого рівня демографічної старості. Ця проблема потребує комплексного підходу щодо її вирішення як на загальнодержавному, так і на регіональному рівнях. Ключові слова: чисельність населення, зростання смертності, зниження народжуваності, негативний природний приріст, демографічне старіння.

Demographic processes and the state of health of the population as a stimulating factor of sustainable development of Chernihiv region. Yermishev O., Batsylyeva O., Kuchenko T.

Sustainable development of the region is associated not only with the availability of resources but also with their certain combination. The development is impossible in the absence of one of them, even if other resources are in excess. The so-called strategic resources include "human capital", which includes not only innate abilities, talents, education and qualifications, but also the general health resource of the population which directly affects its number and efficiency.

The purpose is to identify regional features, patterns of changes as well as trends in demographic processes and morbidity of the population in Chernihiv region.

Materials and methods. The materials of the research were native (domestic) and world scientific sources, annual collections of statistical data of Chernihiv region and Ukraine on demographic development and morbidity. Research methods used: bibliosemantic, systematic analysis, retrospective analysis of public health by demographic and medical-statistical indicators and medical statistics.

Results. The article highlights the main problems of population formation in Chernihiv region of Ukraine: intensification of mortality, male mortality, negative natural increase, decrease in the total birth rate and high level of demographic old age.

The population of Chernihiv region decreased during the years of independence by $26,44 \%$ (Ukraine - by $18,1 \%$ ). The overall birth rate decreased by $25,02 \%$ and the overall mortality rate increased by $1,76 \%$. The diseases of the circulatory system - 73,65\%; neoplasms $-10,96 \%$; injuries, poisoning and other consequences of external factors $-15,39 \%$ were the main causes of death in 2019 . Despite the reduction in the mortality rate of children under 1 year in 2 times, the number of children in the region decreased by $45 \%$. In addition, the elderly population increased to $19,44 \%$ which led to a regressive type of age structure. 
Conclusions. The stability state of Chernihiv region is significantly deteriorating due to current trends in population development. Falling birth rates and rising mortality (including those of working age) has led to depopulation in almost all regions of Ukraine and Chernihiv region in particular. Demographic indicators of the population in Ukraine indicate a deep demographic crisis, as a result of which the population has decreased by 9,7 million since 1991 and in Chernihiv region - by 361,5 thousand.

At present, there is a number of objective prerequisites for further depopulation, rejuvenation of mortality rates from most diseases and a high level of demographic old age, etc. Therefore, this problem requires a comprehensive state approach to its solution. Key words: declining birth rate, increasing mortality rate, negative natural increase, demographic aging.

Постановка проблеми. Концепція сталого розвитку, прийнята світовою спільнотою як головний критерій для подальшого розвитку суспільних процесів, включає зв'язки і взаємовпливи між екологічними, економічними і соціальними процесами. Поняття «сталий розвиток» стало популярним після міжнародної конференції з навколишнього середовища та розвитку (Ріо-де-Жанейро, 1992 рік). Під стійким розвитком розуміється невичерпне природокористування, яке має постійно підтримувати розвиток і не має суперечити подальшому існуванню людства.

Концепція сталого розвитку включає і має забезпечувати безперервне відтворення ресурсів різних типів, але забезпечення стійкого відтворення людини має бути основним завданням, яке повинно включати підтримання якісних параметрів, умов життя і праці, обов'язково має узгоджуватися із загальноприйнятими законами розвитку і принципами збереження довкілля. Сталий розвиток $\epsilon$ основою для свідомої зміни напряму суспільного розвитку від неконтрольованого економічного зростання до збереження середовища життєдіяльності людини, в тому числі соціального і натурально-природного. У той же час стійкий розвиток регіону передбачає комплексний збалансований одномоментний розвиток трьох головних підсистем - екологічної, соціальної (в тому числі й населення) та економічної, з яких перші два мають бути превалюючими і бути одним зі способів досягнення національної безпеки [6].

Сталий розвиток регіону тісно пов'язаний як iз наявністю ресурсів, так і з певним їх поєднанням. При відсутності одного 3 них сталий розвиток не можливий, навіть якщо інші ресурси будуть у надлишку. Обов'язковою умовою сталого розвитку $€$ віднесення до стратегічних ресурсів і «людського капіталу», який включає не тільки вроджені здібності, таланти, отриману освіту і придбану кваліфікацію, але й загальний «капітал здоров'я», який безпосередньо впливає на чисельність і працездатність населення.

Важливим показником стійкості на сучасному етапі розвитку України i Чернігівщини зокрема $\epsilon$ динаміка структури населення, за якої серед усіх інших (вікова, освітня, професійна) на перше місце виходить демографічна і медико-статистична, які можна використовувати для динамічного відстеження популяційних процесів і загальних ризиків, які на них впливають. Розвиток населення здебільшого характеризується кількісними, демографічними змінами, але в плані стійкого розвитку важливіше його якісне наповнення [1]. Кількісний аспект розвитку населення структурно забезпечується динамікою чисельності населення, а його перспективи полягають у потенціалі відтворення населення. В якісному аспекті велике значення надається розвитку людської особистості як активної частини суспільства.

Стан стійкості регіону значно погіршується через сучасні тенденції розвитку населення. В усіх регіонах України і Чернігівщини зокрема спостерігається тенденція до зменшення народжуваності і зростання загальної смертності населення у зв'язку з розвитком стійких депопуляційних процесів. Особливе занепокоєння викликає збільшення смертності населення працездатного віку - основного маркера розвитку.

Нині серед дослідників немає загальноприйнятої методики оцінки здоров'я населення. Для цього використовують комплекс різних демографічних і медико-статистичних показників: фізичний розвиток людини, загальна та нозологічна захворюваність, донозологічні стани, інвалідність, соціальні хвороби (алкоголізм, туберкульоз). У цій статті проаналізовані показники загальної та видової захворюваності і статистико-демографічні показники, які лежать в основі найбільш високих рівнів смертності населення.

Окремим непрямим індикатором людського розвитку в Україні можна вважати загальні видатки державного бюджету на охорону здоров'я у відсотках до ВВП, які за останні 20 років не перевищували 4,8\%, а в 2020 році значно зменшилися і становили лише $3,6 \%$. Спостерігається також збільшення видатків місцевих бюджетів на охорону здоров'я із $10 \%$ до $13 \%$ у 2020 році, оскільки перспектива розвитку громад залежить від стабільного і прогнозованого розвитку людського капіталу [4].

Зв'язок авторського доробку з важливими науковими та практичними завданнями. Стабільний розвиток територій країни, за визначенням ВООЗ, має базуватися на зменшенні соціальної, екологічної та економічної нерівності між регіонами, що $є$ і стратегічним напрямом збереження здоров'я населення. Регіональний підхід дає змогу визначити характер і природу патологічних станів організму, особливості виникнення, формування цих станів, їхніх факторів ризику, а також виявити зв'язки захворюваності населення з екологічними факторами довкілля та знайти шляхи для зменшення або подолання їх шкідливого впливу.

Постановка проблеми. Більшість існуючих еколого-медичних і демографічних досліджень впливу довкілля на здоров'я та демографічні процеси насе- 
лення стосуються вивчення зазначеної проблеми в регіонах України із несприятливими екологічними умовами чи в депресивних регіонах зі слабким економічним потенціалом. Значно рідше вивчення вказаних вище закономірностей здійснюють у тих областях, де екологічний стан не вважається складним, а економічний $є$ вищим за середній по країні. До таких регіонів належить і Чернігівщина.

Аналіз останніх досліджень і публікацій. Після Другої світової війни загальна чисельність населення України мала стійкий тренд до збільшення. Із 1991 року вперше було зафіксовано перевищення смертності над народжуваністю, що призвело до нового етапу розвитку країни - депопуляції, який триває i нині. Збільшився загальний коефіцієнт смертності українців відносно 1991 року із 12,9 осіб на тисячу населення до 14,1 у 2019 році при зниженні загального коефіцієнту народжуваності із $12,1 \%$ до $10,2 \%$ [3].

На жаль, реалізація державної комплексної програми «Здоров'я нації» та інших програм відомчого та місцевого спрямування на подолання проблем у сфері охорони та поліпшенні здоров'я населення i негативних медико-демографічної процесів виявилася малоефективною [10]. Загальна чисельність населення України за цей час зменшилася на 21,15\% iз 52 млн осіб у 1990 році до 41 млн 785 тис. осіб у червні 2020 року [3].

За даними ООН, у 2050 році очікується ріст населення планети до 9 млрд людей при збереженні тенденції до зниження народжуваності. Особливо це стосується економічно розвинених країн. Нині очікувана тривалість життя у Свропі для жінок складає 79 років, для чоловіків - 70,5 років. Прогнозується, що загальна кількість населення Землі осіб, старших за 60 років, до 2050 року збільшиться до 2 млрд [8]. В Україні до 2050 року прогнозується скорочення населення на 7,8 млн осіб [6; 10].

Одним із важливих чинників, що впливає на демографічну ситуацію, є репродуктивне здоров'я жінок, яке характеризують показники народжуваності, а також показники здоров'я жінок і дітей, інтегрованим відображенням яких є дитяча та материнська смертність. Незважаючи на тенденцію до зниження рівня материнської смертності, вона в Україні залишається однією із найвищих у Свропі.

На превеликий жаль, аборти залишаються найпоширенішим методом регуляції народжуваності, які вносять свою частку у формування репродуктивного здоров'я жіночої частини населення України, наслідками яких $€$ невиношуваність вагітності та безпліддя. За статистикою, із 10 тис. легальних абортів, проведених у медичних закладах, 5 закінчується летально, а статистика про нелегальні аборти відсутня. В Україні на противагу розвиненим країнам кількість абортів перевищує кількість пологів у 1,5-2 рази, в той же час у Японії цей показник дорівнює 0,06, у Франції та Німеччині - 0,25 [1].
Особливістю України є високий рівень смертності населення працездатного віку і немовлят, а серед смертності від серцево-судинних захворювань, які стоять на першому місці, це збільшення частки осіб чоловічої статі до 40 років серед померлих [7; 13].

На відміну від країн ЄС і інших розвинутих країн, в Україні спостерігається зниження вікових усереднених показників причин смертності за видами захворювань, існує значна різниця між причинами смерті і середнім віком смерті. Серед цих показників найнижче значення має зареєстрований середній вік смерті в Україні від так званих соціальних інфекційних хвороб (туберкульоз, СНІД). Незадовільним також виявився показник очікуваної тривалості життя, середній показник якого становить 71 рік. Він характеризується середньорічним зменшенням і має високі гендерні розбіжності: 75 років у жінок та 66 років у чоловіків. Серед країн світу Україна займає 52-ге місце за цим показником.

Виділення не вирішених раніше частин загальної проблеми, котрим присвячусться означена стаття. В рамках програми «Здоров’я для всіх у XXI столітті» Всесвітня організація охорони здоров'я визначила критерії для національних служб, до яких повинні прагнути всі країни. До цих критеріїв відноситься середня тривалість життя, яка повинна бути не менше ніж 75 років і позитивний природний приріст населення. Незважаючи на те, що нині стан здоров'я населення та демографічна ситуація в Україні i на Чернігівщині зокрема не відповідає зазначеним критеріям, проблема вивчення соціально-демографічних процесів і медико-статистичний аналіз регіональних особливостей є досить актуальними.

Методологічне або загальнонаукове значення та новизна. Формування здоров'я населення залежить від багатьох факторів впливу, серед яких провідну роль відіграють екологічні умови їхньої життєдіяльності. Саме тому пріоритетним складником цілісного вирішення актуальних питань охорони здоров'я в контексті сталого розвитку регіону i України необхідно вважати аналіз регіональних особливостей навколишнього середовища та стану здоров'я населення і можливі їх кореляційні взаємодії для точного встановлення залежностей між різними чинниками довкілля та нозологічними одиницями, що відображають загальне здоров'я популяції. Зміцнення та покращення стану здоров'я можливе лише за умови комплексних управлінських рішень при їх вчасності та більш ефективному використанні, цілеспрямованих сучасних технологій організації профілактичної медицини і забезпечення комплексного покращення стану довкілля для зниження рівня екологозалежних хвороб.

Метою роботи було визначення та аналіз тенденцій, їх закономірностей у загальній захворюваності населення Чернігівщини, в тому числі і екологозалежних хвороб, стану демографічних процесів на регіональному рівні та можливостей покращення ситуації. 
Матеріали та методи. Для дослідження були використані щорічні статистичні звіти державних установ України та Чернігівської області із загальної захворюваності, захворюваності за видами, демографічних змін складу та кількості населення. Використовували методи медичної та демографічної статистики, ретроспективний аналіз здоров'я населення за демографічними та медико-статистичними показниками, бібліосемантичний метод і метод системного аналізу.

Виклад основного матеріалу. Нині Чернігівській область характеризується вираженою несприятливою соціально-демографічною ситуацією, що не зовсім узгоджується 3 потужним виробничим, економічним, кадровим потенціалом і наявними багатими природними ресурсами, вигідним транзитним економічним положенням. Починаючи 3 кінця XIX ст. усі ці умови сприяли бурхливому економічному, промисловому та соціальному розвитку регіону. Інтенсивний розвиток промисловості в області створює напружену екологічну ситуацію та впливає як на демографічну, так і на медико-соціальний складники суспільного здоров'я, що ставить завдання про вдосконалення соціального обслуговування та медико-санітарної допомоги для населення.

Загальна чисельність населення області зменшилася відносно 1995 року на 27,50\% (станом на 1 січня 2020 вона становила 991,3 тис. осіб) (табл. 1). Саме у 1995 році Чернігівщина характеризувалася найбільшою чисельністю жителів регіону за період постійних спостережень, яка дорівнювала 1367,3 тис. iз подальшим поступовим щорічним зменшенням цього показника в середньому на 15,5 тис. осіб.

Постійне населення зменшилося за цей період на 26,64\% і склало 1359,3 тис. осіб. Сільське населення склало 34,8\%, міське - 65,2\%. Ці показники відрізняються від даних 25-річної давності (43,0\% та 57,0\%), що свідчить про стійкі процеси урбанізації території. Чисельність міського населення при цьому збільшилася на 8,2\%, а сільського зменшилася на 8,2\% [12].

Показники співвідношення між сільським і міським населенням у Чернігівській області значно відрізняється від співвідношення показників по Україні, де відсоток сільського населення має досить стабільний характер і становить 30-32\% [3]. Гендерний склад населення має такі значення: жіноче населення - 54,51\%, чоловіче - 45,49\% (у 1995 році чоловіки складали 44,96\% населення, жінки - 55,04\%). За результатами статистичних даних можна сказати, що триває невелике зменшення загальної кількості жіночого населення, а на 1000 жінок припадає 1198 чоловіків. Загалом жіноче населення із 1990 року характеризувалося зменшенням на 27,34\%, чоловіче - на 25,79\%.

Чисельність постійного населення Чернігова у червні 2020 року становила 286,2 тис. осіб і займала 18-ту позицію в рейтингу міст за чисель- ністю населення в Україні. На гендерну структуру населення впливає різний рівень смертності серед чоловіків і жінок, який сформувався під впливом біолого-соціальних та екологічних факторів. Серед дитячого населення регіону переважають хлопчики 3 відносним показником народження 52,12\%, цей же показник у дівчаток становить 47,88\%.

Зі збільшенням віку населення області спостерігається вирівнювання показників гендерної чисельності населення, а молодий і середній вік характеризується паритетом 3 приблизно однаковою чисельністю чоловіків і жінок. Динаміка змін чисельності жіночого населення регіону характеризується досить різким збільшенням у літньому та похилому віці щодо чоловічої частини населення через більш високу смертність чоловіків [10].

Для Чернігівської області, як і для України загалом характерні зміни вікової структури населення 3 тенденцією до старіння. Найбільш питома вага за віком із загальної чисельності населення області приходиться на групу 65 років і старше $(19,9 \%)$ (у містах - 11,04\%, у сільській місцевості - 8,85\%); $6,23 \%$ - 25-29 років; 6,45\% - 65-69 років, 6,68\% - на 50-54 роки; по 8,30\% - на 30-34 роки, $6,94 \%$ - на 45-49 років, 4,46\% - на 20-24 роки [14]. Чисельність дітей до 1 року становлять $0,61 \%$. Найменшу питому вагу серед дорослих займає вікова група $75-79$ років $(3,19 \%)$.

Особи непрацездатного віку (включно до 15 років) складають 14,41\%, населення працездатного віку (16-59 років) - 58,23\%, населення працездатного віку, старше за 60 років, становить 27,36\%. Вікове співвідношення цих груп по працездатності у 1995 році становило $19,50 \% ; 55,57 \% ; 24,94 \%$ і характеризувалося прогресивним типом вікової структури. Нині для Чернігівщини, як і для країни загалом характерний саме регресивний тип вікової структури. За статистичними даними по Чернігівській області, в середньому на 1000 осіб населення припадає майже 290 осіб пенсійного віку [9].

Більш поглиблено було вивчено та проаналізовано стан природного руху населення за народжуваністю та смертністю, які є основними демографічними явищами, здатними повноцінно характеризувати якісний склад, зміни, динаміку та загальну чисельність населення. Так, регіон характеризується зниженням загального коефіцієнту народжуваності на 37,66\% із 1995 року і становив по області у 2019 році 1,2\%.

По роках спостережень найнижчий коефіцієнт народжуваності 1,028 та 1,082\% був виявлений у 2019 році та 2001 році. Починаючи із 1995 року, спостерігалися хвилеподібні зміни коефіцієнту (від 1,396 до 1,137\%) із найвищим його показником $1,396 \%$ у 2012 році. За нашими даними, у 2019 році загальний коефіцієнт смертності склав 18,6\%, що на 0,3\% вище порівняно із 1995 роком із коефіцієнтом 18,9\%. У період 2002-2009 років спостерігався найвищий коефіцієнт смертності (від 19,9 до 21,6\%). 
Єрмішев О.В., Бацилєва О.В., Кученко Т.А. $\quad$ ДЕМОГРАФІЧНІ ПРОЦЕСИ ТА СТАН ЗДОРОВ’Я...

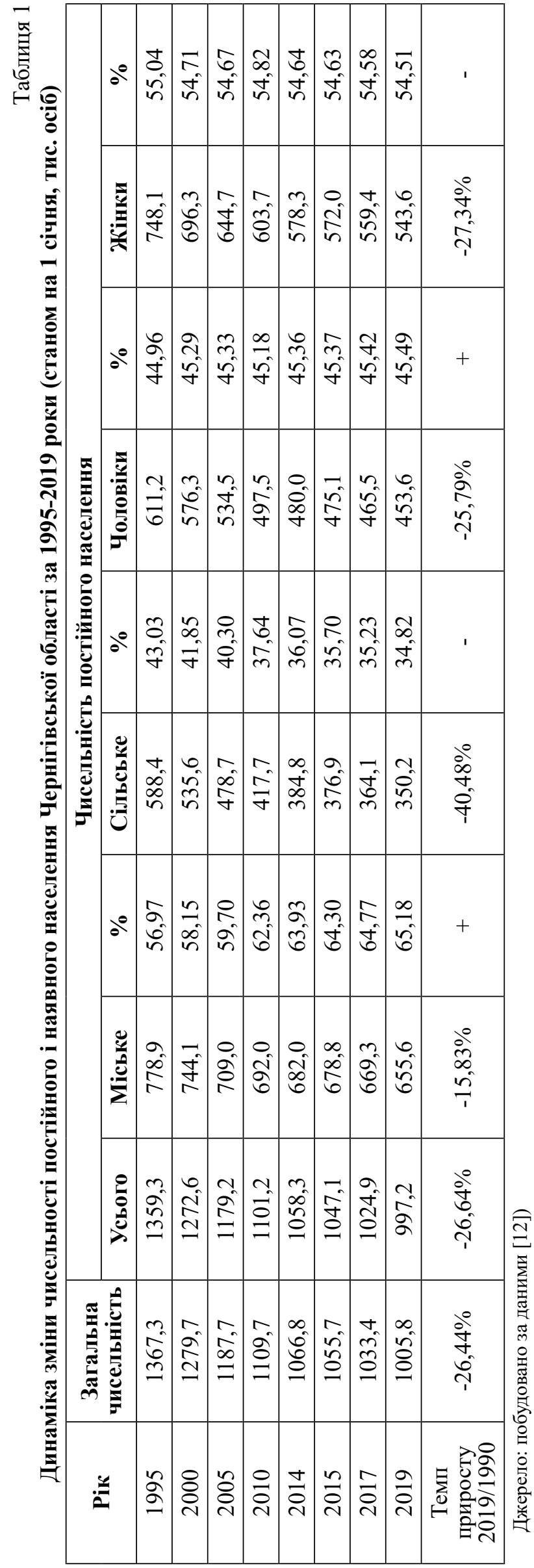


Виявлена досить стабільна тенденція до зниження природного приросту населення за період 1995-2019 років із 10689 осіб до 12455 осіб, зниження сумарного коефіцієнту народжуваності на $25,02 \%$ із 1,371 до 1,028 . За час дослідного періоду відбулося зниження зі зміщенням найвищого коефіцієнту народжуваності із 20-24 років на 25-29 та 30-34 роки [2; 12].

Із 1990 року спостерігається поступове зниження чисельності дитячого населення Чернігівщини, яке зменшилося більш ніж на 6 тис. осіб з одночасним зростанням загальної чисельності дітей, народжених поза шлюбом і у неповних сім'ях. Поширені серед сучасної молоді неформальні сімейні стосунки та економічна зумовленість більш пізніх шлюбів i народження дітей також негативно впливають на розвиток демографічних процесів регіону.

Спостерігається загальна тенденція в Україні, як і в країнах Свропи до збільшення кількісті дітей, народжених жінками, які не перебувають у зареєстрованому шлюбі. У регіоні цей показник збільшився в 1,7 рази і у 2019 році становив 22,9\%. За цей період значно зменшилася кількість зареєстрованих шлюбів із 8,1 до 5,2 на 1000 осіб, що становило 37,04\%. Так, найменша кількість шлюбів була укладена у 2004 та 2016 роках із показником 4,9 на 1000 осіб. Також у регіоні збільшилася загальна кількість зареєстрованих розлучень із 3,3 до 3,8 на 1000 осіб із найбільшим показником розлучень у 2011 та 2018 роках, який становив 4,0\% [12].

У 2019 році на Чернігівщині налічувалося 435,4 тис. домогосподарств, із яких 60,2\% припадало на міські поселення, більшість із яких приходиться на малі міста. На сім'ю в середньому припадає 2,30 особи. За відсотковим співвідношенням за кількістю членів сім’і 39,0\% усіх сімей складаються із двох осіб, 25,3\% - 3 однієї людини, 20,7\% iз трьох, а з чотирьох і більше членів - 15,0\%. До складу 91,5\% сімей входить тільки одна дитина, дві дитини мають 7,4\% сімей, більше двох дітей зустрі- чається лише в $1,1 \%$ сімей. Приблизно в третині усіх домогосподарств до складу сім'ї входять діти віком до 18 років [9].

Загальне збільшення кількості розлучень у регіоні призводить до формування неповних сімей, у яких виховується майже 5 тис. дітей різного віку. За статистикою, найбільш небезпечний період для розлучень 1-4 рік і 5-9 рік перебування у шлюбі, коли розпадаються $38,3 \%$ та $27,2 \%$ сімей. Парадоксальна ситуація виявляється у Чернігівській області, де, на відміну від України, спостерігається зменшення загальної кількості розлучень, але причиною цього стало зменшення кількості укладання шлюбів.

Позитивною виявилася динаміка загального зменшення кількості абортів у жінок фертильного віку. Так, на кожні 100 пологів у 2001 році цей показник знизився до 26,4 абортів у 2019 році. Найвищий показник зафіксовано серед жінок віком від 18 до 34 років (11,2 на 1000 жінок відповідного віку). 10,7\% від загальної кількості абортів припадає на первинно вагітних, із них 2\% - у віці до 14 років, 40 - у віці 15-17 років, 61 - у віці 18-19 років [12; 17].

До надважливого показника демографічних процесів, пов'язаних із громадським здоров'ям населення, відноситься рівень загальної смертності, який відображає поширеність різних нозологічних форм захворювань, що є основною причиною смертей населення. Коефіцієнт смертності населення Чернігівської області за віком знизився до 24 років по 5 вікових групах, одночасно спостерігалося зростання цього показника у групах від 25 до 69 років. Починаючи із 2007 року, у віковій групі 70 років і старше спостерігається зниження коефіцієнта смертності, яке можна пов'язати з розвитком сучасної геріатричної медицини. За гендерними ознаками різко відрізняється смертність у жінок і чоловіків на кожну 1000 населення. Так, у жінок за рік реєструють 8 смертей, у чоловіків - удвічі більше. Цей показник становить 16 осіб на 1000 осіб за рік $[3 ; 12]$.

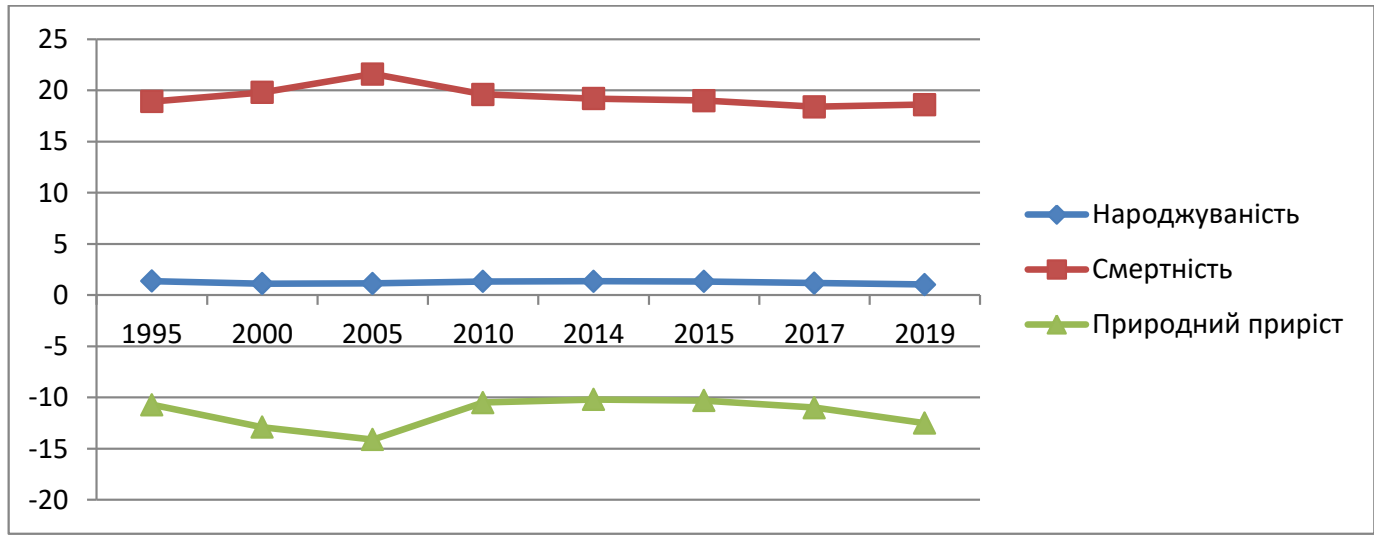

Рис. 1. Основні коефіцуіснти демографічних прочесів (природного приросту населення, народжуваності та смертності) Чернігівської області у 1995-2019 роках

Джерело: побудовано за даними [12] 
За нашими спостереження, основною причиною смертності населення у 2019 році були хвороби органів кровообігу, їх виявлено у 73,65\% померлих, але 3 тенденцією до незначного зниження. На другому місці знаходяться онкозахворювання, які є причиною 10,96\% смертей. Третє місце посідають зовнішні причини із 5,16\%, на четвертому місці хвороби органів травлення 3 тенденцією до зростання $(3,17 \%)$, на п'ятому - захворювання органів дихання iз 2,38\%. Хвороби органів дихання в Чернігівській області, як і по Україні загалом до 2015 року посідали четверте місце, але з 2008 року це місце зайняли соціальні інфекційні хвороби - СНІД і туберкульоз. Захворювання на СНІД є причиною 47,78\% усіх випадків смерті в цьому класі, а туберкульоз $38,92 \%$ [5; 12].

Показники смертності дітей до 1-го року у Чернігівській області з 1990 року знизилися майже утричі і ця тенденція зберігається. У 2019 році він склав 7,3\% проти $15,1 \%$ у 1995 році. Основними причинами покращення стану можна вважати створення мережі сучасних перинатальних центрів із підвищенням ефективності диспансеризації новонароджених і поліпшенням медичного спостереження за вагітними жінками. Перше місце серед причин смертності малюків посідають патологічні стани, які виникають ще у перинатальному періоді, друге місце посідають деформації та хромосомні аномалії, вроджені дефекти розвитку, на третьому місці хвороби нервової системи, на четвертому - хвороби органів дихання, на п'ятому - нещасні випадки та інші зовнішні причини смерті [5; 12].

Для інтегральної оцінки стану здоров'я населення у світовій практиці використовують такий демографічний показник, як середня очікувана тривалість життя. Проаналізувавши цей показник, починаючи із 1995 року, можна зробити висновок, що він скорочувався до 2008 року, а вже після 2009 року почав збільшуватися та досягнув вихідних цифр (у 1995 році 67,1 роки, у 2019 році - 70,7 роки). Не дивлячись на покращення, область продовжує значно відставати за цим показником від країн Свропейского Союзу, де ця різниця становить у середньому 10, а 3 деякими країнами значно більше років і навіть на 2\% нижче середнього рівня по Україні. Тривогу викликає велика різниця в тривалості життя у чоловіків і жінок, яка знаходиться в межах 10,03 років [2].

Із 1990 року спостерігається значне покращення стану загальної виробничої травматизації працездатного населення, яке кардинально знизилося на 75,52\%, у тому числі зі смертельними наслідками майже удвічі; первинний вихід на інвалідність знизився у 1,3 рази [5]. За статистикою, найвищий рівень серед хвороб, що призводять до смерті, мають хвороби системи крові та кровообігу. На наш погляд, на першому місці серед заходів із попередження виникнення цих патологій має бути широка профілактична просвітницька робота серед населення для привертання уваги до здорового способу життя, серед яких раціональне харчування, фізична активність і боротьба із шкідливими звичками на зразок вживання алкоголю та тютюнопаління. Також необхідно збільшувати фінансування медичних заходів 3 акцентом на діагностичний профіль для раннього виявлення захворювань, розширювати мережу існуючих кардіохірургічних закладів, особливо в районних центрах, довести кількість та якість кардіохірургічних втручань типу шунтування та стентування до рівня світових стандартів.

Для зменшення показника смертності від серцево-судинної патології необхідно розширити та покращити програму, порядок проведення первинної профілактики по виникненню хвороб системи кровообігу. 3 огляду на те, що серцево-судинна патологія має поліетіологічний характер виникнення i формування, профілактика і лікування для різних вікових груп населення мають бути суто специфічними. Якщо основною причиною розвитку патології в осіб похилого та старечого віку є природні вікові зміни у тканинах, органах і гіпертензія, то у молодих чоловіків високий рівень смертності асоціюється із гострим і хронічним стресом, а також формуванням залежностей до алкоголю і нікотину, він тісно пов'язаний зі способом життя [7;8].

Найбільш ефективним результатом по зниженню рівня серцево-судинних захворювань та смертності $\epsilon$ проведення профілактичного скринінгу з обов'язковим урахуванням віку, статі, факторів ризику, а не загальне проходження профілактичних оглядів особами у віці до 65 років 3 відсутністю симптомів, яке ніяк не впливає на зменшення смертності. У 2016 році були опубліковані Європейські рекомендації з профілактики хвороб системи кровообігу по звуженню вікового інтервалу для проведення скринінгу [11; 15].

Набрала чинності стратегія ООН щодо досягнення поставлених цілей сталого розвитку, яка впроваджена у дію 31 січня 2016 року. Держави-члени $\mathrm{OOH} \mathrm{погодилися} \mathrm{досягти} 17$ цілей і 1693 задач, які містить стратегія, до 2030 року. Усі цілі сталого розвитку пов'язані зі здоров'ям або мають вплив на політику охорони здоров'я. ЦСР-3 закликає «забезпечити здоровий спосіб життя і сприяти благополуччю усіх у будь-якому віці», а ЦСР-3.4 передбачає скорочення передчасної смертності від неінфекційних захворювань на $30 \%$ до 2030 року [16].

Основним змістом демографічної стратегії країни є вирішення демографічних проблем. Для цього повинні бути розроблені сучасні методології демографічного розвитку України, необхідно підвищити якість наукових розробок у галузі демографічних досліджень і забезпечити їх фінансовою підтримкою.

Головні висновки. Демографічні показники населення Чернігівщини, як i населення України загалом свідчать про глибоку демографічну кризу, наслідком якої є зменшення населення на 361,5 тис. 
осіб та на 9,7 млн осіб відповідно з тенденцією до депопуляції. До причин цього процесу відноситься високий рівень демографічної старості та омолодження смертності від більшості хвороб.

Загалом для Чернігівського регіону притаманні проблеми, які характерні i для України. Спостерігаються тенденції до зниження сумарного коефіцієнту народжуваності, кількості зареєстрованих шлюбів і збільшення смертності чоловіків, вікового розриву смертності між чоловіками і жінками, неповних сімей. Викликають занепокоєння стабільно високі показники захворюваності і смертності від так званих соціальних хвороб сучасності (туберкульозу, ВІЛ / СНІДу, венеричних захворювань, а також алкоголізму та наркоманії).

На нашу думку, стійке покращення стану громадського здоров'я і демографічних процесів, які 3 ним пов'язані, не можливе насамперед без профілактично спрямованої системи охорони здоров'я, спрямованої на відмову від шкідливих звичок, активацію роботи, особливо серед населення молодшого i середнього працездатного віку по формуванню моделей поведінки, спрямованої на здоровий спосіб життя. Необхідно змістити акценти відповідальності за здоров'я населення із державних органів на особистісний рівень шляхом найскорішого запровадження страхової медицини, запровадити еконо- мічні механізми контролю і стимуляції ефективності роботи медичних працівників.

Обов'язково потрібно розробити і запровадити довгострокову цільову комплексну міжгалузеву програму «Здоров’я нації». На нашу думку, до неї доцільно залучити працівників усіх рівнів $\mathrm{MOH}$ України, починаючи 3 дитячих садочків і завершуючи ВНЗ. Саме вони мають доносити до населення інформацію з приводу профілактичних природних методів продовження життя, можливостей зменшення кількості фізичних і психічних розладів. Також до програми необхідно віднести заходи із подолання демографічної кризи, які б охоплювали не тільки питання відтворення населення, але і запобігали трудовій міграції, створюючи стимули і механізми для розвитку регіональних економік і економіки держави загалом. У цільову програму обов'язково повинні бути включені цілі зі стратегії сталого розвитку ООН, також повинен бути забезпечений контроль за їх виконанням на найвищому рівні.

Перспективи використання результатів дослідження. У подальших дослідженнях буде продовжено соціально-гігієнічний моніторинг за станом здоров'я населення і надано пропозиції щодо участі у розробці цільової програми «Здоров'я нації» на рівні регіону.

\section{Література}

1. Афанасьєва Ю.В. Аналіз чинників репродуктивної дисфункції сучасної української родини. Актуальні проблеми державного управління. 2014. № 1. С. 309-316.

2. Статистична інформація Державної служби статистики України. Інститут демографії та соціальних досліджень імені M.В. Птухи НАН України. URL: http://database.ukrcensus.gov.ua/.

3. Демографическая ситуация в Украине. URL: http://www.unian.net.

4. Заклади охорони здоров’я та захворюваність населення України у 2017 році : статистичний збірник / За ред. О. Кармазіної. К. : Держслужба статистики України, 2018. URL: http://www.ukrstat.gov.ua.

5. Захист дітей, які потребують особливої уваги суспільства : статистичний збірник. К. : Державна служба статистики України, 2014. 79 с.

6. Либанова Э.М. Демографические сдвиги в контексте социального развития. Демографія та соціальна економіка. 2014. № 1. C. 9-29.

7. Маркович I.I. Вплив медико-демографічних показників на реформування медичної галузі як складника системи безпеки України. Україна. Здоров'я наиії. 2013. № 4(28). С. 29-34.

8. Мировые демографические тенденции. Женева : Экономический и Социальный Совет ООН, 2011. 35 с.

9. Палієнко О.А. Демографічна криза в Україні: шляхи ії подолання. Young Scientist. 2017. С. 133-136.

10. Позняк О.В., Шевчук П.С. Демографічні перспективи України до 2060 року. Демографія та сочіальна економіка. 2014. № 1. C. $72-84$.

11. Порівняльний аналіз підходів до профілактики в Свропі та Україні / В.М. Лехан, Л.В. Крячкова, О.П. Максименко та інші. Україна. Здоров’я начіï. 2017. № 3(44). С. 159-165.

12. Статистична інформація Головного управління статистики у Вінницькій області за 2019 piк. URL: https://www. chernigivstat.gov.ua.

13. Статистична інформація Управління охорони здоров'я Чернігівської обласної державної адміністрації, Чернігівського обласного центру громадського здоров'я. Показники стану здоров'я населення, діяльності та ресурсного забезпечення комунальних закладів охорони здоров'я Чернігівської області за 2018-2019 роки. URL: https://ociat.com.ua/.

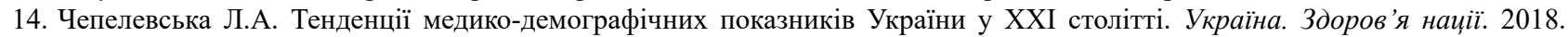
№ 1(47). C. 48-52.

15. Щорічна доповідь про стан здоров'я населення, санітарно-епідемічну ситуацію та результати діяльності системи охорони здоров’я України. 2016 рік / МОЗ України, ДУ «УІСД МОЗ України». К., 2017. 516 с.

16. European Guidelines on cardiovascular disease prevention in clinical practice. 2016 / M.F. Piepoli, A.W. Hoes, S. Agewall et al. European Heart Journal. 2016. № 37(29). P. 2315-2381. https://doi.org/10.1093/eurheartj/ehw106.

17. Poston D.L., Bouvier L.F. Population and society: an introduction to demography. 2nd edition. New-York : Cambridge University Press, 2017. $532 \mathrm{p}$. 


\title{
РОЗВИТОК ПРИРОДНО-ЗАПОВІДНОГО ФОНДУ УКРАЇНИ
}

\author{
УДК 574:911.2 \\ DOI https://doi.org/10.32846/2306-9716/2020.eco.6-33.23
}

\section{ФУНКЦІОНААЫНЕ ЗОНУВАННЯ ТЕРИТОРІЙ НАЦІОНАМЬНИХ ПРИРОДНИХ ПАРКІВ СВІТУ ТА УКРАЇНИ}

\author{
Гетьман B.I., Мовчан М.М. \\ Державна екологічна академія післядипломної освіти та управління \\ вул. Василя Липківського, 35, корп. 2, 02000, м. Київ \\ wi.getman@gmail.com
}

\begin{abstract}
У статті розглянуто питання функціонального зонування територій національних природних парків України і національних парків світу як ключової проблеми їх територіальної організації або планування. У порівняльному аналізі показано як позитивні явища, так і недоліки вітчизняного та світового природоохоронного планування, насамперед рекреаційних територій.

Основним способом «самореалізації» національних природних парків є функціональне зонування їх території. Воно здійснюється для створення необхідних умов виконання національним природним парком функцій: природоохоронних (збереження біорізноманіття території, забезпечення екологічно збалансованого природокористування) і рекреаційних. Функціональне зонування є основним розділом проектів організації природно-заповідних територій та об'єктів України, охорони, відтворення та використання їх природних комплексів, що розробляються на об'єктивній науковій основі. Воно є однією $з$ важливих проблем заповідної справи.

Практичний досвід створення та діяльності національних природних парків України переконує, що планування їх територій має принципово важливе значення і є основною передумовою для забезпечення врівноваженого та безконфліктного функціонування таких поліфункціональних природно-заповідних установ.

Результатом функціонального зонування території національних природних парків $є$ схема чи картосхема як наочне відображення просторових функцій, які ця територія має виконувати. На ній виділяють територіальні ділянки (функціональні зони), які різняться за функціями та цілями охорони, охоронними режимами і формами практичної діяльності в їх межах.

Функціональне зонування територій національних природних парків України здійснюється за вільним типом: загальний рисунок - мозаїчний, ділянки кожної зони представлені кількома контурами, тобто вони мають кластерний характер. У статті порушені питання щодо рекреаційних навантажень у межах вітчизняних і зарубіжних національних (природних) парків та їх нормативів. Ключові слова: функціональне зонування, планувальна організація, планувальні структури, національний природний парк, рекреаційні навантаження.
\end{abstract}

Functional zoning of the territories of national natural parks of the world and Ukraine. Getman V., Movchan M.

The issues of functional zoning of the territories of national natural parks of Ukraine and national parks of the world as the key problem of their territorial organization or planning are considered. In a comparative analysis, both positive phenomena and shortcomings of local and world environmental planning, primarily recreational areas, are shown. The issue of recreational pressure within local and foreign national (natural) parks and their standards is also raised.

It should be noted that the literature does not yet contain sufficiently scientifically substantiated methodological recommendations for the allocation of functional zones, their optimal areas, configurations, permissible anthropogenic (recreational) loads on parts of nature protected areas and sites. The practical experience of creation and functioning of the Ukrainian NPP assures that the problem of planning their territory is of fundamental importance.

Its practical solution is a basic prerequisite for ensuring the balanced and conflict-free functioning of these multifunctional nature protected areas. Functional zoning of the NPP territory can also be considered as a target spatial-functional model of the protected area. Accordingly, the practical activities for its protection are territorially differentiated by the allocated functional zones.

It is the way to implement this model. The planning organization is based on the features of the functional zoning of national parks, as well as on the basis of the territorial configuration of the landscape sites (forest areas, systems of lakes, groups of islands, river deltas and banks of large reservoirs).

The planning organization of national parks is the functional zoning of their territory, which is conditioned by natural factors, on the basis of which different types of spatial planning structures are formed, a kind of "frames" along the directions of natural axes taking into account the existing systems of settlement, production, transport and engineering structures. Key words: functional zoning, planning organization, planning structures, national nature park, recreational pressure.

Актуальність дослідження. Основним розділом проектів організації природно-заповідних територій та об'єктів України, охорони, відтворення та використання їх природних комплексів $є$ функціональне зонування, я розробляється на об'єктивній науковій основі і водночас є однією з важливих проблем заповідної справи.

Функціональне зонування здійснюється 3 метою практичної реалізації основних функцій природно-заповідних територій та об'єктів: збереження 
цінних природних та історико-культурних комплексів і об'єктів; створення умов для організованого туризму, інших видів і форм рекреації (рекреаційної діяльності) в природних умовах із додержанням заповідного (диференційованого) режиму; проведення наукових досліджень ландшафтних (далі ЛК) комплексів та їхніх змін в умовах рекреаційного використання, розроблення відповідних наукових рекомендацій (охорона і використання природних ресурсів); здійснення екологічної освітньо-виховної роботи; сприяння соціально-економічному розвитку регіону (місцевості) [19].

Функціональне зонування - це розділення природно-заповідних територій та об'єктів на ділянки (зони) з різними режимами збереження, відтворення та використання природних комплексів [16]. Однак для зазначених територій та об'єктів ще не розроблені загальні теоретичні і методичні питання щодо зонування, не існує єдиної моделі його структури. Нині жодний міжнародний чи вітчизняний документ не засвідчує чітких критеріїв зонування.

Аналіз останніх досліджень i публікацій. В Україні існує певний досвід проведення поліфункціонального зонування територій національних природних парків (далі - НПП). У цьому питанні заслуговують на увагу наукові доробки провідних вчених України С.Ю. Поповича (1992; 2007), Т.Ф. Панченко (2015), П.Г. Шищенка (1988) та інших.

Варто зазначити, що в літературних джерелах відсутні науково обгрунтовані методичні рекомендації щодо виділення функціональних зон, їх оптимальних площ, конфігурацій, допустимих антропогенних (рекреаційних) навантажень на ділянки природно-заповідних територій та об'єктів. Функціональне зонування територій НПП України здійснюється за вільним типом: загальний рисунок - мозаїчний, ділянки кожної зони представлені кількома контурами, тобто вони мають кластерний характер. Однак щодо цього питання і нині не припиняються дискусії.

Мета дослідження - актуалізувати тему пошуку нових (креативних) шляхів і форм здійснення функціонального зонування територій НПП України для оптимального збереження та охорони заповідного біотичного і ландшафтного різноманіття.

Методи дослідження. У статті дотримано чотирьох рівнів методології науки: філософсько-світоглядного, загальнонаукового, конкретно-наукового (методи ландшафтознавства) і техніки досліджень, а також використано аналітичний методологічний прийом (метод аналізу). Також застосовано низку інших методів, зокрема загальнонаукові (логічні) метод синтезу, абстракції, індукції і дедукції; конкретно-наукові (методи ландшафтознавства, а саме спостереження, історико-географічний, порівняльно-географічний та інший методи).

Виклад основного матеріалу. Що розуміють під національним парком у світі і національним природним парком в Україні? Термін «національний парк» вперше 3'явився у Сполучених Штатах Америки, де 1 березня 1872 року спеціальним декретом 18-го президента Улісса Гранта був створений «для користі і блага нації» перший у світі Йєллоустонський національний парк («Країна чудес») площею 899104 га. У 1890 році в США організували два нових НП «Джосемайт» і відомий широкому загалу «Секвойя». Нині у США діють 58 національних парків і 359 природно-заповідних територій найвищої категорії. У Європі перший національний парк був створений у Голландії в 1905 році, потім у Швеції («Сарек», 1909 рік), Швейцарії (1914 рік). Нині у світі існує понад 2,5 тис. національних парків.

За єдиним природоохоронним визначенням, прийнятим на $\mathrm{X}$ Генеральній Асамблеї Міжнародної спілки охорони природи і природних ресурсів (далі MCOП, IUCN), яка відбулася у Нью-Делі в листопаді 1969 року, національний парк (далі - НП) - це значна територія (необхідна для здійснення процесів саморегуляції екологічних систем), у складі якої одна або кілька екосистем, мало змінених або не змінених експлуатацією та поселенням людини, яка характеризується різними типами ландшафтів, багатством рослинного і тваринного світу, а також різноманітністю геоморфологічних систем, особливо цінних із наукової, освітньої, виховної та рекреаційної точок зору або яка характеризується природними пейзажами високої естетичної цінності [7].

У 1962 році на I Всесвітньому конгресі 3 національних парків, який відбувся у Сіетлі (США) як окрема категорія охоронних об'єктів був виділений природний парк. Основна функція природних парків полягає в організації умов для рекреації, туризму. В Україні природному парку відповідає регіональний ландшафтний парк.

У національних парках (II категорія за класифікацією МСОП) охорона природи частково поєднується 3 рекреацією, тобто відпочинком людей у природному, мало зміненому середовищі. Це означає, що вони виконують насамперед природоохоронну, а також рекреаційну функцію. В багатьох НП під рекреаційне використання відводиться до 5-10\% території, однак природоохоронні задачі переважають над рекреаційними (хоча скрізь допускається екотуризм.). На відміну від заповідників, національні парки не можуть бути повністю закритими для відвідування [1].

Основним режимом на території НП, включаючи землі, які на час включення були неприродними, $\epsilon$ режим невтручання. Не менше 75\% площі вважаються суворо охоронними без регулювальних заходів і порушень природної сукцесії. Антропогенні ландшафти там займають незначну площу.

На Другій світовій конференції щодо розвитку національних парків, яка відбулася у 1972 році в Сллоустонському НП, було висунуто низку вимог: територія національного парку має підлягати функціональному зонуванню 3 чітким використанням 
кожної із зон, необхідно обмежити або повністю заборонити користування автотранспортом, використовувати менш небезпечний вид пересування, ретельно обгрунтувати необхідність будівництва мережі доріг, зменшувати інтенсивність потоків рекреантів, пропонуючи їм паліативні природні території поза межами НП.

У наукових колах країн, зокрема пострадянського простору, незмінними залишаються дві точки зору (підходи, моделі) щодо пріоритетних функцій національного парку. Перша - національний парк є природоохоронним об 'єктом, наближеним по статусу до заповідника (А. Банніков, В. Криницький). Друга національний парк є рекреаційним об 'єктом 3 підвищеними вимогами до охорони природи (М. Реймерс, Ф. Штільмарк) [6].

В Україні термін «національні природні парки» вперше офіційно з'явився із прийняттям Закону України «Про природно-заповідний фонд України» від 16 червня 1992 року. До цього часу існувала назва «державний природний національний парк», затверджена Постановою Ради Міністрів Української РСР «Про класифікацію і мережу територій та об'єктів природно-заповідного фонду Української РСР» від 22 липня 1983 року № 311. Із 1972 року фігурувала назва «державний природний парк» відповідно до затвердженої Урядом «Класифікації заповідних та інших територій УРСР, що охороняються державою».

Відповідно до ст. 20 зазначеного вище Закону України національні природні парки - це природоохоронні рекреаційні, культурно-освітні, науково-дослідні установи, які створюються з метою збереження, відтворення та ефективного використання природних комплексів та об'єктів, мають особливу природоохоронну, оздоровчу, історико-культурну, наукову, освітню та естетичну цінність.

Нині в Україні функціонують 53 національних природних парки. Перший (Карпатський НПП) оголошено таким Постановою Ради Міністрів Української РСР від 3 червня 1980 року (спочатку як державний природний, пізніше як державний природний національний). Однак перший український національний парк було створено у 30-ті роки минулого століття митрополитом Андреєм Шептицьким. Нині на його місці знаходиться ландшафтний заказник загальнодержавного значення «Грофа» площею 2533,8 га (ІваноФранківська область, Рожнятівський район) [17].

Практичний досвід створення та діяльності НПП України переконує, що проблема планування їх території досить важлива: іï практичне вирішення $\epsilon$ основною передумовою для забезпечення врівноваженого і безконфліктного функціонування цих поліфункціональних природно-заповідних установ. Основним способом «самореалізації» НПП є функціональне зонування його території. Воно здійснюється 3 метою створення необхідних умов для виконання національним природним парком приро- доохоронних (збереження біорізноманіття території забезпечення екологічно збалансованого природокористування) і рекреаційних функцій [9].

Функціональне зонування території НПП - це чітка диференціація у просторі його функцій. Воно може розглядатися як процес теоретичного пізнання та практичної реалізації існуючої інформації про парк. Результатом функціонального зонування території НПП є схема чи картосхема як наочне відображення просторових функцій, які ця територія має виконувати. На ній виділяють територіальні ділянки (функціональні зони), які різняться за функціями та цілями охорони, охоронними режимами і формами практичної діяльності в їх межах [7].

Функціональне зонування території НПП можна розглядати і як_цільову просторово-функціональну модель охоронної території. Тому практична діяльність 3 їх охорони територіально диференційована за виділеними функціональними зонами. Функціональне зонування території $є$ шляхом до реалізації цієї моделі. Склад функціональних зон і значеннєві показники їх територій у різних (вітчизняних і зарубіжних) національних парків відрізняються. Розглянемо спочатку схему функціонального зонування, прийняту для територій НПП України.

Відповідно до ст. 21 Закону України «Про природно-заповідний фонд України» 3 метою забезпечення виконання НПП покладених на них завдань щодо створення умов для організованого туризму, відпочинку та інших видів рекреаційної діяльності в природних умовах із додержанням режиму охорони заповідних ЛК і об'єктів на їх території виділяють зони регульованої і стаціонарної рекреації [12]. Крім зон рекреації, також виділяють заповідну і господарську зони. Назви зон визначаються за їх основною функцією. Зона може поділятися на підзони. Межі зон проводяться за природними лініями (контурами) і поділяються на басейни річок, гірські хребти, береги водойм, лісові виділи.

У зоні регульованої рекреаиії дозволяється влаштування та відповідне обладнання туристських маршрутів і екологічних стежок, забороняється діяльність, яка може негативно вплинути на стан природних ландшафтів розміщеної по сусідству заповідної зони. Площа зони регульованої рекреації може становити 25-55\% від загальної території парку рекреаційного типу і 30-60\% - від природоохоронного типу.

Зона стачіонарної рекреачї̈ призначена для розміщення готелів, мотелів, кемпінгів, інших об'єктів обслуговування відвідувачів парку. Площа цієї зони становить 5-10\% в умовах обмеженого рекреаційного використання і 10-20\% - активного рекреаційного використання території парку. Можуть виділятися підзони інтенсивної та екстенсивної рекреації. Співвідношення площ таких територій знаходиться в межах 1:2.

Заповідна зона призначена для охорони та відновлення найбільш цінних природних комплексів, 
режим якої визначається відповідно до вимог, встановлених для природних заповідників. Величина заповідної зони національних парків у світі визначається за міжнародними стандартами. В Україні iï площа може становити 20-30\% (20\% - для зони Лісостепу, 10\% - для Степу) від площі території НПП (якщо він має розвинуту рекреаційну функцію) і $30-50$ (60\%), якщо має розвинуту природоохоронну функцію. МСОП пропонує для національних парків мінімальну площу заповідної «території-ядра» до 1000 га $[3 ; 10]$.

Заповідна зона НПП, розміщених у відносно екологічно стабільних регіонах і на мало порушених природних територіях гірських (високогірних, гірсько-лісових), рівнинних (лісових, водно-болотних, зандрових, моренно-зандрових, лиманних, солончакових, плавневих) ландшафтів і на морських акваторіях має становити більше третини від усієї площі парку.

Заповідна зона НПП, розміщених в екологічно нестабільних регіонах і на середньо порушених природних територіях (акваторіях) лісостепових, лучно-лісових, заплавних, прісноводних ландшафтів, має становити понад $20 \%$ від площі парку. Заповідна зона НПП, розташованих у не досить екологічно стабільних регіонах і на значно порушених природних територіях степових, лучних, байрачних, піщано-черепашкових, скельних, подових ландшафтів, має становити $15 \%$ від усієї площі парку або 10\% від площі його природних ділянок [16].

y господарській зоні ведеться традиційна господарська діяльність із дотриманням вимог щодо охорони природного навколишнього середовища. Площа цієї зони залежно від іiі складу може становити 5-25\% від території парку. При непогано розробленому i законодавчо затвердженому функціональному зонуванні НПП України лише незначна їх частина відповідає II категорії міжнародної класифікації - національний парк (охорона екосистем і рекреація).

Так, площа, зайнята антропогенними ландшафтами у вітчизняних НПП занадто велика (на що є суб'єктивні причини з огляду на значну розораність країни) і має досить дивні розходження між парками - від 1\% в Азово-Сиваському НПП до 95\% у «Подільських Товтрах». Те, що в НПП «Подільські Товтри» на господарську зону припадає значний відсоток його території, а на заповідну менше 1\% (0,61\%), засвідчує «ефективність» природоохоронної діяльності в країні. Одне тільки «радує» - це найбільший (якщо не рахувати такого на острові Гренландія площею 70 млн га) національний парк Свропи (261 316 га) [8].

Загалом антропогенні ландшафти займають до половини (і більше) території наших національних парків. Для порівняння, у Польщі ця величина коливається від $1 \%$ до $20 \%$ і становить у середньому 4\% [13]. В Україні існує практика (функ- ціонального зонування) виділяти землі, вилучені 3 господарського користування, і землі, надані НПП у постійне користування (хоча у зазначеному вище Законі такого «феномену» чітко ніде не прописано). Це, мабуть, було продиктовано прагненням збільшити площу природно-заповідного фонду України i «дотягнутися» до європейського зразка (10-15\% від площі країни).

Частка земель, які знаходяться у постійному землекористуванні НПП України, невелика і складає в середньому $1 / 4$ частини від їх загальної площі, а по установах вона змінюється із напрочуд дивною амплітудою - від 1\% у тих же «Подільських Товтрах» (крутосхили річкової долини Дністра шириною 100 м і протяжністю 120 км, які практично не можна використати) до 100\% в Азово-Сиваському НПП. У ворогуючій з Україною Росії, наприклад, більшість національних парків належить до II категорії МСОП і порівняно з нашими вони мають значно суворіший режим і більшу частину земель у власному користуванні (83\%) [1].

Цікаві особливості функціонального зонування мають національні парки Німеччини. Так, перший у цій країні національний парк «Баварський Ліс» має заповідну зону, три зони розвитку лісів, буферну зону та зону рекреації, яка включає дві підзони: інтенсивної рекреації (включаючи сектори історичних об'єктів, зоологічний, розважальний) та пішохідного туризму й альпінізму. Основну частину парку займає резерват (до 70\% від загальної площі його території).

Йєллоустонський національний парк у США також має певні особливості у складі функціональних зон (з пріоритетом охоронюваних територій): території, доступні для автомобілістів, займають 25\% від загальної площі парку; території, не доступні для автомобілістів, - 75\% (включаючи підзони охоронюваного ландшафту - 50\%, найпростішого облаштування ділянок для відпочинку - 25\%) [14].

Крім зазначених, є й інші особливості функціонального зонування національних парків. Наприклад, виділення значних за площею спортивно-рекреаційних зон, які займають до 65\% від території парку (Канада); охоронних (буферних) зон, які в 5 разів і більше перевищують площу самих національних парків (Франція); фауністичних зон туризму, мисливства (країни Африки); гірських фауністичних зон з обмеженнями для туристів: заборона магнітофонів, транзисторних радіоприймачів, яскравого одягу (Італія) [2].

На основі функціонального зонування національних парків, а також територіальної конфігурації місць ландшафту (лісові масиви, системи озер, групи островів, дельти річок, узбережжя крупних водойм) базується їх планувальна організація. Вона складається 3 планувальної структури і функціонального зонування території. На формування планувальної організації суттєво впливають такі типи іiі основних 
елементів: лінійні (природні осі) - річки, прибережні смуги водойм, гірські хребти, а також транспортні магістралі, які перетинають парки, пішохідні і паркові дороги; точкові - населені пункти, виробничі комплекси $[5 ; 20]$.

Планувальна організаџія національних парків - це зумовлене природними факторами функціональне зонування їх території, на основі якого формуються різні типи просторово-планувальних структур, свого роду «каркасів» за напрямами природних осей з урахуванням існуючих систем розселення, виробництва, транспорту, інженерних споруд.

За різних природних і соціально-економічних умов планувальна організація національних парків може мати такі планувальні структури (структурні схеми): кільцеву, лінійну, тупикову і комбіновану (рис. 1) [14].
За умови використання кільцевої планувальної структури парку заповідна зона займає центральне положення, рекреаційні - периферійне; лінійної функціональні зони поступово чергуються вздовж природних осей (приморські, прирічкові райони); за тупикової структури центральне положення займають рекреаційні зони, а заповідна зона охоплює периферійні території (акваторії) парку (гірські, озерні райони); комбінована планувальна структура об'єднує всі попередні форми (тупиково-кільцева, лінійно-тупикова). Остання є найбільш поширеною схемою планувальної організації національних парків.

Кільцева планувальна структура характерна для багатьох вітчизняних і зарубіжних національних парків, таких як Карпатський, «Шацький» і «Синевир» (Україна), «Йеллоустонський» (США), «Татранський» (Чехія), «Вітоша» (Болгарія). За a)

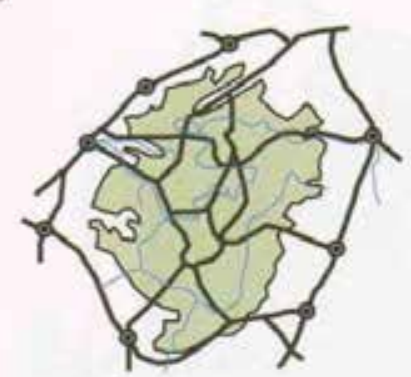

6)

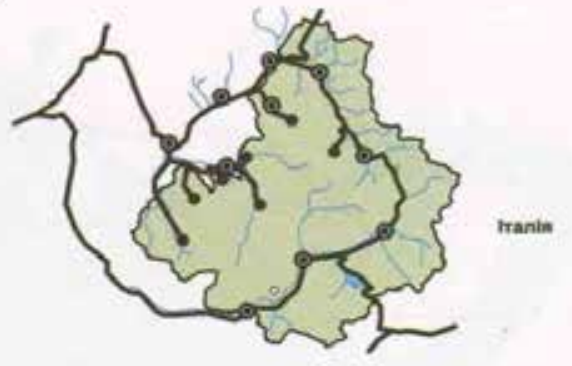

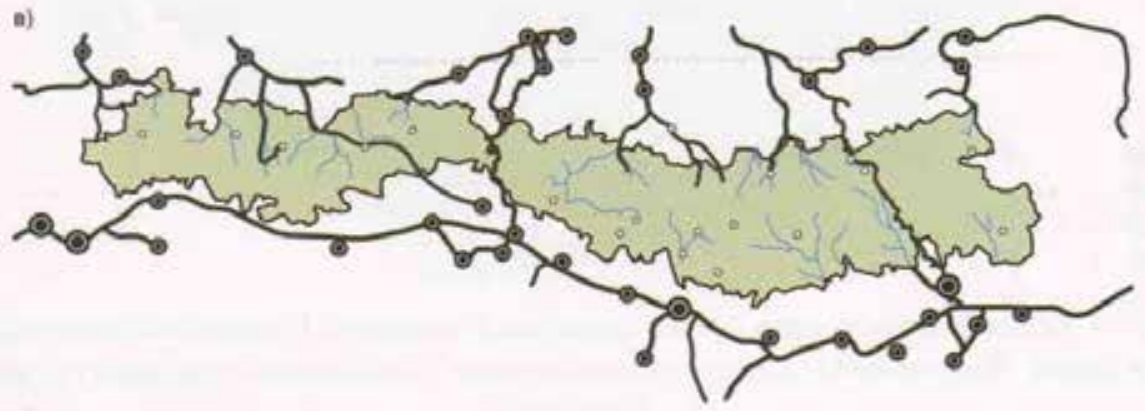

r)

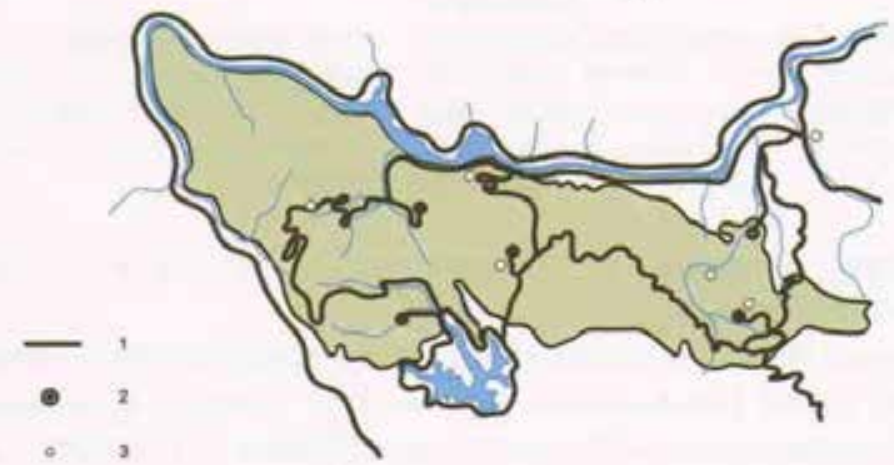

Рис. 1. Схеми планувальної організації території національних парків: а) кільцева (парк «Сімліпал» (Індія); б) тупикова (парк «Вануаз» (Франція); в) лінійна (парк «Централен Балкан» (Болгарія); г) комбінована (парк «Тара» (Сербія). 1 - головні паркові дороги; 2 - населені пункти; 3 - туристичні бази 
комбінованою схемою здійснена планувальна організація відомих зарубіжних національних парків: «Баварський Ліс» (Німеччина), «Лахемаа» (Естонія), «Аукштайтія» (Литва) [2; 14].

Значна кількість зарубіжних національних парків створюється на прибережних територіях морів, річок та інших великих водойм здебільшого за лінійною схемою планувальної структури йдеться про Прибайкальський (Росія), Метропарк (США), Гауя (Латвія), Куршська коса (Литва) [11; 14].

За комбінованою схемою організована планувальна структура національного парку «Pyrenees» (Франція), який розміщений уздовж гірського хребта вузькою смугою шириною від 1,5 до 20 км. У цьому парку 44\% від загальної кількості місць для відпочинку належить стаціонарним закладам (готелі, туристичні притулки), а 64\% - пристосованим оселям місцевих жителів. Цей національний парк міг би бути прикладом для наших вітчизняних парків, які могли б мати на балансі свої стаціонарні рекреаційні об'єкти типу названих вище, а також інтенсивно використовувати можливості сільського зеленого туризму (садиби сільських жителів).

Важливе місце під час розроблення планувальної організації (функціонального районування територіï) НПП України у проектах організації території, охорони, відтворення та рекреаційного використання їх природних комплексів і об'єктів посідає врахування допустимих антропогенних (рекреаційних) навантажень, рекреаційних потреб населення, кількості населених пунктів у регіоні.

Рекреаційне навантаження - це агрегатний показник антропогенного впливу (протягом комфортного періоду), що віддзеркалюється кількістю відпочивальників на одиниці площі, часом їх перебування на об'єкті рекреації і видом відпочинку. Нині для території НПП України запропоновано орієнтовні нормативи допустимого рекреаційного навантаження 1 люд.-день/га, а конкретно для зони регульованої рекреації - близько 5 люд.-день/га, стаціонарної рекреації - 20-50 люд.-день/га [4]. Для американських національних парків чинні нормативи допустимих рекреаційних навантажень на 1 га значно вищі і становлять від 35 до 60 людей, що пояснюється набагато досконалішим рекреаційним облаштуванням (асфальтовані дороги, готелі, кемпінги).

Для забезпечення функціонування національного природного парку формують оптимальну для його території систему транспортних комунікацій, яка охоплює паркові автодороги - парквеї (для екскурсійно-туристського обслуговування), режимні дороги (для утримання заповідних зон, проведення науково-дослідних робіт, екологічного контролю за станом і режимом природно-заповідних територій), рекреаційно-господарські дороги (для функціонування відповідних об'єктів), зовнішні автодороги (для зв'язку національного парку з іншими поселеннями).
У національних парках туристичні пішохідні маршрути класифікуються так: прогулянкові (в обидва кінці) - до 7 км протягом 2 годин; пізнавальні, одноденні - до 18 км протягом 8 годин; пізнавальні, триденні - до 40 км протягом 20 годин; туристично-тематичні, багатоденні - до 75 км протягом 40 годин; туристично-спортивні, багатоденні - до 130 км протягом 48 годин [14].

У рекреаційних зонах національних природних (i регіональних ландшафтних) парків, у межах яких є водойми, можна створювати пляжні комплекси з урахуванням мінімальної довжини берегової смуги на одного відвідувача: для проточних водойм - 0,5 м, для непроточних водойм - 1,0 м. Згідно 3 нормами (ДБН 360-92, пункт 5.27) на морських пляжах для дорослих

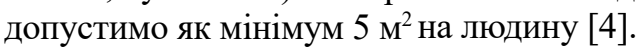

Отже, функціональне зонування території НПП можна розуміти як форму його територіальної організації або територіального планування. Останнє як галузь науково-практичної діяльності у різних країнах має різні офіційні назви: ландшафтне планування (Німеччина), краєвлаштування (Литва), просторове планування (США), фізичне планування (Голландія). Територіальне планування (організація) полягає в обгрунтуванні такого впорядкування ландшафту (влаштування території ландшафту), за якого створюється конфігурація його територіальних елементів (місць, плям), що забезпечує максимально ефективне виконання заданих функцій.

Головні висновки. Функціональне зонування це поділ природно-заповідних територій і об'єктів на ділянки (зони) з різними режимами збереження, відтворення і використання ландшафтних (природних) комплексів. Функціональне зонування національного парку є головною передумовою для його розвитку, гарантією збереження біорізноманіття та раціонального екологічно зорієнтованого природокористування. Результатом проведеного функціонального зонування території національного парку є схема (картосхема) як наочне відображення просторових функцій, які ця територія має виконувати.

На особливостях функціонального зонування національного парку, а також на основі територіальної конфігурації ландшафтних місць базується їх планувальна організація, яка складається із планувальної структури і функціонального зонування території. Планувальна організація національних природних парків - це зумовлене природними факторами функціональне зонування їх території, на основі якого формуються різні типи просторово-планувальних структур - кільцева, лінійна, тупикова і комбінована.

Важливе місце під час розроблення планувальної організації (функціонального районування територіï) національних природних парків України у проектах організації території, охорони, відтворення та рекреаційного використання їх природних комплексів і об'єктів посідає врахування допустимих рекреаційних навантажень. 


\section{Література}

1. Гетьман В.I. Національні природні парки України. Київ : Редакція газет природничо-математичного циклу. (Бібліотека «Шкільного світу»). 2012. 128 с.

2. Гетьман В.І. Методичні рекомендації щодо визначення рекреаційних навантажень у межах природно-заповідних територій та об’єктів. Полтава : «Дивосвіт», 2017. 43 с.

3. Гродзинський М.Д. Пізнання ландшафту: місце і простір : монографія. У 2-х т. Київ : ВПЦ «Київський університет», 2005. Т. $1.431 \mathrm{c}$

4. Забелина Н.М. Национальный парк. Москва : Мысль, 1987. 175 с.

5. Заповідна справа в Україні / під загальною редакцією Гродзинського М.Д. Київ : Географіка, 2003. 306 с.

6. Заповідники і національні природні парки України. Київ : Вища школа, 1999. 232 с.

7. Клюшин В.А., Михайлова И.Ф. Архитектурно-планировочная организация национальных парков. Москва : ЦНТИ, $1976.55 \mathrm{c}$.

8. Меллума А.Ж. Функциональное зонирование национального парка «Гауя» как основа для разработки программы дифференциальной охраны природы. Растительный мир охраняемых территорий. Рига : Зинатне, 1978. С. 12-19.

9. Менеджмент охоронних лісів України / під загальною редакцією акад. НАН України Ю.Р. Шеляга-Сосонко. Київ : Фітосоціоцентр, 2003. 299 с.

10. Методические рекомендации по архитектурно-планировочной организации природных парков Украинской ССР. Київ : КиевНИИПград, 1978. 89 с.

11. Методичні рекомендації щодо складу та змісту проекту організації території національного природного парку, охорони, відтворення та рекреаційного використання його природних комплексів і об'єктів. Київ : Центр екомоніторингу України, $2005.95 \mathrm{c}$.

12. Национальные парки в Польше. Варшава : Шевелье, 1989. 16 с.

13. Панченко Т.Ф. Ландшафтно-рекреаційне планування природно-заповідних територій : монографія. Київ : Логос, 2015. $176 \mathrm{c}$.

14. Попович С.Ю., Устименко П.М. Рослинність і функціональне зонування Сіверсько-донецького природного національного парку. Украӥнський ботанічний журнал. № 3. 1992. Т. 49. С. 25-31.

15. Попович С.Ю. Природно-заповідна справа : навчальний посібник. Київ : Арістей, 2007. 480 с.

16. Природно-заповідний фонд України загальнодержавного значення. Довідник. Київ : Омега- Л, 1999. 240 с.

17. Проект організації території національного природного парку «Синевир», охорони, відтворення та рекреаційного використання його природних комплексів і об'єктів, затверджений наказом Міністерства екології та природних ресурсів України від 27 березня 2003 року № 47/ДС.

18. Система категорій природно-заповідного фонду України та питання іiї оптимізації / Т.Л. Андрієнко та інші. Київ : Фітосоціоцентр, 2001. 60 с.

19. Шеляг-Сосонко Ю.Р., Устименко П.М. Критерії функціонального зонування природних національних парків. Український ботанічний журнал. № 3. 1988. Т. 45. С. 79-81.

20. Шищенко П.Г. Прикладная физическая география. Київ : Выща шк. Головное ид-во, 1988. 192 с.

21. Global ecology: a New Arena of Political Conflicts / Ed. By W. Sachs. London, New Jersy, 1993. 262 p.

22. Tolle P., Forest J. National park servise in Sonth Florida. 1981. 79. № 8. P. 512-515. 


\title{
СУЧАСНИЙ СТАН НАСАДЖЕНЬ ІСТОРИЧНОЇ МАНДШАФТНОЇ ДІАЯНКИ “ДРУХНІЙ САД" У ДЕНДРОПАРКУ “ОАЕКСАНДРІЯ" НАН УКРӒ̈НИ
}

\author{
Мордатенко І.Л. \\ Державний дендрологічний парк «Олександрія» \\ Національної академії наук України \\ м. Біла Церква, 09113, Київська обл.
}

Fiesta012@ukr.net

Парк «Олександрія» спочатку як літня, а згодом як зимова резиденція графів Браницьких був заснований у 1788 році на західній околиці Білої Церкви на лівому березі річки Рось на площі понад 200 га. Він створювався за ландшафтним типом планування території, для чого було використано існуючі природні елементи: вікову діброву, річку Рось, нерівності рельєфу у вигляді балок. Свого часу «Олександрія» була культурним і духовним центром Східної Польщі, а пізніше - Південних губерній Росії.

У першій половині XX ст. парку було нанесено великих збитків. Було втрачено не лише архітектурні споруди, а й ландшафтні композиції. Більшість паркових композицій через відсутність догляду заросла самосівом, було знищено багато екзотів. Тому роботи з відновлення історичних ландшафтів парку є дуже важливими.

Історична ландшафтна ділянка «Дружнього саду» розташована в західній частині парку і складається із 3 частин: «Сад Юпітера», «Сад, присвячений Катерині ІІ», «Сад Г. Потьомкіна». Була оброблена велика кількість архівних матеріалів щодо видового складу насаджень на цій території. Основним джерелом інформації, яке дає нам уяву про минуле, є старовинний план парку, датований 1858 роком, та архівні фотографії і малюнки.

Після проведення інвентаризації деревних рослин було встановлено, що насадження «Дружнього саду» представлено 42 видами, які відносяться до 2 відділів - Pinophyta (6 видів із 2 родин і 6 родів) та Magnoliophyta (36 видів із 19 родин і 26 родів). 3'ясовано, що найбільшою кількість родів представлено родини Pinaceae та Rosaceae. Найбільшою кількістю рослин представлені роди Acer, Fraxinus, Carpinus, Tilia. Найчисельніше представлені такі види деревних рослин: Acer platanoides, Fraxinus excelsior, Tilia cordata, Carpinus betulus. Розподіл видів дерев і кущів за класами висот дозволив встановити такі дані: дерев першої величини налічувалося 19, другої та третьої величини - по 3, четвертої- по 4. До класів високих кущів було віднесено 5 видів, середніх -5 , низьких - 2 види рослин. Ключові слова: дендропарк, насадження, деревна рослинність, ландшафтна композиція.

The current condition of plants of historical landscape area "Druzhnii sad" in the dendrological park "Alexandria" NAS of Ukraine. Mordatenko I.

Alexandria Park, firstly was a summer and later a winter residence of the Branytsky family. It was founded in 1788 on the western suburbs of Bila Tserkva, on the left bank of the Ros River on an area of over 200 hectares. It was created according to the landscape type of planning of the territory, for which the existing natural elements were used: the age-old oak, the river Ros, relief disturbance in the form of beams. One time, "Alexandria" was the cultural and spiritual center of Eastern Poland, and later - the southern provinces of Russia.

In the first half of the twentieth century, the park was seriously damaged. Not only architectural structures but also landscape compositions have been lost. Most of the park compositions were overgrown with self-seeding due to lack of care, many exotics were destroyed. That is why, the historic landscapes restoration works of the park are very important.

The historic landscape area "Druzhnii sad" is located in the western part of the park and consists of 3 parts: "Jupiter's Garden", "Garden dedicated to Catherine II", "Garden of G. Potemkin". A large number of archival materials on the species composition of plantations in this area were considered. The main source of information that gives us an idea of the past is the ancient plan of the park, dated 1858 and archival photographs and drawings.

After taking an inventory of woody plants, it was found that the plantings of the "Druzhnii sad" are represented by 42 species belonging to 2 departments - Pinophyta (6 species from 2 families and 6 genera) and Magnoliophyta (36 species from 19 families and 26 genera). It was found that the largest number of genera are families: Pinaceae and Rosaceae. The largest number of plants are genera: Acer, Fraxinus, Carpinus, Tilia. The most numerous are such species of woody plants as Acer platanoides, Fraxinus excelsior, Tilia cordata, Carpinus betulus. The distribution of species of trees and shrubs by height classes established: trees of the first size - 19, the second and third size -3 , the fourth -4 . Key words: arboretum, planting, lignosa, landscape composition.

Постановка проблеми. Старовинні садиби це великий пласт вітчизняної культури, який через різні обставини довго залишався мало дослідженим. Вивчення життя і побуту дворянських садиб минулих епох дає можливість більш змістовно дослідити умови формування світогляду політичної та культурної еліти XVIII - XIX ст. та перейняти найкраще 3 їхнього досвіду. Тому ми вважаємо, що питання з відновлення старовинних парків України, а саме їх реконструкції, є дуже актуальним.
За минулі два століття з часу заснування дендропарку «Олександрія» відбулися зміни в структурі деревних насаджень і руйнування значної частини декоративних паркових композицій. Здебільшого це стосується досліджуваної ділянки, розташованої в східній частині дендропарку. Реконструкція цієї ландшафтної ділянки буде важливим внеском у загальну тенденцію збереження і відновлення ландшафтів старовинних парків, яка визначена прийнятою 21 травня 1981 року у Флоренції Міжнародним 
Комітетом по історичних садах (International Committee for Historic Gardens) Флорентійською хартією (Charter historic garden sandlandscapes (Florencecharter), яка ратифікована Україною [19].

Об'єкт досліджень - структура насаджень історичної ділянки «Дружній сад».

Предмет досліджень - таксаційні показники деревних насаджень ділянки «Дружній сад».

Мета досліджень - встановити сучасний склад і стан насаджень історичної ландшафтної ділянки «Дружній сад» і надати рекомендації щодо іiі реконструкції. Для досягнення зазначеної мети необхідно виконати такі завдання: встановити первинний таксономічний склад ділянки «Дружній сад»; дослідити сучасний стан ділянки, визначити територіальні межі насаджень 3 подальшим нанесенням їх на план.

Новизна. У статті вперше грунтовно досліджено архівні матеріали по ландшафтній ділянці «Дружній сад»; вперше проведена подеревна інвентаризація 3 відповідним нанесенням отриманих даних на карту.

Методологічне або загальнонаукове значення. На основі вивчення іконографічних і архівних матеріалів буде проведено реконструкцію алейної сітки, малих архітектурних форм та оптимізацію деревних насаджень і трав'янистого покриву ландшафтної ділянки «Дружній сад» для подальшого експонування, що вплине на збільшення кількості відвідувачів.

Аналіз останніх досліджень і публікацій. На пострадянському просторі основні підходи щодо відновлення складу та структури насаджень старовинних парків викладені у роботах В.А. Агальцевої [1], Н.А. Ільїнської [7; 8], Д.С. Ліхачева [13] та інших.

Н.А. Ільїнська, працюючи над відновленням палацових парків-пам'яток садово-паркового мистецтва, встановила, що завершеного вигляду парки здебільшого набували через 40-50 років після початку будівництва (період розквіту). Багато ансамблів протягом своєї історії перебудовувалися та доповнювалися, тобто зазнавали певних часових нашарувань. Н.А. Ільїнська [6] вважає обов'язковим перед початком відновлюваних робіт проведення архівних досліджень, які характеризують об'єкт на різних етапах розвитку, та археологічних розкопок.

За даними В.А. Агальцевої [1], при вирішенні питання щодо реконструкції насаджень необхідно керуватися такими положеннями: якщо збереглося 50-70\% дерев, то ніяких підсадок проводити не потрібно; якщо залишилося 30-40\% і є проміжки у 20-30 м і більше, то доцільно висадити великомірні саджанці точно на місцях відпаду старих дерев; якщо маємо менше 15-20\% від первинної кількості посаджених дерев і вони знаходяться в незадовільному стані, то проводиться повна заміна рослин.

Основні підходи щодо відновлення планування доріжно-стежкової мережі, складу та структури насаджень старовинних парків викладені у роботах Ю.А. Бондарь, А.К. Салатич [2], Т.Е. Ісаченко
[9], Г.А. Полякова [14]. В Україні найбільший вклад у справу відновлення старовинних парків внесли Л.І. Рубцов [16], О.А. Косаревський [11], І.Д. Родічкін [15]. Багато уваги збереженню та відновленню паркових композицій приділено у роботах провідного українського дендролога М.А. Кохна, який із колегами протягом 1973-1977 років в Україні експериментально розробили прийоми реконструкції паркових композицій [12]. Значний внесок у дослідження дендрофлори старовинних парків зробив Ю.О. Клименко [10].

Матеріали і методи досліджень. У роботі були використані методи комплексного аналізу (історико-аналітичний), іконографічний, натурний (фотофіксація, обміри, замальовки). Хронологічні межі досліджень - кінець XVIII - початок XXI ст. Під час опрацювання літературних першоджерел було застосовано історико-аналітичний метод.

Інвентаризацію деревних насаджень здійснювали під час натурних обстежень і польових маршрутних досліджень [18]. Висоту дерев визначали за допомогою вимірювального приладу ВН-1 № 4515. Видовий склад, походження видів деревних рослин та їхні екологічні особливості визначали за довідковою літературою «Дендрофлора України» [4-6], латинські назви таксонів видового рангу та їх систематичну структуру погоджували зі списком "The Plant List" [21]. Планувальну структуру визначали за супутниковими картами Google Maps 2019-2020 років.

Виклад основного матеріалу. Початок будівництва дендропарку припадає на другу половину XVIII ст. У минулому це був величезний парк-садиба графів Браницьких, який мав багато композицій, сенс і семантика яких були пов'язані з особистими, чисто сімейними подіями. Центральними фігурами, які вплинули на долю графині Олександри Браницької, були князь Григорій Потьомкін і імператриця Катерина II, яким вона була багато в чому зобов'язана, відповідаючи їм глибокою особистою прихильністю [3]. Саме їм присвячені інтимні паркові композиції, розташовані в східній частині парку. Архівні матеріали досить бідно висвітлюють цю частину парку, яка зберегла до наших часів ореол історичної таємниці.

У 1818 році в Херсоні відбулася подія, наслідки якої залишається загадкою. При проведенні ремонтних робіт у Свято-Катерининській церкві зі склепу Потьомкіна катеринославський архієпископ Іов виніс посудину (ймовірно із серцем князя), помістив iii у свою карету, щоб відправити його, за однією з версій, у маєток графині Браницької (в Білу Церкву) [20]. Можна припустити, що ця посудина і стала ключовим елементом для реалізації Олександрою у своєму маєтку грандіозного проекту - мавзолею Г. Потьомкіну. Зберігся проект цього мавзолею, виконаний відомим російським архітектором I. Старовим (рис. 1). На жаль, у зв'язку 3 приходом до влади Павла I цей проект не був повністю (в первісному вигляді) втілений у життя. 


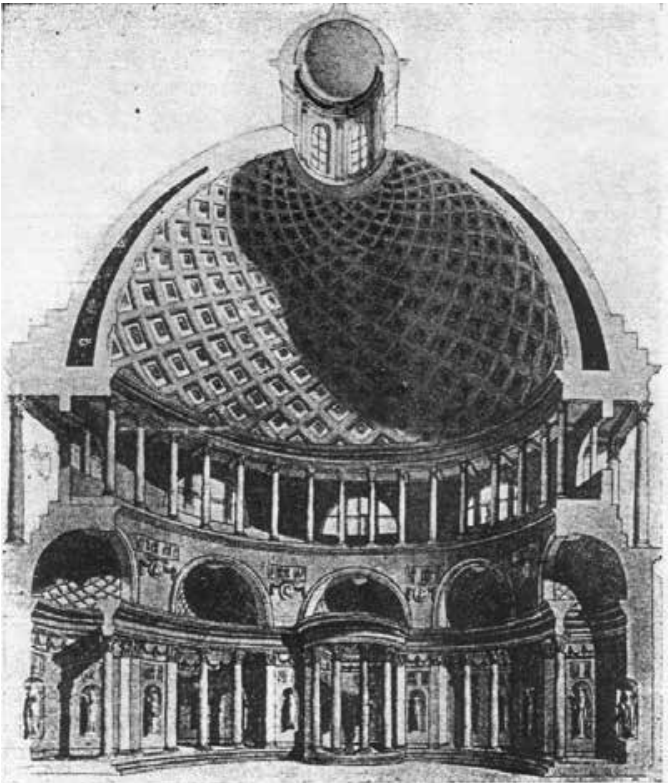

Рис. 1. Проект мавзолею на честь Великого князя Г. Потьомкіна-Таврійського

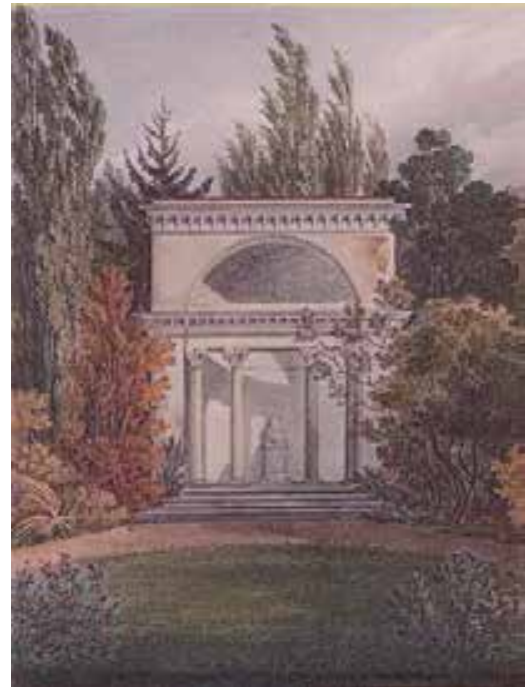

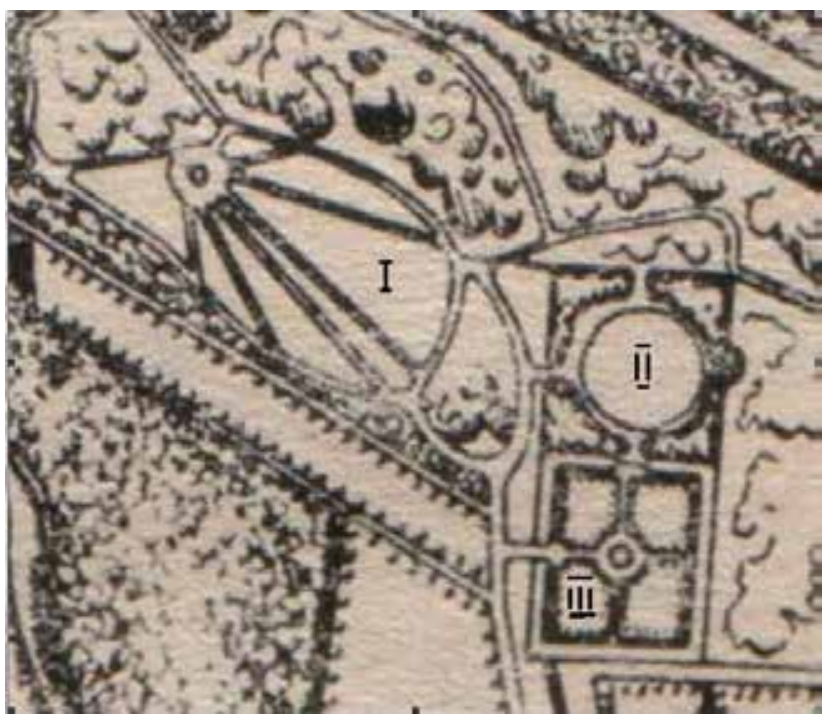

Рис. 2. Фрагмент «Генерального плану дендропарку «Олександрія» (1858 року): I - «Сад Юпітера», II - «Сад, присвячений Катерині II», III - «Сад Г. Потьомкіна»

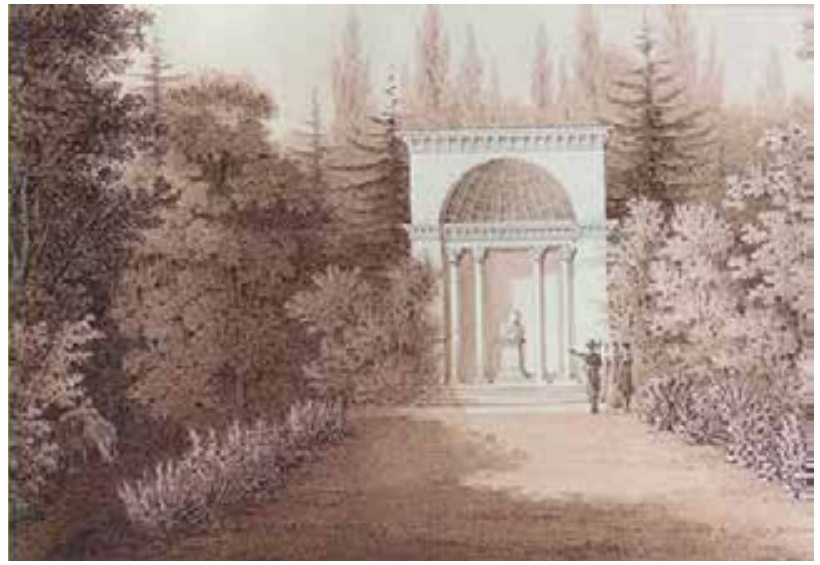

Рис. 3. «Ротонда». Вілібальд Ріхтер, 1828 рік

Основним джерелом інформації, яке дає нам уяву про минуле, є старовинний план парку, датований 1858 роком (рис. 2), а також невеликі іконографічні матеріали. Так, на Генеральному плані пристрою Білої Церкви 1858 року ця ділянка з меморіальними садами складалася із 3 частин: «Сад Юпітера», «Сад, присвячений Катерині ІІ», «Сад Г. Потьомкіна». Усі ці сади були складниками одного саду, який мав назву «Дружній сад».

«Сад Юпітера» спочатку був садом регулярного планування, який складався із численних ділянок різної геометричної форми. У середині XIX ст. сад перебудували у ландшафтному стилі. В західній частині знаходилася партерна композиція Юпітера, яка пред- ставляла собою круглу площину зі скульптурою в центрі, від якої віялом розходилися прямі доріжки («промені»), об'єднані овальної алеєю. Неширокі, променеподібні доріжки по черзі віялом із півночі на південь виходили на курган під назвою «Могила коня», «Сад Катерини II» та «Сад князя Г. Потьомкіна».

«Сад Катерини ІІ» був єдиною в «Олександрії» повністю закритою композицією. Основними посадками, згідно з умовними позначеннями на карті, були хвойні дерева. Всередині саду росло багато бузку, тут знаходилася Ротонда із позолоченими воротами [3]. Спочатку в Ротонді знаходився бюст Г. Потьомкіна (рис. 3), але з подальшим будуванням меморіального комплексу «Дружній сад» він був перенесений 
у «Сад Г. Потьомкіна», а на його місці було встановлено бюст Катерини II (рис. 4).

Ділянка була обнесена суцільною, приблизно в ріст людини, стіною із залізними воротами. Додатково по периметру сад був густо обсаджений деревами і кущами. Тому Сад і Ротонду не можливо було оглянути через огорожу. Для того, щоб потрапити туди, потрібно було отримати особливий дозвіл від власників садиби. «Сад Г. Потьомкіна» був обсаджений по внутрішньому периметру чагарником або стриженою огорожею із Carpinus betulus $\mathrm{L}$.

Iз 1917 по 1946 роки парк, а разом 3 ним i «Дружній сад» зазнав суттєвих змін: було зруйно-

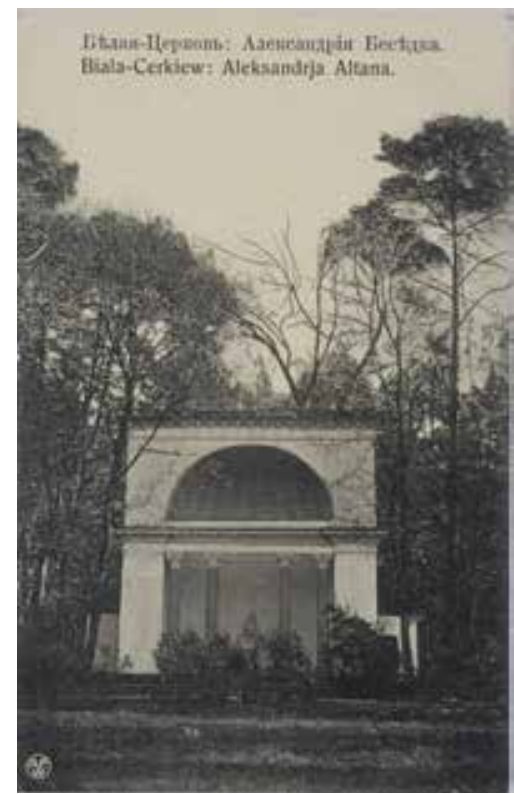

Рис. 4. «Ротонда». Фото 1914 року вано архітектурні споруди (рис. 5), змінився і видовий склад насаджень парку. За воєнні роки було вирізано значну частину цінних насаджень, а на вільних місцях масово сходив самосів аборигенних деревних порід. Із карти Салатіча 1949 року [17] видно, що на досліджуваній території насадження перетворилися в змішані насадження паркового типу (рис. 6). При цьому досить цікавим $є$ той момент, що на картах 1858 і 1949 років, а також на сучасній карті (рис. 7) коло перед Ротондою так і не покрилося рослинністю, хоча і «Сад Юпітера», $\mathrm{i}$ «Сад Г. Потьомкіна» повністю втратили свій вигляд.

Часткові відновлювальні роботи цієї частини парку (відреставрована Ротонда і розчищена від дерев i чагарників партерна зона) були проведені в 60-х роках XX ст. під керівництвом архітектора Д.М. Криворучка (рис. 8).

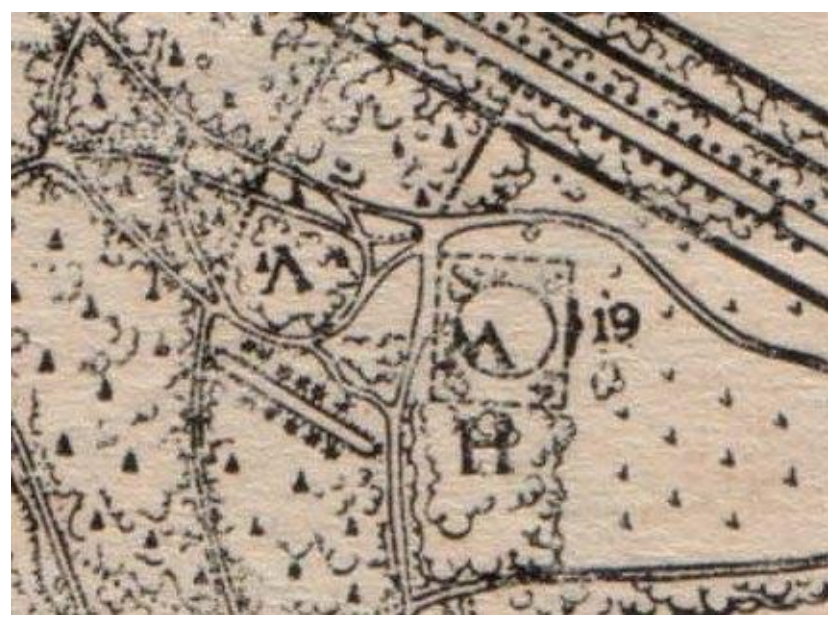

Рис. 6. Фрагмент плану парку «Олександрія» станом на 1949 рік

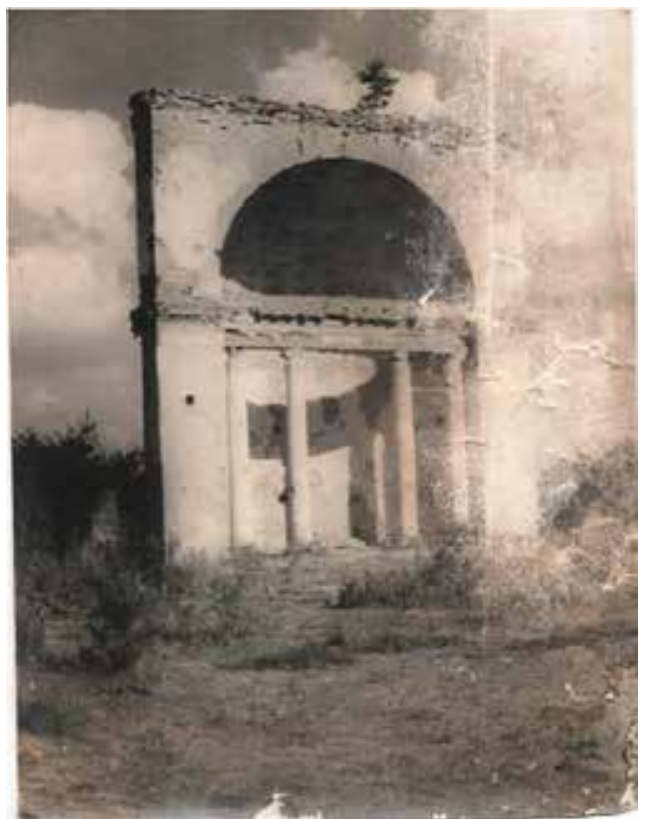

Рис. 5. Ротонда після Великої вітчизняної війни 


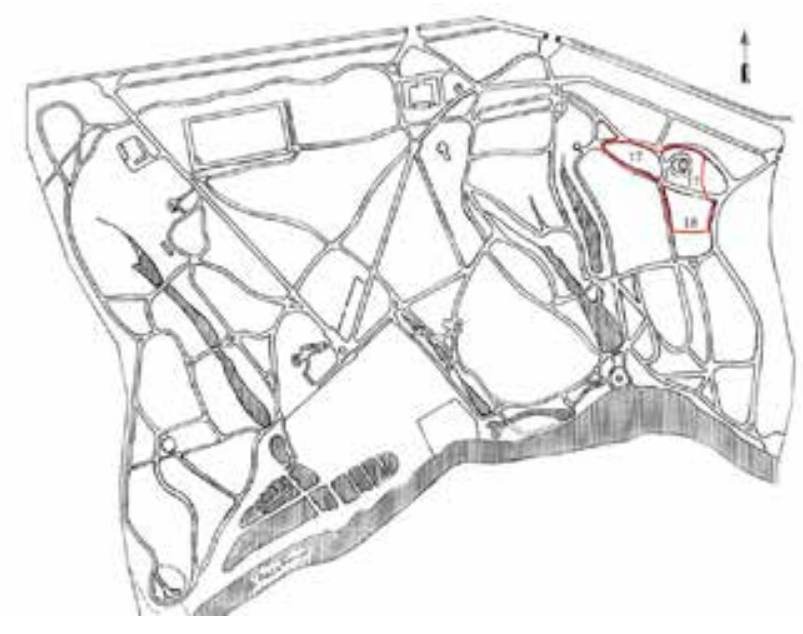

Рис. 7. Досліджувана територія на сучасній схемі парку

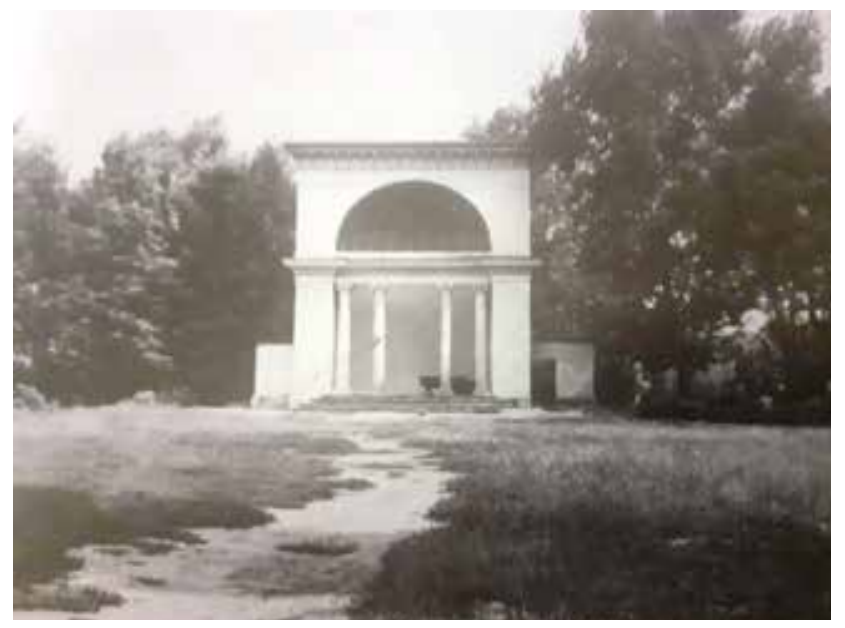

Рис. 8. Ротонда після реставраиії Д.М. Криворучка, 1968 рік

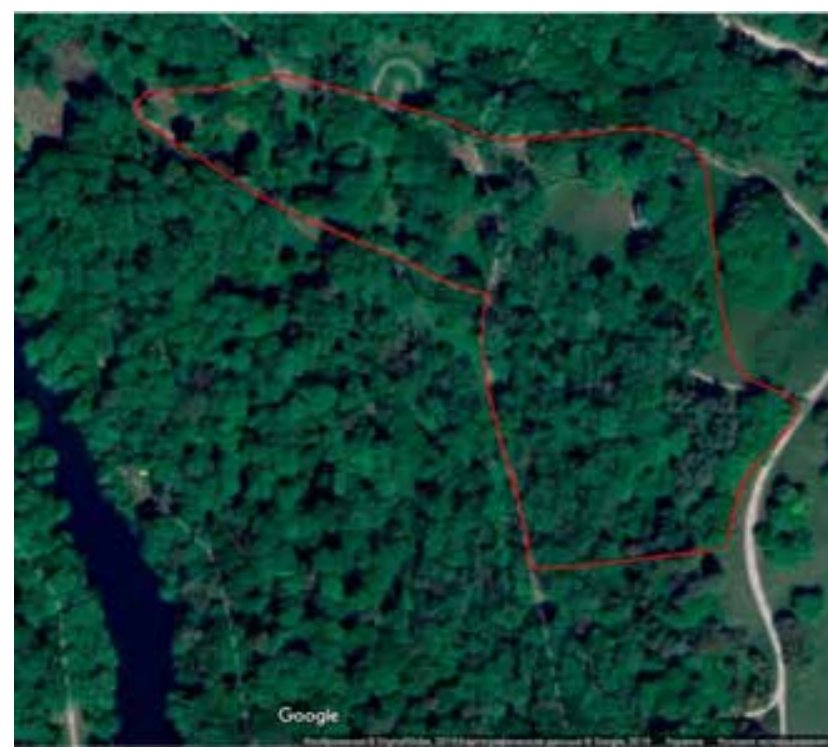

Рис. 9. "Дружній сад» (супутникова карта Google Maps, 2019 рік)
На початок проведення деревної інвентаризації усі складники «Дружнього саду» знаходилися в різному стані. У 1956-1959 роках на ділянці «Саду Юпітера» були висаджені інтродуценти: Maclura pomifera (Rafin.) Schneid, Catalpa bignonioides Walt., Junglans nigra L., Picea abies (L.) Karst. У 2008-2011 роках у «Саду Юпітера» та «Саду Катерини» були проведені часткові роботи з прибирання самосіву, обрізки сухих гілок, а також із омелою білою (Viscum album L.). У «Саду Г. Потьомкіна» ніякі роботи не проводилися.

Результати інвентаризації вказують, що деревні насадження «Дружнього саду» було представлено 42 видами, які відносяться до 2 відділів - Pinophyta (6 видів із 2 родин і 6 родів) та Magnoliophyta (36 видів із 19 родин і 26 родів) (табл. 1,2 ).

Найбільшою кількістю родів представлено родини Pinaceae та Rosaceae - 4 і 5 відповідно. Найбільшою кількістю рослин представлені роди Acer, Fraxinus, Carpinus, Tilia. Найчисельніше представлені такі види деревних рослин: Acer platanoides (63 екземпляри), Fraxinus excelsior (61 екземпляри), Tilia cordata (32 екземпляри), Carpinus betulus (26 екземплярів) (табл. 3). Із загальної кількості видів і форм деревних рослин, які зростають на досліджуваній території, 29 видів мають життєву форму дерево (69,0\%), 12 є кущами $(28,6 \%), 1$ вид дерева ліана $(2,4 \%)$.

Визначено розподіл видів дерев і кущів за класами висот: дерев першої величини - 19, другої та третьої величини -по 3, четвертої - по 4. До класів високих кущів віднесено 5 видів, до середніх - 5, низьких - 2 види рослин (табл. 4).

Головні висновки. Згідно 3 проведеними дослідженнями історичної ландшафтної ділянки «Дружній сад» дендропарку «Олександрія» можна зробити такі висновки:

1. Видовий склад деревних насаджень «Дружнього саду» представлено 42 таксономічними групами, які відносяться до 2 відділів - Pinophyta (6 видів із 2 родин і 6 родів) та Magnoliophyta (36 видів із 19 родин і 26 родів).

2. Найбільше родове представництво мають родини Pinaceae та Rosaceae -4 та 5 відповідно. Найбільш кількісно представлені роди Acer, Fraxinus, Carpinus, Tilia. Найчисельніше серед видів представлені Acer platanoides (63 екземпляри), Fraxinus excelsior (61 екземпляр), Tilia cordata (32 екземпляри), Carpinus betulus (26 екземпляри).

3. За життєвими формами насадження ділянки «Дружнього саду» розподілені на деревні (29 видів) 69,0\%, 12 - кущові (28,6\%), деревні ліани - 1 вид $(2,4 \%)$.

4. За класами висот розподіл видів дерев і кущів такий: дерев першої величини - 19, другої та третьої величини - по 3, четвертої - по 4. До класів високих кущів віднесено 5 видів, до середніх - 5, до низьких -2 види рослин. 
Таксономічний склад деревних рослин дослідної ділянки «Дружнього саду»

\begin{tabular}{|c|c|c|c|c|}
\hline \multirow{2}{*}{ № п/п Систематичні одиниці } \\
\cline { 3 - 5 } & \multirow{2}{*}{ Назва відділу } & родин & родів & видів \\
\hline 2. & Pinophyta & 2 & 6 & 36 \\
\hline 2. & Magnoliophyta & 19 & 26 & $\mathbf{3 2}$ \\
\hline
\end{tabular}

Таблиця 2

Систематична структура дендрофлори дослідної ділянки «Дружнього саду»

\begin{tabular}{|c|c|c|c|}
\hline \multirow{2}{*}{$\begin{array}{c}\text { № } \\
\text { II/II }\end{array}$} & \multirow{2}{*}{ Назва родини } & \multicolumn{2}{|r|}{ Систематичні одиниці } \\
\hline & & рід & види \\
\hline \multicolumn{4}{|c|}{ Відділ Pinophyta } \\
\hline \multirow[t]{2}{*}{1.} & \multirow[t]{2}{*}{ Cupressaceae Gray } & Juniperus & Juniperus sabina L. \\
\hline & & Thuja & Thuja occidentalis L. \\
\hline \multirow[t]{4}{*}{2.} & \multirow[t]{4}{*}{ Pinaceae Lindl. } & Abies & Abies alba Mill. \\
\hline & & Larix & Larix sibirica Ledeb. \\
\hline & & Picea & Picea abies (L.) Karst. \\
\hline & & Pinus & Pinus sylvestris L. \\
\hline \multicolumn{4}{|c|}{ Відділ Magnoliophyta } \\
\hline 1. & Adoxaceae E. Mey. & Sambucus & Sambucus nigra L. \\
\hline 2. & Anacardiaceae R. Br. & Cotinus & Cotinus coggygria Scop \\
\hline \multirow[t]{2}{*}{3.} & \multirow[t]{2}{*}{ Betulaceae Gray } & Carpinus & Carpinus betulus L. \\
\hline & & Corylus & Corylus avellana $\mathrm{L}$. \\
\hline 4. & Bignoniaceae Juss. & Catalpa & Catalpa bignonioides Walter. \\
\hline \multirow[t]{2}{*}{5.} & \multirow[t]{2}{*}{ Caprifoliaceae Juss. } & Lonicera & Lonicera caprifolium L. \\
\hline & & Symphoricarpos & Symphoricarpos albus (L.) S.B. Blanke \\
\hline 6. & Celastraceae R. Br. & Euonymus & Euonymus europaea L. \\
\hline \multirow[t]{2}{*}{7.} & \multirow[t]{2}{*}{ Cornaceae Bercht. \& J. Presl. } & Cornus & Cornus mas L. \\
\hline & & Swida & Swida alba (L.) Opiz \\
\hline 8. & Fabaceae Lindl. & Robinia & Robinia pseudoacacia L. \\
\hline \multirow[t]{3}{*}{9.} & \multirow[t]{3}{*}{ Fagaceae Dumort. } & \multirow[t]{3}{*}{ Quercus } & Quercus iberica Steven \\
\hline & & & Quercus robur L. \\
\hline & & & Quercus rubra L. \\
\hline 10. & Hippocastanaceae Burnett & Aesculus & Aesculus hippocastanum L. \\
\hline \multirow[t]{2}{*}{11.} & \multirow[t]{2}{*}{ Hydrangenaceae Dumort. } & Deutzia & Deutzia scabra \\
\hline & & Philadelphus & Philadelphus coronaries L. \\
\hline 12. & Junglandaceae DC. ex Perleb & Juglans & Juglans nigra L. \\
\hline \multirow[t]{2}{*}{13.} & \multirow[t]{2}{*}{ Malvaceae Juss. } & \multirow[t]{2}{*}{ Tilia } & Tilia americana L. \\
\hline & & & Tilia cordata Mill. \\
\hline 14. & Moraceae Gaudich. & Maclura & Maclura pomifera (RAF.) C.K. Skhneid \\
\hline \multirow[t]{2}{*}{15.} & Oleaceae Hoff. \& Link. & Fraxinus & Fraxinus excelsior L. \\
\hline & & & Fraxinus pennsylvanica \\
\hline 16. & Rosaceae Juss. & Amelanchier & Amelanchier alnifolia (Nutt.) Nutt. Ex M. Roem. \\
\hline & & Chaenomeles & Chaenomeles japonica (Thunb.) Lindl. Ex Spach \\
\hline & & Crataegus & Crataegus leiomonogyna Klok. \\
\hline & & & Crataegus submollis Sarg. \\
\hline & & Padus & Padus avium Mill. \\
\hline & & Spiraea & Spiraea salicifolia $\mathrm{L}$. \\
\hline & & & Spiraea $\times$ vanhouttei (Briot) Zabel \\
\hline 17. & Salicaceae Mirb. & Populus & Populus $\times$ canescens (Aiton) Sm. \\
\hline 18. & Sapindaceae Juss. & Acer & Acer campestre L. \\
\hline & & & Acer platanoides L. \\
\hline & & & Acer pseudoplatanus L. \\
\hline & & & Acer saccharinum L. \\
\hline 19. & Ulmaceae Mirb. & Ulmus & Ulmus scabra Mill. \\
\hline & Разом & 33 & 42 \\
\hline
\end{tabular}


Кількісний склад деревної рослинності ділянки «Дружнього саду»

\begin{tabular}{|c|c|c|}
\hline № ா/II & Назва рослини & Кількість, шт. \\
\hline \multicolumn{3}{|c|}{ Дерева } \\
\hline 1. & Abies alba Mill. & 4 \\
\hline 2. & Acer campestre L. & 26 \\
\hline 3. & Acer platanoides L. & 63 \\
\hline 4. & Acer pseudoplatanus L. & 1 \\
\hline 5. & Acer saccharinum L. & 1 \\
\hline 6. & Aesculus hippocastanum L. & 1 \\
\hline 7. & Carpinus betulus L. & 26 \\
\hline 8. & Cornus mas L. & 23 \\
\hline 9. & Catalpa bignonioides Walter. & 1 \\
\hline 10. & Cotinus coggygria Scop. & 19 \\
\hline 11. & Crataegus leiomonogyna Klok. & 6 \\
\hline 12. & Crataegus submollis Sarg. & 3 \\
\hline 13. & Fraxinus excelsior L. & 61 \\
\hline 14. & Fraxinus pennsylvanica & 6 \\
\hline 15. & Juglans nigra L. & 1 \\
\hline 16. & Larix sibirica Ledeb. & 6 \\
\hline 17. & Maclura pomifera (RAF.) C.K. Skhneid & 2 \\
\hline 18. & Padus avium Mill. & 1 \\
\hline 19. & Picea abies (L.) Karsten. & 3 \\
\hline 20. & Pinus sylvestris L. & 16 \\
\hline 21. & Populus $\times$ canescens (Ait.) Smitt. & 5 \\
\hline 22. & Quercus iberica Steven & 1 \\
\hline 23 & Quercus robur L. & 4 \\
\hline 24 & Quercus rubra L. & 5 \\
\hline 25. & Robinia pseudoacacia L. & 20 \\
\hline 26. & Thuja occidentalis L. & 9 \\
\hline 27. & Tilia americana $\mathrm{L}$. & 5 \\
\hline 28. & Tilia cordata Mill. & 32 \\
\hline 29. & Ulmus scabra Mill. & 1 \\
\hline & Рaзом & 351 \\
\hline \multicolumn{3}{|c|}{ Кущі } \\
\hline 1. & Amelanchier alnifolia (Nutt.) Nutt. Ex M. Roem. & група \\
\hline 2. & Chaenomeles japonica (Thunb.) Lindl. Ex Spach & куртина \\
\hline 3. & Corylus avellana $\mathrm{L}$. & $>20$ \\
\hline 4. & Deutzia scabra & 2 \\
\hline 5. & Euonymus europaea L. & масово \\
\hline 6. & Juniperus sabina L. & куртина \\
\hline 7. & Philadelphus coronaries L. & 4 \\
\hline 8. & Sambucus nigra L. & масово \\
\hline 9. & Spiraea salicifolia $\mathrm{L}$. & куртина \\
\hline 10. & Spiraea $\times$ vanhouttei $($ Briot) Zabel & куртина \\
\hline 11. & Symphoricarpos albus (L.) S.B. Blanke & куртина \\
\hline 12. & Swida alba (L.) Opiz & 12 \\
\hline \multicolumn{3}{|c|}{ Деревовидна ліана } \\
\hline 1. & Lonicera caprifolium $\mathrm{L}$. & масово \\
\hline
\end{tabular}

Таблиця 4

Розподіл видів деревних рослин за класами висот

\begin{tabular}{|c|c|c|c|c|c|c|c|}
\hline \multirow{3}{*}{ Відділ рослин } & \multicolumn{7}{|c|}{ Життсві форми } \\
\hline & \multicolumn{4}{|c|}{ дерева } & \multicolumn{3}{|c|}{ кущі } \\
\hline & Д1 & Д2 & Д3 & Д4 & $\mathbf{K B}_{\mathbf{B}}$ & Kc & $\mathbf{K}_{\mathbf{H}}$ \\
\hline Pinophyta & 3 & - & 1 & - & - & - & 1 \\
\hline Magnoliophyta & 16 & 3 & 2 & 4 & 5 & 5 & 1 \\
\hline Разом & 19 & 3 & 3 & 4 & 5 & 5 & 2 \\
\hline
\end{tabular}




\section{Література}

1. Агальцева В.А. Сохранение мемориальных лесопарков. Москва : Лесная пром-сть, 1980. 250 с.

2. Бондарь Ю.А., Салатич А.К., Садовенко Я.Л. Восстановление старинных ландшафтных парков : методические рекомендации по проектированию. Киев : КиевНИИП Градостроительства, 1974. 84 с.

3. Галкін С., Гурковська О., Чернецький Є. Структура та символіка старовинного парку «Олександрія» в Білоцерківській резиденції графів Браницьких. Біла Церква : Видавець О. Пшонківський, 2005. 96 с.

4. Дендрофлора України. Дикорослі і культивовані дерева і кущі. Голонасінні : довідник / за ред. М.А. Кохна, С.І. Кузнецова Київ : Фітосоціоцентр, 2001. 207 с.

5. Дендрофлора України. Дикорослі і культивовані дерева і кущі. Голонасінні : довідник / за ред. М.А. Кохна, Н.М. Трофіменко. Київ : Фітосоціоцентр, 2005. Ч. II. 716 с.

6. Дендрофлора України. Дикорослі і культивовані дерева і кущі. Покритонасінні : довідник / за ред. М.А. Кохна. Київ : Фітосоціоцентр, 2002. Ч. 1. 448 с.

7. Ильинская Н.А. Восстановление исторических объектов ландшафтной архитектуры. Ленинград : Стройиздат, 1984.151 с.

8. Ильинская Н.А. Восстановление исторических объектов ландшафтной архитектуры. С.-Петербург : Стройиздат, 1993. $160 \mathrm{c}$.

9. Исаченко Т.Е. Дворянские усадьбы и ландшафт: три века взаимодействия. Вестник СПбГУ. Серия 7, 2003. Вып. 4. № 31. С. $88-101$.

10. Клименко Ю.О., Кузнецов С.І. Комплексна оцінка паркових насаджень (методичні підходи і рекомендації). Київ, 2014. 66 с.

11. Косаревський І.О. Парки України. Київ : Держ. вид. літератури в буд. та архітектурі, 1961. 176 с.

12. Кохно М.А., Черевченко Т.М. До питання про методику реконструкції старовинних парків. Інтродукція та акліматизація рослин в Україні. 1977. Вип. 10. С. 21-23.

13. Лихачев Д.С. Заметки по реставрации мемориальных садов и парков // Восстановление памятников культуры. Москва, 1981. C. 95-120.

14. Полякова Г.А. Результаты современных методов реставрации старинных парков. [Электронный ресурс]. Режим доступа: http://science-bsea.narod.ru/2006/leskomp_2006/poljakova_rezult.

15. Родичкин И.Д., Родичкина О.И. Сады, парки и заповедники Украинской ССР. Заповедная природа. Преобразованной ландшафт. Садово-парковое искусство. Київ : «Будівельник», 1985. 167 с.

16. Рубцов Л.И. Садово-парковый ландшафт. Киев : Изд-во АН УССР, 1956. $211 \mathrm{c.}$

17. Салатич А.К. Парк Олександрія / за ред. О.Л. Липи. Київ : Вид-во Академії архітектури УРСР, 1949. 105 с.

18. Селочник Н.Н., Кондрашова Н.К. Общая оценка состояния насаждений по данным рекогносцировочного и детального лесопатологического исследований. Состояние дубрав Лесостепи. Москва : Наука, 1989. С. 138-153.

19. Флорентійська хартія Міжнародного комітету з історичних садів 1981 року. URL: http://icomosspb.ru/index.php/component/ joomdoc.

20. Чернецкий Е.А. Мемориал светлейшему князю Григорию Потёмкину-Таврическому в Белой Церкве. Відділ культури Білоцерків. міськвикон. Білоцерків. центр. бібл. сист. Благодійний фонд «Творча ініціатива». Білоцерків. міськ. організація українського товариства охорони пам’яток-історії та культури. Наук.-інформ. вид. Біла Церква : «Мустанг». 1997. 44 с.

21. The Plant List (2013). Version 1.1. URL: http://www.theplantlist.org/ (accessed: 1st January). 


\title{
СИСТЕМА ЕКОАОГІЧНОї ОСВІТИ ДИЯ СТАМОГО РОЗВИТКУ
}

\author{
УДК 37.017:502 \\ DOI https://doi.org/10.32846/2306-9716/2020.eco.6-33.25

\section{СУЧАСНІ ТЕНДЕНЦIÏ МЕТОДИЧНОГО КОНТЕНТУ ЕКОАОГІЧНОї ОСВITИ}

\author{
Лазебна О.М., Волошина Н.О. \\ Національний педагогічний університет імені М.П. Драгоманова \\ вул. Пирогова, 9, 02000, м. Київ \\ Voloshynanatali@gmail.com,olga.lazebnaya@gmail.com
}

\begin{abstract}
У роботі викладені результати досліджень, присвячені питанням становлення екологічно компетентної особистості відповідно до соціальних запитів сьогодення. Методичний контент екологізації суспільства передбачає використання арсеналу, здатного забезпечити формування активного, дієвого, компетентного суб'єкта соціуму майбутнього.

Ефективна реалізація дистанційного навчання студентів, задоволення їхніх освітніх потреб, доступ до якісного професійного контенту потребують належної підготовки професорсько-викладацького складу закладу вищої освіти. Такий формат надання освітніх послуг має свої особливості, які базуються на основі сучасних педагогічних, інформаційних та комунікаційних технологій і вимагають прискорення реформування системи вищої освіти в Україні.

Використання для освітнього процесу дистанційного простору Moodle у підготовці екологів дає можливість створювати навчальні курси 3 фахових дисциплін, завантажувати інформаційні матеріали, отримувати оnline-консультації, надсилати виконані завдання, проходити тестові контролі та оцінювати діяльність студентів в електронному журналі. У процесі викладання різних предметів і спеціальних дисциплін у ЗВО викладач насамперед орієнтується на специфічний контент, бере до уваги нормативно-правові документи, регламенти, які диктують необхідні програмні результати внаслідок освоєння курсу, добирає методологію подачі матеріалу.

Соціальні мережі як методичний інструментарій екологізації суспільства в сучасних умовах $є$ ефективним засобом наукової, творчої та виховної роботи зі студентами в аспекті проведення конкурсів, дискусій, відкритих форумів для обговорення актуальних екологічних проблем, що дозволяє виявляти ініціативу та свободу вибору проблемної теми і ії змістовне наповнення в аспекті студентського життя. Ключові слова: екологічна освіта, екологічна компетентність, фахова компетентність, екологічна культура, навчально-виховний процес, дистанційне навчання.
\end{abstract}

Current trends in methodological content of environmental education. Lazebna O., Voloshyna N.

The paper presents the results of research on the issues of becoming an environmentally competent person in accordance with the social demands of today. The methodical content of the greening of society involves the use of an arsenal that can ensure the formation of an active, effective, competent subject of society of the future.

Effective implementation of distance learning of students, meeting their educational needs, access to quality professional content requires proper training and readiness of the teaching staff of higher education institutions. This format of providing educational services has its own features, based on modern pedagogical, information and communication technologies and require accelerated reform of the higher education system in Ukraine.

The use of remote space Moodle in the training of environmentalists allows you to create training courses in professional disciplines, download information materials, receive online consultations, send completed tasks, take tests and evaluate student activities in the electronic journal. In the process of teaching different subjects and special disciplines in free economic education, the teacher takes into account the specifics of the subject, compliance with the standard, but can also expand some sections of the program and reduce others using different teaching methods.

Social networks, as a methodological tool for greening society in modern conditions is an effective means of scientific, creative and educational work with students in terms of competitions, discussions, open forums to discuss current environmental issues, which allows initiative and freedom to choose the topic and its content in the aspect of student life. Key words: ecological education, ecological competence, professional competence, ecological culture, educational process, distance learning.

Постановка проблеми. На початку третього тисячоліття в Україні відбувається становлення нової системи освіти, орієнтованої на входження до світового простору. Цей процес супроводжується історичними змінами в педагогічній теорії та практиці навчально-виховного процесу. Зміст освіти збагачується новим процесуальним умінням, розвитком здібностей оперування інформацією, творчим вирішенням проблем науки та ринкової практики 3 акцентом на індивідуалізацію освітніх програм.

Екологічна педагогіка, освіта як цілісне культурологічне явище, яке включає процеси навчання, виховання, розвитку особистості, повинна спрямовуватися на формування екологічної культури як складника національного i громадянського виховання усіх верств населення України [3; 4]. 
Актуальність дослідження. Нині актуальною є потреба в реалізації екологічного концепту у формувальних процесах становлення особистості як майбутнього учасника розбудови суспільства, яка орієнтується на утвердження соціальних запитів євроінтеграції, векторного розвитку принципів «сталого розвитку» в усіх сферах життя людини. Досягнення реальних результатів можливе шляхом екологізації суспільства. Доцільною нині є просвітницька діяльність громадських екологічних організацій. Екологізація освітнього процесу передбачає використання методичних прийомів екологічного змісту на всіх етапах предметного циклу. Фахівціекологи повинні володіти арсеналом подачі контенту екологічного змісту для усіх верств населення і соціального статусу.

Предметом екологічної педагогіки є проблема екологічного виховання та освіти, а предметом екології культури - проблема впливу природи на культуру, у вузькому розумінні - питання збереження культурного середовища.

Мета дослідження - пошук методичного контенту екологізації суспільства шляхом висвітлення можливостей використання деяких методичних прийомів у формуванні екологічно ціннісних характеристик особистості серед студентської молоді.

Методика досліджень передбачає аналітичний огляд з метою виділення категорії «екологічна компетентність» у культурологічному контексті та фаховій підготовці еколога. Узагальнення поняття дозволило застосувати методи дистанційного навчання у процесі формування інформаційної компоненти як теоретичного підгрунтя для розвитку екологічної компетентності у студентів. Творчий підхід у поєднанні 3 використанням мультимедіа забезпечує виховний потенціал формувального процесу екологічних ціннісних характеристик особистості.

Виклад основного матеріалу. Як складник Національної системи екологічна освіта грунтується та функціонує на основі чинного законодавства про освіту та Національної стратегії розвитку освіти України на період до 2021 року [1].

Мета екологічного виховання та освіти в галузі навколишнього середовища випливає із сучасного розуміння їх сутності, визначеної колективними зусиллями фахівців багатьох країн світу, специфіки професійної орієнтації закладів вищої освіти. Вона досягається поетапно шляхом вирішення освітніх i виховних завдань та вдосконалення практичної діяльності.

Концептуальні підходи екологічної освіти і виховання складають суть робіт низки дослідників: В.П. Андрущенка, О.М. Заблоцької, Н.А. Пустовіт, О.Л. Пруцакова, Л.М. Титаренко, Л.В. Юмашева та інших. Враховуючи швидко змінювані тенденції розвитку суспільства, проблема залишається актуальною та набуває нових акцентів, що потребує змін методологічних підходів, здатних забезпечити фор- мувальні процеси ціннісних характеристик особистості, у тому числі й екологічних.

Значення екологічного виховання і освіти та формування високоморального ставлення до навколишнього середовища особливо зростає нині, коли матеріалізовані сили знань уже зрівнялися, а у багатьох випадках навіть перебільшують сили природи. Необхідно, щоб інтелектуальний потенціал людини, іiі моральні якості розвивалися в унісон із технічною могутністю.

Екологічна компонента в освіті повинна тільки пояснювати ті чи інші особливості взаємодії певних наук із довкіллям. Головна мета полягає не лише у формуванні відповідної екологічної свідомості. Необхідним є формування особистої відповідальності за стан природного середовища, що виникає лише за умов зростання моральності людини, за умови ненасильницької боротьби з агресивно-споживацькою ідеологією та відмовою від співробітництва з олігархічним класом. Екологічна компонентна в освіті за допомогою різних засобів може формувати такі глобальні риси особистої свідомості, за допомогою яких людина буде здатна дійти певних висновків, зробивши їх взірцем для власної поведінки:

- перехід від агресивно-споживацької цивілізації до альтернативного типу споживання ресурсів, визначальною рисою якого буде розкриття глибинних потенцій буття людини замість нарощування потреб;

- самообмеження потреб, яке повинно грунтуватися не на змушенні, а на вільному волевиявленні індивідів;

- формування структури цивілізованої особистості та способу іiї життя [5].

У зв'язку з тим, що у світі склалася кризова екологічна ситуація, назріла об'єктивна потреба в зміні парадигми загальної освіти та її екологічних складників. Знання, які здобувається як поступове, а іноді й стихійне явище, не детерміноване соціально-екологічними змінами, стають недостатніми для глибокого розуміння та управління складною системою «людина-природа».

Освітня мета передбачає формування фізичного, психічного та духовного здоров'я людини і всього суспільства [3]. Ціннісні орієнтири особистості безпосередньо визначатимуть і ступінь культурного розвитку людини й суспільства. Нині актуалізується потреба в методологічному доробку щодо способів впливу на почуття людей, їх свідомість, погляди і уявлення. Увага приділяється навчально-виховному процесу, який забезпечує достатньою інформаційною базою слухача та відповідає сучасним потребам щодо можливостей особистісного зростання в умовах контексту розбудови держави.

Підготовку спеціалістів у галузі екології нині здійснюють у різних навчальних закладах. Наша країна має гостру потребу у фахівцях такого профілю, оскільки екологічні проблеми все більше погли- 
блюються, а вирішувати їх у змозі лише висококваліфіковані фахівці-екологи. Однак бути кваліфікованим фахівцем у своїй галузі не досить, особливо для еколога. Саме для нього основним завданням $\epsilon$ формування особистості, а головне у вихованні майбутнього еколога - формування його екологічно спрямованої життєвої позиції, яка в майбутньому впливатиме на ефективність професійної роботи, на екологічну культуру та особистісну екологічну діяльність, на участь у виконанні зобов'язань перед суспільством як із захисту довкілля, так і самої людини [4].

Одним із суб'єктивних факторів, які гальмують створення системи неперервної екологічної освіти, $\epsilon$ те, що на практиці не завжди використовуються наявні для цього можливості. Хибною є позиція, відповідно до якої основне навантаження з екологічної освіти повинно здійснюватися тільки в процесі викладання окремих дисциплін. Провідним є положення про те, що в основу досягнення головної мети екологічної освіти покладена інтеграція усіх навчальних предметів, оскільки в кожному із них закладено власний екологічний потенціал: вивчення загальноосвітніх дисциплін суспільства, соціальний характер всесвітнього руху на захист навколишнього середовища, ставлення суспільства до природи, шляхи впровадження науково-технічного прогресу й оптимізації взаємодії людини з навколишнім середовищем.

Реалії сьогодення потребують спрямованості на дієве контентне освітнє середовище щодо формуючого впливу пов'язаних між собою складників: екологічної компетентності, екологічного мислення та екологічної діяльності людини на всіх рівнях суспільного буття. Так, екологічну компетентність можна визначити як інтегрований результат навчальної діяльності студентів, який насамперед формується завдяки опануванню змісту предметів екологічного спрямування і набуттю досвіду використання екологічних знань у процесі вивчення предметів загального і професійного циклів та інформаційних технологій, а їі структуру - як сукупність мотиваційного, інтелектуального та діяльнісного складників [6; 7].

Аналіз сучасної екологічної освіти у ЗВО дозволив виявити певну суперечність, сутність якої полягає в тому, що формування екологічної компетентності має загально-педагогічний, соціокультурний статус і вимагає комплексного підходу, тоді як реалізація зазначених завдань звужена до предметоцентричного формату в межах курсу екології. Вона обмежується теоретичною підготовкою, відірваною від практично-професійної, конкретної екологічної діяльності у професійній сфері і побуті [3].

Формування екологічної компетентності студентів $є$ неперервним процесом їх постійного включення в екологічну діяльність шляхом отримання досвіду участі у практичних заходах зі збереження та покра- щення стану довкілля, розвитку екологічно значимих особистісних якостей (гуманність, емпатійність, бережливість) на основі використання технології активного навчання [7;8]. Особистісно орієнтований підхід передбачає об'єктивацію індивідуальних здібностей, здатності й можливості реалізації здобутого інформаційного контенту, він дозволяє варіювати механізми традиційного та інноваційного підходів у досягненні певної навчально-виховної мети.

Планування та проведення студентських конференцій сприяє набуттю вмінь логічного викладу здобутої інформації, дає можливість розвивати комунікативні компетенції особистості. Кафедра екології НПУ імені М.П. Драгоманова щорічно проводить тематичні студентські конференції, коли підготовка й організація заходу здійснюються нарівні студентським активом та викладачами, а результати роботи оприлюднюються на сайті факультету природничо-географічної освіти та екології.

Завдання підготовки креативного, мобільно й системно аналізуючого, інформативно обізнаного фахівця окреслюють вимоги до освітнього процесу, мотивують до розробки курсів із застосуванням новітніх методологічних розробок. Важливо подати інформацію найбільш повно й у достатньому обсязі, необхідно використати методичні прийоми, які дозволяють вдало й цікаво подати інформацію та сприяють творчому процесу мислення студентів щодо пошуку альтернатив вирішення екологічної проблеми.

Враховуючи реалії сьогодення, дистанційна форма навчання превалює в освітньому процесі. В НПУ імені М.П. Драгоманова навчальний процес відбувається за допомогою інформаційної платформи "Moodle". Ця система дозволяє застосовувати прийоми подання теоретичного матеріалу у формі презентації та навчальних відео, що значно розширює можливості сприйняття лекційного контенту.

Методика розробки практичного заняття передбачає систему роботи на трьох рівнях, застосування методичного інструментарію, що максимально дозволить опрацювати матеріал й набути вміння користуватися набутим. Перше завдання спрямоване на оволодіння основним термінологічним словником, що наповнює професійне спілкування майбутнього фахівця. Вставити слова, фрази - нескладне завдання. Водночас потребує від студента роботи з теоретичним матеріалом, освоєнням його. Контроль за рівнем засвоєння здійснюється у формі опитувального тесту, створеного за допомогою інструменту в системі "Moodle" як «тест-пропущені слова».

Друга група завдань потребує розуміння конкретного поняття і подається у вигляді завдання «доповнити схему» чи дати визначення. Понятійнокатегоріальний апарат у професійній роботі визначає розуміння правильного використання засвоєних термінів, їх доцільне використання, вказує на рівень фаховості майбутнього працівника. Цей рівень може 
бути оцінений системою у вигляді інструменту «тест-відповідності». На цьому етапі респонденти шукають правильні відповіді між поняттями й визначеннями контенту конкретної дисципліни.

Третій рівень методичної розробки завдання потребує не тільки розуміння поняття, достатнього словарного запасу, а й уміння його застосовувати у ситуаційному завданні. На цьому етапі використовується інструмент системи "Moodle" «тест - ессе». Заданий інструментарій дозволяє поставити дискусійне, проблемне, ситуативне завдання і потребує власної конкретної відповіді. За виконані під час дистанційного курсу завдання студент отримує бали, які фіксуються в електронному журналі курсу.

Розробка завдань курсу систематизує роботу слухача, сприяє формуванню словникового запасу професійної мови, наповнює понятійно-категоріальний апарат респондента і дозволяє йому оперувати здобутими знаннями.

Проведення конкурсного заходу «Екологічне селфі» цілком відповідає потребам студентської молоді в частині використання сучасного технологічного потенціалу як інструменту щодо вияву позиції, взаємодії з навколишнім середовищем. Тематикою конкурсних робіт обрано проблеми проживання в гуртожитку студентської спільноти в контексті екологічного складника як сфери благополучного існування людини. Метою заходу визначено донесення до громадськості проблеми поводження з відходами, пошук шляхів вирішення у конкретному випадку. Після створення наочної фото-інструкції про те, як правильно утилізувати побутові відходи, відбувається інформування спільноти та розміщення відповідної інформації в соціальній мережі Фейсбук. За цим посилання ви можете детальніше із згаданою фото-інструкцію: https://www.facebook.com/ NPUecology/posts/813908335849096.

Продовжуючи тематику використання соцмереж як методичного інструментарію екологізації суспільства, було проведено конкурсну програму з метою збору пропозицій щодо створення екологічної реклами. Виконавець потребує навичок роботи
3 гаджетами і має здобути інформацію про предмет реклами. Обов'язковим елементом $є$ творчий підхід, який виявляється у довільному виборі тематики роботи, її змістової частини і застосування технології викладу матеріалу. Роботу бажано виконати у світлі проблем студентського життя. Маємо такий приклад виконаного завдання, який доступний за посиланням: https://fb.watch/22dV5imIky/. Варто зазначити, що такий інструментарій є надзвичайно цікавим, він спонукає до діяльності, однак потребує певних вмінь і навичок комунікаційного профілю, вміння працювати $з$ технічним складником.

Головні висновки. Реалії сьогодення вимагають нових підходів до екологічної освіти громадян і нових підходів в питанні підготовки фахівців екологічної галузі. На підставі аналізу інформації 3 проблеми дослідження можна зробити висновок про те, що екологічна компетентність студентів природничого напряму $є$ важливою характеристикою, складником їхньої подальшої професійної діяльності. Враховуючи сукупність екологічних знань, уявлень, поглядів, переконань, ідеалів, моральних оцінок студентів відносно навколишнього середовища, природи загалом, які інтегруються в особистісну систему екологічних цінностей, вона є визначальною щодо напряму життя і діяльності особистості.

Інформатизоване суспільство сприяе пошуку новацій методології викладацької роботи на всіх щаблях освітнього процесу. Використання платформ дистанційного навчання, зокрема системи "Moodle", дозволяє опрацювати програмний матеріал фахової підготовки майбутніх спеціалістів.

У нормативних документах однією з компетентностей студентів, які вивчають природничі науки, а саме студентів-екологів, $є$ вміння працювати з мультимедіа та соціальними мережами. Інформатизоване суспільство створює потребнісний ресурс методичного забезпечення формування ціннісних характеристик особистості, в тому числі й екологічних. Стосовно інструментарію і засобів формувального процесу, то доцільно поєднувати методичні прийоми традиційного та інноваційного контенту.

\section{Література}

1. Віртуальна спільнота «Освіта в інтересах сталого розвитку в Україні». Що таке сучасна екологічна освіта в Україні? http://ecoosvita.org.ua/storinka/shcho-take-suchasna-ekologichna-osvita-v-ukrayini.

2. Гуренкова О.В. Формування екологічної компетентності майбутніх фахівців водного транспорту в умовах кредитномодульної системи навчання : автореф. дис. канд. пед. наук: 13.00.04. Київ, 2009. 20 с.

3. Енциклопедія сучасної України. Екологічна освіта. http://esu.com.ua/search_articles.php?id=18681.

4. Крисаченко В.С., Хилько М.І. Екологія. Культура. Політика. К. : Знання України, 2001. 598 с.

5. Некос А.Н. Екологічна освіта та виховання, географічні та педагогічні основи : автореф. дис. на здобуття наук. ступеня канд. географ. наук: 11.00.04. Харків, 1994. С. 5.

6. Карпенко В.П., Мостов'як І.І., Пушкарьова-Безділь Т.М. Оцінювання сформованості екологічних компетентностей : навчально-методичний посібник. 2017. Одеса : НУ «ОМА», 2017. 59 с.

7. Титаренко Л.М. Формування екологічної компетентності студентів біологічних спеціальностей університету : автореф. дис. на здобуття наук. ступеня канд. пед. наук: 13.00.07. Київ, 2007. 22 с.

8. Юмашева Л.В., Перфилова И.Л., Соколова Т.В. Экологическая компетенция и экологическая компетентность как интегрированный результат экологического образования. Интернет-журнал ICEE. 2012. № 7. С. 157-161. 


\title{
ТЕОРЕТИКО-МЕТОДОАОГІЧНІ ПИТАННЯ В ГААУЗІ ОХОРОНИ ДОВКІМАЯ
}

УДК 635.49:631.427.1(477.63-21)

DOI https://doi.org/10.32846/2306-9716/2020.eco.6-33.26

\section{TARAXACUM OFFICINALE WIGG ЯK БIOIHДИКАTOP АКУМУАЯЦIї ВАЖКИХ МЕТАМІВ У ГРУНТІ ГІРНИЧО-МЕТААУРГІЙНОГО РЕГІОНУ}

\author{
Комарова I.O. \\ Криворізький державний педагогічний університет \\ пр. Гагаріна, 54, 50086, м. Кривий Ріг, Дніпропетровська обл. \\ Irinysich@i.ua
}

\begin{abstract}
Основою містобудівного комплексу міста Кривий Ріг є залізорудна промисловість, яка базується на одному із найбільших у світі родовищ. Результатом антропогенної діяльності в місті є порушення біогеохімічних циклів і накопичення важких металів у верхніх шарах літосфери, їх поглинання рослинами з подальшою міграцією трофічним ланцюгом. Деякі рослини досить стійкі до забруднення грунтів і можуть використовуватися як біоіндикатори. Саме тому використання найрозповсюдженіших видів урбанофлори в системі екологічного моніторингу дозволяє оцінювати рівень забруднення різних міст і промислових
\end{abstract} агломерацій.

У публікації проаналізовано валовий і рухомий вміст важких металів ( $\mathrm{Zn}, \mathrm{Pb}, \mathrm{Cd}, \mathrm{Ni}, \mathrm{Cu})$ в урбоекосистемі Кривого Рогу. Серед металів першого та другого класів небезпеки зафіксовано пропорційне збільшення їх вмісту від умовного контролю до ділянок високого рівня забруднення. Встановлено, що вміст кадмію дещо знижений порівняно із контролем на ділянках, розташованих у зонах із незначним і помірним рівнями забруднення. Визначено спадаючий ряд рухомих форм важких металів на ділянках із високим і помірним рівнями забруднення: $\mathrm{Zn}>\mathrm{Pb}>\mathrm{Cu}>\mathrm{Ni}>\mathrm{Cd}$, а для незначного рівня та умовного контролю він трансформований так: $\mathrm{Zn}>\mathrm{Ni}>\mathrm{Pb}>\mathrm{Cu}>\mathrm{Cd}$.

Встановлено, що абсолютним лідером за накопиченням і безбар'єрною міграцією в системі «грунт - корені рослин» $є$ цинк. Зафіксовано активне накопичення коренями рослин нікелю та кадмію із чіткою закономірною градацією між ділянками різного рівня забруднення. Незважаючи на високі концентрації кадмію в коренях, виявлений міцний антиконцентраційний бар'єр для мікроелементу як у контролі, так і за умов забруднення (транслокаційні коефіцієнти $<1,0$ ).

В умовах забруднення T. officinale не є металоконцентратором купруму, а з підвищенням рівня забруднення і плюмбуму. Наявність зв'язку між накопиченням важких металів у грунті та коренях рослин дозволяє використовувати Taraxacum officinale Wigg для здійснення біоіндикації. Ключові слова: техногенне середовище, важкі метали, транслокаційні коефіцієнти, забруднення, стійкість рослин, біоіндикації, Taraxacum officinale Wigg.

Taraxacum officinale Wigg as a bioindicator of heavy metals accumulation in soil of the mining and metallurgical region. Komarova I.

Soil is an active acceptor for some elements, heavy metals in particular. Microelements are firmly sorbed and interact with soil humus layer. As a result, poorly soluble compounds are formed. Disruption of biogeochemical cycles leads to heavy metal accumulation in top layers of lithosphere and their uptake by plants with further migration in trophic chain. At the same time some plants are sensitive to soil contamination and can be used as bioindicators.

The objective of the paper is to assess protective attributes and specifics of translocation of different threat level elements of a synanthrope - Taraxacum officinale Wigg. The object of the study is the roots of Taraxacum officinale Wigg and the soils of plant habitat. Sampling sites were constructed in administrative regions of Kryvyi Rih city with different levels of emissions release into atmosphere from stationary pollution sources.

Technogenicity of researched heavy metal mobile forms for the areas of high and moderate contamination forms a falling row which is ranked as follows: $\mathrm{Zn}>\mathrm{Pb}>\mathrm{Cu}>\mathrm{Ni}>\mathrm{Cd}$. But a nonsignificant difference was fixed in cadmium and nickel accumulation in the area № 4. For sampling sites of insignificant level and conditional control heavy metal accumulation row is ranked as follows: $\mathrm{Zn}>\mathrm{Ni}>\mathrm{Pb}>\mathrm{Cu}>\mathrm{Cd}$.

The results of the determination of $\mathrm{Ni}, \mathrm{Cu}, \mathrm{Zn}, \mathrm{Pb}$ and $\mathrm{Cd}$ content in plants roots indicate that Taraxacum officinale Wigg is capable of their accumulation. $\mathrm{Zn}$ is an absolute leader in accumulation and bareer-free migration in the system "soil-plants roots". We were observing mobility decrease of one of the most dangerous elements $-\mathrm{Cd}$. The interrelation between heavy metal accumulation in soil and plants roots enables to use Taraxacum officinale Wigg for applying phytoindication. We consider it essential to conduct further detailed research of Taraxacum officinale adaptive reactions with a view to further creating of bioindication scales. Key words: soil, plant, translocation coefficient, technogenic environment, heavy metals, contamination, Taraxacum officinale Wigg, bioindication.

Постановка проблеми. В умовах зростаючого рівня забруднення навколишнього середовища гірничо-металургійних регіонів України актуальності набуває питання ранньої діагностики якості довкілля. В цьому аспекті не виключенням $є$ екологічний стан Кривого Рогу, який характеризується значним рів- 
нем забруднення важкими металами атмосфери, грунтів і формуванням техногенних ландшафтів, що актуалізує розробку та впровадження інноваційних природоохоронних заходів.

Аналіз останніх досліджень і публікацій. Едафотопи $\epsilon$ активними акцепторами більшості елементів і їхніх сполук, зокрема й важких металів (далі - ВМ) [1; 2]. Мікроелементи активно сорбуються та взаємодють із гумусовими сполуками, в результаті чого їхня рухливість зменшується [3]. Поряд із цим необхідним складником моніторингових досліджень урболандшафтів є визначення спроможності певних елементів до транслокації в системі «грунт - рослина» $[4 ; 5]$.

У вегетативних органах рослин часто фіксують різну концентрацію важких металів, що зумовлено властивостями самих мікроелементів і видоспецифічністю метаболічних процесів у рослинах. Так, вміст $\mathrm{Cd}$ у рослинах залежить від біологічних особливостей і наявності елементостатичних бар'єрів на кордоні «корінь - стебло» [6; 7]. Коливання вмісту $\mathrm{Cu}$ на різних грунтах і в кліматичних умовах вказує на значну варіабельність його накопичення рослинами $[8 ; 9 ; 10]$.

При вивченні особливостей надходження Zn у рослини був виявлений ген ZNT1, який відповідає за його транспортування [11]. Іони Рb стимулюють процеси пероксидного окиснення ліпідів, що підтверджується підвищенням вмісту ТБК-активних продуктів у вегетативних органах [12]. Вміст Ni у грунтах здебільшого залежить від забезпеченості елементом грунтоутворюючих порід. Найбільші концентрації Ni здебільшого становлять до 3,0 мг/кг при варіаціях у різних видах рослин від 0,1 до 8,1 мг/кг [13]. Аналіз наукової літератури свідчить, що індикаторними видами техногенного забруднення можуть слугувати сільськогосподарські культури $[14 ; 15]$, деревні рослини [16;17], трав'янисті види $[9 ; 18]$.

Новизна. Дослідження пристосувань певних видів рослин до дії полютантів не втрачає актуальності для практичного застосування в біоіндикації стану довкілля, а також має теоретичне значення для подальшого розвитку екологічної фізіології рослин. Проте визначення особливостей накопичення важких металів та їхніх транслокацій у розповсюджених видів урбанофлори, зокрема Taraxacum officinale Wigg., в умовах Криворіжжя ще не розглядалося.

Мета дослідження - визначити рівень акумуляції важких металів різного класу небезпеки в едафотопах Кривого Рогу та 3'ясування можливості використання Taraxacum officinale Wigg для здійснення біоіндикації довкілля в гірничо-металургійному регіоні.

Матеріал і методи дослідження. Об'єктом дослідження були грунти i корені Taraxacum officinale Wigg. Пробні площадки закладалися в чотирьох адміністративних районах Кривого Рогу
3 різним рівнем надходження викидів від стаціонарних джерел забруднення в атмосферне повітря (за даними Головного управління статистики). Так, у Металургійному районі (понад 102,4 тис. т на рік) закладені пробні площадки №№ 1-4 із високим рівнем забруднення. У Покровськомуі Довгинцевському районах (обсяги викидів 3,8 і 2,4 тис. т) розташовані площадки №№ 5-6 із помірним рівнем забруднення. У Саксаганському районі, в якому найменші обсяги викидів (до 640 т), закладені площадки №№ 7-8 із незначним рівнем забруднення. Територія умовного контролю розташована на відстані понад 50 км від промислових підприємств (площадка № 9).

Проби грунту відбиралися на кожній ділянці методом «конверта» 3 шару грунту 0-10 см, висушувалися до абсолютно сухої ваги, потім із них складали репрезентативний зразок. Відбір та пробопідготовку рослинного матеріалу, аналіз проб здійснювали за загальноприйнятими методиками [19; 20]. Вміст валових і рухомих (амонійно-ацетантна витяжка $\mathrm{pH}=4,8$ ) форм $\mathrm{Zn}, \mathrm{Pb}, \mathrm{Cu}, \mathrm{Ni}, \mathrm{Cd}$ у грунтах та елементів у рослинному матеріалі визначали на атомно-абсорбційному спектрофотометрі C-115 (Україна). Коефіцієнт транслокації розраховували як співвідношення вмісту елемента в коренях рослин до вмісту його рухомих форм у грунті $[21 ; 22]$. Результати експерименту обробляли статистично: розраховували помилку середнього арифметичного, обчислювали критерій достовірності відмінностей між показниками варіантів (t-test). Різницю вважали достовірною за $\mathrm{P}<0,05$.

Виклад основного матеріалу. Обговорюючи вміст рухомих форм важких металів у грунтах міста та їхній відсоток до валової форми, необхідно зазначити, що отримані результати $\epsilon$ статистично достовірними для усіх ділянок, крім ділянки 5 із вмістом кадмію та ділянки 6 із вмістом нікелю (табл. 1). Серед металів першого класу небезпеки відсотковий вміст валової форми Zn пропорційно зростав від 10,5\% в умовному контролі до 55,1\% для територій із високим вмістом забруднення. Вміст рухомої форми цинку підвищувався на ділянках із високим рівнем забруднення від 5,5 до 16 разів порівняно із контролем. У цей діапазон потрапила ділянка 7, на якій перевищення цинку становило у понад 6 разів (табл. 1).

Серед інших металів першого класу не зафіксовано дисбалансу між пробними площадками за рівнями забруднення. Так, вміст Рb порівняно із контролем збільшився від 3 до 8,5 разів на площадках із помірним і незначним забрудненням та від 18 до 32 разів на площадках із високим рівнем. Отримані результати вмісту кадмію дещо знижені порівняно iз контролем на ділянках 5-8, розташованих у зонах iз незначним i помірним рівнями забруднення, a на ділянках із високим рівнем зафіксоване перевищення від 6 до 47 разів (табл. 1). Серед металів другого класу небезпеки на ділянках незначного та помірного рівнів забруднення спостерігалося 
Вміст рухомих форм важких металів у грунті $(\mathrm{M} \pm \mathbf{m}, \mathbf{n}=\mathbf{3})$

\begin{tabular}{|c|c|c|c|c|c|}
\hline $\begin{array}{c}\text { Пробні } \\
\text { площадки }\end{array}$ & $\mathbf{N i}$ & $\mathbf{C u}$ & $\mathbf{Z n}$ & $\mathbf{P b}$ & Cd \\
\hline \multirow{2}{*}{1} & $10,93 \pm 0,05^{*}$ & $6,36 \pm 0,05^{*}$ & $39,49 \pm 1,42^{*}$ & $15,05 \pm 0,05 *$ & $2,52 \pm 0,15^{*}$ \\
\hline & $80,6 \%$ & $15,5 \%$ & $55,1 \%$ & $13,1 \%$ & $35,4 \%$ \\
\hline \multirow[b]{2}{*}{2} & $6,62 \pm 0,18^{*}$ & $18,01 \pm 0,55^{*}$ & $98,24 \pm 16,61 *$ & $19,88 \pm 0,24 *$ & $8,11 \pm 0,19^{*}$ \\
\hline & $21,9 \%$ & $17,6 \%$ & $14,5 \%$ & $14,6 \%$ & $64,9 \%$ \\
\hline \multirow{2}{*}{3} & $8,39 \pm 0,22 *$ & $20,64 \pm 0,73^{*}$ & $63,92 \pm 0,49^{*}$ & $26,13 \pm 0,31 *$ & $12,17 \pm 0,20^{*}$ \\
\hline & $24,5 \%$ & $15,8 \%$ & $25,5 \%$ & $15,0 \%$ & $42,6 \%$ \\
\hline \multirow{2}{*}{4} & $6,87 \pm 0,02 *$ & $6,38 \pm 0,22^{*}$ & $34,01 \pm 2,67^{*}$ & $25,5 \pm 0,60^{*}$ & $1,65 \pm 0,16^{*}$ \\
\hline & $63,3 \%$ & $22,3 \%$ & $15,8 \%$ & $26,0 \%$ & $38,8 \%$ \\
\hline \multirow{2}{*}{5} & $6,82 \pm 0,32 *$ & $1,62 \pm 0,02^{*}$ & $33,23 \pm 0,38^{*}$ & $6,89 \pm 0,91^{*}$ & $0,35 \pm 0,01$ \\
\hline & $39,9 \%$ & $9,5 \%$ & $21,3 \%$ & $25,3 \%$ & $31,8 \%$ \\
\hline \multirow{2}{*}{6} & $2,29 \pm 0,11$ & $2,84 \pm 0,70^{*}$ & $20,58 \pm 2,67 *$ & $3,37 \pm 0,88^{*}$ & $0,23 \pm 0,17^{*}$ \\
\hline & $18,6 \%$ & $14,6 \%$ & $10,45 \%$ & $5,9 \%$ & $14,3 \%$ \\
\hline \multirow{2}{*}{7} & $4,34 \pm 0,17^{*}$ & $1,26 \pm 0,06^{*}$ & $16,66 \pm 0,90 *$ & $6,88 \pm 0,59^{*}$ & $0,15 \pm 0,01^{*}$ \\
\hline & $41,7 \%$ & $13,9 \%$ & $25,9 \%$ & $22,4 \%$ & $27,8 \%$ \\
\hline \multirow{2}{*}{8} & $4,58 \pm 0,08^{*}$ & $1,37 \pm 0,12^{*}$ & $40,32 \pm 3,36^{*}$ & $2,47 \pm 0,65^{*}$ & $0,17 \pm 0,01 *$ \\
\hline & $31,6 \%$ & $9,4 \%$ & $33,1 \%$ & $12,3 \%$ & $23,9 \%$ \\
\hline \multirow{2}{*}{9} & $1,44 \pm 0,03$ & $0,56 \pm 0,06$ & $6,17 \pm 0,44$ & $0,82 \pm 0,04$ & $0,26 \pm 0,04$ \\
\hline & 18,7 & 6,1 & 10,5 & 5,3 & 33,8 \\
\hline
\end{tabular}

Примітка: чисельник - вміст рухомих форм елементу у грунтах, мг/кг грунту; знаменник - відношення рухомих форм до валових, \%; * - різниця достовірна 3 контролем $(\mathrm{P}<0,05)$

збільшення їх вмісту порівняно з контролем від 2 до 5 разів, а на ділянках високого рівня забруднення від 6 до 36 разів (табл. 1).

Серед відношень рухомих до валових форм важких металів спостерігалися значні коливання та відсутність чіткої градації між ділянками різних рівнів забруднення (табл. 1). Загальна техногенність досліджених рухомих форм важких металів для ділянок із високим і помірним рівнем забруднення утворює спадаючий ряд, який набуває такого вигляду: $\mathrm{Zn}>\mathrm{Pb}>\mathrm{Cu}>\mathrm{Ni}>\mathrm{Cd}$. Однак зафіксована незначна різниця в накопиченні кадмію та нікелю на ділянці 4. Для пробних ділянок незначного рівня та умовного контролю ряд накопичення важких металів виглядає так: $\mathrm{Zn}>\mathrm{Ni}>\mathrm{Pb}>\mathrm{Cu}>\mathrm{Cd}$ (табл. 1 ).

$\mathrm{У}$ наших попередніх дослідженнях було встановлено, що середній вміст гумусу в едафотопах Кривого Рогу знаходиться на рівні 1-4,5\%. Найбільша кількість органічної речовини виявлена у грунтах Металургійного району, який характеризується високим рівнем забруднення. Це можна пояснити активними вторинними сукцесійними процесами відновлення рослинного та грунтового покривів. 3 огляду на отримані результати вмісту різних форм важких металів і деяких буферних характеристик грунту [23], вважаємо за доцільне розглядати транслокаційні коефіцієнти, зокрема на прикладі синантропного виду T. officinale, з метою оцінки ступеню доступності мікроелементів у середовищі існування рослини та для подальшого використання показника як чутливого біоіндикатора їх вмісту.
Обговорюючи активне накопичення коренями нікелю, необхідно зазначити про чітку закономірність збільшення елементу удвічі на площадках високого рівня. Виключенням у цьому списку є площадка № 4, на якій зафіксована різниця більше ніж утричі порівняно із контролем. Площадки незначного та помірного рівнів характеризувалися тенденцією до збільшення нікелю в 1,5 рази порівняно із контролем. Однак на ділянці № 8 встановлено статистично достовірне зниження вмісту нікелю, яке становило $2,25 \pm 0,47$ мг/Г (табл. 2).

На пробних площадках високого рівня забруднення зафіксовано перевищення купруму в коренях рослин у 6 разів, а на ділянках 5 і 8 - до $15 \%$. Виключенням є площадки 3 та 7, на яких зафіксовано незначне зниження порівняно із контролем. Необхідно зазначити, що ці дані є статистично не достовірними аналогічно з результатами по ділянці 6 , хоча на цій ділянці рівень накопичення вищий, ніж у контролі (табл. 2).

Абсолютним лідером по накопиченню коренями був цинк. Спостерігалося закономірне збільшення та чітка відмінність у накопиченні коренями на площадках різного рівня забруднення. Так, максимальне накопичення від 75,10 $\pm 0,018$ мг/Г було встановлено на ділянці № 2 до 47,52 $\pm 2,29$, що становило від 9,8 до 6,2 разів порівняно із контролем (табл. 2). На площадках помірного й незначного рівнів забруднення спостерігалося статистично закономірне збільшення накопичення металу удвічі. 
Таблиця 2

Вміст важких металів у коренях Taraxacum officinale Wigg, мг/кг грунту та значення коефіцієнту транслокації в системі «грунт - корінь» (* - різниця достовірна 3 контролем, $\mathbf{P}<0,05 ; \mathrm{M} \pm \mathbf{m}, \mathbf{n}=3$ )

\begin{tabular}{|c|c|c|c|c|}
\hline $\begin{array}{c}\text { Пробна } \\
\text { площадка }\end{array}$ & Елемент & Корінь & $\begin{array}{c}\text { Коефіціснт варі- } \\
\text { ації, \% }\end{array}$ & $\begin{array}{c}\text { Коефіціснт транслокації } \\
\text { елементу в системі } \\
\text { «грунт - корінь» }\end{array}$ \\
\hline \multirow{5}{*}{1} & $\mathrm{Ni}$ & $5,70 \pm 0,67 *$ & 20,27 & 1,92 \\
\hline & $\mathrm{Cu}$ & $2,49 \pm 0,06^{*}$ & 4,07 & 2,55 \\
\hline & $\mathrm{Zn}$ & $52,83 \pm 1,04^{*}$ & 3,41 & 0,75 \\
\hline & $\mathrm{Pb}$ & $3,14 \pm 0,22 *$ & 12,32 & 4,80 \\
\hline & $\mathrm{Cd}$ & $8,03 \pm 0,39 *$ & 8,34 & 0,31 \\
\hline \multirow{5}{*}{2} & $\mathrm{Ni}$ & $6,92 \pm 0,17 *$ & 4,24 & 1,04 \\
\hline & $\mathrm{Cu}$ & $2,59 \pm 0,06 *$ & 3,94 & 6,94 \\
\hline & $\mathrm{Zn}$ & $75,10 \pm 0,02 *$ & 0,41 & 2,15 \\
\hline & $\mathrm{Pb}$ & $4,87 \pm 0,55^{*}$ & 19,61 & 4,08 \\
\hline & $\mathrm{Cd}$ & $9,38 \pm 0,52 *$ & 9,68 & 0,86 \\
\hline \multirow{5}{*}{3} & $\mathrm{Ni}$ & $8,86 \pm 0,39 *$ & 7,68 & 0,95 \\
\hline & $\mathrm{Cu}$ & $2,92 \pm 0,50 *$ & 29,50 & 7,08 \\
\hline & $\mathrm{Zn}$ & $70,58 \pm 5,06 *$ & 12,43 & 0,91 \\
\hline & $\mathrm{Pb}$ & $4,81 \pm 0,33 *$ & 11,96 & 5,43 \\
\hline & $\mathrm{Cd}$ & $7,67 \pm 0,06^{*}$ & 1,30 & 1,59 \\
\hline \multirow{5}{*}{4} & $\mathrm{Ni}$ & $5,58 \pm 0,56 *$ & 17,47 & 1,23 \\
\hline & $\mathrm{Cu}$ & $0,44 \pm 0,06$ & 23,72 & 14,35 \\
\hline & $\mathrm{Zn}$ & $47,52 \pm 2,29 *$ & 8,34 & 0,72 \\
\hline & $\mathrm{Pb}$ & $3,62 \pm 0,22 *$ & 10,66 & 7,00 \\
\hline & $\mathrm{Cd}$ & $8,14 \pm 0,02 *$ & 0,48 & 0,20 \\
\hline \multirow{5}{*}{5} & $\mathrm{Ni}$ & $3,89 \pm 0,32 *$ & 14,43 & 1,75 \\
\hline & $\mathrm{Cu}$ & $0,68 \pm 0,07 *$ & 18,32 & 2,37 \\
\hline & $\mathrm{Zn}$ & $13,67 \pm 0,68 *$ & 8,58 & 2,43 \\
\hline & $\mathrm{Pb}$ & $1,99 \pm 0,36$ & 31,43 & 3,46 \\
\hline & $\mathrm{Cd}$ & $2,31 \pm 0,22 *$ & 16,46 & 0,15 \\
\hline \multirow{5}{*}{6} & $\mathrm{Ni}$ & $4,45 \pm 0,29 *$ & 11,23 & 0,83 \\
\hline & $\mathrm{Cu}$ & $0,60 \pm 0,07$ & 20,31 & 4,71 \\
\hline & $\mathrm{Zn}$ & $12,02 \pm 1,47 *$ & 21,13 & 1,71 \\
\hline & $\mathrm{Pb}$ & $1,76 \pm 0,29$ & 28,32 & 1,96 \\
\hline & $\mathrm{Cd}$ & $2,75 \pm 0,12 *$ & 7,66 & 0,08 \\
\hline \multirow{5}{*}{7} & $\mathrm{Ni}$ & $2,25 \pm 0,47^{*}$ & 36,36 & 1,93 \\
\hline & $\mathrm{Cu}$ & $0,63 \pm 0,06^{*}$ & 16,17 & 2,02 \\
\hline & $\mathrm{Zn}$ & $16,54 \pm 1,10^{*}$ & 11,53 & 1,01 \\
\hline & $\mathrm{Pb}$ & $1,48 \pm 0,14^{*}$ & 16,46 & 4,65 \\
\hline & $\mathrm{Cd}$ & $2,11 \pm 0,30^{*}$ & 24,60 & 0,07 \\
\hline \multirow{5}{*}{8} & $\mathrm{Ni}$ & $2,80 \pm 0,19$ & 11,85 & 1,64 \\
\hline & $\mathrm{Cu}$ & $0,46 \pm 0,04$ & 13,17 & 2,97 \\
\hline & $\mathrm{Zn}$ & $15,05 \pm 1,43 *$ & 16,51 & 2,68 \\
\hline & $\mathrm{Pb}$ & $2,08 \pm 0,16^{*}$ & 12,99 & 1,19 \\
\hline & $\mathrm{Cd}$ & $3,27 \pm 0,55^{*}$ & 29,01 & 0,05 \\
\hline \multirow{5}{*}{9} & $\mathrm{Ni}$ & $2,44 \pm 0,23$ & 16,17 & 0,59 \\
\hline & $\mathrm{Cu}$ & $0,49 \pm 0,02$ & 7,12 & 1,14 \\
\hline & $\mathrm{Zn}$ & $7,66 \pm 0,12$ & 2,81 & 0,81 \\
\hline & $\mathrm{Pb}$ & $1,34 \pm 0,07$ & 9,33 & 0,61 \\
\hline & $\mathrm{Cd}$ & $1,08 \pm 0,09$ & 12,91 & 0,24 \\
\hline
\end{tabular}


Аналізуючи результати накопичення плюмбуму в коренях $T$. officinale, необхідно зазначити, що фіксувалося чітке розмежування між територіями різного рівня забруднення. Максимальні значення зафіксовані на ділянці 2, що співвідносно перевищенню в 4 рази порівняно із контролем. Мінімальні значення для площадок із високим рівнем встановлені на ділянці 3, вони є статистично достовірними і утричі перевищують дані контролю (табл. 2). Експериментальні дані, отримані на площадках помірного рівня, мають незначне перевищення від контролю, але статистично вони не достовірні. Значення вмісту плюмбуму з території незначного рівня забруднення мають перевищення в 1,5 рази від умовного контролю.

Подібно до нікелю, відбувалося активне накопичення коренями рослин кадмію (табл. 2). На площадках із високим рівнем забруднення зафіксоване збільшення накопичення у 8-9 разів порівняно iз контролем (табл. 2). Ділянки помірного рівня характеризувалися статистично достовірним збільшенням накопиченням металу від 2,31 $\pm 0,02$ до $2,75 \pm 0,12$ мг/г. Території незначного рівня характеризувалися дещо відмінними показниками за накопиченням. Максимальне значення відповідає $3,27 \pm 0,55$ мг/г, що співвідносно перевищенню до контролю утричі. Отримані результати свідчать про значну акумуляцію іонів важких металів коренями T. officinale, що здебільшого пов'язано як із підвищеним вмістом зазначених елементів у пилових викидах підприємства, так і з певними особливостями процесів надходження іонів металів до рослин.

Наведені у табл. 2 результати визначення вмісту в коренях рослин нікелю, купруму, цинку, плюмбуму та кадмію свідчать про здатність T. officinale до їхньої акумуляції. Логіку акумуляції мікроелементів можна відобразити у спадаючих рядах, які диференційовані за ступенем забруднення територій (табл. 3).

Для характеристики стану забруднення природного середовища доцільно визначати не лише рухомі форми забруднюючих речовин у грунті, а й коефіцієнт їх переходу у системі «грунт - рослина». 3 огляду на це були розраховані транслокаційні коефіцієнти для бар'єрного блоку «грунт - корені рослин». Міцний антиконцентраційний бар'єр як у контролі, так і за умов забруднення (транслокаційний коефіцієнт <1,0) притаманний лише для кадмію. Однак на площадці 4 у рослин спостерігався мікроконцентаційний зв'язок (транслокаційний коефіцієнт >1). Для більшості пробних площадок транслокація плюмбуму та купруму із грунту до коренів рослини відбувається безбар'єрним шляхом. Лише в умовному контролі зафіксований антиконцентраційний бар'єр.

Експериментальні результати дозволяють говорити про широке варіювання інтенсивності транслокації іонів цинку із грунту в корені. На ділянках із високим рівнем забруднення зафіксовано міцний бар'єр, окрім площадки 2, на якій зафіксовано показник із значенням 2,15 (табл. 2). Чіткого бар'єрного ефекту на територіях із помірним і незначним рівнями забруднення не зафіксовано, а для ділянки 9 значення коефіцієнту дорівнює 0,81 , що свідчить про наявність ефективного бар'єрного механізму (табл. 2). Для нікелю інтенсивність транслокації із грунту до коренів практично однакова на всіх ділянках, окрім 9 та 6, на яких спостерігається бар'єрний ефект.

Визначено, що найменше накопичується коренями рослин $\mathrm{Cu}$, який безбар'єрно пересувається iз грунту, а міцний антиконцентраційний бар'єр як у контролі, так і за умов забруднення є лише для $\mathrm{Cd}$. Оскільки накопичення кадмію в коренях займає не останнє місце, то можна припустити, що цей елемент потрапляє до рослин фоліарним шляхом.

Головні висновки. В умовах техногенного забруднення важкими металами екологічний фактор формування елементного складу рослин відіграє значну роль. За результатами виконаних досліджень можна дійти висновку, що процеси транслокації більшості важких металів до коренів T. officinale Wigg мають широке варіювання. Лідером накопичення як у грунті, так і в коренях рослин $є$ цинк, який надходить до вегетативних органів безбар'єрним шляхом. Для кадмію зафіксовано наявність високого бар'єрного ефекту у системах «грунт - корінь».

Перспективи використання результатів дослідження. Наявність зв'язку між накопиченням важких металів у грунті та коренях рослин дозволяє використовувати $T$. officinale Wigg для здійснення біоіндикації довкілля. Вважаємо за необхідне подальше детальне дослідження адаптивних реакцій кульбаби лікарської з метою створення біоіндикаційних шкал.

Таблиця 3

Ряди накопичення важких металів у коренях T. officinale

\begin{tabular}{|c|c|c|c|}
\hline $\begin{array}{c}\text { Пробна } \\
\text { площадка }\end{array}$ & $\begin{array}{c}\text { Ряди накопичення } \\
\text { важких металів }\end{array}$ & Пробна площадка & $\begin{array}{c}\text { Ряди накопичення } \\
\text { важких металів }\end{array}$ \\
\cline { 1 - 2 } $\mathbf{1}$ & $\mathrm{Zn}>\mathrm{Cd}>\mathrm{Ni}>\mathrm{Pb}>\mathrm{Cu}$ & 6 & $\mathrm{Zn}>\mathrm{Ni}>\mathrm{Cd}>\mathrm{Pb}>\mathrm{Cu}$ \\
\hline $\mathbf{2}$ & $\mathrm{Zn}>\mathrm{Cd}>\mathrm{Ni}>\mathrm{Pb}>\mathrm{Cu}$ & 7 & $\mathrm{Zn}>\mathrm{Ni}>\mathrm{Cd}>\mathrm{Pb}>\mathrm{Cu}$ \\
\hline $\mathbf{3}$ & $\mathrm{Zn}>\mathrm{Cd}>\mathrm{Cu}>\mathrm{Ni}=\mathrm{Pb}$ & 8 & $\mathrm{Zd}>\mathrm{Nb}>\mathrm{Cu}$ \\
\cline { 1 - 2 } $\mathbf{4}$ & $\mathrm{Zn}>\mathrm{Ni}>\mathrm{Cd}>\mathrm{Pb}>\mathrm{Cu}$ & 9 & $\mathrm{Zn}>\mathrm{Ni}>\mathrm{Pb}>\mathrm{Cd}>\mathrm{Cu}$ \\
\hline $\mathbf{5}$ & $\mathrm{Zn}>\mathrm{Ni}>\mathrm{Cd}>\mathrm{Pb}>\mathrm{Cu}$ & &
\end{tabular}




\section{Література}

1. Wuana R.A., Okieimen F.E. (2011). Heavy metals in contaminated soils: a review of sources, chemistry, risks and best available strategies for remediation. Isrn Ecology.

2. Aminiyan M.M., Aminiyan F.M., Mousavi R., Heydariyan A. (2016). Heavy metal pollution affected by human activities and different land-use in urban topsoil: a case study in Rafsanjan city, Kerman province, Iran. Eurasian Journal of Soil Science, 5 (2), 97

3. Ali H., Khan E., Sajad M.A. (2013). Phytoremediation of heavy metals-concepts and applications. Chemosphere, 91 (7), 869-881.

4. Tangahu B.V., Sheikh Abdullah S.R., Basri H., Idris M., Anuar N., Mukhlisin M. (2011). A Review on heavy metals (As, Pb and $\mathrm{Hg}$ ) uptake by plants through phytoremediation. International Journal of Chemical Engineering, 2011.

5. Minkina T.M., Mandzhieva S.S., Chaplygin V.A., Bauer T.V., Burachevskaya M.V., Nevidomskaya D.G., Zamulina I.V. (2017). Content and distribution of heavy metals in herbaceous plants under the effect of industrial aerosol emissions. Journal of Geochemical Exploration, 174, 113-120.

6. Fujimaki S., Suzui N., Ishioka N.S. et al. (2010). Tracing cadmium from culture to spikelet: noninvasive imaging and quantitative characterization of absorption, transport and accumulation of cadmium in an intact rice plant. Plant Physiol, 152, 1796-1806.

7. Dias M.C., Monteiro C., Moutinho-Pereira J. et al. (2013). Cadmium toxicity affects photosynthesis and plant growth at different levels. Acta Physiol. Plant, 35, 1281-1289.

8. Hall J.L., Williams L.E. (2003). Transition metal transporters in plants. Ibid, 54 (393), 26101-26113.

9. Hänsch R., Mendel R.R. (2009). Physiological functions of mineral micronutrients (Cu, Zn, Mn, Fe, Ni, Mo, B, Cl). Curr. Opin. Plant Biol, 12, 259-266.

10. Wodala B., Eitel G., Gyula T.N. et al. (2012). Monitoring moderate $\mathrm{Cu}$ and Cd toxicity by chlorophyll fluorescence and $\mathrm{P} 700$ absorbance in pea leaves. Photosynthetica, 50 (3), 380-386.

11. Pence N.S., Larsen P.B., Ebbs S.D., Letham D.L., Lasat M.M., Garvin D.F., Kochian L.V. (2000). The molecular physiology of heavy metal transport in the $\mathrm{Zn} / \mathrm{Cd}$ hyperaccumulator Thlaspi caerulescens. Proceedings of the National Academy of Sciences, 97(9), 4956-4960.

12. Hossian M.A., Piyatida P., da Silva J.A.T., Fujita M. (2012). Molecular mechanism of heavy metal toxicity and tolerance in plants: central role of glutathione in detoxification of reactive oxygen species and methylglyoxal and in heavy metal chelation. J. Bot, Article ID 872875, 37.

13. Rascio N., Navari-Izzo F. (2011). Heavy metal hyperaccumulating plants: how and why do they do it? And what makes them so interesting? Plant science, 180(2), 169-181.

14. Juknys R., Vitkauskaitė G., Račaitė M., Venclovienè J. (2012). The impacts of heavy metals on oxidative stress and growth of Spring Barley. Cent. Eur. J. Bot, 7 (2), 299-306.

15. Radulescu C. et al. (2013). Heavy metal accumulation and translocation in different parts of Brassica oleracea L. Romanian Journal of Physics., 58 (9-10), 1337-1354.

16. Stratu A., Costica N., Costica M. (2007). Wooden species in the urban green areas and their role in improving the quality of the environment. Present Environment and Sustainable Development, 10(2), 173-184.

17. Bessonova V.P., Kryvoruchko A.P. (2017). Changes in the structural indices of annual shoots of Quercus rubra under anthropogenic impact. Biosystems Diversity, 25 (3), 191-196.

18. Zupan M., Kralj T., Grcman H., Hudnik V., Lobnik F. (2003). The accumulation of Cd, Zn, Pb in Taraxacum officinale and Plantago lanceolata from contaminated soils. Proc VII ICOBTE, Uppsala Sv.

19. Практикум по почвоведению / под ред. И.С. Кауричева. Москва : Агропромиздат, 1986.

20. Методические указания по определению тяжелых металлов в почвах сельхозугодий и продукции растениеводства. Москва : ЦИНАО, 1989.

21. Barman S.C., Sahu R.K., Bhargava S.K, Chaterjee C. (2000). Distribution of heavy metals in wheat, mustard and weed grains irrigated with industrial effluents. Bull. Environ. Conta. Toxicol, 64 (4), 489-496.

22. Gupta S., Nayek S., Saha R.N. Satpati. (2008). Assessment of heavy metal accumulation in macrophyte, agricultural soil and crop plants adjacent to discharge zone of sponge iron factory. J. of Environ. Geol, 55 (4), 731-739.

23. Silich I.O. (2015). Buffer properties as index of edaphotope heavy metal pollution of Kryvyi Rih urban ecosystems // Agroecological journal : NAAS Institute of Agroecology and Environmental Management, 4, 34-44. 


\title{
ОЦІНКА ЕКОСОЗОАОГІЧНОГО ПОТЕНЦІААУ ТЕРИТОРІЇ ЗА ДОПОМОГОЮ АНАМІЗУ СИНФІТОІНДИКАЦІЙНИХ МОДЕАЕЙ ДИНАМІКИ
}

\author{
Хом'як І.В., Мшанецька В.В., Костюк В.С., Шпаковська Л.В., \\ Демчук Н.С., Андрійчук Т.В., Онищук І.П. \\ Житомирський державний університет імені Івана Франка \\ 1008, вул. Велика Бердичівська, 40, м. Житомир \\ ecosystem_lab@ukr.net
}

\begin{abstract}
Прогнозування динаміки екосистем під час зміни режиму експлуатації та заповідання - важлива теоретична та прикладна проблема. 3 одного боку, моделювання складних самоорганізованих систем - це складне завдання. Воно ускладнюється наявністю великої кількості елементів, з'єднаних між собою численними зв'язками, і стохастичною залежністю від безкінечної кількості зовнішніх факторів. 3 іншого боку, суб'єктивний підхід до охорони природного середовища несе серйозні загрози. Керуючись добрими намірами замість наукових прогнозів, ми можемо завдати шкоди об'єктам, які мали зберігати. Практична діяльність, пов'язана зі збереженням раритетних об'єктів, ризикована без використання прогнозів динаміки екосистем на основі узагальнених теоретичних моделей.

Біосферні резервати - це великі території з високою різноманітністю оселищ, що мають різну екосозологічну цінність і природоохоронний статус. Це розмаїття формується не тільки наявністю ділянок із різними умовами середовища (едафічним чи орографічними) та незалежним розподілом видів в екологічному континууму. Важливим фактором формування видового та ландшафтного різноманіття є належність екосистеми до певної стадії сукцесії. Отже, ми маємо не тільки врегульовувати небезпечний вплив людської діяльності на раритетні оселища, а й гарантувати існування на цій території екосистем із різними показниками динаміки.

Вихідними даними для пропонованих нами моделей $є$ синфітоіндикаційні матеріали обробки стандартних геоботанічних описів. Оскільки рослинні угруповання є добрими індикаторами природної та антропогенної динаміки, то їхнє використання для побудови вищеназваних моделей $є$ зручним і точним інструментом [1]. Точне визначення антропогенного впливу на екосистеми вимагає постійного цілодобового моніторингу за всією територією резервату, що є технічно нездійсненним завданням. Визначення природної динаміки стандартними методами є недопустимим у межах об'єктів природно-заповідного фонду через порушення досліджуваних екосистем. Синфітоіндикація дає змогу виконувати завдання моніторингу, моделювання та прогнозування змін довкілля, уникаючи технічних і методологічних проблем інструментальних методів. Ключові слова: Міжнародний біосферний резерват, Полісся, автогенні сукцесії.
\end{abstract}

Assessment of the ecosozological potential of the territory through the analysis of synphytoindication dynamic models. Khomiak I., Mshanetska V., Kostiuk V., Shpakovska L., Demchuk N., Andriichuk T., Onyshchuk I.

Forecasting the dynamics of ecosystems is an important theoretical and applied problem when changing the mode of use of natural habitats. Modelling of complex self-organized dynamic natural systems is a difficult task. It has a large number of elements that are interconnected by numerous connections. Such systems have a stochastic dependence on an infinite number of external factors. On the other hand, the subjective approach to environmental protection poses serious threats. We can harm rare objects of nature if we use good intentions instead of scientific predictions. Practical activities for the conservation of rare natural objects are risky if we do not use the forecasts of ecosystem dynamics made on the basis of generalized theoretical models.

Biosphere reserves are large areas with a high diversity of habitats, which have different ekosozological value and level of conservation status. The diversity of habitat of biosphere reserve habitats is formed by sites with different environmental conditions (edaphic or orographic) and independent distribution of species in the ecological continuum. Belonging of an ecosystem to a certain stage of succession is an important factor in creating species and landscape diversity too. We must regulate the dangerous impact of human activities on rare habitats, but also guarantee the existence of ecosystems with different indicators of dynamics in this area. The basis for our models of ecosystem dynamics is synphytoindication analysis of standard geobotanical descriptions. Plant communities are good indicators of natural and anthropogenic dynamics, so their use to build the above models is a convenient and accurate tool. Accurate identification of anthropogenic impacts on ecosystems is a technically difficult task. Determination of natural dynamics by standard methods is unacceptable in nature reserves, because it destroys rare habitats. Synphytoindication allows to perform tasks of monitoring, modeling and forecasting of environmental changes, avoiding technical and methodological problems of instrumental methods. Key words: International biosphere reserves, Polissya, autogenic successions.

Постановка проблеми. Залучення широкої громадськості до розв'язання природоохоронних проблем має цілу низку позитивних моментів [7], однак це може створити певні труднощі. Кожен учасник процесу, крім декларованих аргументів щодо цієї проблеми, може мати й супутні особисті інтереси.
Вони можуть мати кар'єрний чи репутаційний характер або психологічне коріння. В окремих випадках може бути й корупційний складник. Водночас він може виходити як від представників офіційних учасників процесу, так і від представників громадських організацій. Останнє явище завдає великої шкоди 
природоохоронному руху через компрометації участі в ньому громадськості та природоохоронного активізму.

Актуальність дослідження. Коли в процесі ухвалення рішення про екосозологічний статус якогось об' єкта дискусія ведеться під дією суб' єктивних мотивів, то існують високі ризики завдання шкоди як довкіллю, так і самому природоохоронному руху. Нині розробляються численні підходи для уникнення суб'єктивізму в екосозології. Одним із них може бути моделювання та прогнозування стану екосистем у межах наявного або проєктованого об'єкта природно-заповідного фонду або оселища з потенційними раритетними видами.

Зв'язок авторського доробку 3 важливими науковими та практичними завданнями. Дослідження пов'язані 3 розбудовою мережі природоохоронних територій різного рівня - від заказників місцевого значення до міжнародних біосферних резерватів, зокрема, з розбудовою Смарагдової мережі та Українсько-Білоруського біосферного резервату. Прогнози, основані на пропонованій методиці, може бути використано під час оцінки впливу на довкілля різних видів господарської діяльності.

Аналіз останніх досліджень і публікацій. Питання об'єктивної екосозологічної оцінки надорганізмових систем порушувалося досить давно. Це відображалося як у наукових роботах, так i в нормативних актах, що регулюють практичні аспекти охорони природи [15]. Наприклад, Наказом Міністерства охорони навколишнього природного середовища України від 27 травня 2009 р. № 257 визначається методика синфітосозологічної оцінки рослинних угруповань [6]. Однак вона все одно допускала велику частину суб'єктивних суджень окремих дослідників. У 2014 р. Яків Петрович Дідух запропонував зробити оцінку оселищ більш суворою [4]. Він рекомендує взяти 12 ознак екосистеми й оцінити їх за чотирибальною шкалою. Отже, оцінка оселищ може коливатися від 4 до 48 балів. Це дає змогу поділити їх на п'ять класів. Незважаючи на те, що в основі такої оцінки лежать об'єктивні ознаки, зокрема динамічні, використання іiі для прогнозування наслідків експлуатації чи охорони природи супроводжується певними проблемами.

Виділення не вирішених раніше частин загальної проблеми, котрим присвячується означена стаття. Для прогнозів наслідків людської діяльності із прийнятною для практичної діяльності точністю необхідно будувати математичні моделі процесів динаміки в екосистемах [16]. Насамперед ідеться про процеси природної динаміки та вплив на неї антропогенного фактора або рівня антропогенної трансформації екосистем [10]. Базовою інформацією про такі процеси може слугувати реакція представників флори або стану рослинних угруповань [14].

Синфітоіндикаційні моделі динаміки екосистем мають усі переваги і проблеми біоіндикатор- ного методу [13]. Його точність знижується через відсутність видів у створених базах даних, низьку кількість видів у описах і домінування евритопних видів [2]. Там, де трапляється менш ніж 5 видів на опис, або якщо 3 наявних менш ніж 5 наявні в базі даних, то ми маємо похибку завелику для практичних і теоретичних висновків. Цей метод дає добрі результати тільки в екосистемах із великою кількістю вищих судинних рослин, які перебувають у базі даних, та їхні амплітуди толерантності до антропогенного фактора добре досліджені [11]. 3 цієї причини ми часто не можемо оцінити численні екосистеми, показники динаміки яких нижчі за 2 бали. Їхні автотрофні блоки можуть бути ще не сформовані або представлені організмами, відсутніми в базах даних (ціанобактеріями, водоростями, лишайниками та іншими).

Мета та завдання дослідження. Метою дослідження є перевірка можливостей застосування синфітоіндикаційних моделей динаміки екосистем для прогнозування наслідків запровадження заповідного режиму. Задля виконання мети було поставлено такі завдання: визначити синфітоіндикаційні показники природної динаміки для окремих типів екосистем; побудувати моделі залежності показників природної динаміки та факторів середовища; побудувати двовимірні моделі залежності антропогенної трансформації та показників природної динаміки, наприклад, проєктованого українсько-білоруського міжнародного біосферного резервату.

Матеріали та методи досліджень. Матеріалами дослідження є 854 стандартних геоботанічних описів із фітоценотеки лабораторії «Теорії екосистем» Житомирського державного університету імені Івана Франка. Описи зроблено експедиційними та напівстаціонарними польовими методами [8] в період із 2004 по 2019 роки.

Класифікацію рослинних угруповань проводили згідно із принципами еколого-флористичної класифікації шкали Браун-Бланке. Для визначення синтаксонів використовували новий «Продромус рослинності України» [5; 12].

Синфітоіндикаційний аналіз здійснювали за принципами, запропонованими Я.П. Дідухом і П.Г. Плютою [2]. У роботі використовували уніфіковану шкалу Дідуха-Плюти для визначення абіотичних показників: HD - багаторічний режим зволоження, FH - змінність зволоження, RC - кислотність, SL - загальний сольовий режим, CA вміст карбонатів, NT - вміст доступного нітрогену, $\mathrm{AE}$ - аерація грунту, TM - терморежим, OM - омборежим, KN - континентальність, CR - кріорежим, LC - освітленість [2].

Рівень антропогенної трансформації описувався за допомогою шкали Дідуха-Хом’яка [3; 11], а показник природної динаміки за оригінальною 21-бальною шкалою, розробленою в лабораторії «Теорії екосистем» $[9 ; 14]$. 
Новизна. Уперше було використано лінійні та поліноміальні моделі залежності між синфітоіндикаційними показниками антропогенної трансформації та природної динаміки.

Методологічне або загальнонаукове значення. Отримані результати може бути використано для побудови прогностичних алгоритмів зміни природної динаміки (напрямів і темпів) під дією антропогенної діяльності.

Виклад основного матеріалу. За еталон природної динаміки нами взято автогенну сукцесію, яка відбувається в напрямі формування угруповань енергетичного клімаксу. Ї̈̈ показник ми визначаємо за кількістю накопиченої в екосистемі надземної фітомаси певного віку, закономірна зміна якої відбувається під час вищеназваного типу динаміки. Низка закономірних змін в автотрофному блоці ланок сукцесійних змін дає змогу створити синфітоіндикаційну шкалу природної динаміки.

Показник динаміки в екосистемах проєктованого біосферного резервату змінюється від 2,33 до 16,14 балів із середнім значенням 8,69. Амплітуда коливання показників динаміки в 13,8 бала (66 \% шкали) вказує на високу різноманітність ландшафтів. 3 ура- хуванням піонерних екосистем вона зростає до $77 \%$. Це високий показник, щодо ландшафтного різноманіття, але він не перекриває ті 33 \% шкали, які належать передклімаксичним лісам. Це досить поширена картина для території Полісся, де такими лісами $\epsilon$ окремі невеличкі масиви старих дубових лісів. На території, відведеній для біосферного резервату на час дослідження, таких екосистем помічено не було.

Окремі типи екосистем, визначені за класами їхніх автотрофних блоків, відрізняються за показниками динаміки (табл. 1). За середніми значеннями найнижчі показники динаміки мають сегетальні екосистеми 3 автотрофним блоком Stellarietea mediae, рудеральні Agropyretea intermedio-repentis та рудералізовані літоральні Isoëto-Nanojuncetea. Найвищі в лісових екосистем із класами Quercetea roboripetraeae, Querco-Fagetea та Quercetea robori-petraea.

Водночас за мінімальними значеннями показника динаміки ми спостерігаємо дещо іншу картину. Тут перша п'ятірка побудована так: Potametea $\rightarrow$ Stellarietea mediae $\rightarrow$ Plantegenetea majori $\rightarrow$ Lemnetea $\rightarrow$ Isoëto-Nanojuncetea. Поява серед них евтрофних і мезотрофних екосистем вказує на те, що вони здатні набувати дуже низьких значень, хоча

Таблиця 1

Показники динаміки для екосистем, диференційованих за класами автотрофних блоків згідно з підходом Браун-Бланке

\begin{tabular}{|l|c|c|c|c|c|}
\hline $\begin{array}{c}\text { Тип екосистем відповідно до класу } \\
\text { автотрофного блоку }\end{array}$ & Середнє & Мінімум & Максимум & Амплітуда & $\begin{array}{c}\text { Частка } \\
\text { перекриття } \\
\text { шкали }\end{array}$ \\
\hline Agropyretea intermedio-repentis & 3,63 & 3,51 & 4,70 & 1,19 & 0,06 \\
\hline Alnetea glutinosae & 9,46 & 7,90 & 12,34 & 4,44 & 0,21 \\
\hline Artemisietea vulgaris & 4,25 & 3,64 & 5,70 & 2,06 & 0,10 \\
\hline Asplenietea & 12,66 & 8,48 & 16,29 & 7,81 & 0,37 \\
\hline Epilobietea angustifoli & 10,66 & 5,75 & 14,05 & 8,30 & 0,40 \\
\hline Galio-Urticetea & 9,04 & 6,15 & 11,94 & 5,80 & 0,28 \\
\hline Isoëto-Nanojuncetea & 3,61 & 3,22 & 3,83 & 0,61 & 0,03 \\
\hline Koelerio-Corynephoretea & 6,62 & 5,22 & 7,91 & 2,69 & 0,13 \\
\hline Lemnetea & 3,64 & 3,12 & 4,56 & 1,44 & 0,07 \\
\hline Molinio-Arrhenatheretea & 4,93 & 3,52 & 5,99 & 2,47 & 0,12 \\
\hline Nardo-Callunetea & 7,65 & 5,34 & 9,86 & 4,52 & 0,22 \\
\hline Oxycocco-Sphagnetea & 8,86 & 5,96 & 11,77 & 5,80 & 0,28 \\
\hline Phragmiti-Magnocaricetea & 4,43 & 3,53 & 7,13 & 3,60 & 0,17 \\
\hline Plantegenetea majori & 7,73 & 3,03 & 4,97 & 1,94 & 0,09 \\
\hline Potametea & 3,72 & 2,33 & 5,21 & 2,88 & 0,14 \\
\hline Quercetea robori-petraea & 12,91 & 11,68 & 15,67 & 3,99 & 0,19 \\
\hline Querco-Fagetea & 13,37 & 10,04 & 16,14 & 6,10 & 0,29 \\
\hline Rhamno-Prunetea & 10,90 & 9,56 & 11,82 & 2,26 & 0,11 \\
\hline Quercetea robori-petraeae & 13,72 & 11,68 & 15,67 & 3,99 & 0,19 \\
\hline Robinietea & 10,50 & 7,50 & 13,89 & 6,39 & 0,30 \\
\hline Salicetea purpureae & 9,32 & 8,31 & 10,10 & 1,80 & 0,09 \\
\hline Scheuchzerio-Caricetea nigra & 5,28 & 3,53 & 8,21 & 4,68 & 0,22 \\
\hline Stellarietea mediae & 3,08 & 2,42 & 3,97 & 1,55 & 0,07 \\
\hline Trifolio-Geranietea & 6,49 & 4,36 & 9,83 & 5,48 & 0,26 \\
\hline Vaccinio-Piceetea & 12,34 & 8,35 & 14,86 & 6,51 & 0,31 \\
\hline & & & & & \\
\hline
\end{tabular}


здебільшого зафіксовані описи є на більш просунутих стадіях сукцесії.

Аналогічні зміни спостерігаємо і за максимальними для окремих класів показниками динаміки. Перша п'ятірка - це ряд із Epilobietea angustifoli $\rightarrow$ Vaccinio-Piceetea $\rightarrow$ Quercetea robori-petraea $\rightarrow$ Quercetea robori-petraeae $\rightarrow$ Querco-Fagetea. Така картина повністю відповідає теоретичним основам едафо-динамічної моделі. В останню входять Isoëto-Nanojuncetea $\rightarrow$ Stellarietea mediae $\rightarrow$ Lemnetea $\rightarrow$ Agropyretea intermedio-repentis $\rightarrow$ Plantegenetea majori. Особливе положення посідає клас Asplenietea. Він має дуже високі значення показника динаміки завдяки затіненню рослинністю класу Querco-Fagetea. Насправді такі наскельні екосистеми $з$ домінуванням папоротеподібних потрібно виділяти окремо. Стандартний геоботанічний опис вносить їх у наскельний комплекс як єдине ціле. Насправді ми маємо справу з мозаїкою, де є виходи гірських порід із показниками динаміки 2-5 балів та ліси із показниками 8-17 балів.

Розподіл екосистем за їхньою амплітудою показника динаміки чи відсотком перекриття шкали дає змогу розділяти їхні фітоценози на евридинамічні, стенодинамічні та мезодинамічні. До першої групи входять екосистеми 3 високою амплітудою показника динаміки. Вона коливається від 9 до 5 балів. Сюди належать екосистеми із класами рослинних угруповань Epilobietea angustifoli, Vaccinio-Piceetea, Robinietea, Querco-Fagetea, Oxycocco-Sphagnetea, Galio-Urticetea, Trifolio-Geranietea. До стенодинамічних належать екосистеми, амплітуда показника динаміки яких не перевищує 3 балів. До них відносять ті, що мають автотрофний блок у вигляді класів Potametea, Koelerio-Corynephoretea, MolinioArrhenatheretea, Rhamno-Prunetea, Artemisietea vulgaris, Plantegenetea majori, Salicetea purpureae, Stellarietea mediae, Lemnetea, Agropyretea intermediorepentis та Isoëto-Nanojuncetea. Серед останньої групи велика частка синантропних екосистем або тих, які часто піддаються антропогенній трансформації - $45 \%$.

На території проєктованого біосферного резервату трапляються екотопи 3 дуже широкою амплітудою коливання показників середовища. Це $є$ передумовою до формування високої різноманітності оселищ і видів, які в них перебувають. Оскільки природна динаміка $є$ поєднанням двох процесів сингенезу та ендоекогенезу, то певні відхилення від середніх (оптимальних) значень показників призводять до їхнього сповільнення.

Сингенез часто $є$ неможливим, поки в результаті ендоекогенезу не сформувалися певні наближені до оптимуму умови. Таке відхилення здатне не тільки сповільнити хід автогенної сукцесії, а й повністю іiі зупинити, спричинивши катастрофічний клімакс. Отже, фактори, які мають дуже широку амплітуду, стають причиною існування більш довгих і різноманітних сукцесійних серій. До таких чинників належать багаторічний режим зволоження, аерація грунту, омборежим (аридність/гумідність) та змінність зволоження. До чинників, які слабко змінюються в екотопах проєктованого біосферного резервату, належать освітленість грунту, кислотність, терморежим і кріорежим.

Відхилення від оптимальних показників факторів середовища призводить сповільнення темпів автогенної сукцесії. Побудувавши математичні моделі залежності між величиною факторів середовища та показником природної динаміки, ми можемо встановити тип зв'язку та його силу.

За допомогою непрямої ординації ми можемо побудувати лінійну модель впливу певного фактора середовища на процеси динаміки. За отриманими даними можемо спостерігати дуже відмінний рівень таких впливів (табл. 3). Він характеризується величинами коефіцієнта кореляції від 0,1 до 0,86.

До чинників середовища, які найменше корелюють із показником динаміки, належать вміст карбонатів, кріорежим і терморежим. Тут простежується залежність із їхньою амплітудою зміни величини. До факторів, які найсильніше впливають на показник динаміки, належать загальний сольовий режим, омборежим та освітленість. Два останніх напрями пов'язані зі змінами вертикальної структури екосистем (поява ярусності), що впливають на рівень освітлення грунту та особливості мікроклімату. Сольовий режим (трофність) один із основних факторів середовища, який визначає диференціацію екосистем. Особливостями едафотопу Полісся є висока грунтова різноманітність із значною часткою бідних на елементи мінерального живлення грунтів.

У межах проєктованого біосферного резервату спостерігається широкий спектр екосистем із різним ступенем антропогенної трансформації. Її мінімальні

Таблиця 2

Статистичні параметри показників факторів середовища на території просктованого біосферного резервату

\begin{tabular}{|c|c|c|c|c|c|c|c|c|c|c|c|c|}
\hline $\begin{array}{c}\text { Статистичний } \\
\text { показник }\end{array}$ & HD & FH & RC & SL & CA & NT & AE & TM & OM & KN & CR & LC \\
\hline середнє & 13,55 & 5,73 & 7,12 & 6,77 & 5,89 & 5,98 & 8,23 & 8,35 & 13,00 & 8,40 & 8,00 & 6,53 \\
\hline максимум & 21,00 & 8,71 & 8,92 & 9,21 & 8,63 & 8,28 & 14,50 & 10,61 & 14,85 & 13,00 & 9,50 & 8,25 \\
\hline мінімум & 9,81 & 2,42 & 4,53 & 4,37 & 3,40 & 3,00 & 5,33 & 6,26 & 8,00 & 6,90 & 6,00 & 3,59 \\
\hline Амплітуда & 11,19 & 6,30 & 4,39 & 4,85 & 5,23 & 5,28 & 9,17 & 4,35 & 6,85 & 6,10 & 3,50 & 4,66 \\
\hline
\end{tabular}


Таблиця 3

Лінійна залежність показника динаміки від величини чинників середовища визначена 3 використанням лінійних моделей

\begin{tabular}{|c|c|c|}
\hline $\begin{array}{c}\text { Чинник } \\
\text { середовища }\end{array}$ & $\begin{array}{c}\text { Величина } \\
\text { достовірності } \\
\text { апроксимації }\end{array}$ & $\begin{array}{c}\text { Коефіціснт } \\
\text { кореляції }\end{array}$ \\
\hline HD & 0,18 & 0,42 \\
\hline FH & 0,16 & 0,40 \\
\hline RC & 0,19 & 0,44 \\
\hline SL & 0,52 & 0,72 \\
\hline CA & 0,01 & 0,10 \\
\hline NT & 0,07 & 0,26 \\
\hline AE & 0,26 & 0,51 \\
\hline TM & 0,02 & 0,14 \\
\hline OM & 0,35 & 0,59 \\
\hline KN & 0,08 & 0,28 \\
\hline CR & 0,01 & 0,11 \\
\hline LC & 0,73 & 0,86 \\
\hline
\end{tabular}

значення рівні 4,98 бала, що відповідає олігогемеробним екосистемам із низькою антропотолерантністю. Для екосистем із сформованими автотрофними блоками середне значення показника антропогенного фактора дорівнюе 7,26 (мезогемеробність). Для такого типу екосистем максимум антропогенної трансформації рівний 11,8 бала (еугемеробність). Ще вищі показники ведуть до руйнування угруповань вищих судинних рослин аж до їхнього знищення. 3 цієї причини синфітоіндикаційна модель не описує полі- та метагемеробні екосистеми. Амплітуда коли- вання антропогенної трансформації для екосистем із визначеними фітоценозами дорівнює 6,81 бала, що відповідає 38 \% шкали. Для всіх типів екосистем 13,02 бала, або $72 \%$ шкали.

Між показником природної динаміки та показником антропогенної трансформації є обернена лінійна залежність із величиною достовірності апроксимації 0,26 та коефіцієнтом кореляції 0,51 (рис. 1). Аналіз графічної моделі демонструє різницю відхилення від лінії тренду на ранніх і пізніх стадіях автогенної сукцесії. На пізніх стадія вона набагато нижча. Отже, на ранніх стадіях сукцесії ми можемо спостерігати як олігогемеробні (найчастіше болотні екосистеми), так і еу-, полі- та метагемеробні екосистеми.

Математичну лінійну модель, що описує цю взаємну залежність, можна відобразити за допомогою формули:

$$
H E=-0.1588 S T+8.6353,
$$

де $\mathrm{HE} \mathrm{-} \mathrm{показник} \mathrm{антропогенної} \mathrm{трансформації}$ екосистем, a ST - показник природної динаміки.

Оскільки антропогенний фактор діє аналогічно 3 іншими факторами середовища, то щодо нього спостерігаються закономірності, визначені законом оптимуму. Відповідно до цього ми можемо побудувати поліноміальну модель взаємозв'язку між показником природної динаміки та рівнем антропогенної трансформації (рис. 2). Вона матиме дещо кращі показники кореляції $(0,51)$ за величини достовірності апроксимації 0,26.

Формула, що описує таку математичну модель, має такий вигляд:

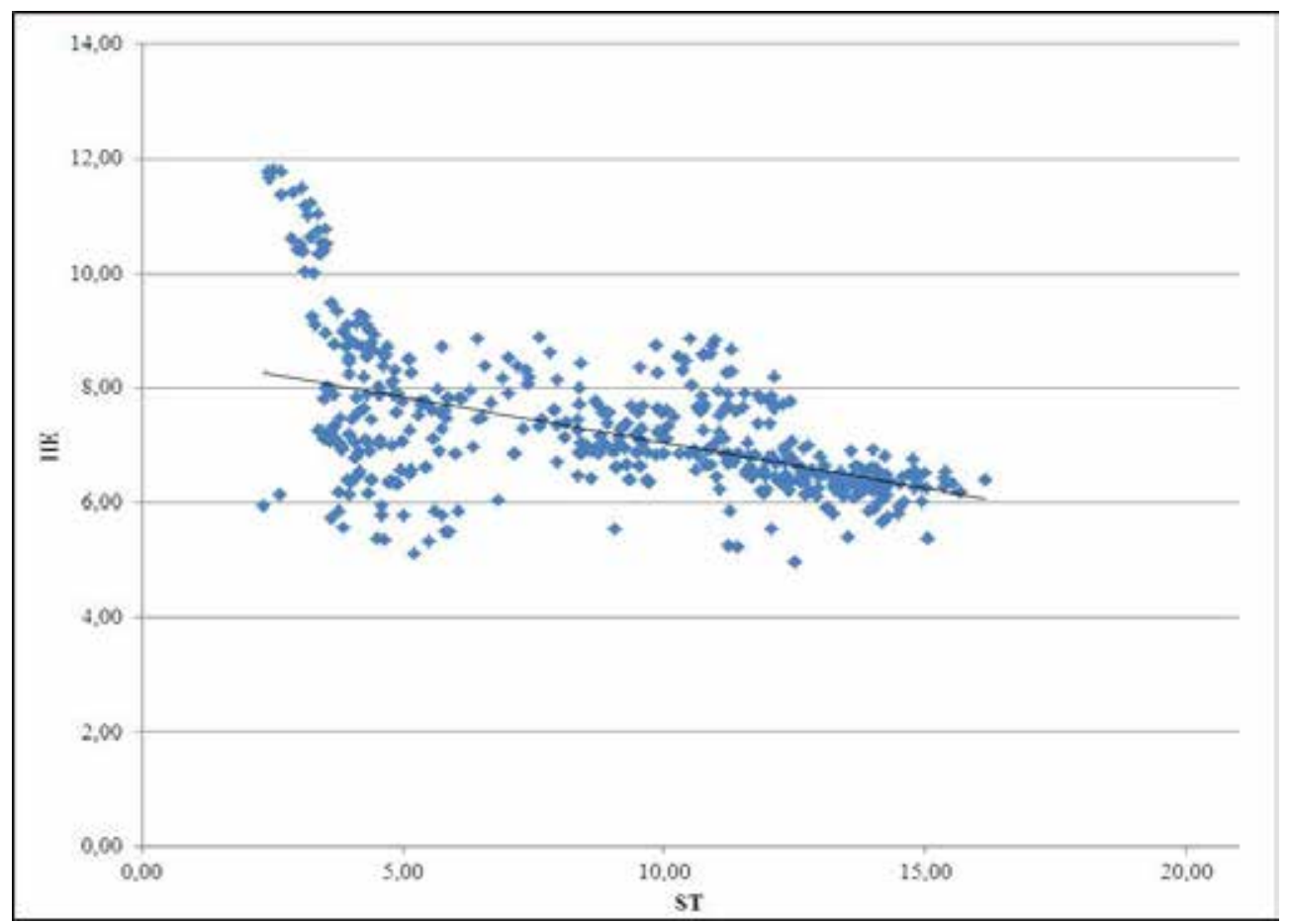

Рис. 1. Лінійна ординаційна залежність між показником природної динаміки та антропогенної трансформації екосистем 


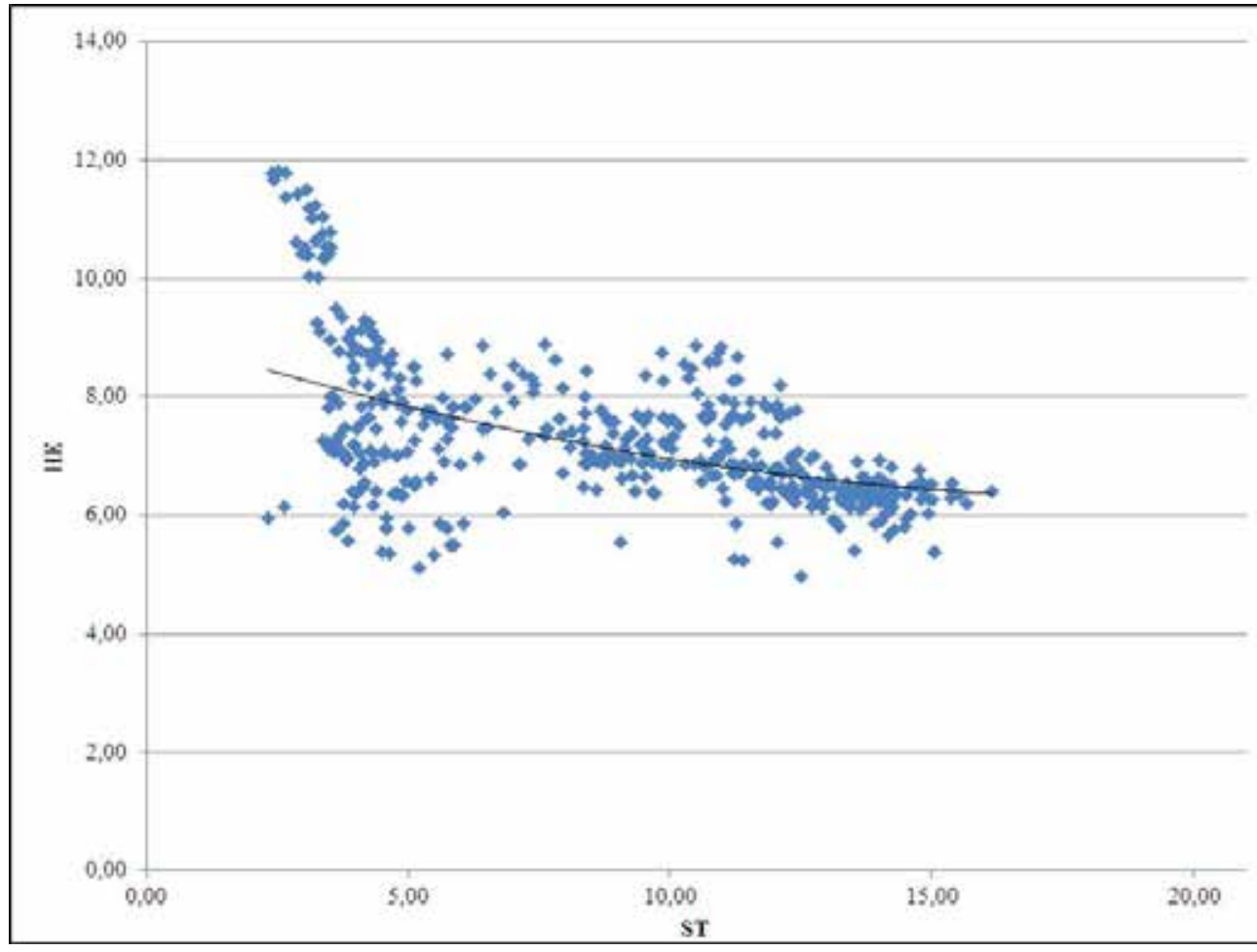

Рис. 2. Модель поліноміальної залежності між показником динаміки та показником освітленості

$$
H E=0,072 S T^{2}-0,2837 S T+9,0716,
$$

де $\mathrm{HE}$ - показник антропогенної трансформації екосистем, а ST - показник природної динаміки.

Головні висновки. За отриманими даними, показник динаміки в екосистемах проєктованого біосферного резервату коливається від 2,33 до 16,14 балів із середнім значенням 8,69. Різноманітність екосистем проєктованого біосферного резервату можна розділити за перекриттям шкали показника природної динаміки на евридинамічні, мезодинамічні та стено- динамічні. Належність раритетних оселищ до певного типу за амплітудою показника динаміки має враховуватися під час обрання методів його охорони.

Перспективи використання результатів дослідження. Моделювання взаємозв'язку показників природної динаміки та антропогенної трансформації, може стати основою для прогнозування наслідків зміни строгості заповідного режиму. У поліноміальній моделі другого ступеня така залежність має показник кореляції 0,51 , що робить прогнози цінними для практичної діяльності.

\section{Література}

1. Бурда Р.І., Дідух Я.П. Застосування методики оцінки антропотолерантності видів вищих рослин при створенні «Екофлори України». Український фітоценотичний збірник. Київ, 2003. № 1. С. 34-44.

2. Дідух Я.П., Плюта П.Г. Фітоіндикація екологічних факторів. Київ: 1994. 280 с.

3. Дідух Я.П., Хом'як І.В. Оцінка енергетичного потенціалу екотопів залежно від ступеня їх гемеробії на прикладі Словечансько-Овруцького кряжу. Український ботанічний журнал. 2007. № 1. С. 235-243.

4. Дідух Я.П. Оцінка стійкості та ризиків втрати екосистем. Наукові записки НаУКМА. 2014. Т. 158: Біологія та екологія. С. $54-60$.

5. Дубина Д.В., Дзюба Т.П., Ємельянова С.М. та ін. Продромус рослинності України. Київ : Наукова думка, 2019. 784 с.

6. Зелена книга України / за загальною редакцією члена-кореспондента НАН України Я.П. Дідуха. Київ : Альтерпрес, 2009. $448 \mathrm{c}$.

7. Коніщук В.В. Онтологія становлення екосозологічного та інвайронментологічного напрямів. Агроекологічний журнал. 2017. № 2. C. 49-58.

8. Миркин Б.М., Наумова Л.Г., Соломещ А.И. Современная наука о растительности. Москва : Логос, 2001. 264 с.

9. Хом'як І.В. Динаміка надземної фітомаси під час автогенних сукцесій на перелогах для території Правобережного Полісся. Екологічні науки. 2016. № 12-13. С. 33-39.

10. Хом'як І.В. Особливості антропогенного впливу на природну динаміку екосистем Українського Полісся. Екологічні науки. 2018. № 1. С. 69-73.

11. Хом’як І.В., Демчук Н.С., Василенко О.М. Фітоіндикація антропогенної трансформації екосистем на прикладі Українського Полісся. Екологічні науки. 2018. № 3. С. 113-118. 
12. Хом’як І.В., Онищук І.П., Коцюба І.Ю., Брень А.Л., Шкилюк Ю.В. Рецензія на монографічне видання «Продромус рослинності України». Екологічні науки. 2020. С. 170-173.

13. Khomiak I., Onishchuk I., Demchuk N. Phytoindicators of ecosystem dynamics in Ring-banc Ukrainian Polissia. Science Rise: Biological Science. 2018. № 4. P. 25-30.

14. Khomiak I., Harbar O., Demchuk N., Kotsiuba I., Onyshchuk I. Above-graund phytomas dynamics in autogenic succession of an ecosystem. Forestry ideas. 2019. № 1. P. 136-146.

15. Li Hea, Jing Shenab, Yang Zhangb. Ecological vulnerability assessment for ecological conservation and environmental management. Journal of Environmental Management. Vol. 206. P. 1115-1125.

16. McGarigal K., Compton B.W., Plunkett E.B., DeLuca W.V., Grand J., Ene E., Jackson S.D. A landscape index of ecological integrity to inform landscape conservation. Landscape Ecology. Vol. 33. P. 1029-1048. 


\title{
МЕТОДИКА ОЦІНКИ ТЕХНОГЕННОГО НАВАНТАЖЕННЯ НА СКААДНИКИ ДОВКІМАЯ ТА Ї̈ ПРОГРАМНА РЕАМІЗАЦІЯ
}

\author{
Чугай А.В., Бучинська І.В., Ільӥна В.Г. \\ Одеський державний екологічний університет \\ вул. Львівська, 15, 65016, м. Одеса \\ avchugai@ukr.net
}

\begin{abstract}
Для підтримання довкілля в належному стані з метою забезпечення якісного життя та благополуччя теперішнього і майбутніх поколінь одним із головних завдань є оцінка і мінімізація техногенного навантаження на складники довкілля. Єдиного підходу до комплексної оцінки стану довкілля під впливом техногенного навантаження в Україні немає. 3 урахуванням сучасного екологічного стану існує нагальна потреба у створенні системи модулів навантаження на окремі складники довкілля, які характеризують структуру техногенного навантаження. Було розроблено й обгрунтовано застосування окремих модулів навантаження на складники довкілля (повітряний басейн, водні об'єкти, геологічне середовище), апробовані для регіонів Північно-Західного Причорномор'я. В Україні розроблені і функціонують різноманітні програмні комплекси, які призначені для обробки й аналізу даних екологічного моніторингу, картографічної візуалізації просторово-часового розподілу характеристик забруднення й техногенного навантаження на довкілля. Усі вони є складними комплексними системами. Для оптимізації процедури розрахунку модулів навантаження на окремі складники довкілля розроблено програмний модуль «ТЕХНОГЕННЕ НАВАНТАЖЕННЯ», який дає змогу прискорити процес розрахунку і спростити побудову графічного представлення результатів розрахунків. 3 цією метою було застосовано пакет Microsoft Office Access. Розроблений програмний модуль дає змогу суттєво спростити процедуру розрахунку, а саме під час зміни бази вихідної інформації (збільшення обсягу, зміна об'єкта дослідження) необхідності проводити розрахунки знову немає. Модуль автоматично під час зміни вихідної інформації проводить розрахунок необхідних показників. Розроблений модуль є нескладним для роботи і може бути застосований в окремих навчальних курсах під час викладання дисциплін екологічного спрямування. Ключові слова: модуль техногенного навантаження, складники довкілля, програмний модуль.
\end{abstract}

Methods of assessment of technogenic load on components of the environment and its software implementation. Chugai A., Buchynska I., Ilina V.

To maintain the environment in good condition in order to ensure quality of life and well-being of present and future generations, one of the main tasks is to assess and minimize the technogenic load on the components of the environment. There is no single approach to a comprehensive assessment of the state of the environment under the influence of technogenic load in Ukraine. Given the current environmental situation, there is an urgent need to create a system of load modules for individual components of the environment, which characterize the structure of technogenic load. The application of separate modules of loading on the components of the environment (air basin, water bodies, geological environment), tested for the regions of the North Western Black Sea, was developed and substantiated. In Ukraine, various software packages have been developed and are operational, which are designed for processing and analysis of environmental monitoring data, cartographic visualization of the spatio-temporal distribution of pollution characteristics and technogenic load on the environment. They are all complex integrated systems. To optimize the procedure for calculating the load modules for individual components of the environment, a software module "TECHNOGENIC LOAD" has been developed, which allows to speed up the calculation process and simplify the construction of a graphical representation of the calculation results. Microsoft Office Access was used for this purpose. The developed software module allows to significantly simplify the calculation procedure, namely when changing the base of the source information (increasing the volume, changing the object of study) the need to perform calculations again is absent. The module automatically calculates the required indicators when changing the source information. The developed module is simple to work with and can be used in some training courses in teaching environmental disciplines. Key words: module of technogenic load, components of the environment, software module.

Постановка проблеми. Під техногенним навантаженням на природне середовище розуміється співвідношення сили техногенних впливів і ступеня відновлених можливостей природних екосистем, яке може визначатися за реакцією їхніх складників (абіогенних і біогенних). Нині для підтримання довкілля в належному стані з метою забезпечення якісного життя та благополуччя теперішнього і майбутніх поколінь одним із головних завдань є оцінка й мінімізація техногенного навантаження на складники довкілля.

Актуальність дослідження. На жаль, єдиного підходу до комплексної оцінки стану довкілля під впливом техногенного навантаження в Україні не існує. Більшість робіт у цьому напрямі було присвячено аналізу антропогенного впливу або техногенного навантаження на регіони України загалом. Водночас застосовувався різний набір показників i, відповідно, обробки й інтерпретації масивів інформації. Тому з урахуванням сучасного екологічного стану існує нагальна потреба у створенні системи модулів навантаження на окремі складники довкілля, які характеризують структуру техногенного навантаження на довкілля.

Зв'язок авторського доробку 3 важливими науковими та практичними завданнями. Робота 
відповідає основним напрямам екологічної політики України згідно з проєктом Стратегії сталого розвитку України до 2030 р. і Законом України «Про Основні засади (стратегію) державної екологічної політики України на період до 2030 року» [1]. Також представлені результати досліджень відповідають основним напрямам наукової діяльності кафедри екології та охорони довкілля, кафедри інформаційних технологій Одеського державного екологічного університету.

Аналіз останніх досліджень і публікацій. Питанням оцінки техногенного впливу на навколишнє природне середовище присвячено роботи багатьох дослідників, зокрема робота [2], у якій застосовано методи кластерного аналізу для аналізу територій України за показниками антропогенного впливу. 3 урахуванням можливості проводити оцінку за окремими показниками, зокрема за показниками утворення відходів виробництва і споживання на будьякій території, проведено дослідження Т.П. Шаніною і В.Ю. Приходько [3]. У роботі [4] із застосуванням набору показників, які можна використовувати для оцінки техногенного навантаження, проведено аналіз екологічного стану регіонів України.

Виділення не вирішених раніше частин загальної проблеми, котрим присвячусться означена стаття. У роботі [5] автором запропоновано проводити оцінку техногенного навантаження на окремі складники довкілля. 3 цією метою розроблено й обгрунтовано застосування окремих модулів навантаження на складники довкілля (повітряний басейн, водні об'єкти, геологічне середовище), які були апробовані для регіонів ПівнічноЗахідного Причорномор'я. Для оптимізації процедури розрахунків розроблено програмний модуль «ТЕХНОГЕННЕ НАВАНТАЖЕННЯ».

Методологічне або загальнонаукове значення. Застосування модулів техногенного навантаження на окремі складники довкілля 3 метою оцінки й порівняльного аналізу - це багатоступенева процедура. У iï складі можна виділити такі основні етапи:

1) формування початкової бази даних з вихідною інформацією;

2) розрахунок окремих модулів на складники довкілля з урахуванням площі регіону;

3) побудова графічного матеріалу для подальшого просторо-часового аналізу.

Звичайно, усі вказані процедури можна виконати iз застосуванням відомого й поширеного пакету Microsoft Office Excel. Але ж виконання другого i третього етапів потребує додаткової механічної роботи. Саме тому одним із завдань дослідження 3 метою оптимізації процедури розрахунку стало створення програмного модуля, який би спростив виконання розрахунків і формування відповідного графічного матеріалу.

Виклад основного матеріалу. В Україні розроблені і функціонують різноманітні програмні комп- лекси, які призначені для обробки й аналізу даних екологічного моніторингу, розрахунку полів концентрацій 3Р, картографічної візуалізації просторово-часового розподілу характеристик забруднення й техногенного навантаження на довкілля, а також автоматизовані системи контролю забруднення природних середовищ. До них можна віднести автоматизовані системи контролю стану природних середовищ, Урядову інформаційно-аналітичну систему 3 питань надзвичайних ситуацій [6;7]. Також прикладом програмного комплексу $є$ досить відомий i поширений комплекс «ЕОЛ», який призначений для розрахунку розсіювання домішок від стаціонарних джерел забруднення в приземному шарі атмосфери, а також математичного моделювання поширення домішок в атмосферному повітрі [8]. Багато програмних продуктів створюється нині із застосуванням ГІС-технологій. Одним із прикладів такого продукту є ЕкоГІС-Київ [9].

Усі перелічені вище програмні продукти є складними комплексними системами, які характеризуються багаторівневою ієрархічною структурою й призначені для розв'язання комплексу завдань. Прикладом розроблення прикладного програмного пакету для оцінки техногенного навантаження на довкілля $є$ запропонований A.I. Волковим пакет Environmental Decision Support Systems [10]. Також прикладом застосування прикладного програмного комплексу $\epsilon$ запропонований білоруськими вченими пакет [11], який дає змогу виконати комплексну оцінку антропогенного впливу на повітряний басейн за даними моніторингу атмосферного повітря.

Як уже зазначалось, із метою спрощення процедури розрахунку окремих модулів техногенного навантаження на складники довкілля було розроблено програмний модуль «ТЕХНОГЕННЕ НАВАНТАЖЕННЯ», який дає змогу прискорити процес розрахунку і спростити побудову графічного представлення результатів розрахунків. 3 цією метою було застосовано пакет Microsoft Office Access.

На рис. 1 наведено блок-схему програмного модуля «ТЕХНОГЕННЕ НАВАНТАЖЕННЯ».

Для реалізації цього модуля на першому етапі було створено базу вихідних даних, які містять інформацію про обсяги викидів забруднювальних речовин (ЗР), скидів ЗР і стічних вод (СВ), утворення відходів і накопичення відходів, а також відомості щодо площі регіону дослідження. База даних формується в пакеті Microsoft Excel, i функціонально програмний модуль пов'язаний із вихідною базою даних.

Загальний інтерфейс модуля «ТЕХНОГЕННЕ НАВАНТАЖЕННЯ» в пакеті Microsoft Access наведено на рис. 2.

На наступних етапах модуль дає можливість отримати результати розрахунків окремих модулів навантаження на складники довкілля, а також гісто- 


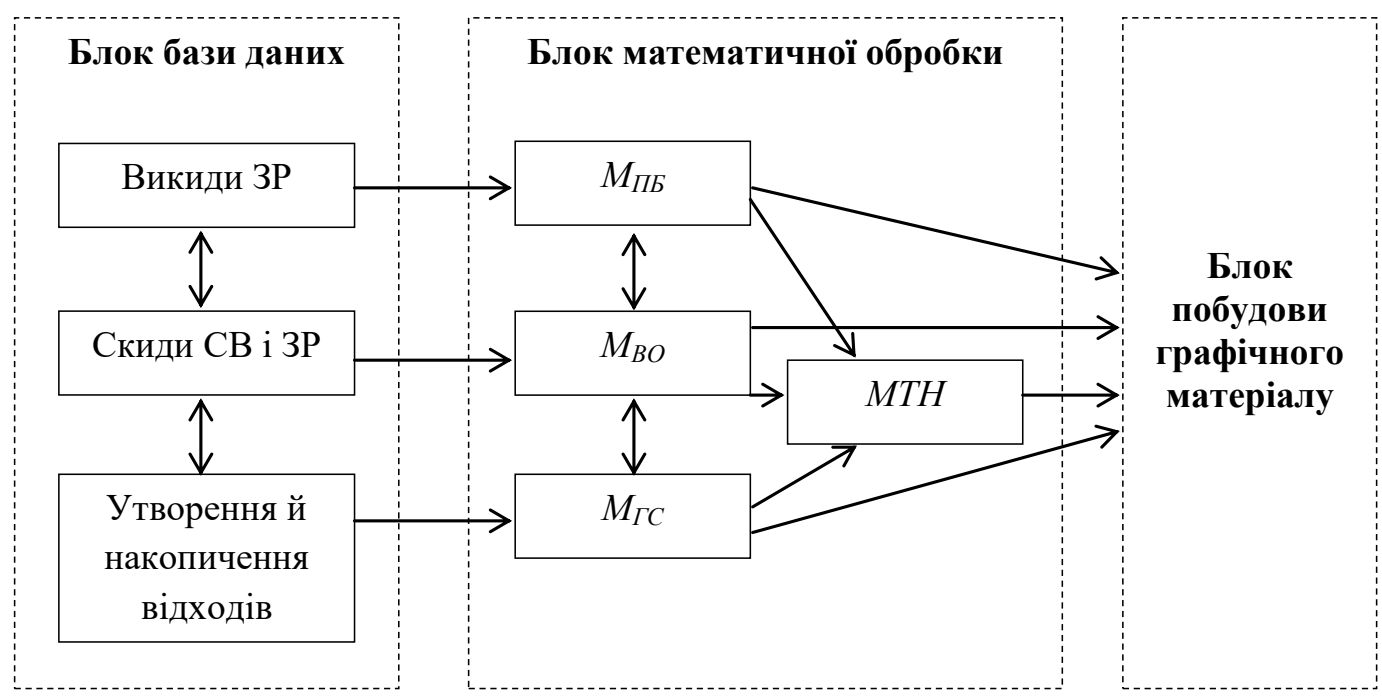

РИс. 1. Структурна схема програмного модуля «ТЕХНОГЕННЕ НАВАНТАЖЕННЯ»

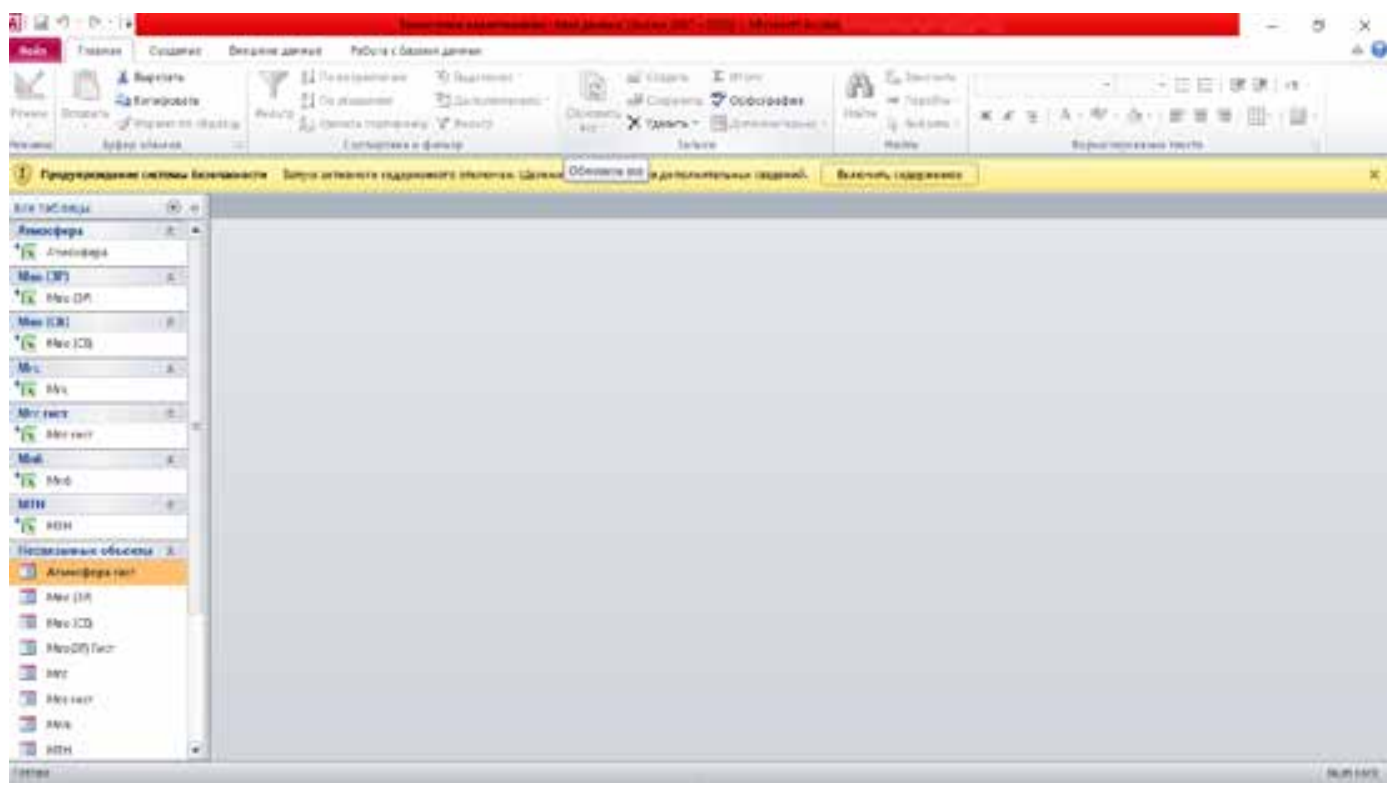

Рис. 2. Інтерфейс програмного модуля «ТЕХНОГЕННЕ НАВАНТАЖЕННЯ»

грами динаміки зміни розрахованих показників. Приклад реалізації цих етапів наведено на рис. 3-5.

Запропонований нами програмний модуль «ТЕХНОГЕННЕ НАВАНТАЖЕННЯ» сутТєво спрощує процедуру розрахунку. База вихідної інформації може збільшуватися або змінюватися зі зміною об'єкта дослідження. Тобто немає необхідності проводити розрахунки знову, якщо змінюється вихідна інформація. Розроблений модуль є нескладним для роботи, не потребує будь-якої спеціальної підготовки для користувачів.

Він може бути застосований в окремих навчальних курсах, які містять змістовні практичні модулі щодо оцінки техногенного навантаження на довкілля.

Головні висновки. У роботі представлено програмну реалізацію методики оцінки техногенного навантаження на окремі складники довкілля. На основі отриманих результатів можна зробити такі висновки:

1. В Україні нині розроблені і функціонують різноманітні програмні комплекси, які призначені для обробки й аналізу даних екологічного моніторингу, розрахунку полів концентрацій 3Р, картографічної візуалізації просторово-часового розподілу характеристик забруднення й техногенного навантаження на довкілля тощо. Усі вони є складними комплексними системами, які характеризуються багаторівневою ієрархічною структурою та призначені для розв'язання комплексу завдань.

2. 3 метою спрощення процедури розрахунку окремих модулів техногенного навантаження на складники довкілля розроблено програмний модуль 

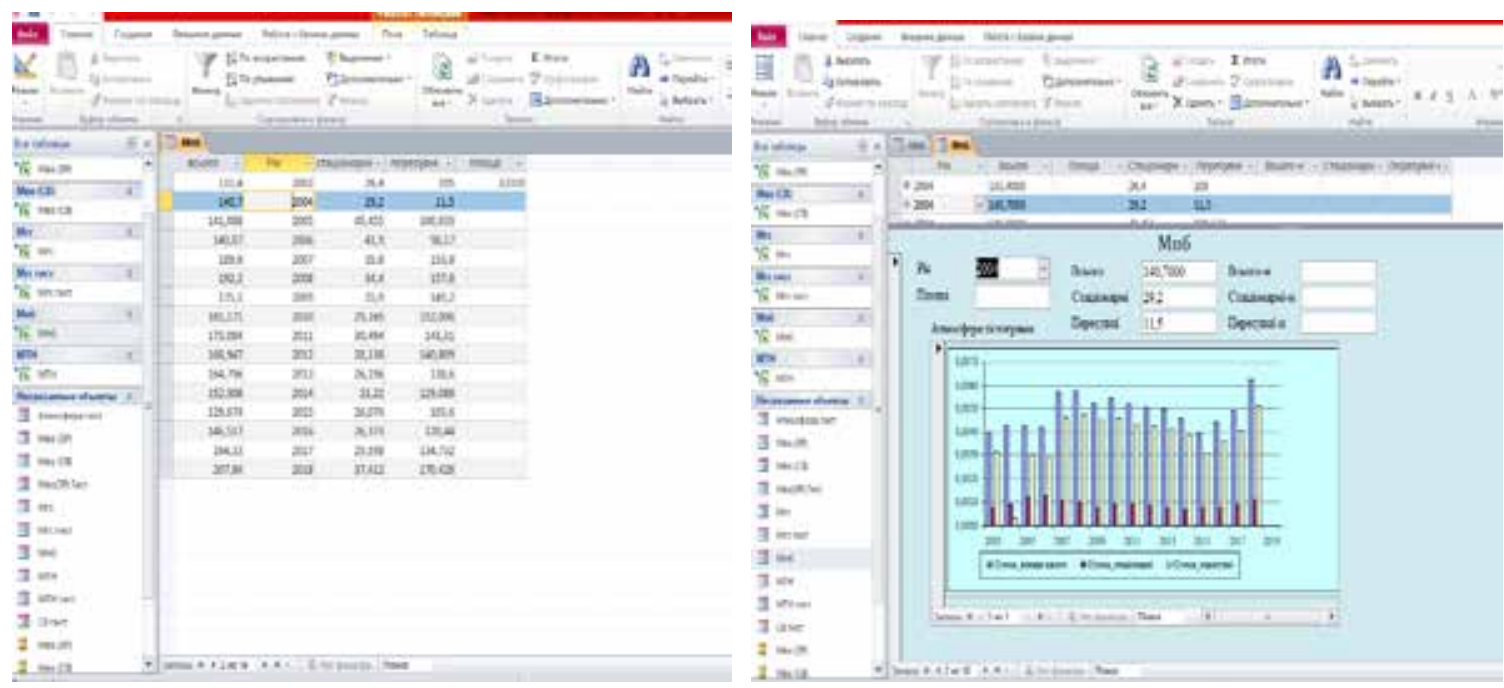

Рис. 3. Розрахунок модуля навантаження на повітряний басейн і його графічне відображення
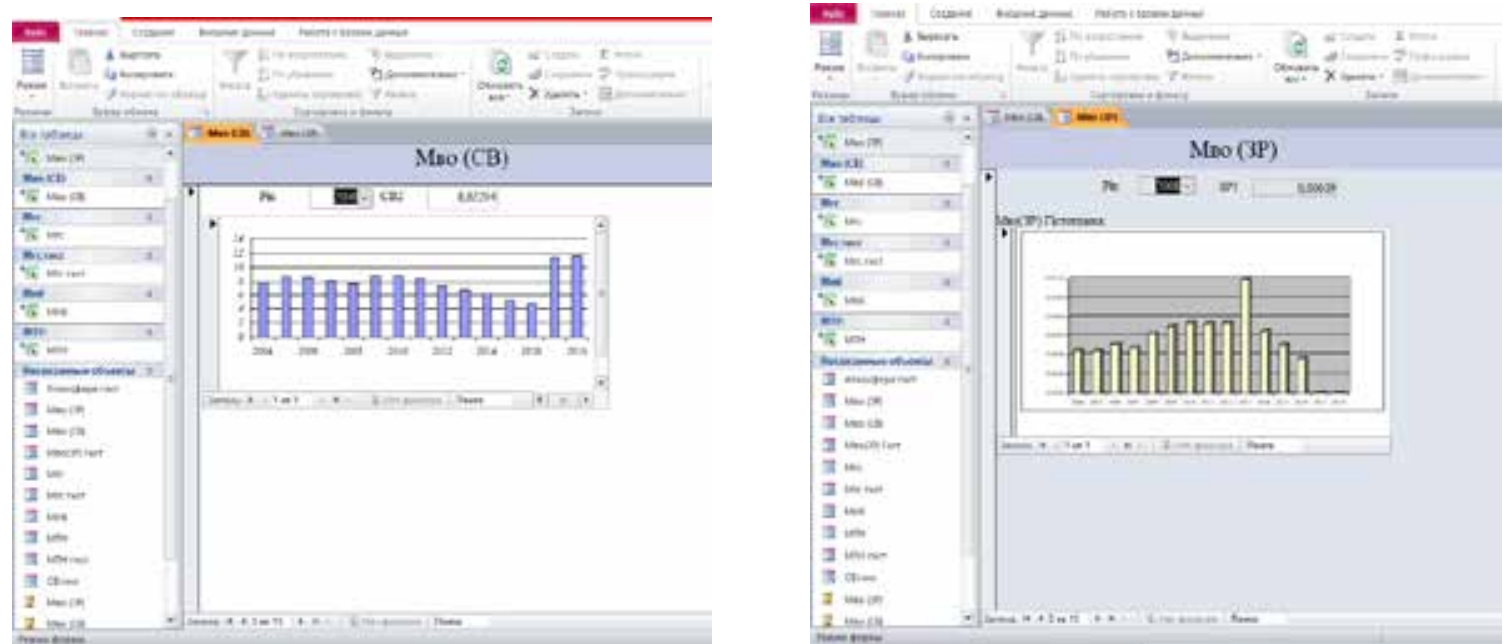

Рис. 4. Графічне відображення модуля навантаження на водні об'єкти
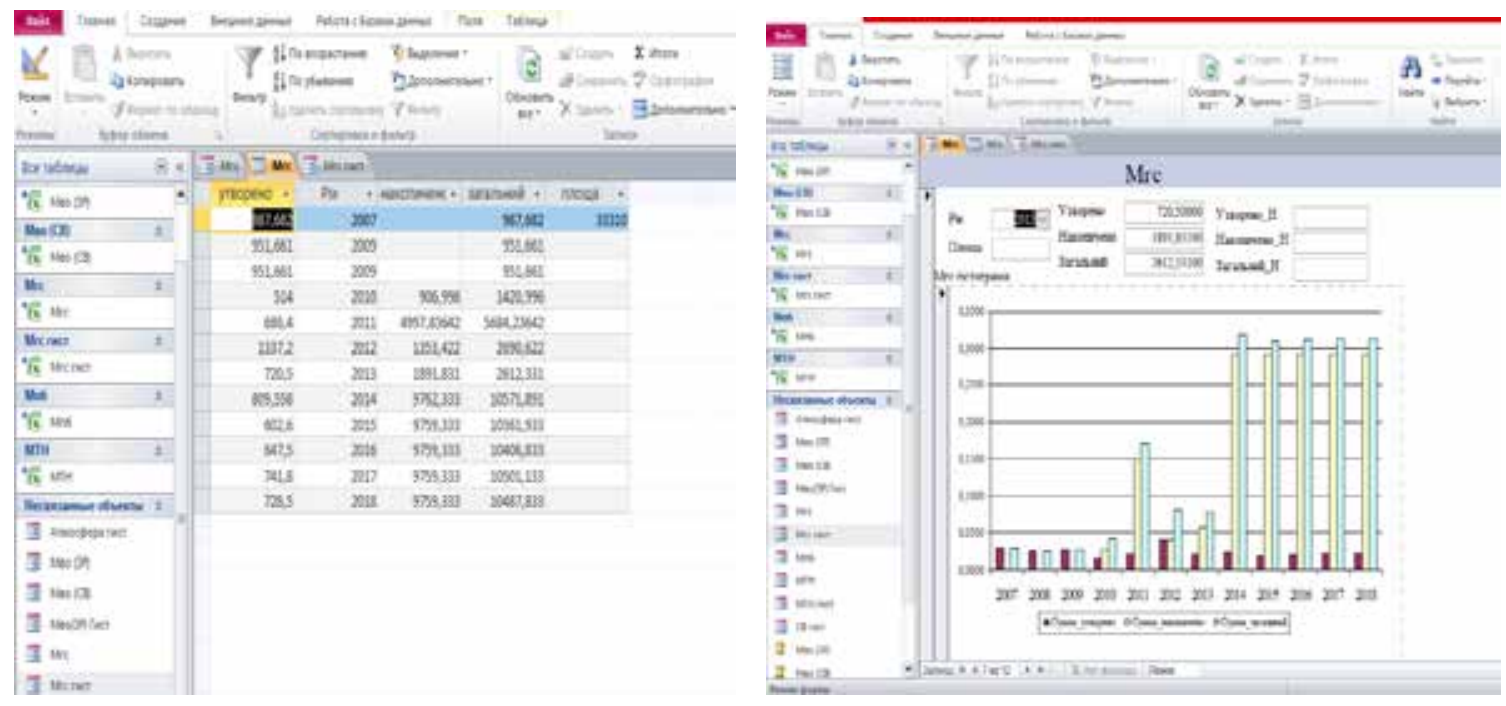

Рис. 5. Розрахунок модуля навантаження на геологічне середовище і його графічне відображення 
«НАВАНТАЖЕННЯ» із застосуванням пакету Microsoft Office Access.

3. Розроблений програмний модуль дає змогу суттєво спростити процедуру розрахунку, а саме під час зміни бази вихідної інформації (збільшення обсягу, зміна об'єкта дослідження) необхідності проводити розрахунки знову немає. Модуль автома- тично під час зміни вихідної інформації проводить розрахунок потрібних показників.

Перспективи використання результатів досліджень. Розроблений модуль $є$ нескладним для роботи і може бути застосований в окремих навчальних курсах під час викладання дисциплін екологічного спрямування.

\section{Література}

1. URL: https://zakon.rada.gov.ua/laws/show/2697-19 (дата звернення: 16.02.2020).

2. Балуєва О.В., Чинкуляк Н.М. Кластерний аналіз територій України за показниками антропогенних навантажень на навколишнє природне середовище. Ефективна економіка. 2013. № 12. URL: http://www.economy.nayka.com.ua/?op=1\&z=2574 (дата звернення: 14.12.2019).

3. Стан і якість природного середовища прибережної зони Північно-Західного Причорномор'я : монографія / за ред. Сафранова Т.А., Чугай А.В. Харків : ФОП Панов А.М., 2017. 298 с.

4. Лесь А.В., Ращенко А.В. Оцінка впливу забруднення на довкілля в контексті можливості запровадження альтернативних методів аграрного виробництва. Вісник ЖНАУ. 2014. № 1-2 (2). С. 203-211.

5. Чугай А.В. Оцінка техногенного навантаження на складові довкілля Одеської області. Екологічні науки. 2020. Вип. 28. С. 102-110.

6. Чугай А.В. Моніторинг довкілля. Методи вимірювань параметрів навколишнього середовища. Конспект лекцій. Одеса: TEC, 2014. $66 \mathrm{c}$.

7. URL: http://sim.nuou.org.ua/files/sim/seminar/DSNS1.pdf (дата звернення: 01.06.2020).

8. URL: http://www.sfund.kiev.ua/rus/products/ecology.htm (дата звернення: 07.06.2020).

9. Попов О.О., Яцишин А.В. Інформаційні системи для вирішення задач комплексного радіоекологічного моніторингу AEC. URL: C:/Users/\%D0\%90\%D0\%BD\%D0\%B3\%D0\%B5\%D0\%BB\%D0\%B8\%D0\%BD\%D0\%B0/Downloads/ Mtit_2014_72_3\%20(1).pdf (дата звернення: 30.05.2020).

10. Волков А.І. Перспективи використання систем підтримки прийняття рішень щодо оцінки та контролю рівня техногенного навантаження на довкілля. Вісник ХНУ ім. В.Н. Каразіна. Серія «Екологія». 2019. Вип. 20. С. 32-41.

11. Bakunova O.M., Abraztsova V.M., Bakunov A.M., Burkin A.V. Improvement of anthropogenic environmental loads assessment methods using modern information technologies. International Academy Journal Web of Scholar. 2019. № 10 (40). P. 28-32. URL: https://core.ac.uk/download/pdf/322469752.pdf (дата звернення: 07.06.2020). 


\section{ВIДОМОСТI ПРО АВТОРIB}

Агарков Олександр Володимирович (Київ) - кандидат технічних наук, доцент, доцент кафедри теоретичної і прикладної механіки, Державний університет інфраструктури та технологій.

Андрійчук Тамара В'ячеславівна (Житомир) - кандидат біологічних наук, старший викладач кафедри екології та географії, Житомирський державний університет імені Івана Франка.

Антоняк Галина Леонідівна (Львів) - доктор біологічних наук, професор кафедри екології, Львівський національний університет імені Івана Франка.

Афтаназів Іван Семенович (Львів) - доктор технічних наук, професор, зав. кафедри нарисної геометрії та інженерної графіки, Національний університет «Львівська політехніка».

Баландюх Юрій Андрійович (Львів) - аспірант кафедри екології та збалансованого природокористування, Національний університет «Львівська політехніка».

Бацилсва Ольга Валеріївна (Вінниця) - доктор психологічних наук, професор, професор кафедри психології, Донецький національний університет імені Василя Стуса.

Биковець Наталя Петрівна (Ізмаїл) - кандидат технічних наук, доцент, завідувачка кафедри загальнонаукових дисциплін, Дунайський інститут Національного університету «Одеська морська академія».

Боженко Анна Леонідівна (Миколаїв) - викладач кафедри екології, Чорноморський національний університет імені Петра Могили.

Бойко Катерина Євгеніївна (Київ) - старший викладач кафедри «Екологічна безпека», Державна екологічна академія післядипломної освіти та управління.

Боруцька Юлія Зіновіївна (Львів) - кандидат геологічних наук, в.о. доцента кафедри туризму, Львівський національний аграрний університет.

Бражник Ігор Дмитрович (Одеса) - аспірант III курсу факультету експлуатації суднових енергетичних установок, Національний університет «Одеська морська академія».

Бугіль Світлана Ярославівна (Львів) - кандидат економічних наук, доцент кафедри туризму, Львівський національний аграрний університет.

Бурлуцька Марія Едуардівна (Одеса) - кандидат географічних наук, доцент кафедри гідрології суші, Одеський державний екологічний університет.

Бучинська Ірина Вікторівна (Одеса) - асистент кафедри інформаційних технологій, Одеський державний екологічний університет.

Валерко Руслана Анатоліївна (Житомир) - кандидат сільськогосподарських наук, доцент кафедри загальної екології, Житомирський національний агроекологічний університет.

Волошина Наталія Олексіївна (Київ) - доктор біологічних наук, професор, завідувач кафедри екології, Національний педагогічний університет імені М.П. Драгоманова.

Галаган Оксана Костянтинівна (Кременець) - кандидат біологічних наук, доцент, доцент кафедри біології, екології та методики їх навчання, Кременецька обласна гуманітарно-педагогічна академія імені Тараса Шевченка.

Гарбар Діана Анатоліївна (Житомир) - кандидат біологічних наук, доцент кафедри екології та географіiі, Житомирський державний університет імені Івана Франка.

Герасимчук Людмила Олександрівна (Житомир) - кандидат сільськогосподарських наук, доцент кафедри загальної екології, Житомирський національний агроекологічний університет.

Гетьман Володимир Іванович (Київ) - кандидат географічних наук, доцент кафедри заповідної справи та рекреаційної діяльності, Державна екологічна академія післядипломної освіти та управління.

Горобей Марина Сергіївна (Київ) - молодший науковий співробітник Центру науково-екологічної інформації, Державна екологічна академія післядипломної освіти та управління.

Гринь Григорій Іванович (Харків) - доктор технічних наук, професор, професор кафедри хімічної технології неорганічних речовин, каталізу та екології, Національний технічний університет «Харківський політехнічний інститут».

Гринь Світлана Олександрівна (Харків) - кандидат технічних наук, доцент, доцент кафедри хімічної техніки та промислової екології, Національний технічний університет «Харківський політехнічний інститут».

Гришко Віталій Миколайович (Кривий Ріг) - кандидат біологічних наук, старший науковий співробітник, старший науковий співробітник відділу оптимізації техногенних ландшафтів, Криворізький ботанічний сад Національної академії наук України.

Демчук Наталія Станіславівна (Житомир) - кандидат біологічних наук, старший викладач кафедри екології та географії, Житомирський державний університет імені Івана Франка.

Дудяк Роман Петрович (Львів) - кандидат економічних наук, доцент кафедри туризму, Львівський національний аграрний університет. 
Дух Ольга Ігорівна (Кременець) - кандидат біологічних наук, доцент, доцент кафедри біології, екології та методики їх навчання, Кременецька обласна гуманітарно-педагогічна академія імені Тараса Шевченка.

Срмішев Олег В'ячеславович (Вінниця) - кандидат біологічних наук, доцент, доцент кафедри біофізики і фізіології, Донецький національний університет імені Василя Стуса.

Жук Володимир Михайлович (Львів) - кандидат технічних наук, доцент, доцент кафедри гідротехніки та водної інженерії, Національний університет «Львівська політехніка».

Іваненко Ірина Миколаївна (Київ) - кандидат хімічних наук, доцент, доцент кафедри технології неорганічних речовин, водоочищення та загальної хімічної технології хіміко-технологічного факультету, Національний технічний університет України «Київський політехнічний інститут імені Ігоря Сікорського».

Іващенко Тарас Григорович (Київ) - доктор технічних наук, старший науковий співробітник, завідувач кафедри екологічного аудиту та експертизи, Державна екологічна академія післядипломної освіти та управління.

Ільїна Валентина Григорівна (Одеса) - кандидат географічних наук, доцент кафедри екології та охорони довкілля, Одеський державний екологічний університет.

Кірсанова Валентина Василівна (Ізмаїл) - кандидат біологічних наук, доцент кафедри загальнонаукових дисциплін, Дунайський інститут Національного університету «Одеська морська академія».

Кияшко Володимир Тимофійович (Київ) - кандидат технічних наук, доцент, професор кафедри публічного управління для сталого розвитку та екологічного менеджменту, Державна екологічна академія післядипломної освіти та управління.

Клименко Олексій Олексійович (Київ) - магістр спец. 101 - Екологія, Державна екологічна академія післядипломної освіти та управління.

Ковалевич Оксана Валентинівна (Кременець) - здобувач освіти за освітньо-професійною програмою Екологія VI курсу, Кременецька обласна гуманітарно-педагогічна академія імені Тараса Шевченка.

Ковальчук Вікторія Валентинівна (Київ) - кандидат фізико-математичних наук, доцент, доцент кафедри теоретичної і прикладної механіки, Державний університет інфраструктури та технологій.

Комарова Ірина Олександрівна (Кривий Ріг) - кандидат біологічних наук, старший викладач кафедри ботаніки та екології, Криворізький державний педагогічний університет.

Копій Марія Леонідівна (Львів) - кандидат сільськогосподарських наук, асистент кафедри екології, Національний лісотехнічний університет України.

Косарчук Валерій Володимирович (Київ) - доктор технічних наук, професор, завідувач кафедри теоретичної і прикладної механіки, Державний університет інфраструктури та технологій.

Костюк Віталій Степанович (Житомир) - кандидат біологічних наук, старший викладач кафедри екології та географії, Житомирський державний університет імені Івана Франка.

Красовський Володимир Васильович (Хорол) - кандидат біологічних наук, старший науковий співробітник, директор, Хорольський ботанічний сад.

Кубов Володимир Ілліч (Миколаїв) - кандидат фізико-математичних наук, доцент кафедри автоматизації й комп'ютерно-інтегрованих технологій, Чорноморський національний університет імені Петра Могили.

Кузнєцов Павло Володимирович (Харків) - кандидат технічних наук, доцент, доцент кафедри обчислювальної техніки і програмування, Національний технічний університет «Харківський політехнічний інститут».

Куцан Наталія Володимирівна (Київ) - студент II курсу магістратури хіміко-технологічного факультету, Національний технічний університет України «Київський політехнічний інститут імені Ігоря Сікорського».

Кученко Тетяна Анатоліївна (Вінниця) - старший викладач кафедри ботаніки та екології, Донецький національний університет імені Василя Стуса.

Лазебна Ольга Миколаївна (Київ) - кандидат педагогічних наук, доцент кафедри екології, Національний педагогічний університет імені М.П. Драгоманова.

Лесів Марта Степанівна (Львів) - аспірант кафедри екології, Львівський національний університет імені Івана Франка.

Лесік Сергій Миколайович (Київ) - аспірант кафедри технології неорганічних речовин, водоочищення та загальної хімічної технології хіміко-технологічного факультету, Національний технічний університет України «Київський політехнічний інститут імені Ігоря Сікорського».

Лисенко Ольга Іллівна (Кривий Ріг) - провідний інженер відділу природної та культурної флори, Криворізький ботанічний сад Національної академії наук України.

Мальований Мирослав Степанович (Лівів) - доктор технічних наук, професор, зав. кафедри екології та збалансованого природокористування, Національний університет «Львівська політехніка».

Машков Олег Альбертович (Київ) - доктор технічних наук, професор, Заслужений діяч науки і техніки України. проректор з наукової роботи, Державна екологічна академія післядипломної освіти та управління.

Мовчан Микола Михайлович (Київ) - кандидат сільськогосподарських наук, завідувач кафедри заповідної справи та рекреаційної діяльності, Державна екологічна академія післядипломної освіти та управління. 
Мордатенко Ігор Леонідович (Біла Церква) - кандидат біологічних наук, старший науковий співробітник відділу збагачення дендрофлори, Державний дендрологічний парк «Олександрія» Національної академії наук України.

Мшанецька Вікторія Вікторівна (Житомир) - магістрант кафедри екології та географії, Житомирський державний університет імені Івана Франка.

Наконечна Юлія Олександрівна (Одеса) - аспірант кафедри екології та охорони довкілля, Одеський державний екологічний університет.

Онищук Ірина Петрівна (Житомир) - кандидат біологічних наук, доцент кафедри екології та географії, Житомирський державний університет імені Івана Франка.

Петроченко Вячеслав Ілліч (Київ) - кандидат технічних наук, старший науковий співробітник, провідний науковий співробітник, Інститут водних проблем і меліорації Національної академії аграрних наук України.

Петроченко Олексій Вячеславович (Київ) - кандидат технічних наук, помічник ректора, Київський національний університет будівництва і архітектури Міністерства освіти і науки України.

Пількевич Юлія Георгї̈вна (Київ) - здобувач наукового ступеня, начальник відділу матеріально-технічного забезпечення, Київський національний університет будівництва і архітектури

Погорелова Марина Полікарпівна (Одеса) - кандидат географічних наук, старший викладач кафедри гідрології суші, Одеський державний екологічний університет.

Поліщук Олександр Ігорович (Львів) - аспірант кафедри екології, Львівський національний університет імені Івана Франка.

Розорінов Георгій Миколайович (Київ) - доктор технічних наук, професор, професор кафедри акустичних та мультимедійних електронних систем, Національний технічний університет України «Київський політехнічний інститут імені Ігоря Сікорського».

Романчук Марина Євгенівна (Одеса) - кандидат географічних наук, доцент кафедри екології та охорони довкілля, Одеський державний екологічний університет.

Салій Ігор В'ячеславович (Київ) - кандидат технічних наук, професор, директор Галузевого навчального центру з питань охорони праці, Державна екологічна академія післядипломної освіти та управління.

Тимчук Іван Степанович (Львів) - кандидат сільськогосподарських наук, докторант кафедри екології та збалансованого природокористування, Національний університет «Львівська політехніка».

Тупкало Віталій Миколайович (Київ) - доктор технічних наук, професор. завідувач кафедри менеджменту та інформаційних технологій, Київський інститут інтелектуальної власності та права Національного університету «Одеська юридична академія».

Улицький Олег Андрійович (Київ) - доктор геологічних наук, доцент кафедри геології, директор навчально-наукового інституту екологічної безпеки та управління Державної екологічної академії післядипломної освіти та управління, професор кафедри «Екологічна безпека», Державна екологічна академія післядипломної освіти та управління.

Феденко Юрій Миколайович (Київ) - кандидат технічних наук, асистент кафедри технології неорганічних речовин, водоочищення та загальної хімічної технології хіміко-технологічного факультету, Національний технічний університет України «Київський політехнічний інститут імені Ігоря Сікорського».

Хом'як Іван Владиславович (Житомир) - кандидат біологічних наук, доцент кафедри екології та географії, Житомирський державний університет імені Івана Франка.

Хохлов Андрій Вікторович (Київ) - кандидат технічних наук, старший науковий дослідник, старший науковий співробітник, Інститут сорбції та проблем ендоекології Національної академії наук України.

Хохлова Людмила Йосипівна (Київ) - кандидат технічних наук, старший науковий дослідник, старший науковий співробітник, Інститут сорбції та проблем ендоекології Національної академії наук України.

Чаусов Микола Георгійович (Київ) - доктор технічних наук, професор, професор кафедри механіки, Національний університет біоресурсів і природокористування України.

Чугай Ангеліна Володимирівна (Одеса) - кандидат географічних наук, доцент, декан природоохоронного факультету, Одеський державний екологічний університет.

Шевченко Зінаїда Миколаївна (Київ) - історик, вчитель-методист, Заклад загальної середньої освіти № 210 Облонського району м. Києва.

Шевченко Роман Юрійович (Київ) - кандидат географічних наук, завідувач кафедри екологічного моніторингу, геоінформаційних та аерокосмічних технологій, Державна екологічна академія післядипломної освіти та управління.

Шпаковська Лілія Валеріївна (Житомир) - лаборант кафедри екології та географії, Житомирський державний університет імені Івана Франка. 
HOTATKИ 
Наукове видання

\section{ЕКОЛОГГЧНІ НАУКИ}

- Екологічний моніторинг

- Екологія водних ресурсів

- Екологія і будівництво

- Екологія і виробництво

- Загальні проблеми екологічної безпеки

- Збереження біологічного та ландшафтного різноманіття

- Поводження з відходами

- Проблеми еколого-збалансованого розвитку

- Розвиток природно-заповідного фонду України

- Система екологічної освіти для сталого розвитку

- Теоретико-методологічні питання в галузі охорони довкілля

Адреса редакції:

Державна екологічна академія післядипломної освіти та управління вул. Митрополита Василя Липківського, 35, корпус 2, Київ, 03035; тел. +380 9942867 00;

www.ecoj.dea.kiev.ua e-mail: info@ecoj.dea.kiev.ua

Видавничий дім «Гельветика»

Свідоцтво суб’єкта видавничої справи ДК № 6424 від 04.10.2018

Україна, 03150, м. Київ, вул. Велика Васильківська 74, оф. 7

Тел. +38 (048) 70938 69, +38 (095) 93448 28, +38 (097) 7230608

E-mail: mailbox@helvetica.com.ua

Підписано до друку 21.12.2020. Формат 64х84/8.

Папір офсетний. Гарнітура Times New Roman. Цифровий друк.

Ум. друк. арк. 22,55. Тираж 100. Замовлення № 0221/56.

Ціна договірна. Віддруковано з готового оригінал-макета 